


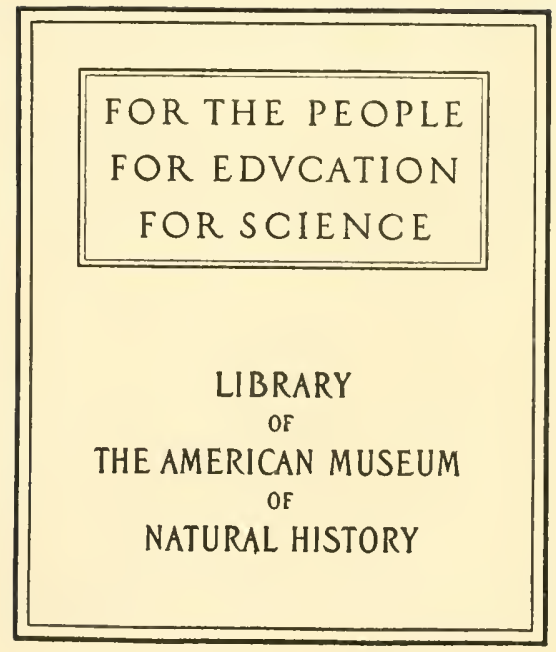






\section{CAT A L OGUE}

OF THE

\section{F I S H E S}

IN THE

\section{B R I T I S H U S E U M.}

BY

ALBERT GÜNTHER, M.A., M.D., Ph.D., F.Z.S., ETC. ETC.

VOLUME FIRST.

L O N D O N :

PRINTED BY ORDER OF THE TRUSTEES.

1859. 


$$
\begin{array}{r}
59.7: 0742.1 \\
47.12=11: 5-11
\end{array}
$$




\section{A T' A L O GUE}

OF THE

\section{ACANTHOPTERYGIAN FISHES}

IN THE

COLLECTION

OF THE

\section{B R I T I S H M S E U M.}

BY

DR. ALBERT GÜNTHER.

VOLUME FIRST.

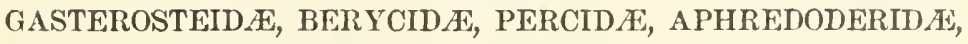
PRISTIPOMATIDA, MULLIDE, SPARIDA.

L O N O N :

PRINTED BY ORDER OF THE TRUSTEES. 18.59. 
PRINTED BY TAYLOR AND FRANCIS,
RED LION COURT, FLEET STREET. 


\section{PREFACE.}

Turs Catalogue contains a description of all the species of Fish in the Collection of the British Museum, and of the species which are known to exist in other Museums, but which are desiderata in the National Collection, and therefore-most desirable to be procured.

Most of the new and more interesting species have been figured. Descriptions of the skeleton of many of the specimens have been added.

Dr. Günther gives the following observations as to the method followed in its formation:- "This volume of the Catalogue contains the greater portion of Cuvier's Percoides, Sciomoides, Sparoides, and Manides, with many other genera which, I believe, ought to be associated with them. There is no ichthyologist of the present day, who, looking at the great number of new forns discovered since Cuvier's period, would not think it advisable to subdivide some of the families adopted in the 'Règne Animal,' and subsequently in the 'Histoire Naturelle des Poissons' (as indeed was suggested by Cuvier himself), and to employ a part only of the characters assigned by him to the different families. Further, when genera and even species are known, in which the absence or presence of vomerine teeth is not constant, this character can no longer stand as distinctive of two large families like Cuvier's Percoides and Sciomoides. The same is the case with the character of a smooth or serrated præopercular edge. Instead of those characters has been substituted that of the relative development of the dorsal and anal fins. Thus, several portions of the Percoides of Cuvier have been separated, and form. together with some of his Scicenoides and Sparoides, and with the Mcenides, families of themselves.

“This Catalogue comprises all the species, descriptions of which have been published in works accessible to me. The number of known species having been considerably increased in the last thirty years, and the descriptions of the new species being scatterud throurh 
a great many Journals, Voyages, and Reports, such a general synopsis as is offered in the present Catalogue will meet a real want in Iehthyology. In confirmation of this, we need only compare the result of this volume with the number of speeies contained in the corresponding parts of the 'Histoire Naturelle des Poissons' by Cuvier and Valenciennes, the last general ichthyologieal work. There we find 777 species, 92 of which are described twice or thrice under different names*; 154 of the remaining 685 speeies are very doubtful, generally from insuffieient description, and mostly established by Cuvier himself. The present Catalogue contains 1177 speeies, 917 of which are considered as properly distinguished, the remainder being merely enumerated. Thus we have-

Total number of species in Cuv. \& Val. ......... 777

Total number of speeies in this Catalogue ........ 1177

Species apparently well characterized in Cuv. \& Val.... 531

Species apparently well characterized in this Catalogue. . 917

"The Collection of the British Museum, together with its Library, have enabled me to introduce original diagnoses of most of the species, and to compile the synonymy and revise that stated by Cuvier, thus raising this work above the point of a mere compilation. The Collection contains many typical specimens, as there have been embodied into it, besides other minor collections,-

"1. The Collection of Gronov, purehased with his MS. descriptions.

"2. Fishes of India, eollected by General Hardwicke.

" 3 . The entire Collection of British Fishes, by Mrr. William Yarrell.

"4. The Collection of the Fishes of the Frith of Forth, and Scottish Rivers, by Dr. Parnell.

"5. The Collection of Chinese Fishes, made by Mr. John Reeve and his som John Russell Reeve, deseribed by Sir John Richardsun, and the drawings of them taken from living or fresh speeimens.

* "Cuvier.... was ongelukkig in het scheppen van nieuwe soortbepalingen. Zijn groot ichthyologisch werk is vol van dubbele of meer voudige beschrijvingen eener zelfde soort, die naar rerschillen van zeer ondergeschikte waarde, afhankelijk van geslacht, leefijd en klimat, als zoovele verschillende speries plats namen."Bleckes, Natuurl: Tijdschr. Nederl. Ind. i. 1851, p. 344. 
"6. 'The Collection of the Royal Naval Hospital of Hasla".

7. 'The Collection of Fishes of the Red Sea, described jy, and procured from Dr. Rüppell.

" 8 . The Collection of Fishes of Japan, deseribed by Prof. Schlegel, and received from the Leyden Museum.

" 9. The Collection of Fishes of A mboyna, cleseribed by Dr. Bleeker, and presented by him to a charitable institution in Holland.

"10. Fishes from the Cape, presented by Sir Andrew Snith, M.D.

"11. The Collection of Freshwater Fishes of India, collected by Dr. Griffith, described by Dr. Maeclelland, and presented by the IIon. Fast India Company (mostly Cyprinoids).

"12. 'The Fishes of the Seas of Madeira and the Canary Islands, described and presented by the Rev. 1R. T. Lowe.

"13. A Collection of the skulls and skeletons of German Fishes, made by Dr. A. Günther.

"By the kindness of the late Dr. Horsfield, the types of the species of Indian Fishes deseribed by Dr. Cantor have been examined at the Museum of the Hon. East India Company.

"Wherever I have not had an opportunity of examining the species, and have been obliged to borrow the characters for a diagnosis from another deseription, I have added the authority. 'There remain, however, species which are either insufficiently deseribed, or founded on characters so slight that it is doubtful whether they will stand as species, - or which are established from figures not executed by, or under the inspection of, naturalists : these are mentioned in notes, without a description, and with the synonymy only. Whoever has gone through the labour of examining such descriptions, of making the best of them, and of determining fishes by them, will know the amount of time fruitlessly spent, and will understand how to appreeiate the more recent accounts of Bleeker, which combine with the distinctness of a diagnosis the accuracy of a deseription.

" To conclude, I add some explanatory remarks on my way of taking the measurements of specimens, of counting the scales, \&c. :-

"1. The height of the boly is always its greatest depth.

$\because 2$. The length of the head is the distance between the end of the snout and the posterior extremity of the bony operculum. 'The lenyth of the snout is the distance between the end of the snout and the vertical from the anterior margin of the eye. 
"3. The total length is the distance between the end of the snout and the extremity of the caudal fin, when stretched out.

"4. The last dorsal and anal ray is, generally, bifid to the base: it is counted as one, because only one interneural and interhæmal spine corresponds to it.

“5. L. lat. gives the number of pierced scales constituting the lateral line from the humeral arch to the root of the caudal fin, i.e. the number of transverse series of scales covering the body between the points mentioned. The scales of the lateral line are often smaller or larger, or irregular, and not congruent with the transverse series; in these cases I havo counted the transverse series.

"6. L. transv. gives the number of scales in a series, which runs from the origin of the dorsal fin obliquely downwards to the median line of the abdomen, crossing the lateral line. It indicates the number of longitudinal series of scales between the origin of the dorsal fin and the lateral line, and between this and the abdomen. Sometimes the transverse line has such an oblique direction that the number of its scales would be greater than that of the Iongitudinal series : in this case I count the latter.-The numbers of the lateral and transverse lines are of specific value.

" 7 . The statement of the size of the eye, relative to the length of the head and its parts, is to be applied cautiously, this organ being comparatively mnch larger in young specimens than in mature ones. Statements taken from mature speeimens of different species, of course have every right to be received into the diagnosis.

"8. In the descriptions of the skeleton the terminology given by Prof. Owen has been used.

“9. In the statement of the length of the vertebral column, the centrum only of the last caudal vertebra is included.

"The Plates referred to, and executed by Mr. Ford, will be published as a separate volume."

JOHN EDWARD GRAY.

British Museum,

May 5, 1859. 


\title{
I NDEX OF THE WORKS
}

\author{
QUOTED IN TIIS VOLUME.
}

Sec. IV. a. Ch. Anıstorelns. De Natura Animalium Libri novem.

- De Partibus Animalium Libri quatuor.

- De Generatione Animalim Libri quinque.

Ex versione Latina Theodori Garce. Venetis, 1503, fol.

Sec. 1. p. Ch. Cajus Plinius. Historiæ Mundi Libri xxxvii.

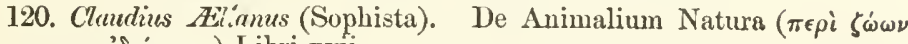
isıótᄁтos) Libri xvi.

150. Athenceus (Naucratita). Deipnosophistarum Lib. xv. (Lib. vii. de P'iscibus.)

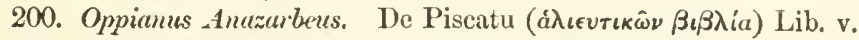

400. Decius Margnus Ausonius. Carmen de Mosella.

1270. Albertus Magnus. De Natura Animalium. Lib. xxiv. de Piscibus. Edit. Lugdun. 1651.

1551. Petrus Bellonius. Historia Naturalis Piscium Marinarum. Paris, 4to.

1553. - - De Aquatilibus Libri ii. Paris, $8 \mathrm{vo}$.

1554. Gullelaus Rondfletuls. Libri de Piscibus Marinis. Lugd., fol. 1560. - - Universa Aquatiliun Historia pars altera. Lugd., fol. (Lib. iv.-vii. de l'iscibus.)

1554. Hippolytus Sulvianes Typhernas. Aquatilium Animalifum Historiæ Liber primus. Roma, 1554.

1558. Conradus Gesner. Fischbuch irs Teutsch gebracht von Conrad Forer, M.D. Frankf., fol.

1604. Casparies Schwenclffeld. Theriotropheion Silesiæ. Lignicii, 4to.

1624. Stephanas a Schonevelde. Ichthyologia-Slesvici, Holsatia et Emporii Hamburgi. Hamburr, 4to.

1638. Ulysses Aldrovandus. De Piscibus Libri v. et Cetis Liber i. Bononia, fol.

1648. Georgius Marcgratus. Historixe Rerum Naturalium Brasilixe Libri viii. Lugd. Bat., fol. (Lib. iv. de P'iseibus.)

1686. Franciscus Willughby. De Historia Piscium Libri quatuor, jussu et sumtibus Societatis Regiro Loudinensis editi. Ed. Jolumes Rajus, Lond., fol.

1685. - - Ichthyographia. Sumtibus Soc. Regire Londin. Lund., fol.

1713. Juannes Ray. Synopsis Methodica Piscium. Lond., 8vo.

718. Friederious Ruyschius. Theatrum Universale, cura $H$. Ruysch. Ainttelod., fol. (contains also the figures of Remard). 
1726. Franciscus Vulentinus. Descriptio Amboinensis. Amstelod., fol. (Pars iii. de Piscibus Amboin. \&c.)

1726. Ludoricus Ferdinandus Marsilius. Danubius Pannonico-Mysicus, fol. (Vols. iv. and vi. de Piscibus.)

1727. Hans Sloane. Voyage aux îles de Madère, des Barbades, de Nièves, de St. Christophe et de la Jamaique. Londres, 1707 et 1727. 2 vols. fol.

1731. Murcus Catesby. Historia Naturalis Carolinæe, \&c. Lond. 1731 1742 , fol.

1734. Henricus Ruysch. A Description of 300 Animals. Lond., 12no. (Fishes, pp. 149-190.)

1735. Alpini, Prosp. Historixe Naturalis Agypti ii. partes. Lugd. Batav., 4 to.

1738. Petrus Arteor. Bibliotheca Ichthyologica. Lugd. Bat., 8vo.

-. Philosophia Ichthyologicn. Lugd. Bat., 8vo.

- Genera Piscium. Lugd. Bat., 8vo.

- Synonymia Piscium. Iugd. Bat., 8vo.

-. Descriptiones Specieram Piscium. Lugd. Bat., 8vo.

1735. Canolus Linneus. Systema Naturæ. Ed. 1. Lugd. Bat., 8vo. 1749-69. —. Amœnitates Academicæ. Holm., Lips., tet Lugd. Batav., 8 vo.

1754. - Museum Adolphi Friederici. Stockh., fol.

1766. - - Systema Nature. Ed. 12. Holm., 8vo.

1788. —- Systema Naturæ, cur. Gmelin. Ed. 13. Lips., 8vo.

1740. Jacobus Theodorus Klein. Historia Naturalis Piscium. Gedre, $1740-49,4$ to.

1754. Louis Renard. Poissons que l'on trouve autour des Moluques. Amsterd., fol.

1754. Laurentius Theodorus Gronorius. Museum Ichthyologicum. Lugd. $1754-56$, fol.

1763. - - Zoophy Incium. Lugd. 1763, 17v4, 1781, fol.

1780. — - Systema Ichthyologicum, or Catalogue of Fish, collected and described by $\dot{L}$. T\%. Gronow: published by $J$. E. Gray: printed by order of the Trustees of the British Museum. fond. 185̆4, 8ro.

1757. Fricdericus Hassclquist. Iter Palestinense. Holmiæ, 8vo.

1758. Sehr, $A$. Locupletissimi Rerum Naturaliunı Thesauri accurata Descriptio. Tom. iii. Amstelod., fol.

I761. Schaffer. Piscium Bavarico-Ratisbonensium Pentrs. Ratisb., 4to. 1767. Petrus Ascanius. Icones Rerum Naturalium. Copenh. 1767-75, fol. 1768. Brïnnich. Ichthyologia Massiliensis. Copenh., 8vo.

1769. Pallas. Spicilegia Zoologica. Petrop. 1769-79.

1811. - Zoographia Rosso-Asiatica. Petersb., 4to.

1769. Pennant. British Zoology. (Vol. iii.) Lond., 8vo.

1784. - - Arctic Zoology, vol. iii. Lond., 4to.

1790. - - Indian Zoology. Ed. 2. Lond., 4to.

1769-77. Duhamel du Moncưu et De la Marve. Traité générale des Pesches. Paris, fol.

1770. Gouan. Ilistoria Iiscium. Strasb., 4 to. 
1770. Köleuter. Papers on Fishes in Novi Commentar. Petropol. ix.-xix., and in Nova Acta, vol. xiii.

1771. Osbcck, $P$. A Voyage to China. Loud., 8vo.

1775 Forskial, $P$. Niebuhr, C. Descriptiones Animalium, quxe in itinere orientali observavit $P$. Forskål. Haunix, 4 to.

1777. Otto Friedericus Miiller. Prodromus Zoologia Danica.

1779. -... Zoologia Danica. Copenh., fol.

1780. Otto Fabricius. Fauna Grönlandica. Copenlı̨. 1780.

1782. Bloch. Naturgeschichte der Fische Deutschlands. Berl. 1782-84, 4 to.

1785. - - Ausländische Fische. Berl. 1785-95, 4to. Plates, fol.

1801. - Systema Ichthyologiæ. Ed. Schnciler. Berl., 8vo.

1785. Meitinger. Icones Piscium Austrix. Viennæ, 1785-94, fol.

1787. Cavolini. Nemoria sulla Generazione dei Pesci. Napoli, 4 to.

1792. - Abhandlung uber d. Erzeugung der Fische. Uebers. von Zimmermann. Berl., 8ro.

1787. Purra. Descripcion de diferentes Piezas de Fistoria Natural. Havana, 4 to.

1790. White, $J$. Journal of a Voyage to New South Wales. Lond., 4to.

1793. Thumbery. Paper in Nov. Act. Scient. Suec. IIolm., 4 to.

1797. Mungo Park. Description of eight new Fishes from Sumatra, in Traus. Linn. Soc. Lond.

1798. Lacépède. Histoire des Poissons. Paris. 1798-1803, 4to.

1799. Sonnini, C. S. Voyage dans la Haute et Basse Egypte. Paris, 8 vo.

1800. Cuvier. Leçons d'Anatomie Comparée. Paris, 1800-1805, 8vo.

1829-30. —. Le Règne Animal. 2 édit. Paris, 8vo.

1802-8. Donoran, $E$. The Natural History of British Fishes. Lond., 8vo.

1803. Russell. Descriptions and Figures of Fishes of Coromandel. Lond., fol.

1803. Shaw. General Zoology. · Lond., 8vo.

1804. Hermann. Observationes Zoologicæ l’osthumæ. Strasb., 4to.

1807. Tirton, William. The British Fauna. Swansea, $12 m$.

1809. Delaroche, $F$. Observations sur les Poissons recueillis dans un voyage aux îles Baléares. Ann. Mus. d'Hlist. Nat. tom. xiii.

1809-13. Description de l'kgypte. Ilistoire Naturelle. par Geoffroy St. Hilaire. Paris, fol.

1810. Risso. Ichthyologie de Nice. Paris, 8 vo.

1827. —. Histoire Naturelle de l'Europe Méridionale. Paris, 8 vo.

1812. Rosenthal. Tabulæ Ichthyotomicr. Berl. 1812-22, fol.

1814. Mitchill, S. $L$. Report in part on the Fishes of New York. New York, $12 \mathrm{mo}$.

1815. - Memoir on Ichthyology, in Trans. Lit. and Philos. Soc. New York.

1817. - Descriptions of three species of Fishes, in Journ. Acad. Nat. Sc. Philad. i.

1818. _ - The Fishes of New York, described and auranged, in Amer. Monthly Mag.

1817-25. Lesuen, C: A. P'apers in the Joum. Acad. Nat. Sc. Plilad. 
1820. Lichtenstein, H. Paper in Abhandl. Berl. Acad.

1822. Buchanan IIamilton. An Account of the Fishes of the Ganges. Edinb., 4 to.

1824. Murtens, G. v. Reise nach Venedig. Ulm, 8vo.

1824. Quoy et Gaimard. Voyage autour du Monde sur les corvettes de S. M. l'Uranie et la Physicienne, sous le commandement de Freycinet. Zoologie: Poissons. Paris, 4to. Atlas, fol

1825. Conch. Some particulars of the Natural IFistory of Fishes found in Cornwall, in Trans. Linn. Soc. Lond., vol. xiv.

1825. Jurine. Poissons du Lac Leman. Genève, fol.

1826-30. Lesson. Zoologie, in Dhperrey, Voyage de la Coquille. Paris, 4 to. Atlas, fol.

1827. Hartmann, G. L. Helvetische Ichthyologie. Zürich, 8vo.

1828. Fleming. History of British Animals. Edinb., 8vo.

1828. Rüppell. $\Lambda$ tlas zu der Reise im Nördl. Africa. Frankf., fol.

1837. - - Neuo Wirbelthiere. Fische. Frankf., fol.

1852. —. Verzeichniss der Fische des Senckenberg'schen Museums. Frankf., 4to.

1828-49. Cuvine et Valenciennes. Histoire Naturelle des Poissons. Paris, 8 vo.

1829. Ayassiz, L. Selecta Genera et Species Piscium, quit in itinere per Brasiliam collegit J. B. de Spix. Monach., fol.

1850. - Lake Superior. Boston, 8vo.

1829. Cocco. Paper in Giomale di Scienz, per la Sicilia. Palermo.

1829-44. Guérin-DLéneville, $\boldsymbol{F}$. $\boldsymbol{E}$. Iconogıaphie du Règne Aninal de G. Cuvier. Paris et Londres, 8vo.

1830. Bennett, E. T. Catalogue of Zoologieal Specimens from Sumatra, in the Memoir of the Life and Services of Thomas Stanford Raffles. Lond., 4to.

- Papers in the Zoological Journal and in Proc. Zool. Soc. Lond.

1830. Bennett, J. Fishes of Ceylon. Lond., fol.

1830-35. Gray, J. E. Illustrations of Indian Zoology. Lond., fol.

1831-42. - - Papers in Zoological Miscellany. Lond., 8vo.

18:30. Reisinger. Specimen Ichthyologix Hungaria. Budx.

1830. Stark. Paper in Jameson's Edinb. Journ.

18:32-41. Bonaparte. Iconografia della Fauna Italica. Tom. iii. Pesci. Roma, fol.

1832. Expédition Scientifique de Moree. Tom. iii. Zoologie, par Geoffroy St. Hilaire, Deshayes, etc. Paris, 4 to. Atlas, fol., 1835.

1832. Vatencimnes. Descriptions de plusiems espèces nouvelles de Poissons du grenre $\Lambda$ pogron, in Nouv. Anu. Mus. Ilist. Nat.

1836. - - lehthyologie, in Histoire Naturelle des Iles Canaries par W'bb et lierthelot. Paris, fol.

1846. - - Doissons, in Dnpetil Thomars' Voyage autour du Morde sur la frégate la V'ómis. Parris, 8vo. Atlas, fol.

1833. Brandt at Ratzilurg. Medieinische Zoologie. Band ii. 13erl., 4to. 18:33. Isere', R. T. On the Fishes of Mateirn. Troc. Zool. Soe. p. 142.

1835. - Deseription of a n*w genus of Fishes (Mlepidosaurus), and Aiditional ()hervations, in Trans. Kool. Soc. i. 
1836. Lore, $R$. T. P'iscium Maderensium species quadam nove, in Trans. Cambr. Philos. Soc. p. 195.

1841. - - A Synopsis of the Fishes of Madeira, in Trans. Zool. Soc. ii.

1843. - - The Fishes of Madeira. Iond., 8ro.

1849. - - Supplement to the Synopsis, in Trans. Zool. Soc. iii. - On a new genus of the Family Lophiidæ, $l_{\text {. }} c$.

1834. Bèlınger. Zoologie dı Voynge aux Indes Orientales. Paris.

1834. Griffith, E. The Animal Kingdom. Tol. x. Class Pisces. Lond., 8vo.

1834. Quoy et Gaimard. Voyage de l'Astrolube sous le commandement de M. J. Dumont d' Urrille. Zoologie. Tom. iii. Poissons, p. 645. Paris, 8vo. Atlas, fol.

1835. Ekström. Die Fische in den Scheeren von Mörliö, übers. von Creplin. Berl., 8vo.

1835. Jacquemont. Voyage dans.l'Inde. Poissons. Paris.

1836. Fries och Ekström. .Skandinariens Fiskar. Stockh., 4to.

1836. Richardson, Sir J. Fauna Boreali-Americana. Part iii. Fisl. Lond., 4to.

1839-40. - - On some new species of Fishes from Australia, in Proc. Zool. Soc.

1842-43. - Descriptions of Australian Fishes, in Ann. \& Mag. N. II.

1843. - - Icones Piscium. Lond., 4to.

1844 45. - Ichthyology, in theVoyage of H.M.S. Sulphur. Lond., 4tc

1846. - Ichthyology, in Voyage of II.M.SS. Erebus and Terror.

1846. - - Reports on the Ichthyology of the Seas of China and Japan, in Report of the Fifteenth Meeting of the British Association. Lond., 8vo.

1848. - V Vyage of H.M.S. Samarang. Fishes. Lond., 4to.

1849. - - Descriptions of Allstralian Fishes, in Trans. Zool. Soc. iii.

1857. - - System of I chthyology, in the Encyclopredia Britannica.

1838. Kirtland. Report on the Zoology of Ohio. Columb., 8vo.

1840. - Descriptions of four new species of Fishes, in Boston Journ. Nat. Hist. iii.

1841. - - Descriptions of the Fishes of the Ohio River. Ibid.

1838. Kröyer. Danmarks Fiske. Kjöbenhavn.

1838. Parnell, $R$. The Natural History of the Fishes of the Firth of Forth. Edinb., 8vo.

1839. Storer. Report on the Ichthyology of Massachusetts. Bost. Journ. Nat. Hist. ii.

1843-50. - Papers in Bost. Journ. Nat. Hist.

1840. Nordmam. Ichthyologie Pontique, in Voyage dans la Russie Méridionale de Demadoff, tom. iii. Paris, 8vo. Atlas, fol.

1841. Eichwald. Fanna Caspio-Caucasica. Petrop., fol.

1841. Sykes. On the Fishes of the Dukhun, in Trans. Zool. Soc. ii.

1841. Thompson, W. Paper in Ann. \& Mag. Nat. Hist. vol. vii.

1841. Furell A History of British Fishes. 2nd edit. Lond., 8ro.

1842. Dckay. Zoology of New York. (Part iv. Fishes.) New York, 4to.

1842. Jenyns, L. The Zuology of the Voyage of M.M.S. Beagln. Fishes. Lond., 4 to. 
184:3. C'osta. Storia e Notomia del Branehiestono lubrico. Napoli, fol.

184t. Forster, J. R. I)escriptiones Animalium, qua in itinere ad maris anstralis terras observavit J. R. Forster. Ed. H. Lichtenstrin. Berlin, sro.

1845. Ayres. Paper's in Bost. Jomm.

1845. Guichenot. Poissons, in Ramon de la Sugren, Ifistoire Naturelle de Cuba. Paris, sro. Atlas, fol.

1845-5t. Iefibre, Th. Voyage en Abyssinie. Paris, 8vo. Atlas, fol.

1845. Tschucti. Fama Peruama. Ithtlyologie. St. Gallen, fol.

1845-49. Müller und Trosehel. Hora Iehthyologice. Berol., fol.

1846. Mülden, J. Ceber den Bau und die Grenzen der Ganoiden. Berl., 4 to.

1846-49. Bhecke, $P$ : Some papers in Verhandelingen van het Bataviansch (ienootschap. Bataria.

- Papers in Natumkundig Tydschrift roor Nederlandsch Indië*:-

1850. - - (Borneo, i.) Bydrage tot de kemis der ichtlyologische futuma van Bomeo.

-_. (Seleroparei.) Orer eenige nieuwe soorten van Scleroparei van den Indischen Archipel.

- Orer twee nieuwe soorten ran Callionymus.

-.- Over eenige nieuwe soorten ran Belone en II miramphus.

- C. Orer drie nieuwe soorten van Tetraödon van den Indischen Archipes.

-_. (Java, i.) Fauna Iclithyologica Jave insularumque adjacentium genera et speeies nove.

- - Visschen ran Banka.

-... Visschen van Borneo.

1851. _- Over eenige nienwe soorten ran Blemnioiden en Gobioiden. (Bonne, ii.) Nieuwe bydrute to de kemis der ichthyologisc.je famma vall Bonneo.

- - Oxybelus Brandesii.

- (Bomeo, iii.) 1)rde bydrage tot de kemnis der iehthyologische fauma ran Jomeo.

—. Clstilinoides.

- - Nienwe bydrage tot de kemnis der Percoidei, Scleroparei, Scirnoidei, Sparoidei, Mrnoidei, Chætodontoidei en Scomberoidei van den Soenda-Moluksehen Archipel.

_- (Borneo, iv.) Vierde bydrage tot de kennis der ichthyolngische famna van 130 meo.

-. (Celebes, i.) Nieuwe bydrage tot de kennis der ichthyologische fauna van Celebes.

-. (Banda, i.) Bydrage tot de kennis der ichthyologische fnuma van de Banda-rilanden.

- Visschen van Solor.

* To shorten the numerous quotations in the text, many of the papers are marhed with the name of the loeality only, the ichthyologieal fama of which has heen descrihed hi Dr. Blecker, as indieated by the nume's in parentheses. 
1851. Blecker, $P$. (Malireel.) Orer eenige nieuwe geslachten en soorten van Makreelachtige risschen.

- - (Pleuronect.) Over eenige nieuwe soorten van Pleuronecteoïden.

- Over eenige nieuwe soorten van Megalops, Dussumieria, Notopterus en Astronesthes.

- - Visschen van Billiton.

- (Borneo, v.) Vijfde bydrage tot de kemnis der ichthyologische fauna van Borneo.

- (Riouw.) Bydrage tot de kennis der ichthyologische fauna van Riouw.

1852. - ( Singapore.) Bydrage tot de kennis der ichthyologische fauna van Singapore.

-. (Blitong.) Bydrage tot de kennis der ichthyologische fauna van Blitong (Billiton).

- (Timor, i.) Bydrage tot de kennis der ichthyologische fauna van Timor.

-. (Amb. and Cer.) Bydrage tot de kennis der ichthyologische fauna van de Molnksche eilanden. Visschen van Amboina en Ceram.

- Borneo, vi.) 7iesde bydrage tot de kennis der ichthyologische fauna van Borneo.

- (Banka.) Bydrage tot de kennis der ichthyologische fauna van het eiland Banka.

- (Amboina, ii.) Nieuwe bydrage tot de kennis der ichthyologische fauna van Amboina.

- (Sumatra, i.) Diagnostische beschryvingen van nieuwe of weinig bekende vischsoorten van Sumatra.

- Nienwe visschen van Banda Neira.

- (Ceram, ii.) Nieuwe bydrage tot de kennis der ichthyologische fauna van Ceram.

- (Bauka, ii.) Nieuwe bydrage tot de kennis der ichthyologische fauna van het eiland Banka.

- (Celebes, iii.) Derde bydrage tot de kennis der ichthyologische fauna van Celebes.

_- Index specierum Piscium Malayo-Moluccensium in voluminibus i., ii. et iii. Uiarii Societatis Scientiarum Indo-Batavæ descriptarum, adjectis locis habitationis.

1853. - - (Amboina, iii.) Derde bydrage tot de kennis der ichthyologische fauna van Amboyna.

- - (Ternate.) Bydrage tot de kennis der ichthyologische fauna van Ternate.

- Orer eenige nieuwe soorten van Homaloptera.

—. Exocœtus hexazona, eene nieuwe soort van Banka.

- - (Sumatra, ii.) Diagnostische beschryvingen van nieuve of weinig bekende vischsoorten van Sumatra.

—. Sycidium parvei, Bleeker.

- (Batavia.) Diagnostische beschryvingen van nieuwe of weinig bekende vischsoorten van Batavia.

- (Ternate, ii.) Nieuwe bydrage tot de kennis der ichthyologische fauna van Ternate en IIalmaheira (Gilolo). 
1853. Bleeker, $P$. Index specicrum Piscium Malayo-Moluccensiun 11 volumine iv. Diarii Soc. Scient. Indo-Batava descriptarum, adjectis locis habitationis.

- (Solor.) Bydrage tot de kennis der icht'syologische fauna ran Solor.

- (Celebes, iv.) Vierde bydrage tot de kennis der ichthyologische fauna van Celebes.

- Nalezingen op de ielthỵologisehe fauna ran het eiland Bauka.

—. (Ceram, iii.) Derde bydrage tot de kennis der ichthyologische fauna van ('eram.

- (Amboina, iv.) Vierde bydrage tot do kennis der ichthyologische fauna van Imboina.

-.. (Borneo, vii.) Zevende bydrage tot de kcunis der ichthyologische fauna van Borneo.

—. (Sumatra, iii.) Nieuwe tientallen diagnostische beschryvingen ran nieuwe of weinig bekende visehsoorten van Sumatra.

- Antenuarius notophthaimus.

-- Index specierum Piseium Malayo-Molnceensium in vol. v. Diarii Soc. Scient. Indo-Batavx descriptarum, adjectis locis habitationis.

- - (rilolo.) Bydrage tot de kennis der iehthyologische fauna van IJalmaheira (Ciilolo).

(Pauda, iii.) Derde bydrage tot de kennis der ichthyologische fiuna van de Banda-eilauden.

- Diagramma hrmatochir.

1854. - - Species I'iscium l'atariensium nora vel minus cognitre.

-_. (Timor, ii.) Nieuwe bydrage tot de kennis der ichthyologiscle fauna ran 'limor.

-. (Floris.) Bydrage tot de kennis der ichthyologische faum rai: het eiland Floris.

- Syngnathus tapeïnosoma.

-... Hingramma polytanioides.

- (Japan.) Faunie Fehthyologicæ Japonicæ speeies nove.

- - ( Amboina, r.) Vyfde bydrage tot de kennis der iehthyologische fauna van $\Lambda$ mboina.

—. Fleotris tolsoni.

-_. Index speeiernu Piscium Malayo-Moluecensium et Japonensium in vol. vi. Wiarii Soc. Sciont. Indo-Batave descriptarum, adjectis locis habitationis.

1854. vii. - (Kokos.) Byclinge tot de kennis der ichthyologische fauna van de Kokos-eilanden.

- (Sumatra, iv.) Overzigt der iehthyologische fauna van Simatra met beschryving van eenige nieuwe soorten.

- Jets over Vissehen levende in Zeesteeren, en over eene nieuwe soort van Oxybeles.

- (Celcbes, v.) Vyfde bydrage tot de kennis der ichthyologische fauna van Celebes.

- Iehthyologische waarnemingen, gedaan op verselillente reizeu in de residentic Banten.

- Oror enengen nionwr visselen van de Kokos-eilanden. 
1854. vii. Bleeker, P. (Batjan.) Bydrage tot de kennis der ichthyologische fauna van Batjan.

- (Java, ii.) Specierum Piscium Javanensium novarum vel minus cognitarum diagnoses adumbratio.

- (Celebes, vi.) Zesde bydrage tot de kennis der ichthyologische fauna van Celebes.

- Dactylopterus cheirophtbalmus.

—. Nog iets over Visschen levende in Echinodermen.

- _. Index specierum Piscium Malayo-Moluccensium in vol. viı. Diarii Soc. Scient. Indo-Batavæ descriptarum, adjectis locis habitationis.

1855. viii. - (Borneo, viii.) Achtste bydrage tot de kennis der ich thyologische fauna van Borneo.

- (Kokos, iii.) Derde bydrage tot de kennis der ichthyologische fauna van de Kokos-eilanden.

- Antennarius lindgreeni.

- (Ternate, v.) Vyfde bydrage tot de kennis der ichthyologische fauna van Ternate.

- (Batoe.) Bydrage tot de kennis der ichthyologische fauna van de Batoe-eilanden.

- (Amboina, vi.) Zesde bydrage tot de kennis der ichthyologische fauna van Amboina.

- (Celebes, vii.) Zevende bydrage tot de kennis der ichthyologische fauna van Celebes.

_... (Kokos, iv.) Vierde bydrage tot de kennis der ichthyologische fauna van de Kolkos-eilanden.

- Index specierum Piscium Malayo-Moluccensium in rol, viii. Diarii Soc. Scient. Indo-Batavæ descriptarum, adjectis locis habitationis.

ix. - - (Batoe, ii.) Tweede bydrage tot de kennis der ichthyologische fauna van de Batoe-eilanden.

- (Gilolo, ii.) Nienwe bydrage tot de kennis der ichthyologische fauna van IIalnaheira (Gílolo).

- Nieuwe bydrage tot de kennis der ichthyologische fauna van Sumbawa.

- (Batjan, ii.) Tweede bydrage tot de kennis der ichthyologische fauna van Batjan.

- Nalezingen op de Vischfauna van Sumatra.

- - (Celebes, viii.) Achtste bydrage tot de kennis der ichthyologische fauna van Celebes.

- - (Jara, iii.) Verslag van eenige verzamelingen van Visschen van Oost-Jara.

-. (Borneo, ix.) Negende bydrage tot de kennis der ichthyologische fauna van Borneo.

- Bydrage tot de kennis der ichthyologische fauna van het eiland Groot-Oby.

- (Batjan, iii.) Derde bydrage tot de kennis der ichthvologische faima van Batjan.

- Index specierum Piscium Malayo-Moluccensinm in vol. ix Diarii Soc. Scient. Indo-Batave descriptarum, adjectis locis habitationis. 
1856. x. Bleeker, P. Tweede bydrage tot de kennis der ichthyolngisch fauna van het eiland Bintang.

- (Ternate, vii.) Zevende bydrage tot de kennis der ichthyologische fauna van Ternate.

- Carcharias amblyrhynchos.

_. Index specierum Piscium in roluminibus i.-x. Diar"i So Scient. Indo-Batavæ deseriptarum.

xi. - Verslag omtrent eenige vischsoorten gevangen aan de zuidkust van Malang in Oost-Java.

-. (Banda, v.) Vyfde bydrage tot de liennis der ichthyologische fauna van de Banda-eilanden.

- (Boeroe.) Bydrage tot de kennis der ichthyologische fauna van het eiland Bocroe.

- Verslag van eenige rerzamelingen van zee- en zoetwatervissche $u$ van het eiland Banka.

xii. - - (Ternate, viii.) Achtste bydrage tot de kennis der ichthyolo ische fauna van Ternate.

- (Nias.) Bydrage tot de kennis der ichthyologische fauna van het eiland Nias.

-. (Batoe, iii.) Derde bydrage tot de kennis der ich thyologische fauna van de Batoe-eilanden.

- Nieuwe bydrage tot de kennis der ichthyologische fauna van Bali.

- Index specierum Piscium in vol. xi. et xii. Diarii Soc. Scient. Indo-Batavæ descriptarum.

-. (Java, ir.) Descriptiones specierum Piscium Javanensium norarm vel minus cognitarum diagnosticæ.

-. (Sangi.) Bydrage tot de liennis der ichthyologisehe faunn van Sangi-eilanden.

—. Verslag omtrent eenige visehsoorten ran Timor-lioepang en Timor-delhi.

1857. xiii. - (Boeroe, ii.) Tweede bydrage tot de kennis der ichthyologische fauna van Boeroe.

1858. xv. -... (Java, v.) Visschen van Jara's zuidkust.

-. Holacinthus pseudamularis van Batavia.

- (Goram.) Bydrage tot de kennis der Vischfauna van den Goram-archrpel

-. (Jilliton, ir.) Vierde bydrage tot de kennis der Viselıfauna van Billiton.

- (Singapore, ii.) Tweede bydrage tot de kennis der Vischfautna van singapore.

1849. - - Overzigt der te Batavia roorkomende Gladschubbige Labroiden in Verhand. Bat. Genootsch. xxii.

_- (Perc.) Bydrage tot de kennis der Percoiden van den Malayo-Molukschen Archipel. Ibid.

- - Bydrage tot de kennis der Seleroparei van den SoendaMoluksehen Arehipel. Ibirl.

—. Bydrage tot de kennis der Blennioiden en Gobioiden van den Soenda-Molulsschen Archipel. Ibid.

- B Bydrage tot de kennis der ichthyologische fauna ran het eiland 3ali. Itrid. 
1849. Blecties, 1'. Bydrage tot de liemuis der iclithyologische fauma vari het eiland Ifrara. Ibid.

1850. — - Brdrage tot de kemis der Sciænoiden van den SoentaMolukschen Archipel. in Verhand. Batav. Genootsch. xxiii.

_- Bydrage tot de kemnis der 'Sparoiden van den SoendaIIolukschen Archipel. Ibid.

_- Bydrage tot de kennis der Mænoiden van den M. Archipel. Ibid.

- - Bydiage tot de kennis der Visschen met doolhof vormige lifuwen (Labyrinthici) van den S.-M. Arripel, I bid.

- Bydrage tot de liennis der Chætodontoiden van den S.-MI. Archipel. Toid.

- Bydrage tot de liemnis der Teuthieken ran den S.-.1. Archipel. Ibid.

- J Bydrage tot de kennis der Notaeanthini van den S...... Archipel. Ilirl.

- B. Bydrage tot de kemnis der ichthyologische tamal van Midden- en Oost-Java. Ibid.

1852. - - Brdrage tot de kennis der Makreelachtige Visschen van den Soenda-Molukschen Arehipel in Verhand. Batar. Genootsch. xxir.

- Bydrage tot de liemis der Snoekachtige Visschen ram den Soenda-Molulisehen Arehipel. Ibid.

-_. Bydrage tot de liemis der Chirocentroidei, Lutodeiri, kc., van den Soenda-Molukschen Archipel. Ibicl.

_- Bydrage tot de kemis der IIaringahtige Visschen van den Soenda-Molukschen Archipel. Ibid.

- Brdrage tot de kemnis der Pleuronecteoïden van den Soenda-Molukschen Archipel. Ibid.

_- Bydrage tot de kennis der Blootkakige vissehen van den Soenda-Molnkschen Archipel. Ibid.

_- Bydrage rot de lemis der Balistini en Ostracions vam den Indisehen Airhipel. Ibid.

- Bydrage to1 de liemis der l'lagiostomen van den Indis:hen Archipel. Ibill.

185:3. - Talezingen op de ichthyologisehe fauna van Bengalen en Ilindostan. Batarin, 4to.

18.57. - - Bydrage tot de liemin der Sphyrenoiden in Vorhamdri. Bataar. Genootsch, xxvi.

-. Nieuwe Nalezingen of Ichthyologie vau Japan. Ibid

1856. - - Beschryvingen van nieuwe en weinig bekende Vischsoorten van Amboina, in Acta Societ. Nederland. vol. i.

—. Beschrvingen ran nienwe en weinig bektende Vischeorton van Mamado en Maloassal. Ihid.

—. Conspectus sperierum l'iscium Moluecensimn. Ibid. vol. ii.

- Tiende bydrage tot do kemis der ishthyologisolde finmi van Bomeo. "Rirl.

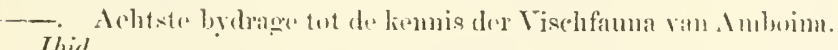

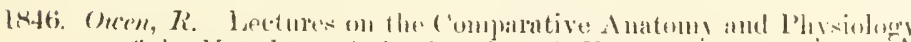

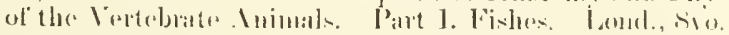


1853. Ouen, $R$. Deseriptive Catalogue of the Osteologieal series contained in the Collection of the Royal College of Surgeons. Vol. i. Fishes. Lond., 4to.

1847. Brisout de Barnerille. Sur le genre Centropriste, Cur., in Revuo Zoologique.

1847. Gay. Historia Fisica y Politica de Chile. Zoolog. ii. Paris, 8ro. Atlas, fol.

1847. Schomburgk, $R$. Reisen in Britisch-Guiana. Leipzig, 8vo.

1848. - The History of Barbadoes. Lond., 8vo.

1850. Cantor, T... Catalogue of Malayan Fishes. Calcutta, 8vo.

1850. Guichenot. Reptiles et Poissons dans l'Exploration Seientifique de l'Algérie. Zoologie. Paris, fol.

1850. Temminck and Schlegel. Fauna Japouica. Poissons. Lugd. Bat., fol.

1851. Poey, $F$. Memorias sobre la Historia Natural de la Isla de Cuba. IHabana, 4to.

1851. White, $A$. List of the Specimens of British Animals in the Collection of the British Museum. Fish. Lond., 1851. 1'rinted by order of the Trustees.

1853. Filippi. Nouvelles espèces de Poissons. Revue et Magasin Zool. p. 164.

1853. Günther, A. Die Fische des Neckars. Stuttg., 8ro.

1854. — - Beiträge zu den Süsswasserfischen. Wiegm. Archir.

1853-54. Hombron et Jacquinot. Voyage au Pôle Sud par Humontd' Urville. Poissons. Paris, 8vo. Atlas, fol.

1854-59. Baird and Girard. Papers in the Smithsonian Reports; in the Proc. Acad. Nat. Sc. Philad.; in the Reports of the U.S. Pacif. Railroad Expedition; in U.S. Naval Astronom. Expedition; in Marcy's Exploration of the Red River.

1855. Castelnau, Francis de. Animaux nouveaux on rares, recueillis pendant l'expédition dans les partics centrales de l'Amérique du Sud. Poissons. Paris, 4to.

1855. Prters. Uebersicht der in Mossambique beobachteten Fisehe in Wiegm. Archiv, p. 234.

1856. Holbrook. Ichthyology of South Carolina. Charlest., 4 to.

1858. Heckel und Kner. Die Siisswasserfische der Oestreichischen Monarchie. Jeipz., 8vo. 


\section{SYSTEMATIC INDEX.}

Subclass I. TELEOSTEI.

\section{Order I. ACANTHOP'TELYYIII.}

Fam. 1. Gasterosteide.

l. Gage

1. aculeatus, $L . \ldots \ldots \ldots, 2,500$

a. gymun'us ........ a

b. semiarmatus ......

c. semiloricatus ....... 4

d. trachurus ........ 4

e. noveboracensis ..... 4

2. argyropomus, C' et $V$. 4, 500

2a. williamsoni, Girard . . 500

3 . brachycentrus, $C$. et $V$. . 5

4. biaculeatus, Shuw ..... 5

5 . tetracanthus, $C$. et $V$. . . 5

6. spinulosus, Jen....... 5

7. pungitius, $L$. . . . . .

a. pungitius ........ 6

b. occidentalis .......

8. maineusis, Storer ..... 6

9. concinnus, Rich. ..... 6

10. quadracus, Nitch...... 7

11. spinachia, $L$. . . . . . 7 cataphractus, Pall. ....... 2 niger, $C$. et $V$........... . $\quad 2$ plebeins, Gir........... 2 inopinatus, Gir......... 2 pygmæus, Agass. ..... 2 inconstans, Kirtl. . . . . . . serratus, Ayres ....... internedius, Gir. ...... pugetti, Gir. ......... microcephalus, Gir. .... loricatus, Reinh........ . dimidiatus, Reinh. .......

Fam. 2 Berycide.

1. Nonocentris, Schncid. .... 1. japonicus, Houtt. . .....
2. Hoplostethus, C.t $V$. Pike

1. mediterraneus, $C$. et $\because \cdots 9$

:3. 'Traclichthys, Shaw ..... . 10

1. australis, Sheue ........ 10

2. *elougatus, Gthr. ..... 10

4. * Anoploraster, Gtlu: . . . 12

1. cornutus, $C$. ct $V$. . . . 12

4 u. Heterophthalmus, Blok. 500

1. katoptron, Bleck. ..... 501

5. Beryx, Cur. . . . . . . . 12

1. lineatus, $C$. et $Y$. . . . 1:3

2. *affinis, Gthr. ...... 13

3. decadactylus, $C$. et $I$. . . 16

4. splendens, Loxe. . . . . . . 16

5. delplini, C. et $I$. ..... 16

6. Polynixia, Lorce . . . . . 10

1. nobilis, Lowe . . . . . . . . 17

2. * lowei, Gthr. . . . . . . 17

7. Myripristis, ('uv. . . . . I!), 500

1. jacobus, $C$. et $V$. . . . . 19

2. pralinius, $C$. et $V$. ..... 20

3. knntee, C. et V. . . . . . 20

4. bleekeri, Gthr. . . . . . 20

5. leiguathos, I al. ....... 21

6. parvidens, Blecli. ..... 21

7. murdjan, Forsk....... 21

8. adustus, Bleek. . . . . . . 22

9. microphthalnus, Bleck.. 24

10. vittatus, $C$. et $I . \ldots \ldots 24$

11. japonicus, $C$. et $V . \ldots \ldots .25$

12. * trachypoma, Gthr. ... 25

13. hexagonus, Lacép. . . . . . 27

14. lima, C. et $V$. ........ 28 borbonicus, $C$. et $\boldsymbol{V}$. . . . 19

axillaris, $C$. et $V$. . ... 19

botche, Bleek. . . . . . . . 19

violaceus, Bleek. . . . . . . 19

8. Holocentrum, Artedi. . . . . . 28

1. longipinne, C. et $V$. . . . 28

2. * furcatum, Gthr. . . . 29

3. * macropus, Gthr. . . . . 31

4. poecilopterum, Bleek... 32 
Page

5. * erythr'cum, Gther. . . . 32

6. * microstoma, Gthr. .... 34

T. rubrum, Forsk. ....... 35

8. laticeps, $C$. et $V$. .... 38

9. pinctatissimum, $C$. et $V$. . 38

10. sterens nuscarum, $C$. et $V$.

11. hastatum, $C$. ct $V \ldots \ldots$. .

12. spiniferum, C'. et $V$. ...

13. binotatun, $Q$. et $G$. ...

14. caudimaculatum, Riipp. .

15. tiereoides, Bleck. ......

16. spinosissimum, Schleg. ..

17. diadema, Lacép... . . . . . .

18. melanotopterum, Bleek. .

19. violaceum, Bleek. . . . . .

20. cornutum, Blecl:........

21. tiere, $C$. et $V$.........

22. sammala, Forsk. .......

23. operculare, $C$. ct $V$. . . .

24. *lave, Gthr. . . . . . .

25. spinosum, Agass. .....

26. retrospinis, Gruich. . . . . . ascensionis, $L$. . ...... argenteum, $C$. ct $I \ldots \ldots$ marianuni, $C$. ct $I^{\top} \ldots \ldots \ldots$ leonoides, 13lekk. ..... binotatum, Bleck. . .....

9. Rhynchichthys, $C$. et $V$. .

1. jelamidis, $C$. ct $V \ldots \ldots$. .

2. brachyrhyuchus, Bleeli... rostratus, Gronor. . . . . .

\section{Fan. 3. Pencida.}

First Gromp. Pfincina.

1. Perca, Artedi ...........

1. fluviatilis, $L \ldots \ldots \ldots \ldots$

2. flavescens, Mitch...... (acuta ............

3. gracilis, $C$. et $V \ldots \ldots \ldots \ldots$

2. Percichthy, (xir. ......

1. lrevis, Jon. . . . . . . . .

2. trucha, $C$. ct $V . \ldots \ldots \ldots$

3. melanops, Giv. .......

4. ciliata, $K$. et $v$. Hass. ...

5. marginata, $C$. et $V \ldots \ldots$.

3. Paralabrax, Gir...........

1. nebulifer, Gir. .....662,50

2. clathratus, Gir. ... 6.3, 501

4. Isabrax, Cux. ......... 6.3

1. lupus, Lacép. . . . . . . . 6.?

2. clongatus, Gicoffr. ..... 64

3. lineatus, J3. . . . . . 64

4. osculatii, Filippi....... (ie

5. rufus, Mitch. ......... (i.)

t. pallidus, Miteh.......

]

7. multilineatus, $C$. et $V .67,501$

8. notatus, Smith ....... 67 nigricans, Dikay ..... $6: 3$ albidus, Dckay ....... (6.)

5. Lates, Cur........... 67

1. nilutiens, Gm. ...... \$ $\$ 7$

2. calcarifer, BT. ....... 68

6. Cnidon, $M$. et $T$. . . . . ( i

]. clinensis, $\boldsymbol{M}$. ct $T$. . . . (jo

7. Psammoperea, Rich. ..... (5)

1. waigiensis, $C$. of $V$. ... (i)

2. * macrojtera, fithr. .... (i!)

8. Percalabrax, Srhley....... 70

1. japonicus, C. et V...... 71

9. Aceriuk, Cur.......... 72

1. cermua, L. . . . . . . . 72

2. rossica, $C$. et $V$. ....... $7: 3$

3. schratzer, $L_{\ldots} \ldots \ldots \ldots \ldots .73$ (zillii, Gervats ...... 72)

10. Pelcarina, Nordm. . . . . 7:

1. demidoffii, Norlm. .... TA

11. Lucioperca, Cu. ........ T4

1. wolgensis, Prell. ....... 74

2. amelicana, $C$. ct $V$. ... T4

3. sandra, Cuk. ........ 75

4. marina, l'all. . . . . . . . T5

5. canadensis, Smith ..... 75)

6. grisea, Deliry. . . . . . . . 76 bolea, Gir. ........... 501

12. Pilcoma, I)ckoy ....... T6

1. semifasciatum, Intiay . . T(;

2. carbonarium, $B$. et $\dot{r}$. . . 76

13. Boleosoma, Deliay ..... 77

1. tessellatum, Delay . . . 77

2. lepidum, B. ot $6 . \ldots . .77$

3. maculatum, Agriss. . ... 77 olmstedi, Storev ...... 77

14. $\Lambda$ spro, C'ur. ......... 78

1. vulgaris, $C$. et $Y$. . . . . 78

2. zingel, $I_{\text {. }}$.......... 78

15. Etelis, $C$. et $V$. . . . . . . 79

1. carbunculus, $C$. et $V$. . . 79

16. Centroponus, Lacép). . . . 79

1. undecimalis, $B 7$...... 79

17. Niphon, $C$. et $V$. . . ... 80

1. spinosus, C. ct I. ..... 80

18. Enoplosus, Lacép. ..... 80

1. arinatus, White...... 81

Second Group. SerRanina.

19. Aprion, $C$. et $V$. ...... 81

1. virescens, $C$. ct $V$. .... $8 \mathrm{I}$

20. A psilus, $C$. ot V. ...... 82

1. fuscus, $C$. rt $V . \ldots \ldots . .82$

21. Centropristis, $C$. ot $V$.... 82

1. bivittatus, $C$, ot $V$..... 82 


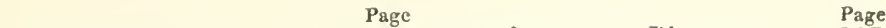

2. radialis, Q. et $G \ldots \ldots \ldots$ \&.' $\quad 14$. brumneus, $B l \ldots \ldots \ldots \ldots 107$

3. radians, $Q$. et $G . \ldots \ldots \ldots$ 8.3 15. kawamebari, Sehle' .... 107

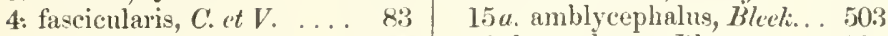

5. conceptionis, $C$. et $V \ldots \ldots 84 \quad 16$. lanceolatus, $B l \ldots \ldots \ldots 107$

6. hepatus, Gm. . . . . . . . 84 17. albofuscus, Lucép. . . . . 108

7. luciopereanus, Pocy ... $84 \quad$ 18. sexfasciatus, $K$. et $2 . M I . .108$

8. tabacearius, C. et $V$. ... 85 19. mystacinus, Poey ..... 109

9. præstigiator, Poey..... 85 (octocinetus, Schleg.... 109)

10. brasiliensis, Barnerille . . $85 \quad$ 20. oceanicus, Lacép. ..... 109

11. phobe, Poey ........ 8.5 21. trimaculatua, C. et V.... 109

12. psittacinus, Vul...... 8t 22 . diacanthus, $C$. et $V . \ldots$ Ilo

13. atrobranchus, $C$. et $V . \quad \ldots \quad 80 \quad$ 23. striatus, Bl. ........ 110

14. atrarius, $L \ldots \ldots \ldots \ldots \ldots \quad 86 \quad$ 24. stigmapomus, Rich. ... 111

15. hirundinaceus, Lungsel. . $87 \quad 25$. tigris, $C^{\prime}$ et $V$......... I1: philadelphicus, $L \ldots \ldots$. $82 \quad 26$. boenack, $B l . \ldots \ldots \ldots$ 112 nebulosus, Custelu. ..... 82 27 . * nigri, Gthr. . . . . . 11:2 flavescens, $C$. et $V \ldots \ldots \ldots \quad 82 \quad 28$. semipunctatus, $C$. et $V . \ldots 114$

22. Callanthias, Loue .... $87 \quad 29$. tigrinus, $731 . \ldots \ldots \ldots 114$

1. peloritams, Cocco ..... 87 :30. papilionacens, $C$. et $V . \ldots 114$

23. Anthias, Selencid........ 88 31. oxyrhynchus, C. et $V$. . 114

1. sacer, Bl. ........ 8s 32 argus, Sehucid. ...... 115

2. borbonius, $C$ et $\boldsymbol{V}$. . 89, 502 semifasciatus, Guy. . . . 98

2u. manadensis, Bleck. ... 502 33. rogaa, Forsk......... 116

2b. pleurotænia, Bhel.... 50.2 34. zananella, Lileek. ..... 116

2c. cheirospilos, Bleck. ... 502 ruber, B1. ....... 93

3. squamipinnis, l'et..... 89) 3.5. pachyeentrum, C. et V. . 116

4. *asperilinguis, Gth.... 89 36. exthrens, C. ot V..... 110

5. tonsor, C. et V. ...... 91 37. microprion, Bleek..... 116

6. furcifer, C. et V...... 91 38. cyanostignatoides, Bleck. 117

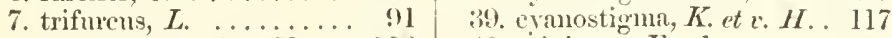

8. filamentosus, C. et $Y \ldots . .502$ 40, miniatus, Forsk. ..... 118

$8 a$. zonatus, C. et $V$. ..... 50.3 Tufus, Hombr. ef Jaeq. . . 98

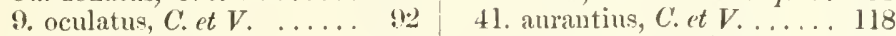

10. rasor, Rich...........9.93 4.. sexmaculatus, Riipp.... 118

11. schlegelii, Gthr....... 93 43. nigripinnis, Blerk..... 118

12. *longinamus, Gthr. .... 94 44. hemistictus, Reipp. . . . 119

13. cichlops, Bleck. . . . 95, 50:3 45. guttatus, B1. . . . . 119

lepidolepis, Bleek. .....501 40 . ouatalibi, C. t. $V . \ldots \ldots 120$

hechtii, Bleek. ...... 501 47. treniops, $C$. et $V . \ldots \ldots .121$

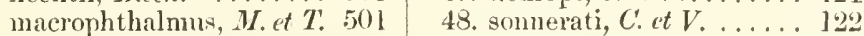

2.t. * Anyperodon, Gith: ... 95 49. urodelus, Forst...... 122

1. lencogramnicus, Rrine. $96 \quad 50$. analis, $C$. et $V$. . . . . 19:3

25. l'rionodes, Jen........ $90 \quad 51$. zanana, $C$. et $V . \ldots \ldots .12 .3$

1. fasciatus, Jer........ $16 \quad$ pixanga, C. et $V \ldots \ldots \ldots 98$

26. Serranus, $C u \ldots \ldots \ldots \ldots 97 \quad$ gruativere, $C$. vt $V . \ldots .98$

1. phaëton, $C$. et $V . \quad \ldots \ldots .100 \quad 52$. leopardus, Lacép. . . . . 12:3

2. creolus, $C$. et V. . . . . $100 \quad 53$. coronatus, $C$. et V..... 124

3. colonus, Val. ........ $101 \quad$ 54. spiloparcens, $C$. et $V . \ldots 125$

4. louti, Forsk. ....... $101 \quad 55$. limbatus, $C$. et $V . \ldots \ldots 125$

5. flavinarginatus, Riipp... 10:3 56. nouleny, C. et V...... 1:26

lepidopterus, Forst. ... $97 \quad$ 57. lutra, C. et V........ 126

8. scriba, L. . . . . . . . . $103 \quad 58$. goldınami, Bleck. . . . 126

9. humeralis, C. et V..... $104 \quad 59$. pavonimus, $C$. et $V \ldots \ldots .126$

10. albomaculatus, Jen. .... $105 \quad$ jansenii, Bleek. . . . . . 99

11. rlyncholepis, Bledi... 105 60. angnlaris, C. vt V. . . . 126

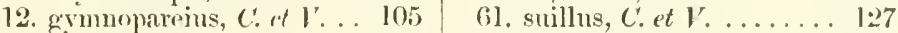

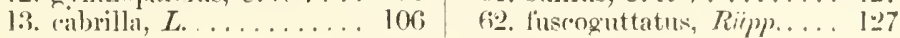




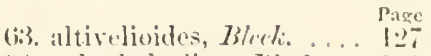

(it. polyplekadion, Hleck. . 125

(ji). salnumoides, Lacrip). . . 1:2k

(i). epistictus, Schle\%. . . . . 120

(i7. bittavieusis, Jileel. . . . . 129)

68. albogutatus, Bleck. . . . 1:29)

69. polystipma, biluk. . . . . . 129

70. 1119*ulatus, B\%. ...... 1:30

71. rallenis, M. et T...... 1:30

7.2. niveatus, $C$. at $I^{r}, \ldots \ldots .1 .30$

73. * marogrititer, fith: .... l:;

aspersus, Jem. ....... m

itaiara, Licht. . . . . . . 9!)

74. gigas, brïm. . . . . . . l:32

75. moara, schlory. . . . . . 1:3:3

76. gorecensis, $C:$ rt $\mathrm{J} . \ldots . . .1: 3: 3$

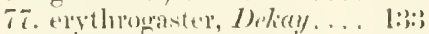

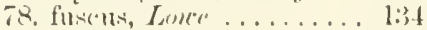

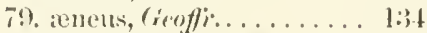

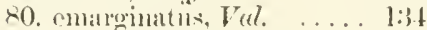

81. nigritus, IIolb. ... . . . 1:34

8.2. acutirostris, $C$. et $I$. . . 1:3:s

8:3, mancinalis, $b \%$. . . . . . 1:3.5

84. horridus, $K$. et ז. II. . . . 1:36;

8.). clapan, C. ot V. ...... 1:37

86. sobies, Bleck. ........ 1:37

87. summant, Fomsli. ..... 1:37

88. nicromotatus, Rüp)..... 18:3

89. tumilabivis, $C$. et $\left.\right|^{r}$. . . . 1:38

90. how'suii, Blew........ 1:k

91. boulon, Cir. . . . . . . 1:38

9.2. celehicus, Bbleti. ..... l:3:)

9:3. variolosus, frurst. . . . . 1:3!)

94. hoerliii, Blet... . . . . . 1:3:)

\%). aliaala, Schley. . . . . . . 140

9; : :

97. nitutzolii, ('. et I. ...... 1.t0)

(rytlumus, $($. r $V$. ... 19

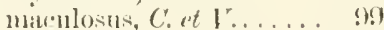

alexandriuns, $C$. et $I \ldots \ldots .99$

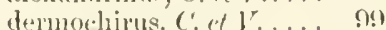

kimbandtii, H/wli...... !n

lebretonianus, 11 . r.t.J. !)

9R. hexagonatus, Furst. . . . 140 (t. hexorronatus .... 14], 50:3)

b. merrit, Bl. ........ 141

99. morio, $C^{\prime}$, ot $l$. . . . . 142

100, impetiginosus, $M$. et $T$... 14:

101. ongus, B1. ......... 142

(uelas, l'eters ....... 14:3)

102. undulosus, $C$. et $r$. . . 14:3

103. tsirimenara, Selley. .... 14.4

104. "punctatissimus, Fithr. . 144

105. ripestris, $C$. ot $Y$. . . . 145

10(3, flavo-erelulens, Lurmon. . 14:)

107. "spiniser, Githe. . . . . . 14ti

108. ura, $C$. it $5 . \ldots \ldots . .145$
105. pinge

10.). melamurns, Geoffr...... $1+7$

110. villorti, Rich.......... 1.48

111. mbulestis, $C$, of $Y$. ... 1 tx

112. bontoirles, IBleck. . . . . 1 1!)

l l:3. man'ospilos, Bleek. . . . . 1 19)

11. areolitus, Forsk. . . . . 14. 14

115. awoata, Schley. ....... 150

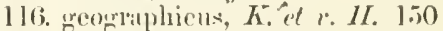

117. reticuluris, $K$. et $t$. II. . 150

118. gainardi, black. . . . . . 150

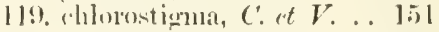

120. "ulindricus, fithr. . . . 151

121. labifimis, Jon. . . . . . 1.52

lisulatus, $($ : et. $V . \ldots \ldots$ !)

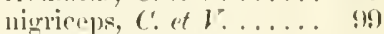

miliaris, $C$. ot $V . \ldots \ldots$

thavountatus, Preess.... \$9

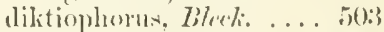

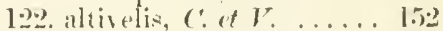

12:3, incmuis, $C$. ot $V$. . . . . 15:3

124. quovamus, $C$. et $F \ldots \ldots$ 15:3

125). olfiix, Jen. . . . . . . . 15:3

126. derouspterus, silley. . . . 1.5.t

pautleclinus, Iacép...... 98

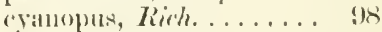

127. formosus, Shum . . . . . . 15.

127 a. malanotrenia, B/ech. . . 50.t

128. latifascoutus, Sihley. ... 154

129. morrhua, $C$. ot $V$. . . . . 154

1:30. biertetatus, $C$. of $I 5, \ldots .156$

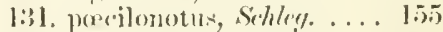

1:32. lemuisentus, $C$. ef $V \ldots \ldots$ 1.5is

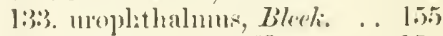

list. lineatus, $(\ldots$ ot $V$. . . . . 1.5ti

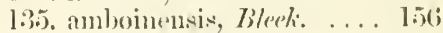
cliloroceplin] $c$. et $l^{-}$. 100

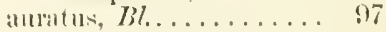

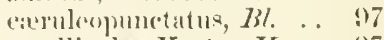

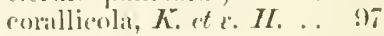
alumtinus, B1. ...... varjegatus, lich....... ! leseresii, livk......... 95 lumarius, fousk. ...... $\$ 7$ trenioclinus, $C$ et $7 \ldots \ldots 97$ rosels, (․ rt $I$. . . . . 97 pexummus, Less. ....... 97 Hblominalis, Peters .... 97 groliatl, Pitcrs........ 97 parlinsonii, $C$. et $V . \ldots .97$ aravin, $C$, ot 1 ........ 97 cardinalis, $(\therefore$ et $V \ldots \ldots . .97$ Immulatus, Schuteil...... 97

27. l'lectropomm, (

1. maculatum, Bl. ....... 15ti

2. loopardiuum, Lućp). . . . 157

3. oligacanthus, Blerk. . . . . 1.78

4. melanokincimin, Lacip). . 15 
5. nimorubrum, $($. et 7 Page

(i. Ammulatum, Githr...... 158

7. semicinctum, C. et $V . \ldots 160$

8. susulit, $C$. et $V$...... 160

9. dentex, $C$. et $V \ldots \ldots \ldots . .160$

10. *ocellatum, (ithr. . 1(il, 504

11. * cinctum, Gith........ 162

12. seriatum, $C$. et $V \ldots \ldots .16 ; 3$

13. aculeatum, $C$. et $V$. . . 16:3

14. Jiasilianum, $C$. et 7 ... 164

15. chloropterimn, C. et $V$. . 164

16. pictun, Tschudi....... 164

17. nonacanthus, $M$. et $T$. . 164

18. macrophthalmus, Tschuli 105

1!). paytense, Less. . . . . . . 165

20. hispanum, $C$. et $I \ldots \ldots . .165$

21. puella, $C$. ('t $l^{r}$. . . . . 16i

vitulinum, Ivery ...... 1(i,

2.2. indioro, loey ........ 16t;

2:3. bovinum, $\dot{l}^{2}\left(x^{2}\right)$. . . . . . 160

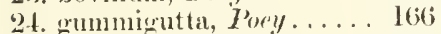

25. Futta-valium, Pưy . . . 16it

'6. chlorurum, c. et $7^{\circ} \ldots \ldots .167$

nimicius, Prey ....... 167

accenstum, Poey ....... 167

27. mirolor, Selmeid. . . . . 1157

28. "l'melupponna, Gith. .... 16i7

1. "macracanthus, Githi. . 16i7

29. Polypition, ('ut. . . . . . 168

1. cernium, Tal......... 10 (39)

30. *l'ogronoperca, Githr. ... 169)

1. punctata, $C$. et $1 . \ldots 169,504$

31. Grammistes, $f r t$. . . . 17l

1. oricntalis, Srhneid...... 171

"). lihypticus, $C$. et $V$..... 171

1. saponacents, schneil. . . . 172

2. menatus, $C$. of $I$. . . . . 17:3

3. naculatus, $H o l b r . \ldots . . .173$

33. Aulacocephalus, Schley. . . 17:3

1. schlegulii, Gthr........ 173

34. Diploprion, $K$. et $r . M . \ldots 174$

1. bifasciatum, $K_{\text {. et }}$ v. II. . 174

3i). Myriodon, Hris. . . . . . . 174

1. Waigiensis, Q. et $(x \ldots \ldots$ 175

3ti. Genyoroge, Cant. . . . . . . 175

1. nigra, Forsk. . . . . . . . 176;

2. micolor, $C$. et $I^{\gamma} \ldots \ldots \ldots 176$

3. sebre, $C$. et $V \ldots \ldots \ldots \ldots$. 176;

4. bengalensis, $\not 31 . \ldots .178,504$

5. caeruleovittata, ('. (t $I^{r} .179,504$

5 a. spilura, Jem. . . . . . 504

b. viridis, $T^{r} a l . \ldots \ldots \ldots \ldots .180$

7. octovitlata, C. et I. ... 180

8. josea, ( . et $V \ldots \ldots \ldots \ldots . . .180$

9. gibba, Forsk. . . . . . . 180

10. notata, (. et $I$....... 181

11. marginata, (r. et $1 \% \ldots . .181$
12. bottonemsis, Page

13. rivulata, $C$. st $I . \ldots \ldots .182$

14. caeruleopunctata, $C$. et $I^{\prime} .182$

15. melanum, Rïpp...... 183

16. amboinensis, Bleck. . . . 183

17. nielanospilos, Bleck. .... 183

18. fulva, Forst. ......... 184

19. civis, $C$. ct $V$. . . . . . 184

duodecim-lineata, $C$. et $V .175$

l'ufolineata, $C$. ct $V$. ... 175

axillaris, $C$. et $V \ldots \ldots \ldots .175$

Havipes, $C$. et $I \ldots \ldots \ldots .175$

analis, $C$. et $V \ldots \ldots \ldots \ldots 175$

amrantiaca, C. et $I$..... 175

sanguinea, $C$. et $I^{\gamma} \ldots \ldots \ldots 175$

vitiana, IIombr. et Jacq. . 175

37. Mesoprion, Cuv. ........ 184

1. miclochir, Bleek. . . . . 186

2. chrysurus, Bl. . . . . . . 186

3. sparis, Schlef......... 188

4. dentatus, Guich......... 188

5. cuponotatus, Rich..... 190

6. bohal, Forsh. . . . . . . . 190 (quadrigutatus, Cıv. .. 191)

7. caudalis, $C$. et $V$...... 191

8. bitreniatus, $C$. ot $\dot{V}$. ... 191

9. waigiensis, $Q$. et $G$. . . 191

10. chrysotrenia, Bleck. . . . . 192

11. aroentimaculatus, Forsk. 192

12. lineatus, Q. et $G \ldots \ldots \ldots 193$

1:3. gembra, Sillneid. ..... 19:3

14. cynodon, $C$. et $I$. . . . . 194

15. griseus, $C$. et $V \ldots \ldots \ldots \ldots 194$

16. buccanella, C. et $I^{\prime}$. . . 198

17. aуa, B7. . ......... 198

18. borensis, $C$. t $T$. . . . 199

19. erytlirinus, Riïpp. . . . . . 199

20. rangus, $C$. et $I$. . . . . 199

21. madras, $C$. et $I^{\prime} \ldots \ldots \ldots .200$

22. jolniii, Bl. . . . . . . . 200

23. fuscescens, $C$. ct $V$. . . . 201

24. fulviflamma, For'sk. ... 201

25. uninotatus, C. ct $I$. . . 202

26. mahogoni, $C$. et $V$. . . . . 203

27 . vivanus, $C$. et $V$. . . . . 203

28. anmularis, $C$. ct $V$. . . . . 204

29. malabaricus, Schneil.. . . 204

30. erythropterus, BI. . . . . 205

31. lineolatus, Ruipp... . . . 205

32. timoriensis, Q. et $G, \ldots 205$

3.3. isodon, C. et $V$. . . . . . 206;

34. dodecacinthus, lileck. . . . 206

35. dodecacinthoides, lileck. . 206i

:6. aurormbens, $C$. et $V$. ... 207

37. vitta, $Q$. et $G \ldots \ldots \ldots . .207$

38. bleckeri, Citl, . . . . . . 208

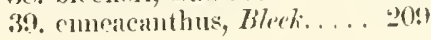


Page

40. sennieinctus, Q. et (r. . . . 209

41. quinquelineatus, $C$. et $V .209$

42. sobra, $C$. et $V \ldots \ldots \ldots .209$

43. decussatus, $C$. et $\zeta$. . . 210

44. ret lospinis, $C$. ot $I^{r} \ldots \ldots 210$

45. pomacanthus, Bleck. ....2 210 anrolineatus, $C$. et $V$. . . 184 richardi, $C$. ct $V$. . . . . 184 tieniops, C. et $V$. . . . . . 184 cyanopterus, $C$. et $V$.... 184 pargus, $C$. ot $V$. ...... 185 Havipinnis, $C$. et $I \ldots \ldots 185$ rubellus, $C$. et $V$. . . . . 185 sillaoo, $C$. et $V$. . . . . . 185 fulgens, $C$. et $V \ldots \ldots \ldots \ldots 185$ lutjanus, $B$. . . . . . . 185 chirtah, $C$. et $V$....... 185 carowi, $C$. et $V \ldots \ldots \ldots \ldots$ 185 albo-aureus, Lacép. . . . . 185 linulatus, Mungo Park . 185 olivaceus, $C$. ct $V$. . . . . 185 erythrognathus, $C$. ct $V$. . 185 emeryii, Richards. . . . . 18. elongatus, 11 ombr. et Jucq. 185 argenteus, $H_{0 m b r}$. et Jucq. 185) cuudanotatus, Poey. . . . 185

38. Glaucosoma, Schley. . . . . 211

1. biirgeri, Richarels. .....2 211

\section{Third Group. Pentacenatina.}

89. P'entaceros, $C$. et $V$. . . . . 212

1. richardsonii, Smith .... 212

2. capensis, $C$. et $V \ldots \ldots . .212$

3. *decacanthus, Gthr. ... 21:3

40. Oreosoma, C. et $V$. . . . 214

1. atlanticum, $C$. et 7 . ... 215

Fourth Group. PIR I CANTHINA.

41. Priacanthus, $C$. et $V$.

215

1. macrophthalmus, $C$. et $V .215$

2. boops, Forst. . . . . . . . 216;

(macropus, $C$. et $V . \ldots .216$ )

3. bonariensis, $C$. et $V$. ... 216;

4. japonicrs, Langsel. . . . . 217

5. niphonicus, $C$. et $V$... 217

6. blochii, Bleck. . . . . . . . 218

7. benmelyari, Schleg. . . . . 218

8. hamruhr, Forsk... . . . . . 219

9. carolinus, $C$. ot $V$. . . . . 21!

10. schmittii, Jleek. . . . . . . 220

11. holocentium, Bleck. . . . 2:20

12. macracanthis, $($. of $V$. . 2.20

1:3. dubius, Seluleg......... 221

14. taycuts, Rirhurls..... . : :-21

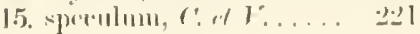

crucutatus, Lacép. . . . . . 21.) argenteus, $C$. et $V$. . . . . 2li) macropterus, $C$. et $V$.... 215 fax, $C$. et $I \ldots \ldots \ldots \ldots .215$

Fifth Group. A pogoxins.

42. Ambassis, Comuners. . 222, 505

1. *robustus, Schley. . . . . 22.2

2. commersomii, C. pt $V$. . . . 22:3

3. urotenia, Bleek. . . . . . . 224

4. kopsii, Bleck. . . . . . . . 224

5. apogonoides, Blcek. . . . . 22-1

6. batjanensis, Bleck. . . . . . 225

7. dussumieri, $C$. et $V$. . . 225

8. thermalis, $C$. et $V$. . . . 225

9. nalua, $C$. et $V$. . . . . . 22:

10. interiupta, Bleek. . . . . . 226;

11. buruensis, Bleck. . . . . . . 226

12. wolffii, Bleek. . . . . . . 220

li3. vachellii, Rich. . . . . . 227

14. macracantlus, Bleek. . . . 227

15. macrolepis, Bleck. . . . . 227

16. ulta, C. et $V$. . . . . . . 227

17. langa, Buch. Httm. . . . . 228

18. oblonga, Buch. Hum. . . . 228

19. bogoda, Buch. Mam. . . . 228 lalı, Buch. II baculis, Buch. Hutm. . . . 22: barlovi, Sylies........ . 22. urerylozona, $C$. et $V$. . . 2.2.

43. Micioüchthys, Rïpr. . . . . 228

1. coccoi, Rípp. . . . . . . . 229)

41. Apogon, Lacép. . . . . . . . 29.29

1. inberbis, $L \ldots \ldots \ldots \ldots . .2: 30$

2. heptastigma, Ehenb. . . . 2:31

3. livalosoma, Bilevk. ...... 2:31

4. themualis, $($. et $V \ldots \ldots . .232$

5. pecilopterus, K. et $2 . M$. . 2:3

6. rodini, Bleek. . . . . . . 23:2

7. axillaris, Fal. . . . . . . . 23:2

8. hypselonotis, Bleek. . . . 2:3:2

9. liptacanthus, Bleck. . . . 2:32

10. nigromaculatus, $M$. ct $J$. . $23: 3$

11. orbicularis, $\boldsymbol{K}$. et $\leadsto . M$. . 2:3:3

12. nematopterus, Bleck... . . 2:3:3

13. trimiculatus, $C$. ct $V$. . . 2:3:3

14. rhodopterus, Bleck. . . . . 2333

15. kuilomatodon, Bleck. . . . 2\%

16. maronitophorus, Bleck. . 2:3.1

17. treniatus, Ghremb. . . . . . 2:3.t

18. amboiuensis, Bleek. . . . . 2:3.1

19. sampiensis, Bleck. . . . . 2. 2:3ij

20. ('(r)unensis, Bleek. . . . . . 2:3,

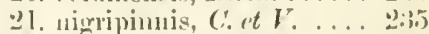

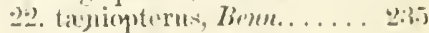

2:3. nomochoms. Siliel. . . . . 2:30 
24. nuculosus, $C$. ct I ..... Page

25. enueastigna, Riij). . . . 236

26. * riippellii, Gth... . . . . 236;

27. nova guiner, Ful. . . . . 237

28. cupreus, Ehrenb. . . . . 2 237

29, hoevenii, Bleck. . . . . . . 237

30. truncatus, Bleck. . . . . . . 237

31. bifasciatus, Riipp. . . . . 238

32. timoriensis, Blcek. . . . . 238

33. bandanensis, Bleck. . . . . 238

34. amuularis, Riipp. . . . . . 239

35. lineatus, Schleg. . . . . . . 239

36. qundrifasciatus, $V^{7} u l . \ldots .239$

37. semilineatus, Sohleg. . . . 240

38. chrrsopomus, Blec.k. . . . 240

39. kalosoma, Bleck. . . . . . 240

40. frenatus, Fal. . . . . . . . 241

41. kallopterus, Block. . . . . . 241

42. fasciatus, White....... 241

43. cyanosoma, Bleck. . . . . 242

44. cyanotwenia, Blesk. . . . . 242

45. multiteniatus, Beek. . . 242

46. liartzfeldii, Blcek. . . . . 242

47. chrysotania, Bleck. . . . 242

48. "victorice, Gth......... 243

49. melas, Bleck. ........ 243

50. cantoris, Bleck. . . . . . 24:3

51. meaco, Bloke. . . . . . . . 244

52. lineolatus, Ehrenb. . . . . 244

53. fucatus, Cant. . . . . . . . . 244

54. macropterus, $K$. ct $v . M$. . 244

55. bletkeri, Gthr. ...... 245

56. macropteroides, Bleck. . . 245

57. buruensis, Bleek. . . . . . 245

58. zosterophorus, Bleck. . . . 245

latus, Ehrenb. . . . . . . . 229

multitreniatus, $C$. ct $V$. . . 229

coccineus, Rüpp. . . . . . . 229

ceylonicus, $C$. et $V$..... 229

moluccensis, $r$ al. . . . . 229

yuanensis, Tal. ....... 2.29

nove hollandire, $\mathcal{V}_{a l} . . . ., 2.9$

lateralis, $F u l . . . . . . . .229$

schlegelii, Bleck. . . . . . 229

fuscus, $Q$. et $G$. . . . . 2. 2?

45. Apogonichthys, Bleck. . . 245

1. gracilis, Bleek. . . . . . 24t;

2. auritus, $C$. et 7 . . . . . . 246

3. polvstigma, Bleek. . . . . . 240

4. amblyuropterus, Bleek. . . 246

5. glaga, Bleek. . . . . . . 247

6. carinatus, $C$. et $V$. .... 247

7. perdix, Bleek. . . . . . . 247

8. aprion, Richards. . . . . . 247

9. americauus, Castch. . ... 247

46. Chilodipterus, Laeé). . . . . 248

1. ortovittatus, $C$. et $Y$.... 24r
2. limeatus, Forst. Page

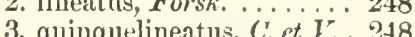

4. apogonoides, Bleck. . . . 249

5. anblywopterus, Blesk. . 249

47. Scombrops, Schleg. . . . . . 249

1. chilodipteroides, Bleck. . . 249

48. Poinatomus, Risso . . . . 249

1. telescopium, Rissu ... . 250

49. Acropona, Schleg. . . . . . . 250

1. japonicum, Gthr. . . . . 250

Sixth Group. Girystina.

50. *Oliurorus, Gthr. ...... 251

1. macqualicusis, $C$. ct $I$. . 251

2. gigas, Oucu ......... 251

51. Crystes, $C$. et $V$. ...... 252

1. sảmonoides, Lacép. . . . . 252

nuëcensis, $B$. ct $G$. . . . 252

fasciatus, Eoff. ....... 252

52. Arupis, Jenyns . . . . 252

1. yeorgianus, $C$. et $V$. ... 253

2. salar, Richards. ....... 253

3. truttaceus, C. et $V$. ... 254

53. Huwo, Cur. .......... 255

1. nivricans, Cul. ...... 255

54. Pereilia, Givard ...... 255

1. villissii, Gir. ......... 255

54 \%. Lembus, $G$ thr. . . . . 505

1. *naculatus, Gthr. . . . . 505

55. Centrar hius, Cuv. ...... 256

1. aneus, Lesuen . . . . . . 256

2. pomotis, buind ....... 256

3. interuptus, Givard ... 257

4. irideus, Bosc . . . . . . 257

5. hexacanthus, $C$. et $V \ldots \ldots 257$

6. nitidus, Girard . . . . . 257

7. fasciatus, Lesu'w . . . . 258

8. obscurus, Deluly ..... 258

9. gulosus, $C$. et $I^{\prime} \ldots \ldots \ldots .258$

10. tetracanthus, $C$. ot $V \ldots \ldots 258$ viridis, $C$. et $V$. ..... 256

56. Bryttus, C. ('t $V$. . . . . 258

1. punctatus, $C$. et I...... 259

2. albulus, Girard ........ 259

3. longulus, Baird . . . . . . 259

4. Horidensis, Holbr: . . . . . 260

5. melanops, Givard .... . 260

6. murinus, Girard ..... 260

7. fasciatus, $H o l b r . . . . .260$

8. gloriosus, $I I c l b)$. . . . . 260 reticulatus, $C$. et 7 . ... 258 diaphanus, Giveul ..... 258 signifer, Girard . . . . . . 258 himilis, frivard ....... 258 niclops, firud ....... 2.5 


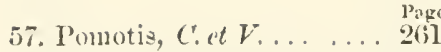

1. anritus, $L$. ........ 20

2. rubricauda, Storer . . . . 26.2

3. elongatus, Molbr. . . . . 20 (i:

4. speciosils, B. it $G . \ldots \ldots$ ov $(j ; 3)$

i). chietodon, Baivd ...... 2tii;

6. heros, 13. et (r. . . . . . . 2(i:3) (macrochir, Kirtl. . . . . 2(j:s)

7. microlophus, (ithr. . ... : 064

S. maryinatus, IIolbr. . . . 26.4

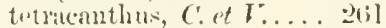
ravenelii, $C$, ct $t: \ldots \ldots .26 ;$ holbrookii, $C$. et $V$...... 2(i]

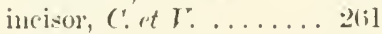
gibbusus, $C$. et $V$. ......2 $24 i 1$ rolis, cot $V$. ........ $2(i 1$ ('atesbri, C. rt $I . \quad \ldots \ldots .261$ breviceps, B. et $G$. . . . 2 201 appendix, Witch. . . . . nitidus, firtl. . . . . . . 2(il luma, Givarel .... . . . . o ovil aquilensis, Inaird ......2 2lil

58. Anoplus, sebling. . . . . . 2014

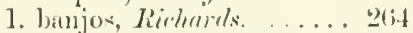

59. *Odontone cetes, (ither. . . . 20(i.)

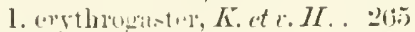
60. Jules, $r .1$ : ........ 2 (bit)

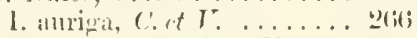

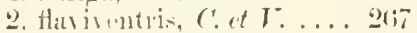

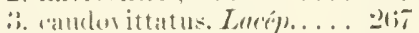

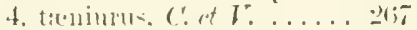

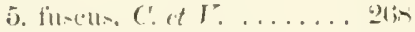

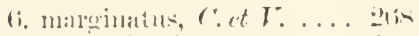

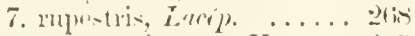

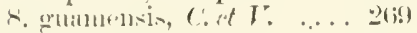

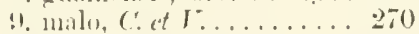

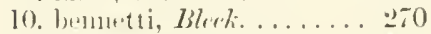

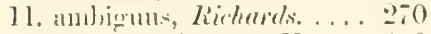

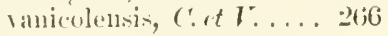

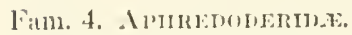

1. Aphredoderus, Lesuen . . . 20 J 1. salvamus, Gillinums ......

Fam. 5. l'nstip(omativ.l.

1. Thernon, ('ur........ 274

]. theraps, $($. t $V \ldots \ldots \ldots, 274$

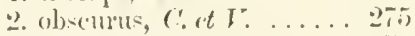

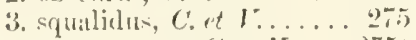

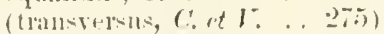

4. virmatus, C. et $V^{r}$. . . . . 2.76

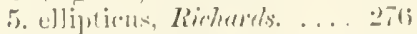

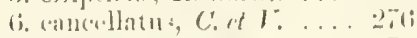

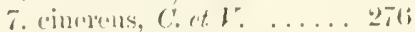

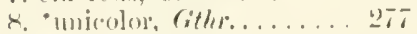

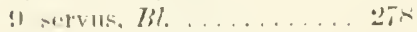

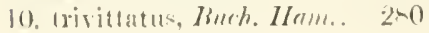

11. ghebul, Ftrene Page

12. oxyrhyncluus, Srhley.... . 281

13. quadrilineatus, $B l \ldots \ldots$ o...

14. curieri, Bloek......... . 2*2

15. argenteus, $C$. et $V . . . .2 .283$

16. candovittatus, Richards. . 20xt rubricatus, Risherels. .... 274 microlepis, Riipp. .... 274 bouzetiauus, IIom.et Jueq. 27t

2. Helotes, Ciu. ........... 284

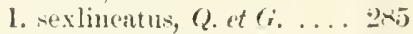

2. octolineatus, Jen. . . . . J (1)

3. polytaenia, Blorli. . . . . 20.5

3. Macquaria, C. 1t. I: . . . . 285

1. anstraliasicat, C. et $I \ldots . .2 \times 6$

4. Pristipoma, Cue: ...... 2-6

1. cavifion, C. et $7 . \ldots .286$

2. serruk, C. et $I$. . . . . . 2 287 (atmitum, C. et I...... 2.5)

3. melanoptermu, C. it l... 2-7

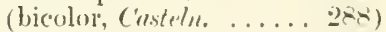

4. viruinicum, $L . \ldots \ldots \ldots, 2 \times 8$

5. surinamenes, $B 1 ., \ldots \ldots .288$

6. nigrum, Met. . . . . . . 2x!)

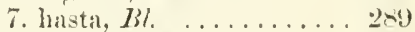

8. nages, Riipp. . . . . . . 290

๑) punctulatum, Riijp. . . . 290

10. dussumieri, $C$. ol I. . . . 20)

11. arentenu, Forsti. . . . . 291

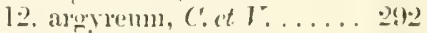

1:3. pililoo, Richerels. . . . 20.2

14. pailiceli, ('. et 1 . . . . 2)

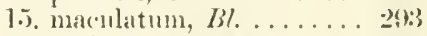

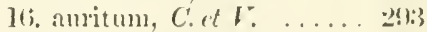

17. therapon, bleck....... 2983

18. "terribile, (ithe. . . . . . 294

19. (rocro. C'. et $I$. . . . . . 2916

20. coro, Bl. . . . . . . . . .

21. catharina, $C$, it $1 \% \ldots$. . .

2.2. rogerii, ('ict $l$. . . . . . . :98

23. bennettii, Louer . . . . . . 2! Is

2.4. enceptionis, C. et $7, \ldots .300$

2.). stridens, Forsk. . . . . . $3($ ( )

2(i. limeatum, $C$. of $r$. . . . 800

27. fisciatum, cot 1 . . . . 301

2s. lulromaculatum, Miteh. . 301

29. viritlense, C. et $T$. . . 302

30. suillum, C. rt $V$...... 302

:31. peroteti, c. et $\mathrm{V}$. ..... 302

:32. octolineatum, C. ot $I$. . . :30:3

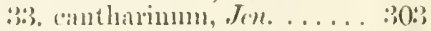

:4. j: ponicum, C. ct $\mathrm{V}$. . . . 30:3

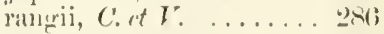

jubelini, cto ot r........

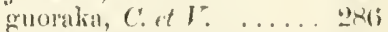
chloronotum, Rich. .... 20,

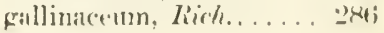


granmopocilum, Rich... $\begin{gathered}\text { Page } \\ 286\end{gathered}$ leucuum, $C$. et $V$. . . . . 280 scapulare, Tsch. ...... 506

5. Conodon, C. et $V . \ldots \ldots 304$ 1. plumieri, $B l$. . . . . . 304

6. Hæmulon, Cux. . . . . . . . . 305

1. formosum, L. . . . . . . 305

2. elegans, $C$. et $V$....... 306

3. "microphthalmum, Gthr. 306

4. "macrostoma, Gtllr. . ... 308

5. chromis, Brouss. . . . . 310

6. schrankii, Ayass. . . . . 310

7. canna, $C^{\prime}$ et $V$. ...... 311

8. album, $C$. et $V^{\circ}$........ 311

9. xanthopterum, $C$. et $V$. . 312

10. caudimacula, $C$. et $V, \ldots 313$

11. chrysopterum, L. ..... 313

12. "chrysargreum, Githr... 314

13. quadilineatum, $C$. et $V$. 316

14. aurolineatum, $C$. et. $V$. . 316 arcuatum, $C$. ot $V$. . . . 305 obliquatum, Bern. . . . . 305 modestum, Tsch. ..... 507

7. Hapalogenys. Richards. . . 317

1. nigripinnis, Schleg. .... 317

2. mucromatus, Eyil. ot Sour. 318

8. Diagramma, Cur. ....... 318

1. gibbosum, H. et J. . . . . 31!

2. crassispinum, Riipp. ... 319

3. *affine, Gthr. ........ . \$19

4. griseum, $C$. et $\dot{V}$. . . . . 32 I

5. pertusum, Tlunb. ..... 321

6. mediterraneum, fuich. . . 321

7. centurio, $C$. et $V$. . . . . :322

8. shotaf, Forsk. . . . . . . 322

9. foetela, Forsk. . . . . . 322

10. gatteriua, Forsk. . . . . 322

11. pardalis, $K$. et $r$. $I$. . . . 323

12. punctatum, Ehreub. . . . 323

13. cinctum, Schley. . . . . . . 325

14. chretodonoides, Lacép. . . 326

15. pien, $C$. et $I^{\prime} \ldots \ldots \ldots \ldots .326$

16. orientale, $B l$. . . . . . . 326

17. pictum, Thunb. ...... 327 (balteatum, $K$. et $r . H . .328$ )

18. poecilopterum, $C$. rt $V$. . 329

19. Iessonii, $C$. et $V$. . ... . 329

20. blochii, $C$. et $V$. . . . . . 329

21. albovittatum, Riipp. . . . $3: 30$

22. lineatun, $L$. . . . . . $3: 30$

23. radja, Blrek. . . . . . . 3:31

24. sebre, Blcek. . . . . . . . $3: 31$

25. goldmanni, Blork. . . . . 331

26. hrematochir, Bleck. . . . . 3:32

27. polytrenia, Bleek. . . . . . 3:32

28. poly tænioides, Bleck. . . . . 3:3:3

29. chrysotænia, Bleck. . . . . 3.3:3
30.* Page

30. "reticulatum, Gthr. ... 334

31. "nitidum, Gthr. ...... 335

9. *Hyperoglyphe, Gthr. . . . 337

1. porosa, Richards. . . . . . 337

10. Lobotes, Cuv. ......... 337

1. auctorum, Githr........ 338 citrinus, Richards. ..... 337 emarginatus, $B$. et $G_{0} \ldots . .337$

11. Datnioides Bleek: ..... 338

1. polota, Buch. Ham. . . . 339

2. microlepis, Bleeh. ...... 339

12. Gerres, Cuv. . . . . . . . . 339

1. plumieri, $C$. et $V$. .... 340

2. poeti, C. et $V$......... 341

3. Thombers, $C$. et $I$. . . . 341

4. zebra, Mïll. et Trosch. . 343

5. subfaseiatus, $C$. et $V \ldots \ldots 349$

6. *ovatus, Gthr. ....... 343

7. abbreviatus, Blcek. ... 345

8. filamentosus, $C$. et $V$. . 345

9. pumetatus, $C$. et $I^{\prime} \ldots \ldots .346$ (macracanthus, Bleek. . 346)

10. gula, $C$. et $V$. . . . . . 346

11. "nigri, Githr. . . . . . . 347

12. "squamipinnis, Gthr. . . 349

13. japonicus, Bleek. . . . . 351

14. acinaces, Bleek. . . . . . . 351

15. kapas, Bleel. . . . . . . 352

16. aprion, $C$. et $V$. . . . 352

17. orena, Forsk. . . . . . . 352

18. macrosoma, Bleck. . . . 353

19. aroveus, Forst:. . . . . . 35.3

20. oblongus, $C$, et $I$. . . 354

bilobus, $C$. et $I$. . . . . . 3399

peruvianus, $C$. et $V . \ldots .339$

richii, $C$. et $V$. . . . . . . 339

lineatus, Humbolult. . . . . 339

limbatus, $C$. et $V$. ..... 339

lucidus, $C$. et $V$. . . . . . 339

argenteus, Buird ..... 339

13. Seolopsis, Cur. . . . . . . 354

1. japonicus, $B l$. . . . . . 354

2. margaritifer, C. et $V$. 35.5, 507

3. ciliatus, Lréép. ....... 355

4. auratus, Munyo Purk. . . 356

5. torquatus, $C$. et $V$.... 356

6. bilineatus, $B l$. . . . . 357

7. bimaculatus, Rïp). ... 357

8. inermis, Scleleg. ....... 357

9. monogramma, $K$. et c. $\boldsymbol{H}$. . 358

10. phreops, Bens. ...... 358

11. temporalis, C. et $I \ldots: 30,507$

12. personatus, $C$. vt $V$. . . 360

13. frenatus, $C$. ot $V$. ..... : : (i1

14. cancellatus, $C$. et $I \ldots \ldots, 361$

15. bleelieri, Githr. . . . . . :361

16. ghanam, Forsli. . . . . : 36:2 
17. pectinatus, $K$. et $\varepsilon, I I . \quad$ Page

18. longulus, Richards. . . . 36:3

19. leucotrenia, Bleek. . . . . . 363

20. leucotanioides, Bleck. . . 303

21. caninus, $C$. et $I^{r}$. . . . . 364 pomotis, Richards...... 35t

truiopterus, $C$. et $Y$.... 354

14. Heterognathodon, Blerk. . . 364

1. bifasciatus, Bleck. ..... 364

2. hellmuthii, Bleck. . . . . 364

3. xanthopleura, Bleek. . ... 365

4. macrurus, Bleck. . . . . . . 305

5. nemurus, Bleck. . . . . . . 365

6. microdon, Blekk. . . . . . . 366 guliminda, $C$. et $V$. ... 364

15. Dentex, Cur. ........ 360

1. vulgaris, $C$. et $V$. . . . . . 3, 6

2. argyrozona, $C$. et $I$. ... 348

3. *proorbitalis, Gthr. . . 368

4. rupestris, C. et $\boldsymbol{V}$. ..... 370

5. macrophthalmus, $B l \ldots \ldots 370$

(i. filosus, $Y$ ral. ........ 371

7. nufar, Ehrenb. ....... 371

8. hypselosoma, Bleck. . . . 371

9. griseus, Schley. ...... 372

10. microdon, Blek. ...... 372

11. rivulatus, Riipp....... 872

12. multidens, $C$. et $V$. ... 373

13. hasta, $C$. et $V$. . . . . 373 macrocephalus, Lacép). . . \$66; gobioides, Solamder. . . . . 366 thunbergii, Lacép. . . . . . . 366 crnodon, Bl. ........ 366 rivulatus, Bemn. . . . . . . 366 waigiensis, Q. et $G$. .... \$(66

16. "Synagris, Gthr. . . . . . . 373

1. furcosus, $C$. et $V$. .... 373

2. treniopterus, $C$. et $V$. . . 374

3. mulloides, Bleek. . . . . . 374

4. upeneoides, Blcek. . ... 375

5. zysion, Blek. . . . . . . 375

6. ovenii, Bleck. . . . . . . 375

7. metopias, Bleck. ...... : :76

8. hexodon, Q. et $G$. .... 376

9. peromii, C. et $V \ldots . . . .37$. 37 ;

10. variabilis, Ehrenb. . . . 376;

11. luteus, Schneid. ...... 377

12. cclebicus, Bleck. . . . . . 377

13. nematopus, Bleek. . . . 377

1.1. japonicns, Bl. . . . . . . 378

15. filannentosus, Rüpp. . . . 37

16. 1) mumus, Bleek. . . . . . 378

17. simensis, Lacép. . . . . . . :3:!

18. nematophorns, Bhleek. . . 339

19. macromemus, filler. .... :

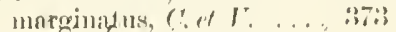
taumbuloirlos. Blorli. . . . ::Т:? tolu, $C$ et $V$ Page

striatus, $B l \ldots \ldots \ldots$

mesoprion, Bleck. ..... 373

ruber, $C$. et $V$. ....... 37:3

17. Pristipomoides, Bleek... . 380

1. typus, Bleek. . . . . . . . 380

18. 1'entapus, Cur.......... 380

1. anrolineatus, Lacép. 381,507

2. vitts, Q. et $G$........ 381

3. peronii, $C$. et $V$. . . . . . 381

4. vittatus, $B l$. ....... 382

5. porosus, $C$. et $V$....... . 382

6. nubilus, Cant. . . . . . . 382

7. unicolor, $C$. et $I$. . . . . 382

8. setosus, $C^{\prime}$. et $I$... . . . . \$382

9. "paradiseus, Gth...... 38:3 iris, $C^{\prime}$. et $V^{\prime}$. ....... $: 380$

19. Chætopterus, Schleg. ....385

1. dubius, Gthr. ....... 3त5)

20. Aphareus, C. et $\boldsymbol{V}$. .... 355

1. furcatus, Lué́p). ....... 346

2. rutilans, Cur......... 386

21. Mrena, Cuv........... 38t;

1. vulgaris, $C$. et $V$. .... $38(;$

2. vomerina, $C$. et $V^{r} \ldots \ldots .387$

3. zebra, Brïn. . . . . . . . 387

jusculum, C. et $\dot{\eta} \ldots \ldots \ldots .380$

22. Smaris, Cur.......... 3*7

1. vulgaris, $C$. et IV ..... 388

2. alcedo, Risso ........ 388

3. maurii, Bonop. ....... 3 389

4. gracilis, Bonap. . . . . . . 389

5. melanurus, $C$. et $V$. ... 389

6. balteatus, C. et $I^{\prime}$. . . . . 389

7. insidiator, $C$. et $V \ldots \ldots .390$ martinicus, $C$. et $I$. ... 887

23. (resio, Commers. . . . . . . 890

1. lunaris, Ehrenbrf. . . . . 390

2. xanthonotus, Bleck. . . . 391

3. pisang, Bleck. . . . . . . . . :391

4. pinjalo, Bleck. ........ 3991

5. maculatus, $C$. ot $\zeta$. ... 391

6. crerulaureus, Lacép. . . . \$9:2

7. striatus, Riipp. . . . . . 39.

8. chrysozona, $K$. et $\imath$. $\boldsymbol{H}$. . . 392

9. argenteus, $1: l . \ldots \ldots \ldots \ldots$. $39: 3$

10. tile, $C$. et $Y . \ldots \ldots \ldots . . .39: 3$

11. "cylindricus, Gthr. ... 39:3

12. gvimnopterus, Bleck. . . . 39)4 tricolor, $C$. et $V \ldots \ldots \ldots .390$ enning, 131. . . . . . . . 390)

24. Ervplizichthys, Schleg . . . :395

1. schlegelii, Rich....... 39),

2. nitidus, Rich. . . . . . . . 39)

3. cyanescens, (illy ...... :39)

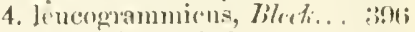

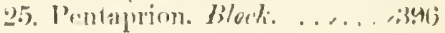


1. gerreoides, Bleck. ..... Page

26. Polycentrus, Mirll.et Troseh. 3906

1. sohomburghii, $\boldsymbol{M}$. «t 'T'. . 3916

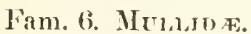

1. Upeneoides, Jitek....... 397

1. vittatus, Forsk. . . . . . . 997

2. tragula, Rieh.......... 398

3. sulphureus, C. ct $Y$. . . 398

4. moluccensis, Blect. . . . 399

5. bensasi, Schleg. . . . . . . 399

6. sundaicus, Bleck. . . . . . 399

7. vlamingii, C. et $r \ldots \ldots 400$ teniopterus, ('. et I. . . . 397 subvittatus, Srhleq. . . . : :907

2. Epeneichthis, Tileck. .... 400

1. porosus, C. et tr....... 400

3. Mullus, L. . . . . . . . . . 400

1. barbatus, $L$. ....... 401

2. surmuletus, $L$. ......4 401

4. Mulloides, Blick. ....... 402

1. flavolineatus, Lacép. . . . 403

2. flavovittatus, Poey...... 403

3. vanicolensis, C. ot $V$. . . 40.t

4. zeylonicus, $C$. et $V . \quad \ldots .404$

5. japonicus, Houtt. . . . . 404 martinicus, C. et I: .... 402 parvus, P'owy ........ 402 balteatus, $\dot{C}$. et $r . \ldots \ldots 402$ mauritianus, Bemn....... 402

5. Upeneus, C. et T. ....... 404

1. baberinus, Laeép. . . . . . 405

2. macronemus, Lacép. . . . 405

3. barberinoides, Bleek. . . . 406

4. indicus, Shau,......... 406

5. spilurus, Bleck. ........ 406

6. pleurospilos, Bleok. . . . 407

7. brandesii, Bick....... 407

8. malabaricus, $C$. et $I$. . . 407

9. trifasciatus, Lncép... . . . 407

10. maculatus, $13 l$. ..... 408

11. punctatus, C. et $V$..... 408

12. prayensis, $C$. et $I$. . . . 40 40

13. cyclostoma, Lacép. . . . 409

14. oxrcephalus, Bleck. . . . 409

15. chrysoplemron, Schleg. . 410

16. jansenii, Bteek. ...... 410

17. dubius, Schleg/, ...... 411

18. bilineatus, $C$. et $V \ldots \ldots .411$

19. crassilabris, $C$. et $I$. . . 411 auriflamma, Forsk. . . . 404 cherserydros, Lacép. . . . . 404 cinnabarinus, $C^{r}$. et $V$. . . 404 fraterculus, $C$. et $V$. ... 404 atherinoides, $C$. et $V$. . . 404 cyprinoides, C. ot $V$. . . 404 litens, $C$. et $r . \ldots \ldots .404$
Fill. 7. Syarina.

First Group. Cantianixa.

1. Cantharus, Cur........ 41:3

1. lineatus, Mont. . . . . 41:3

2. brama, B1. ........ 416

3. orbicularis, $C$. ot $\mathrm{J}$. ... 416

4. emarinatus, $C$. co $r^{2} \ldots . .410$

5. blochii, $C_{\text {s et }} V_{\text {. . . . . . . 4 } 410}$

(i. orrandoculis, $C$. of $I \ldots .417$

7. cieruleus, C. et $\mathrm{I}$.....44 417

8. maculatis, $C$. et $1: \ldots 417$

9. lineolatus, $C$. ct $I \ldots \ldots$. 4 is

senegalensis, $C$. of $r$..... 4l:3

2. Box, Cur. .......... 418

1. vulgaris, $C$. et $I$. . . . $4 \mathrm{l}$ ह

2. salpa, $L$. . . . . . . . . 4:0

3. goreensis, $C$. et $\boldsymbol{V} \ldots \ldots$ 421

salpoides, $C$. $V$. ..... 418

8. Scatharus, C. et $I . . . \ldots .442$.

1. griecus, $C$ et $V$. . . . 4. 422

4. Oblata, Cnt. . . . . . . 42.)

1. melanurn, $L$. . . . . . . 422

5. Crenidens, $C$. et $Y$. . . . 424

1. forskalii, C. et $V$. .... 424

6. "Pachymetopon, Gthi.... 424

1. * grande, Gthr. ....... 424

7. Dipterodon, $C$. et $V$. . . . 426

1. capensis, $C$. et $V$. .... 426

8. *Proteracantleus, Gthr. . . 426

1. sarissophorns, Cant. ... 42:

9. rivella, Gray .......... 427

1 punctata, Gray ........ 427

2. tricuspidata, Q. et $G . \ldots 42 \varepsilon$

8. simplex, Richurds. . . . . 426

4. * zonata, Githr. . . . . . 429

leonina, Rich......... 427

10. Doydixodon, Ial. ..... 431

1. freminvillei, $V a l . \ldots \ldots 431$

11. *Tephreops, Githr. . . . 431

1. richardsonii, Gthr...... 432

2. zebra, Rich. ....... 432

12. * Crymnocrotaphus, Gthr. . 432

1. * curvidens, Gth. . . . . 4.3,2

\section{Second Group. \\ II A I' J, O D A C TY LINA.}

13. Haplodactylus, $C$. «. $V$. . $4: 34$

1. punctatus, C. ct $V$. . . . 4. 434

2. vermiculatus, Gay ..... 434

3. guttatus, Giuy. . . . . . . 434

4. arctidens, kich....... 435

5. "lophodon, Gthr. . . . 4.35,

Third Groujl. Sangix.1.

14. Sarers, Klein ........ 1::-

1. rulgatlis, (ieoffi. . . . . . t: t:i 
Page

2. rondeletii, $C$. ct $V \ldots \ldots .440$

3. capensis, Smith ...... 442

4. vetula, $C$. et $V$. ......444

5. linentus, $C$. ct I. . . . . . 444

6. noct, Ehrenbg. . . . . . 444

7. algenters, $C$. et $I$. . . . . 445)

8. auriventris, Pet....... 445

9. annularis, $L$. . . . . . 445

10. Havo-lineatus, $C$. et $V$. . 446;

11. unimaculatus, $B l$. . . . 446

12. ovis, Mitch.. . . . . . . 447

13. rlomboides, $L$. . . . . 447

14. fasciatus, $C$. ot $V$. . . . 448

15. cervinus, Louc ....... 448

16. aries, $C$. et $V$. . . . . . 449

17. *ambassis, Gthr. . . . . 449 ascensionis, $C$. et $T^{\%}$.... 437 arenosus, Dekay . . . . . . 507

15. Charax, Risso ....... 452

1. puntazzo, L. ....... 453

\section{Fourth Group. Pagrina.}

16. Lethrinus, Cuv: . . . . . 4 45.3

1. rostratus, $\boldsymbol{K}$. et $v$. II. . . 454

2. amboinensis, Bleek. ... 455

3. moensii, Bleek. . . . . . . 455

4. nematacanthus, Blek: . . 456

5. * richardsonii, Gthr. . . . 456;

6. reticulatus, $C$. et $I$. . . . 457

7. chrysostomus, Rich. ... 457

8. latifrons, Riip). . . . . 458

9. harak, Forsk. . . . . . . . 458

10. ramak, Forsk. . . . . . . 459

11. cocosensis, Bleck. . . . . 459

12. atlanticus, $C$. vt $V$. . . . 460

13. kallopterus, Bleek. . . . . 460

14. nebulosus, Forst. . . . . . 460

15. opercularis, $C$. et $J$. ...4461

16. xanthotrenia, Bleck. ....461

17. leutjanus, Lacép. ...... 461

18. " glyphodon, Gthr. . . . . 462

19. mahsena, Forsk. . . . . . 463

20. mahsenoides, $C$. et $I^{Y}$. . 464

21. hrematopterus, Schleg. . 464

22. latidens, $C$. et $V$. . . . . 464

gothofredi, $C$. et $V$. . . . . 453

fasciatus, $C$. ct $V$. . . . 453

frenatus, $C$. ct $V \ldots \ldots \ldots .453$

korelv, C. et $V . \ldots \ldots \ldots 453$

macilatus, $C$. et $I^{\circ} \ldots \ldots .453$

cinereus, $C$. et $V$. . ... 45.

microdon, $C$. et $I$. . . . 4. 45.3

olivaceus, $C$. et $V$. . . . 453

waigiensis, $C$. et $I$. . . . 453

sordidus $C^{\prime}$. ct I: ..... 454

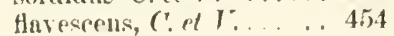

azureus, $C$. et $V \ldots \ldots \ldots .454$

caruleus, $C$. et $V$. ..... 454

croceopterus, $C$. et $\boldsymbol{V}_{\text {. . . . } 454}$

argenteus, $C$. ct $V$..... 454

borbonicus, $C$. et $V$..... 454

geniguttatus, $C$. et $V$. . . 454

genivittatus, $C$. et $V^{r} \ldots .454$

charorhynchus, Schneid. . 451

virescens, $C$. et $I$. .... 454

kalwa, $C$. et $V . \ldots \ldots \ldots 454$

abbreviatus, Gthr. ...... 454

erythropterus, $C$. et $V$. . 454

erythucantlius, C.et. I... 454

alboguttatus, $C$. et $I$. . . 454

xanthopterus, $C$. ct $I$. . 4 454

miniatus, Forst. ...... 454

anatarius, Rich. ....... 454

cyanoxanthus, Rich. .... 454

cinnabarinus, Rich. ....454

17. Spharodon, Rïpp. ..... 46i)

1. grandoculis, Forst. . . . 465

2. heterodon, Bleck. . . . . 465

18. Pagrus, Cux... . . . . . . . 465

1. vulgaris, $C$. et $T$. . . . 466

2. orphus, Risso ........ 467

3. laniarius, $C$. et $V^{\prime} \ldots \ldots .467$

4. unicolor, $Q$. et $G$. .... 468 (micropterus, C. et $I$. . 468)

5. major, Schleg. . . . . . . 470

6. tumifrons, Schleg. ..... 470

7. cardinalis, Lacép). . . . . 470

8. auriga, Tal. ........ 471

9. ehrenbergii, $C$. et $I$. . . 471

10. filamentosus, $C$. et $V^{r}$. . 471

11. spinifer, Forsk. . . . . . 472

12. argylops, $L$. . . . . . 472

huita, $L . \ldots \ldots \ldots \ldots \ldots .465$

lata, Solund. ........ 465

macrocephalus, $\lceil$ ial. ... 465

19. Pagellus, $C$. et $T^{7} \ldots \ldots . . .473$

1. erythrinus, $L \ldots \ldots \ldots \ldots .473$

2. centrodontus, De la $R$. . 476

3. *owenii, Gthr. ...... 478

4. ncarne, Cuv. ........ 480

5. bogaraveo, Briunn. . . . . . 480

6. mormyrus, L. . . . . . 481

7. lithognathus, $C$. ct I: .. 483 breviceps, $C$. ct $V$..... 473

20. Chrysophrys, Cuv. ..... 483

1. aurnta, L. ......... 484

2. crassirostris, $C$. et $V$. . . 484

3. globiceps, $C$. et $V$..... 485

4. crerulcosticta, $C$. «t $T^{*}$. . 485

5. laticeps, $C$. et $V$. . . . . 485

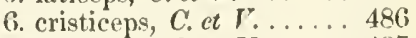

7. gibbiceps, $C$. ct $V \ldots \ldots .487$

8. calamus, $($. o $T$. ..... 487 
(microps, Guich. Page Fifth Group. Pre

9. sarba, Forsk. . . . . . . 488

10. haffara, Forsk. . . . . . 488

11. bifasciata, Forsk. . . . . 488

12. aries, Schleg. ....... 489

13. taurina, Jen. . . . . . . . 489

14. hasta, Schn. . . . . . . . 490

15. calamara, $C$. et $\mathscr{V}$. ..... 493

16. berda, Forsk. . . . . . . . 494

17. *australis, Gthr....... 494

18. aculeata, $C$. et $I$. . . . 496 bilobata, Lacép. . . . . . . . 483 coracinus, $C$. et $I$. . . . . 483 madagascariensis, $C$. ct $V .483$ annularis, $B l$. . . . . . 483 forsteri, Schn........ 483
21. Pimelepterus, Lacép. . . . 497

1. boscii, Lacép. . . . . . . . 497

2. fuscus, Comm. ....... 498

3. waigiensis, Q. et $G$. . . 498

4. lembus, c. et V. . . . . 498

5. ternatensis, Bleek. . . . . 499

6. tahmel, Forsk. . . . . . 499 dussumieri, $C$. et $r$. . . 497 raynaldi, C. et $I$. . . . . 497 oblongior, Cant. ....... 497 incisor, C. et $V$. ...... 497 indicus, C. et $V$. . . . . 497 levifrons, Tsehudi . . . . . 497 (22. Boridia, C. et $V_{\text {. . . . . . } 499}$

1. grossidens, C. et I. ... 499) 


\section{ERRATA.}

Page 30, line 25 from bottom, read the third not quite twice as long as the second.

"97, " 5 from bottom, Lutjanus lunulatus, B1. Schn. p. 329, is to be erased.

" 98, .. 8 from bottom, Serranus anrantins, Cuv. \& Val. ii. p. 3n.j, is to be erased.

"169, Platp. XIY. fig. A is to be erinsed. 


\section{A'I'A LOG UE}

OF

\section{F I S H E S.}

\section{Subclass I. TELEOSTEI.}

Fishes with ossified skeleton and completely separated ertebræ; the posterior extremity of the vertebral column aither bony, or covered with bony plates. Bulb of the aorta simple, with two opposite valves at the origin; branchiæ free.

\section{Order I. ACANTHOPTERYGII.}

Part of the rays of the dorsal, anal, and ventral fins not articulated, forming spines. The inferior pharyngeal bones separated. Air-bladder, if present, without pneumatic duct.

Cfr. Müller, in Eeri. Abhandl. 1844, p. 199.

\section{Fam. 1. GASTEROSTEIDÆ.}

Form of body elongated, compressed; eyes lateral ; eleft of mouth extending on the sides of the muzzle, oblique; villiform teeth in both the jaws and on the pharyngo-branchials, none on the palate or on the tongue. Three branchiostegals. Opereular bones not armed; infraorbital arch articulated with præoperculum; parts of 
the skeleton forming external mails. Seales none, or in the form of scaly plates along the side. Isolated spines before tho dorsal fin; ventral fins abdominal, but pubic bones attached to the humeral areh; ventral with one strong spine, and generally with anothes single short ray. Swim-bladder simple, oblong; cxea pylorica in small number.

Fresh and brackish waters and seas of botlı the Aretic regions.

Onls one genus.

\section{GASTEROSTEUS*}

Gasterostens, Arterli, Gicnera, 1). 52 ; Linn. Syst. Nat. p. 189; Cue. Regrue Anim.; Cux. \&. Val. iv. p. 479.

Centriseus, Klein, Pisc. Miss. iv. p. 48 .

Gasterosteus and Spinachia, Flem. Brit. Anim. p. 219

Charaters the same as of the family.

\section{Gasterosteus aculeatus.}

Pungitius piscis, Albrert. Mugn. Aletror. r. cap. 36. albesti, Jonston, iii. cap. 3.

Pisciculi aculeati prius genus, Romdel. ii. p. 206 ; Cicsuer, fol. $160 \mathrm{a}$. Pisciculus aculeatus, Willughly, p. 341. t. 10. f. 1; Ruy, p. 145.

Gasterosteus, no. 1, Artelli, Species, p. 96; Gronou. Zoophyl. 11. 405.

* Doubtful species:-

1. Oboiarius aculeatus, Steller.-Gasteracanthus cataphractus, I'cllas, .Gasterostens eataphractus, Tiles. Mem. Acul. I'etersh. iii. p. 22ti. pl. 8. f. 1.-Gastcrosteus obolarius, Cur. f. Ful. iv. p. 500.- Coast and Rivers of Kuintsoliatka.

2. Gasterosten: niger, Cur. \& Fal. iv. p. 503.-Newfoundland.

3. Gasterosteus plebeius, Girard, l.c. p. 147, and $L$. S. I'acif. R. R. Exped. Fishes, p. 81.-California.

4. Gasterosteus inopinatus, Girurd, $l l . c e$-Califoruia.--The two latter fishes prove that the form of the ther-spined Stickleback with the posterior part of the side naked is also met with in North America, but even there limited to the more temperate parts. The eharaeters given by Girard otherwise are too vague to admit of any opinion on the specific right of these fishes.

5. Gasterosteus pygmaus, Agass. Latic Superior, p. 314. pl. 4. f. 1.-Lake Superior.

6. Gasterosteus ineonstans, Kivtlund, in Boston Journ. Wat. Hist. iii. p. 273. pl. 2. f. 1.-Ohio.

7. Gasterosteus serratus, Ayres, Proe. Cal. Acad. Nat. Sc. i. 1855, p. 47; Girard in U.S. P'ucif." R. R. Exped. Fishes, p. 88.-Culifornia.

8. Gasterosteus intermedius. Firard, Proc. Ac. Nat. Sc. Thilad. 1856, p. 135, and $U$. S. P'wif. R. K. Exped. Fishes, 1). 8:.-Cape Flattery.

9. Casterostens pugetti, Givard, U. S. P'ucif. K. K. Fxped. F'ishes, p. 92.Fort Steilacoom, P'uget's Sound.

10. Gasterosteus mievoceplaalus, Girard, Proc. Ac. Nat. Se. Ihilad. 185t, p. 1:3:3, and $U$. S. P'ucif: R.'R. Fixperl. F'ishes, p. 91.-Four C'recks, Tulare Valles, U.S.

11. Gasterosteus loricatus, Reinh. Tielcusk. Srlsk. Natur. ng Muth. Afh. vii. 18:38, p. 1:33.-Grecnland.

12. Gusterosteus dimirliatus. hrmh. I. I. Creenland 
Gasterosteus aculeatus, Linn. Syst. p. $489 ;-$ Gronov. Syst. ed. Gray, p. 167 ; Bloch, t. 53. f. 3 ; Bl. Schn. p. 122 ; Donor. Brit. Fishes, i. pl. 11 ; Turton, Brit. Faun. p. 101 ; Fleme. Brit. An. p. 219; Fries och Ekstr. Skand. Fisk. p. 17. t. 4. f. 1; Thompson, Ann. \& Mag. Nat. Hist. 1841, vii. p. 95; White, Catal. Brit. Fishes, p. 35.

Centriscus, sp., Klein, Pisc. Miss. iv. p. 48. t. 13. f. 4, 5.

Gasterosteus ter-aculeatus, Lacép. iii. p. 296.

D. $1|1| \frac{1}{10-12}$. A. $\frac{1}{8-9}$. P. 10. V. 1/1. Cæc. pylor. 2. Vert. 15/16.

Sides of the body with a more or less complete scries of scaly plates. The two anterior dorsal spines one-third of the heigh of the body.

Var. A. Gasterosteus gymuros.

Gasterosteus gymnurus, C'ur. Règne Anim.

— leiurus, Cuv. \& V Val. iv. p. 481. pl. 98. f. 4; Yarr. Ann. \& Mag. Nat. Irist. iii. p. 522, and Brit. Fishes, i. p. 95; Owen, C'atal. p. 56 ;

Coste, Mémoires Sci. Sav. Etrang. x. 1848; Günther, Neckarfische, p. 29.

Quarter-armed Stickleback, Parn. Ichth. Frith of Forth, p. 30. t. 25.

Four or five scaly plates above the pectoral fin ; the remainder of the body naked.

Middle and Southem parts of Europe; England, France, South Germany, Baltic.

a. Adult. New River. Museum Leach.

$b-e$. Adult. Greenwich. Presented by W. Yarrell, Esq.

f, \%. Adult. Poole Heath. Dorset. Presented by W. Thompson, Esq.

$h-k$. Adult. Wandsworth. Museum Leach.

$l, m$. Adult. Lochend.

n. Adult. Duddington Loch.

$o-r$. Adult. England.

s. Adult: nou good state. Baltic. From the Haslar Collection.

t. Adult. From the Haslar Collection.

u. Half-grown : bad state.

$v-y$. Half-grown. Presented by Dr. Johnston.

z. Half-grown. Museum Leach.

a. Adult.

B. Adult: skeleton.

Var. B. Gasterosteus semiarmates.

Gasterosteus semiarmatus, Cuv. \& V Val. iv. 493 ; Yarr. l.c. f. 127 b, and Brit. Fishes, i. p. 94; Parn. l. c. p. 32. t. 22.

The front part of the side with a series of ten to fifteen scaly plates.

France; Belgium; England.

$a-d$. Adult. Greenwich. Presented by W. Yarrell, Esq.

$e, f$. Adnlt. Tweed. Presented by Dr. Johnston. 
Var. C. Gasterostedos semiloricatus.

Gasterostens semiloricatus, Cuv. \& V Val.iv.p. 494; 77ompson, l. c. p. 95. The series of sealy plates rea hing to the front end of the equdal keel. France; Ireland.

Var. D. Gasterosteus trachuros.

Gasterosteus trachums, $C u v$ \& $V a l$. iv. p. 481. pl. 98. f. 1 ; Yarr. l.c. f. 127 a, and Brit. Fishes, i. p. 90 ; Parn. l. c. p. 33. t. 25.

—_ aculeatus, Ekström, Fische Mörkö, p. 153.

- _.. trachurus, var. pontica, Nordm. in Demid. Voy. Russ. Mérid. iii. p. 357 .

The sides of body and tail entirely covered with a series of sealy plates.

Northern parts of Europe; North Germany, Enyland, France.

a. Adult. Greenwich. Presented by W. Yarreli, Esq.

b. Adult. Marsh at Plymouth. Museum Leach.

c. Adult. Poole Heath, Dorset. Presented by W. Thompson, Esq.

d,e. Adult. Tweed. Presented by Dr. Johnston.

f. Adult. England. Presented by Mr. Moore.

g. Adult. Frith of Forth.

$h-k$. Half-grown. Frith of Forth.

l-n. Adult. Gotha River, Sweden.

o. Half-grown. Norway. Presented by G. Woodfall, Esq.

$p-u$. Fine specimens. From the Haslar Collection.

$v, w$. Adult. From the Haslar Collection.

$x-\alpha$. Half-grown. From the Haslar Collection.

$\beta-\delta$. Adult. Europe.

$\epsilon-\theta$. Young. Europe.

Var. E. Gasterosteus noveboracensis.

Gasterosteus aculeatus, Schopff.

- noveboracensis, Cuv. \&V $V_{u l}$. iv. p. 502 . pl. 98. f. 3 ; Dekay, New York Fauna, Fishes, p. 66. pl. 6. f. 17 (bad).

Entirely similar to the preceding varicty, but with the rentral spine rather longer, reaching to the posterior extremity of the pubie bone.

Fresh waters of the northern parts of North America.

a. Adult. Greenland.

b. Several young speeimens. North Ameriea.

\section{Gasterosteus argyropomus.}

Gasterostens argyropomus, Cur. \& V Val. iv. p. 498.

$$
\text { D. } 1|1| \frac{1}{12} \text {. A. } \frac{1}{10} \text {. } \quad \text { P. } 9 . \quad \text { V. } 1 / 1 \text {. }
$$

Sides without any plates; the anterior dorsal spines about onethird of the height of borly.

Italy.

a-e. Fine specimens. Rome. l'resented by W. C. Trevelyan, Esq. 


\section{Gasterosteus brachycentrus.}

Gasterosteus brachycentrus, ('ur. of $V_{k}$ l. iv. p. 499. pl. 98. f. 2; Thompson, l.c. p. 100; Yarr. Brit. Fishes, i. p. Of; Ileck. Kner, Siisswetsserfische, f. 17.

- aculeatus, var., White, Catul. Brit. Fishes, p. 35.

$$
\text { I) } 1|1| \frac{1}{13} \text { : A. } \frac{1}{9} \text {. P. } 10 . \quad \text { V. } 1 / 1 \text {. }
$$

Three or four sealy plates above the pectoral fin. The anterior dorsal spines only one-fifth of the height of the body; the ventral spine one-third of the length of the os innominatum.

Itally.

\section{Gasterosteus biaculeatus.}

Gasterosteus biaculeatus, Shur, Zool. iv. p. 608: Penn. Arct. Zool. ii. p. 385 ; Cur. Sol. Viv. p. 50:3.

— cuvieri, Givud, Bost. Journ. vi. p. 254. pl. 7. f. 1.

$$
\text { D. } 1|1| \frac{1}{12} \text {. A. } \frac{1}{8} \text {. P. } 9 . \quad \text { V. } 1 / 1 \text {. }
$$

Sides of the tail without sealy plates. The ventral spine with a spinous process at the outer side of its base. Blackish.

Coasts of Newfoundland and Labrador.

Gusterostezs biaculeatus, Dekay, New York Fauna, Fishes, p. b5, pl. 3. f. 9, is a different fish, probably identical with Gasterosteus noveboracensis. Strangely enough he says, "Vent with an anterior pouch, analogous to that observed in Syngnathus." (?)

\section{Gasterosteus tetracanthus.}

Gasterosteus tetracanthus, Cuc. \& Ful. iv. p. $49 y$.

$$
\text { D. } 1|1| 1 \mid \frac{1}{15} \text {. A. } \frac{1}{10} \text {. P. } 11 \text {. V. } 1 / 1 \text {. }
$$

Sides of the posterior part of body naked; the anterior dorsal spines shorter than one-third of the height of the body. (Cuv.)

Italy.

\section{Gasterosteus spinulosus.}

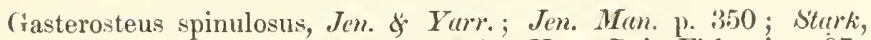
Jameson's Edlinb. Journ. 1830, p. 327; Yarr. Brit. Fishes, i. p. 97; Purn. l. c. p. 36. t. 25.

- aculeatus, var., Thompson, l. c. p. 103.

$$
\text { D. } 1|1| 1 \mid \frac{1}{8} \text {. A. } \frac{1}{8} \text {. P. } 9 . \quad \text { V. } 1 / 1 \text {. }
$$

Sides of the posterior part of body naked; the anterior dorsal spines about one-fourth of the height of the body; tho ventral spine does not reach the posterior extremity of the pubic bone.

Fresh waters of Great Britain.

๘. Arlult. Isle of Arran. Museum eeach.

b. Half-grown. Berwick. Presented by Dr. Johnston. 


\section{Gasterosteus pungitius.}
D. $9 \mid \frac{1}{9}$.
A. $\frac{1}{9-10}$.
I'. 11. V. $1 / 1$.

Nine very short isolated dorsal spines; the tenth spine two-thirds lower than the second dorsal. Sides naked, the caudal keel sometimes with very thin scales.

Northern parts of Europe: England, France, North Germany, Baltic. Northern parts of America; Newfoundland; New York.

A. European variety: Gasterosteds pungitus.

Pisciculi aculeati altermu genus, Rondcl. ii. p. 206.

Pisciculus pungitivus, Gesner, fol. $160 \mathrm{a}$.

aculeatus minor, Willughly, p. 342 ; Ruy, p. 14in.

Pungitii alterum genms, Alilor. v. cap. 36 ; Jouston, tab. 28. fig. $a$. (left-hand figure).

Gasterostens no. 2, Artedi, Spec. p. 97 ; Cronox. Znophlyl. n. 406.

- pungitius, Lim. Syst. p. 491 : Gromor. Syst. "rl. Givay, p. 167; 13l. ii. p. 108. t. 53. f. 4; Bl. Schu. p. 12:3; Lsscip. iii. p. 297; Donor. Brit. Fiskes, ii. pl. 32 ; Pallns, Vonm): iii. 1. 228; Turton, Brit. Faun. p. 101; Flm. Brit. Lnim. p. 21!); ('m. S. Ful. iv. p. 50r; Thompson, t.e. p. 103; Ekstrim, Fische Iforlio, p. 159; Fries och Ekstr. p. 20. pl. 4. f. 2; Iarrell, Brit. Fishes, i. p. 99; rarn. l.c. p. 37. t. 26; White, Catal. Brit. Fishes, p. 36.

a. Adult. Battersea Fields. Museum Leach.

$b$ d. Adult. Cobham (Surrey). Museum Leach.

e. Many specimens. (iotlua River, Sweden.

$f$. Adult: not good state. Raltic. From the Haslar Collection.

g, h. Adult.

$i, k$. Half-grown. From the Haslar Collection.

B. American variety: Gasterostecs occidentalis.

Gasterosteus occidentalis, Cur. S. V'al. iv. p. 509: Hekay, New Jork Fauna, p. 68. pl. 42. f. 135 .

— pungitius, storer, Rep. Mass. p. 32.

- nebulosus, Agass. Lake Superior, p. 310. pl. 4. f. 2.

I-n. Arlult. North America.

\section{Gasterosteus mainensis.}

Storer, Bost. Jurn. i. p. 46.4.

$$
\text { J). } 7 \mid \frac{1}{9} \text {. A. } \frac{1}{8} \text {. }
$$

Baek with seven spines, the last longest; a broad ohlong seruated plate on the side, with numerous dusky transverse bands.

Fresh water. Iline.

\section{Gasterosteus concinnus.}

Richurlsom, Fanm. Bor.-Amer., Fishess. p. ist.
1). $7 \mid \frac{1}{3}$.
1. $\frac{1}{9}$.
V. 11 . 
The eighth spine one-third lower than the sceond dorsal. No seales whatever on the body. (Rich.)

Fresh waters from the Saskatchewan to the Great Bear Lake.

This species may be identieal with the former.

\section{Gasterosteus quadracus.}

Gasterosteus quadracus, Mitch. Trans. Lit. \&. Phil. Soc. i. p. 430. pl. 1. f. 11 (bad); Cux. \& Tal. iv. p. 504; Dekay, New Iork Fauna, pl. 6. f. 18.

- apeltes, Cur. \&. Val. iv. p. 505; Storer, Report, p. 31.

? - millepunctatus, Ayres, Bost. Journ. Nat. Hist. iv. p. 294. pl. 12. f. 3.

$$
\text { 1). } 3-4 \mid \frac{1}{12} \text {. A. } \frac{1}{10} \text {. }
$$

No bony cuirass between the ventral fins; without any scaly plates, and no keel on the side of the tail.

Fresh waters of New York.

\section{Gasterosteus spinachia.}

Aculeatus vel Pungitius marinus longus, Schonev. p. 10. t. 4. f. 3 ; Willughby, p. 340 ; Ray, p. 145.

Gasterosteus no. 3, Artedi, Gencra, p. 52; Gronov. Zoophyl. no. 407. — spinachia, Jimn. Syst. p. 492; Bloch, t. 53. f. 1; Bl. Schn. p. 123. t. 33. f. 2 ; Lacép. iii. p. 301; Donoc. Brit. Fishes, ii. pl. 45; Turt. Brit. Fann. p. 101; Flem. Brit. Anim. p. 219; Cur. \& Val. iv. p. 509 ; Ekstr. Fische Mörkö, p. 163; Fries och Ekstr. p. 21. t. 4. t. 3; Jen. Man. p. 351; Yarrell, Brit. Fishes, i. p. 101; Thompson, l.c. p. 104; Parn. l.c. p. 38. pl. 26: White, Cutal. Brit. Fishes, p. 36 .

Centriscus, sp., Klein, Pisc. Miss. iv. p. 48. no. 1. t. 4. f. 5.

Gasterosteus mariuus, Gronor. Syst. cd. Gruy, p. 168.

Spinachia vulgaris, Flem. Brit. Anim. p. 219.

$$
\text { D. } 15 \mid 6-7 . \quad \text { A. 6-7. P. } 10 . \text { V. 1/1. Cæe. pylor. } 2 .
$$

Back with fifteen free spines. Body laterally covered with sealy plates.

Along all the northern European coasts.

a. Adult. Plymouth. Museum Leach.

b. Adult: skin. Plymonth. From Mr. Yarrell's Collection. $c-h$. Adult. Brighton. Presented by J. G. Children, Esq.

i. Adult. Brighton. Presented by Dr. A. Günther.

k. Adult. English Channel.

l. Large female specimen. Wales. Presented by Mrs. Gray. $m-p$. Half-grown. South Wales. Presented by F. Stokes, Esq.

q. Adult. Berwick on Tweed. Presented by Dr. Johnston.

$r$ Very large specimen: not good state. Polperro. Presented by J. Conch, Esq.

$s-w$. Adult and half-grown specimens. Frith of Forth.

$x-\iota$. Adult and half-grown specimens. Europe. 


\section{Fam. 2. BERYCID A.}

Form of body oblong or rather elevated, compressed; eyes lateral, large; cleft of mouth extending on the sides of the muzzle, more or less oblique; villiform teeth in both the jaws, and generally on the palate. Eight or four branchiostegals. Opereular bones more or less armed. Scales ctenoid, seldom bon 5 , or wanting. Ventral fins thoracic, with more than five soft rays, in one genus with less. Cacea pyloriea in inereased number.

Tropical and temperate seas.

The genera of this most natural family have been improperly seattered by Cuvier in the families of Triglidæ and Percidx. Lowe was the first who defined this group, in his admirable work on the "Fishes of Madeira." He overlooked, however, the genus Rhynchichthys, apparently a less aberrant form than Monocentris, which may be considered as a connecting link with the first family.

\section{Synopsis of the Genera.}

Scales forming a bony mail; several isolated spines in front of the dorsal fin .........

One dorsal. No vomerine teeth. Abdomen ser-

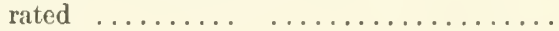

1. Monocentris.

2. Hoplostetius.

One dorsal. Vomerine teetl. Abdomen serrated. 3. Trachichtнуs.

No scales .................. 4. Anorlogastek.

One dersal. Vomerine teeth. No barbel..... 5. Beryx.

Two barbels .................. 6. Polymixia.

Two dorsals. l'reopercular spine none....... 7. Mrripristis.

Two dorsals. Praopereular spine. Jaws equal, or the lower prominent $\ldots \ldots \ldots \ldots \ldots$

8. Holocentrum.

Twe dorsals. Preopercular spine. Snout projecting beyond the mouth............

9. RHYNCHCHTHY'

\section{MONOCENTRIS.}

(iasterosteus, sp., Houttuyn.

Seiæna, sp., Thumberg.

Monocentris, Bl. Schn. p. 100; Cuv. \& Val. ir. p. 461.

Lepisacanthus, Lacŕp. iii. p. 321.

Muzzle blunt, rounded, protruding, with the eleft of mouth bencath; eye moderate. Villiform teeth in both the jaws and on the palatines, but none on the vomer. Eight branchiostegals. Opereular houes scarcely denticulated; suborbital bones with radiating bouy ridges. Scales very large, bony, fornuug together a mail. Several isolated spines in front of the dorsal. Ventrals reduced to a 
single strong spine and a few very short rays; caudal not forked. Swim-bladder?

Sea of Japan.

\section{Monocentris japonicus.}

Gasterosteus japonicus, Honttuym, Act. Soc. Harl. xx. pt. 2. p. 329.

Sciæna cataphracta, Thumberg, Nov. Act. Scient. Suec, xi. p. 102. tab.3.

Monocentris carinata, Bl. Schn. p. 100. tab. 24 (copied).

Lepisacantlius japonicus, Lacép. iii. p. 321.

Monocentris japonicus, Cuv. \& Val. 1v. p. 461. pl. 97 ; Funu. Japon. p. 50. pl. 22. f. 1 .

D. 6 11. A. 10. P. $13 . \quad$ V. $1 / 2$. L. lat. 13 . L. transv. $2 / 4$.

Anterior dorsal and ventral spines rery strong and thick. Head shorter than the height of the body.

Sea of Japan.

a. Adult. Japan.

b. Adult: skin in spirits. Purchased of Mr. Frank.

$c, d$. Adult: stuffed. China Seas.

e. Half-grown: stutfed. Purchased.

\section{HOPLOSTETHUS.}

Hoplostethus, Cuv. \& Val. iv. p. 469.

Trachichthvs, sp., Lowe, Fishes of Madeira, p. 55.

Muzzle very short, rounded, not protruding; eleft of mouth oblique; eye large. Exceedingly fine villiform teeth in both the jaws and on the palatines, but none on the romer. Eight branchiostegals. Operculum entire, a strong spine on the scapular bone and at the angle of præopereulum; suborbital arch with radiating ridges. Scales ctenoid, of moderate size; abdomen serrated. One dorsal with a spinous and with a soft portion; ventrals with six soft rays; pectoral blunt and rounded behind; eaudal deeply forked. Swim-bladder simple; pyloric appendages numerous.

Mediterranean; coast of Madeira.

\section{Hoplostethus mediterraneus.}

Hoplostethus mediterraneus, Cuv. \& Val. iv. p. 469. pl. 97 bis.; Guichenot, Explor. Algérié, Poiss p. 42.

Trachichthys pretiosus, Lone, Suppl. Fishes of Madeira, in Proc. Zool. soc. 1839, p. 77, and Fishes of Mudeira, p. 55. tab. 9.
D. $\frac{6}{13}$ :
A. $\frac{3}{9}$. V. $1 / 6$.
L. lat. 28-29. Vert. 11/15.

Pectoral fin reaching beyond the origin of the anal fin; the serrated ventral keel composed of eleven to thirteen scales. Pale reddish or rose-coloured.

Mediterranean; coast of Madeira.

a. Adult. Madeira. Presented by the Zoologieal Society.

Skeleton.-Cfr. Owen, Osteol. Catal. i. p. 56. 


\section{TRACHICHTHYS.}

Trachichthys, Shax, Nat. Misc. x. pl. 378, Cur. of Val. iii. p. 229

Amphiprion, Bl. Schn. p. 551.

Trachichthys, sp., Love, Fishes of Madeira, p. 55.

Muzzle very short, rounded, not protruding; cleft of mouth oblique; thin prominent, eye large. Exceedingly fine villiform teeth in both the jaws, on the palatines, and on the vomer. Wight branchiostegals; a strong spine on the seapular bone and at the angle of præopereulum, a small one on the opereulum; suborbital arch with radiating ridges. Seales etenoid, rather small, aldomen serrated. One dorsal, ventral with six soft rays; eaudal forked. Swin-bladder" Pylorie appendages?

Australian Sea.

\section{Trachichthys australis.}

Trachichthys australis, Shawe, Nut. Misc. tab. 378, and Zool. iv. p. 630; Cur. \& Val. iii. p. 229 ; Loure, Fishes of Malleira, p. 55 et seq.

Amphiprion cariuatus, Bl. Sehn. p. 551.

$$
\text { D. } \frac{3}{12} \text {. A. } \frac{2}{10} \text {. V. } 1 / 6 \text {. P. } 13 \text {. }
$$

Scales rough, rather irregularly arranged, those of the lateral line not larger; the serrated ventral keel composed of eight scales. The heighit of the body not quite one-half of the length between snout and the base of the caudal.

Australian Seat.

«. Adult: stufled. New Holland. (Shaw's original specimen.)

\section{Trachichthys elongatus. (P'LATE 1. fig. A.)

$$
\text { I). } \frac{4}{11} \text {. A. } \frac{3}{9} \quad \text { V. } 1 / 4 \text {. I. lat. ea. } 65 \text {. }
$$

Siales rough, those of the lateral line not larger: the serrated ventral keel composed of eleven or twelve scales. The height of the body one-third of the length between snout and the base of the eaurlal.

"Skin, in spirits. Great Barrier Island (New Kealand). Purchased of $\mathrm{Mr}$. Sowerby.

6. Yommer. Australua.

Description.- This new species differs as much in the form of the body from the other, as a Jace from a Crucian Carp. 'The length of the heal is less than the heght of the body. The snont is excerdingly short, about onc-thmel of the diameter of orbit. The upper maxillary reaches a little behind the rye; it is elongate and styliform like the intomaxillary, but dilated at the cuch. The lower jaw is shorter than the uper, and furnished in front with two little knobs: the interniaxillaries are searcely separated from ome another by a noteh. All the teeth are fine. villiform; those 
of the jaws and palatine bones in narrow bands, and those of the romer in a small pateh.

The interspace between the eyes is one-thind of the length of the head, and convex: the seales of the nape extend nearly to above the middle of the cye. The remainder of the upper surface of the head is scaleless, and oceupied by cavities. There are two narrow bony ridges running from the nape to the front of the snout; they converge in the middle, inchuling posteriorly a narrow triangular cavity. Between these ridges and the supereiliary margin there is on each side another ridge, slightly arched, and ruming from the suprascapulary to the posterior nostril; there is a pair of large cavities between these and the inner ridges: lastly, there is a third cavity between the ridge just mentioned and the supereiliary arch. This latter cavity is absent in Beryx affinis, the onter ridge and the superciliary margin being confluent in that species. The nostrils are close together; the anterior small, round; the posterior larger, short, ovate. The eye is placed high up the sides, its diameter is ncarly one-third of the length of the head. The infraorbital areh is transformed into a channel, covered by a half-transparent skin, like the cavities of the skull; several bony ridges eross it: the anterior infraorbital is very narrow in front and scarcely denticulated; none of the bones extend to the præoperculum.

'The operenlum is not twice as high as wide: no scales are visible on it, except at its npper extrenity, but lroad ridges, rough and slightly arched; the spine at its upper angle is scarcely visible. The subopereulum is entire, and notehed before the pectoral ; the interopereulum is rough and slightly serrated. The prooperculum has on the hinder and under part two parallel ridges with a channel between; they are slightly roughened and meet at a right angle, where there is a projecting triangular spine with a sharp hony ridge; the edges of this spine have a fine, hardly visible serrature. The spine does not cxtend to the gill-opening. Cheek sealy. The scapulary bone has a distinct spine, much more feeble than in the other species. Humeral bone not serrated.

The dorsal fin is placed somewhat nearer the base of the caudal than the tip of the snout; its height crpuals its length. 'The spines and rays are much more slender than in Trachichthys anstralis, and not roughened. The spines become longer behind: the fourth is abont as long as the last ray, one-half of the longest; the longest ray is the third, much longer than one-half of the d'peth of the body. The caudal is moderately forked, with pointed lobes of moderate length, about one-fifth of the total. The origin of the anal fills under the end of the dor'sal, it is rather higher than long, but much lower than the dorsal; the spines and rays are smooth, the former gradually becoming longer behind; the third spine is much shorter than the first ray (which is the longest), and even somewliat shorter than the last. The pectorals are slightly rounded, short, their l'ngth being one-seventh only of the total. 'The ventrals equal the pertorils in length; they are inserted a little holind the pertorals; their spine is equal to the third of the anal fin. 
The scales are smaller and smoother and more regularly arranged than in Trachichthys australis; their margin is strongly ciliated. The s'aly plates between the root of the ventrals and the anus are imbricate, each armed with a strong spine directed backwirds.

Along the middle of each lobe of the eaudal fin a black streak.

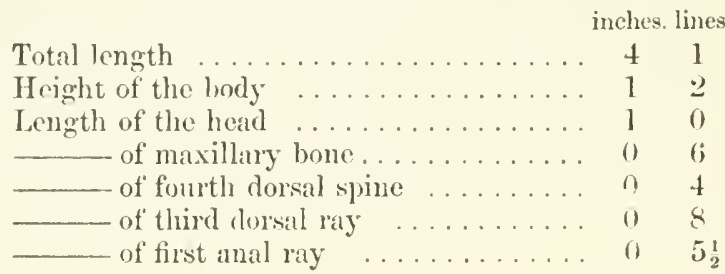

\section{ANOPLOGASTER.}

Hoplostethus, sp., Cur. \& I al. ix. p. 470.

Muzzle very short, rounded, not protmuling; cleft of mouth oblique, chin prominent; eyc large. Villiform teeth in both the jaws, several larger ones in the lower, none on the palate. light branchiostegals. Opereulum entire, a strong spine at the angle of praopereulum; suborbital arch with radiating ridges. Seales none; skin covered with rough tubercles. One dorsal, ventral with six soft rays; pectoral pointed?, caudal deeply forked. Swim-bladder?

Tropical parts of the Atlantie.

\section{Anoplogaster cornutus.}

Hoplostethus comutus, Cuv. S. F'ul. ix. p. 470.
D. $\frac{3}{12}$.
A. $\frac{2}{6}$.
V. $1 / 6$.

Suborbital arch with seven cavities: the bony ridges of the liear terminating in several blunt points. ( $V a l$.

\section{BERYX.}

C'ur. Rigne Anime; Cur. \& I"al. iii. p. 226.

Nuazle short, with oblique eleft of month and prominent chin; eye large. Villiform teeth in both the jaws, on the vomer and palatine bones. Fight (cxecptionally seven) and more branchiostegals. Opercular bones serrated; opereulum generally distinetly spiniferous; propperculum without spine. S'cales moderate or large, etenoid. One dorsal; rentrals with seven and more rays. Cauclal forked; anal with four spines. Air-bladder simple. Pylorie appendages in increased number $(2011-30)$.

Sura of Madeira: Indian Ocean: Australian heas. 


\section{Beryx lineatus.}

Cuv. \& Val. iii. p. 226.
B. 8 .
D. $\frac{6}{13}$.
A. $\overline{15}$.
V. $1 / 7$.
L. lat. 51.
L. transv. 7/17.
Cac. pylor. ea. 20.

The height of the body is one-third of the total length, the length of the head one-fourth. Opereulum with two small spines; pectoral one-fifth of the total length; the inferior lobe of the caudal rather longer than the superiol. Red, with lighter longitudinal bands.

King George's Land.

a. Adult: stuffed: not good state. (Isle de France.)

\section{Beryx affinis. (Plate II.)}
D. $\frac{7}{12}$.
A. $\frac{4}{12-13}$.
V. $1 / 7$.
L. lat. $41-43$.
L. transv. 6/12.

The height of the body is $3 \frac{1}{4}$ in the total length, the length of the head $3 \frac{2}{3}$; operculum with two distinct spines; pectoral onefifth of the total length; the inferior lobe of the eaudal scarcely longer than the superior.

Coasts of Australia.

$a-c$. Adult: stuffed. Australia. Purchased of Mr. Warwick. d. Adult: has been in ehloride of zinc. From the Haslar Collection.

Description.-This species is closely allied to $B$. lineatus, but differs in many respects, which, unimportant in themselves, altogether lead me to think it a distinct speeies.

The form is oblong, moderately compressed, deepest forwards from the nape to the commencement of the soft portion of the dorsal fin, contracting considerably at the origin of the anal. The dorsal line is strongly arehed from the front end of the dorsal fin to the tip of the short muzzle. There is another convexity, but much slighter, along the base of the dorsal fin. The ventral line is straight between the origin of the anal and the mandibular joint, rising steeply towards the extremities of snout and tail. The greatest height of the body at the origin of the dorsal fin, is $3 \frac{1}{4}$ in the total length. The length of the head equals the height above-named. The large eye is placed high up, but not interfering with the upper outline of head; it leaves a space below it deeper than its diameter, which is nearly one-third of the length of head. The muzzle is short, reaching about five-sixths of the diameter of the eye. The nostrils of one side are close together, one before the other; the anterior is placed a little lower, and is oval and small; the posterior is larger and more elongated.

The intermaxillaries are thin at the sides. separated in front from one another by a deep notch; they are furnished with a band of very fine villiform teeth, and with several larger ones at the inner extremity, near the notch; their upper posterior processes are rather small and feeble. The palatine bones are armed with a euneiform band of minute teeth, the broader end in front; the small patch.of 
vomerine teeth is triangular. The lower jaw is thickened and clumsy at the tip, which projects considerably beyond the upper, and is recoived into its notch; the lateral edge is slightly undulating and furmished with a series of small teeth, but the teeth on the anterior prominence are, like the upper ones, larger and conical. The maxillaries are styliform at the interior extremity, but very broad at the exterior; they are smooth, and not denticulated; the broad end is overlapped by the supplementary bone, tapering behind and roughened above. The gaje is oblique, steeply ascending; the maxillary reaches, when the mouth is closed, rather behind the middle of the eye.

The eye is surrounded by the infraorbital areh, which is transformed into a channel, the outer side of which is eovered above by a narrow, bony, roughened streak, and beneath by a broad transparent membrane; the lower edge of the arch is slightly serrated. The preorbital has not the curved and prominent tooth which is to be observed in $B$. decadactylus and splendens; but in this species such a process arises from the maxillary, near its upper extremity, in front of the eyc. The turbinal bones are peeuliarly shaped and have curved edges; they are roughened in front and laterally denticulated, and have it notch, to receive the curved process of the maxillary bone.

The interspace between the eyes becomes gradually narrower in front, and is one-fourth of tie length of the head. There may be distinguished four very narrow bony ridges ; each of the two external ones forms the superciliary ridge, terminates abruptly in an obtuse extremity just above the nostrils, and is lost behind in the infraorbital arch. 'lhe two internal ridges arise from one point on the same level with the front end of the two external ones, and on the suture of the frontal bones; they immediately diverge, receiving a 1 arrow-shaped groore between, and racliate near the nape into three bony ridges, the inner of which is very short, but the two outer ones extend nearly to the suprascapular. Between all these ridges are cavities covered by a half-transparent membrane only.

'The operculum is more than twice as high as wide (the spine included); it is covered with seales on its anterior half, the remainder being striated; the strix terminate in mitrginal points, becoming coarser towards the spines; there is a slight noteh above and beneath the spines. The upper spine is rather stronger, and produces a distinet transverse ridge on the opercle; both the spines have a parallel direction and are rather distant from one another. 'The suboperculum has a concave posterior margin and has some spinous teeth below. The interoperculum has a very deep noteh near the angle of prapopereulum, and is not only serrated along its margin, but has a roughened surface, sometimes with projecting spines. The preoperculum has two parallel margins with a channel between, covered with a half-transparent membrane. Both the posterior margins have an exceedingly fine serrature; that of the inferior ones is coarser. The margins meet at a right angle, slightly projecting, and armed with coarse spinous teeth. The check is scaly. The suprascapular has a prominent spine, rather larger than those of the 
operculum and running in the same direction; it might be taken for a third opercular spine. The scapular and coracoid bones are nearly entire. The scales of the nape reach far between the eyes.

The dorsal fin is more distant firom the occiput than from the root of the caudal; the distanees are $=3: 2$. The spines gradually become longer behind, the length of the first being $5 \frac{1}{2}$ in that of the seventh; the first ray is still longer-one-half of the height of the body, and nearly twice as long as the last; it is brauched. The length of the base of the dorsal fin is much longer than the pectoral; its origin corresponds to the level of the 7 th scale of the lateral line, its end to that of the 27 th. The spines are rather slender, and show sometimes a longitudinal groove.

The caudal fin is exceedingly deeply forked, one of the longest outer rays being more than four times as long as the middle, and as long as the head; both the lobes appear to be equal in length (the extremities are rather injured). The upper and lower side of the base is furnished with four short imbricate spines.

The length of the base of the anal fin nearly equals that of the pectorals ; its origin eorresponds to the level of the 15 th scale of the lateral line, its end to that of the 32nd. The spines are slender and become gradually longer behind; the fourth is rather shorter than the first ryy, which equals the sixth dorsal spine, and is more than twice the length of the last; its lower edge is straight.

The pectoral fin is placed about one-third of the height up the side, not very long, and pointed, equaling one-fifth of the whole length of the fish. The rays are regular and slender; the first two unbranched; the third the longest.

The ventral fins are placed just below the base of the pectorals; they are ovate and much shorter than the latter, their length being one-seventh only of the total. The spine is strong, striated, about three-fourths of the entire length of the fin. A narrow elongated scale at their exterior axil.

The scales are of moderate size, with smooth surface and fine posterior serrature; in several of the dorsal scales the middle part of the serrature projects beyond the margin. The lateral line is nearly straight, uninterrupted.

The specimens are now discoloured, but appear to have been red, with iridescent streaks.

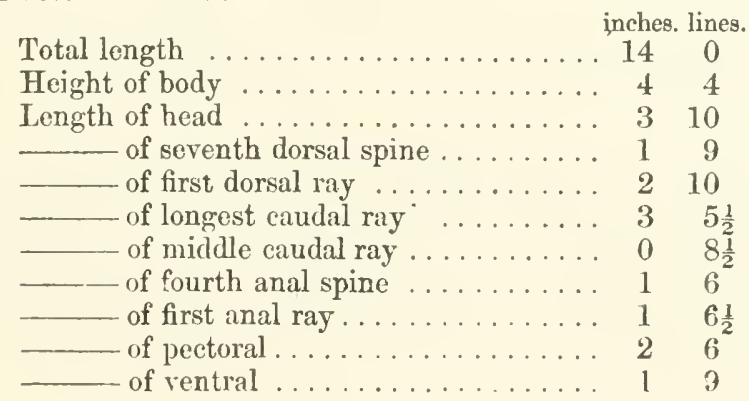




\section{Beryx decadactylus.}

Beryx decadactylus, Cur. \& Val. iii. p. 222 ; Barker-Webb \& Berthelot, IIist. Nat. Iles Canar. Ichthyol. p. 13. pl. 4.

Beryx splendens, Lowe, Cambr. Phil. Trans. vi. tab. 3 (not descript.).
B. $8(7)$.
D. $\frac{4}{16-19}$.
A. $\frac{3-4}{28-29}$. V. $1 / 10$.
L. lat. 64-65.

L. transv. 34-35.

The height of the body is equal to the length of the head, and $2 \frac{1}{2}$ in the total. The upper maxillary bone reaches to below the middle of the eye. Opereulum with an indistinet spine.

Sea of Madeira.

\section{Beryz splendens.}

Lowe, Proc. Zool. Soc. 1833, p. 142 ; Cambr. Phil. Trans. vi. p. 197 (not figure); Fishes of Madeira, p. 47. pl. 8.
B. $8(9)$.
D. $\frac{4}{13-15}$.
A. $\frac{4}{26-29}$.
V. 1/10-13.
L. lat. $71-76$.
L. transv. 8/20. Cæc. pylor. 25-30.

The height of the body is equal to the length of the head, and three to four times in the total. The upper maxillary bone reaches to below the middle of the eye. Opereulum with two fecble spines.

- Sea of Madeira.

a. Adult. Madeira. Presented by the Rev. R. T. Lowe.

b. Large specimen: stuffed: not good state. Madeira. From the Collection of the Zoological Society.

\section{Beryx delphini.}

Cuv. \& Val. ix. p. 454; Cuv. Règne Anim. Ill. Poiss. pl. 14. f. 3.
B. 10 .
D. $\frac{5}{16}$.
A. ? V. 1/13.
Cæe. pylor. 24.

Taken from the stomach of a dolphin in the Indian Ocean.

\section{POLYMIXIA.}

Polymixia, Lowe, Tráns. Cambr. Phil. Soc. 1838, vi. p. 198.

Nemobrama, Valenc. in Barker-Webb \&. Berthelot, Ichth. Iles Canar. p. 40.

Muzzlo short, with nearly horizontal eleft of mouth, and the upper jaw longest; eye large. Villiform teeth in both the jaws, on the vomer, the palatine and pterygoid bones. Four branchiostegals. Two barbels on the throat. Opereulum without spine; preopereulum indistinctly erenulated. Scales moderate. Ono dorsal; ventrals with six or seven rays. Caudal forked: anal with three or four spines.

Atlantic Ocean. 


\section{Polymixia nobilis.}

Polymixia nobilis, Love, l.c. tab. 4.

Nemobrama webbii, Val. l. c. p. 41. pl. 8
D. $\frac{5}{36-38}$.
A. $\frac{3-4}{16-18}$.
V. $1 / 6$ or 7 .
L. lat. 48-54. Vert. 29.

Abore uniform greenish; dorsal and anal black anteriorly.

Sea of Madeira, and St. Helena.

a. Adult. Madeira. Presented by the Rer. R. T. Lowo.

b. Adult: stuffed. St. Helena. Presented by General Hardwicke

c. Adult: stuffed. Old Collection.

One of the specimens exhibits seven rays in the rentral fins, as stated by Valenciennes. There are even eight in the figure given by him.

\section{Polymixia lowei. (Puate VII. fig. A.) \\ D. $\frac{5}{30}$. A. $\frac{3}{16}$. V. 17 . L. lat. 50 .}

Above uniform greenish; sides golden shining (in spirits). Caribbean Sea.

a. Adult. Cuba. From the Collection of the Zoological Society.

Description of the specimen.-This species rery much resembles in general appearance the only one hitherto known, but differs in having at least six dorsal rays less. The height of the body is nearly equal to the length of the head, and $3 \frac{3}{4}$ in the total. The greatest depth of the body is below the origin ot the dorsal fin; in front of this point the upper profile is slightly convex, but, rapidly descenda from the eye to the snout; the profile behind that point gradually descends to the caudal fin. The lower profile is nearly'straight between the snout and the anal fin.

The head has an obtuse and short snout, with the upper jaw orerlapping the lower; the interspace between the eyes is onefourth of the length of the head, and is covered with scales to near the anterior margin of the eyes. The cleft of mouth is wide, the upper maxillary reaching to behind the eye ; it terminates posterioriy in a broad plate with a convex posterior edge and a concave superior and inferior one. The lower jaw has a slight prominence in front, much smaller than in Myripristis, \&c. The eye is placed high up the sides, but does not interfere with the upper profile of head; its diameter is rather more than one-third of the length of head; the space below it is less than its diameter. The suborbital arch is broader as far as the maxillary reaches, and transformed into a half-channel, covered with a transparent skin. This part of the suborbital arch, the maxillary, and the dentary, are scaleless; all the remainder of the sides of the head is corered with scales of moderate size.

The opercles have no spines at all ; the operenlum and suboperculum are so uniformly covered with scales, that the border between them can be seen only after the scales are removed. The former is twice as high as wide, and the lower margin is straight, obliquely 
descending upwards; the sub- and inter-operculum have rounded lower margins, and both are situated in an oblique direction upwards. The prooperculum has a scaleless portion at its angle, which is rounded and indistinctly crenulated; the posterior margin descends obliquely towards behind. Of the humeral areh the supurascapula alone is slightly denticulated.

The two barbels arise in front of the branchiostegals from the basihyal (Owen), and reach as far behind as the base of the pectoral fin.

Pseudobranchia well developed.

The dorsal fin arises above the middle of the fish (the caudal not included), with five feeble spines, gradually becoming longer behind, but the fifth being about one-half only of the first ray, which is the longest; the following rays become shorter and shorter to the seventeenth, the remainder being very short and nearly equal in length. The last ray is one-fourth only of the first. The distance between the dorsal and caudal fins is $3 \frac{1}{2}$ in the length of the former. The cuudal fin is deeply forked, with pointed and equal lobes; the length of a lobe is about one-fifth of the total, and that of the middle (shortest) ray is one-fourth of the length of a lobe. The anal fin is similar in shape to the dorsal, but much shorter and lower. The third spine is about one-third of the first ray, which equals the fifth dorsal ray; the end of the fin fills just below that of the dorsal. The pectorals are short, pointed; they reach beyond the level of the origin of the dorsal, and are equal in length to that of the first dorsal ray. The ventral fins are very short; their spine is elosely attached to the first ray, and both ean be separated from one another by the linife only; the first ray is not branched, but articulated; the length equals the diameter of the eye, and the fin reaches scarcely beyond the pectoral.

The seales are rather oblique and irregular, with distinct coneentric layers on the free part and without serrature.

All the tceth are in very broad, velvet-like bands; that of the intermaxillary is elongate, cuneiform, broadest on its inner extremity ; nearly all the band is not covered by soft parts, and free, ontside of the mouth; the band of the mandibulary is narinwer and undulating. One broad band extends on the palatine and pterygoid bones, and confluent with it is an exceedingly lange and ovate patch of teeth on the entopterygoid bone. The vomerine teeth form a narrow band, tapering behind. The tongue and the branchial bones are covered with broad patches of villiform tecth. Thus this fish offers the most complete dentition in this and the following families.

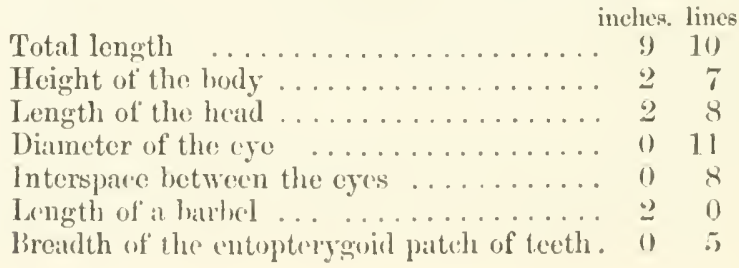




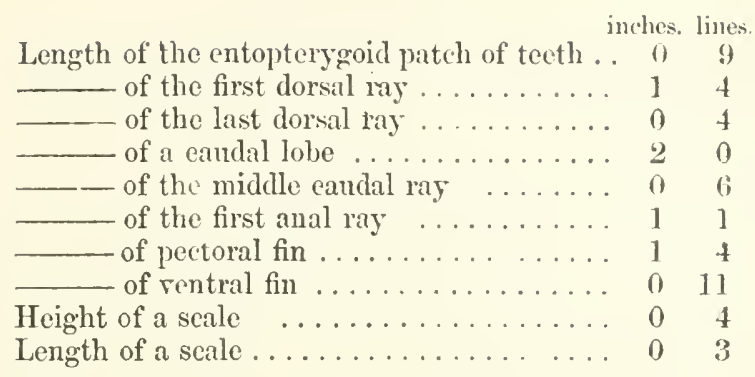

\section{MYRIPRISTIS*.}

Myripristis, Cur. Rène Anim.; Cuv. \& Val. iii. p. 100.

Ifuzzle short, with oblique eleft of month $\dagger$ and prominent chin ; eye generally large. Villiform tecth in both the jaws, on the vomer and palatine bones. Eight (exceptionally seven) branchiostegals. Opercular bones serrnted; operculum generally with a spine, præopereulum without spine. Scales large, ctenoid. Two dorsals, searcely united; ventrals with seven rays. Caudal forked; anal with four spines. Swim-bladder divided by a contraction; the anterior part extending to the otocrane. Pyloric appendages in moderate number.

Tropical seas of both hemispheres.

\section{Myripristis jacobus.}

Cuv. \&. I'al. iii. p. 162.
D. $10 \mid \frac{1}{14-15}$.
A. $\frac{4}{13}$ V. $1 / 7$.
L. lat. 36-38.
L. transv. $3 / 6$.
Caec. pylor. 9. Vert. 27.

The height of the bedy is one-third of the total length, the length of the head one-fourth; the interspace between the eyes is onefourth of the length of the head. The upper maxillary reaches a little to behind the middle of the eye; opereulum striated, the stria terminating in fine points at the hinder edge of the opereulum, abore a very feeble spine. Pectoral shorter than ventral; the third and fourth anal spines nearly equal in length, but the former broader. Gill-opening and base of pectoral fin brownish black.

Caribbean Sea; coast of Brazil.

a. Adult. Brazil. Presented by Lord Stuart.

b-e. Adult: skins. Jamaica. From Dr. Parnell's Collection.

f. Adult. Fine patria. From the Haslar Collection.

g. Adult: stuffed. Sine patria.

$h$. Young. Sine patria. From the Haslar Collection.

* 1. Myripristis borbonicus, Cuv. \& Val. vii. p. 489.-Isle de Frarce.

2. _- axillaris, Cuv. \& Val. vii. p. 491.-Isle de France

3. - botche, Bleek. Perc. p. 52.-Bataria.

4. —- violacens, Bleek. Banda, i. p. 234.-Banda.

+ In Myripristis lime the eleft of mouth is horizontal. 


\section{Myripristis pralinius.}

Myripristis pralinius, Cuv. \& Val. iii. p. 170, and vii. p. 486. Myripristis seychellensis, Cur. \& Val. iii. p. 172.
D. $10 \mid \frac{1}{15-16}$.
A. $\frac{4}{14-15}$.
L. lat. 38.
L. transv. $3 / 6$.

The height of the body is three times in the total length, the length of the head $3 \frac{1}{2}$; the interspace between the eyes is $4 \frac{1}{2}$ in the latter. The upper maxillary bone reaches to below the middle of the eye, and is distinetly denticulated beneath; a series of larger teeth along the outer margin of the upper jaw. Striæ and denticulations of the opereular pieces very fine; opercular spine indistinct. Pectoral longer than ventral, reaching to the level of the anus; the third and fourth anal spines are nearly equal in length, but the former is rather thicker. Red, with the upper part of the gill-opening and the base of pectoral black.

From the Isle de France through the Indian Ocean to the Pacific.

a. Adult. Celebes. From Mr. Frank as $M$. indicus.

$b-d$. Adult: stuffed. Louisiade Archipelago. Voyage of the Rattlesnake.

e. Adult. India.

\section{Myripristis kuntee.}

Sullanaroo-kuntee, Russ. Cor. Fishes, pl. 104.

Myripristis kuntee, Cuv. \& Val. vii. p. 487.

$$
\text { D. } 10 \mid \frac{1}{16} \text {. A. } \frac{4}{13} \text {. }
$$

The height of the body is one-third of the total length; the irterspace between the eyes rather narrower than one-fourth of the length of the head; the fan-like ridges on the head five or six in number; naxillary bone not serrated; teeth earduliform along the edge of the upper jaw. Shoulder, gill-opening, and base of the pectorals brownish black. ( $V a l$.)

Coast of Coromandel. Isle de France.

This species may prove to be the same as $M$. pralinius, the denticulation of the maxillary bone being a character of very little raluc.

\section{Myripristis bleekeri.}

Myripristis pralinius, Bleek. Banda, i. p. 234 (not Cux.).
D. $10 \mid \frac{1}{15}$.
A. $\frac{4}{13-14}$.
L. lat. 40 .

The height of the body is $3 \frac{1}{5}-3 \frac{2}{5}$ in the total length, the length of the head $4-4 \frac{1}{2}$; the interspace between the eyes is $3 \frac{1}{3}-3 \frac{1}{2}$ in the latter, vertex with 8 to 10 bony ridges on cach side, fan-like arranged. In front of both the jaws some larger tecth; the upper maxillary bone reaches to behind the middle of the eye, and is denticulated at the inferior angle. Opercular spine feeble. The dorsal fins nearly equal in height; pectorals longer than ventrals. 
Red, the upper part of the gill-opening and the base of the pectoral black. $(B l$.

Sea of Banda Neira.

\section{Myripristis leignathos.}

Valenc. Voy. Vénus, v. p. 316. pl. 4. f.1.

$$
\text { D. } 11 \mid \frac{1}{12} \text {. A. } \frac{4}{13} \text {. L. lat. } 38 \text {. }
$$

The height of the body is 3 times in the total length, the length of the head $3 \frac{3}{4}$; the interspace between the eyes is one-fourth of the length of the head. No larger teeth in the jaws; the upper maxillary reaches to behind the middle of the eye, and is nou denticulated; scapulary entire. Uniform red. ( $\mathrm{Val}$. )

Vew Ireland.

\section{Myripristis parvidens.}

Bleek. Amb. Ceram, p. 260; ? Cuv. \& Val. iii. p. 173.
D. $10 \mid \frac{1}{13-14}$.
A. $\frac{4}{12-13}$.
L. lat. 30 .

The height of the body is $3 \frac{1}{4}$ or 3 in the total length, the length of the head $3 \frac{3}{4}$; the interspace between the eyes is $3 \frac{1}{2}$ in, the length of the head. No larger teeth in the jaws; the upper maxillary reaches to behind the middle of the eye, and is not denticulated; opereulum with a fecble spine; seapulary cntire. Violet-reddish; fins rose-coloured, the outer rays of the caudal violet; opercular membrane and base of the pectoral deep black. $(B l$.

Sea of Amboyna.

\section{Myripristis murdjan.}

Sciæna murdjan, Forskal, p. 48.

Perca murdjan, Schneider, p. 86; Lacép. 1v. pp. 396, 418.

Russell, t. 105.

Myripristis murdjan, Cuv. \& Val. iii. p. 177, vii. p. 495; Rüppell, Atl. p. 86. t. 23. f. 2, and Fische des Rothen Mcers, p. 95 ; Bleeker, Amboina, iii. p. 19.
B. $8(7)$.
D. $10 \mid \frac{1}{13-14}$.
A. $\frac{4}{12-13}$.
L. lat. 28-30.
L. transv. 3/6. Vert. 10/15.

The height of the body is contained $3 \frac{1}{4}$ in the total length, the length of the head $3 \frac{3}{4}$; the interspace between the eyes is twoninths of the latter. The upper maxillary reaches behind the middle of the eye. Operculum with a feeble spine above; the upper maxillary with some denticulations; suboperculum notched before the pectoral fin. Pectoral reaching a littlc beyond the ventral to the level of the eleventh scale of the lateral line; the third anal spine stronger, but rather shorter than the fourth. Rosecoloured, seales with a violet edge; the soft dorsal, anal, and ventral fins with a white front margin, and the anterior rays with a 
violet-brownish cross-band; caudal fin above and beneath whiteedged, and each lobe with a violet-brownish longitudinal streak.

lied Sest Amboyna.

(t. Half-grown: stuffed. Red Sca. From the Frankfort Jiuseum.

๖. Adult. India. From Mr. Frank's Collection.

c, l. Adult. India.

\section{Myripristis adustus.}

Blecker, Amboina, iii. p. 18.
D. $10 \mid \frac{1}{15}$.
A. $\frac{4}{11-12}$.
L. lat. $28-30$.
Vert. 11/15.

The height of the body is $3 \frac{1}{4}$ in the total length, the length of the head $3 \frac{3}{4}$; the interspace between the eyes is one-fourth of the latter. The upper maxillary bone reaches to behind the middle of the eye; opereulum with a short feeble spine. Pectoral reaching a little beyond the ventral to the level of the tenth seale of the lateral line. 'The third anal spine stronger', lout rather shorter, than the fourth. Above reddish-violet, seales with a violet edge; gill-opening and base of the pectoral black; the spinous dorsil violet; the other vertical fins rose-colomrer, with broad black tips.

Sea of Amboyna.

$a, b, c, d$. Adult. Amboyna. From Mr. Fiank's Collection. e, f. Adult. Sine patria. From Mr. Frank's Collection. \%. Half-grown. Amboyna. From Mr. Frank's Collection.

Skeleton.-The bones forming the roof of the skull are so elosely attached to one another and show such continuous ridges, that it is nearly impossible to point ont the sutures between the single bones without separating them altogether. The supraoceipital crest is limited to the posterior part, without extending on its upper surface. There are two principal ridges longitudinally running along the middle of the interspace between the eycs. Leaving posteriorly a narrow eavity between them, they are close side by side anteriorly, and then diverge to form a short triangular groove for the posterior processes of the intermaxillary bones. Between each of these ridges and the orbit is an longate cavity, tapering at both ends; the longer posterior part belongs to the prineipal frontal bone, the shorter anterior to the turbinal; both the turbinal bones receive between them the short groove for the processes of the intermaxillaries; from about the middle of the upper part of the orlit arises another ridge, similar to those mentioned, and running backwards soon radiates into branches, which again bifureate and form the fan-liko expansion characteristic of the species of $M y \times i-$ pristis and Holocentrum.

The maxillary bone is styliform in its inner half, then suddenly widens into a broal plate, with an acute angle behind and a rounded one in front; the latter is furnished with several granular prominenees; the supplementary bone is oblong, about four times as long as broad, and has a styliform upper process. The intormaxillaries are separated from one another by a small noteh, thes 
are three-fourths as long as the mixillary, and have a slight prominence behind. 'The mandibularies are rather short and ligh; wach is distinguished by a small protuberance in front.

The elentition is chictly formed by broad bands of fine villiform tecth; at severil places are small, short, granular prominences, similar to those of the angle of maxillary, and more like apophyses than true teeth. Such granulations maj be seen strongest in front of both the jaws, on the protuberanees of the bones, but moreover also on the outer edges of intermaxillary and mandibulary. The band of the upper jaw is nearly twice as broad as that of the dentary bone; both reach to the extremities of their bones. All the other teeth are excedingly fine and velvet-like; those of the romer form a triangular pateh with concave sides, those of the palatines a cunciform band, broad anteriorly, and do not extend beyond that bone. The teeth of the pharyngo-branchials are placed in an ovate group with several smaller ones besides.

The inficaorbital arch is rather nirrow and nearly equally broad, the prxorbital not being widened on aceount of the shortness of the suout. It is transformed into a bony half-channel, the open side of which is covered by a thin membrawe, and the edges of which are finely serrated. The arch has inside a narrow, concave, and thin plate for supporting the cye-ball from beneath. The entopterygoid is very broad, and attached to the hasisplienoid by a narrow ligament only, so that the bottom of the orbit is nearly entirely bony.

All the opercles are distinctly striated as far as they are not covered by scales. The operculım is more than twice as high as wide; on its upper third it has a flat ridge terminating in a distinct point, above and below which is a slight notch; the serrature is fine, but distinct, The subopereulum is narrow, witl a shallow notch before the peetoral fin, and three or four very slight denticulations beneath. The interoperculum is two and a half as long as high, distinetly, but more finely serrated than the opereulum, and has a convex lower margin. The pricoperculum is distinguished by two nearly parallel serrated edges; the posterior pair is finely serrated, like the interoperculum, the serrature of the supplementary ridge being rather indistinct; the inferior pair has both the edges equally and finely serrated. Both the pairs meet at a rather obtuse angle, and here the serrature is somewhat stronger and more like that of the opereulum.

The skull of Myripristis shows the remarkable peculiarity of a large oval opening, elosed by an elastic membrane-an internal tympanum. The opening appears to belong to the alisphenoid bone; at the bottom of the eavity is plaeed a large otolith. The membranaceous cover is in immediate connexion with the lobe of the anterior. part of the air-blidder, and attached to it is an elastic, bony, excavated plate, in form similar to the tragus of the common Bat, and arising from the lower posterior angle of the opening. $A$ similar form of connexion between the air-bladder and the restibulum is found in Holocentrum, Priacunthus macrophthalmus, Sparus, Sargus, Salpa, \&c.

The hemeralateh is likewise striated and serrated, but more so at 
the bones which are situated higher up the sides. The humeral is formed as in the Percidæ generally, but rather shorter; the urohyal is triangular, short and broad.

The pubric bones are peculiarly shaped, short, much higher (in the vertical line) than broad (in the horizontal); they are attached to one another with an upper suture, terminating in a point anteriorly, and with a second very coneave one in front. They form together a trihedral eavity with the entrance from beneath; each of them terminates behind in a broad process, which together form a plate, in form not unlike one of the scales of the fish. There is another styliform process along the entrance to that cavity, arising from the symphysis of the bases of the ventral fins.

The hyal and branchial apparatus show no peculiarity.

There are eleven abdominal and fifteen caudal vertebre, the length of the abdominal part of the vertebral column being $1 \frac{1}{3}$ in that of the caudal. The hæmal spines are stronger and somewhat longer than the neural. Twelve ribs; the fourth to the eighth rib have another small rib (epipleural spine) attached; but such epipleurals, belonging to the posterior ribs, are inserted on the vertebræ themselves. The ribs of the eleventh vertebra are very broad, swordshaped, and separated from one another. The strongest interhæmal is apparently formed by two, belonging to the second and third dermohæmals; it has a deep longitudinal groove, and is as long as the first eight rertebræ together.

\section{Myripristis microphthalmus.}

Bleek. C'er. Amb. p. 261.

$$
\text { D. } 10 \mid \frac{1}{14-15} \text {. A. } \frac{4}{12-13} \text {. L. lat. } 30 \text {. }
$$

The height of the body is $2 \frac{4}{5}$ in the total length, the head is onefourth; the interspace between the eyes is one-fourth of the length of head, and the diameter of the eye is $2 \frac{1}{2}$ in the same. Several larger canine-like teeth in the jaws; the upper maxillary bone dentieulated, reaching to behind the middle of the eye. Seapulary entire. Rose-coloured, the scales of the back with violet margin; fins rose-coloured; root of the pectoral black. ( $B l$.

Sea of Amboyna.

\section{Myripristis vittatus.}

Cuv. \& Vul. vii. p. 492.

$$
\text { D. } 10 \mid \frac{1}{14} \text {. A. } \frac{4}{12} \text {. }
$$

The upper maxillary bone with five or six distinct denticulations; the spine of opereulum very indistinet; opereulum striated; the third anal spine very strong and thick. On each side five or six blackish longitudinal bands; the rertical fins yellow, the others reddish; no black at the gill-opening, or at the basc of the pectoral fin. ( $V_{a l}$.)

Sea of Isle de France. 


\section{Myripristis japonicus.}

Myripristis japonicus, Cur. \& Val. iii. p. 173. pl. 58; Faun. Japon. p. 23. pl. 9 a; Richardson, Ichth. China, p. 222.

? Myripristis pralinius, Richardson, l. c. p. 223.
D. $11 \mid \frac{1}{14}$.
A. $\frac{4}{11}$.
L. lat. 27-29.
L. transv. $3 / 7$.

The height of the body is equal to the length of the head (opercular spine included), and one-third of the total; the interspace between the eyes is one-sixth of the length of head. The upper maxillary bone reaches a little behind the middle of the eye, and is not denticulated. The operculum is strongly striated, the strix terminating in points at the posterior edge; a very strong and long opercular spine, each scale with one or more stronger spinous teeth in the middle of the posterior edge; the third anal spine much stronger and also longer than the fourth, about the same size as the opercular spine. Uniform red.

Japanese Sea; Isle de France.

a. Large specimen: stuffed. Japan. Purehased.

b. Adult: stuffed. Isle de France. From Dr. Janvier's Collection.

c. Half-grown: skin in spirits.

d. ? Half-grown : skin in spirits. China. Presented by J. R. Reeves, Esq. (Lateral line 30. D. 11 $\mid \frac{1}{13}, \quad$ A. $\frac{4}{12}$.)

\section{Myripristis trachypoma. (Plate III.)}
B. 8 .
D. $11 \mid \frac{1}{13}$.
A. $\frac{4}{10-11}$.
V. $1 / 7$ P. 15.
C. $\frac{4-3}{25}$.
L. lat. 29 .

\section{L. $\operatorname{transv}, 3 / 7$.}

The height of the body is nearly equal to the length of the head (opercular spine included), and $2 \frac{3}{4}$ in the total; the interspace between the eyes is one-sixth of the length of head. All the teeth villiform; the upper maxillary bone reaches behind the middle of the eye, and is not denticulated. Opereles covered with spines, and operculum with a rather strong spinous prominence; scales ctenoid, but the denticulations equal; the third anal spine much stronger and also longer than the fourth. Red, with longitudinal bands.

Caribbean Sea.

a. Adult. Cuba.

b. Adult. West Indies. Purchased of Mr. Serivener.

Description.-This new species is entirely different from the other one from the West Indies, viz. Myripristis jacobus, and is closely allied to Myripr. japonicus.

Two characters alone justify a scparation from the latter-the scales in the Japanese species having one or two spinous teeth, stronger than the other part of the serrature, and the much larger size of the opercular spine. The form of the body is the same.

All the teeth are villiform, except those which cover the two prominences in front of - the lower jaw. The lateral margin of the lower jaw is not straight, but undulating; the vomerine teeth form a small obtuse-angled triangle. The upper maxillary bone is very 
broad behind, abont half as broad as long; the supplementary bone clongate, sword-shaped, and covered with minute spines, like the lower jaw. The eye is about one-third of the length of head (opercular spine included ), and nearly cirenlar. 'There are the bony ridess and grooves on the upper surface of the skull, covered with a thin and half-transparent skin, as in the other species of Myripristis: an clongate groove extends from the occiput to the middle of the space between the eyes; on the hinder part it is half divided into two by a narrow longitudinal ridge. In the middle of the forehear are two ridges, divergent postcriorly and anteriorly, forming posteriorly the carity mentioned, and in front a space for the upper processes of the intermaxillary; these ridges are in direct contact with one another, remaining separated in other species. Jictween ach of these ridges and the orbit is situated another elongate carity, tapering at both ends, and cxtending beyond the nostril. On the sides of the vertex are two or three bony ridges with a rough surface, but they are not fun-like arranged, as in other species. The suborbital arch is transformed into one continuous carity, the bony edges of which are conspronous and finely serrated. All the opereular pieces are striated, and each strual terminutes in a small spine before reachimy the posterior edlye of the bone, the bones thus receiving a rough, spinous appearance. The operele is narow, with a transwerse licel towards the top, ending in a strong promincnt spine, of about the size of the first dorsal spene; along its base is a series of etenoid scales: there is a notch above the spine, but the lower edge is straight and spiniferous. The subopercle is very narrow, with a sinus just before the base of the pectoral fin, and a slight transverse ridge beneath, terminating in a small point. The margin above the simus is slightly comvex and spiniferous. In the interopercle may be distinguished a stmight posterior edge, a right angle, and a rather unclulating lower margin; it is spiniferous in all its cireumferenee. The preoperele exhibits two concentric ridges, finely serrated, and with a channellike eavity between; the cavity is again covered with a transparent shin; the angle is rounded; the ehecks are eovered with seales.

'There are six scales between the oceiput and the first dorsa' spine. The spinous clorsul is $2 \frac{1}{3}$ as long as the soft, but nearly counal in height; they are united by a low membrane, reaching from the cleventh to the twelfth spine. 'The third, fourth and fifth spines are longest, the fourth twice as long as the first; the eleventh is only half the size of the first. The twelfth spine, or the first of the soft dorsal, is a little longer than the preceling, and placed on the level of the seventeentl scale of the lateral line. 'The fourth and fifth rays are longest, their length being contained $2 \frac{1}{2}$ in the greatest depth of body.

'The anal fin eommenees opposite the second dorsal with a minute spine; the second is ronsiderably larger, the third longest and stromgest, not quite an long as the third dorsal one; postcriorly it is providerl with a renp durlow, in which the fourth spine together with the connereting membrane may he hiclden. This fouth spine

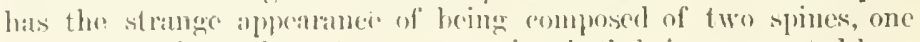

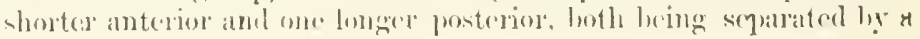


longitudinal furrow; this spine is as long as the first dorsal one. The first ray is articulated, but not bifid; the second is longest, even a little longer than the longest dorsal ray; the following rays gradually decrease in length, and the end of the anal falls short behind that of the dorsal.

The caudal fin is moderately forked, and its length is contained $5 \frac{1}{3}$ in the total.

The pectorals reach to the level of the anus, are rather pointed, and their base falls below the first dorsal spine. The first ray is only one-third of the length of the fin, and not branched as the second; the fourth and fifth are longest.

The ventrals are shorter than the pectorals, placed immediately below their root, and do not reach as far behind; they are composed of a strong, flat, striated spine, not much shorter than the longest ray, and of seven branched rays. There is a deformity on one side of one of the specimens, which, if present on both the sides, or in a dried specimen, one-half of which only is preserved, might lead to the creation of a nominal species, or even genus: viz. on the right side there are, besides the long outer spine, five rays only, and a small inner spine instead of the two others, The spines of all the fins are striated.

The scales are smooth, finely and equally serrated on the posterior edge; the largest ones are placed, not in the lateral line, but in two series below that; they are twice as high as long, and one of the largest eovers not even one-third of the eye.

The colour appears to have been red, without any spot; there are longitudinal bands visible along each series of scales; the bands are silvery above the lateral line, and slightly reddish (shining golden in life?) beneath.

\begin{tabular}{|c|c|c|}
\hline & inche & limes. \\
\hline Total length.... & 7 & 5 \\
\hline Length of head & 2 & 8 \\
\hline 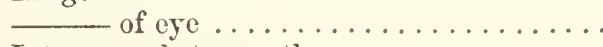 & 0 & 9 \\
\hline pace between the eyes $\ldots \ldots \ldots \ldots$ & 0 & $5 \frac{1}{2}$ \\
\hline t height of body ............. & 2 & 10 \\
\hline igth of fourth dorsal spine . . . . . . . . & 1 & 1 \\
\hline aird anal spine $\ldots \ldots \ldots \ldots$ & 0 & $11 \frac{1}{2}$ \\
\hline of ventral spine $\ldots \ldots \ldots \ldots \ldots$ & 1 & \\
\hline of a large seale $\ldots \ldots \ldots \ldots \ldots$ & 0 & 7 \\
\hline h of a large seale $\ldots \ldots \ldots \ldots \ldots$ & 0 & $3 \frac{1}{2}$ \\
\hline
\end{tabular}

\section{Myripristis hexagonus.}

Lutjanus hexagonus, Lacép. iv. p. 213.

Myripristis hexagomus, Cur \& Irul. iii. p. 171, rii. p. 489 ; Foy. de l'Astrol., Poiss. p. (674. pl. 14. f. 5 (not good).
1. $10 \mid \frac{1}{14}$.
A. $\frac{4}{13}$.
L. lat. 33 .
L. transv. $3 / 7$.

The height of the borly is three tines in the total iength, the lengtl of the head $3 \frac{1}{4}$; the interspace between the eyes one-fifth of the length of the head. Oprelulum with a vere distinct spine: the 
iupper maxillary reaches far behind the middle of the eye, and is denticulated beneath. Subopereulum not notehed. Pectoral reaching a little beyond the ventral, to the level of the fifteenth seale of the lateral line; the third anal spine much stronger and also longer than the fourth. Red; the front edges of the soft dorsal, of anal, and of rentrals, and the upper and lower edges of the eaudal, pure white. Gill-opening and a spot in the arm-pit brownish black.

Seas of Isle de France, Boeroe.

a. Adult. Mauritius. From the Collection of the Zoological Society.

\section{Myripristis lima.}

Cur. \&. Íal. vii. p. 493; Règne Anim. Ill. Poiss. pl. 14. f. 2.

$$
\text { D. } 11 \mid \frac{1}{14} \text {. A. } \frac{4}{11} \text {. V. } 1 / 7 \text {. L. lat. } 46-47 .
$$

The height of the body is equal to the length of the head, and one-third of the tutal; the interspace between the eyes is one-sixth only of the length of the head. The lower jaw has a horizontal direction, and not an oblique one, as in the other speeies of Myripristis. Opereulum with three or four distinct points at the angle. Caudal not deeply forked, with rounded lobes. Uniform red. (Val.)

Sea of Isle of France.

\section{HOLOCENTRUM*.}

Holocentrum, Artedi in Scba, iii. tab. 27. f. 1; Cut. \& Fal. iii. p. 182. Corniger, Ayass. in Spix, Pisc. Bras. p. 121.

Muzzle moderate, nearly horizontal ; jaws equal in front, or the lower slightly prominent; eye large. Villiform teeth in both the jaws, on the vomer and on the palatine bones. Eight branchiostegals. Opercular bones and suborbitals serrated ; opereulum with two spines, a large spine at the angle of pracoperculum. Seales moderate, etenoid. Two dorsals, searcely united; ventrals with seven rays. Caudal forked; anal with four spines, the third very long and strong. Swim-blarlder simple, oval. Pylorie appendages in inereased number.

Tropical Seas of both hemispheres.

\section{Holocentrum longipinne.}

Jiquaraca, Murcyr. p. 147; Lichtenst. Abhanll. Berl. Acad. 1820, p. 279. Catesby, Hist. Nut. Carol. ii. pl. 2. f. 2.

Matejuels, Parra, p. 23. pl. 1:3. f. 2.

* 1 Perca ascensionis, (Limn.) Osheck, Reise nach China, p. 38s.-Amphacanthus aseensionis, Bl. Schn. p. 2I0.-Lutjanus ascensionis, Lacép. iv. p. 197.--Holocentrum ascensionis, Cuv. of $V^{2}$ ul. iii. p. 212.-Ascension Island.

2. Holocentrum argenteum, Cuv. of Iral. vii. p. 502; Foy. Astrol., Poiss. p. 677. pl. 14. f. 2.-New Guinca.

3. Holocentrum marianum, Cuv. of lol. iii. p. 219--Martinique.

4. Holocentrum leonoides, Blick. Perc. p. Tht.-Celebes.

5. Ilolocentrum binotatum, Blect. Gorrm. p. 20(1).-Croran. 
Bodianus pentacanthus, Bloch. t. 225 (very bad); Shan, Zool. iv. p. 570 . pl. 83 (very bad).

jaguar, Lacép. iv. p. 286 (bad).

Scixna rubra, Bl. Schn. p. 82 (not Forsk.).

Amphiprion matejuels, Bl. Schn. p. 206.

Holocentrus sogho, Blorh. t. 232.

Holocentrum longipmne, Cur. \& Val. iii. p. 185, vii. p. 490.
D. 11
15.
A. $\frac{4}{11}$. V. $1 / 7$.
L. lat. $47-50$.
L. transv. 47 .
Cæc. pylor. 25. Vert. 11/16.

The height of the body is $3 \frac{1}{2}$ in the total length. the length of the head four times; the interspace between the eyes is $6 \frac{1}{2}$ in the latter (opercular spine included). Operculum with two flat spines, the lower of which is the smaller. 'The third and fourth dorsal spines longest, the soft dorsal fin as high as the body; the length of the caudal is $3 \frac{1}{2}$ in the total, the upper lobe much longer ; the third and fourth anal spines longest, but the former much longer and stronger ; the ventral fins reach near to the anus, much longer than pectoral. Reddish, with more or less distinet shining longitudinal bands.

Caribbean Sea; Coast of Brazil.

a. Fine specimen. Cuba. Presented by the Zoological Society.

b. Adult. Cuba. Presented by the Zoological Society.

$c-k$. Adult and half-grown: skins. Jamaica. From Dr. Parncll's Collection.

l. Half-grown. st. Christophers. Presented by Dr. J. E. Gray. $m$. Adult. West Indies. From the Haslar Collection.

n, o. Adult: not good state. West Indies.

$p-r$. Adult: stuffed. West Indies. From Mr. Serivenor's Collection.

s. Half-grown: stuffed: not good state. Bahia.

t. Adult. America. Presented by the Zoological Socicty $u-x$. Adult: stuffed. America.

y. Half-grown. America. Presented by the Zoological Society.

\section{Holocentrum furcatum. (Plate IV.)}

\section{11 16. A. $\frac{4}{10}$. L. lat. 50 . L. transs. 47.}

The height of the body is equal to the length of the head, and not quite one-fourth of the total length. The interspaec between the eyes is $6 \frac{3}{4}$ in the length of the head. Snout shorter than the diameter of the eye; the upper maxillary reaches nearly to bclow the middle of the eye. Operculum with one very large spine and several very small ones beneath; the præopereular spine one-half of the length of the posterior edge of proopereulum, the second to fifth dorsal spines longest, not quite one-half the height of the body ; the soft dorsal fin elongate; eaudal very deeply forked, with slender ind elongate lobes, the upper much longer than the lower. The hird anal spine longest, but one-eighth only of the total length Red, with lighter longitudinal bands.

a. Adult: stuffed. South Sea. 
Description of the specimen.-This species would belong to those with the form of the body elevated but for its long and slender candal fin and the posterior part of the tail, which is narrower than in other species, but stouter than in $H$. longipinne.

The lower jaw is slightly prominent, and the upper maxillary reaches nearly to below the middle of the eye. The length of the snout is six-seventlss of the diameter of eye. The upper profile of the head is slightly convex; the two oony ridges between the eyes run nearly parallel, and distant from one another, to receive in front the groove for the processes of the intermaxillary bones, which is equal in length to that of the snont. The fan-like expansion is formed by about ten or eleven radiating ridges; the turbinal bones do not terminate in a prominent process. The diameter of the eye is one-third of the length of head; the anterior suborbital has a strong prominent tooth in front. The opereles are irregularly striated. The opereulum terminates in an uncommonly strong spine, beneath which are several very small ones, not much larger than the other denticulations of the margin. The sub-and interoperculum have four or five small spinous teeth in their upper third; the remainder of the margins is entire. The preoperenlum has a vertical posterior margin, fincly serrated, and a strong and straight spine at the angle; the lower margin is indistinctly serrated.

The spines of the dorsal fin are strong, the seeond to fifth longest. The soft dorsal is rather elongate; the first ray is equal in length to the fifth spine, the third not quite twice as long and the last onethird only of the first. The upper lobe of the caudal fire is fery elongate, its length is $3 \frac{\mathrm{z}}{3}$ in the total; the lower is $4 \frac{3}{5}$ in the same length. Also the soft part of the anal fin is rather elongate, longer than the third spine, but lower than tho dorsal. The peetorals are much shorter than the elongate ventrals; they reach to the level of the sixteenth scale of the lateral line, whilst the extremity of the latter corresponds to the twenty-first.

The seales are distinctly serrated on all the posterior margin. The coloration appears to have been red in life, with lighter longitudinal bands; the fins are now entirely uniform.

Total length ................. 1011

Height of the body . . . . . . . . . . $2 \quad 9 \frac{1}{2}$

Length of the head ............. $2 \quad 9 \frac{1}{2}$

Interspace between the eyes ......... 0 . $4 \frac{2}{3}$

Length of the snout.............. 0 10

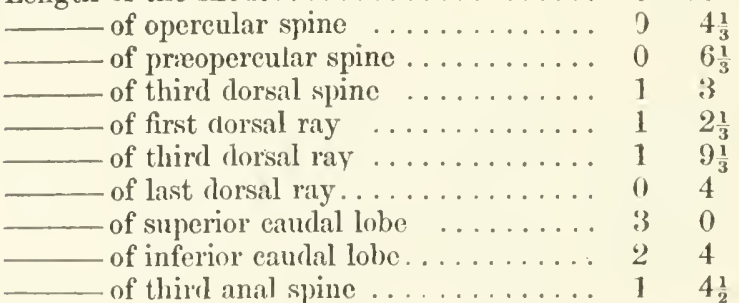




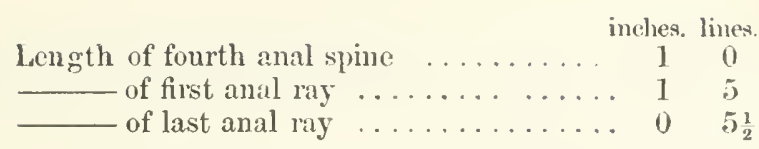

3. Holocentrum macropas. (Plate I, fig. B.)

D. $11 \mid 15$. A. $\frac{4}{9}$. L. lat. 52. L. transv. 47.

Body rather elongate. Ventral fins very long, as long as the head. Opereulum with a very strong spine, and a very small one beneath; preopercular spine moderate, one-third of the length of the posterior margin of preoperculum.

a. Adult: stuffed. Isle de France. Purehaser of Sir A. Smith.

Description of the specimen.-Although the greater part of the fins in the specimen are injured, 1 do not hesitate to found on it a speeies, as the ventrals are well preserved, and offer a character whereby it may be distinguished from every other species of the genus. In the measurements given in this species, the total length is to be understood from the snout to the root of the ceuclal fin only, as this fin is nearly entirely lost.

'The height of the body is nearly equal to the length of the head, and $3 \frac{3}{5}$ in the total; the interspace between the eyes is $6 \frac{1}{4}$ in the length of the head; the two bony ridges radiate behind in about ten branches. The snout is pointed, its length being $\frac{5}{6}$ ths of the diameter of the eye; the groove for the proeesses of the intermaxillary bones is still shorter; the turbinal bone does not terminate in an anterior prominent spine: the upper maxillary reaches not quite to below the middle of the eye. The diameter of the eye is $3 \frac{2}{5}$ in the length of the head all the surrounding infraorbital bones are serrated and the anterior is armed in front with a very strong enrved tooth. 'The opereulum is distinetly striated, the strix terminating in fine marginal points; the upper spine is very strong, as in $I I$. furatum, whilst the inferior resembles more one of the other denticulations. 'The subopereulum has also some strive, terminating in spinous points, coarser than those of the opereulum. Interopereulum striated and serrited. Both the edges of the præopereulum are finely serrated, like the operculum; the spine at the angle is of moderate length.

The third, fourth and fifth dorsal spines are longest, nearly onehalf the height of body. The soft dorsal has no spine in front, and does not appear to have been elevated. The caudal fin has been forked. 'The first spine of the anal is minute, the second straller than the opereular spine, the third strongest, scarcely longer than the longest of the dorsal fin, the fourth is a little shorter than the fourth; the first ray is rather elongate, and higher, than the longest of the dorsal fin. The pectorals are short, and probably have not reached further than to the level of the eleventh or twelfth seale of the lateral line. The ventral fins are formed by one spine 
and seven soft lays; the former is slender, and as long as the third anal spine; of the rays the third is longest, equal to the height of the body, and reaching to the level of the twenty-third scale of the lateral line.

The scales are finely serrated.

The coloration appears to have been red, with longitudinal bands of a dusky colour.

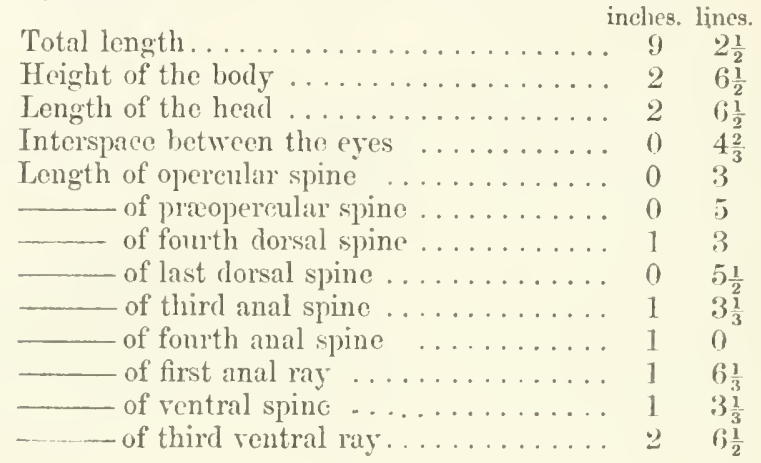

\section{Holocentrum pœcilopterum.}

Bleeker, Kokos-Eilanden, p. 3isf.

$$
\text { I). } 11 \mid \frac{1}{13} \text {. A. } \frac{4}{9} \text {. I. lat. } 52 \text {. }
$$

The height of the body is $3 \frac{3}{4}$ in the total length, the length of the head $3 \frac{1}{2}-3 \frac{2}{3}$. Opereulum with two strong spines, the lower of which is smallest. The upper maxillary bone reaches to behind the middle of the eye. The fourth and fifth dorsal spines lonerst; the soft dorsal fin is less than half as high as the body; the length of the caudal is $5 \frac{1}{2}$ in the total, the upper lobe is longer; the third anal spine rery thick, and nearly twice as long as the longest of the dorsal fin; ventral fius not very much longer than the peetorals. lied, with lighter longitudinal bands; the first dorsal yellow, with two longitudinal series of large round rose-coloured spots. (Bl.)

Sea of Cocos Island.

\section{Holocentrum erythrum. (l'LATE V.)}
D. 11
15. A. $\frac{4}{10}$.
I. liat. ts.
L. tiansr. 36 .

The height of the body is nearly cqual to the length of the head, and $: 3 \frac{1}{3}$ in the total; the interspace between the eyes is $5 \frac{1}{2}$ in the length of the head. The upper maxillary bone reaches to below the middle of the eye; jaws equal in front; the groove for the processes of the intermaxillaries is slightly longer than the diameter of the eye; turbinal hone terminating in a buny anterior process, slightly forked, but not corering the intermaxillary. The 
third to sixth dorsal spines longest, one-third of the height of body ; both lobes of the caudal equal, and one-fifth of the total length. The third anal spine is not very much longer than the fourth, not twice as long as the longest of the dorsal, and $5 \frac{3}{4}$ in the total length. Ventral fins scarcely longer than the pectorals. Red, with lighter longitudinal bands; the spinous dorsal with a longitudinal series of round white spots, always one betwecn two spines.

Sea of S. Christoval.

a. Adult. From the Collection of the Zoological Society.

b. Adult: stuffed. S. Christoval. Voyage of the Herald.

Description.-This species appears to be near Holoc. pocilopterum, from which, however, it differs in several respects, as is evident from the diagnosis giver above; from Hol. tiere it may be distinguished by eleven dorsal spines, and from $H$. tieroides by a greater number of scales in the lateral line. It belongs to the species with high body and compressed head. The snout is rather pointed, and equal to the diameter of the eye; the vomerine teeth stand in an obtuseangled triangle, with a rather concave posterior edge. The anterior infraorbital bone has a rather strong tooth in front of the supplementary bone of the maxillary, and another rather smaller one beneath the anterior half of the orbit; between them are five or seven small ones; the remainder of the infraorbital arch is finely serrated. The number of the radiating ridges on the occiput varies on both sides from seven to nine. All the opercles are very strongly striated over all their surface, and deeply denticulated behind; so also the scapulary bone. The size of the opercular spines varies: there are-

In specimen $\alpha$. on the right side, two strong spines, the upper rather longer.

In specimen $a$. on the left side, two spines, the lower indistinet.

In specimen $b$. on the right side, two strong spines, the upper rather longer.

In'specimen $b$. on the left side, two equal strong spines.

The præopercular spine has two deep grooves, and is one-half of the length of the posterior margin of præoperculum; suboperculum serrated along its whole length, interoperculum entire in its anterior half.

The spinous dorsal is very low, its longest spine being one-third only of the height of the body; the last spine is two-thirds of the first. The longest ray of the soft dorsal is the third, being longer than one-half of that height. The soft dorsal begins on a level with the twenty-eighth scale of the lateral line. The caudal fin has, as usual, some spinous rays on the upper and lower side of the root; the lobes are equal to one-fifth of the total length, and pointed. The anal commences opposite the soft dorsal; the first spine is minute; the second very small, shorter than the shortest of the dorsal; the third longest, but shorter than the longest ray of the anal, and contained $5 \frac{3}{4}$ in the total length; the fourth spine slender, twice as long as the first of the dorsal fin; the first ray is the longest, one-fifth of the total 
length, and more than four tines as long as the last. The pectoral fins reach to the level of the nineteenth seale of the lateral line, the ventrals to that of the twenty-second.

The scales are not striated, but finely serrated at the posterior margin ; one of the largest eovers one-third of the oye, and is twothirds as long as high.

The coloration appears to bo red, with bands of a lighter tinge along each series of seales. No other markings are visible, except the round whitish spots, rorming a series along the middle of the spinous dorsal; there is another triangular spot behind the tip of caeh spine. In life the round spots may have been blue, and the triangular ones rose-coloured.

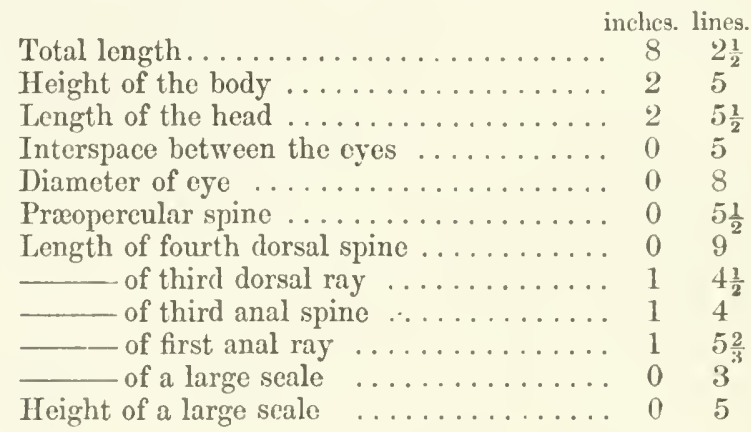

6. Holocentrum microstoma. (PLATE VI. fig. A.)
D. $11-12 \mid 13$.
A. $\frac{4}{9}$.
I. lat. 47-53.
L. transF. $4 / 7$.

The height of the body is nearly four times in the total length, the length of the head $3 \frac{2}{3}$; the interspace between the eyes is $4 \frac{3}{5}$ in the latter. Lower jaw rather prominent; snont rather pointed, shorter than the diameter of eye; the uppes maxillary reaching to below the anterior third of the eye. Opereutum with two prominent spines, the upper of which is the longer. Præopereular spine small, not much stronger than that of opereulum. The fourth, fifth and sixth dorsal spines longest, one-half of the height of body; lobes of the candal equal; the third anal s\}mne much longer and stronger than the fourth, one-fifth of the total length; peetorals shorter than ventrals. IRed, with lighter longitudinal bands; a small brownish speek behind the first dorsal spine.

a. Adult. Amboyna. From Mrr. Frank's Collection.

๖. Half-grown. Old Collection.

Description...The form of the body is rather elongate, the snout of moderate length, four-fifths of the diameter of eye (difference from $I I$. laticeps). 'The interspace between the eyes is nearly equally broar behind and in front, but. with a slight concavity above the middle of the eye. The two bony ridges are ristant from one 
anther and parallel; the groore for the processes of the intermaxillary bones goes not very far behind, its length being the same as that of the snout. The turbinal bone terminates in front in an obtuse point, scarcely covering the intermaxillary. 'The mouth is smaller than in most of the other species, the upper maxillary reaching to below the anterior third of the eye only. The diameter of the eye forms nearly one-third of the length of the head (opercular spine always included).

All the opercles are striated and denticulated, as the scapular and humeral bones. The preoperculum has a short spine, rather longer than one-third of the posterior margin of this bone; the margin is vertical.

The dorsal spines are moderately thick; the spinous and soft dorsal fins are equal in height, one-half of the depth of the body. The lobes of the caudal are equal, pointed, and $5 \frac{2}{3}$ in the total length. The first spine of the anal fin is minute; the second shorter than the shortest of the dorsal; the third longest, even longer than the rays, one-fifth of the total length; the fourth is strong, about the length of the second of the dorsal, and may be entirely hidden in a groove of the third. The pectorals are rather short, one-sixth of the total length, and reach to the sixteenth scale of the lateral line. The spine of the ventrals is one-third of their own length, rather slender; the length of the longest ray is nearly one-fifth of the total, and the fin reaches to the level of the twenty-second scale of the lateral line.

The scales are not striated, but finely serrated at the posterior margin; one of the largest not covering cren one-fourth of the eye.

Red, with violet tinge on the back, and silvery on the belly; lighter bands along each series of seales. The tins are now uniform. yellowish white; an indistinct brownish speck is still visible between the first two dorsal spines.

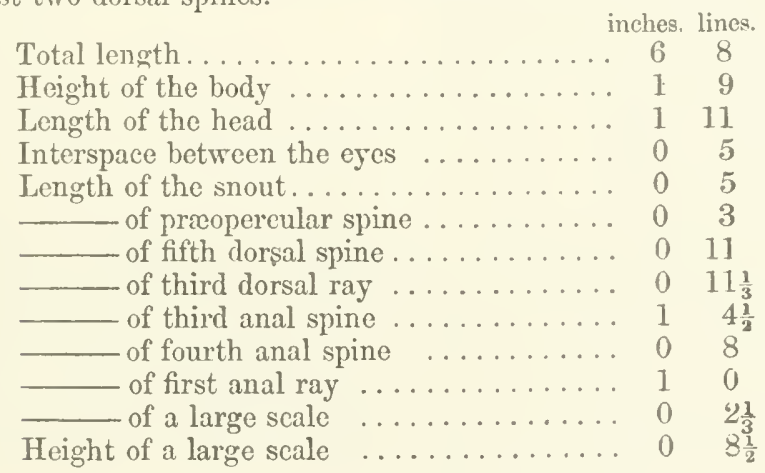

\section{Holocentrum rubrum.}

Seba, iii. 27. 1.

Scirna rubra, Forsk. p. 48 (not Bl. Schn.).

Renard, Poiss. t. 29. f. 159 ; Valentyn, Ind. iii. p. 320 . f. 137. 
Perca rubra, Bl. Schn. p. 90.

praslin, Lacëp. iv. p. 418.

Holocentrum alborubrum, Lacép. iv. p. 372 ; Richardson, Ichth. China, p. 223.

orientale, Cuv.\& Val. iii. p. 197, vii. p. 497 ; Bleeker, Perc. p. 53. Holocentrus ruber, Rüpp. Atl. p. 83. t. 22. f. 1 , and N. W. Fische, p. 96. Holocentrum marginatum, Cuv. \& Val. iii. p. 216.

— spinosissimum, Richardson, l. c. p. 223 (not Fauna Japon.)
D. 11 | 12-13.
A. $\frac{4}{9}$.
L. lat. 35-37.
L. transv. $3 / 6$.

\section{Cæc. pylor. 20. Vert. 11/16.}

The height of the body is equal to the length of the head (opercular spine included) and $3 \frac{1}{2}$ in the total ; the interspace between the eyés is one-fifth of the length of the head. 'The groove for the processes of the intermaxillary much shorter than the diameter of eye. Operculum with two strong prominent spines, the lower of which is the smaller. The third, fourth and fifth dorsal spines longest; the soft dorsal fin rather higher than the spinous. The length of the caudal is $4 \frac{2}{3}$ in the total, both the lobes being equal in length. The third anal spine very long and strong; its length is $4 \frac{1}{3} 5$ times in the total. The ventral fins reach near to the anus, and are rather longer than the pectorals. Scales scarcely striated. Red, with eight whitish longitudinal bands; the outer edges of the caudal blackish; the ventrals whitish, black between the third spine and the first ray.

Red Sea; Indian Archipelago; Chinese and Japanese Seas.

a. Half-grown: stuffed. Red Sea. From the Frankfort Museum.

b. Adult. Amboyna. From Mr. Frank's Collection.

c. Adult: skeleton. Amboyna. From Mr. Frank's Collection.

d, e. Adult: stuffed. Louisiade Archipelago. Voyage of the Rattlesnake.

$f, g$. Adult: stuffed. Louisiade Archipelago. Presented by the Lords of the Admiralty.

h. Half-grown. Philippines.

i. Adult: not good state. Japan.

$k$. Adult. China.

l. Adult: stutted. China. Presented by J. R. Reeves, Esq. m. Adult. India.

The specimens in which Sir J. Richardson thought he recognized $H$. alborubrum, Laccp., and $H$. spinosissimum, Temm. et Schleg. decidedly belong to the above species: he mentions specimen $l$. as having seven rays in the anal fin; but I can distinctly see nine, as usual in the species of Holocentrum. The specimen from the Red Sea differs from the East Indian ones in having the third anal spine longer ; in the former it is contained $4 \frac{1}{3}$ in the total length, whilst. it is one-fifth only in specimens collected in the seas of Japan, Amboyna, and in the Louisiade Archipelago.

Skeleton.-The upper surface of the skull is flat, without deep grooves or high ridges. The supraoccipital crest is limited to the posterior part of the occiput, without extending on its upper surface. There are two parallel bony ridges running along the middle of the 
interspace between the eyes; there is no distinct cavity between them, nor on any other part of the skull, except the groove for the posterior processes of the intermaxillaries; this groove is narrow, elongate, nearly equally broad anteriorly and posteriorly, and extends between the principal frontals to the level of the anterior fourth of the orbit. These bony ridges radiate behind in ten or more branches, fan-like arranged; the hinder part of the upper roof of the orbit is covered with spines, directed backwards.

The maxillary bone is styliform in its inner half, then gradually widens into a moderately broad plate, with a straight anterior edge, and the posterior rather concave; the supplementary bone is very narrow, tapering above. The intermaxillailes are separated from one another by a small notch ; they are nearly as long as the maxillaries, and have a slight prominence behind. The mandibulary without protuberance in front.

The dontition is formed by villiform bands only, without any canines or granular prominences. The bands on the jaws reach to the extremity of the bones; the vomerine teeth are arranged in two narrow bands, meeting under an obtuse angle; the palatine teeth form a narrow band extending on the pterygoid. The teeth of the pharyngobranchials are placed in several round patches, one of which is larger and ovate.

The infraorbital arch is rather narrow, and nearly equally broad, the proorbital being not much widened; its ossification is complete, and there is no outer membrane. The lower edge only is serrated; the præorbital strongly armed with spinous teeth, directed backwards; the anterior and posterior ones are strongest. 'The turbinal bone overreaches the intermaxillary with a short point. The infraorbital arch has inside a broad concave plate, forming nearly a half-circle, and supporting the eye-ball, together with the entopterygoid, which is very broad, and attached to the basisphenoid by a narrow ligament only.

All the opercles are distinctly serrated and striated as far as they are not covered by scales. The operuulum is one and a half as high as wide (the pine included); on its upper third it has two flat ridges, divergent and terminating in two flat spines, the upper of which is long and strong; the serrature is rather coarse, and formed by small spinous teeth, the terminations of the strix. The subopereulum is elongate, crescent-shaped, its denticulations scarcer and coarser than those of the operculum; the edge before the pectoral is entire. The interoperculum has posteriorly a notch at the place where the præopercular spine passes; the denticulations are very coarse and directed backwards. The præoperculum has a simple ridge only, with regular serrature on both the edges; they meet nearly at a right angle. The proopereular spine runs in the same line with the lower edge, and its length is $2 \frac{1}{2}$ in that of the posterior edge.

The vestibular opening is elongate or irregularly ovate: I could not find any bony plate in connexion with the tympanum, as is found in Myripristis adustus. 
The supraseapular and coracoid are distinctly denticulated; the other fumeral bones show no remarkable peculiarity. 'The urohyal resembles that of Myripristis, but is not so high, and more arrowshaped. The pultir bones are very much like those of Myripristis, but rather more elongate.

There are eleven abdominal and sixteen caudal vertebre $\boldsymbol{r}$, the length of the abdominal part of the vertebral column being $1 \frac{2}{5}$ in that of the caudal. The homal spines are stronger than the neural. Nine ribs; the first to fifth ribs have epipleural spines; but such appendages belonging to the posterior ribs are inserted on the vertebra themselves. The ribs of the eleventh vertobra are very broad, sword-shaped, and separated from one anothor. 'The strongest interhamal is appatrently formed by two, belonging to the secend and third dermohamals; a high bony ridge arise's fiom the joint of each of these dermohomals, and both ridors are attarched to one another by a transparent plate. The length of this interhamal erpuals that of the first nine vertebra.

\section{Holocentrum laticeps.}

C'ue. \&) Tral. iii. p. 211 , vii. p. 500.
D. $11 \mid 13$.
A. $\frac{4}{9}$.
L. lat. 42.
L. transv. 3/T.

'The height of the body is 3 ? in the total length, the length of the head $3 \frac{2}{3}$; the interspace between the cyes is one-fourth of the latter; the length of the snont is less than the radius of the eye'; the upper maxillary does not reach to below the middle of the eye; opereular spines equal, or the lower longer thin the upper; the preopercular spine short, about one-third of the length of the posterior margin of prooperculum. 'The fourth and fith dorsal spines longest, about one-half the height of body ; the uyer lobe of the eaudal rather longer than the lower. The third anal spine longer and stronger than the fourth, and $5 \frac{2}{3}$ in the total length; pectoral and ventul fins equal in length. Colden shining (in spirits), seales minutely dotted with black; the upper latl with seven brown lomegitudinal bands ; an oblique black streak betweren each pair of the dersal spines, reaching fiom the tip of one spone to the hase of tlee precesling; the other fins not coloured.

Scal of Batavia.

a. Arult female. From the Collection of the Zoological suredety

b. Half-grown. From the Haslar Collection.

\section{Holocentrum punctatissimum.}

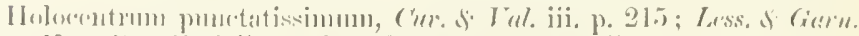

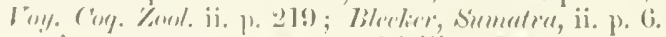

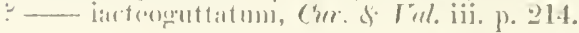

$$
\text { 1). I1 | 12-13. 1. } \frac{1}{9-10^{\circ}} \text { I. lait. 12. }
$$

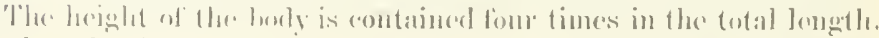

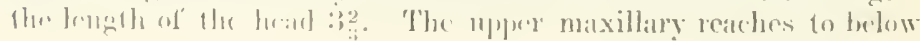


the middle of the eye; opereulum with two spines, the upper of which is the longer. Snout shorter than the half-diameter of the eye. 'The third and fourth dorsal spines longest, more than half as high as the body, and shorter than the soft dorsal. The upper lobe of the eaudal is longer, and $5 \frac{1}{4}$ in the total leugth; the third anal spine very strong, and one-fifth of the total. Rose-coloured, with seattered purplish dots; the first dorsal black-edged, and with a series of deep blue spots.

H. lucteoguttutum is considered as a varicty of $I I$. punctatissimum, and is distinguished by a double series of spots on the dorsal fin.

Sumatra; Caroline Islands.

\section{Holocentrum stercus muscarum.}

C'ux. \&. Tul. vii. p. 503.

$$
\text { D. } 11 \mid 11 \text {. A. } \frac{1}{8} \text {. }
$$

The third spine of the anal fin is shorter than one-fifth of the total length. Dorsal fin immaculate, the spinous part with a whitish edge; on the prooperculum and on each side a lougitudinal serics of blacek dots. $(V(e l)$.

sea of Guam.

\section{Holocentrum hastatum.}

1)ulumel, Péches, ii. pl. 5. f. 2.

Holocentrum hastatum, Cue. \& V ral. iii. p. 208, vii. p. 499. pl. 59.

$$
\text { D. } 11 \mid 14 . \quad \text { A. } \frac{4}{9} \text {. L. lat. 44. Cac. pylor. } 16 .
$$

'The height of the body is $3 \frac{1}{3}$ in the total. Operculum with a strong spine, of about the size of that of the procopereulum; sometimes one or two smaller ones beneath. The fourth and fifth dorsal spines longest, not shorter than the rays; the length of the caudal fin is about one-fifth of the total; the lobes are equal. The third anal spine very long, one-fifth of the total length. Red, with longitudinal bands; a large black spot between the first three dorsal spines, and a smaller one between the last three rays.

West $A$ frican Coast.

a. Young: dried: not good state. Sine patria Frun Mr. Yarrell's Collection.

\section{Holocentrum spiniferum.}

Sciæna spinifera, Forsk. p. 49.

Perca spinifera, Bl. Schn. p. 86 ; Lacép. iv. p. 418.

Iolocentrum leo, Cur. \& Tul. iii. p. 204; Less. Voy. Coq. ii. p. 222; Cuv. Règne Anim. Ill. pl. 14. f. 1 ; Bleeker, Kokos Isliends, p. 355; Foy. Astrol. Poiss. p. 678. pl. 14. f. 3.

Uolocentrus spinifer, Rïpp. $N$. W. Fische, pp. 96, 97. t. 25. 1. 1 (not Atlas).
I). $11 \mid 15$.
A. $\frac{4}{10}$.
I lat. $44-45$.
I. transv. $4 / 8$.

Crec. pylor. 16. Vert. 10/15.

The height of the body is equal to the length of the head, and 31, 
in the total; the interspace between the eyes is one-ninth of the length of the head. Præopercular spine more than half as long as the posterior edge of pracoperculum. The second, third, and fourth dorsal spines are longest, of about the same length as the third anal one; the soft dorsal fin is rather lower than the spinous. The length of the caudal is $5 \frac{1}{2}$ in the total, both the lobes are equal. The third anal spine is very much longer and stronger than the fourth, its length is $7 \frac{1}{2}$ in the total. Posterior edge of præoperculum very oblique. Rose-coloured, with a deep red spot behind the eye, and another above the roof of the pectoral; the spinous dorsal deep red; the other fins yellow.

Red Sea; Eactern coast of Africa through the Indian Occan to the Pacific.

๘. Adult: stuffed. Red Sea.

b. Large specimen: stuffed. Isle de France. From Dr. Janvier's Collection.

c. Large specimen: stuffed. Louisiade Archipelago. Voyage of the Rattlesnake.

d, e. Half-grown : stuffed. Louisiade Archipelago. Voyage of the Rattlesnake.

f. Large specimen: stuffed. Sine patria.

g. Half-grown: stuffect. Sine patria.

H. spiniferum, from the Red Sea, appears to be at least a variety of $H$. leo, from the East.Indies. Neither in the descriptions, nor in the figures given of the latter, are the deep red colour of the spinous dorsal, and the spots behind the eye mentioned. Noreover, the dorsal spines of the East Indian specimens are rather thicker, but equally long. Dried specimens are entirely similar in other respects.

\section{Holocentrum binotatum.}

Quoy \& Gaim. Voy. Astrol. Poiss. p. 679. pl. 14. f. 4 (not Bleck.).

D. $11 \mid 13$. A. $\frac{4}{9}$. L. lat. 34 . L. transv. $3 / 6$.

The height of the body is equal to the length of the hoad and $3 \frac{1}{3}$ in the total; the interspace between the eyes is $4 \frac{3}{4}$ in the length of the head; both the jaws equal in front; snout shorter than the diameter of eye, pointed; the groore for the process of the intermaxillary bones rather longer than the diameter of eye; the turhinal bone terminates in front in a proeess, covering the intermaxillary. 'The upper maxillary reaches to below the middle of the eye. Opercles striated, deeply serrated ; the upper opercular spine longest ; the spine of proopereulum rather longer than one-half of the posterior edge of that hone. The third and fourth dorsal spines longest, rather more than one-half of the heirht of body ; lobes of the caudal equal in length; the thirr anal spine much longer and stronger than the fourth, one-fifth of the total length. Red, with lighter longitudinal bands; pectorals ycllowish.

Sea of New Guinea and Guam.

a. Adult. Old Collection. 
holocentrum binotutum, Bleek. Goram, p. 207, is not only different trom our specimen, bnt also from that of Quoy and Gaimard. His fish appears to be more elongated having also forty-three scales in the lateral line; it has moreover a black bloteh on the dorsal fin, which eertainly would not have been overlooked by the French naturalists.

\section{Holocentrum caudimaculatum.}

Holocentrum spiniferum, Cuv. \& Val. iii. p. 206, vii. p. 498; Rüpp. Atlas, p. 86. taf. 23. f. 1 (not $N$. W.).

? Holocentrus ruber, Bennett, Fishes of Ceylon, pl. 4.

Holocentrus caudimaculatus, Rïp. N. IV. Fische, p. 97.

$$
\text { D. } 11 \mid 14 \text {. A. } \frac{4}{10} \text {. }
$$

The height of the body is equal to the length of the head, and $3 \frac{1}{33}$ in the total. The soft dorsal fin is rather higher than the spinous; the length of the candal is $6 \frac{1}{2}$ in the total, both the lobes are equal; the third anal spine is much longer and stronger than the fourth, its length is $4 \frac{1}{2}$ in the total. Posterior edge of proopereulum vertical; operenlum with two prominent spines, the lower of which is smaller; edge of subopereulum entire; the upper outline of head straight. Uniform red; a white spot on the back of tail (in life).

Red Sea; Ceylon?

\section{Holocentrum tiereoides.}

Blecker, Amboina, iv. p. 334.

$$
\text { D. } 11 \mid 12-13 . \quad \text { A. } \frac{4}{9^{10}} \text {. L. lat. } 40 \text {. }
$$

The height of the body is equal to the length of the heal, and 33 in the total. Jaws equal in front, the upper maxillary reaching to below the middle of the eye. The pracopereular spine longer than one-half of the diameter of the eye; two unequal opercular spines; seapulary not serrated; the fourth, fifth, and sixth dorsal spines longest. Red. $(B l$.)

Sea of A mboyna.

\section{Holocentrum spinosissimum.}

Temm. S. Schley. Fuun. Japon. p. 22. pl. viii. A. (Richardson, Iththyol. (hina, p. 223, belongs to II. rublum.)
D. 11
14. A. $\frac{4}{9}$.
L. lat. 36.
L. transv. $3 / 7$.

Seales exceedingly deeply striated and serrated. The height of the body is $3 \frac{1}{4}$ in the total length, the length of the head $3 \frac{1}{3}$; snout much shorter than the eye. Opereulum with a strong striated spine; one or two smaller ones beneath. Proopereular spine long, with a very prominent longitudinal ridge. The third anal spine is exceedingly thick, and its length is about one-fifth of the-total. The eaudal lobes equal. Red; each series of seales with a lighter longitudinal baud.

Sea of Japan. 


\section{Holocentrum diadema.}

Iolocentrus diadema, Lacép. iv. pp. 372, 374, iii. pl. 32. f. 3 ; Rüpz). Atl. Fische, p. 84. t. 22. t. 2.

Perca pulchella, Benn. Kool. Journ. iii. p. 377. pl. 9. f. 3.

Iolocentrum diadema, Cur. S. Ial. iii. p. 213; Less. Voy. Duperr. Zool. ii. p. 220. pl. 25. f. 2 ; Blecker, simboina s. Ceram, p. 259.

D. $11 \mid \frac{1}{13}$. A. $\frac{4}{9}$. L. lat. 48. L. transv. $3 / 7$. Tert. 11/16.

The height of the body is $3 \frac{3}{5}$ in the total length, the length of the head four times; the interspace between the eyes is one-fifth of the latter. Opereulum with two prominent spines, the upper of which is the stronger, netrly equal in size to that of the propopereulum. The fourth, fifth, and sixth dorsal spines longest, as high as the longest ray, but shorter than the anal spine. The length of the caudal is one-sixth of the total, both the lobes being equal. The third anal spine is exceedingly strong, and about one-fifth of the total length. The rentral fins reach near to the amss, but the pectorals are much shriter. Red, with eight to cleven silvery longitudinal bands; the spinous dorsal black, with a white longitudinal band; the other fins rose-coloured.

Red Sea; Madagasear; Ceylon; Chinese Sea ; Inclian Archipelago. -

a. Idult. Borneo.

b. Half-grown. China Seas. Presented by Capt. Sir Edward Belcher.

c. Half-grown. Tonga Islands. From the Haslar Collection.

๘. Half-grown. Fecjee Islands. Voyage of the Herald.

๔. Half-grown: rery bad skin. Ceylon. From the Collection of the Yoologieal Society.

$f$. Adult. Madigasear. Presented by Dr. J. E. Gray.

g. Adult: skeleton. India. From Mr. Frank's Collection.

$h, i$. Adult. India. From Mr. Frank's Collection.

Skeleton.-The general structure of the skeleton being the same as in Holocentrum rubmin, I give a detailed deseription of those parts only which exhibit specifie peculiarities.

The fan-like expansion on the vertex is formed by ten or more radiating branches; the groove for the posterior processes of the intermaxillaries reaches a little beyond the level of the anterior margin of the orbit. 'The maxillary and mandibulary bones as in $H$. violeceum. The intermaxillaries are not separated from one another by a noteh; they are three-quarters of the length of the maxillaries, and have a prominent flat protuberance posteriorly.

The dentition is formed by villiform bands only; those on the jaws reach to the posterior extremity of the bones; they are broad in front and tapering behind, the intermaxillary band less than that of the mandibulary. The vomerine teeth are plaeed in a small, triangular, equilateral patch, those of the palatine bones in a narrow band, extending on the pterygord. The teeth of the pharyngohranchials form two broad patches on cach side, with a few smaller 
ones besides; the hypobranchials are separated from one another' clongate, triangular, and entirely eovered with villiform teeth.

The preorlitel is searcely widened in front, but armed with a strong, thick, and striated spinous tooth; several small ones tollow posteriolly, but they are scarcely larger than the remainde' of the serrature of the infratorbital areli. The anterior end of the terlsieul lone is broad and obtuse.

The serrature of all the opereles is very distinct and complete; even the seales, corering in a single series the base of the operculum, are similarly striated and serrated; likewise the suprascapula ani the coracoid. But the preopereular spine is rather short, not much larger than that of the operenlum, its length being "2 $\frac{1}{2}$ in that of the posterior edge of the preoperculum.

The vestibuler opening is elominate, ovate, of moderate size.

The viohygel as in 11 . violacenem.

The length of the ablominal part of the vetebred columu is $1 \frac{1}{5}$ in that of the caudal. The hamal and newral spines are of equal strength. The length of the strongest interhamal copuals that of the first seven vertebro.

\section{Holocentrum melanotopterum.}

Blecker', Cécubes, viii. p. 302 .

$$
\text { I). } 11 \mid \frac{1}{1+-15} \cdot \quad \text { A. } \frac{4}{9-10} \text {. L. lit. } 43 \text {. }
$$

The height of the body is $3 \frac{1}{1}$ in the total length, the length of the head $3 \frac{2}{3}-3 \frac{3}{5}$. The upper maxillary hone reaches to below the middl. of the eye. Operculum with two strong spines, the mplece of which is rither longer. The second, third, and fourth dorsal spines longest, but not laalf as high as the hody, and shorter tham the longest ray ; the lobes of the camdal equal, and $j \frac{1}{2}$ in the total length; the third anal spine nearly equal to the longest dorsal spine. lied; the first dorsal black, with rose-coloured spots between the middle spines. (Bl.)

Sca of Celebes.

\section{Holocentrum violaceum.}

Blecter, - tmboinet, iv p. 33is.

D. $11 \mid 1$ t. A. $\frac{4}{9}$. I. lat. 36-37. I. transv. 3, 6. Vert. 11/16.

The height of the body is $: 3 \frac{1}{6}$ in the total length, the length of the head 33 ; the distance between the eyes is $5 \frac{1}{2}$ in the latter; the length "of the snout is not much less than the dianeter of the eje; jaws nearly equal in front; the turbinal bone with a bitid process, covering the intermaxillary. Opereulum with two Hat spines, distant from one another, the lower of which is the smaller; preoperenlum with the posterior edge vertical; the third, fourth, and fiftl dorsal spines longest, shorter than the preopereular edge mentioned; caudal lobes equal; the thisd anal spine strong, but one-sixtl of the total length only; rentral and pectoral fins nearly equal in length. Violet: areh seale with a rose-colomed transverse 
streak; snout and fins red; the spinous dorsal violet, with rosecoloured streaks.

Amboyna.

a. Adult. Amboyna. From Mr. Frank's Collection.

b. Half-grown. Amboyna. From Mr. Frank's Collection.

c. Adult: skeleton: Amboyna. From Mr. Frank's Collection.

d. Adult. Amboyna. From Mr. Stevens's Collection.

Skeleton.-The gencral structure of the skull is very similar to that of $H$. rubrum, but with such modifications as to indicate the specific difference as well as the external characters do. The narrow interspace between the eyes is still more conspicuous in the skeleton. The groove for the posterior processes of the intermaxillary bones is very like that of $H$. rubum, and extends between the principal frontals, but scarcely beyond the level of the anterior margin of the orbit. The fan-like expansion on the vertex is formed by seren or eight radiating branches.

'The maxillury bone is styliform at its origin only, and soon becomes broader, forming a triangular plate with the posterior edge rather concave and the anterior convex: the supplementary bone is unusually developed, forming nearly one-half of the outer part of the maxillary; it is crescent-shaped, with a small os intercalctre at its upper extremity; it is roughened by streaks, the maxillary itself heing smooth. The intermaxillaries are separated from one another by a small motch; they are $\frac{3}{4}$ as long as the maxillaries, and have posteriorly, in the middle of their length, a very prominent flat protuberance. The mandibularies slow a slight swelling in front, corresponding with an aceumulation of the villiform teeth.

'The dentition is formed by villiform bands only, without any' canines or granular prominences. The bands on the jaws reach to the posterior extremity of the bones; but, whilst those of the intermaxillaries are nearly equally broad in their whole length, those of the mandibularies are broadest in front and tapering behind. The vomerine teeth are arranged in two narrow and short bands, meeting at a right angle; the palatine teeth form a narrow band, extending far on the pterygoid bone. The ter th of the pharyngobranchials form two broad patches on eacl side, with several smaller ones besides.

The infraorbital arch is rather narrow and nearly equally broad, the procorbital widening anteriorly ; its ossification is complete; but there may be seen traces of a very narkow channel, corered on the outside with streaks of a thin meínbrane,-a structure much more developed in other genera of this fumily and in many other fishes. The lower edge of the arch is scrrated. The praorbital is strongly armed with eight or mine spinous teeth, directed backwards, the anterior and posterior of which are very strong. The turbinal bone ormreaches the intermaxillary, with a prominent and bifurcate spine. The posterior part of the hinder opening of the nostril has two very small spines, reaching into the cavity; they may bo easily lost by a less careful preparation of the skull. The inner parts of the orhital cavity are formed as in 11 . rubrum. 
The description given of the opercles of $H$. murum may be applied also to this species; but the serrature and the spines are rather stronger; the suboperculum moreover is indistinctly denticulated above the præopercular spine only; this spine is very long, its length being $1 \frac{1}{2}$ in that of the posterior edge of the præoperculum.

The vestibular opening is small, only twiee as large as the posterior nostril: if there is a bony plate in connexion with the tympanum (cfr.Myripristis adustus, p. 23), it must be exceedingly thin and small.

The suprascapula is distinctly serrated, but neither the humeral nor the coracoid. The urohyal is irregularly three-sided, with one anterior and two posterior angles; the lower and upper sides are convex, the hinder coneave; the lower angle of the two posterior ones reaches further behind than the upper. The pubic bones as in H. rubrum.

There are eleven abdominal and sixteen caudal vertebra, the length of the abdominal part of the vertebral column being $1 \frac{1}{3}$ in that of the caudal. The hrmal spines are not stronger than the neural. Nine ribs; the first to seventh ribs have epipleural spines, and similar appendages are inserted on the anterior and posterior vertebræ. The form of the ribs of the eleventh vertebra and that of the tirst interhæmal spune is similar to those of $H$.rubrum, but the length of the latter equals that of the turst cight vertebræ only.

\section{Holocentrum cornutum.}

Bleeker, Ceram, iii. p. 240.
D. $12 \mid \frac{1}{12-13}$.
A. $\overline{9}_{9-10}^{4}$
L. lat. 36 .

The height of the body is equal to the length of the head, and $3 \frac{2}{3}-3 \frac{3}{4}$ in the total. A spine directed ontwards, in the inferior and anterior angle of the orbit. The maxillary bone does not reach to the middle of the eye; the præopercular spine not much shorter than the diameter of the eye ; the upper opercular spine longest; seapular bone much serrated. The third to sixth dorsal spine longest, and nearly equal to the soft dorsal; the third anal spine muel longer. Rose-coloured, with nine darker longitudinal bands, one of them terminating in a black caudal spot; the membrane of the spinous dorsal black, with red spots; the other fins red the anal fin between the third spine and first ray, and the caudal on the outer edges, dark violet. ( $B l$.

Rivers of Ceram; Sea of Amboyna.

\section{Holocentrum tiere.}

Cuv. \& Val. iii. p. 202; Voy. Coq. ii. p. 221, Poiss. pl. 25. \& 1 (not good).

$$
\text { D. } 12 \mid 14 . \text { A. } \frac{4}{9} \text {. }
$$

Operculum with two prominent spines, equal in length; the spinous dorsal low; none of the other vertical fins elongate; lobes of the caudal equal in length. Uniform red.

Sea of Otaheiti. 


\section{Holocentrum sammara.}

Scirena sammara, Furstal, p. 48; Lacép. iv. p. 314.

Perea sammara, Bl. Schn. p. 89.

Labrus angulosis, Lacép). iii. p. 430. pl. 22. f. 1.

Holocentrum sammara, Rüpp. Atl. Fische, t. 22. f. 3 ; Cux. \& V Val. iii. p. 216 ; Bleeker, Pere. p. 54 , and Amboina, ii. p. 555.

Holocentrum christianum (Ehrenberg); Cur. \& Val. iii. p. 219 : cfi. Rïpp. Atl. p. 85.
1). $10 \mid \frac{1}{11-12}$.
A. $\frac{4}{7-8}$.
L. lat. 40 .
L. transv. 4/7. Vert. 11/16.

The height of the body is four times in the total length, the length of the head $3 \frac{1}{1}$; the distance hetween the eyes is $4 \frac{1}{3} \mathrm{in}$ the latter; the length of the snout is nearly equal to the diameter of the eye. The upper processes of the intermaxillaries reach far between the eyes; turbinal bone not covering the intermaxillary; lower jaw very prominent. Opereulum with two distinet spines, the lower of which is rather the smaller. Lobes of the caudal equal. The third anal spine is $4 \frac{2}{3}$ in the total length. The spinous dorsal with a deep black blotch between the first and fourth sines, and with two series of white spots, one along the upper margin, and the other alone the base.

Red Sea; Cape of Good Hope; Anıoyna; Sumbawa.

a. Adult. Amboyna. From Mr. Frank's Collection.

h. Adult. Amboyna. From Mr. Stevens's Collection.

c, r. Adult: stufferl. Red Sea. From the Frankfort Museum.

e. Adult: stuffed: not good state. Cape Seas. Presented by Sir A. Smith.

$f, g$. Half-grown. India. Presented by the Zoological Society.

$h, i$. Adult: skeletons. India Presented by the Zoologieal Society.

k. Arlult. Indic.

1. Adult. India. From the Haslar Collection.

Sleeteton.-The general structure of the skeleton being the same as in the preceding species, I give a detailed deseription of those parts only which exhibit specifie peculinities. The fun-like exyansion on the vertex is formed by nine or more radiating branches. "The orbital edge of the frontals is coneare, these hones forming a slight prominence ahove the anterior part of the eye. 'The groove for the posterior processes of the intermaxillaries reaches far behind, nearly to the level of the seeond third of the cye. The maxillary bone is styliform at its origin only, and then forms an oblong plate with an irregrularly convex anterior margin, and with the posterior rather concive. The supplementary bone is emposed of two pieces, the posterior of which is larger and slightly dentienlated in front. The intermaxillaries are separated from one anotier by a deep notch; they are three-quarters of the length of the maxillary bones, and hive a very prominent and flat protuberance behind. The mandibularies are distinguished by their length, eonsiderably overreaching the upper jaw.

The hands of villiform teeth of the jaws reach to their posterior 
extremity, and are tapering belind. The vomerine tecth are placed in a small triangular pateh, broader than long. The pterygoid bones as well as the palatines are furnished with narrow bands.

The proeorbital is somewhat widened anteriorly and armed with a rather strong tooth, the posterior denticulations differing little in size from one another. The turbinal bone is obtuse and seareely prominent. The posterior nostril has no spinous teeth.

The opercles are feebly striated and armed; the denticulations of the subopereulum are even indistinet; the præopereular spine is flat, triangular, and one-third only of the length of the posterior margin of the pracopereulum. Supraseapula distinetly, coracoid indistinetly serrated.

The vestibular opening is elongate, but equals in size the posterior opening of the nostril.

The length of the abdominal part of the vertcbral column is $1 \frac{1}{3}$ in that of the caudal. The hæmal spines are rather stronger than the neural. The length of the strongest interhæmal equals that of the first seven vertebræ.

\section{Holocentrum operculare.}

Cue. \& Val. vii. p. 501 ; Bleeker, Banda, i. p. 233 ; Voy. Astrol. Poiss. p. 676. pl. 14. f. 1 .

$$
\text { D. } 10 \mid \frac{1}{12-13} \text {. A. } \frac{4}{9-10} \text {. L. lat. } 38 \text {. }
$$

The height of the body is one-fourth of the total length, the length of the head rather more than one-third. The upper maxillary does not reach to the middle of the eye; opereulum with two spines, the upper of which is the longer. The third, fourth, and fifth dorsal spines longest. The lobes of the eandal are equal, and $5 \frac{2}{3}$ in the total length; the third anal spine is $5 \frac{1}{2}$ in the same length. Red: each seale on the head and back with a violet margin; operculum brownish; the first dorsal black, along the base and the upper edge white; the other fins rose-coloured.

Sea of New Ireland; Banda.

\section{Holocentrum læve. (Plate VI. fig. B.) \\ D. $10 \mid \frac{1}{11}$. A. $\frac{4}{7}$. L. lat. 40 . L. transv. $4 / 7$.}

Body rather elongate; the interspace between the eyes is onefourth of the length of head; the lower jaw rather prominent, snout not much shorter than the diameter of eye; opercular spines nearly equal; sub- and inter-opereulum entire, or scarcely denticulated; dorsal spines slender, the seeond, third and fourth longest; caudal lobes equal, pointed; the third anal spine is $5 \frac{1}{2}$ in the total. Red, with lighter longitudinal bands.

a. Adult: stuffed. Louisiade Arehipelago. Voyage of the Rattlesnake.

b. Adult: stuffed. Guadaleanar (Salomon Islands). Voyage of the Herald.

c. Half-grown. Amboyna. Iturehased of Mr. Frank. 
Description.-This species, in the form of the body and the number of the fins, is allied to H. summaru, but is distinguished by the feeble development of the spines; the seales are nearly smooth, with indistinct serrature; the opercles are searcely striated; the sub- and inter-operculum and the humeral are entire, the spines are short and flat; the dorsal spines slender and somewhat flexible; the anal spine relatively short, and not very strong.

The height of the body is four times in the total length, the length of the head $3 \frac{1}{3}$. The interspace between the eyes is nearly equally broad behind and in front, but with a slight concarity of the edges above the middle of the eye; the two bony ridges between the eyes diverge slightly in front to receive the groose for the processes of the intermaxillary bones; behind they terminate in a fan-like expansion, with about seven or eight radiating bony ridges; the groore reaches far backwards, and is about four-fifths of the length of the diameter of eye. The turbinal bone is not prominent. The upper maxillary does not reach to the middle of the eye, and the snout has the same length as the groove mentioned. The diameter of the eye is nearly one-third of the length of the head; the infraorbital arch is slightly denticulated, the tooth in front is ohtuse, flat, and short. The strix of the opercles have nearly disappeared in old specimens; in younger they are visible, especially on the inter-operculum, where they even terminate in small marginal teeth. The operenlum has two flat spines, nearly equal in length ; the upper and lower margins are obsoletely denticulated ; the sub-and inter-operculum entire ; the præoperculum has a vertical posterior margin, very finely serrated, and a flat short spine at the angle, rather longer than one-third of the posterior margin ; the inferior edge of the præoperculum and the seapulary are serrated; the humeral is entire.

The first dorsal is formed by ten dorsal spines, rather elongated and slender; the sceond, third and fourth are the longest, not much shorter than the rays. The soft dorsal has a short spine in front, rather longer than the last of the spinous dorsal. The caudal is decply forked; the upper lobe, which appears to be rather longer than the lower, is one-fifth of the total length. The anal spines have about the same relative length as generally in the species of Holocentrum; but the third is rather short, and $5 \frac{1}{2}$ in the total length. The pectoral fins are shorter than the ventrals, they reach to the level of the thirteenth scale only of the lateral line; the ventrals terminate on the level of the fifteenth, far distant from the anus, which corresponds to the twenty-first scale.

The scales are not striated, but very fincly ciliated at the posterior margin; one of the largest covers fully one-fourth of the eye.

The colour appears to be red, with lighter longitudinal bands; the fins show now no eolour at all, except in the half-grown specimen, which has the spinous dorsal with a blackish superior edge.

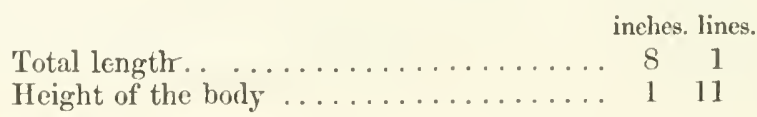




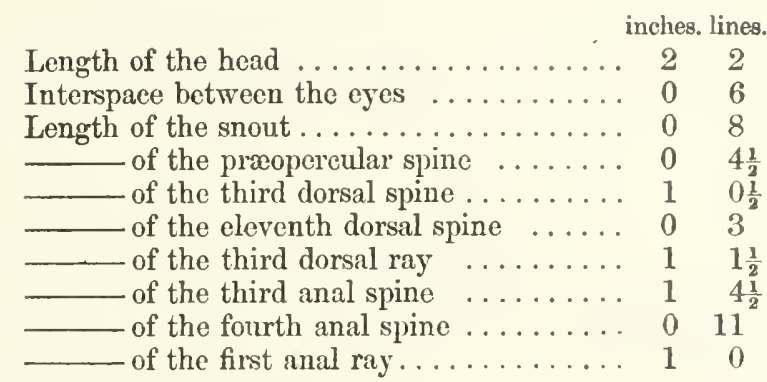

\section{Holocentrum spinosum.}

Corniger spinosus, Agass. in Spix, Pisc: Bras. p. 121. taf. 75. Holocentrum cornigerum, Cuv. \& Val. viii. p. 481.

$$
\text { D. } 12 \mid 15 \text {. A. } \frac{4}{12} \text {. }
$$

The height of the hody is $2 \frac{1}{2}$ in the total length. Infraorbital arch with four very strong spines, curved and directed backwards, longer than those of the prxoperculum the anterior is shortest, one-third only of the length of the second, the second half the size of the third and fourth; the posterior suborbital bones strongly denticulated. Opereulum and limbe and scales of præoperculum covered with acnte spines; præoperculum with two strong spines at the angle, the upper of which is the longer; operculum with two spines of equal size, but shorter than those of the former.

Coast of Brazil.

\section{Holocentrum retrospinis.}

Holocentrum retrospinis, Guichen. Poiss. in Ramon de la Sagra, Hist. de ll Ile de Cuba, p. 35. pl. 1. f. 3.
D. $12 \mid 14$.
A. $\frac{3(?)}{11}$.

The height of the body is $2 \frac{1}{2}$ in the total length, the length of the head $2 \frac{3}{4}$. The infraorbital arch is armed beneath with three long spines, curved and directed forwards; the spines of the præorbital and of the posterior part of the infraorbital arch with smaller spinous teeth. Both limbs of the præoperculum denticulated, with $\varepsilon$ rather strong flat spine; operenlum and suboperculum armed with spinous teeth, the former with two long spines, the lower of which is the stronger. Spines of the fins rather slender; the soft portions of the dorsal and anal fins rounded, and as high as the spinous. Caudalis forked; scales deeply serrated. Uniform red.

Cuba.

This fish has a remarkable similarity to the preceding species, from the development of the armature of the head; but the spines of the infraorbital have an opposite direction. Guichenot describes the suboperculum as entire, and not denticulated; but it is evident from 
the figure that he has snistaken the interopereulum for it, the margin of the suboperculum being as strongly armed as that of the opercle. He mentions three anal spines only; but that would be an exception to the rule in this genus.

\section{RHYNCHICHTHYS*}

Holocentrus, sp., Gronov. Zoophyl. p. 65. tab. 4. f. 3, and Syst.ed. Gray, p. 173.

Rhynchichthys, Cuv. \& Val. vii. p. 503, viii. p. 508.

Muzzle more or less elongate, pointed, with pronmnent upper jaw ; eye large. Villiform teeth in both the jaws, on the vomer and the palatine bones. Eight branchiostegals. Opereular bones serrated; opereulum and angle of praopereulum with distinct spines. Scales moderate, etenoid. 'Two dorsals, scareely united; ventrals with seven rays. Caudal forked; anal with four spines, the third longest. Swim-bladder?

Tropical seas of both the hemispheres.

\section{Rhynchichthys pelamidis.}

Cuv. \& Val. vii. p. 504. pl. 208.

$$
\text { D. } 10 \mid \frac{1}{12} \text {. A. } \frac{4}{12} \text {. L. lat. } 35-40 \text {. }
$$

Bluish grcen, silvery on the sides and on the belly; a series of black spots between the dorsal spines.

Indian Ocean.

There is some similarity in the exterual physiognomy of this species and Lepidoleprus japonicus; moreover the number of the ventral rays is also increased in the latter fish. In other respects these fishes differ greatly from each other.

\section{Rhynchichthys brachyrhynchus.}

Blecker, Amboina, iii. p. 17.

$$
\text { D. } 10 \mid \frac{1}{13-14} \cdot \text { A. } \frac{4}{11-12} \text {. L. lat. } 25 .
$$

Snout not projecting much beyond the mouth. Rose-coloured: the spinous dorsal brownish; the anterior rays of the soft dorsal and of the anal, a transverse band at the base, and a longitudinai band on each lobe of tue caudal, deep violet; ventral fins black. (Bl.)

Sea of Amboyna.

* 1. Holocentrus rostratus, Gronov. l. c.-Caribbean Sea. It is a pity that the specinen on which Gronovius founded this species is not contained in his Collection of dried fishes, which is now in the British Museum. There las not been found one fish of the wholv funily of Beryeide in this Collection. 


\section{Fam. 3. PERCID E.}

Percoidei, pt., Cuv. Rirgne Anim.; Cuv. \&. Vul. ii. p. 1 ; Muller, Berl. Abhandly. 1844, p. 201.

Percide, pit., Owen, Lect. Comp. Anat. Tert. i. p. 49.

Percidse et 'Theraponida, pt., Richurdson.

Body generally oblong, and covered with etenoid scales; lateral line continuous:. Nouth in front of the snout, with lateral eleft, rarely at the lower side. Eyo lateral. All or some of the opereles serrated or armedt. Seven or six branchiostegalsł. Dentition complete; teeth pointed, in villiform bands, with or withont canines; teeth either on the romer, or on the romer and palitine bones. No barbelş. Cheek not cuirassed. Dorsal fin formed by a spinous portion and by a soft; ventrals thoracic, with one spine and five soft rays. Stomach cacal; pyloric appendages generally in small number. Swim-bladder presunt, simple $\|$. Intestines little folded

Carnivorous fishes, inhabiting the fresh waters and seas of all parts of the globe.

\section{Synopsis of the Genera.}

The following Synopsis is merely to facilitate the determining the position which a species of fish takes in the system of the l'ercoids known at present, whilst in the deseription itself a series his been adopted which is thought best adapted to the natural relations of the genera. Without fully repeating the diagnoses of the genera, it would have been impossible to follow the same suceession in this Synopsis, and it would have failed in accomplishing the purpose above named. Thus it is not intended to give, in the single eategories of the Synopsis, the forms most elosely allied to one another, but certain forms are brought together by an artificial method. Finally, I consider the number of the spines to be a natural generic character, which, simple as it is, has hitherto been neglected in the definition of genera.

\section{A. Anomalous genera.}

* With a barbel. Two dorsals; operculum spiniforous, praoperculum denticulated; scales imbedded in the skin ...

30. Pogonoperca

* No teeth at all on the palute. Natural characters of Serranus

2.. Prionodes.

\section{B. Nornal genera.}

\section{Seven bo unchiostegals.}

A. All the teeth villiform, without canines.

* Some species of Ambassis excepted.
\$ Cfr. Percilia.
\# In Pileoma and Bolcosonia absent. $\dagger$ Except Ajsilus.

Except Pogonoperia.

E. 2 
1. Two distinct dorsals, separate or united only at the base.

* Pseudobranchice.

a. Scales adherent.

* Pyloric appendages in small number.

a. Body oblong, flat.

1 D. with 7 spines. The anal fin without conspicuous spines; operculum and preoperculim spiniferous, without serratures; seales minute...

1 D. with 8 spines.

it Scales rather large. The dorsal fin moving in a sealy sheath; preoperculum with a strong spine at the angle, and with an entire lower limb.

31. Gramistes.

† Scales rather small.

aa. Operculum without spincs

16. Centropomus.

$\beta \beta$. Operculum spiniferous

34. Diploprion.

+ D. with 9 spines. Teeth on the tongue; the anal fin generally with three spines; præopereulum with denticulations beneath

4. Labrax.

+ D. with 10 spines. The anal fin with two spines; inueiferous cavities of the bones of the skull much developed; præoperculum dentieulated; scales small

7. Psammoperca.

D. with 12 spines. The anal fin with three spines; opercles with very long and pointed spines; scales very small .....................................

+ D. with 13-14 spines. The anal fin with two spines; præopereulum and præorbital serrated ; seales small; head naked above.

10. Percarina.

17. Nipion.

1. Perca.

B. Bndy cylindrical, clongate. Mouth situated at the lower side of the snout; anal fin with a single spine; proxoperculum serrated; senles small .....

* Pyloric appendages in increased number.

a. Form of body oblong. Pseudobranehix developed; tongue smooth; the first dorsal with eleven, the anal fin with three spines; proopereulum with strong spinous teeth beneath; seales rather small.

8. Percalabrax.

B. Body and vertical fins greatly elcuated. Pricopereulum with spinous teeth at the angle

18. Enoplosug

* No pseudobranchice.

** Prcoperculum with strong spines at the lower border. The first dorsal with seven to eight, the anal fin with three spines; scales moderate; pricorbital strongly serrated

14. Asrno

5. IATES.

* Prcoperculum with smnoth lower limb, and with a strong spine at the angle; procorbital entire

6. CNidon. 
b. Seales deciduons.

a. The lateral line commencing heneath the second dorsal. An acute ridge from the eye extending backwards over the opercles

43. Microicituys

B. The lateral line commencing behind the head.

aa. Teeth on the palatine bones.

as Proopereulum with a double serrated ridge. The first dorsal with six to seven, the anal with two spines; operculum spiniferous ...................

$\beta \beta$. Prooperculum with a double entire ridge. The first dorsal with six, the anal with two spines; operculum spiniferous

44. APOGON.

45. Apogonichitiys.

bb. No tecth on the palatine bones. Eye very large. No denticulations on the bones of the skull. Many pancreatic cæca

\section{8. Ромatomus.}

\section{The spinous dorsal little developed.}

Scales minute, enveloped in the epidermis; spines of the dorsal variable in number.

32. Rirypticus.

\section{One dorsal fin.}

a. With two or three anal spines.

a. Pyloric appendages in small number.

aa. Operculum with a strong bony ridge.

Opercles denticulated; scales small

29. Polyprion.

bb. Operculum without bony ridge.

§. No teeth on the palatine bones.

Opercles spiniferous; the muciferous channels of the bones of the skull much developed; scales rather small

9. ACERINA.

§. Teeth on the palatine bones.

* Opercutum spiniferous.

* Scales moderate.

+ D. with 12-13 spines. Body rather elevated

35. Myriodon.

$\dagger$ D. with 8 spines. Head entirely covered with scales

38. Glaucosoma.

** Scales small.

† Operculum very strongly armed; præoperculum with strongly serrated lower limb; dorsal with nine spines. Known only from stuffed specumsns.

$\dagger$ Operculum moderately armed; præoperculum not, or obtusely serrated. Dorsal with eleven spines.

33. Aulacocephalus.

50. Oligorus.

* Bones of the skull without any dentrculations or spines.

Dorsal with ten spines; scales rather small.................

20. Apsilus. 
B. Pyloric uppendayes in increased number.

* Preoperculum with spinons tecth at the lower limb. Natural clistracters of Mectropoma ...................................

* Pronpereulum fincly serrated Dorsal with nine slender

spines; operculum spiniferous; scales moderate ........ 5.. Arr. Aris.

\title{
b. With four or fire anal spines.
}

Scales sometimes osseous. Body high, trimgular; anal fin witl five spines; proeoperculum denticulated; opereulum rounded

고. Thachyoua.

39. Pextaceros.

41). Olicosoma.

No true scales; osseous protuberances.

c. Anal spines none.

B. Canine teeth at the outer side of the villiform bands.

1. Two clorscts.

* Anal with two spines.

1. Scales small, adherent. Twelve to fourteen dorsal spines; opereuhum spiniferous; prooperculum with a simple serrated edge

11. Licionerca.

b. Scales large, deciduous. Six dorsal spines; pricopercuhum with a double serrated edge

46. Chilodipterus.

* Anal with thice spines.

a. Operculum produced into a long, denticulated point .........

b. Operculum with two points, not denticulated; scales moderate, adherent. Nine dursul spines

49. Асторома.

15. ETELIS.

c. Operculum with two feeble points; seales moderate, deciduous. Eight dorsal spines; no denticulations on the bones of the skull

\section{Scosminor's.}

\section{One clorsal.}

a. Canmes very small. Vomerine teeth in an angular band or a short triangular patch. Dorsal generally with the formula $\frac{10}{12}$, anal with $\frac{3}{7}$; operculum spiniferous; propoperculum serrated, without noteh ; scales moderate or rather small

21. Centhopisistis.

b. Canines distinct.

a. Scales moderate.

aa. Prcoperculum serrated.

aa. Snout short, blunt, with a rather narrow proorbital ; dorsal generally with ten, anal with thrce spines; caudalis forked, and mostly one or several of the fins clongate; operculum spinifurous.

23. Antinas.

Bij. Snout rather elongate and high, with flat sides, and with a large broad preorbital.

* Prcenperculum without or with a very open notch behind ......................

* Praepperculum with a decp notih, recriving a linob of interingerculum......

1.8. I'ropoperefum ontire. Dorsal with ten, unal with three spines ; operculum spiniferous..............

\author{
37. Mesornon. \\ 36. Gexтокове. \\ 19. Aj'kion.
}


B. Srates smull.

ar. I'renperenlem with the loner lind, smouth.

aa. Tectle on the patations. Dorsar gonerally with nine or elevon spines, anal with there: ofereculum spiniferous ............................

$\beta 3$. No tecth on the palatines.

2ti. Senraxi:

2) A.ruprobon

bh. Pronperentum with spinous tecth bonenth. Number of -p pines of the vertical fins variable; operrolum spiniterous

27. R'LFETROPOA

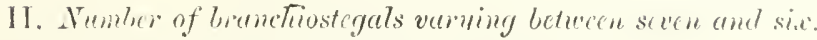

A. Turo dorsels. The first with nine spines, anal with three. Operentum spiniferons, propoperenhum and prixorbital serrated. Seriles smath, lieal covered with seales above.

P. One dorstel. With ten spines, anal with three; operculum with two points, priaperculum with a single smooth ridge. Scales norlerate The number of the pylorie appendages increased

2. Prencurus

III. Sie branchiostegals.

A. All the teeth villiform

1. Two dorsels.

a. Seales deciduozs. Proopereulum with a double denticulated ridge; the first dursal with seven, the anal with three spines, a recumbent spine in front of the dorsal, pointing forward

42. DMBASSIS.

1. Sceles allewent.

* D. with $1+$ or 15 spines. Opereles not dentieulated; operculum with one point

12. Pileos.

* D. with 9 spines. Opereles not dentieulated; opereuhum with one point

* D. with 6 spines. Opereles not dentieulated; opereulum with two points...

13. Boleusoma

i⿱⺈. IIUno.

\section{․ One dorsal.}

u. Scalcs moderate, fincly or minutely serruted.

a. Opcreulum. with a membranaceous coloured lobe above the angle.

aa. No tecth on the palatine lones

57. Ponotis.

b6. Teeth on the palatine bones

56. Brytrus.

$\beta$. Opereulum without a memlranaecous lobe.

aa. The number of the anal spunes weriahle, mostly more then there. Teeth on the palatine bones ind on the tongue; operculum witl two flat points; prieoperculum scarcely denticulated

55. Centrarciuvo.

b6. Three anal spines. Dorsal with ten spines; ofereulum spiniferous; preopereulum serrated..

b. Scakes small, rouegh. Chin very prominent, snout covered with etenoid seales, eye lange; prasopereulum with prominent erenulated angle; dorsal with ten, anal with three spimes

(i). DULES.

H. P'ulacantues 
B. Jaws with a lateral series of larger tecth, or with eanines.

1. With canines. Snout very short, rounded ; fins partly elongated; dorsal with eleven spines; opereulum spiniferous; privoperculum entire

2.). Callasthis.

2. With a latcral series of larger teeth.

a. Opereulum spiniferous; spines of the fins slender. Form of borly eylindrical; dorsal deeply notched, the first portion with nine spines: prxopercalum serrated; scales small

3. Paralabrix.

1.: Operculem not armed; spines of the fins very strong. Form of body rather elevated; dorsal decply notehed, the first portion with ten spines; seales rather small.

c. Operculum indistinctly armed; basal half of the dorsal fin scaly. Form of the body compressed, oblong; one dorsal, with ten spines; scules moderate, not serrated; caudal deeply forked....

58. Axopurs.

59. OnONTONECTES.

\section{Number of the branchiostegals varying between five and six.}

No cunine or palutine teeth. Two dorsals, united at the base only; the first with nine spines, the anal with three; no distinet aimature on the upercles; seales moderate........ 5t. Peicilia.

These genera may be combined into more natural groups. In these gromps one or other of the manifold characters predoninates, without being applicalle to erery member of the group. If we follow Cuvier and make the categories strictly depend upon one character. then we are obliged to separate Perce and P'ercichthys. merely because the former has seven, the latter sometimes six branchiostegals-or Grammistes and Rhyplicus, merely because in the former the spinous part of the dorsal is more developed, and separated from the soft one by a deep noteh--or Apogon and Chiloclipterus, because in one there are conspicuous canines; and yet there are no fishes more closely allied than those of the three pairs mentioned. When we become acpuainted hereafter with more generic forms, then the l'ercile will be divided into many groups or families with more exact characters; and the following natural combination is merely in attempt at a systematic division of these fishes.

I. Group with the type of Perea.-Mostly tresnwater fishes, or sea fishes entering the rivers. Form of the body oblong, rarely cylindrical or elevated. Opereles strongly denticulated or armed. Seales conspicuonsly etenoid, small, or of moderate size. Cleft of mouth horizontal or slightly oblique. Mostly with two dorsals; the number of spines constant in the species of one genus. liarely more than ten pyloric appendages.
1. PFIRCA.
7. I YAMMOPERCA.
13. DOL.еоOола.
2. P'inoichtiys.
8. Prercalatirax.
14. Asino.
3. P'arallabrax.
9. A Cl:rina.
4. IABRAX.
10. Pencarina.
5. l.ATES.
11. Lechopres.
15. ETELAs.
6. CNIDON.
12. Pulicua.
16. C.nthopunus.
17. Niplton.
18. ENol'losi's.

Percina. 
II. Group with the type of Serranus.-Mostly inhabitants of the sea. Form of the body oblong, rarely elevated. ()pereles denticulated or armed. Scales conspicuously etenoid, small, or of moderate size. Cleft of month slightly oblique. Mostly with one dorsal; the number of spines constant, or little variable in the species of one genus. Sorpetimes more than ten pyloric appendages.

Serranina.

19. Aprion.

20. Apsilus.

21. Centropristis.

22. Callantinas.

23. Anthias.

24. ANYPEROdON.

25. PiIONODFS.
26. Sernanus.

27. Plectropona.

28. Trachypoma.

29. Poltymion.

30. Pogonoperca.

31. Grammistes.

32. Rhypticus.
33. Aulacocephalus.

34. Diploprion.

35. MYRIODON.

36. Genyonoge.

37. Mesoprion.

38. Glaticosoma.

III. Group with the type of Pentaceros.-Osseous scales or protuberances, or the integuments of the head bony. Pentaceratina.

39. Pentachios.

40. Oreosoma.

IV. Group, with the type of Priacanthus.-Cleft of the mouth approaching the vertical line, ehin prominent; scales small, strongly ctenoid, rough ; the number of spines constant ; few pyloric appendages.

Priacanthina

\section{Priacanthus.}

V. Group with the type of Apogon.-Inhabitants of the sea and of fresh waters, with deciduous seales generally of large size. Form of the body more or less elevated. Opereles mostly denticulated or armed; cleft, of the mouth oblique, or approaching the vertical line. Two dorsals.

Apogonina.
42. Ambassis.
43. Micnoichthys.
46. Chilodipterus.
44. Apogon.
47. Sсомвrop's.
45. Apogonichthys.
48. Pomatomus.
49. ACROpoma.

VI. Group with the type of Grystes.-Inhabitants of the sea and chiefly of fresh waters. Form of the body oblong or elevated. Opercles indistinctly denticulated or armed, or entirely smooth. Seales minutely ciliated, or eyeloid. Cleft of the mouth more or less oblique. Mostly with one dorsal; spines sometimes in variable number in ono genus. Sometimes many pylorie appendages. Fishes deviating most from the original type of the Percoids; and Dutes approaching to the Therrponida.

50. Oligorus.

51. Ginystes.

52. ARripis.

53. Huro.
54. Pencilia.

55. Centranchus.

56. Bryturus.

57. Pomotis.

Grystina.

58. Anoplus.

59. ODONTONECTES.

60. Dules. 


\section{First Group. PERCINA.}

\section{PERCA*.}

Perca, sp., Artcti, Gencru, p. 39; Cue. Rö́gne Anim. ; Cur. \&. Vul. ii. p. 19 .

Seren branchiostegals. All the tecth villiform, without eanines: terth on the palatine hones, tongne smonth. Two dlorsals; the first with l:3 or 1-t spines; anal fin with two spines. (Jpereulum spiniferous; propoperculum and pracorbital serrated. Scules small ; lead naked ubure.

Fresh waters of the Aretic Regions.

\section{Perca fluviatilis.}

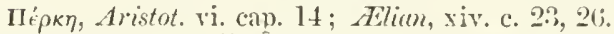

l'er'al, Plin. xxxii. cap. 9, 10; Ausun. v. 115; Juhuston, Tlueum. 1). $42: 3$.

P'rea Huviatilis, Romelet. ii. pp. 196, 197; Sulviuni, f'. 2.24 ; 220 ;

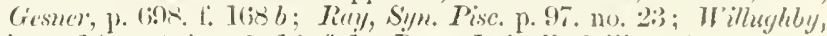
iv. c. 14. p. 2!)1. t. 5. 13. fo 1; Pem. Brit. Kool. nii. p. 34 j.

—- thu iatilis major, Aldrore, v. cap. 39. p. 6.2.2.

— major, Schomer. p. 5i).

—_ no. 1, dotedi, Genere Piscium, p. 39.

- Ihuriatilis, Limn. i. p. 481, and Farm. Suec. p. 117; Lacép. iv.

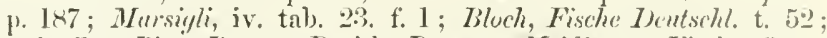

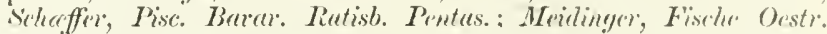
ta). 5) ; Hon. Lirit. Fishes, iii. pl. 52; Shaw, Kool. iv. p. 545. pl. T9; Turt. Brit. Ianen. p. 100; Cux. \&. Vul. ii. p. 20. pl. 1-8 (anctomy); Flom. Irit. Anim. p. 213; Nilss. Prodi. Ichth. Sorndin. p. 81; Jurine, Inoss. Lac Leman, pl. 3; Bomey. Fanen. Ital. iii. 79. f. 1;

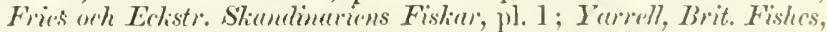
p. 1; Purn. Fish. Frith of Forth, p. 8; 1)emidoff. Toy. Tiuss. Mervil. iii. p. 35.5; C'ur. Règre Arim. Ill. I'viss. pl. 1-4, (annt.) pl. 6; Gïnther, Neckarfische, p. 10, and Wirem. Archie, 1855, p. 198;

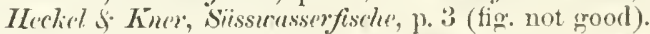

- vulgaris ot helvetica, Gronor. Mres. Irhth. cel. Giray, pp. 113, 114.

__ italica, Cuv. Tiégne Anim.; C'uc. \& I'ul. ii. p. 45.
I). $14-15 \mid \frac{1-2}{13-14}$.
A. $\frac{2}{8-9}$.
Cæc. pylor. 3
Vert. 21/20-21.

Total length equal to $3 \frac{3}{4}$ the height of the body. Inferior edge of operculum entire, or very weakly dentienlated; inferior edge of preojerculum with a few strong spinous teeth, dirceted forwards; operculum smooth, more than 70 transverse rows of sealest; trans-

* Perca plumieri, Cuv. \&. I'rl. ii. p. 51, established from a figure of Plumier, is the same fish as we find hereafter deseribed as Conodon antillanus, Cut: \& $V^{*}$ at. r. p. 151 .

+ In the Poreidne with small seales, the rows exhibit many irregularities, especially near the Lateral line. I more constant result is gained by counting the transwerse rows. instead of the acales of the laternl line 
verse line $\frac{9}{19}$. A large black mark on the posterior paru of the first dorsal fin.

Europe; Asiatic Russia.

$a, b$. Large specimens: stuffed. England.

c. Adult: stuffed. England.

d, é: Adult. England.

f. Half-grown. England. Presented by J. Doubleday, Esq.

g. Half-grown. England. Presented by the Zoological Socicty.

h. Half-grown. Peterborough. Presented by C. Watkins, Esq.

$i, k$. Young. London. Presented by W. Yarrell, Esq.

l. Adult: skin. Norfolk. Mr. Yarrell's Collection.

$m-t$. Adult and half-grown: skins. England. Mr. Yarrell's Collection.

u. Adult: stuffed. Loch Lomond, Scotland.

v. Half-grown : stuffed. Duddingston, Scotland.

w. Half-grown: stuffed. Loch Maben, Scotland.

$x, y, z$. Half-grown. Switzerland. Presented by Prof. Agassiz.

$\boldsymbol{a}, \boldsymbol{\beta}$. Large specimens. Sweden. From Mr. Lloyd's Collection.

$\gamma$. Young. Sweden. From Mr. Lloyd's Collection.

§. Adult: skin. Sweden. Mr. Yarrell's Collection.

є. Adult: skin. Europe. Mr. Yarreli's Collection.

$\zeta, \eta$. Adult. Europe. Presented by the College of Surgeons.

$\theta$, ı. Half-grown. Europe. Presented by the College of Surgeons.

$\kappa, \lambda$. Half-grown. Sine patria. From the Haslar Collection.

$\mu$. Young. From the Collection of the Zoological Socicty.

$\because$. Adult: skeleton. England.

\section{Perca flavescens.}

Bodianus flavescens, Mitchill, Ph. Trans. New York, i. p. 421.

Perca flavescens, Cuv. Règne Anim.; Cuv. \&. Val. ii. p. 46 ; Richardson, Faun. Boi.-Amer., Fishes, p. 1.pl. 74; Storer, Report, p. 5, and Synopsis, p. 17, and Bost. Journ. Nat. Hist. iv. p. 175; Kirtlend, in Bost. Journ. v. p. 337. pl. 27. f. 2 (bad); Dekul, New York Fuma, Fishes, p. 3. pl. 1. f. 1 ; Holbrook, Ichth. S. Carol. p. 2. pl. 1. f. 1: Agassiz, Lake Superior, p. 291.

- granulata, Cur. \& Val. ii. p. 48. pl.9, cop. by Dekay, Nev York Falena, p. 5. pl. 68. f. 220.

— serrato-granulata, Cuc.S. Val. ii. p. 47 ; Dekay, l.c. pl. 22. f. 64.

D. $13-\left.14\right|_{\frac{1-2}{13-14}}$. A. $\frac{2}{7-8}$. Cæc. pylor. 3. Vert. 21/20.

Total length equal to $3 \frac{3}{4}$ or four times the height of the body. Inferior edge of operculum with a few weak denticulations; inferior edge of prooperculum with about ten rather slender spinous teeth, directed forwards; operculum striated; 60 to 65 transverse rows of scales; transverse line $\frac{6}{17}$. A large black mark on the posterior part of the first dorsal fin.

United States; Canada.

a. Adult. New York. From Mr. Brimdt's Collection.

b. Adult. Boston. Presented by J. Winstone, Esq. 
c. Adult: f'cmale skceleton. Ohio. From Mr. Frank's Collection as Perca americana.

d. Adult: stufferl. Canada.

e. Adult. N. America. From Mr. Warwick's Collection.

$f, g$. Adult. N. America. From Mr. Warwick's Collection.

h. Adult: stuffed. N. America. Prescnted by Edw. Doubleday, Esc1. $i, k$. Adult: skins. Montezuma, U.S. From Dr. Parnell's Collection.

l. Intestines of specimen $c$.

Skeleton.-Thes structure of the single bones of the skull is exactly the same as in the Common Perch; the slight differences are the following: the radiating streaks on the upper surfuce of the head and on the operculum, which are to be seen also in the Common Perch, are here deeper and more developed; the spines of the operculum are more acute, and there is benceath the longest a third, much smaller, but very conspicuous; there are eight spinous teeth ulong the lower limb, directed forwards. Vert. 21/20. The first interhamal is attached ts the twenty-second vertebra, as in the Common Perch; and from an examination of the skelctons, I am still more inclined to consider both to be varicties of one and the same species.

\section{Var. Perica acota.}

C'uv. \&Val. ii.p. 49. pl. 10; Richardson, Faun. Bor.-Amer., Fishes, p. 4 ; Dekay, New York Funna, Fishes, p. 6. pl. 68. f. 222.

$$
\text { D. } 13-14 \mid \frac{2}{14} \text {. A. } \frac{2}{7} \text {. }
$$

Total length equal to $3 \frac{3}{4}$ the height of the body. Inferior edge of opereulum with a few rather strong denticulations; inferior edge of preoperculum with numerous weak spinous tecth; operculum striated ; transverse rows?; transverse line?. No black spot on the first dorsal fin.

Lake Ontario.

\section{Perca gracilis.}

C'uv. \& Val. p. 50; Richardson, Fuun. I3or.-Amer., Fishes, p. 4.

$$
\text { D. } 13 \mid \frac{1}{14} \text {. A. } \frac{2}{6} \text {. }
$$

Total length equal to five times the height of the body. Inferior enge of operculum entire; edges of prseoperculum with numerous nearly equal, very small spinous teeth; opereulum striated; more than 70 transverse rows of sceales; transverse line $\frac{3}{17} . \Lambda$ small black spot on the hinder jart of the dorsal fin.

Luke Skaneateles (system of Ontario); Canada.

a. Adult: stuffed. Canada.

This species is considered by Holbrook to be a variety of Perca favescens. 


\section{PERCICHTHYS.}

Peres, sp., Cun.\& Val. ii. p. 19.

Percichthys, Giverd, Proc. Ac. Nat. Sc. Philad. 1854, p. 197, and U.S. Nav. Astron. Exped. ii., Zool. p. 230.

Seven or six branchiostegals. All the teeth villiform, without eanines; teeth on the palatine bones, tongue smoot'. 'Two dorsals, the first with nine (or ten) spinos; anal fin with threo spines. Operculum spiniferous; præoperculum and præorbital serrated. Scales small; head covered with scales above.

Fresh waters of the Neotropical region. (Java.)

\section{Percichthys lævis.}

Perea lævis, Jenyns, Zool. of the Bcagle, Fishes, p. 1. pl. 1.

$$
\text { D. } 9 \mid \frac{1}{11} \cdot \quad \Lambda . \frac{3}{9} \text {. }
$$

Height of the body not quite one-fifth of the total length, the head not quite one-fourth. Head above covered with scales, as far as the eonnecting line of the nostrils; seales rather smooth, senreely at all ciliated. Candals slightly notched. Yellowish brown (in spirits), covered all over with small dusky spots, one oceupying the base of each scale. (Jenyns.)

Santa Cruz River, Patagonia.

\section{Percichthys trucha.}

Perca trueha, C'uv. \& Val. ix. 1. 429; Cuichen. in Gay, Itistmia de Chile, Zool. ii. p. 146. pl. 1 b. fig. 1. [It appears doubtful, from Girard's examination, whether this figure is made from a specimen, or from the deseription given by Valeneiennes.]

Percichthys trucha, Girard, Proc. Ac. Nat. Sc. Philad. 185.4, p. 197.

? l'ereichthys ehilensis, Gir. in U.S. Nav. Astron. Ixped. ii., Kool. p. 231. pl. 29. f. 1-4.

$$
\text { B. 7. D. } 9 \mid \frac{1}{13}, \quad \Lambda . \frac{3}{10} \text {. }
$$

The upper maxillary bone reaching to below the middle of the eye ; sub- and interoperculum seareely denticulated ; caudalis moderately emarginated; scales ciliated. Yollowish brown, spotted with darker.

Rio Negro (Patagonia); fresh waters of Chili.

\section{Percichthys melanops.}

Givard, Proc. Ac. Nat. Sc. Philad. 1854, p. 197 ; U.S. Nnv. Astron. Exped. ii., \%ool. p. 233. pl. 30. f. 1-5).

B. 6. D. $10 \mid \frac{1}{10}$. $\quad$ A. $\frac{3}{9}$. L. lat. 58-60. L. transv. 10/22.

Branchiostegals six; the upper maxillary bone reaching to the level of the anterior margin of the eye; opereular spinic not very 
eonspicuous. Ground-eolour whitish, minutely and densely dotted with black; dots erowded in the middle of the scales in the shape of a central blotch.

Rio de Maypo, Chili.

The two following species are too little known to be brought into this genus witl certainty; but being evidently good species, 1 think it better to plaee them here than to neglect them.

\section{Percichthys ciliata.}

Perca ciliata (Kull \&. r. IItesselt), ('tuv. \& V Vul. ii. p. 5\%.

$$
\begin{array}{l|l|l|l}
\text { D. } 9 & \frac{1}{11} \cdot \quad \text { A. } \frac{3}{10} \text {. }
\end{array}
$$

Height of the borly not quite one-fourth of the total length. Scales strongly ciliated. Abore uniform greenish; no black spot on the rlorsal fin.

Jatra.

\section{Percichthys marginata.}

Perca marginata, Cul. \&. $V$ al. ii. p. 5:?.

$$
\text { D. } 9 \mid \frac{1}{17} \text {. A. } \frac{3}{10} \text {. }
$$

Height of the body one-fourth of the total length; erlge of operanlum entire: edges of prooperenlum equally and finely dentienlaterl: catulat fin forked, black-edged.

II (U). - ?

\section{PARALABRAX.}

Paralabrax, Givard, Irome. Ac. Nut. Sc. Pleilud. 1850, p. 131.

Habit cylindrical. Six branchiostegals. Psoudobrandhix? Teeth villiform, with a series of larger ones on cuch sirle of the jaws: tecth on the palatines, tongue smooth. ()ne dorsal, decply intehed, the first portion with nine spines; the anal fin with three. Operenlum spiniferous; procoperculum serrated. Scales small.

Fresh waters of California.

\section{Paralabrax nebulifer.}

Labrax nebulifer, Girard, I'ros. Ac. Nat. So. I'hilat. 185.4. p. 142. Paralabrax nebulifer, Givarl, l. c. 18.56, p. 131.

$$
\text { D. } 9 \mid \frac{1}{14} \cdot \text { A. } \frac{3}{8} \text {. }
$$

Total length not quite fuur times the height of the hody: lateral linc:"; third dorsal spine longest. Jack reddish brown, with large rloud-like blackish blotches; snout covered with small roundish spots; a dark band from the orbit across the checks to the gills.

Monterey (California). 


\section{Paralabrax clathratus.}

Labrax clathratus, Girard, Proc. Ac. Nat./Sc. Philud. 1854, p. 143. Paralabrax clathratus, Girerd, l. c. 1856, p. 131

$$
\text { D. } 9 \mid \frac{1}{13} \text {. A. } \frac{3}{7} \text {. }
$$

Total length not quite four times the height of the body; lateral line?; fourth dorsal spine longest. Back purplish; back and sides covered with darker blotches; second dorsal spotted; a dark templestreak.

San Diego (California).

\section{LABRAX*.}

Labrax, Cuv. Règne Anim.; Cuv. \&. Val. ii. p. 55.

Seven branchiostegals; pseudobranchix developed. All the teeth villiform, without canines; teeth on the palatine bones and on the tongue. Two dorsals, the first with nine spines; anal fin generally with three. Opereulum spiniferous; præopereulum serrated, and with denticulations at the lower limb; proorbital entirc. Scales rather small or moderate. Number of pyloric appendages few (4-5).

Shores of the Arctic Regions; Rivers of North Ameriea.

\section{Labrax lupus.}

$\Lambda a ́ \beta \rho a \xi$, Artstot. i. cap. 5, iv. cap. 11, v. cap. 10 , vi. cap. 13,19 , viii. cap. 19, and De Put Anim. iv. cap. 8, viii. cap. 2, 30; Altan, i. cap. 30 , ix. cap. 7 , x. cap. 2 , xvi. cap. 12 ; Athen. lib. vii. xiv. ; Oppien, i. cap. 5, ii. cap. 34, 58.

Lupus, Plin. ix. cap. 17, 5t, xxxii. cap. 2; Bellon. Arput. i. p. 113 ; Salv. Aquat. xxviii. p. 108. f. 30; Rendel. Pisc. Mur. ix. cap. 7, cum fig.; Gesner, iv. p. 506 ; Aldror. Pisc. iv. eap. 2. p. 490, cum fig.; Jonston, ii. cap. 2; Willuyllby, iv. cap. 1. p. 271. tab. R. 1; Ray, Sym. Pisc. p. 83.

Perca no. 7, Artecti, Gen. Pisc. p. 41.

Perca labrax, Lim. Syst. Nat. i. p. 482 ; Risso, Ichth. Nic. p. 299. and Hist. Nut. iii. p. 406 ; Nilss. Prodr. Ichth. Scandin. p. 82 ; Penn. Brit. Kool. p. 348. t. 66 ; Donov. Brit. Fishes, pl. 43; Turton, Brit. Funn. p. 100 ; Flem. Brit. Anim. p. 213; Son ini, Voy. i. p. 217. pl. 3 ; Schagerström, R. Fet. Acal. IIamd. 1829, St. i. p. 90. tab. 3. f. 5-7; Murtens, Reise nach Vcncliy, ii. p. 428; Gronov. ed. Gray, p. 115 (not Pullas).

Perca punctata, Guecl. Syst. Nat. i. p. 1311 ; Lacép. iv. p. 418; Risso, Hist. Nut. iii. p. 407.

Centropomus lupus, Lacép. iv. p. 267.

Perca diacantha, Lucép. iv. p. 418; Schncid. Bl. Syst. p. 85.

Sciena labrax, Block, iii. p. 45. t. 301 (bad); Shaw, Zool. iv. p. 534.

_ punctata, Bloch, t. 305 (jun.); Shreu, Zool. iv. p. 536. diacantha, Bloch, t. 302 ; Shavo, Zool. iv. p. 5ise.

* 1. Labrax nigrieans, Dekay, New Fork Fanna. Fishes, p. 12. pl. 50. f. 160.Freshwater ponds of New York.

2. Lahrax albidus, Dekay, t. e. p. 13. pl. 51. f. 165.-Lake Erie. 
Labrax lupus, Cuv. Rigne Anim.; Cur. S. Ital. ii. p. 5ti. pl. 11 ; I"arr. Brit. Fishes, i. p. 8; Bomu). Foum. Itul.; ('ur. Rigne -lum. Ill.

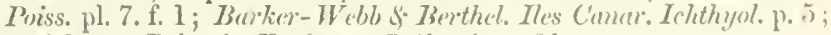
Guichenot, Poiss. in Explorat. "'Algivie, p. 31.

Geoffr. Descr. de l'Ey., Poiss. pl. 20. f. 2, 3 (Perche nocte et sinueuse).
D. $9 \nmid \frac{\mathrm{l}}{12-13}$.
A. $\frac{3}{10}$.
Cinc. pylor. 5.
Vert. 12/13.

Total length equal to $4 \frac{1}{2}$ the height of the hody ; 60 to 70 transverse rows of seales: inferior edge of prieopereulum with three strong spinous teeth, directed forwards. 13ack and sides greenish grey, in females and younger individuals with small black spots; belly white.

Niediterranear; coasts of Iortugal, Frunce, and England.

a. Large specimen: stuffed. England.

b. Adult. England.

c. Adult: stuffed. England.

d, e. Half-grown. England.

f. Half-grown. England. Presented by W. Yarrell, Esq.

g. Half-grown: stuffed. England.

h. Young. England. Old Collection.

i. Young. England. Presented by W. Yarrell, Esir.

$k$. Adult: stuffed. Frith of Forth.

1. Adult. Europe. From the Haslar Collection.

m-o. Half-grown. Europe.

$p, q$. Young. Europe.

$r$, s. Adult: stuffed. Europe.

t. Adult: skin. Solway.

u. Half-grown: skin. South Devon.

$v$. Half-grown: skin. Ingland. From Mr. Yarrell's Collection.

$w, x$. Adult: skin. Lisbon.

y. Adult : slin. Burope.

z. Adult: skcleton. England.

\section{Labrax elongatus.}

Perea clongata, Geoffr. Deser. de P'Eg., P'oiss. pl. 19. f. I.

Labrax elongatus, C'uv. \& V'al. ii. p. 77.

$$
\text { D. } 9 \mid \frac{2}{14} \text {. } \Lambda . \frac{2}{10} \text {. }
$$

Total length rqual to five times the height of the body; transverso rows?; inferior erge of procopereulum with more than five spinous teeth of moderate size. Back and sides greenish grey; belly white.

North coast of Egypt.

\section{Labrax lineatus.}

Schöpf, Schriften der Gesellsch. Nuturforsch. Frounde, viii. p. 160. Perea saxatilis, $13 l$. Schn. p. 89.

Sciana lineats, Bl. t. 304 . 
Centroponus lineatus, Lacép. iv. 25\%.

Rocens striatus, Mitchill, Rivgrort, p. 25.

Perca mitchilli, Mitrhill, Tirans. Nme Emel, i. p. 413. pl. :3. f. 4.

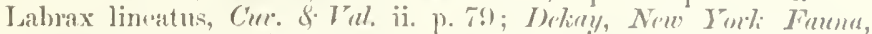
Fishes, p. 7. pl. 1. f. 3; Haird in Niuth Smithson. Report, 1. 321; Itollor. Ichth. S. C'arel. p. 17. pl. 4. f. 1.

$$
\text { D. } 9 \mid \frac{1}{12} . \quad \text { A. } \frac{3}{11} \text {. I. lat. } 57-62 \text {. I. transv. 9/11. }
$$

'Total length equal to $4 \frac{1}{3}$ the height of' body; teeth of the tongue: in two elongate oval patches; teeth of the inferior edge of proesperculum not much stronger than those of the hinder one. Seven or eight black longitudinal bands.

Lustern coasts of North Ameriea from Maine to Georgia.

a. Adult. North America. From Mr. Warwick's Collection.

b, c. Arlult. North America. From Mr. Warwick's Collection.

d. Adult: stuffed. North America. Presented by Edward

Doublerlay, Esi .

e. Adnlt: skin. New York. From Dr. I'arnell's Collection.

f. Adult: skin. New York. From Dr. Parnell's Collection.-Th" bands are irregularly waved and interrupted (Prea mitchilli intermpta).

\section{Labrax osculatii.}

Filimi, Rev. Magaz. Zool. 1853, p. 164.
ก. $9 \mid \frac{1}{13}$.
A. $\frac{3}{13}$.
L. lat. 56 .
I. transv. $9 / 15$.

The height of the body is one-third of the total length; tecth of the tongue arranged in a single oval patch; teeth of the inferior edge of prooperalum not much stronger than those of the hinder one. Seven or eight black longitudinal bands.

Eastern erasts and rivers of the Inited States.

\section{Labrax rufus.}

Morone anfa, Mitskill, Report, p. 18.

Perca muncronata, Rafinesque, Monthly Mugazine, ii. p. 205.

P Jerea americana, Schiop? Nutueforscher, xx. p. 17, and Schriftem dere

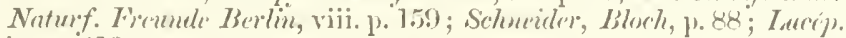
iv. 1. 412.

1.abrax musronatus, C'ur. \& Vul. ii. p. 80. pl. 12; IBairl in Ninth Smithson. Rirport, p. 32:3.

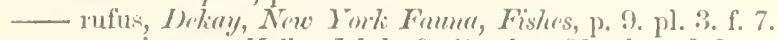

_ americanus, IIolbr. Ichth. S. C'arol. p. 21. pl. 3. f. 2.
1). $9 \mid \frac{1}{12-13}$.
A. $\frac{3}{9-11}$.
('ace. pylor. $4(-5)$.
J. lat. $50-55$.
Vert. $11 / 14$.

Total length equal to :3 $\frac{1}{2}$ the height of body; edges of prexopereulum nearly equally and fincly denticulated. Brownish grey, with more or less olsolete darker bands.

Eastern shores of the Uniterl States from Massachusetts to South Carolina. 
a. Large sperimen. Bostun. Presented by W. Winstone, Esq.

b. Adult female : skeleton. New York. From Mr. Rrandt's Collection.

c. Adult. New Orleans, From Mr. Cuming's Collection.

d. Half-grown. America. Old Collection as Perca totog.

$e, f$. Adult and half-grown: skins. New York. From Dr. Parnell's Collection.

$g$. Intestines of specimen $b$.

The liver is proportionally small, divided hy a slight incisure into two parts, the left of which is larger, and distinguished by a still slighter furrow. There are four pyloric appendages, half as long as the stomach. Two separated ovaria. Pseudobranchia well developed.

Skeleton.-The paroccipital crest is high, triangular, pointed behind; the upper side in a straight line with the surface of the head, obliquely ascending. The ridges at the side of the skull are modificd into muciferous channcls: the pracorbital bone exhibits several cavitics, as in Acerina cernua, but not quite so deep; ihey communicate with the suborbital arch, which is narrow and forms the middle part of this channel; at the upper postcrior corner of the orbit the channel is continued by an excavated bony ridge, minning to the mastoid bone; here it is turned up and backwards, passes the upper articulation of the suprascapula, and is lost ncar the suture of the supraoccipital and of the frontal bones. A second pair of muciferous channels is found at the upper surface of the head, runuing in a straight line from the maxillary bone between the orbits to the middle of the frontals, opening by two or three lateral holes. The third muciferous channel runs in an elevated second ridge of the præoperculum, as in Chilodipterus, Apogon, \&c.; it is contimed on the lower surface of the mandibula, where it opens by four oval holes. I have formerly (Wiegm. Arch. 1855 , p. 200) pointed out that such muciferous channels are to be found also in Perca and Lucioperca, and I may now add, in all the Percoids, but less developed: not forming a good generie character by itself, but combined with the fine serrature at the lower limb of the propoperculum, it may some day cause the separation of this species from $L$. lupus, \&c.

The suborbital arch has no interior process for supporting the eye-ball from beneath, as is observed in a great many Percoids. The maxillary bone has the superior margin more convex than the inferior one. Opereulum with two points, the upper one short and rounded, the lower prominent and acute. Propopenlum finely serrated throughout; posterior margin straight-lined; angle rounded; lower margin slightly convex ; intoropereulum with some excessively minute denticulations; suboperculum entire. All the tecth are villiform, arranged in bands: those of the romer form an obtuse angle. The interior plate of the pubic bones is broad, in immediate contact with that of the other side, without leaving an interspace between. The first interhrmal is of moderate strength, equal to the length of the second to sixth vertebra, and attached to the hremal of the twelfth. 


\section{Labrax pallidus.}

Morone pallida, Mitchill, Report, p. 18.

Bodianus pallidus, Mitchill, Trans. Lit. \&. Phil. Soc. i. p. 420.

Labrax pallidus, Dekay, Neu York Fauna, p. 11. pl. 1. f. 2.

$$
\text { D. } 9 \mid \frac{1}{12} \text {. A. } \frac{3}{7} \text {. }
$$

The height of the body is $3 \frac{1}{2}$ in the total length; the edges of the præoperculum nearly equally and finely denticulated. Light bluish above, paler beneath.

Eastern shores of the United States.

a. Adult. America.

\section{Labrax multilineatus.}

Chuv. \&. Val. iii. p. 488; ? Kirtland in Bost. Journ. v. p. 21. pl. 7. f. 1 (not good).
D. $9 \mid \frac{1}{13-14}$.
A. $\frac{3}{12}$.

Total length equal to $3 \frac{1}{2}$ the height of the body ; 50 transverse rows of scales. Sixteen to nineteen black longitudinal bands.

River Wabash.

\section{Labrax notatus.}

Labrax notatus (Smith), Richardson, Faun. Bor.-Amer., Fishes, p. 8.

$$
\text { D. }\left.9\right|_{\frac{1}{12}} \text {. A. } \frac{1}{12} \text {. }
$$

Total length equal to four times the height of the body; lateral line with 58 scales. Marked with rows of spots, five above and five below the lateral line, very regularly interrupted and arranged.

Coast of Canada.

\section{LATES.}

Lates, Cuv. Règne Anim.; Cuv. \& Val. ii. p. 88.

Seven hranchiostegals; pseudobranchiæ absent. All the teeth villiform, without canines; teeth on the palatine bones, tongue smooth. Two dorsals; the first with seven or eight, the anal fin with three spines. Operculum spiniferous; præoperculum with strong spines at the angle and at the lower limb; præorbital strongly serrated. Scales moderate.

Nile. Mouths of the large East Indian rivers.

\section{Lates niloticus.}

\átos, Athen. p. 311.

Perca nilotica, Gmel. Syst. Nat. $1312 ;$ Bl. Srhn. p. 87.

Centropomus niloticus, Lacép. iv. p. 278. 
Prospe: Alpin, Res. Ey. iv. c. 2 ; Sommini, Voy. ii. p. 292. t. 22. f. 3 ; IIusseiq. Voy. p. 35i; Geoffi. Descr. de I Ey., Poiss. pl. 9. f. 1.

I ates niloticus, Cux. \& Vul. ii. p. 89, iii. p. 490.

$$
\text { D. } 7(-8) \mid \frac{1}{12} \text {. A. } \frac{3}{8(-9)} \text {. Cxc. pylor. } 5 \text {. }
$$

Prooperculum with a right angle; coracoid with five denticulations; second and third spine of the analis nearly equal in length. Back brownish, sides and belly silvery white.

Nile.

\section{Lates calcarifer.}

IIolocentrus calcarifer, Bloch, t. 244.

Russell, ii. t. 131.

Holocentrus heptadactylus, Lacép. ir.pp. 344, 391.

Coins vacti, Ham. Buch. Gunges, Fishes, t. 16. f. 28.

Lates nobilis, Cur. \& Vul. ii. p. 96. t. 13; Richurtson, Ichth. Chinu, p. 222; Bleeker, I'err. p. 27; C'untor, Contul. p. 1; Hugeman in Natuurk. Tyelschr. Neterl. Ind. 1851, p. 348.

$$
\text { D. } 7-8 \mid \frac{1}{12} \text {. A. } \frac{3}{8-9} \text {. }
$$

Præopereulum with an obtuse angle; coracoid with six to ten denticulations; third spine of analis nearly twice as long as second. Back and sides brownish, shining, belly white.

Mouths of the large East Indian rivers.

a. Haif-grown. India. From Mr. Brandt's Collection as Lates argenteus.

3. Half-grown. India. Presented by the Zoological Society.

c. Half-grown. India. Presented by G. R. Waterhouse, Esq.

$d, e, f$. Adult: stuffed. Ganges. From Mr. Warwick's Collection.

g. Adult: stuffed. China. Presented by the East India Company.

h. Half-grown: stuffed. China. Presented by J. R. Reeres, Esiq.

i. Adult: skin. China. From Mr. Warwick's Collection.

\section{(i. INIDON.}

Cnidon, Mïll. \& Trosch. Hor. Ichth. p. 21.

Seven branchiostegals; pseudobranchix absent; all the teeth villiform, without canines; teeth on the palatine bones. Two dorsals; the first with seven, the anal fin with three spines. Operculum spiniferous; procopereulum with the lower limb entire, and the posterior dentienlated; a spine au the angle. I'reorbital nearly entire. Pyloric appendages?

Philippines.

\section{Cnidon chinensis.}

Miill. \& Trosch, I. c.

Manilla.
D. $7 \mid \frac{1}{13}$
$\Lambda \frac{3}{y}$. 


\section{PSAMMOPERCA.}

Labrax, sp., Cuv. \& I ral. ii. p. 83.

Psammoperca, Richardson, Toy. Erebus \&. Terror, Fishes, p. 116, and Ichthyology, p. 275.

Seven branehiostegals. Tecth on the vomer and palatine bones erowded, granular; no canine teeth; tongue smooth. Two dorsals, slightly continuous, moving in a sealy sheath; the first with eight, the anal with three spines. Opereulum with a small, præopereulum with a strong spine, the latter with an entire lower limb. Scales rather large.

East Indian and Australian seas.

\section{Psammoperca waigiensis.}

Labrax waigiensis, Cuv. \& Vul. ii. p. 83; Bleeker, Naturk. Tydsche. Nederl. Ind. ii. p. 479; Lesson, Voy. Coq. Zool. 237.

Psammoperca datnioides, Richurdson, Voy. Erebus \&. Terror, Fishes, p. 116. pl. 57. f.' 1, 2.

waigiensis, Bleeker, l.c. v. p. 177.

$$
\text { D. }\left.8\right|_{\frac{\mathrm{j} 2-13}{13}} \text {. A. } \frac{3}{9} \text {. L. lat. 50-55. }
$$

Height of body one-fourth of total length. Hinder edge of preoperculum denticulated, a long spine at the angle.

Australia ; Waigiou.

a. Adult: stuffed. Australia.

b. Half-grown: stuffed. Victoria, Australia. Voyage of H.M.S. Herald.

c. Adult: skin. China. From Mr. Warwick's Collection.

\section{Psammoperca macroptera.}

$$
\text { D. } 8 \mid \frac{1}{13} \text {. A. } \frac{3}{13} \text {. }
$$

Height of the body one-third of the total length; præorbital and suborbital arch strongly serrated; hinder edge of præopereulum serrated, a triangular spine at the angle.

a. Dried. Vietoria. Australia. Voyage of H.Mr.S. Herald.

The specimen upon whieh I found this new species shows very well the eharaeters of the genus, and the peculiarities by which it is distinguished from the only other species hitherto known; but the seales are partly detached, or spoiled by fat. It is distinguished by the great elevation of the body, by the high third dorsal spine, and the long anal fin.

The length of the head is $4 \frac{2}{5}$ in the tutal; it is compressed, the interspaee between the eyes being one-sixth only of the length of the head, or rather more than one-half the diameter of eye. The snont equals in length that diameter, and is laterally cover ed br the 
præorbital, which widens above, and is furnished by strong spinous teeth beneath, directed backwards; this serrature becomes finer on the suborbital arch. The upper maxillary is styliform, and forms posteriorly a triangular plate; it does not appear to reach the middle of the eye. The eye is placed high up the side, and does not interfere with the upper outline of the head; its diameter is nearly onc-fourth of the length of the head. 'The operculum has a somewhat rounded posterior angle, without distinet point; the vræoperenlum is finely serrated along the posterior limb, and armed with a triangnlar and keeled spine of moderate size at the angle; the lower limb has no denticulation whatever.

The greatest depth of the body is between the origns of the second dorsal fin and the anal, the profile rising steeply from the occiput to the highest point; the tail (without caudal). behind the end of the dorsal, is as high as long.

The third spine of the dorsal fin is very long, one-sixth of the total length; the first is small ; the second shorter than one-half of the third; the fourth, fifth and sixth rapidly decrease in length; the seventh and eighth are short, and inserted between both dorsals. The first spine of the second dorsal is a little longer, one-half of the height of the fin. The rays are nearly equal in length, much shorter than the spinous part, and form a rounded fin. Caudul rounded, with eighteen rays. The anal fin resembles in shape the soft dorsal, but its base is longer, and the longest lay is somewhat higher. The spines are of moderate strength; the second is rather longer than the third, and two-thirds the length of the longest ray. 'The pectoral and ventral fins are nearly equal in length; the latter do not reach to the vent; their spine equals the fifth of the dorsal.

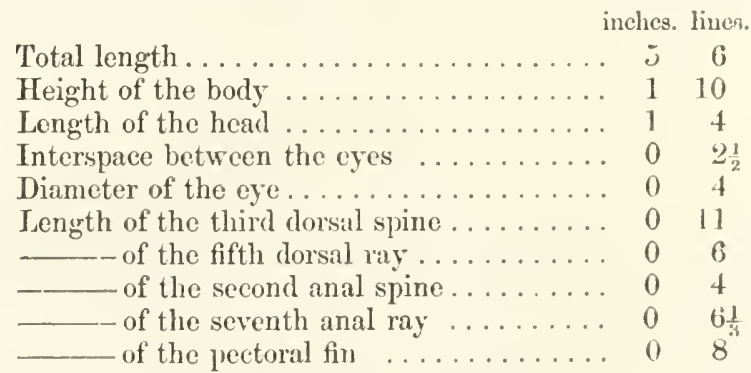

\section{PERCALABRAX.}

Labrax, sp., Cur. \& I al. ii. p. 85.

Percalabrax, Temm!. \& Schiley. F'uuu. Jupon. p. 2.

Lateolabrax, Bleck. Verheund. Batur. ( enowtsch. xasi. p. 5i).

Seven branchinstegals: pseudohranchix developed. All the teeth villiform, without eanines, toeth on the palatine homes: tongue 
smooth. Two dorsals, the first with eleven, the anal fin with three spines. Operculum with two points; prieoperculum serrated bohind, and with strong spinous teeth beneath; preorbital cutire. Scales rather small. Number of pyloric appendages increased (13).

Shores of China and Japan.

\section{Percalabrax japonicus.}

Labrax japonicus, Cur. \& I Tal. ji. p. 85.

Percalabrax japonicus, Fum. Japon. p. 2. pl. 2. f. 1.

Lateolabrax japonicus, Bleck. l. $c$.
D. $11 \mid \frac{1}{13-14}$.
A. $\frac{3}{8}$.
Cice. pylor. 13.
Vert. $16 / 19$.

'Total length equal to somewhat more than form times the height of body; inferior edge of præopereulum with five spinous teeth, directed forvards. Back greenish grey, with round blackish spots; first dorsal fin spotted.

Chinese and Japanese seas.

a. Adult. China. Presented by J. R. Reeves, Esq.

b. Adult. China. Presented hy the East India Company.

c. Adult. China. From the Haslar Collection.

d. Half-grown. China.

e. Young. China. Presented by the East India Company.

f. Young. Chusan. Presented by the East India Company.

g. Young. Chusan. Iresented by the East India Company.

h. Adult: stuffed. Japan.

i. Young: stuffed. China. Presented by J. R. Reeves, Esq.

$k$. Intestines of specimen $b$.

This species is in general appearance allied to Lates, exhibiting also a eoneavity of the mpper profile of head; and the tongue is smooth, without teeth; but the pseudolranchice are as much developed as in the speeies of Labrax.

Skeleton.-The skull is rather flat above, the paroceipital erest not much elevated above the level, not extending beyond the supraoccipital, and acutely pointed behind. The muciferous channcls are not, or very moderately, developed, as for instance that between the orbits. The suborbital areh with an interior flat process; the maxillary bone without process, and with divergent straight-lined margins. Operenlum with two points, botle acute, the upper short, the low.er very elongate. The hinder limb of the propopereulum is minutely serrated, the angle and the lower limb bear four or five strong spinous teeth, direeted forward; the sub- and inter-operculum are entire. The neural spines of the first ten vertebro are strong and broad; the first interhæmal is exceedingly strong; the plates between the two bony eentres of this bone (between the interhremal of the first, short anal spine and that of the seeond, strong one) are not united, forming a deep sheath; it is attached to the hamals of the serenteenth and eighteenth vertelora. 


\section{ACERINA*.}

Acerina, Cue. Regne Anim.; Cur. \&. Trul. iii. p. 3.

Seven branchiostegals. All the teetl villiform, without ennines; no teeth on the palatine bones or on the tongue. (One dorsal with thirteen to nincteen spines, the and fin with two. ()perenlum and preopereulum spiniterous. Muciferous clammels of the lomes of the skull very developed. Sicales rather small.

livers of the Palaarctic liegion.

\section{Acerina cernua.}

C'ernua fluviatilis, Bellon. Aquet. p. 291; Gesrer, pp. 191, 192, 220;. Willuyhby, p. 334; Ruy, p. 144.

l'erce thuriatilis genus minus, fesner, pp. 701, 825.

l'iscis Danubii, Schröll German., G'sue't, p. 20. f. Itil.

Porens fluviatilis, Perea fluviatilis minor, de., Cicsuer, f. $160 \mathrm{a}$.

Perea minor, l'orens, P'orenlus, Ec., Srhoner. p. 56.

- Huviatilis minor, Allror. v. cap. 3t; Junston, iii. tit. 3. cap. 2.. t. $2 \times . f$.

Danubii incola, Piscis Schröllus, Aldrox. v. cap. 3,5.

Scrollus, Jonston, iii. tit. 3. cap. 3. t. 28. f. " (right hand).

Scrollus danubianms, Tillughby, p. 335; Ray, p. 143.

Goldtisch, Scheenlif. Theriogr. Siles. p. $44 \mathrm{I}$.

Perca no. :3, Artedi, Spece. p. 80.

- 110. 4, Artedi, Generu, p. 40.

_ cemun, Limn.; Gronor. Syst. ed. Groey, p. 112; Scheffer, I'isc.

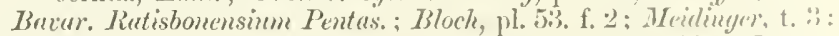
Don. Brit. Fishes, ii. pl. 39; Turton, Brit. Founu, p. 100 ; Jenzus. Man. 334; Mieller, Zool. Dan. Prodr. 392.

Perea no. 1, Klein, Hist. Pise. v. p. 40.

Duhumel, Pêches, iv. p. 39. pl. 8. f. 1; Mursigli, iv. p. 67. tab. 23. f. 2 (Perea no. 2).

Gymuocephalus cermua, B1. Schn. p. 345; White, Catal. of Brit. Fishes, p. 12.

Holocentrirs post, Lacép. is. p. 35\%.

Cermua fluviatilis, Flem. Iirit. Anim. p. 212.

Acerina vulgaris, Cuw. of lal. iii. p. 4. pl. 4l, vii. p. 448; Fries och Echström, Sliand. Fisk. p. 9. t. 1. f. 2; Yarmell, Brit. Fishes, i. p. 18; ('ur. Rigne Anim. Ill. pl. 9. f. 2; Novelmermm in 1) entideff",

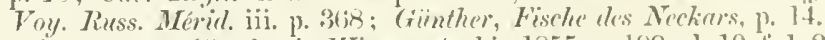

Acerina cernua, Giinther in Wicym. Archie, 185.) p. 199. pl. 10. t.' 1, 2.

$$
\begin{aligned}
& \text { D. } \frac{13-15}{12} . \quad \text { A. } \frac{2}{5-6} \text {. I. lat. } 55-60 \text {. Vert. } 15 / 20-21 \text { (22). } \\
& \text { Cace. pylor. } 3 .
\end{aligned}
$$

Greenish olive, marbled and spotted with brown; dorsal and caudal fins brown-spotted. Head without seales.

Rivers of England, France, Switzerland, Germany, Swerkers. Norway, Russia, Sibcria.

a. Adult. Danube. (yymnothorax.)

b. Adult. Switzerland. Presented by I'rof', Agassi\%.

* Accrina zillii. Gicreres, Aun. Si. Mret. 1848, 1. 203, does not belong to thrgerus.-Algiers. 
c. Several specimens. Gotha River (Sweden). Frum Mr. Lloyd's Collection.

d, e. Adult. Europe. Presented by W. Yarrell, Esq.

f. Adult. Europe.

g. Adult: skin: not good state. England.

\section{Acerina rossica.}

Perca tanaicensis, Güldenstelt, Nor. Comment. Ac. Petrop. xix. p. 457. t. 2 .

- acerina, Pall. Zoogr. iii. p. 244.

Acerina rossica, Cux. \&. Fal. iii. p. 17, vii. p. 449 ; Nodmamn in Demidoff; Voy. Russ. Mérid. iii. p. 369. pl. 2. f. 2.
D. $\frac{17-19}{12-14}$.
A. $\frac{2}{5-7}$.
L. lat. 55. Vert. 40.
Crec. pylor. 3.

Brown, spotted with black.

Russian rivers falling into the Black Sea.

\section{Acerina schrætzer.}

Schraitser Ratisbonensis, Willughby, p. 335; Ray, p. 144.

Perca no. 3, Schraz. Mrarsigl. iv. p. 68. t. 23. f. 8.

- no. 5, Artedi, Generi, p. 40.

- no. 2, Klein, Hist. Pisc. v. p. 41.

—, Gronor. Zoophyl. no.'289.

— schrietzer, Lim. Syst. Nut. ed. 12. gen. 168. sp. 31 ; Bloch, t. 332 ; Schaffer, Pisc. Barar. Rutisbon. Pentas.; Meidinger, t. 2.

Gymnocephalus schretzer, Bl. Schn. p. 345.

Holocentrus schraizer, Lacép. iv. p. 347.

Perca danubiensis, Gromox. Syst. Nat. ed. Gray, p. 112.

Acerina schraitzer, Cux. \&. Tiul. iii. p. 13.

D. ${ }_{12-13^{\circ}}^{18-19}$ A. $\frac{2}{6-7}$. L. lat. 75 . L. transv. $\frac{7-8}{13-14}$. Vert. 1523 .

Ciec. pylor. 3.

Brownish olive, with three or four black longitudinal bands dorsal and eaudal fins brown-spotted.

Danube.

a, b. Adult. Switzerland. Presented by Prof. L. Agassiz.

\section{PERCARINA.}

Perearina, Nordmam in Dcmidoff's Toyage dans la Russie MÉrid. iii. p. 357.

Seven branchiostegals. All the teeth villiform, without eanines ; no teeth on the palatine bones; tongue smooth. Two separate dorsals, the first with ten, anal fin with two spmes. Mueiferous eavities of the bones of the skull much developed. Operenlum witl one spine; preoperculum denticulated, with simple edgu. Scales small.

Dniestrer. 


\section{Percarina demidoffii.}

Nordmann, l. c., Poiss. pl. 1. f. 1.
D. $10 \mid \frac{3}{10-12}$.
A. $\frac{2}{9-10}$.
L. lat. 34-36.

In habit similar to Acerina cernua. Caudalis forked. Yellowish, with round black spots on the back, and with a large brown semilunar blotch on the neck.

Dniester.

\section{LUCIOPERCA.}

Lucioperca, Cur. Regne Amm.; Cuv. \& Val. ii. p. 110.

Seren branchiostegals. Tecth in villiform bands, some on the jaws and on the palatines being longer ; teeth on the palatine bones; tongue smooth. Two dorsals, the first with $12-14$, the anal fin with two spines. Operculum spiniferous; præopereulum serrated, with a simple edge. Scales small.

Rivers of the Arctic Regions.

\section{Jucioperca wolgensis.}

Perca wolgensis, Pall. Voy. (Trarl. Franç.) p. 99. pl. 8; Linn. Cimel. p. $1309 ; B 1$. Schn. p. 91 .

Centroponus sandat, var., Lacép. iv. p. 263.

Perca asper, Pall. Zoogr. Ross. iii. p. 247.

Lucioperea wolgensis, Cur. \&. Yal. ii. p. 117, vii. p. 441 ; Nordmann in Demidoff, Voy. Russ. Mérid. iii. p. 303. pl. 1. f. 2; Gïnther, Wiegm. Arch. 1854, p. 210.

$$
\text { D. } 13 \mid \frac{1}{22} \cdot \quad \text { A. } \frac{2}{9-10} .
$$

Operculum with a rather obtuse and flat point behind; crown. operculum, præ- and suboperculun covered with scales; 80-85 transverse rows of scales; three ececa pylorica; no large black spot on the posterior part of the first dorsal fin.

Rivers of Southern and Asiatic Russia.

\section{Lucioperca americanz.}

Lucioperea americana, Fulenciemes, ii. p. 122. pl. 16 ; Firtland, Zool. Ohio, p. 19, and Bost. Joum. iv. p. 237. pl. 9. 1. 2 (bad) : Rich. Faun. Bor.-Amer., Fishes, pl. 10 \& 14; Dekay, New York Finna, Fishes, p. 17. pl. 50. f. 163 ; Agass. Lake Super. p. 294.

$$
\text { D. } 14 \mid \frac{1}{19-21} \cdot \text { A. } \frac{2}{13} \text {. }
$$

Operculum with a strong acute spine behind; occiput, operculum. præ- and suboperculum covered with scales; 100 transverse rows of scales; three ceca pylorica ; a large black spot on the posterior part of the first dorsal fin.

Canada; United States.

a. Targe specimen: stiuffed. Clbany River. Presented by sir J. Richardson. 
b, c. Adult: stuffed. Albany River. Presented by Sir J. Richardson. d, e. Adult: stuffed. Albany River. Presented by the Hudson's Bay Company.

$f$. Large specimen: skin. Albany River.

$g, h$. Half-grown and young: skins. New York. From Dr. Parnell's Collection.

\section{Lucioperca sandra.}

Incioperca (Schilus), Gesner, f. $176 b$; Schonev. p. 43; Willughby, p. 293; Ray, p. 98; Marsigli, Damub. iv. t. 22. f. 2.

Schilus seu Nagemulus, Aldror. v. cap. 59 ; Jonston, iii. c. 7. t. 30. f. 15 .

Perca, sp. 2, Artcdi, Genera, p. 39, and Species, p. 76 (classical description); Gronor. Zoophyl. no. 299 ; Klem, Hist. Pisc. v. p. 36. pl. 7. f. 3.

- lucioperca, Lim. Syst. Nat.p. 1308; Gronov. Syst.ed. Gray, p. 115 ; Schaffer, Pisc. Baicar. Ratisbon. Pentas.; Bloch, Fische Deutschl. t. 51: Bloch, Schneid. p. 83; Meidlinger, Pisc. Austr. t. 1; Pall. Zoogr. Rosso-As. iii. p. 246 ; Show, Zool. v. p. 547.

Centropomus sandat, Lacép. iv. pp. 248, 25.5.

Lucioperca sandra, Cur. Rène Anim.; Cur. \& I Tal. ii. p. 110. pl. 15; Cuv. Règne Anim. Ill. Poiss. pl. 7 a. f. 2 : Nordmam in Demidoff, Voy. Russ. Méril. iii. p. 362 ; Giunther in Wregm. Arch. 1855, p. 205.

$$
\text { D. }\left.13(14)\right|_{21-22} ^{1-2} \text {. A. } \frac{2}{11-12} \text {. }
$$

Operculum with a rather obtuse and flat point behind; crown, operculum and suboperculum with a few scales; more than 100 transverse rows of scales; six cæca pylorica; no large black spot on the posterior part of the first dorsal fin.

Large rivers of the European Continent.

a. Adult. Lake of Ladoga.

b. Adult. Switzerland. Presented by Prof. Agassiz. c-e. Half-grown. Sweden.

f. Large specimen: stuffed. Europe. Mr. Yarrell's Collection.

\section{Lucioperca marina.}

Perca labrax, Pall. Zoogr. iii. p. 243 (numbers of the fins wrong).

Lucioperca marina, Cuv. \&. Val. ii. p. 120; Eichw. Znol. Spec. iii. p. 82.

$$
\text { D. } 14 \mid 2 \dot{3} \text {. A. } 14 \text {. }
$$

Both the dorsal fins continuous ; parts of the upper surface of the head, the opercles, and cheeks scaly. Dorsal and caudal fins spotted.

Caspian and Black Seas.

\section{Lucioperca canadensis.}

Lucioperca canadensis (C. H. Smith), Griff. Amin. Kingd. x. pl. 7. p. 275. pl. 68. f. 221 ; Richarlson, Fann. Bor.-Amer., Fishes, p. 11.

$$
\text { D. } 12 \mid \frac{1}{17} \text {. A. } 12 .
$$

Operenlum with a spine hehind, and with four acute spines 
on the under margin. Lateral line? Cacea? First dorsal with three rows of large round black spots, the second witl four streaks of the same colour.

Canada (Quebec).

\section{Lucioperca grisea.}

Dekay, New Fork Fauna, Fishes, p. 19.

$$
\text { D. } 14 \mid \frac{2}{17-18} \text {. A. } \frac{2}{11-12} \text {. }
$$

Operculum with an acuto spine behind, above and beneath which is a very small one; crown partly, opereuium, pra- and suboperculum entirely covered with scales; 105 transverse rows of seales; seven cæea pylorica. All the fins black-spotted.

Fresh waters of the Northern parts of the United States.

a. Adult. Ohio. From Mr. Frank's Collection as Perca umericana.

b. Intestines of the came.

c. Adult: skin. Obio. From Dr. Parnell's Collection.

\section{PILEOMA.}

Pileoma, Dekay, New York Fuuna, Fishes, p. 16.

Six branchiostegals. All tho teeth minute, villiform, without canines; teeth on the palatines and on the vomor. Opereulum with a spine, præopereulum entire. Two separate dorsals, tho first with fourteen or fifteen spines; spines of the anal indistinet. Seales of moderate or rather small size. No air-bladder.

Fresh waters of North America.

\section{Pileoma semifasciatum.}

Pileoma semifasciata, Dekay, l.c. pl. 50. f. 162.

?- zebra, Agass. Lake Super. p. 308. pl. 4. f. 4 .

$$
\text { D. } 14 \mid 15-16 . \quad \text { A. } 10 \text {. }
$$

The height of the body is one-sixth of the total length, the length of the head one-fifth; the interspace between the eyes is nearly as broad as their diameter long. Body with narrow black eross-bars, alternately longer and shorter.

a, b. Adult: skins. Lake Erio. From Dr. Parnell's Collection. c. Adult: skins. Ohio Canal. From Dr. Parnell's Collection.

\section{Pileoma carbonarium.}

Baird \& Girard, Proc. Ac. Nat. Sc. Philad. 1853, p. 387.

$$
\text { D. } 15 \mid 13 . \text { A. } 11 .
$$

The length of the head one-fifth of the total. Hody with transverso bars of black a black spot at the base of the caudal, the latter barred; batse of ilorsulen tianl, and ventrals black. (B. $\delta \cdot G$.)

Kio salado ('l'exts) 


\section{BOLEOSOMA*.}

Bolcosoma, Dekay, Nere Fork Fuma, Fishes, p. 20.

Six branchiostegals. Minute card-like teeth, without canines; teeth on the palatine bones; tongue smooth. Two dorsals, the first with nine or ten feeble, the anal fin with indistinet spines. Operculum witl a single point, prapereulum smooth. Seales moderate. No air-bladder.

Fresh waters of the United States.

\section{Boleosoma tessellatum.}

Dekay, l. c. pl. 20. f. 57.

$$
\text { D. } 9 \mid 14 . \text { A. } \frac{2}{8} \text {. }
$$

Nape depressed, contracted; a deep furrow between the eyes; caudalis trumcated. Brownish, with oblong quadrate spots on tho baek and sides.

Rivers of New Fork.

\section{Boleosoma lepiduın.}

Baird \& Girard, Boc. Ac. Nat. Sc. Philad. 18.53, p. 388.

$$
\text { D. } 9 \mid 11 \text {. A. } \frac{2}{6} \text {. }
$$

The head forms one-fourth of the total length. Redrlish, with indistinet transverse blackish bars; base of the seales black; fins immaculate; a vertical black spot beneath the cye. $\left(B . \& G_{0}\right)$

Upper tributaries of the Rio Nueces, Texas.

\section{Boleosoma maculatum.}

Agass. Lake Super. p. 305. pl. 4. f. 3.

$$
\text { D. } 9 \text { 12. A. } 11 \text {. }
$$

The length of the head is one-fifth of the total; the pectoral fin rather shorter. Irregularly spotted on the back and the siles. dorsal and eaudal fins barred transversely with black. (Ag.)

Pie (Lake Superior). latum.

This fish may prove to be the same species as Boleosoma tessel-

* gassiz (Lake Supcr. p. 299) refers to this genus Etheostoma olmstedi, Storer (Bost. Journ. iv. p. 61. pl. 5. f. 2). Agassiz also gives the diagnoses of two other genera, elosely allied to the above, Etheostoma and Precilosoma. All these small fishes from North America are too little known to admit of their separation into a family (Etheostomata. Ag.) Pilsma has a great resemblanee to Lacioperca. 


\section{ASPRO.}

Aspro, Cuv. Rène Anim.: Cuv. \& Val. ii. p. 188.

Body elongated, cylindrical; snout thick, projecting beyond the mouth; mouth situated at the lower side. Seven branchiostegals. All the teeth villiform without eanines; teeth on the palatine hones; tongue smooth. Two separate dorsals; anal fin with a single pine. Operculum spiniferous, præoperculum serrated ; præorbital entiro. Seales small.

Rivers of the European Continent.

\section{Aspro vulgaris.}

Asper pisciculus, Rondel. ii. p. 207 ; Gesner, pp. 403, 478; Aldrou.v. cap. 28 ; Jonst. iii. c. ii. t. 26. f. 18; Willughby, p. 294; Ray, p. 98 ; Marsigli, Danub. iv. pl. 9. f. 2, 3. pp. 27, 28.

Gobius asper, Gesner (ed. Francof.), f. $162 b$.

Perca, sp. 3, Artedi, Genera, p. 40.

_ _ asper, Linn. Syst. i. p. 1309; Bloch, t. 107. f. 1, 2 ; Schaffer, Pisc. Bacar. Ratisb. Pentas.; Gronov. Zoophyl. p. 92. no. 303, and Syst. cd. Cray, p. 115; Hartm. Ichthyol. Helvet. p. 68; Shaw, Zool. iv. p. 551.

Dipterodon asper, Lacép. iv. p. 170.

Aspro vulgaris, Cuv. \& Val. i1. p. 188. pl. 26; Cur. Règne Anim. II. pl. 6. f. 2 ; Nordmann in Demidoff's Voy. Russ. Mérid., Poiss. p.

$$
\text { D. } 8 \mid \frac{1}{11-12} \cdot \text { A. } \frac{1}{11-12} \text {. }
$$

Back brownish, sides with a yellowish east, four or five dark transverse bands.

Rhone; Danube.

a. Adult. Danube.

b. Adult. Switzerland. Presented by Prof. Agassiz.

\section{Aspro zingel.}

Gesner, Paralip. p. 19; Marsigli, Danub. iv. pl. 9. f. 3; Klein, IFist. Pise. v. p. 28.

Perca zingel, Lime. i. p. 1310; Schaffer, l. c.; Bloch, t. 106; Meidinger, Pisc. Austr. t. 4.

Aspro zingel, Cut. \& V Val. ii. p. 194.
D. $13-15 \mid \frac{1}{18-20}$.
A. $\frac{1}{11-13}$.
I. lat. 95 .
L. $\operatorname{transv} \cdot \frac{7}{13-14}$.

Back greenish brown, sides with a yellowish cast; irregularly spotted and marbled with dark brown, across the back four more or less conspicuous bands.

Damube.

1. Large specimen. Europe. Presented by the Zoologieal Society.

With the formula: $10,15 \mid \frac{1}{19}$. A. $\frac{1}{11}$. 


\section{ETELIS.}

Etelis, Cuv. \& Val. ii. p. 127.

Seven branchiostegals. Teeth in villiform bands; canine teeth in the jaws, those of the palatines being equal; tongue smooth. Two dorsals, the first with nine, the anal fin with three spines. Caudalis deeply notched. Operculum spiniferous; præopereulum with a simple edge, indistinctly denticulated. Scales moderate.

Seas of the Seychelles and Isle de France.

\section{Etelis carbunculus.}

Cuv. \& Val. ii. p. 127.
D. $9 \mid \frac{1}{11}$.
A. $\frac{3}{8}$.
L. lat. 50 .
L. transv. 6/14.

Height of the body one-fourth of the total length; præopereulum minutely denticulated. Bright red in life, with golden shining lines along the rows of seales.

Seychelles; Isle de France.

a. Very large specimen: stuffed. Isle de France.

\section{CENTROPOMUS.}

Centropomus, sp., Lacépède, Hist. Nat. Poiss. iv. p. 248.

Centropomus, Cuv. Règne Anim.; Cuv. \& Val. ii. p. 102.

Soven branchiostegals. All the teeth villiform, without eanines; teeth on the palatine bones, tongue smooth. Two distinctly separated dorsals, the first with eight, the anal fin with three spines, the second of which is exceedingly long. Operculum without spinous point; præoperculum with two denticulated edges. Scales moderate.

Neotropical part of the Atlantie Ocean.

\section{Centropomus undecimalis}

Camuri, Marcgrave, p. 160.

Sciæna undecimalis, Bloch, t. 303

Platycephalus undecimalis, Bl. Schn. p. 59.

Centropomus undecim-radiatus, Lacép. iv. p. 267.

- undecimalis, Cuv. \& Val. ii.p. 102. pl. 14; Schomb. Hist. Barbad. p. 665, and Reis. Brit. Guian. iii, p. 620; Ramon de la Sagra, Hist. Cul. Poiss. p. 9.

Perca loubina, Lacép. iv. pp. 397, 418, 421.

Sphyræna aureoviridis, Lacép. v. p. 324. pl. 9. f. 2 (bad).

$$
\text { D. } 8 \mid \frac{1}{10} \text {. A. } \frac{3}{6} \text {. }
$$

Silvery white, back greenish, a brownish band along the lateral line. Height of the body one-fifth of the total length.

Atlantic shores of Tropical America. (Lima?)

a. Adult. South America. 
b. IIalf-grown: not good state. South Aneriea.

c, d. Young. South Ameriea. I'resented by sir R. Schomburgk.

e. Adult: not good state. Bahia. Hom M. Parzudaki's Collection.

f. Fine specinen. Pernambuco, Presented by J. Y. G. Smith, Esq.

7. Nrult: bad state. Surinam.

$h$, i. Half-grown: not good state. Demerara. Presented by Dr. Hancock.

$k$, l. Young. British Guiana. Presented by Sir R. Sclomburgk.

m. Half-grown. West indies.

n. Young. West Indies.

o, r. Adult: fue specimens. St. Domingo. From Mr. Cuming's Collection.

$q-s$. Adult and young: skins. Jamaica. From 1)r. Parnell's Coullection.

t. Adult. America. From the Haslar Collection.

u. Half-grown. America. From the Haslar Collection.

\section{NIPHON.}

Niphon, Cur. \& V Val. ii. p. 131.

Seven branchiostegals. All the teeth villiform, withont eanines: teeth of the palatine benes"? tongue?. Two dorsils. the first with twelve, the anal fin with three spines. Opereulun and preoperculum with very long and strong pointed spines, the latter with strong tecth at tho lower limb. Scales very small.

Japanese Sea.

\section{Niphon spinosus.}

('ux. \&. Val. i. p. 131. pl. 19; Faun. Japon. p. 1. pl. 1. f. 1.

$$
\text { D. } 12 \mid \frac{1}{11} \cdot \quad \text { A. } \frac{3}{2} \text {. }
$$

Head elongate, nearly one-third of total length; spine of the prapereulum as long us its inferior limb. Coloration uniform.

Japanese Sear.

a. Arlult: stuffed. Japan.

b. Half-grown: stuffed. Japan.

\section{ENOPLOSUS.}

Enoplosus, Lacépède, Hist. Nat. I'oiss. iv. p. int1; Cuv. \& Iral. ii. p. I.,3).

borly and vertical fins greatly elevated. Sieven branchiostegals. All the tereth villiform, withont canimes ; teeth on the palatine bones and on the tongrese. Two dorsals. Operenhum withont spine; prarupereulum serrated, and with spinous tecth at the angle. Soules modrolite.

Anstralian hials. 


\section{Enoplosus armatus.}

Chætodon armatus, White, Voy. N. S. Wales, pl. 3. f. 1.

Enoplosus whitii, Lacép. iv. p. 5) 11.

— armatus, Cuv. \& I'al. ii. p. 133. pl 20.

D. $7 \mid \frac{1}{14-15}$. A. $\frac{3}{15}$. Cxc. pylor. 15. Vert. 25.

Upper profile of head very coneave; body one-half as high as long, much compressed; all the fins, exeept eaudal, much clongate and pointed. White, with eight black transverse bands.

Coast of New South Wales.

a. Adult. Sydney. Presented by Lieut. Alexander Smith, R.N.

b. Adult. Sydney. Presented by Mr. Williams.

$c-e$. Adult. Sydney. From the Haslar Collection.

f. Several speeimens. Australia. From the Haslar Collection.

g. Adult. Australia.

h. Adult: stuffed. Australia. From Mr. Warwick's Collection.

i. Adult: stuffed. Australia.

k. Adult: skin. Australia. From Mr. Gould's Collection.

l. Adult: skin. Australia.

m. Half-grown: skin. Australia. From Mr. Gould's Collection.

\section{Second Group. SERRANINA.}

(For characters, see page 57 .)

\section{APRION.}

Aprion, Cuv. \& Val. vi. p. 543.

Seven branchiostegals. Teeth villiform, with canines in both jaws; teeth on the palatine bones; tongue smooth. One dorsal with ten spines, the anal fin with three. Opereulum spiniferous; præopereulum entire, with a single ridge. Scales moderate.

Coasts of the Soyehelles.

\section{Aprion virescens.}

Cuv. \& Val. vi. p. 544. pl. 168.
D. $\frac{10}{11}$.
A. $\frac{3}{8}$.
L. lat. 50 .
L. transv. 20.

The height of the body is one-fifth of the total length, the length of the head one-fourth; the diameter of the eye is one-fourth of the length of the head. The lower jaw rather prominent; suprascapula denticulated. Candalis deeply forked. Greenish, with a black spot between the seventh and ninth dorsal spines ( $V$ al.)

Seychelles. 


\section{APSILUS.}

Apsilus, Cuv. \&. Val. vi. p. 548.

Seven branchiostegals. All the teeth villiform, without eanines; teeth on the palatine bones; tongne with minute teeth. One dorsal with ten spines, the anal fin with three. No serratures or spines on the bones of the skull. Seales rather small.

Cape Verde.

\section{Apsilus fuscus.}

Cuv. \& Val. vi. p. 549. pl. 168 b.

$$
\text { D. } \frac{10}{10^{\circ}} \text { A. } \frac{3}{8} \text {. L. lat. } 65 \text {. }
$$

The height of the body is one-fourth of the total length, the length of the head one-fifth; the diameter of the eye is $4 \frac{1}{3}$ in the latter, and $1 \frac{1}{2}$ in the distance from the end of the muzzle; the upper maxillary bone reaching only to the posterior half of the distance mentioned. Caudal very deeply forked; the dorsal spines feeble, the fourth the longest. Brown; dorsal marbled with darker. $(V a l$.

Porto Praya (Cape Verde).

\section{CENTROPRISTIS*.}

Centropristes, sp., and Serranus, sp., Cur. Règnc Anim.; Cuc.\& Val. ii. p. 241 \&c., iii. p. 36.

Centropristes, Brisout de Barncrille, Rev. Zool. 1847, p. 130.

Diplectrum and Centropristes, Holbr. Ichth. S. Carol. pp. 32, 42.

Seven branchiostegals. Teeth villiform, with very small eanines in both jaws; teeth of the vomer in an angular band or a short triangular patch; teeth on the palatine bones; tongue smooth. One dorsal with the formula $\frac{10}{12 \text { or minus } 12}$; the anal fin with $\frac{3}{7(6)}$. Operculum spiniferous; præoperculum serrated, sometimes with a projecting rounded angle. Scales moderate or rather small.

American parts of the Atlantic; Mediterranean; Japanese Sea.

\section{Centropristis bivittatus.}

Serranus bivittatus, Cur. \& Val. ii. p. 241.

$$
\text { D. } \frac{10}{12} \text {. A. } \frac{3}{7} \text {. }
$$

Teeth of the angle of preopereulum strong, and produced into a small bundle; its posterior limb rery obliquely deseending back-

* 1. Perca philadelphica, Linn. Syst. Nat. p. 1314; Bl. Schn. p. 91.-Philadelphia.

2. Centropristis nebulosus, Castelnau, Anim. noux. ou rares de l'Amér. du Sud, Poiss. p. 5. pl. 1. f. 4.-Rio de Janeiro.

3. Serranus flaveseens, $\mathrm{Cuv}$ \& $\mathrm{Val}$. vi. p. 506.-Martinique. [Centropristes gigas, Owen, belongs to the genus Oligorus.] 
wards; caudalis slightly notched. On each side a brown longitudinal band above the lateral line, another beneath; head with some blue streaks; on the hinder half of dorsal fin two parallel series of square violet spots.

Martinique ; Cuba.

\section{Centropristis radialis.}

Serranus radialis, Quoy \& Gaimard, Voy. de Freyc. p. 316 ; Cuv. \& Val. ii. p. 243.

$$
\text { D. } \frac{10}{12} \text {. A. } \frac{3}{7} \text {. }
$$

Angle of præopereulum enlarged, rounded, striated, with long spinous teeth; its posterior limb obliquely descending backwards, finely denticulated; eaudalis slightly notched. On each side three longitudinal series of large irregular blotehes; anterior part of dorsal fin with a longitudinal violet band; posterior half and caudalis spotted.

Coast of Brazil.

a. Adult. Ameriea. From the Haslar Collection.

b. Large specimen. Bahia. Purchased of M. Parzudaki.

c. Large specimen. Old Collection.

d. Adult: bad skin. Ameriea. Old Collection.

\section{Centropristis radians.}

Serranus radians, Quoy \& Gaim. Voy. de Freyc., Poiss. pl. 58. f. 2. ___ irradians, Cur. \&.Val. ii. p. 244; Castelnau, Anim. nouv. ou rares de l'Amér. du Sud, Poiss. p. 3.

$$
\text { D. } \frac{10}{12} \text {. A. } \frac{3}{7} \text {. }
$$

Angle of præopereulum enlarged, rounded, with about eight long spinous teeth; lower half of its posterior limb provided with equally strong denticulations, directed upwards; upper half finely serrated. Body with eight to thirteen transverse streaks, crossed by four to six longitudinal bands; eheeks with some bluish streaks; dorsal fin with longitudinal stripes; caudalis spotted.

Coast of Brazil ; Montevideo.

\section{Centropristis fascicularis.}

Serranus fascicularis, Cuv. \& Val. ii. p. 245. pl. 30, ix. p. 431.

Dipleetrum fasciculare, Holbr. l.c. pl. 5. f. 1.

$$
\text { D. } \frac{10}{12} \text {. A. } \frac{3}{7} \text {. }
$$

Præopereulum posteriorly with two prominent groups of very strong teeth; its inferior limb entire. Caudalis with rather elongate lobes. Body with dark cross-bands and with five or six bluish longitudinal lines; dorsalis with longitudinal stripes.

Coast of Brazil ; Charleston. 


\section{Centropristis conceptionis.}

Serranus conceptionis, Cur. \& I Iul. ii. p. 246; Less. Voy. Coq. Zool. ii. p. 236; Gay, Chile, Zool. ii. p. 148.

$$
\text { D. } \frac{10}{12}, \text { A. } \frac{3}{6} \text {. }
$$

Only six soft rays in the anal fin; angle of preoperculum produced posteriorly, with stronger teeth; both its limbs serrated. Body uniform brownish; dorsal fin marbled in front, striped behind. Conception.

a. Adult. From the Haslar Collection.

\section{Centropristis hepatus.}

?"H

Sachettus Venetorum, Willughby, iv. c. 30 ; Ray, p. 139.

Labrus no. 2, Artede, Synon. p. 53 (synon. pars).

Labrus hepatus (part.), L. Gm. p. 1283; Bl. Sčch. p. 245; Lacép. iii. pp. 424,456 .

__- adriaticus, Brünnich, Spol. Mass. p. 98. no. 11; Gm. Syst. p. 1297;

Bl. Schn. p. 262.

Holocentrus striatus, Bloch, t. 235. f. 1 ; Bl. Schn. p. 314.

Lutjanus adriaticus, Lacép. iv. p. 222.

Holocentrus triacanthus, Lacép. iv. p. 376 .

— siagonotus, De la Roche, Ann. Mus. xiii. p. 352. pl. 22. f. 8.

- hepatus, Risso, Irhthyol. Nice, p. 292.

Serranus hepatus, Cur. \& I Ial. ii. p. 231; Faun. Japon. p. 5; Guichen. Explor. Sc. Algér. Poiss. p. 34.

$$
\text { D. } \frac{10}{12(11)} \text {. A. } \frac{3}{7} \text {. I. lat. } 42 \text {. }
$$

Caudal fin truncated; prooperculum with finely serrated limbs and a rounded angle. Body with five black eross-bands; a black bloteh on the first soft rays of the dorsal fin.

Mediterranean; Cape of Good Hope.

$a, b$. Adult and young. Dalmatia.

c. Fine specimen. Mediterranean. From the Haslar Collection. d, e. Adult: not good state. From the Haslar Collection.

f. Adult. From the Old Collection. $g, h$. Adult.

\section{Centropristis luciopercanus.}

Serranus luciopereanus, Pocy, Memor. Cuba, p. 56. lam. 9. f. 1.
D. $\frac{10}{12}$.
A. $\frac{3}{7}$.
I. lat. 70 .
I. transr. $7 / 20$.
Cæe. pylor. 2.
Vert. $10^{\prime} 14$.

The lower jaw more elongate and prominent than in the other species; the diameter of the cye is one-fourth of the length of the head; preorbital projecting in front, partly covering the jaw-bones. Præoperculum serrated, without projecting angle; interopereulum entire. Caudalis forked. Reddish olive, with many irregular dark transverse spots. (Poey.)

rona 


\section{Centropristis tabacarius.}

Centropristes tabacarius, Cur. \& Val. iii. p. 44; Ramon de la Sagra, Hist. Cub. Poiss. p. 28.

Serranus jacome, Poey, Memor. Cuba, 1851, p. 57. Iam. 2. f. 1.
D. $\frac{10}{12}$.
A. $\frac{3}{7}$.
L. lat. 70 .
Cæc. pylor. 5.
Vert. 10/14.

Præoperculum very finely serrated; the distance between the eyes is $\frac{3}{4}$ ths of the diameter. Reldish brown; a large white spot on the lateral line beneath the first seven spines, a smaller one above the lateral line beneath the first ray; a third immediately beneath the last four rays of the dorsal.

Caribbean Sea.

a. Half-grown. West Indies. Presented by the Zoological Society. b. Adult: skin. West Indies. From Mr. Scrivener's Collection.

\section{Centropristis præstigiator.}

Serranus præstigiator, Poey, Memor. Cuba, 1851, p. 58. lam. 2. f. 2.
D. $\frac{10}{12}$. A. $\frac{3}{7}$.
L. lat. 70 .
L. transv. 8/24.
Cæc. pylor. 5 .
Vert. $10 / 14$.

Præorbital not projecting; operculum with three spines; præoperculum serrated, without projecting angle; sub- and inter-operculum entire. Caudalis emarginate. Brown, with irregular black transverse bands and spots; belly yellowish.

Cuba.

$a, b$. Adult: not good state. From the Haslar Collection.

\section{Centropristis brasiliensis.}

Brisout de Barneville, Rev. Zool. 1847, p. 131.

$$
\text { D. } \frac{10}{12} \text {. A. } \frac{3}{7} \text {. L. lat. } 50 \text {. }
$$

Præoperculum rounded throughout, serrated; operculum with three flat points; the length of the head is two-fifths of the length of the trunk (without caudalis); the distance between the eyes is one-half of the diameter. Brown, with indistinct cross-bands ; dorsalis with three black spots.

Coast of Brazil ; Caribbean Sea; St. Helena.

a. Adult: stuffed. St. Helena. Presented by General Hardwicke.

\section{Centropristis phœbe.}

Serranus phœbe, Poey, Memor. Cuba, 1851, p. 55. pl. 2. f. 3.
D. $\frac{10}{12}$.
A. $\frac{3}{7}$.
L. lat. 48.
L. transv. 5/12.

Præorbital not projecting; operculum with two spines; præoperculum serrated behind, and at a part of the lower $\operatorname{limb}$, without 
projecting angle; sub- and inter-operculum entire. Caudalis emarginate; pectorals extending to a white eross-band at the side of the belly; ground-colom brownish.

Cuba.

a. Adult. South America. Presented by Sir R. Schomburgk.

b. Adult. South America. Presented by Sir R. Schomburgk.

$c$, d. Adult: skins. West Indies. Purchased of Mr. Serivener.

\section{Centropristis psittacinus.}

Serranus psittacinus, I'alenc. Foy. I'énus, Zoul. Poiss. p. 299. pl. 1. f. 1.

$$
\text { D. } \frac{10}{12} \text {. A. } \frac{3}{7} \text {. L. lat. } 53 \text {. }
$$

Opereulum with three spines; præopereulum rounded; the diameter of the eye one-fifth of the length of the head. Green; the upper parts of the head and back red. Two large sjots on the tail, and six smaller ones along the lower part of the body and tail, black, with red edge. ( $\mathrm{V} a \mathrm{l}$. )

Galapagos Archipelago.

\section{Centropristis atrobranchus.}

Cur. \&. I"al. iii. p. 45.

$$
\text { D. } \frac{10}{12} \text {. A. } \frac{3}{7} \text {. }
$$

Operculum with a single spine; preopereuhm angular. Yellowish, with five brown vertical bands; a black spot at the gill-opening beneath the operenlum, another on the dorsal fin above the second vertieal band. Dorsal fin with small round spots.

Caast of Mrazil.

\section{Centropristis atrarius.}

Perea atraria, Lim. Syst. Nat. i. p. 485, and Lim. Gm. i. p. 1314; Gronor. Syst. ed. Gray, p. 111; 13l. Sckn. p. 88.

Schöpff in Schuift. der Vaturforsch. Frende Berlin, viii. p. 164.

Coryphrna nigrescens, Bl. Schn. p. 297.

Perca varia, Mitchill, Report, p. 10.

Lutjanus trilobus, Lacép. iv. p. 246.

Centropristes nigricans, $C u r . \&$. $V$ al. iii. p. 37. pl. 44; Règne Anim. Illustr. Poiss. pl. 9 a. f. 1; Dekay, New Tork Fauna, p. 24. pl. 2. f. 6 (5 in text).

- rufus, Cur. \&. Val. iii. p. 47.

— atrarius, IIolh. 1. c. p. 42. pl. 7. f. 2.

D. $\frac{10}{11}$. A. $\frac{3}{7}$. L. lat. 50. Vert. 10/14. Cxe. pylor. 4 (Holbr. 7).

The height of the body is $3 \frac{1}{2}$ in the total length, the length of the hearl one-third; the diameter of the eye is $4 \frac{1}{2}$ in the length of the hear. Suprascapula dentienlated; operculum with two spines; the third dorsal spine rather longer than the following; caudal fin forked, and with the midlle ritys a little elongate, but generally mutilated. Groyish brown, each scale darker in the centre and on 
the edge: dorsalis with some lighter bands: in the fresh fish, body with broad, vertical, dark bands.

Atlantic coasts of the United States.

a. Adult. North Ameriea. Purehased of Mr. Warwick.

b. Adult: skin. New $\mathrm{Y}^{\mathrm{O}^{2} \mathrm{~m}} \mathrm{k}$. From Dr. Parnell's Collection.

c. Adult: skin. Gronov soriginal specimen.

Holbrook (l.c.p.46) distinguishes two species, one being found to the north of Cape Hatteras, the other to the south of it. The first, he says, is the fish described by Sehöpff, or Coryphana nigireseens, Bl., and Perca varia, Miteh. The peetoral fin is said to be longer than the ventral in the southern species, and coterminal with it in the northern. Further, the air-bladder is sacculated in the southern ( $C$. atrarius, Holbr.), and nerer in the northern (C. nigricans, Holbr.). I have, at present, no opportunity of confirming these observations.

\section{Centropristis hirundinaceus.}

Centropristis hirundinaceus, (Langsdorf) Cuv. \& Ial. vii. p. 450 ; Trun. Japon. p. 14. pl. 5. f. 2.

$$
\text { D. } \frac{10}{10} \text {. A. } \frac{3}{6} \text {. }
$$

Operculum with two spines. Candalis forked; rose-coloured above; the dorsal rays and spines with brown spots.

Japanese seas.

\section{2\%. CALLANTHIAS.}

Callanthias, Lowe, Proc. Zool. Soc. 1839, p. 76, and Fishes of Madcira. p. 13.

Six branchiostegals. T'eeth villiform, with eanines in both jaws; teeth on the palatine bones; tongue smuoth. One dorsal, with eleven spines, the anal fin with three. Operculum spiniferous; pracoperculum entire. A part of the fins elongate. Scales moderate.

Coasts of Madeira.

\section{Callanthias peloritanus.}

Bodianus peloritanus, Cocco, Giornale di Scienze per la Sicilia, Pulermo, 1829, p. 138.

Anthias buphthatmos, Bunap. Faun. Ital., Pesci, pl. . f. 3.

Callanthias paradisæus, Lowe, Suppl. Syn. Mad. Fishes, in Proc. Zool. Soc. 1839, p. 76, and Fishes of Madeira, p. 13. t 3 (excellent deseription).

D. $\frac{11}{10}$. A. $\frac{3}{10}$. L. lat. 22-24. Vert. 11/13. C'æc. pylor. 3.

Muzzle exceedingly short; fourth and fifth soft rays of dorsal fin, and both the lobes of caudil fin, elongato. Back rose-coloured, sides and fins with a yellow tint.

Madeira.

a. Adult: fine specimen. Madeira. Presented by the Rer. R. 'T. Iowe. 


\section{ANTHIAS.}

Anthis, sp., Bl. Schn. p. 303; Cuv. Sal. ii. p. 249.

Caprodon, Temm. \& Schleg. Furer. Japon. Poiss. p. 64.

Seven branchiostegals. Teeth villiform, with canines in both the jaws; teeth on the palatine bones; tongne smooth. or with small teeth. One dorsal, generally with ten spines; the anal fin with three. Caudalis forked, generally one or several of the fins very elongate. Opereulum spiniferous, preoperculum serrated. Seales moderate.

Nearly all the seas of the temperate and tropical regions.

In separating these fishes from the true Serroni, I apply the larger size of the scales as an absolute character, ruther than the upper maxillary bone being corered with scales-the latter character occurring too often in fishes which eannot be separated from the true Serrani. Excluding the last four species, which may probably form types of separate genera, we have a very natural group, with the same physiognumy, with rather large scales, and nostly with remarkably developed fins. On the other hand, I am rather inclined to bring the Servanus creolus also into this genus, as it has the exterior appearance of Anthias; but I am prohibited from doing so by its very small scales, in which and other respects it resembles very much Aipsitus fuscus.

\section{Anthias sacer.}

?'AvOías, Aùotias, Aristot. vi. c. 10, 16, 17, ix. c. 2, 37.

Ant'sire prima species, Rondel. vi. c. 11. p. 188; Gesner, pp. 55, 62, and Enlit. Franlif. p. 15; Aldroe. i. e. 10; Jonston, i. eap. 1. t. 16; Willughby, p. 325; Ray, p. 138.

Labrus, sn. 3, Artedi, Synon. p. 5.4.

- anthias, Lim. Syst. Nat. i. p. 128:3.

Perea pennanti, Bloch, Schrift. Nuturf. Freunde Berlin, x. pl. 9. f. 1. Anthias sacer, Bl. t. 315; H3. Schn. p. 303; Cur. \& V Ial. il. p. 250. pl. 31 ; Loxe', Fishe's of Madeira, p. 19. t. 4.

Lutjanus anthias, Lucip. iv. p. 197; Risso, Ichthyol. de Nice, p. 260.

$$
\text { D. } \frac{10-11}{15} . \quad \text { A. } \frac{3}{7} \text {. L. lat. } 37 \text {. }
$$

Third spine of dorsal, ventral, and caudal fins much clongate. Red in life; head with three yellow bands; two bands on the side of occiput, and a series of spots at the base of the dorsal fin brownish green.

Mediterranean; Madeira.

a. Large specimen: not good state. Madeira. Old Collection as Perca imperator.

b. Adult: male. Madeira. From the Haslar Collection.

$c-e$. Adult. Madeira. From the Haslar Collection.

f. Adult. Madeira. Presented by Sir A. Smith.

\%. Fine specimen. Madeira. l'resented by the Koological Society.

h. Half-grown. Sicily. Presented by W. Swrinson, Ksq. 
i. Adult. Dalmatia.

$k, l$. Half-grown. Adriatic. From Mr. Frank's Collection. $m, n$. Adult. Europe. Presented by the Zoological Society.

o. Half-grown. Europe. From Mrr. Frank's Collection.

p. Half-grown. Europe. From Mr. Frank's Collection.

q. Adult: not good state. Europe. From the Haslar Collection.

$r$. Adult: rery bad state. Europe. Old Collection.

s. Half-grown: stuffed. Europe. From Mr. Yarrell's Collection.

\section{Anthias borbonius.}

Serranus borbonius, Cur. \&. Val. ii. p. 263 (not Quoy \& Gaim.).

$$
\text { D. } \frac{10-11}{17} \text {. A. } \frac{3}{7} \text {. }
$$

Third spine of dorsal, ventral, and caudal fins much clongate. Angle of preopereulum with three stronger teeth. Greyish, with large brown spots.

Isle de Franec.

a. Adult. Mamritius. Presented by the Zoological Society.

\section{Anthias squamipinnis.}

Peters, Wiegm. Archiv, 185.5, p. 236.

$$
\text { D. } \frac{10}{18} \text { A. } \frac{3}{8} \text {. L. lat. } 44 \text {. L. transv. 3/15. }
$$

The third dorsal spine filiform ; rentrals not elongate; fins covered with rather large scales far beyond the base. Opereulum with two strong spines; præopereulum with stronger denticulations at the angle. Red, with a blue line from the orbit to the root of the pectorals. (Peters.)

Coast of Mozambique.

\section{Anthias asperilinguis. (Plate VIII.)}
B. 7. D. $\frac{10}{15}$.
A. $\frac{3}{7}$.
L. lat. $3 \%$.
L. transv. $4 / 17$.

Only ventral and caudal fins much clongate; tongue with teeth; præoperculum minutely serrated, with some obsolete denticulations at the angle.

a. Adult. South America. Presented by Sir R. Schomburgk.

Description of the specimen.-The form of the body is rather elevated and compressed, its height being comprised $2 \frac{1}{2}$ in the total length (without caudal fin). The head is rather short, with very obtuse and short muzzle; it is one-third of the total length (without caudal); the eye is large, its diameter being much larger than the distance between the eyes or the extent of the snout, and forming nearly one-third of the length of the head. The head is covered all over with etenoid scales, much smaller than those of the trunk. The cleft of the mouth is very oblique, the upper maxillary bone suddenly widening, 
and very brosd behind, not extending to tho verticul fion tho contre:

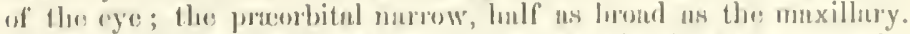
'Theres is only ome small opening of thes nostril, situated ubove: the

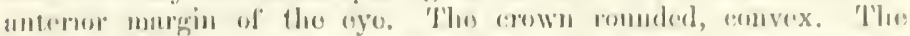

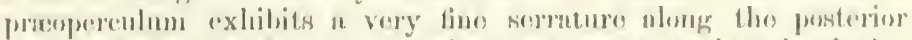

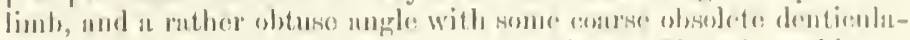

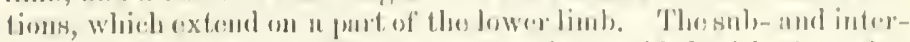

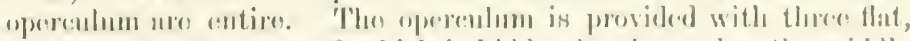

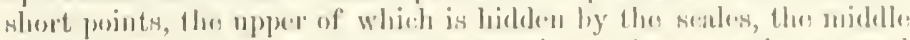

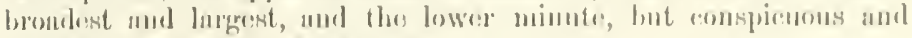
immolintely bementh the formor.

'The dorselis anmenenes just above the posterior margin of tho

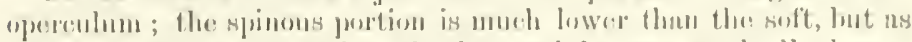

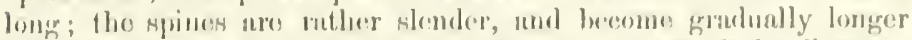

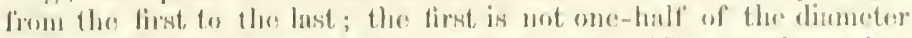
of the cyo, thes last more than twiee ne long. Tho mombane be-

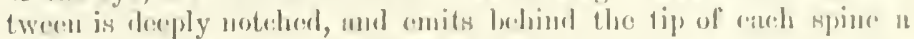

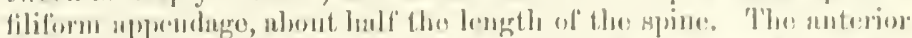

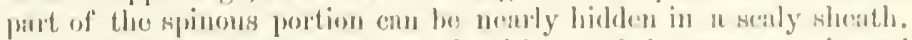

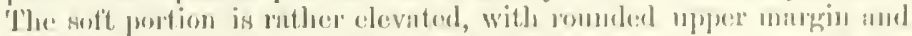

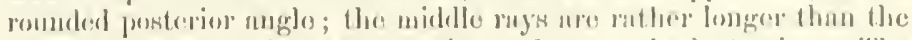

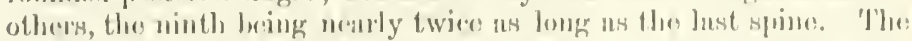

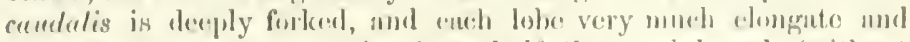
pointed; the longent my is obout luelf tho total dength (withont coudal); smaller decidusus seales cover a grout part of mele lobes.

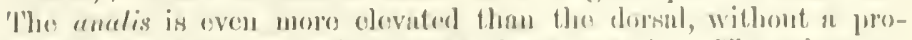

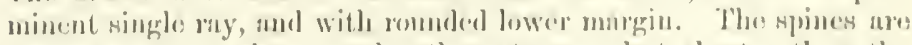

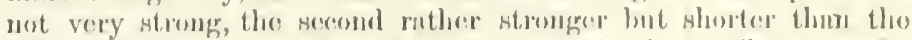
third, which rexeeceds in length tho last dorisal spinn. 'The pretoralis

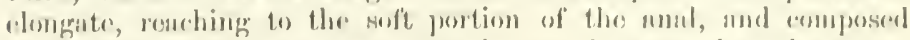
of cighteen rays, tho middle of which are longest, that otheres be-

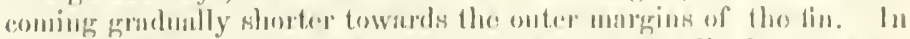

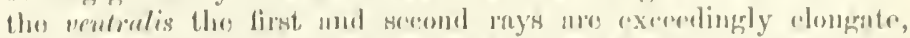

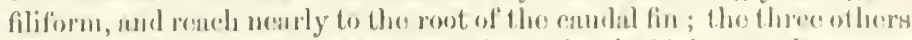

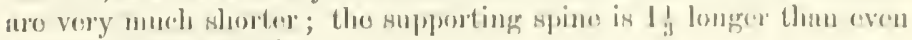
tho thind of the smalis.

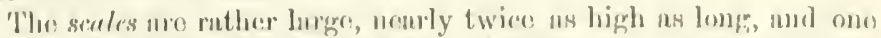

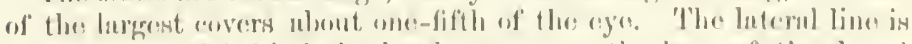

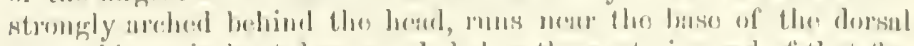

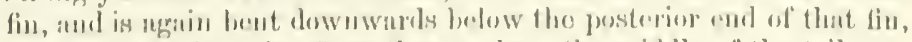

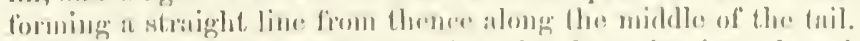

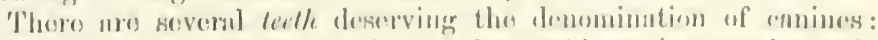

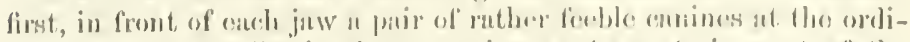

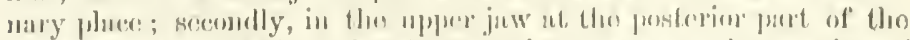

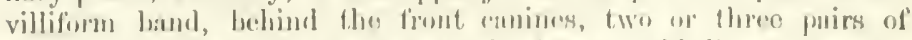

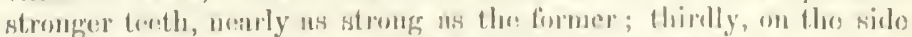

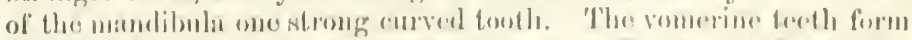

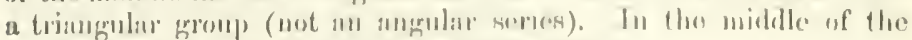
tongun thero is nut oval patch al villiform teath.

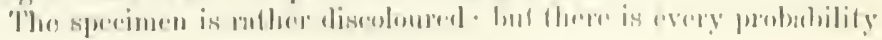


of its having been rose-coloured, with parallel obliquo and longitudinal shining golden bands following the series of seales. There are visible on the sides of the head two oblique bands of indistinet colour, one ruming from the back edge of the orbit aeross the operculum, the other from below the eye to the inferior part of the opereulum.

Length of the specimen $9^{\prime \prime}$.

\section{Anthias tonsor.}

Serranus tonsor, Cuv. \& Val. ii. p. 262.
D. $\frac{10}{12}$.
A. $\frac{3}{6}$.

Third spine of dorsal, ventral, and eaudal fins mueh elongate. No large tecth on the angle of prooperculum.

Shores of Brazil.

\section{Anthias furcifer.}

Serranus furcifer, Cuv. ๖. $V a l$. ii. p. 264.
D. $\frac{9}{18}$.
A. $\frac{3}{9}$.

Only the caudal fin olongate, upper part longer. Reddish, on each side with four small round violet spots; fins not streaked.

Shores of Brazil.

\section{Anthias trifurcus.}

Perea trifurea, Limn. Syst. Nat. i. p. 489.

Iutjanus tridens, Lacép. iv. p. 246.

Centropristes tridens, Cuv. \& Val. iii. p. 43 ; Holbr. Ichth. S. Carol. p. 47. pl. 7. f. 1 .

$$
\text { D. } \frac{10}{11} \text {. A. } \frac{3}{10} \text {. }
$$

Dorsal spines with very long filaments; tail trifureate. Grey, with a purple tint, and six dusky cross-bars on the sides of body ; a black spot at the posterior extremity of the spinous dorsal.

Coasts of South Carolina and Georgia.

\section{ช. Anthias macrophthalmus.}

Centropristis macrophthalmus, Miiller \& Troschel in' Schomb. IIist. Barbad. p. 666 (not Anthias macrophthalmus, Bloch).
D. $\frac{10}{11}$.
$\Lambda . \frac{3}{8}$.
L. lat. 58.
L. transv. $7 / 16$.

Caudalis deeply, dorsalis not notched; the last ray of the dorsal and anal fins elongate; the diameter of tho eyo one-third of the length of the head; prooperculum nearly right-angular, with obtuse dentieulations at tho hinder and lower limbs; a largo space of tho angle naked.

Caribbean Sea.

a. Large sperimen: stuffed. West. Indies. From Dr. Janvier's Collection.

b. Fine apecimen. From the Collection of the \%oological Socioty. 


\section{Anthias oculatus.}

Anthias oculatus, Cux. \& I'al. ii. p. 266. pl. 32 ; Ramon de la Sagra, Hist. Cub. Poiss. p. 10.

? Serramus oculatus, Faun. Japon. p. 5 ; Richards. Ichth. China, p. 235.

Hesperanthias oculatus, Loxce.

Centropristis oculatus, Miill. \& Trosch. in Schomb. Mist. Barbadoes, p. 666 .
D. $\frac{10}{11}$. A. $\frac{3}{8}$.
L. lat. 50-51.
L. transv. $6 / 13$.
Cre. pylor. 5 .
Vert. $10 / 14$.

The last ray of the dor'sal and anal fins elongate; lobes of the caudal fin nearly equal in length; dorsalis deeply notched; jaws and angle of prooperculum without scales; maxillary bone with rather large scales.

Martinıque; Madeira. (Japanese seas?)

a. Large specimen. South Ameriea. Presented by Sir R. Schomburgk.

b. Adult. South America. Presented by Sir R. Schomburgk.

c. Very large specimen $\left(20^{\prime \prime}\right)$ : skin. Jamaica. From Dr. Parnell's Collection.

d. Adult: skin. Jamaica. From Dr. Parnell's Collection.

e. Adult: stuffed. Madeira. Presented by the Rer. R. 'L. Lowe.

$f$. Fine specimen. Sine patria.

g. Half-grown: skin. West Indian Islands. Purehased of Mr. Scrivener.

h. Half-grown: skeleton.

Skeleton.-Tho upper surface of the skull is nearly flat between the eyes, exhibiting some low ridges and slight grooves; the oeeipital crest extends on the upper side of the skull as fur only as the posterior margin of the orbit; it is rather low, and not elevated above the level of the skull. The basal part of the maxillary is somewhat flattened; it does not become very broad at its posterior extremity, where it exhibits a coneave anterior margin. The intermaxillary has the posterior processes of moderate length, and a flat crescent-shaped expansion at its posterior half. The præorbital is quadrangular, oblong, twice as long as high; $t$ t e posterior part of the infraorbital arch is nurrow; the second and third of the bones have an excavated plate within, reaching into the inside of the orbital groove. The operculum is armed posteriorly with two points, separated from each other by a groove; the superior is short, without corresponding bony ridge; the inferior is acute and stronger, and forms the termination of a bony longitudinal ridge situated at the inner side of the operculum. The limbs of the procopereulum are directed vertically towards each other, but tho angle itself is rounded; the posterior margin is exceedingly finely serrated, the inferior more coarsely; the angle is distinetly striated, the strie terminating in small spinous teeth. There is a bony elevated ridge within the margin of the preoperculum: it shows no denticula- 
tion whaterer, and is the boundary between the sealy part of the eheek and the scaleless margin of the praeoperenlum.

There arc ten abdominal vertebre and fourteen caudal; the length of the former part of the eolumn is to that of the latter as $2: 3$. 'The interhiemal of the first anal spines is, like those spines themselves, feeble and short.

The teeth of the intermaxillary extend over all the length of the bone; the outer series is formed by larger teeth, four in front of the jaw being canine-like, but nevertheless of rather sinall size. The teetl of the lower jaw form a scries of small eardiform teeth, behind which is another of villiform teeth; it is very narrow, and does not extend on the side of the jaw. The vomerine teeth are arranced in a reetangular narrow band; the palatine band is very narrow, and extends on the pterygoid. The inferior pharyngeal bones form an elongate sword-shaped patch of villiform teeth; the upper pharyngeal teeth are cardiform, and form three or four small groups.

\section{Anthias rasor.}

Serranus rasor, Richardson, Proc. Zool. Soc. 1839, p. 95, and Trans. Zool. Soc. 1849 , p. 73. pl. 4. f. 1 .

D. $\frac{10}{21}$. A. $\frac{3}{9}$. I. lat. 5t. I. transv. 4/18. Cæc. pylor. 6. Vert. 11/15.

Caudalis forked, but none of the fins clongate; the pectoral fin one-fourth of the total length; the lower portions of the fins densely covered with scales; the height of the body one-third of the total length; the head short, forming one-fourth of it. Shining reddish brown, with a bluish stripe from beneath the eye along the lateral line.

Australian seas.

\section{Anthias sch'egelii.}

Caprodon, Temm. \&. Schleg. Fum.Japon., T’oiss. p. 64. pl. 30 ; Richards. Ichth. China, p. 235.

$$
\text { D. } \frac{10}{20} \text {. A. } \frac{3}{9} \text {. }
$$

Caudal fin convex in the middle of the posterior margin, and with a slight noteh above and beneath this convexity; none of the fins elongate, except the pectorals, which are ovate, longer than the head, and $3 \frac{1}{2}$ in the total; head and the lower portions of the fins densely eovered with scales; the height of the body one-third of the total length, the length of the head one-fourth. Rose-eoloured, with two yellow stripes from the snout through the eye, and another from the eye to the angle of the praepersulum; anal fin with round yellow spots.

Japanese Sea.

This fish eertainly belongs to the group of Serranina, and is closest allied to Serranus rasor of Richardson. One might even imagine both 
fishes to be identical, but for the coloration, which is said to be taken, in the figures of both the fishes, from life. Schlegel has established a separate genus, Caprodon, for this fish, having found five branchiostegals only, and ne teeth on the palate; but as we are informed by him that these characters are taken from a mounted specimen. I have no doubt that the condition of the fish is either imperfect, or does not admit of a proper examination.

\section{Anthias longimanus. (Plate VII. fig. B.)}
B. 7 .
D. $\frac{10}{20}$.
A. $\frac{3}{8}$.
L. lat. 65.

The height of the body is $4 \frac{3}{4}$ in the total length. Caudalis forked, but the pectoral only elongate, one-fourth of the total length; head entirely sealy; fins covered with seales on their greater par Vomerine teeth in a quadrangular pateh.

a. Stuffed. From the Collection of the Zoological Society.

Description of the specimen.-This fish resembles Serranus rasor of Richardson, and the Caprodon of the 'Fauna Japoniea,' with regard to the scaliness and the number of rays; but differs by its much more elongated body and the arrangement of the romerine teeth. In the middle third of the fish the height of the body is nearly equal, and is contained $4 \frac{3}{4}$ in the total; the length of the head is $4 \frac{4}{5}$ in the total ; it is eovered with scales all over. The eye is placed high up, but not interfering with the upper outline of the head; it leaves a space below it deeper than its horizontal diameter, which is larger than one-fourth of the length of the head : the vertical diameter is much shorter than the horizontal. The muz le is shortes than the eye. The nostrils of one side are close togeth $r$, one before the other. The intermaxillaries are rather feeble and $t$ in, and they have a triangular process in the middle of their posterior margin. The maxillaries widen from their origin and form a nearly regular triangle, covered with small scales; the lower jaw projects slightly beyond the upper. When the mouth is closed, the maxillary reaches to the seeond third of the orbit. The infraorbital arch is entirely covered with scales; no dentieulations are visible on the præorbital. The interspace between the eyes is convex, and equals the diameter of the eje.

The operculum is armed with two flat prominent spines, the lower of which is much smaller; the sub-and inter-operculum are entire. There is no scaleless space on the præoperculum; its angle is rounded and very finely serrated, like the posterior limb and a part of the inferior. The supraseapula shows several denticulations.

The dorsal fin is elongate, but very low, the seales reaching over two-thirds of its height; it is more distant from tho occiput than from the root of the caudal. The posterior spines and the anterior rays are nearly equal in height; the spines of moderate strength. The caudal fin is slightly forked, und partly covered with seales; the lobes appear to be equal in length, and about one-sixth of the total. 
The origin of the anal fin falls below the fourth dorsal ray, its end below the thirtcenth; it is as low as the dorsal fin; the sccond and third spines are moderate and nearly equal. The pectoral fin is ovate, elongatc, reaching to the vertical from the soft portion of the dorsal fin; the scales between the rays cover two-thirds of the fin. The ventral fins are inserted immediately behind the pectoral; they are somewhat longer than one-half of the pectoral.

The intermaxillaries are furnished with a narrow band of villiform teeth; no canine tooth in front is visible, but there are several, cardlike, inside the mouth in a cluster, occupying the space near the symphysis of the intermaxillaries. The band in the lower jaw is much broader, and there are canines in front of the jaw as well as in the middle of the side. The vomerine teeth form a broad and long quadrangular patch, with the anterior sides shorter and the posterior ones longer $(\diamond)$; there is a cuneiform band of palatine teeth, and a shorter one, ovate, and separated from the former, on the pterygoid bones.

The scales are of moderate size, with smooth surface and fine posterior serrature. The specimen is now discoloured, but appears to have had a red ground-colour. To judge from the species allied to it, its native sea may be some part of the Indian or Australian seas.

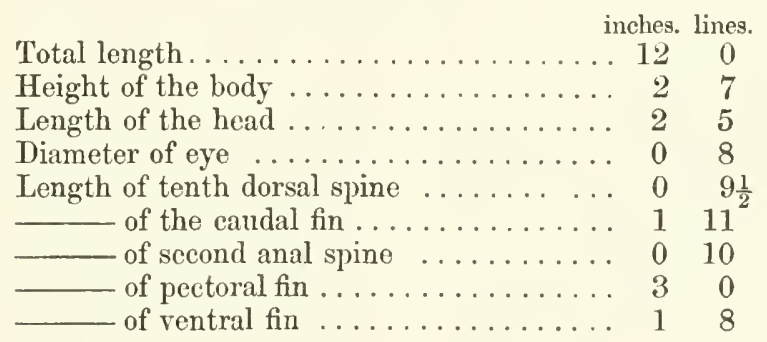

\section{Anthias cichlops.}

Serranus cichlops, Bleeker, Sumatra, i. p. 3.

$$
\text { D. } \frac{5}{15-16} \text {. A. } \frac{3}{6-7} \text {. L. lat. } 45 \text {. }
$$

Second ray of the ventral fins and lobes of the caudalis elongate; angle of præopcrculum with four spinous teeth, much stronger than the others. Red (in life); tail and caudalis jellow.

Priaman (Sumatra)

\section{ANYPERODON.}

Serranus, sp., Cur. \& Val. ii. p. 347.

Seven branchiostegals. Teeth in villiform bands, with canines in both jaws; no teeth on the palatine bones, nor on the tongue. 
One dorsal with eleven spines, the anal fin with three. Operculum with two or three points; præoperculum serrated. Seales small, ctenoid.

From the Seychelles to the Mrolueca Sea.

\section{Anyperodon letcogrammicus.}

Renard, Poiss. t. 1. f. 6; T'ulent. iii. p. 476. f. 409.

Serranus leucogrammicus, (Reinu.) Cur. \& I $V^{*}$. ii. p. 34ĩ ; Bie ket Perc. p. 33 .

$$
\text { D. } \frac{11}{15} \text {. A. } \frac{3}{9} \text {. L. lat. } 80 \text {. }
$$

The height of the body is one-fourth of the total length, the length of the head one-third; the diameter of the eye is one-seventh of the latter. Operculum w th three spines, preoperculum finely and equally serreted; sub- ani inter-operculum with denticulations. Caudalis rounded. Brownish, with three whitish longitudinal bands, and with brown spots above.

Seychelles; Molucea Sea.

a. Adult. Amboyna. From Mr. Franl's Colleetion.

\section{PRIONODES.}

Prionodes, Jenyns, Zool. Beagle, Fishes, p. 46.

Body oblong; muzzle with the lower jaw prominent. Canimo teeth; no teeth on the romer or. the palatine bones. Seven branchiostegals. One dorsal with ten, the anal fin with three spines. Præoperculum serrated; operculum with two or three spines. Scales moderate, etenoid.

The form of this fish, as the Rev. L. Jenyns has pointed out, is so completely that of a Serranus, that we may well hesitate to refer it to another family (Scienidee). One specimen only being known, it is possible either that the absence of romerine teeth is aecidental in that specimen, or dependent on the age of the fish. But if this be not the case, the structure of the fins and of the opercles is as important a character as the absence or presence of a pateh of minute teeth, and therefore I think it better to place this fish in the group of Serranina.

\section{Prionodes fasciatus.}

Jemyns, l.c. p. 4i. pl. 9. f. 1.

$$
\text { D. } \frac{10}{12^{\circ}} \text { A. } \frac{3}{7} \text {. }
$$

Brownish, with numerous dusky eross-bars: the vertieal fins with black ocellated spots. The posterior limb of the preoperculum serrated.

Chatham Island (Galapagos Arehipelago). 


\section{SERRANUS*}

Serranus, sp., Cuv. Règne Anim. : Cuv. \&. 'Val. ii. p. 210.

Seren branchiostegals. Teeth villiform, with very distinet canines in both jaws; teeth on the palatine bones; tongue smooth. One dorsal fin, mostly with nine or eleven, rarely with eight, ten, or twelve spines; anal fin with three. Opereulum with two or three aente points; præoperculum more or less serrated, without spinous teeth on the lower limb. Seales small.

All the scas of the temperate and tropical regions.

\section{Synopsis of the Species.}

I. Serrani with deeply forlsed caudal fin,

A. And with the two middle rays of caudal fin much elongato:

1. S. pliaëton.

13. With the two midille rays of caudal fin shortest :

2. S. creolus,

3. S. colonus.

4. S. lonti,

6. S. filamentosus,

5. S. flavimarginatus,

7. S. zonatus.

II. Serranr with slightly convex or concrve, or with truncated caudal fin.

A. With less than eight soft rays in the anal fin, and with more than twelve in the dorsalis :

8. S. scribn,

9. S. humeralis,

10. S. albomaculatus,

11. S. rhyncholepis,

12. S. gymmopareius.

* 1. Holocentrus anratus, Bl. pl. 236; Bl. Schn. p. 314-Serranus auratus, Cuv. \& I $I^{*}$ l. ii. p. 364 . - East Indies?

2. Holocentrus exrulcopunctatus, Bl. t. 242. f. 4; Bl. Schn. p. 315.-Serranus caruleopunctatus, Cur. of V rel. ii. p. 366.-Habitat - - ?

3. Serranus corallicola, $(K . \& u, H$. $)$ Cuv. \& $I^{\prime} a l$. ii. p. 366.-Java.

4. IIolocentrus argentinus, Bl. t. 235. f. 2.-Bl. Sch\%. p 314.-Serranus argentinus, Cur. \& V Val. ii. p. 2tl.-Wabitat _- ?

5. Serranus viuiegatus, Richurds. Ichth. Chimu, p. 231.-Canton.

6. Serranus revesii, Richards. l. c. 1. 23:2.-Canton.

7. Perea lunaria, Forsk. p. 34.-Peree rogaa var. lunaria, B1. Schlo. p. 335 - Red Sea.

8. Serranus treniocheirus, Cur. \&. Iral. vi. p. 518.-East Indies?

9. Serranus roscus, Cur. \& I $\mathrm{r}$ l. ir. p. 306.--Otaleiti.

10. Serranus peruanus, Less. Toy. Cóg. Zool. ii. p. 234.-Peru.

11. Serramis abdominalis, Peters, in Wirgne, dichie, 1855, p. 237.-Mozam. bique.

12. Serranus goliath, Peters, 1. c.-Mozambique.

13 Serranus parkinsonii, Cue of Tul. ii. p. 329.-- Habitat - ?

14. Bonaci arara, Parra, pl. 16. f. 2.-Johnius guttatex, vals, Bl. Schn. 1. 77. - Serranus arara, Cuv. \& I cal. ii. p. 377.

15. Bonaci cardinal, Parra, pl. 16. f. 1.-Johnins guttatus, Bl. Schm. p. 77.Serranus cardinalis, Cut. \& I $\mathrm{r}$ l. ii. p. 378 .

16. Parra, pl. 36. f. 1.-Lutjanus lumulatus, $B$ I. Sckn p. 329.--Serranus

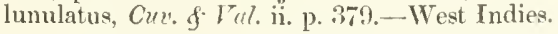

+ 1. Perca lepidoptera, Forst.-Epincphelus lepidopterus, Bl. Schn. p. 30:2. -Serranns lepidopterus, Wichards. Ann. \& Mug Nat. Hist. Ist?. ix. p. 18.-Australia. 
B. With eight or more soft rays in the anal fin.

1. Body with cross-bands or large oblong transverse spots*.

a. Denticulations of præoperculum stronger on the angle:

13. S. cabrilla,

14. S. brunneus, 17. S. albofuscus,

15. S. kawamebari,

18. S. sexfasciatus,

21. S. trimaculatus,

16. S. lanceolatus,

19. S. mystacinus,

22. S. diacanthus,

20. S. oceanicus,

23. S. striatus,

b. Denticulations of præoperculum conspicuous and equal :

25. S. tigris,

27. S. nigri,

29. S. tigrinus,

26. S. boenack,

28. S. semipunctatus,

30. S. papilionaceus.

c. Denticulations of præoperculum exceedingly fine or obsolete: 31. S. oxyrlynchus, 32 . S. argus.

2. Body of uniform coloration or spotted; with neither transverse nor longitudinal bands $\uparrow$.

a. Dorsalis with nine, rarely with eight spines; and

a. With seventeen or eighteen soft rays $f$ :

33. S. rogaa, 34. S. zananella.

$\beta$. With sixteen soft rays (rarely with fifteen to serenteen) $\$$ :

35. S. pachycentrum, 37. S. microprion,

39. S. cyanostigura,

36. S. erythræus, 38. S. cyanostigmatoides, 40. S. miniatus.

$\boldsymbol{\gamma}$. With fifteen (rarely with fourteen) soft rays\|:

41. S. aurantius,

42. S. sexmaculatus,

45. S. guttatus,

48. S. somnerati,

43. S. nigripinnis,

46. S. ouatalibi,

47. S. treniops,

49. S. urodelus,

44. S. hemistictus,

50. S. analis,

51. S. zanana.

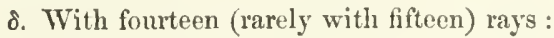

52. S. leopardus, 53. S. coronatus.

c. With twelve rays:

54. S. spilopareus.

* 1. Serranus semifasciatus, Gay, Chile, Zool. ii. p. 151, Ictiol. pl. I b. f. 2.Chile.

† 1. Holocentrus pantherinus, Lacép. iii. pl. 27. f. 3.-Serranus pantherinus, Cuv. \& I rol. ii. p. 3333.-Madagasear.

2. Serranus cyanopodus, Richards. Ichth. China, p. 233.

† 1. Epinephelus ruber, Bloch, t. 331.-Serpentre aurantiue, Cqu. of Val. 1i. p. 30.5 .

§ 1. Scrranus rufus, Hombr. \& Jarq. Ioy. an Pölc Sud, Poiss. p. 35. pl. 1. f. 4. -I Iabitat -...?

|| 1. Serranus pixanga, Cur. \& I Iul. ii. p. 383; Margr. p. 152.-J Jolocentrus punetatus, Bloch, t. $241 ; B l$. Sehn. p. 315 .

2. Serranus guativere, Cul. \& Val. l. c. Parra, pl. 5. f. 1.--Schomburgk. Hist. Barbad. p. 665. 
b. Dorsalis with ten or eleven (rarely with twelve) spines, and a. With eleven or twelve rays:
55. S. limbatus,
56. S. nouleny.

$\beta$. With thirteen or fourteen rays $*$

57. S. lutra,

58. S. goldmanni,

59. S. pavoninus.

$\gamma$. With fourteen or fifteen rays $\dagger$ :

60. S. angularis,

61. S. suillus,

62. S. fuscoguttatus,

63. S. altivelioides,

64. S. polyphekadiou,

65. S. salmonoides,

66. S. epistictus,

67. S. bataviensis,

68. S. alboguttatus,

$\delta$. With fifteen or sixteen rays $t$ :

74. S. gigas,

75. S. moara,

76. S. goreensis,

77. S. erythrogaster,

78. S. fuscus,

79. S. æneus,

80. S. emarginatus,

81. S. nigritus,
82. S. acutirostris,

83. S. marginalis,

84. S. horridus,

85. S. crapao,

86. S. sebx,

87. S. summana,

88. S. micronotatus,

89. S. tumilabris,
69. S. polystigma,

70. S. maculatus,

71. S. galeus,

72. S. niveatus,

73. S. margaritifer.

є. With fifteen to seventeen rays:

98. S. hexagonatus.

$\zeta$. With sixteen or seventeen rays $\$$ :

99. S. morio,

107. S. spiniger,

100. S. impetiginosus, 108. S. ura,

101. S. ongus,

109. S. melanurus,

102. S. undulosus,

110. S. gilberti,

103. S. tsirimenara,

111. S. nebulosus,

104. S. punctatissimus, 112. S. bontoides,

105. S. rupestris,

106. S. flavo-cæruleus,

90. S. hoevenii,

91. S. bontoo,

92. S. celebicus,

93. S. variolosus

94. S. hoedtii,

95. S. akaara,

96. S. apua,

97. S. mentzelii.

* 1. Serranus jansenii, Bleek. Sangi, p. 376.-Sangi Sea.

† 1. Serranus aspersus, Jenyns, Zool. Beag. Fishes, p. 6.-Cape Verdo Islands.

2. Itaiara, Margr. cap. iii. p. 145.-Serranus itaiara, Lichtenst. Berl. Abhandl. 1821, p. 278; Cuv. \& I al.ii. p. 376; Sehomb. Reis. Brit. Guian. p. 621 .

$\ddagger$ 1. Serranus erythrurus, Cuv. \& $V_{\text {all }}$ ii. p. 320.-Malabar.

2. - maculosus, Cuv. \& V al. ii. p. 332.--Habitat - ? If this species should hereafter be recognized, the denomination of marulosus must be changed, Bloch haring given to another Serranus the name of maculatus, which was afterwards altered by Cuvier into catus.

3. - alexandrinus, Cuv. \& Tal. ii. p. 281.-Meditermean.

4. - dermochirus, Cuv. \& Val. vi. p. 513.-Coromanstel.

5. — kunhardtii, Bleek. Natuurk. Tydschr. Nederl. Ind. 1851, p. 169.Sumatra.

6. - lebretonianus, Hoonbr. \& Jacq. I'oy. au Póle Sud, Poiss. p. 33. pl. 1.

$$
\text { f. 3.- Habitat — ? }
$$

\& 1. Serranus rivulatus, Cuv. \& Val. vi. p. 515.-Isle do France:

2. - - nigriceps, Cuv. \& Val. vi. p. 517.-Polynesia.

3. - miliaris, Cuv. \& Val. vi. p. 520.-New Guinea.

4. - - flaroguttatus, Peters, Wiegm. Arch. 1855, p. 235.-Mozambique. 
$\eta$. With eighteen or nimeteen rays:

122. S. altivelis, 123. S. inemis,

124. S. quoyanus,

125. S. olfux.

$\theta$. With nineteen or twenty rays:

126. S. dermopterus.

3. Body with longitudinal bands*:

127. S. formosus, 130. S. biguttatus,

128. S. Iatifaseiatus, 131. S. pœecilonotus,

133. S. urophthalmus,

129. S. morrlua, 132. S. lemniscatus,

134. S. lineatus,

135. S. amboinensis.

I. Serrani with deeply forked caudal fin,

A. and with the two middle rays of caudal fin much clongate.

\section{Serranus phaëton.}

Cur. \&. I"al. ii. p. 310. pl. 34.

$$
\text { D. } \frac{9}{11 ?} \text {. A. } \frac{3}{9} \text {. }
$$

Caudalis forked, with the two middle rays as long as the body, both sheathed together in a membrane, the other rays strong and compressed; præoperenlum with excecdingly fine denticulations. Palatine and vomerine teeth very fine.

$\mathrm{Hab}$. ?

B. With the two middle rays of caudal fin shortest.

\section{Serranus creolus.}

? Iarra, pl. 20. f. 2.

Serranus creolus, Cur. \&. Val. ii. p. 265; Chr. Regne Anim. Ill. Ichthyol. pl. 8. f. 1 (coloration?).
D. $\frac{9}{10}$.
A. $\frac{3}{9}$.
I. lat. 90 .
Vert. $10 / 14$.

Snout short. The upper maxillary hone reaching to below the middle of the eye; procopereulum with rery fine and equal serrature : interoperculum minutely serrated, or without any serrature. Caudal fin deeply forked, with elongate lobes. Reddish, with four small round violet spots on each side; dorsal fin with a blackish longitudinal streak.

Caribbean Sert.

a. Fino specimen. Cuba. From the Collection of the Zoologieal Society.

6. Adult stuffed. West Indies. Purehased of Mr. Serivener.

$c, d$. Fine specimens. Amrrica. From the Hastar Collection.

e. Adult. America.

f. Adult. America. From the Haslar Collection.

g. Arlult: skrletom. America.

* 1. Serranus chlorocephalus, Cur. \&. Ful. vi. p. .20.--Polynesia Identical with S. linertus? 
Skeleton.-The mpper surfice of the skull is rather broad, and divided into two lateral halves by the high supraoceipital crest, which extends to the level of the anterior third of the eye. The crest is thin, transparent, and rounded behind; the two lateral crests between the orbit and the suprascapula are also well developed. Just beneath the anterior end of the supraoceipital crest is a broad and open eavity for receiving the posterior processes of the internaxillaries. The intermaxillary is about two-thirds of the length of the maxillary, and has a very prominent flat process behind. The maxillary gradually widens, and has a rather convex superior margin and a rather concave inferior one; the supplementary bone is narrow. The greater part of the procorbital is as broad as the postcrior infraorbital areh; the latter with a very broad and exeavated inner plate for supporting the eyeball from beneath.

Operculum with three spines, the two lower of which are close together; the sub- and interopereulum are without any serrature in this specimen. The angle of the prooperenlum is rounded, and furnished with several obsolete and obtuse denticulations; the posterior serrature of the bone is minute.

The dentition is feeble: there is in the upper and lower jays a pair of small canines; there are no lateral canines; the other tecth are in villiform bands, that of the intermaxillary reaching nearly to the extremity of the bone, and with an outer scries of scarcely larger teeth. The romerine teeth form a triangular patch with a rather concave posterior side. The palatine teeth form a cunciform band, broader in front, and not extending beyond that bone.

Ten abdominal and fourteen candal vertebre. The interhæmal is attached to the hemal spine of the eleventh vertebra, of moderate strength, and equal to tho length of the first to the seventh vertebra.

\section{Serranus colonus.}

Valenc. Foy. Ténus, Zool. p. 300. pl. 2. f. 1 (not good).

$$
\text { D. } \frac{9}{18} \text {. A. } \frac{3}{10} \text {. } \quad \text { L. lat. } 120 \text {. }
$$

Snout short; proopereulum finely serrated; caudal fin deeply forked, with elongate lobes. Uniform yellow. ( $\mathrm{Fal}$.)

Galapagos Archipelago.

\section{Serranus louti.}

Seba, iii. 27. 7 ; Renard, t. 41. f. 207, t. 21. f. 100 ; Valcntyn, p. 412. f. 205.

Perca louti, Forskal, p. 40.

Labrus punctatus, Laecon. iii. p. 377. pl. 17. f. 2.

Bodianus louti, Bl. Schn. p. 3332; Lucép. iv. p. 286.

Serranus punctulatus, Cuv. \& - Tal. ii. p. 367, ix. p. 435; Bleek. Sun. i. p. 570 ; Quoy \& Gaim. Toy. Astrol. Poiss. p. 654. pl. 3. f. 2.

—louti, Rïpp. Atl. p. 106. pl. 26. f. 2 (not I'al.).
D. $\frac{9}{13-14}$.
A. ${ }_{8}^{3}$.
L. lat. 110). Tert. 10/14.

Caudalis deeply forked, with elongate lobes; dorsal, anal and ren- 
tral fins pointed; denticulations of prooperculum olssolete. Brownish, with small whitish spots.

Red Sea ; Isle de France : Ceylon : Molueca Sea ; Sumatra; Timor ; Waigiou.

«. Adult: skin. Copang (Timor). D. $\frac{9}{13}$.

b. Adult: stuffed. Isle de France. D. $\frac{9}{1 .}$.

c. Adult. Isle de France. From the Collection of the Zoological Society. I) $\frac{9}{14}$.

(l. Adult: skeleton. Isle de Franee. From the Collection of tho Zoological Soeicty. D. $\frac{9}{14}$.

e. Adult: stuffed. Red Sea. D. $\frac{9}{14}$.

$f$. Adult. Sine patria. From the Haslar Collection.

g. Adult: bad state. Sine patria. From the Haslar Collection.

$h$. Half-grown. Amboyna. Purchased of Mr. Frank.

Sheleton.-The crown of the head and the interspace between the eyes are without prominent ridges or decp grooves; they are narrow and rather flat. The supraoceipital and the lateral crests are rather low, the former not extending beyond the supraoceipital bone. The two posterior processes of the intermaxillaries are not received into a common groove, but run on the sides of a narrow longitudinal ridge. The posterior part of the infraorbital areh is narrow, and has inside a broad excavated plate for supporting the eyeball from beneath. The length of the intermaxillary is about two-thirds of that of the maxillary; it has a flat prominenee behind, above which is a deep noteh. The maxillary widens from its second third; the superior margin is nearly straight, the inferior concave; the supplementary bone is excecdingly narrow. The opereulum has three distinet flat spines, the middle of which is longest and nearer the lower than the superior; the sub- and interopereulum are without any serrature; the proopereulum is romed throughout, and has some very indistinct serrature at the rounded angle.

The dentition is rather powerful. There are in the upper jaw two very strong eanines; the outer series is formed by shorter, but thicker teeth than the others, and does not extend to the extremity of the bone. Inside of the canines and the series mentioned is a band of villiform tecth, broadest behind the eanines; and here also are placed several long and stender teeth of more eardiform appearance. 'The lower jaw is armed in front with a pair of canines, and with another in the midkle of its lateral hand, but they are rather smaller than those of the upper jaw. In the rilliform band several cardiform teeth are visible. The vomerine tecth ate arranged in two series, meeting anteriorly at a rather obtuse angle. The band of palatine teeth is narrow, and does not extend on the pterygoid bone.

There are ten abdominal and fourteen eaudal vertebre. The interhamal, is attached to the hamal sjunes of the tenth and elerenth vertebrac; it is slender. and equals the length of the second to the seventh vertebra. 


\section{Serranus flavimarginatus.}

Rïppell, Atlas, Fische, p. 109.

$$
\text { D. } \frac{9}{14} \cdot \quad \text { A. } \frac{3}{8} \text {. }
$$

Caudalis deeply forked, analis and dorsalis pointed behind. Reddish brown, covered with small blue spots; a black band from the eye to the base of caudalis; the vertical fins with a yellow edge; on each side of the tail a black spot. Allied to S. punctulatus.

Red Sea.

\section{Serranus filamentosus.}

Serranus filamentosus, Cuv. \& Vul. vi. p. 508.

Centropristes filamentosus, Mïll. \& Trosch. in Schomb. Hist. Barbad. p. 666 .

$$
\text { D. } \frac{10}{11} \text {. A. } \frac{3}{8} \text {. }
$$

External appearance sparoid. Caudalis deeply forked; the last ray of the dorsal and anal fins elongate, twice as long as the preceding. Denticulations of the prooperculum coarser at the angle; opereulum with two flat spines. Brownish, with small specks in the angle of each scale; sides lighter; dorsal fin with yellow spots along the base. ( Val.)

Isle de France.

\section{Serranus zonatus.}

Serranus zonatus, Cuv. \&. Val. vi. p. 509.

? Serranus argyrogrammicus, Cuv. \& V Val. viii. p. 472.

$$
\text { D. } \frac{10}{11} \text {. A. } \frac{3}{8} \text {. }
$$

Caudalis deeply forked; pectoral fins long, pointed; the last ray of the dorsal and aual fins elongate, twice as long as the preceding. The diameter of the eye one-third of the length of the head; præoperculum rery finely serrated, with coarser denticulations at tho angle; supraseapula denticulated. Rose-coloured in life, with four orange cross-bands, lost on the sides; candal fin with a bright yellow edge. ( $V a l$.

Isle de France.

II. Serrani with the candal fin slightly convex or slightly concave, or truncated.

A. With less than eight rays in the anal fin, and with more than twelve rays in the dorsal.

\section{Serranus scriba.}

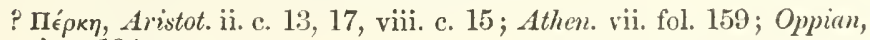
i. v. 124 .

? Perca, Plin. ix. c. 16.

Phycis, Salriani, p. 227. f. 92.

Perca marina, Gesner, pp. 696,819 ; Jonston, i. c. 1. t. 14. f. 8 ; Willughby, p. 327; Ray, p. 140; L. Gm. p. 1313; Brïmich, Ichthyol. Massil. p. 63 ; De la Roche, Ann. Mus. xiii. p. 350.

Perca no. 6, Artedi, Genera, p. 40.

Perca scriba, L. Mus. Ad. Fried. p. 56; Gm. L. p. 1315. 
Holocentrus marinus, Lacép. iv. p. 376 : Risso, Ichth. Nice, p. 291.

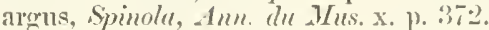

?- favciatus, Wloch, pl. 240: B7. schn. p. 314: Lacép. iv. p. 380 : Risso, Ichth. Nice, p. 2900.

- maroceanus, Bl. Schn. p. 3200.

Lutjanus scriptura, Lacip. iv. p. 229

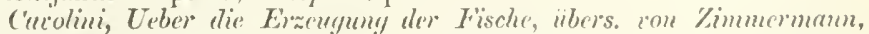
p. 84. t. ?. f. $16-18$.

Serranus scriba, Cur. \& V'al. ii. p. 214. pl. 28: Martens. Ireise uach Venedig, ii. p. 425; Nordmann in Inemietoff, Toy. Reuss. Térid, iii. p. 366. pl. 2. f. 1; Guichen. Explur. Se. Alyere. Toiss. p. 33.
D. $\frac{10}{14}$.
A. $\frac{3}{7}$.
L. lat. 70 .
Vert. 10'14.

Præopereulum equally and fincly denticulated. Borly with five to seven blackish transwerse bauls; head with irregularly reticulated blue lines; vertical and ventral fins with small romd reddish spots.

Mediterrancan; Black Sea.

a. Adult. Dalmatia.

b. Adult: skeleton. Bay of Naples. Presented bys. P. Pratt, Esq.

c. Adult: bad state. Sicily. Presented by W. Swainson, Kisq.

d. Adult. Presented by W. Swainson, Exq.

e. Adult: skin. Mediterranean. Presented by Richard Santhill, Esq.

f. Adult. Mediterranean. From the Haslar Collection.

y. Half-grown. Meliterrancan.

h. Half-grown. Mediterrancan. From the Haslar Collection.

i. Half-grown: bad state. Malta. From the Hasiar collection.

k. Adult: stuffed. Malta. From Mr. Yarrell's Collection.

7. Adult: not good state. Furope. From Mr. Frank's Collectious. $m, n$. Adult : very bad state. Europe.

o. Adult. Europe.

$p \rightarrow$. Adult: stuffed. Europe. From Mr. Yarrell's Collection.

$s, t$. Adult: skin. Europe. From Mr. Farrell's Collection.

u. Young: not good state. Europe. From the Haslar Collection.

Sheleton.-The upper part of the skull is nearly smooth, withont prominent ridges; eren the oreipital erest is not very mueh developed. The bones of the suborbital areh are not distinctly separated from one another, and there is, as in all the Serremi, a broad interior process for supporting the eychall from bencath. The two upper spines of the operenlum are the hinder ends of two strong bony ridges : the third spine is fechle, as is also the ridge belonging to it; the sub- and interoperculum are entire; the edge of the preoperculum is rounded, with ninute denticulations behind, gradually becoming larger at the angle, and disappearing in the middle of the lower limb; the suprascapula is minutely serrated. The number of reltebric as above stated.

\section{Serranus humeralis.}

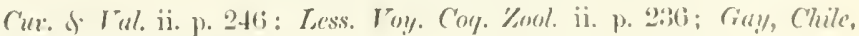
\%ol. ii. p. $14 !$ !

$$
\text { 1). } \frac{10}{14} \cdot \quad \text {. } \frac{3}{7} \text {. }
$$

Iracopereulum equally and finely dentieulated. The hrown colo- 
ration of the back emitting six transwerse bands towards the belly; operculum brown; cheeks brown-spotted: a large brown bloteh in front of the root of the pectoral fin; fins not spotted.

Coast of Chili.

\section{Serranus albomaculatus.}

Jenyns, Zool. of the Beatyle, Fishes, p. 3. pl. 2.

$$
\text { D. } \frac{10}{13} \text {. A. } \frac{3}{7} \text {. }
$$

Caudalis truncated. The length of the head onc-third of the total ; the diameter of the eyes about one-sixth of the length of the head, larger than the distance between them. Præoperculum finely serrated, with coarser dentieulations at the angle and along the posterior. half of the basal margin; smprascapula denticulated. The third dorsal spine very long, more than twice as long as the second, equalling more than half the height of the body. On the sides a series of five or six good-sized snow-white spots, and one placed above. (Jen.)

Galapagos Arehipelago.

\section{Serranus rhyncholepis.}

Bleeker, Celebes, iii. p. 749.
D. $\frac{11}{16-17}$.
A. $\frac{3}{7}$.
L. lat. 80 .

Candalis rounded; the diameter of the eye is $4 \frac{1}{2}$ in the length of the head; upper maxillary bone reaching behind the eye. Præoperculum serrated, with stronger denticulations at the angle; sub- and interopereulum entire; the spinous and soft parts of dorsal fin of equal height. Brown, each seale on the sides with a lighter speck; fins immaeulate. $(B l$.

Sea of Bulncomba (Celebes).

Bleeker compares this species with S.labriformis, Jenyns; he states the number of the rays of the anal fin to be $\frac{3}{7-8}$; but as he always reckons the last as two, I am obliged to remove this species from $S$. labriformis into another group with seren soft rays in the anal fin. Further examination of other specimens will show whether I am right in so doing.

\section{Serranus gymnopareius.}

? Epinephelus striatus, Bloch, t. 330.

Serranus gymnopareius, Cuv. \& $V$ al. ii. p. 248.

$$
\text { D. } \frac{9}{17} \text {. A. } \frac{3}{7} \text {. }
$$

Præopereulum without seales, ouly its posterior limb denticulated; eaudalis truncated. Body with seven ol ight dark-brown crossbands.

Jamaiea (?) 
B. With eight or more soft rays in the anal fin.

1. Body with cross-bands or large oblong transverse spots.

a. Denticulations of præopereulum stronger at the angle.

\section{Serranus cabrilla.}

Xavì, Sulriuni.

Perca, Rondel, vi. eap. 8.

Perca cabrilla, Limn. Syst. i. p. 488.

?- mormyrus, Gionor. Syst. ed. Gray, p. 109.

- marina, var. $\beta$, Briünich.

IIolocentrus virescens, Bl. t. 233 ; Lacêp. iv. p. 357.

- marinus, Lacép. iv. p. 376.

Lutjanus serranus, Lacép. iv. p. 205.

Serramus cabrilla, flavus, Risso, Ichth. Nice, pp. 375, 376.

- cabrilla, Cuv. \&. Tal. ii. p. 223. pl. 29 ; White, Catal of Brit.

Fishes, p. 11; Yarrell, Brit. Fishes, i.p. 11; Nordmam in Demidoff's

Toy. Russ. Mérid. iii. p. 367; Guichen. Explor. Se. Algér. Poiss. p. 33. pl. 1.

Perea channus, Couch in Loud. Mag. Nut. Mist. v. p. 19. f. 6.

$$
\text { D. } \frac{10}{14} . \quad \text { A. } \frac{3}{8} \text {. L. Iat. } 80-90 \text {. L. transv. 9/25. }
$$

Caudalis truncated; denticulations of the angle of the præoperunium not much stronger. Sides of the head with three oblique red bands; hody with seren or more dark-brown eross-bands; sometimes a reddish lateral band.

Mediterranean; Black Sea; coasts of Portugal and France; southern coast of England; St. Paul's (West Indies).

a. Adult. Dalmatia.

b. Adult. Lisbon.

c. Adult: not good state. Lisbon. Presented by G. Hough, Esq.

d. Adult. London market. Presented by Messrs. J. and C. Grove.

$e-g$. Adult and half-grown: skins. Plymouth. From MIr. Yarrell's Collection.

h. Adult: stuffed. Plymouth. Presented by Lient. H. F. Spencer, R.N.

i. Adult: not good state. Madeira. Old Collection as Perca decorata.

$k-m$. Adult and half-grown: skins. Santa Cruz (Teneriffe).

n. Arlult: not good state. Europe.

o. Adult: bad state. Europe. Old Collection.

p, ф. Adult: very bad state. Europe.

r, s. Adult: stuffed. Fingland.

$t$. Adult: stuffed. Europe. Old Collection.

$u, v$. Half-grown: skins. Europe. From Mr. Yarrell's Collection.

u. Young: skin. Europe. From Mr. Yarrell's Collection.

$x$. Adult: skeleton. England.

$y-a$. Half-grown. St. Paul's. Presented by the Lords of the Admiralty.

B. Adult: stuffed. Europe.

$\gamma$. Adult: stuffed. Lisbon. 


\section{Serranus brunneus.}

lpinephelus brunneus, Bloch, t. 328. f. 2; Bl. Schu. p. 300.

Serranus kawamebari, Richardson, Ichth. China, p. 234 (not Faun. Japon.).
D. $\frac{11}{13}$.
A. $\frac{3}{8}$.
L. lat. 95 .

Caudalis rounded. The height of the body is one-fourth, and the length of the head one-third of the total length; the diameter of the eye is one-sixth of the length of the head. The upper maxillary bone reaches beyond the level of the posterior margin of the eye. Pectorals rather longer than rentrals, not extending to the vent. The dorsil spines nearly equal in length, except the first two and the last; the second anal spine not much stronger and not longer than the third. Brownish, with six darker cross-bands, inelining forwards as they descend; the first narrowest from the first dorsal spines to the eye; ehecks with oblique darker bands. Fins immaculate.

Chimese Sea.

a, b. Adult. China. Presented by J. R. Reeres, Esq.

c. Half-grown. China. Presented by J. R. Recres, Esq.

Bloch says, in his great rork on Fishes, that this species is found in Norway-probably beeause be reecired the fish from a friend in Norway; but Schneider gives Japan as its native country. The figure may be easily recognized; but the first curred hand from the eye to the dorsal fin (very characteristic of the species) is omitted.

\section{Serranus kawamebari.}

Temm. s. Schleg. Fanm. Japon. p. 5.

$$
\text { D. } \frac{12}{12} \text {. 1. } \frac{2}{10} \text {. }
$$

Caudalis with a rather convex posterior margin; preoperculun rather deeply serrated, with stronger denticulations at the angle; interoperenlum and supraseapula denticulated; the spinous part of the dorsal fin not much elevated. Brownish, with five darker crossbands; the soft part of dorsalis, the eandal and anal fins with small round spots; opereulum with a deep black spot between the spines; præopereulum with two brown streaks from the eye.

Japanese Sicas.

\section{Serranus lanceolatus.}

Holocentrus lanceolatus, Bloch, t. 242. f. 1 ; Shuw, Zool. iv. p. 567 ; Russell, t. 130.

Semanus lanceolatus, Cuv. \& Val. ii. p. 316 ; Blecker, Perc. p. 35 : Cuntor, Catal. p. 8.

$$
\text { D. } \frac{11}{15-16} \cdot \Lambda \cdot \frac{3}{8} \text {. }
$$

Caudalis rounded. Length of the head atiout one-third of the total ; the diameter of the eye one-sixth or one-serenth of the length of head. sub- and interoperculum entire. Yellowish, with five brown eross- 
bands: first from the orbit over the prapoperculum; second from the crown of the head obliquely over the operculnm to behind the peetoral fins; third very broad, occupying the space between the second and tenth spine, conflnent below with the seeond hand; fourth broad, spanning nearly the eight posterior dorsal rays; fifth in front of the caudal: all the fins with round brown spots.

Bay of Bengal; Batavia; Samarang.

This species is well distinguished by its coloration. Bleeker states that in adult specimens the bands become obsolete, and that the eoloration changes to yellowish marbled with brownish. A single specimen, of about four inches in length, axists in the Colleetion of the East India Museum.

\section{Serranus albofuscus.}

Holocentrus maculatus, $3 l$. iv. p. 96. t. 242. f. 3; Bl. Schn. p. 315.

- albofuscus, Lacóp. iv. pp. 341, 381, 385.

Serramus maculatus, Blecker, Boeroe, p. 398.

$$
\text { D. } \frac{11}{16-17} \text {. A. } \frac{3}{8} \text {. L. lat. } 100 \text {. }
$$

Caudalis rounded; the diameter of the eye one-third (?) of the length of the head; the upper maxillary bone reaching to the level of the posterior margin of the eye; proopereulum serrated, with a mueh longer spinous tooth at the angle; sub- and interoperculum entire: the second, third and fourth dorsal spines iongest; the third anal spine stronger and rather longer than the second. Brown, with large pearl-coloured spots; on the liead four or five, on the back three trinsverse blotches, more or less extending on the dorsal fin : one between scapula and anterior dorsal spines, the sceond between the lateral line and the upper edge of the hinder part of the spinous dorsal, the third across the back of the tail behind the dorsal. Dorsal fin brown, with three round black spots on the soft part; pectorals blackish, with pearl-eoloured spots and a band of the same colour across the middle; anal and ventral fins brown, the former witl a pearl-coloured spot; eaudalis yellow, with large brown spots. (Bl.)

Sea of Boeroe.

\section{Serranus sexfasciatus.}

Serranus sexfasciatus, (Kuhl \&. r. Hass.) Cuv. \& Val. ii. p. 360 ; Blecker, Perc. p. 38.

$$
\text { D. } \frac{11}{15} \text {. A. } \frac{3}{8} \text {. }
$$

Caudalis rounded; sub- and interopereulnm entire; angle of the preopereulum with rery strong teetl. Borly with six dark brown eross-liands; lead uniform ; dorsal and eandal fins with roundish brown spots.

Javinese Suer.

a. Half-grown: skin: bard state. liast lndies. l'resented by B. 11. Hodgson, lisi. 


\section{Serranus mystacinus.}

Serranus mystacinus, Poey, Memorins de Cuba, 1851, p. 52. lam.10. f. 1. ? Serranus octocinctus, Temm. S. Schleg. Faun. Japon. Puiss. 1). 7. pl.4 a.

$$
\text { D. } \frac{11}{14-15} \text {. A. } \frac{3}{9} \text {. L. lat. } 100 \text {. }
$$

The height of the body is $3 \frac{1}{4}$ in the total length, the length of the head three times. Prooperculum with some very strong spinous teeth at the angle, partly extending on the horizontal limb. Caudalis rounded; pectorals reaching a little beyond the rent. Reddish, with ten dark cross-bands ; fins immaculate.

Caribbean Sea.

\section{a. Adult. South Ancrica. Presented by Sir R. Schomburgk.}

Aecording to Poey's statement, this species makes a remarkable exception to most of the Serrani in having at least twelve stems of the pyloric appendages, each divided again into several branches; an increased number is also to be observed in S. inermis, from the same locality. The deseription of $S$. octocinctus, given in the Faun. Japon. p. 7, pl. $4 a$, agrees exactly with the specimen mentioned above. There is another speeimen in the Collection of the British Muscum, said to be from the Isle de Franee, which cannot be separated from the former.

b. Adult: stuffed. Isle de Franee. Presented by Dr. Janvier.

\section{Serranus oceanicus.}

? Perca fasciata, Forstial, p. 40.

Holocentrus oceanicus, Lacép. iv. p. 377. t. 7. f. 3.

—— forskalii, Lacép. iv. p. 377.

Serranus oceanicus, rut. \& Val. ii. p. 302.

Serrani marginalis rar., Blvelier, Perc. p. 34.

$$
\text { D. } \frac{11}{16} \cdot \quad \text { A. } \frac{3}{8} \text {. }
$$

Caudalis truncated; sub- and interoperenlum entire; denticulations of the angle of the præoperculum not much stronger. Reddish, with five darker. cross-bands; head miform ; the anterior half of the dorsalis with a blackish edge: candalis not black-edged.

Red Sca ; Isle de France.

\section{Serranus trimaculatus.}

Epinephelus japonicus, Kirsenst. Reise, pl. 64. f. 2.

Serranus trimaculatus, Cuv. \& Tal. ii. 1. 331; Faun. Japon. Porss. p. 8 ; Richardson, Ichth. China, p. 232.

$$
\text { D. } \frac{11}{15-16} \text {. } \quad \text { 1. } \frac{3}{(7-) 8} \text {. }
$$

Caudalis rounded; sub- and internperculum entire; the hinder limb of the præopereulum serrated; denticulations stronger at the angle; the lower limb entire. Reddish brown, with two large blackish-brown square spots at the root of the hinder half of the 
dorsal fin; a third black transrerse spot across the back of tail. Head, body, hinder part of dorsal fin, candalis and analis with scattered brown spots.

Japanese, Chinese, and Cape Seas.

a. Adult. China.

b. Adult. China. Presented by J. R. Reeres, Esq.

c. Adult: stuffed. Japan.

d. Adult : stuffed. Cape Seas. Presented hy Sir A. Smith.

e. Adult: stuffed. Sine patria.

$f$. Adult : skin. Sine patria. From Mr. Serivener's Colleetion.

\section{Serranus diacanthus.}

Serranus diacanthus, Cuv. \& Val. ii. p. 319.

nebulosus, Richards. (not Cuv. \& Vul., nor Bleek.) Ichth. Chima, p. 232.

_- schihpan, Richards. l. c. p. 231.
D. $\frac{11}{15-16}$.
A. $\frac{3}{8}$.
L. lat. 90.

Caudalis rounded; eye nearly one-fifth of the length of the head; length of the head one-third of the total; subopereulum and interoperculum entire; the inferior limb of the preoperenlum entire, two or three strong spinous teeth at the angle, the posterior limb strongly denticulated. Whitish or brownish (in spirits), with five darker eross-bands; sometimes elouded or spotted with dark brown, besides the cross-bands; fins, in dried speeimens, with an obsolete darker edge-in specimens preserved in spirits, with a lighter edge.

Bay of Bengal ; Coast of Malabar; China Seas; Louisiade Arehipelago.

a. Adult. Bengal. Presented by General Hardwieke.

b. Adult: stuffed. China. Presẹted by J. R. Reeres, Esq.

r. Adult. China. Presented by General Hardwieke (Serramus schithan).

d. Adult. China.

e. Half-grown: bad state. China. Presented by the Hon. E.T. Company.

f. Half-grown. Hong Kong. Presented by Sir d. Richardson.

g. Half-grown. Hong Kong. From the Haslar Collection.

$h$. Half-grown: stuffed. Lonisiade Archipelago, in 30 fathoms. Voyage of the Rattlesnake.

2. Young: stuffed. Lonisiade Arehipelago, in 12 fathoms (sand) Voyage of the Rattlesnake.

k. Adult. India.

l. Adult. India. From the Haslar Collertion.

$m$. Adult. India. l'resented by General IFrriwicke.

\section{Serranus striatus.}

Seba, iii. t. 27. f. 9; Purre, p. 50. pl. 24. f. 1. Anthins striatus, B3l. t. $324 ;$ Bl. Schl. p. 305.

Lutjanus striatus, Lacep. iv. p. 234. 
Sparus chrysomelanurus, Lacép. iv. p. 160.

Anthias cherna, Bl. Schn. p. 310.

Serranus striatus, Cuv. \&.Vul. ii. p. 288; Guichen. in Ramonde la Sagru, IIist. Cuba, Poiss. p. 12.
D. $\frac{11}{17}$.
A. $\frac{3}{8}$.
Vert. 10/14

Distance between the eycs much smaller than their diameter: præoperenlum with fine denticulations (in younger individuals coarse' at the angle). Caudalis rounded. Six or seven broad cross-bands; seattered circular black spots round the eye; a large square black bloteh across the back of the tail, behind the dorsal.

Atlantic shores of Tropical America.

a. Very large specimen ( $3^{\prime}$ long): stuffed. America.

b. Tery large specimen $\left(2 \frac{1}{2}^{\prime} l o n g\right)$ : stuffed. West Indies.

c. Half-grown : stuffed. Cuba. From M. Poey's Collection.

d. Half-grown. Test Indies.

e. Half-grown: skeleton. West Indies.

f. Half-grown : not good state. West Indies.

g. Half-grown. West Indies.

$h, i$. Half-grown. West Indies. From Mr. Scrivener's Collection

k. Half-grown: stuffed. Mexico. Presented by Dr. J. E. Gray.

l. Half-grown : stuffed. Bahia.

m. Half-grown. Puerto Cabello. From Mr. Brandt's Collection.

$n \rightarrow$. Half-grown: skins. Jamaica. From Dr. Parnell's Collection.

Sheleton.-The oceipital erest, being moderately developed behind, is prolonged to the front end of the frontal bones; the orbital edge also of the latter is prominent; the suborbital arch as in S. scriba. The three spines of the opcrenlum correspond to thrce bony ridges, the middle of which is the strongest and slightly eurved. The hinder limb of the præoperculum is rather convex, minutely serrated, and slightly notched above the angle; in young individuals the denticulations of the angle are stronger; the lower limb, sub-and interoperculum, and suprascapula are entire. There are in front of the upper jaw two teeble canines, to which two others correspond in the lower jaw; the other tecth of the upper jaw are villiform, occupyung nearly the whole length of the intermaxillary; in front the $y$ are placed in many irregular series, those of the hinder series becoming gradually longer and bent backwards; the villiform band of the lower jaw occupies nearly all the length of the dental bone; we can clearly distinguish two series at the lateral part of this bone, the interior of which contains stronger tecth than the sxterior. The series of vomerine teeth form a right angle; the palatines are provided only with a single series of minute teeth.

\section{Serranus stigmapomus.}

Richarelson, Ichth. Chine, p. 232.

$$
\text { D. } \frac{9}{17} \text {. A. } \frac{3}{8} \text {. }
$$

Caudalis rounded; præoperculum finely serrated, with rather stronger denticulations at the angle. Brown, with eight regular 
darker cross-bands; a round black spot between the two mper opereular spines; dorsal fin with a pale edge, peetoral and anal fins with a dark one.

China Scas. North-west Coast of Australia?

b. Denticulations of preoperculum conspicuous and equal.

\section{Serranus tigris.}

Cur. \& Val. ix. p. 440.
D. $\frac{11}{17}$.
A. $\frac{3}{11}$.

Caudalis slightly rounded; prxoperculum very finely serrited. Violet, spotted with brownish; eight oblique cross-bands of a light blue colour. ( $\mathrm{Val}$.)

St. Domingo.

\section{Serranus boenack.}

Bodianus boenack, Bloch, iv. p. 44. t. 226; Bl. Schu. p. 330.

Serranus boenack, Cur. S. I' ul. ii. p. 362 (not good); Bleeker, Perc. p. 31.

— boelang, Cur. \&. Ial. ii. p. 308, vi. p. 514; Qnoy. s. Ciaim. Voy. Astrol. Poiss. p. 6.57. pl. 3. f. 4.

- nigro-fasciatus, ILombr. \& Jacquin. Toy. Pike Sul, Poiss. p. 36. pl. 2. f. 1 .

$$
\text { D. } \frac{9}{15} \text {. A. } \frac{3}{8} \text {. I. lat. } 7(\text {. }
$$

Caudalis rounded; sub- and interopereulum with slight dentienlations, prxopereulum finely serrated; the diameter of the eye onesixth of the length of the head. Brown; hody with seven darker eross-bands; fins not spotted; candalis with a black and yellow hinder edge.

Sunda and Molucea Sea.

a. Young. Amboyna. From Mrr. Frank's Collection.

b. Adult: stuffed. Presented by J. Gould, Esq.

\section{Serranus nigri. (PLAte LX. fig. ג.)}

$$
\text { D. } \frac{9}{14} \cdot \quad \text { A. } \frac{3}{8} \text {. I. lat. } 70 \text {. }
$$

Candalis rounded. The heiglit of the body is $3 \frac{4}{5}$ in the total length, the length of the hearl $3 \frac{1}{3}$; the diameter of the eye is $4 \frac{1}{2}$ in the latter. The upper maxillany bone does not reach to the level of the posterior margin of the eye. Sub- and interoperealum entire : pectorals as long as rentrals, not extending to the anal fin. Brown. with seven indistinct vertical bands ; eheeks, 1 pper jaw, the soft part of the dorsal and all the other fins with more or less distinet, round. pale bhuish spots of the size of a seale.

«. River Niger. From Mr. Fraser's Collection.

Description.-The form, as in most of the Servani, is oblong, rather elongate; the greatest height of the body is bencith the front end 
of the dorsal fin, and $3 \frac{1}{5}$ in the total length. Taking the distanee between the lorsal and caudal fins $=1$, it is contained $3 \frac{2}{3}$ in the length of the base of the dorsal, and equal to one-third of the distance between dorsal and snout, and rather smaller than the hase of the anal fin. The length of the head is contained $3 \frac{1}{3}$ in the total; the distance between the eyes is much smaller than their diameter, covered with small scales, which extend beyond the nostrils on the proorbital. The length of the snout from the eye is rather more than the diameter of the eye ; the cleft of mouth moderately oblique; the upper maxillary bone naked, not reaching to the level of the posterior margin of the eye; the mandibulary is covered with minute srales, and longer than the half of the length of the head. The posterior limb of the præopereulum is convex, minutely serrated, the denticulations at the angle being scarcely larger; the lower limb is entire, like the sub- and interopereulum. The operculum terminates in three conspicuous, flat, short, triangular teeth, the middle of which is the longest, but not rery prominent; the upper one is rather mote distant than the lower. The suprascapular bone is eoncealed by the ordinary seales.

The base of the doisalis is protected by an encroachment of the sealy integument, and a tapering row of scales rums up between each pair of spines or rays for two-thirds of the height of the fin. The spinous part is lower than the soft, and the membrane between the spines is deeply notched, but without fringed appendages; the first spine is half the size of the second, the second two-thirds of the third, and the fourth to ninth spines are nearly cqual in length, the last being rather shorter ; all the spines are strong, and the strongest is equal in length to the distance between the dorsal and caudal fins. The soft portion of the dorsal fin is quadrangular, with a straight upper margin; the first ray is one-fourth longer than the last spine, all the following being equal, except the last three, which again diminish in length. The caudalis is rounded throughout, narrow bands of small seales running between the rays to two-thirds of the length of the fin. The analis commences a little behind the conmencement of the soft portion of the dorsal ; the first spine is strong, but short; the second very strong, and nearly equal in length to the dorsal spines, which it much exceeds in strength; the third is more slender and rather shorter. The posterior angle of the fin is rounded, the rays becoming' gradually lenger to the fifth, and dmminishing again from the eighth. The pectoralis is composed of sixteen rays, rounded, as long as the ventral, and covered with thin scales to one-third of the length only. The ventralis reaches just to the vent, has the spine of the same length as the second dorsal, and the second ray rather longer than the first.

The ground-colour is brown, lighter on the belly; seven darker indistinct bands reach to the belly, and are broader than the lighter intervals between. The pale spots are most distinct on the proorbital and maxillary bones, on the anal and ventral fins, and on the inner side of the root of the pectoral ; the pectoral itself is immar"lllate and of a brownish-grey eolour. The dontition is as nsual.

The specimen is five inches long. 


\section{Serranus semipunctatus.}

? Perca septemfasciata, Thunb. Nor. Act. Stockh. 1793, pl. 1. f. 1. Serranus semipunctatus, Cur. \&. Val. ii. p. 341.

$$
\text { D. } \frac{11}{15} \text {. A. } \frac{3}{10} \text {. }
$$

Body with six or seren broad cross-bands; head and fins spotted; eandalis rounded.

Coast of Pondicherry.

\section{Serranus tigrinus.}

Sebre iii. 27. 5.

Crochilus, sp. 4, Klein, Miss. p.

Holocentrus tigrinus, Bloch, t. 2::77; Bl. Schn. p. 314 .

Serranus tigrinus, Cur. \& T al. ii. p. 314 .

$$
\text { D. } \frac{10}{12} \text {. A. } \frac{3}{8} \text {. }
$$

('audalis slightly emarginaterl. Brown, with seven black erossbands, and with ohlong dark blotehes between: head and vertical fins black-spotted; between the third and fifth spines of the dorsalis a large black spot.

(East Indies?)

\section{Serranus papilionaceus.}

Cur. \& Val. viii. p. 471; Valenc. in Barker-Thebb \& Berthelot, Ichth. p. 7.

$$
\text { D. } \frac{10}{15} \text {. A. } \frac{3}{3} \text {. }
$$

Caudalis very slightly notehed; proxopereulum very finely serrated behind and below; the fifth spine of the dorsal fin lonerest, one-half of the height of body; ventral fins reaching to the second spine of the analis. Ground-colour reddish-olive; under-side of the head and breast with violet spots; a broad olive cross-band below the hinder spines of the dorsal fin; two other narrower ones arross the tail: dorsal and anal fins spotted and lineolated.

Coast of (ioree; Canarian Islands.

c. Deuticulations of procoperculum exceedingly fine or obsolete.

\section{:31. Serranus oxyrhynchus.}

Cir. \& Iral. ii. 1. 321 .

$$
\text { 1). } \frac{10}{14} . \quad A \cdot \frac{3}{8} \text {. }
$$

Caudalis tmumaterl; muzle pointerl. Body with seven erosshands; a longitudinal streak from the eye to the angle of operenlum, and another obligur one from thenee along the erlge of operculum ; an oblong spot in the rentre of opereulum. ( $\mathrm{ral}$.)

Hrih. 


\section{Serranus argus.}

- Renard, fol. 2. no. 70 : Valest. iii. p. 459. no. 159.

Cephalopholis argus, Bl. Schn. p. 311. pl. (31.

Serranus argus, cue. \&. Val. ii. p. 360.

$$
\text { D. } \frac{11}{16} \text {. A. } \frac{3}{9} \text {. I. lat. } 95 \text {. }
$$

Caudalis rounded; præopereulum with exceedingly fine denticulations, subopereulum entire, a part of the lower edge of the interopereulum finely serrated; three spines of the operculun very eonspicuous, the middle one longest; maxillary bone reaching behind the level of eye; the diameter of the eye one-sixth of the length of the head, and rather more than one-third of the total. Brown (in spirits), with reddish-brown cross-bands; head, body, and all the fins with numerous small, round, blue, dark-edged spots.

This species may be easily confounded with one of the other bluespotted Serrani, but is distinguished by the cross-bands and by the denticulations of the opercles.

East Indies.

a. Fine specimen. Sine patria. From the Haslar Collection.

2. Body of uniform coloration or spotted; with neither transverse nor longitudinal bands.

a. Dorsalis with nine, rarely with eight spines.

By far the greater part of the species belonging to this group exhibit the præoperculum finely and equally denticulated, without those strong teeth on the angle by which some of the former groups are distinguished. The denticulations gradually disappear in some species. Thus we are really at a loss how to subdivide the numerous species still remaining. The best way would be to base the division on anatomical differences, if such really exist; but we must leave this task to those naturalists who are provided with more abundant materials than we are. The dentition does not offer any essential differences; nor is it practicable to apply the different coloration, as the species would then be very uneiually divided, and of but little use to the naturalist, who is obliged to examine preserved and liscoloured specimens. Hence we can find no other character but the number of the rays, much as we objeet to this method; but we obtain at least one advantage, that of facilitating the determining of species. The number of rays appears rarely to vary more than two, and on endearouring to determine a species we must look for it in two categories: for instance, if there is a specimen with fifteen soft rays, we must look for the species in the category with fourteen to fifteen rays as well as in that with fifteen to sixteen. This method would be false if applied to other genera of fishes with many-rayed fins, where the number often differs more than five or six. A distribution according to the native countries is of little value, so long as it is unaccompanied by other characters : and is of no use at all whenever we have specimens without anv notice of theis origin. 
a. With seventeen or eighteen suft rays.

\section{Serranus rogaa.}

Perca rogaa, Forsk. p. 38.

Bodiamus roraa, $33 l$. Schn. p. 334.

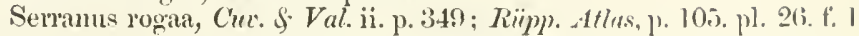
D. $\frac{y}{18}$. A. $\frac{3}{9}\left(\frac{3}{10} R\right.$ Riip?. $)$.

Caudalis truneated; dentieulations of the prepereulum nealy obsolete. Uniform blackish brown; fins black-edgerl.

Red Sea.

a. Adult: stuffied. Red sea.

\section{Serranus zananella.}

Serranns zananella, Blecker, Prec. p. 32.

? Labrus guaza, Lacép. iii. p. 501. pl. 27. f: 1

? Serranus zanamella, Cur. s. Vit. ii. p. 304.
D. $\frac{9}{17}$.
1. $\frac{3}{8}$.
I. lat. 70

Candalis rounded ; inter- and subopereulum cutire; denticulations of the prapopereulum conspicuous. Coloration miform bown: dor salis black-edged.

Jaranese Sea.

B. With sixteen soft rays (ruly with 15-17).

\section{Serranus pachycentrum.}

Cux. \& Vul. ii. p. 205 .

$$
\text { D. } \frac{9}{15} \cdot \text { L. } \frac{3}{8} \text {. }
$$

Caudalis rounded; both limbs of the preoperenlum, and lower limbs of the inter-and suboperenlum finely denticulated: lateral seales each with a slight keel, forming together longitmbinal lines. Dried specimen uniform brown.

Ceylonese Sea.

a. Adult: skin : not good state. Ceylon. I'resented by L. F. Kelatut, MI.D.

\section{Serranus erythræus.}

Cur. \&. Tal. vi. p. 516.

$$
\text { 1). } \frac{9}{16} \quad \text { I. } \frac{3}{9} \text {. }
$$

Caudalis rounded ; denticulations of the preopereulum axeedingly fine. Uniform hrownish: pectoral and eandal funs nearly black: ventrals yellowish. ( $V^{*}(t)$.

Isle de France.

3\%. Serranus microprion.

Blecker, Ambnima, ii. p. 5is.?

$$
\text { I). } \frac{9}{16(17)} \cdot \quad \text { A. } \frac{3}{8} \cdot \text { L. Litt. } 75
$$

Caurlalis rounded; renticnlations of the pres-. suh-, and inter- 
opcrculum searcely visible; the diameter of the eye one-fifth of the length of the head; upper maxillary bone reaehing beyond the hinder margin of the eye; the second anal spine longest. Dark brown on the sides, each scale with a black speek; head with numerous small, round, blue, blaek-edged spots ; fins immaculate.

Seas of Java, China, and Amboyna; Louisiade Arehipelago.

Bleeker gives for the dorsal fin $\frac{9}{15-16}$, which number would be $\frac{9}{14-15}$ aceording to my way of counting the rays; but all our specimens (ex ept one with seventecn rays) exhibit sixteen rays, one of them eoming from Amboyna, and proeured from a Dutch collestion, with the name of $S$. microprion.

a. Adult. Amboyna. From Mr. Frank's Collection.

b. Adult. China.

c. Adult: stuffed. China. Presented by J. R. Reeves, Esq.

d. Adult: stuffed. Louisiade Archipelago. From Mr. M'Gillivray's Collection.

e. Adnlt: stuffed. Louisiade Archipelago (7 fathoms, on sand and coral). Voyage of the Rattlesnake.

f. Adult: stuffed. Louisiade Archipelago (30 fathoms). Voyage of the Rattlesnake.

\section{Serranus cyanostigmatoides.}

Serranus guttatus, Cuv. \& V Vl. ii. p. 357 (not Peters). cyanostigmatoides, Bleek. Perc. p. 31.

$$
\text { D. } \frac{9}{16} \text {. A. } \frac{3}{9-10} \text {. }
$$

Caudalis rounded; sub- and interoperculum denticulated; præoperculum very fincly scrrated, the lower limb entire; operculum with three conspieuous spines, upper one shortest; the diameter of the eye one-sixth of the length of the head; length of the head not quite one-third of the total. Red (in life), all parts with round, blue, dark-edged spots; all the fins, exeept pectoral fins, dark-edged; two white streaks between eye and muzzle.

Seas of Java and Amboyna.

a. Half-grown. Amboyna. From Mr. Frank's Colleetion.

b. Half-grown. Amboyna. From Mr. Frank's Collection.

\section{Serranus cyanostigma.}

Renard, Poiss. Mol. t. 28. f. 153; Valent. iii. p. 392.

Serranus cyanostigma, (Kuhl \& v. Hass.) Cuv. \&. Val. ii. p. 35\%, and Règne Anim. Ill. pl. 8. f. 2 ; Bleeker, Perc. p. 32.
D. $\frac{9}{16}$.
A. $\frac{3}{8}$.
L. lat. 75.

Caudalis rounded; sub- and interopereulum entire, præoperculum very finely serrated; the diameter of the eye $6 \frac{1}{2}$ in the length of the head. Red (in life), with numerous small, round. blue, darkeredged spots on the head and fins; fins blue-edgerl.

Javanese Sea. 
Peters (Wieym. Archiv, 1855, p. 235) unites S. cyunostigma and the following species.

a. Adult. Amboyna. Purchased of Mr. Frank.

\section{Serranus miniatus.}

l'erca miniata, Forsk. 1. 41. no. 41.

Diacope miniata, Cur. \& Val. ii. p. 433.

Serrainus miniatus, Riipp. Atl. Fische, p. 106. t. 26 f. 3.

$$
\text { D. } \frac{9}{15-17} \text {. A. } \frac{3}{9-10} \text {. }
$$

Closely allied to S. guttutus. Caudalis rounded; preoperculum very finely serrated, and with a rather deeided notch above the angle. Red (in life), coresed with small, blue, black-edged rings; pectoral and anal fins immaculate; no fin with a coloured edge. (Riipp.)

Red Sea ; Mozambique.

a. Half-grown: stuffed : discoloured. Sine patria. Old Collection.

$\gamma$. With fifteen (rarely with fourteen) rays.

\section{Serranus aurantius.}

Cuv. \&. Tal. ii. p. 305; Bleck. Sum. i. p. 571.
D. $\frac{9}{14-15}$.
A. $\frac{3}{8}$.
I. lat. 85 .

Caudalis rounded; the diameter of the eye is 5 or $5 \frac{1}{2}$ in the length of the head; upper maxillary bone just reaching the posterior margin of the eye; denticulations of the propopereulum feeble, of the sub-and interopereulum conspicuous. Red; head and front part of back punctulated with brown; the soft part of the dorsal fin and caudalis with a black and yellow edge, the anal fin with a black one.

Seychelles; Sumatra.

\section{Serranus sexmaculatus.}

Riippell, Atl. Fische, p. 107.

$$
\text { D. } \frac{8}{15} \text {. A. } \frac{3}{10} \text {. }
$$

Closely allied to $S$. miniutus. Caudalis romuled. Red (in life), covered with small, blue, black-edged rings; six blackish blotches along the base of dorsal fin. (Riipp.)

lied Sea.

\section{Serranus nigripinnis.}

Bleaker, Batjen, iii. p. 500 ; (? C'ux. \&. Fal. ii. p. 339.)
1). $\frac{9}{14-15}$.
A. $\frac{3}{8-9}$.
L. lat. 100.
(B. 7.)

Caudalis rounded. 'The liameter of the eye one-fifth of the length of the head; the upper maxillary bone reaching to below the posterior 
half of the eye; pricoperculum finely serrated, with rather stronger denticulations at the angle; sub-and interoperculum serrated; the posterior dorsal spines nearly equal in length, longer than the anterior ones; the second anal spine stronger but not longer than the third. Brownish; head and anterior part of the back with numerous small bluish spots, the posterior part of the body with more distant brown spots; the soft part of the dorsal fin, the caudal and anal fins spotted; the caudal and pectoral fins yellow-edged. $(B l$.

Sea of Batjan.

\section{Serranus hemistictus.}

Rüppell, Atlus, p. 109. t. 27. f. 3.
(B. 6.)
D. $\frac{9}{14}$.
A. $\frac{3}{9}$.

Caudalis rounded; præoperculum rounded, with very fine and obsolete serrature; the last dorsal spine longest. Dark olive; head, belly, and fins with small blue spots, those of the operculum blackedged; caudal, anal, and ventral fins with a whitish edge.

Rïppell gives fourteen or fifteen rays for the dorsal fin, and six branchiostegals only.

Red sea.

a. Adult: stuffed. Red Sea.

\section{Serranus guttatus.}

Percæ miniatæ var. B., Forsk. p. 41.

Renard, i. pl. 20. f. 3, pl. 30. f. 162; Valent. iii. p. 358. f. 37.

Bodianus guttatus, $B l$.t. 224: $B l$. Schn. p. 330.

Serranus myriaster, Cuv.\& Val. ii. p. 365: Rüppell, Atlas, p. 107. t. 27. f. 1 ; Richards. Ichthyol. China, p. 233; Quoy \& Gaim. Voy. Astrol.pl.3. f. 1; Less. Voy. Coquille, pl.37; Bleek. Natuurk. Tydschr. Nederl. Indie, vi. p. 192; Quoy \& Gaim. Voy. Astrol. Poiss. p. 653. pl. 3. f. 1.

Serranus guttatus, Peters, Wiegm. Areh. 1855, p. 235 (not C'uv.\& Val.).

$$
\text { D. } \frac{9}{15}\left(\frac{9}{16} C . \& V ., \text { Rïpp. }\right) \text {. A. } \frac{3}{8-9} \text {. }
$$

Caudalis rounded; denticulations of the prooperculum obsolete; its posterior limb not cmarginate. Brownish black; head, body, and all the fins with round, blue, black-edged spots; caudalis, analis, and the hinder half of the dorsalis white-edged.

According to Blceker's description, the fins do not appear to be blue-spotted (probably a variety). The dentieulations of the præoperculum are entirely absent aceording to Rüppell's description, but they are conspicuous in the figure given by the same naturalist. After having removed the skin, I find very small teeth at and above the angle.

Red Sea; Isle de France ; Coast of Mozambique ; Ceylon ; China Seas; Borabora; Australia; Polynesia; Sandwich Islands.

$a, b$. Large specimens: stuffed. Isle de France. 
c. Adult: bad skin. Ceylon. Presented by Dr. Kelaart.

l. Young. Bormeo. From Mr. Frank's Collection.

e. Young: bad skin. From (Gronov's Collection.

\section{Serranus ouatalibi.}

Parra, p. :30. pl. 5. f. 2; Mar.tp. p. 147 (Carauna); Licht. Berl. Abhumull. 1820, p. 278.

Bodianus guativere, $13 l$; Schn. p. 336 .

Gymnocephalus ruber, Bl. Schn. p. 346. pl. 67.

Serranus ouatalibi, Cur. \& V al. ii. p. 381; Guichen. in Ramm de la Satyra, Hist. Cuba, Poiss. p. 15.

- carauna, Cur. \&. I'al. ii. p. 384; Castelnau, Anim. nouv. ou rares de l'Amér. du Sud, I'oriss. p. 1. pl. 1. f. 1 (faulty).
D. $\frac{9}{15}$.
A. $\frac{3}{9}$.
I. lat. 85 .
Cæc. pylor. 8
Vert. 10/14.

('andalis rather truncated; sub- and interoperenlum very slightly denticulated where they are joined; propopereulum serrated, tecth of the angle not prominent, lower limb entire; the upper spine of the operculum largest and longest. Maxillary bone not reaching to the level of the hinder edge of the eye; diameter of the eye $5 \frac{1}{2}$ in the length of the head; length of the head $3 \frac{1}{4}$ in the total. Red (in life); head and body, and sometimes dorsal fin, eovered with numerous small, bluc, black-edged spots, a pair of larger black spots on the symphysis of the lower jaw, and another on the back of the tail, behind the dorsalis.

Caribbean Sea.

a. Adult: stuffed. West Indies.

b. Adult: female. West Indies.

$c-e$. Aclult. West Indies.

$f$. Adult: not good state. West Indies.

\%. Half-grown. West Indies. Old Collection as Perea atomaria.

h. Adult: stuffed. West Indies. From Mr. Serivener's Collection.

i. Adult. S. America. Presented by Sir R. Schomburgk.

k-r. Half-grown: stuffed. West Indies. From Mr. Serivener's Collection.

$s-a$. Half-grow 1 : skins. Jamaiea. From Dr. Parnell's Collection. $y, z$. Adult: stuffer. Lord Howe's Island. Voynge of H.M.S. Herald.-With the formula: D. $\frac{9}{14}$. A. $\frac{3}{8}$.

a. Adtult: bard skin. Cape Verde.

j. Intestines and ovarium of spec. $b$. Both halves of the ovarium are nearly entircly separated.

Skeleton.-The upper surface of the skull is rounded on both sides, with a very low horizontal branch of the oceipital crest between, not extending on the frontal bones; the space between the orbits is concave, with a deep, oblong, triangular grouve in front. The posterior part of the orbit is strongly elevated; the interior orbitoseapular ridge is fecolde, lut projecting bohind into a strong spine; the extcrior is rery broad and strong. eorered by the skin only. 
The upper maxillary bone without process and with nearly straightlined margins. Operculum with three very acute prominent spines, the upper two of which are longest, and much more distant from one another than the middle from the lower; the præoperculum rounded throughout, with very fine and equal denticulations at the posterior limb; sub- and interoperculum entire. The dentition is the same as in $S$. coronatus, but the posterior front teeth of the upper jaw are not quite so long as in that species. There are ten abdominal and fourteen caudal vertebræ. The first interhæmal spine is equal to the length of the sccond to the seventh vertebra, and attached to the hæmal of the first caudal verte' ra.

Castelnau (l.c. pl. 1. f. 3) gives a tolerably good figure of a fish named Serranus ouatalibi, but certainly different from it. The figure being unaccompanied by a proper description, we are unable to determine the species from it alone.

\section{Serranus tæniops.}

Seba, iii. 27. 6.

Serranus tæniops, Cur. \& V Val. ii. p. 370.
D. $\frac{9}{15}$.
A. $\frac{3}{9-10}$.
Caec. pylor. 7 .
Vert. 1014.

Caudalis rounded. The height of the body is one-fourth of the total length; the length of the head is $3 \frac{1}{3}$ in the same length; the diameter of the eye nearly one-sixth of the length of the head; the upper maxillary bone reaching behind the level of the posterior margin of the eye. Denticulations of the preoperculum conspicuous. Red (in life) ; head, body, and fins with numerous small, round, blue, black-edged spots; between eye and muzzle two dark-blue streaks; fins blue-edged.

Atlantic, between Africa and Tropical America.

a. Adult. St. Vincent's. Presented by the Lords of the Admiralty.

b. Adult. Atlantic. From the Haslar Collection.

c. Adult. Atlantic. From the Haslar Collection.

d. Adult. Atlantic. From the Haslar Collection.

e. Adult: male : skeleton. Atlantic. From the Haslar Collection.

f. Adult. S. Africa. From Mr. Stcrens's Collection.

Skeleton.-The paroccipital and parictal bones form together a slight convexity, whilst the space between the orbital margins is rather concave; the ridges are slightly developed; the posterior part of the occipital crest is oblong, quadrangular, higher than long, and emits a low longitudinal branch along the medial line of the upper part of the supraoccipital bone, but which does not extend on the frontals The suprascapula is evidently separated into two bonesan interior, which articulates with the exoccipital; and an onter one, articulating with the mastoid bone; from both articulations num parallel longitudinal ridges to the orbit; the interior one is very inconspicuous in this species, but is strongly developed in S. undelilosus; the exterior ridge is not high, hut very strong. The max- 
illary bone gradually widens from the front towards behind, and is moreover distinguished by a prominent triangular process at the hinder, lower angle. The præopereulum has a rounded angle and rather convex limbs, the posterior of which is minutely serrated; the opereulum with three long, pointed, very prominent spines, and deep notches between, the upper one more distant and the middle one rather longer; the sub-and interoperculum are serrated, the former along the anterior half of its length, and produced into an elongate point behind. There are, above and beneath, two pairs of strong canine teeth; otherwise the dentition is very similar to that of $S$. coronatus, except in the posterior front teeth being much shorter. The first interhæmal spine is of moderate development, being equal to the length of the first six vertebra; it is fixed to the hæmal of the eleventh vertebra.

\section{Serranus sonnerati.}

Perca rubia, Sonnerat.

Serranus sonnerati, Chv. \& Val. ii. p. 299.

$$
\text { D. } \frac{9}{14-15} \text {. A. } \frac{3}{9} \text {. }
$$

Caudalis ruunded; præoperculum with a few obsolete denticulations. Uniform brownish (in spirits); head, in life, with reticulated blue lines.

Coasts of Pondicherry, Ceylon, and Sumatra; Louisiade Arehipelago.

«. Adult. Sumatra. From Mr. Frank's Collection.

b, c. Half-grown: stuffed. Jouisiade Arehipelago. From the Voyage of the Rattlesnake.

\section{Serranus urodelus.}

Perea urodela, Forst. Descr. Anim. Cur. Lichtenst. p. 221.

Serranus urodelus, Cur. \& Vul. ii. p. 306, vi. p. 513; Bleek. Kokoscilanden, p. 39.

$$
\text { D. } \frac{9}{15} \text {. A. } \frac{3}{8} \text {. I. lat. } 85 \text {. }
$$

Caudalis rounded. Sub- and interopereulum slightly dentieulated where they are joined; prooperculum entire below, fincly serrated behind; operculum with three conspicuous spines. Maxillary bone reaching far behind the level of the eye; the diameter of the eye one-sixth of the length of the lread; length of the head one-third of the total. Uniform brown (in spirits); hinder half of the dorsal fin, caudalis, and analis with pale (in life red and blue) spots; eaudalis with two oblique wlitish bands, eonrergent posteriorly.

Amboyna ; Caroline and Kokos Islands.

a. Large specimen. India.

b. Adult. Amboyna. From Mr. Frank's Collection. 
50. Serranus analis.

Cuv. \& Val. ii. p. 307, vi. p. 514; Less. Toy. Coq. Zool. ii. p. 235.
D. $\frac{9}{15}$.
A. $\frac{3}{8}$.

Caudalis rounded. Denticulations of the præopereulum very fine. Uniform whitish; vertical fins black-edged. ( $V$ al. - - [Lesson mentions only thirteen soft rays of the dorsal fin.]

New Ireland.

\section{Serranus zanana.}

Serranus zanana, Cur. \& Val. ii. p. 339.

Serranus spilurus, Cur. \&. Ial. ix. p. 433 ; Bleck. Floris, p. 322.

$$
\text { D. } \frac{9}{14-15} \text {. A. } \frac{3}{8-9} \text {. L. lat. } 65 \text {. }
$$

Caudalis rounded. The height of the body is $3 \frac{1}{2}$ in the total length, the length of the head $3 \frac{1}{5}$; the diameter of the eye is onefourth of the length of the head; upper maxillary bone reaching beyond the hinder margin of the eye; prseoperculum minutely serrated, suboperculum entire, interoperculum scarcely denticulated behind; lateral line very convex, nearest to the sixth, seventh and eighth dorsal spines; the posterior six dorsal spines nearly equal in length, the second anal spine longest and strongest. Brownish grey, marbled with darker; four large, oblong, dark spots along the base of the dorsal; on the back of the tail behind the dorsal a round, brack, white-edged spot, behind which is another smaller one. Across the posterior margin of the caudal a black band.

a. Half-grown. Amboyna. From Mr. Frank's Collection as Serranus spilurus.

b. Half-grown: stuffed. Sine patria.

There can be little doubt of the identity of the specimens described by Valenciennes under two names. But the fish deseribed by Bleeker may prove to be a different species; his fish is covered with small blue spots, and anteriorly punctulated with brown; he does not mention, also, the deep-coloured dorsal blotches, which may disappear in dried specimens, but certainly not in those which are preserved in spirits.

8. With fourteen (rarely with fifteen) rays.

\section{Serranus leopardus.}

Labrus leopardus, Lacép. iii. p. 517. pl. 30. f. 1. Serranus leopardus, Cur. \&. I al. ii. p. 333.

$$
\text { D. } \frac{9}{14} \cdot \Lambda \cdot \frac{3}{9} \text {. }
$$

Caudalis rounded; præoperculum very fincly denticulated. Coloration of diied specimens: pale round spots all over the body, more numerous on the head, chest, and belly; a brown temple-streak with a darker spot belind; on the back of the tail, behind the dorsal. one or two black spots; caudalis with two oblique bands; a series of spots hetween the dorsal spines, and two series between the rays. ( $V a l$.

$H a h$. ? 


\section{Serranus coronatus.}

Perea guttata, $B l$. t. 312 .

Sparus cruentatus, Lacép. iv. p. 157. pl. 4. f. 1.

Serranus coronatus, Cur. \& Val. ii. p. 371.

nigriculus, Cur. \&. Val. ii. p. 375; Guichen. in Ramon de la Sagra,

Hist. Cuba. Poiss. p. 14.

- guttatus, Castelnau, Animaux noureaux, Poissons, p. 1.

D. $\frac{9}{14}$. A. $\frac{3}{8}$. L. lat. 60 . Cæc. pylor. 6 . Vert. $9 / 15$.

Caudalis rounded. Denticulations of the præopereulum very tine, sometimes obsolete; diameter of the eye one-sixth of the length of the head ; length of the head not quite one-third of the total. Pectorals nearly reaching to the front end of the anal fin; the upper maxillary bone reaching beyond the level of the posterior margin of the eyc. Brownisb or brown (in spirits); on the head constantly numerous round whitish spots, sometimes occupying the anterior half or two-thirds of the body ( $S$. nigriculus), or obsolete on the trunk, and replaced by distant dark-brown (in life violet) spots; fins with very numerous small brown spots. Back sometimes with a series of three or four small, round, black spots along the base of the dorsal fin.

Caribbean Sea; Gulf of Mexico; Coast of Brazil.

a. Adult. S. America. Presented by Sir R. Schomburgk.

b. Adult. Puerto Cabello. From Mr. Brandt's Collection.

c. Half-grown. W. Indies.

d. Half-grown: skeleton. W. Indies.

e. Adult. W. Indies.

$f$. Adult. W. Indies. From the Haslar Collection.-With only seven dorsal spines.

g. Adult. Cuba. Presented by the Zoological Soriety.

$h, i$. Adult: skins. Jamaica. From Dr. Parnell's Collection.

k. Adult: skin : bad state. Trinidad. Presented by J. B. Richardson, Esq.

l, m. Adult: stuffed. W. Indies. From Mr. Scrivener's Collection.

\section{Var. NIGRICULUS.}

m. Adult. S. America. Presented by Sir R. Schomburgk. n-s. Adult: stuffed. W. Indies. From Mr. Scrivener's Collection.

Skeleton.-The skeletons of the numerous species of Serranus are very similar to one another: the configuration of the bones forming the roof of the skull, the opercular pieces, and the maxillary bone, exhibit siight differences, of no importance in systematical arrangement, and difficult to be elearly described. In this species the upper part of the skull does not bear very prominent ridges; a slight longitudinal crest runs from tho supraoceipital to the hinder end of the suture between the fiontal bones, which are slightly swollen, and rather elevated above the level of the oceipital; the space between the orbits is slightly concave, filled up by two divergent, rounded ridges of the frontal bones. The maxillary bone is widened behind, with straight superior and inferion' margins. 'The preopereulum is 
rounded throughout, with excessively fine denticulations at the posterior limb. Opereulum with three conspicuons spines nearly of equal size, the two lower ones nearer together. Wherever the denticulations of the preopereulum are as minute as in this species. the sub- and interoperenlum have always an clitire margin. There? are in front of the upper jaw two canines of moderate size, corresponding to two pairs of the lower; the other teeth occups, in at broud band, all the length of the intermaxillary, those in the onter scries being rather stronger; the interior front teeth are excessively long, one being nearly equal to the distance between the eyes. The teeth of the mandibula reach to the end of the dental bone. being arrunged posteriorly in a single series, and further in front in two series; the strongest teeth are in the middle of the side of the dental bone and in front. The series of the vomerine teetl form a right angle; those of the palatine are minnte, in a single series, and do not reach to the posterior end of this hone. As the seeond spine of the and fin is very strong, so is its interhremal correspondingly developed; it is fixed to the hamal spines of the ninth and tenth vertebra, and is as long as the first seren vertebrx together.

$\epsilon$. With twelre rays.

\section{5.t. Serrantus spiloparœus.}

Cur. s. Tal. ii. p. sois.

$$
\text { 1). } \frac{9}{12} \cdot \text { A. } \frac{3}{8} \text {. }
$$

Caudalis rounded; dentreulations of the preoperenlum rery finc. Brown, with dirker rounded spots on the head, obsolete on the body: tins without spots and streaks. ( $T$ ral.)

IIUb. - - - ?

b. Dorsalis with ten ar eleren (rarely with twelve) spines.

[As in the preceding group with nine spines in the dorsal fin, I also divide this according to the number of the soft rays in the same fin, and refer to what I have there said. Most of the species have stronger denticulations on the angle of the procopereulum, whereby they are still more distinguished from those of the preceding gronp.]

\section{a. With deren or twelve rays.}

\section{Serranus limbatus.}

Cue. \& I itl. ii. p. 307

$$
\text { I). } \frac{10}{11} \text {. A. } \frac{3}{9} \text {. }
$$

Caudalis truncated. Proopereulum denticulated, and with a stight notch above the angle; interoperculum without any protuberance. Uniform whitish; dorsal fin black-edged. ( F al.)

Island of Guam 


\section{Serranus nouleny.}

Cur. S. Tal. ii. p. 247.
D. $\frac{11}{12}$
A. $\frac{3}{8}$.

Præoperculum with fine denticulations, those of the angle rather stronger; scapula very conspicuously denticulated. Coloration uniform. ( $V(a l$.

Coast of Coromandel.

$\beta$. With thirteen or fourteen rays.

\section{Serranus lutra.}

Cuv. \& V'al. viii. p. 474.

$$
\text { D. } \frac{11}{13} \text {. A. } \frac{3}{8} \text {. }
$$

Caudalis rounded. Operculum with only one spine behind. Yellowish olive, marbled with blackish; a black spot on the back of the tail behind the dorsal fin. ( $[\mathrm{m} l$.)

Isle de France.

\section{Serranus goldmanni.}

Blecker, Naturrk. Tydschr. Nederl. Indie, ix. p. 4r.4.

$$
\text { D. } \frac{11}{13-14} \text {. A. } \frac{3}{8} \text {. 1. lat. } 85 \text {. }
$$

Caudalis rounded; the diameter of the eye is $4 \frac{1}{2}$ in the length of the head; the upper maxillary bone reaching beyond the posterior margin of the eye. Præoperculum serraterl, with rather stronger dentieulations at the angle; sub-and interopereulum cntire; operculum with three points, the middle of which is the longest; the fourth, fifth and sixth dorsal spines longest; the seennd anal spine longer than those of the dorsal fin, nearly half the height of the body. Greenish, head and body punctulated with brownish; head and anterior part of the back marbled with brown above; the back of the tail with a black half-ring; all the fins irregrularly and thickly dotted with brown, and, the peetorals excepted, edged with black. (Bl.)

Sea of Groot-Oby.

\section{Serranus pavoninus.}

C'ur. \&. I"nl. vii. p. 443.

$$
\text { D. } \frac{10}{13} . \Lambda \cdot \frac{3}{8} \text {. }
$$

Caudalis truncated; muzzle pointed; procoperculum?. Rerldish ; beneath the first four dorsal rays a round black spot, encireled by a white ring; caudal fin with a vertical black line at the base. (I iul.)

Bombay.

$$
\begin{aligned}
& \gamma \text {. With fourteen or fifteen rays. } \\
& 60 \text {. Serranus angularis. }
\end{aligned}
$$

Cur. \& I Ial. ii. p. $.5,53$.

$$
\text { D. } \frac{11}{15} \text { A. } \frac{3}{8} \text {. }
$$

Caudalis truncated; angle of the prxoperculum with four or five 
very strong and broad spinous teeth; interoperculum with some denticulations. Whitish, spotted with olive; vertical fins with. brown spots.

Isle de France : Ceylon.

a. Adult: stuffed. Isle de France.

\section{Serranus suillus.}

Russell, pl. 127.

Bola coioides, Buchanan Hamilton, pp. 82, 369.

Serranus suillus, Cuv. \& Val. ii. p. 335 ; Bleeker, Verhand. Bat. Geenootsch. xxii. p. 9.

Serranus coioides, Cant. Catal. p. 11.

$$
\text { D. } \frac{11}{15} \text {. A. } \frac{3}{8} \text {. }
$$

Caudalis rounded; angle of the præoperculum with very strong spinous teeth. Head, body, and fins greyish, with large round orange spots, those of the dorsal fin sometimes confluent into longitudinal bands.

Coast of Coromandel ; Bay of Bengal ; Gangetic estuaries ; Jara Philippines.

a. Young. Philippines.

\section{Serranus fuscoguttatus.}

lercæ summanæ var. b, Forsk. p. 42.

Serranus fuscoguttatus, Rüppell, Atl. Fische, p. 108. t. 27. f. 2 ; Peters, Wiegm. Arch. 1855, p. 235.

$$
\text { D. } \frac{11}{14-15} \text {. A. } \frac{3}{8-9} \text {. }
$$

Caudalis rounded. Denticulations of the præoperculum stronger at the angle. Light brown, marbled with darker, and covered with rounded blackish-brown spots; a large black blotch behind the dorsal fin across the back of the tail. (Rïpp.)

Red Sea; Coast of Mozambique. (Port Essington?)

a. ? Adult: skin : not good state. Port Essington. "Rock-Cod" of the Colonists.

\section{Serranus altivelioides.}

Blecker, Perc. p. 38.
D. $\frac{11}{15}$.
A. $\frac{3}{8}$.
L. lat. 86.

Caudalis rounded. The length of the head is $3 \frac{1}{5}$ in the total; diameter of the eye one-fifth of the length of the head; the upper profile of the head rather convex; sub- and interoperculum entire. Yellowish ; head, body, and all the fins with small round brown spots. ( $B l$.

Sea of Batavia. 


\section{Serranus polyphekadion.}

Blecker, Pere. p. 39, and Jaca, p. 417.
D. $\frac{11}{15}$.
A. $\frac{3}{8}$.
L. lat. $80-85$.

Caudalis rounded. The length of the head is $3 \frac{1}{3}-3, \frac{1}{1}$ in the total, and the diameter of the eye $5 \frac{1}{2}$ in the length of the hear ; "upuer. profile of the head rather convex; maxillary bone reaching behind the level of the eye. Prooperenlum with stronger denticulations on the angle, sub-and interopereulum entire. 'The fifth and sixth spines of the dorsal fin and the third spine of the anal longest. liosecoloured in life, darker on the back: above with numerous deep brown and yellow specks, beneath with brown spots; all the fins punetulated with brown.

Sea of Batavia.

a. Adult: not good state. Sine patria. ()ld Collection.

\section{Serranus salmonoides.}

Holocentrus salmonoides, Lucép. iii. pl. 84. f. 3.

Serranus salmonoides, Che 5. Tul. ii. p. :34:3.

- luti, Cur. \& Val. ii. p. 3(0:3 (not synon.) ; Lefobre, Toy. .lbyss. Zool. p. 2:30; Poiss. pl. 5. f. ?.

? Serranus polypodophilus, Blecker, Peve. p. 37.

$$
\text { D. } \frac{11}{15} \text {. A. } \frac{3}{8} \text {. I. lat. } 90 \text {. }
$$

Caudalis rounded. The length of the head is three times in the total; the diameter of the eye $5 \frac{1}{2}$ in the length of the head; the upper maxillary bone reaching a little behind the posterior margin of the eye; preopereulum with rather coarse denticulations at the angle; sub- and interoperculum entire; upper profile of the hear rather convex. Brownish yellow, marbled with darker ; head and body with blackish and yellowish round spots; all the fins with rounded black and whitish spots.

Sea of Batavia; Isle de France; lied Sea.

a. Adult: stuffed. Isle de France. From Dr. Janvier's Collection. b. Adult : stuffed. Red Sea.

c. Half-grown. India. From the Haslar Collection. d,e. Half-grown and young. India. From the Haslar Collection.

The eross-bands mentioned by Valenciennes are nothing more than darker blotches of more or less regular shape.

\section{Serranus epistictus.}

Temm. \&. Schleg. Fuun. Jupon. p. 8; Bleek. Verhand. Batar. Gremootsch. xxvi. p. 60. pl. 2. f. 1.

$$
\text { I). } \frac{11}{1+-15} \text {. A. } \frac{3}{8-9} \text {. [. lat. 95. }
$$

The height of the body is four times in the total length, the length of the head $4 \frac{1}{2}$; the diameter of the rye is $4 \frac{1}{3}-4 \frac{1}{1}$ in the latter. The 
upper maxillary reaches somewhat beyond the posterior margin of the eye. Præoperculum with coarser denticulations at the angle; sub- and interoperculum slightly denticulated. The third dorsal spine to the seventh nearly equal in length, and $2 \frac{2}{3}$ in the depth of the body. Caudal fin rounded; the second and third anal spines nearly equal in length. Brownish, with four series of distant, small black spots; the vertical fins with similar spots; the spinous dorsal black-edged.

Japanese Sea

\section{Serranus bataviensis.}

Bleeker, Perc. p. 38.

$$
\text { D. } \frac{11}{15} \text {. A. } \frac{3}{8} \text {. L. lat. } 80 \text {. }
$$

Caudalis rounded. Length of the head three times in the total; the diameter of the eye $5 \frac{1}{3}$ in the length of the head; upper profile of the head rather convex; sub- and interoperculum entire. Brownish, sides reticulated with black and greyish; vertical fins with a blackish edge and lighter spots; ventral and pectoral fins immaculate.

Javanese Sea ; Amboyna.

a. Adult. Java.

b. Half-grown. Amboyná. From Mr. Frank's Collection.

\section{Serranus alboguttatus.}

Cur. \& Val. ii. p. 366 (?) ; Bleeker, Amboina, iii. p. 13.

$$
\text { D. } \frac{11}{14-14} \text {. A. } \frac{3}{8} \text {. L. lat. } 75 \text {. }
$$

Caudalis rounded. Length of the head one-third of the total; diameter of the eye $3 \frac{1}{2}$ or 4 in the length of head; denticulations of the angle of the præoperculum strongest ; suboperculum entire, interoperculum with two or three denticulations; the spinous part of the dorsal fin scarcely lower than the soft; the hinder nine spines nearly equal in length; the second spine of the analis longest, $2 \frac{1}{3}$ in the length of the head. Blackish brown, with small, round, light hlue spots; pectoral fins orange-coloured, punctulated with brown; the other fins blackish brown with pearl-coloured specks; vertical fins with a whitish edge.

Amboyna.

a,b. Young. Amboyna. From Mr. Frank's Collection

\section{Serranus polystigma.}

Bleeker, Sumatra, ii. p. 2.

$$
\text { D. } \frac{11}{15} \text {. A. } \frac{3}{8} \text {. L. lat. } 80 \text {. }
$$

Candalis rounded. The length of the head is $3 \frac{1}{2}$ in the total; the diameter of the eye $4 \frac{1}{2} 5$ in the length of the head; denticulations of the angle of the præoperculum strongest, sub- and interoperculum 
entire; the spinous part of the dorsal fin lower than the soft, the middle spines longest; the second spine of the anal fin one-third of the length of the head. Brownish; all parts eovered with blue specks, smaller than the seales; vertieal and pectoral fins with an orange edge. $(B l$.$) .$

Sea of Amboyna.

\section{Serranus maculatus.}

Perca maculata, $B l$. t. 313 (bad).

Sparus atlanticus, Lacép. iv. p. 158. pl. 5. f. 1.

Serranus catus, Cuv. \& Val. ii. p. 373; Guichen. in Ramon de la Sagra, Hist. Cuba, Poiss. p. 13.

Serranus maculatus, Bleek., is another species: cfr. no. 17.

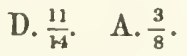

Caudalis rounded; præopereulum very finely serrated, sub- and interoperculum entire. Head not quite one-third of the total length; the third spine to the sixth of dorsal fin, and the second of the anal longest. Dried specimen light brown; head and body with rounded yellowish spots, each with a brown centre; fins immaculate, the vertical ones with a blackish edge.

Cuvier gives seventeen soft rays for the dorsal fin.

Martinique.

a. Adult : stuffed. West Indies.

\section{Serranus galeus.}

Miill. \& Trosch. in Schomburgk's Reisen in Brit. Guiana, p. 621.

$$
\text { D. } \frac{11}{15} \text {. A. } \frac{3}{9} \text {. }
$$

Caudalis rounded. The length of the head is $3 \frac{1}{4}$ in the total ; the diameter of the eye is $6 \frac{1}{3}$ in the length of the head, and much smaller than the distance betwcen the eyes ; maxillary bone reaching far behind the eye; præopereulum with fine serrature, rather stronger on the angle; sub- and interopereulum entire; the spinous part of the dorsal fin low, the third to the eleventh spine nearly equal in length; the third spine of the anal fin longer than the second. Brown, marbled with darker; head, anterior part of body and peetoral fins with seattered blackish-brown spots; spots of the other fins obsolete.

Coast of Brazil.

a. Adult. South America. Presented by Sir R. Schomburgk.

\section{Serranus niveatus.}

Cuv. \& Val. ii. p. 380 ; Castehau, Anim. nouv. ou rares de $I$ Amer. du Sud, Poiss. pl. 1. f. 2.

$$
\text { D. } \frac{11}{14} \text {. A. } \frac{3}{9} \text {. }
$$

Caudalis rounded; præopereulum strongly serrated, with the angle rather produeed backwards. Brownish olivo, with small seattered 
spots of light blue; fins immaeulate; a large quadrangular black spot on the back of tail.

Coast of Brazil.

\section{Serranus margaritifer. (Plate IX. fig. B.)}

$$
\text { D. } \frac{11}{14} \text {. A. } \frac{3}{9} \text {. L. lat. } 85 \text {. }
$$

Caudalis truncated. The height of the body is equal to the length of the head, and $3 \frac{1}{3}$ in the total; the diameter of the eye is one-fifth of the length of the head. Præopereulum finely serrated behind, with some eoarse and obtuse teeth at the angle, and a single one on the lower limb, not direeted forward; sub- and interoperculum minutely serrated. Ventrals reaching to the origin of the anal fin, pectorals shorter. Reddish olive, with four series of pearl-eoloured spots of moderate size. A broad black blotch crossing the baek of the tail.

a. Adult. South America. Presented by Sir R. Schomburgk.

Description.-The body is rather elevated; its greatest height is between the base of the dorsal and peetoral fins, equal to the length of the head, and contained $3 \frac{1}{3}$ in the total. Taking the distanee between the dorsal and caudal fins $=1$, it is contained $4 \frac{1}{2}$ in the length of the base of the dorsal, and $1 \frac{1}{2}$ in the base of the anal, and is nearly equal to one-third of the distance between the dorsal fin and the snout. The distance between the eyes is searcely more than the diameter of the eye, and covered with seales, which extend forward beyond the nostrils, on the præorbital, and in a narrow band on the upper maxillary bone. The length of the snout from the eye is more than the diameter of the eye. The upper maxillary bone does not reach to the level of the posterior margin of the eje. The mandibulary is covered with minute scales, and is longer than one-half of the length of the head. The lips are thiek and fleshy. The posterior limb of the præopereulum is nearly straight, minutely serrated, with very coarse denticulations at the angle; there is a single strong and obtuse spinous tooth on the lower limb, at some distance from the other teeth, half eoncealed in the skin, and pointing downwards. The sub- and interopereulum exhibit a serrature near their meeting angles; the opereulum terminates in three eonspicuous, flat, triangular teeth, the upper of whieh is the most distant, the middle the longest, but not very prominent, and the lower the shortest and the most feeble. The suprascapular bone is concealed by the ordinary scales.

The base of the dorsalis is nearly free, but a tapering row of seales runs up between each pair of spines and rays to half the height of the fin. The spinous portion is rather lower, but longer than the soft, and has a convex upper margin; the membrane between the spines is deeply notehed, and there is behind the top of each spine a small membranaceous appendage. The first spine is the shortest, half the size of the second; the second two-thirds the length of the 
third; the fourth, fifth and sixth are longest; and then the spines beeome gradually shorter, except the last, which is again scarcely longer than the preceding. The soft portion exhibits an entirely rounded upper margin, the rays becoming longer from the first to the sixth, and shorter from the seventh to the last; the first ray is one-fourth longer than the preceding spine. The caudalis is truncated; but when spread ont, it exhibits a rather convex posterior margin with angular lobes. The analis commenees a little behind the commeneement of the soft dorsal portion, and terminates a little before the end of the dorsal; the first spine is not very strong and short, the second thiek and strong, the third more slender, but rather longer, and equal to the second dorsal spine. The margin of the fin is rounded throughout, the second ray being the longest, and the posterior ones beeoming gradually shorter. The pectoratis is composed of eighteen rays, rounded, shorter than the ventral, and covered with minute scales to one-third of the length only. The ventralis reaches to the origin of the anal, the first and second spines being rather long and pointed; the other rays diminish gradually in length; the length of the spine is equal to that of the third dorsal spine. The canine teeth are of moderate length; those of the lower jaw rather small.

The ground-colour is reddish olive, lighter on the belly; on each side of the body are four series of pearl-coloured spots, each occupying the place of fire or six seales. 'The uppermost series reaches from the oeciput along the base of the dorsal fin to the black blotch of the tail, and is composed of eight spots ; the second, following the lateral line, of six; the third, from the angle of operculum, of four; and the fourth, from the base of the pectorals, of five. There is a blackish streak behind the maxillary bone. The black bloteh on the tail occupies nearly the whole space between the dorsal and caudal fins and between the two lateral lines. The fins are nearly unicoloured; a single pearl-coloured spot is to be seen on the seventh spine and on the ventral fins; the anal has a whitish edge; rentrals blackish, with whitish lateral margin; pectorals uniform yellowish.

Length of the specimen $11 \frac{1}{2}$ inches.

This speeies very much resembles the S. tsirimenara, Faun. Japon. p. 7. pl. $4 a$. f. 3, which is said to be common in Japan, and to have sixteen soft rays in the dorsal fin. Still more remarkable is it that the same plate in that work represents another fish, S. octocinctus, so similar to a West Indian fish, S. mystacinus, that they cannot be separated. I have sufficient proof that the native country of the speeimens in the British Museum is eorrectly stated.

\section{$\delta$. With fifteen or sixteen rays.}

\section{Serranus gigas}

Perea gigas, Brünnich, Pisc. Muss. p. 65. no. 81.

Holocentrus gigas, Bl.Schm. p.322; Ipe la Roche, Ann. Mus. xiii. p.318. — mérou, Lacép. iv. p. 3ít; Risso, Ichthyol. de Nice, p. 289.

Serranus gigas, C'ux. \& Vul. ii. p. 270 ; Expéd. Sc. Morée, Zool. pl. 16. f. 1; Guichen. Erplor. Sic. Algir. P'oiss. p. 35. 
Serranus marginatus, Lonve, Proc. Zool. Soc. 1833, p. 142.

- fimbriatus, Lowe, Trans. Cambr. Plilos. Soc. 1836, p. 195. pl. 1 ;

Valenc. in Barker-Webb \& Berthelot, Ichthyol. p. 8. caninus, Valenc. l. c. p. 10.

$$
\text { D. } \frac{11}{15-16^{\circ}} \text { A. } \frac{3}{8} \text {. }
$$

Caudalis rounded; denticulations of the præoperculum gradually becoming larger towards the angle; sub- and interoperculum entire. The height of the body is $3 \frac{1}{3}$ in the total length, the length of the head $3 \frac{1}{2}$. Nearly uniform brownish, lighter towards the belly.

Mediterranean; Atlantic Coast of the Peninsula. (Cape of Good Hope?)

a. Very large specimen. Sine patria.

b. Very large specimen: stuffed. Sine patria.

c. Adult: stuffed. Madeira. Presented by the Zoological Society. Type of S. fimbriatus, Lowe.

d. Very large spetimen : stuffed. Cape of Good Hope. Presented by Sir A. Smith.

c. Young: bad state. Madeira. Presented by the Rev. R. T. Lowe.

\section{Serranus moara.}

Temm. \& Schleg. Faun. Jupon. pl. 4, lower figure.

$$
\text { D. } \frac{11}{15} \text {. A. } \frac{3}{8} \text {. }
$$

Caudalis rounded; præoperculum with coarser denticulations at the angle ; the height of the body not quite one-fourth of the total length. Brownish grey, marbled with darker. (Schley.)

Japariese Seas.

\section{Serranus goreensis.}

Cuv. \& Val. vi. p. 511; Jenyns, Zool. of the Beagle, Fishes, p. 5.

$$
\text { D. } \frac{11}{15-16} \text {. A. } \frac{3}{8} \text {. }
$$

Allied to S. gigas. Caudalis truncated or slightly emarginate. Denticulations of the præopereulum stronger at the angle. The fourth dorsal spine longest, equalling just half the entire length of the spinous portion of the fin. Uniform brown; dorsal and anal fins with a violet edge; rentral fins blackish.

Coast of Gorce; St. Jago; Cape Verde Islands.

\section{Serranus erythrogaster.}

Dekay, New York Fauna, Fishes, p. 21. pl. 19. f. 52 ; Holbr. Ichth. S. Carol. p. 29. pl. 5. f. 2 (dorsal bad).

$$
\text { D. } \frac{11}{16} \text {. A. } \frac{3}{9} \text {. Cre. pylor. } 28 .
$$

Closely allied to $S$.goreensis. Caudalis emarginate. The height of the body is $3 \frac{1}{2}$ in the total length, the length of the head is one-third of the latter. Denticulations of the præoperculum stronger at the angle. The third dorsal spine longest, shorter than the half of the entire length of the spinous portion of the fin. Pectorals rounded, 
distant from the anal. Olive-brown above, with more or less distinet ashy spots; beneath red; the vertical fins with blue borders.

Eastern shores of the United States; Gulf of Mexico; Sea of Jamaica.

a. Adult: skin. Jamaica. From Dr. Parnell's Collection.

\section{Serranus fuscus.}

Lowe, in Trans. Cambr. Philos. Soc. 1838, p. 196 ; Valenc. in BarkerWebb and Berthclot, Ichthyol. p. 9.

$$
\text { D. } \frac{11}{15-16} \text {. A. } \frac{3}{11} \text {. Vert. } 24 .
$$

Candalis truncated; præopereulum with obsolete denticulations. Blackish brown, obscurely marbled with greyish.

Madeira; Canary Islands.

Valenciennes mentions seventeen rays of the dorsal fin.

\section{Serranus æneus.}

Dalouse, Geoffr. St. Hil. Descr. d'Eg. 1'oiss. pl. 21. f. 2.

Serranus æneus, Is. Geoffr. Poiss. d'Eg. p. 208 ; Cuv. \& Val. ii. p. 283.

$$
\text { D. } \frac{11}{16} \text {. A. } \frac{3}{9} \text {. }
$$

Caudalis rounded. Dentieulations of the angle of the proopereulum rather stronger. Brownish green, marbled with lighter; anal and ventral fins with a blno edge; on the side of the head three oblique white bands: the first from the angle of the præoperculum to the middle of the subopereulum, the second from the eye to the posterior angle of the interopereulum, the third from the maxillary across the middle of the interoperculum.

Damietta.

\section{Serranus emarginatus.}

Valenciennes, in Barker-Webb \& Berthelot, Hist. Nat. Iles Canar. Ichthyol. p. 10.

$$
\text { D. } \frac{11}{15} \text {. A. } \frac{3}{11} \text {. L. lat. } 75 \text {. }
$$

The length of the head rather more than one-fourth of the total; the diameter of the eje is one-fifth of the former. Præoperculum distinctly serrated, with a noteh above the angle; intermaxillary bones with teeth in the middle of the upper jaw only. Caudalis truncated, the third dorsal spine longest. Brownish, marblcd with lighter and darker. ( $\mathrm{Val}$.)

Canary Islands.

\section{Serranus nigritus.}

Holbr. Ichthyol. S. Carol. p. 173. pl. 25. f. 2 (the eyo appears to be represented much too small).

$$
\text { 1). } \frac{11}{15}, \quad \Lambda \cdot \frac{3}{10} \text {. }
$$

The height of the borly is $3 \frac{1}{2}$ in the total length, the length of the head not quite three times. The angle of the pricoperculum rather 
prominent, and with stronger denticulations. Caudal rounded. Uniform blackish ; fins without any spots. (Hollbr.)

Coast of South Carolina.

\section{Serranus acutirostris.}

Cuv. \& Val. ii. p. 286, ix. p. 432 ; Valenc. in Barker-Webl \& Berthelot, Iles Canar. Ichthyol. p. 11. pl. 3. f. 1; Guichen. Explor. Sc. Algér. Poiss. p. 35.

$$
\text { D. } \frac{12}{16} \text {. A. } \frac{3}{11} \text {. }
$$

The height of the body is $4 \frac{1}{2}$ in the total length, the length of the head $3 \frac{1}{2}$. Præoperenlum finely serrated behind; angle projecting. with coarser denticulations. Caudalis slightly emarginate; the third aual spine longer than the second. Uniform greenish.

Coast of Brazil ; Canary Islands ; Sea of Messina.

\section{Serranus marginalis.}

Epinephelus marginalis, Bloch, t. 328. t.' 1.

Holocentrus rosmarus, Lacép. iv. pp. 389, 392. t. 7. f. 2.

Serranus marginalis, Cux. \& Val. ii. p. 301; Richards. Ichth. China, p. 233 ; Bleeker, Perc. p. 34.
D. $\frac{11}{15-16}$.
A. $\frac{3}{8}$.
L. lat. 80-90.
Vert. $9 / 15$.

Caudalis truncated. Length of the head $2 \frac{3}{4}$ in the total; diameter of the eye $4 \frac{2}{3}$ in the length of the head. Præoperculum with rather stronger denticulations on the angle, sub- and interoperculum entire. The upper maxillary bone reaching just to the level of the posterior margin of the eje. Pectorals distant from the front end of the anal, and reaching a little behind the tip of the ventrais. Brownish or yellowish; the spinous part of thu dorsal fin, and sometimes the caudal fin, black-etged.

Javanese, Chinese, and Japanese Seas ; Amboynd Timor ; Louisiade Archipelago.

a. Adult. Amboyna. From Mr. Frank's Collection.

b. Adult: skeleton. China.

c. Adult. China.

d. Adult: stuffed. China. Presented by J.1 R. Reeres, Fsq.

e. Adult. China. Presented by J. R. Reeres, Esq.

f. Adult. China. Presented by J. R. Reeves, Esq.

g. Adult. China. Presented by J. R. Reeves, Esq.

h. Half-grown. China. Prescnted by J. R. Reeves, Esq.

i. Adult: stuffed. Japan.

$k$. Adult. India.

7. Adult: bad state. India. From the Haslar Collection.

$m$. Young. India. From the Haslar Collection.

$n-q$. Adult: stuffed. Louisiade Archipelago. Voyage of the Rattlesnake.

r. Adult: skin. Sand-bank near Darnley Island

s. Adult: skin. Copang (Timor). 
Skeleton.-That part of the upper surface of the head which is formed by the supraoceipital and the posterior part of the frontal bones is slightly elevated and rounded on both sides, there being a rather deep groove between those ridges which run from the orbit to the articulations of the supraseapula; the interior of these ridges is elevated behind, becoming ineonspicuous near the orbit. The upper anterior branch of the supraoceipital erest is low, and does not exceed the supraoceipital bone; there is on each side a similar additional crest, arising from the body of the paroccipital one. The space between the orbits is narrow, with a slight median groore. The maxillary bone exhibits a nearly straight superior edge, the inferior being irregularly concave and angular. The opereulum with three distinct, nearly equidistant points, the upper of which is smallest, the middle longest and very proninent; the posterior edge of the præoperculum finely serrated, with rather stronger denticulations at the angle; the lower edge entire, with a longitudinal groove; the subopereulum entire, produced behind into a long soft point; the interoperculum with one or two inconspicuous denticulations. The dentition is very similar to that of S. toniops; there is a pair of strong, but short canines in each jaw. I eannot decide whether another pair, not perfectly developed, between the upper canines, are merely the successors of the latter, or whether they will form a second separate pair of eanines. A similar pair, also not perfectly developed, are to be seen in the lower jaw, but at the outside of the canines which are in function. The fir.st interhamal spine is long and strong, equal to the length of the second to the eighth (inclusive) vertebra, and attached to the hemal spine of the tenth vertebra; it corresponds to the first and second dermohnmal, there being no separate. interhæmal for the first; but this strong interhæmal generally exhibits a prominent longitudinal ridge along its anterior surface, and I consider this ridge to be the interhxmal properly belonging to the first dermohiemal, being a separate bone in an earlier period of life, but afterwards united with that of the second.

\section{Serranus horridus.}

Serranus horridus, (Kuhl\& $r$. Iitiss.) Cuv. \&.Val. ii. p. 321 ; Bleeker, Perc. p. 36 ; Cantor, Catal. p. 9.

$$
\text { D. } \frac{11}{15-16} \text {. A. } \frac{3}{8} \text {. }
$$

Caudalis rounded; head nearly one-third of the total length; eye nearly one-seventh of the length of the head. Sub- and interoperculum entire; præopereulum with rounded angle and a fine, but distinct serrature; the third dorsal spine to the eleventh nearly equal in height, and much shorter than the soft dorsal fin. The upper maxillary reaches beyond the posterior margin of the eye. Upper profile of the head rather concave. Brown, largely marbled with blackish brown; head, body, and fins with roundish brownish-black spots.

Jaranese Sea ; Sea of Pinang.

One stuffed specimen in the Collection of the East India House. 


\section{Serranus crapao.}

Cuv. \& Val. iii. p. 494; Bleeker, Perc. p. 37 ; Richards. Ann. \& Mag. Nat. Hist. 1842, ix. p. 25.

$$
\text { D. } \frac{11}{15} \text {. A. } \frac{3}{9(8 \text { Bleek. })^{\circ}} \quad \text { L. lat. } 80 \text {. }
$$

Caudalis rounded; head one-third of the total length; diameter of the eye one-seventh of the length of the head ; angle of the præoperculum with stronger denticulations; sub- and interoperculum entire. Brownish; all the parts with rounded brown spots.

Sunda Sea; Port Essington.

a. Adult: skin. Port Essington.

b. Adult: skin. Port Essington. Purchased of J. Gould, Esq.

\section{Serranus sebæ.}

Bleeker, Amboina, v. p. 488.
D. $\frac{11}{16}$.
A. $\frac{3}{8}$.
L. lat. 85-90.

Candalis rounded; length of the head $3 \frac{1}{2}$ in the total; diameter of the eye one-fifth of the length of the head; upper profile of the head convex; angle of the præoperculum with stronger spinous teeth; suboperculum entire ; interoperculum with one or two denticulations. The third spine of the dorsal and anal fins longest. Brownish; body and all the fins with round darker spots; the soft part of the dorsal fin and the caudalis with a narrow yellow edge.

Chinese Sea; Amboyna.

a. Adult. China. Presented by Sir J. Richardson.

b. Half-grown. Amboyna. From Mr. Frank's Collection.

\section{Serranus summana.}

Perca summana, Forskal, p. 42.

Bodianus summana, Bl. Schn. p. 334 .

Pomacentrus summana, Lacép. iii. p. 511.

Serranus summana, Cuv. \& Val.ii.p. $344 ;$ Rüpp. N. W. Fische, p. 102 , and Atl. p. 104; Lefebvre, Voy. Abyss. Zool. p. 229. pl. 5. f. 1. leucostigma, Cuv. \& Val. ii. p. 346.

$$
\text { D. } \frac{11}{16} \text {. A. } \frac{3}{8} \text {. }
$$

Caudalis rounded; denticulations of the præoperculum fine and equal; interoperculum with some fine denticulations. Brown, marbled with greyish and spotted with white; a blackish streak passing below the eye ; a black spot on the tail.

Red Sea.

a. Large specimen : stuffed: not good state. Red Sea. Purchased of the Frankfort Museum.

\section{Serranus micronotatus.}

Rüppell, N. W. Fische, p. 90.

$$
\text { D. } \frac{11}{15} \text {. A. } \frac{3}{9} \text {. }
$$

Caudalis rounded ; properculum fincly serrated; opereulum with 
a single spine; seeond dorsal spine longest. Greyish ; head, body, and dorsal fin punctulated with brown; a lighter streak from below tho eye to the base of the pectoral fins. (Riipp.)

Massana (led Sea).

\section{Serranus tumilabris.}

Cuv. \& I'al. ii. p. 346.

$$
\text { D. } \frac{11}{15} \text {. A. } \frac{3}{9} \text {. }
$$

Caudalis rounded; præopereulum with equal and fine dentieulations ; sub- and interopereulum entire ; lips thick, swollen. Brown, marbled with darker; all the parts with rounded greyish-white specks; a black streak behind the maxillary bone.

Seychelles.

a. Adult. Sine patria. From Mr. Brandt's Collection as Epinephelus punctatus.

\section{Serranus hoevenii.}

Bleeker, Perc. p. 36.

$$
\text { D. } \frac{11}{16} \text {. A. } \frac{y}{8} \text {. L. lat. } 80 \text {. }
$$

Caudalis rounded. The length of the head is $2 \frac{3}{4}$ in the total; diameter of the eye one-sixth of the length of the head, much larger than the distance between the eyes, but equal to the distance of the eye from the end of the snout; maxillary bone just reaching the vertical from the posterior margin of the orbit; præoperculum with rather larger denticulations at the angle; sub-and interoperculum entire. Brownish, with round pearl-coloured spots on the sides of the body ; fins immaculate, with a black and yellow edge.

Batavia.

a. Adult. Ampoyna. From Mr. Frank's Collection.

\section{Serranus bontoo.}

Russell, pl. 128.

Serranus bontoo, Cun. Regne Anim. ; Cuv.\& Val. ii. p. 334, vi. p. 523 ; Cantor, Catal. p. 11.

$$
\text { D. } \frac{11}{16} \text {. A. } \frac{3}{8} \text {. }
$$

Caudalis rounued; proopereulum with strong denticulations, strongest at the angle, and with a very oblique lower limb. Brown, with large, scattered ferruginous spots; dorsal and anal fins whitish, with a black and white edge; caudalis greyish at the end, with a bluish spot between each two rays; pectoral fins blackish, with a broad whitish band at the base.

Madras; Vizagapatan; Java.

a. Adult: stufferl. Ceylon. 


\section{Serranus celebicus}

Bleeker, Celebes, i. p. 217.
D. $\frac{11}{15-16}$.
A. $\frac{3}{8}$.
L. lat. 90 .

Candalis truncated. The height of the body is $3 \frac{2}{3}$ in the total leugth, the length of the head $3 \frac{1}{2}$; the diameter of the eye is $4 \frac{1}{2}$ in the length of the head; upper maxillary bone reaching to beneath the centre of the eye; præoperculum strongly serrated, with three or four still stronger denticulations at the angle; sub- and interoperculum denticulated; the fourth dorsal spine longest. Reddish brown, with large; roundish darker spots; all the fins brown-spotted; dorsal and caudal fins yellow-edged.

Celebes.

a. Half-grown. Amboyna. From Mr. Frank's Collection.

\section{Ser ranus variolosus.}

Renard, Poiss. t. 28. f. 153, and t. 3. f. 17 ; Valentyn, Ind. iii. f. 41. Perca variolosa, Forst. MSS.

Serranus variolosus, Cuv. \& Val. ii. p. 354; Bleeker, Perc. p. 35.
D. $\frac{11}{16}$.
A. $\frac{3}{8}$.
L. lat. 110.

Caudalis truncated; head one-third of the total length; diameter of the eye one-fourth of the length of the head; upper maxillary bone reaching to below the posterior half of the eye; præoperculum with rather stronger denticulations at the angle; sub-and interoperculum entire. Brownish, with roundish brown spots on the head, body, and soft part of dorsal fin; the other fins immaculate.

Sunda Sea; Pacific.

a. Adult. Pacific.

b. Adult. Pacific.

c. d. Half-grown. Pacific. From the Haslar Collection.

\section{Serranus hoedtii.}

Bleeker, Amboina, vi. p. 406.
D. $\frac{11}{14-16}$.
A. $\frac{4 ?}{8}$.
L. lat. 120 .

Caudalis truncated, with slightly rounded angles. The diameter of the eye is $4 \frac{3}{5}-4 \frac{4}{5}$ in the length of the head; the upper maxillary bone reaching to the level of the posterior margin of the eye; præoperculum serrated, with four to six rather stronger denticulations at the angle; suboperculum entire; interoperculum scarcely denticulated. The third or the third and fourth dorsal spiries longest; the second and third anal spines nearly equal in length. Bluish; head, body, and all the fins dotted with black ; the soft parts of the dorsal and anal fins yellow-edged: caudal and pectoral fins orange-coloured, with a violet base. (Bl.)

Sea of Amboyna. 


\section{Serranus akaara.}

Faun. Japon. p. 9. pl. 3. f. 1; Richardson, Ichthyol. China, p. 231.

$$
\text { D. } \frac{11}{15-16} \text {. A. } \frac{3}{8} \text {. }
$$

Caudalis rounded. Præoperculum serrated, denticulations at the angle sometimes very strong, sometimes equal to the otlers. The third, fourth and fifth dorsal spines longest, the posterior ones not much shorter; the second and third anal spines nearly equal in length (according to the Fauna Japonica, the second longest); pectorals not reaching the anus. Maxillary bone not reaching behind the level of the eye. Brownish red; head, body, and vertical fins covered witl round bright red spots.

Japanese Seas.

a. Adult: stuffed. Japan.

b. Adult: stuffed. India.

\section{Serranus apua.}

Margr. p. 158; Lib. Princ. i. p. 315.

Bodianus apua, Bloch, t. 229 ; Lacép. iv. p. 296.

? Serranus apua, Cur. \&-Val. ii. p. 287; Guichen. in Rumon de la Sagra, Hist. Cub. p. 11.

$$
\text { D. } \frac{11}{16^{\circ}} \text { A. } \frac{3}{8} \text {. L. lat. } 105 \text {. }
$$

Caudalis truncated, with rounded angles; angle of the præuperculum with stronger denticulations. Brownish, with brown spots on the sides of the head and body; about twenty-five between the opercle and the root of the caudal. The spinous dorsal higher than the soft; the rertical fins with a broad black edge.

Caribbean Sea.

a. Adult: stuffed. West Indies. From Mr. Scrivener's Collection. b, c. Half-grown: stuffed. West Indies. From Mr. Serivener's Collection.

d-f. Adult: skins. Jamaica. From Dr. Parnell's Collection.

\section{Serranus mentzelii.}

Cuv. \& Val. ii. p. 291.

$$
\text { D. } \frac{11}{16} \text {. A. } \frac{3}{8} \text {. }
$$

Caudalis truncated; muzzle short, blunt. Brownish, marbled with reddish brown, and with streaks of the same colour on the belly, anastomosing on the tail. Fins uniform; dorsalis and analis blackedged. ( $V a l$.

Coast of Brazil.

є. With fifteen to serenteen rays.

\section{Serranus hexagonatus.}

D. $\frac{11}{15-17}$. A. $\frac{3}{8}$. L. lat. 80 .

Caudalis rounded. The length of the head is $3 \frac{1}{3}-3 \frac{1}{2}$ in the total: 
diameter of the eye nearly one-fifth of the length of the head, and larger than the distance between the eyes. The upper maxillary bone reaches beyond the level of the posterior margin of eye. The angle of the præoperculum with stronger spinous teeth; sub- and interoperculum entire; the pectoral reaches as far as the ventralthat is, not to the vent. Brownish, covered all over with large rounded or hexagonal spots.

From the Red Sea along the African coast through all the Indian Sras intc the North of Australia and into the Pacific.

Var. A. hexagonata. The spots hexagonal, separated from one another by white lines on the head, on the anterior part of the body, and on the pectoral and caudal fins, but more irregular on the other parts ; sometimes closer together at the base of the dorsal, and there forming three darker blotches.

Perca hexagonata, Forster, Deser. Anim. ed. Licht. p. 189.

Holocentrus hexagonatus, Bl. Schn. p. 323.

Serranus hexagonatus, Cuv. \&. Val. ii. p. 330, vi. p. 516; Guérin, Icon. Poiss. pl. 4. f. 1 ; Richardson, Voy. Sulph. p. 82. pl.38.f. 1 ; Cantor, Catal. p. 7 ; Bleek. Natuurk. Tydschr. Nederl. Indie, vi.p. 191; Gay, Chile, Zool. ii. p. 150.

_ foveatus, Cuv. \& V Val. ii. p. 329.

- stellans, Richardson. Ann. Nat. Hist. 1842, vol. ix. p. 23.

a. Half-grown. Madagascar. Presented by Dr. J. E. Gray.

b. Adult. China. Presented by Sir J. Richardson.

c. Adult. Philippines.

$d, e$. Adult and half-grown. Amboyna. Purchased of Mr. Frank. $f$. Half-grown. Amboyna. Purchased of Mr. Frank.

$g, h$. Young. Amboyna. Purchased of Mr. Frank.

$i$. Half-grown: stuffed. Louisiade Archipelago. Voyage of the Rattlesnake.

$k$. Half-grown : bad skin. Sand-bank near Darnley Island.

l. Adult. India. From Dr. Russell's Collection as Pomacentrus punctatus.

m. Adult. India. Purchased of Mr. Frank.

$n-p$. Half-grown. Feejee Islands. Presented by the Lords of the Admiralty.

Var. B. MFRRA. The spots roundish, without white lines between, sometimes confluent in the middle of the sides, much smaller on the fins.

Seba, iii. 27. 7 ; Klein, Hist. Pisc. v. p. 43. t. 8. f. 3.

Perca taurina, Forsk. p. 39.

Epinephelus merra, Bl. t. 329 ; Bl. Schn. p. 300.

Holocentrus tauvinus, Bl. Schn. p. 321; Lacép. iv. p. 338.

- merra, Lacép. iv. p. 342.

Serranus merra, Cuv. \& Val, ii. p. 325.

q. Half-grown. Singapore.

$r, s$. Half-grown. China. Presented by Sir J. Richardson.

t. Half-grown. Philippines. 
$u, v$. Adult. India. From tho Haslar Collection.

w. Adult. India. Purchased of Mr. Brandt.

$x, y$. Half-grown. India. From the Haslar Collection.

z. Half-grown. Purchased of M. Parzudaki.

\section{$\zeta$. With sixteen or seventeen rays.}

99. Serranus morio.

Cuv. \& Val. ii. p. 285 ; Guichen. in Rumon de la Sagra, IIist. Cuba, Poiss. p. 11.

$$
\text { D. } \frac{11}{17} \text {. A. } \frac{3}{9} \text {. }
$$

Allied to S. gigas, but with stronger denticulations of the præoperculum; caudalis slightly emarginate. In life grey, marbled with brownish ; snout, lower jaw, and branchiostegal membrane red ; anal fin and pectorals orange-coloured, the former with a brown edge; ventral fins with large red spots.

Atlantic coasts of Temperate America; St. Domingo; Cuba.

\section{Serranus impetiginosus.}

Müll. \& Trosch. in Schomburgk's Hist. Barb. p. 665.

$$
\text { D. } \frac{11}{17} \cdot A \cdot \frac{3}{8} \text {. }
$$

Caudalis rounded. Præoperculum rounded throughout, with the posterior limb obliquely descending backwards, and with some obsolete and coarser denticulations at the angle; the distance between the eyes very narrow. Brownish, covered all over with round darkcoloured spots, each spot occupying about four seales; they aro less numerous on the fins than on the snout; a larger oblong black spot at the base of the last three spines and of the first ray of the dorsal fin; another spot, of similar sizc and colour, behind the dorsal fin on the back of the tail.

Caribbean Sea.

a. Adult: skin : not good state. Trinidad. Presented by J. B. Richardson, Esq.

\section{Serranus ongus.}

Holocentrus ongus, Bloch, pl. 234; Bl. Schn. p. 314 ; Lacép. iv. p. 380. Serranus dichropterus, Cur. \& Val. ii. p. 293.

$$
\text { D. } \frac{11}{16} \text {. A. } \frac{3}{8} \text {. }
$$

Caudalis rounded; prooperculum with stronger dentienlations on the angle. Uniform dark brown, the fins with a darker edge; a black streak behind the maxillary bone.

Coasts of Central and South America.

$a, b$. Adult: not good state. Bahia. From M. Parzudaki's Collection. 
c. Half-grown. Bahia. From M. Parzudaki's Colleetion.

d. Adult: very bad state. America. From the Haslar Collection.

I am not enabled, from the short deseription given by Profeşิ Peters (in Wiegm. Arch. 1855, p. 236), of Serranus melas from Mozambique, to distinguish it from the above species.

\section{Serranus undulosus.}

Serranus undulosus, Cur. \& $V$ thl. ii. p. 295.

? Bodianus undulosus, Quoy \&. Gaim. Voy. Freyc. Poiss. p. 310 (said to be caught in the Sea of Waigiou).

$$
\text { D. } \frac{11}{16-17} \text {. A. } \frac{3}{11-12} \text {. Vert. 10/14. }
$$

Caudalis truncated. Præoperculum very finely serrated, with rather stronger denticulations at the angle; sub- and interopereulum entire; pectorals far distant from the anal, and reaching a little beyond the tip of the ventrals; the upper maxillary bone reaching to or a little behind the eye. Brownish grey, with some rather oblique darker bands along the sides of the head, and with irregular, large, oblong blackish spots on the body; fins with narrow blackish edges; pectorals yellow.

This species exhibits the upper jaw covered with minute scales as well as the lower.

Caribbean Sea ; Coast of Brazil.

a. Large specimen. Cuba. Presented by the Zoological Society.

b. Adult: skeleton. Cuba. Presented by the Zoological Society. $c$, d. Half-grown. Cuba. Presented by the Zoological Society. $e-g$. Adult: skins. Jamaica. From Dr. Parnell's Colleetion.

h. Half-grown: skin in spirits. Trinidad. Presented by J. B. Richardson, Esq.

$i, k$. Adult: stuffed. West Indies. From Mr. Serivener's Collection. $l, m$. Half-grown. Puerto Cabello. From Mr. Brandt's Collection. n. Half-growi. Brazil. Presented by Lord Stuart.

o. Adult. America. From the Haslar Collection.

Skeleton.-The upper surface of the skull is concave throughout; there is no ridge nor any other prominence between the elevated orbital edges of the frontals; from these edges a sharp erest on eaeh side runs backwards to the articulation of the suprascapula; the occipital crest emits a median branch in front, which does not extend to the frontal. The maxillary bone is styliform in more than its anterior half, suddenly widening behind, the superior and inferior margins being rather irregularly eurved. The præoperenlum is rounded throughout, finely serrated behind, and exhibits four or six eoarser denticulations at the angle; operculum with three conspicuous spines, the upper of which is the most distant, and not projecting beyond the margin; the middle one is acute, longest and strongest; the lower rounded, short, but prominent. There are two strong eanines in the upper jaw, causing an impression in the lower jaw, and receiving two smaller canines of the mandibula between; 
the posterior front teeth of the upper jaw are rather small-much smaller than in $S$. coronatus: in the remainder of the dentition both species agree with each other. The spines of the anal fin being small, the interhæmal is also much less developed; it is fixed to the eleventh hæmal, and is only as long as the first six vertebrse together.

\section{Serranus tsirimenara.}

Temm. \& Schleg. Faum. Japon. Poiss. p. 7. pl. 4 A. f. 3; Bleek. Verh. Batav. Genootsch. xxvi. p. 62.
D. $\frac{11}{16-17}$.
A. $\frac{3}{7-9}$.
L. lat. 90-100.

The height of the body is four times in the total length; the length of the head $3 \frac{1}{4}-3 \frac{1}{3}$; the diameter of the eye is $4 \frac{2}{5}-4 \frac{3}{4}$ int the latter. The upper maxillary bone reaches rather beyond the posterior margin of the orbit. Præoperculum with rather stronger denticulations at the angle; interoperculum scarcely, suboperculum not serrated. The fifth dorsal spine longest, shorter than one-half of the depth of the body. Caudal fin rounded. Red, with seven or nine rosecoloured blotches, one series of which is above the lateral line, and the other beneath; the dorsal fin with a black upper edge (dorsali spinosa superne parte membranæ emarginata macula trigona nigra. $B l$.).

Japancse Sea.

\section{Serranus punctatissimus. (Plate X. fig. A.)}
D. $\frac{11}{17}$.
A. $\frac{3}{8}$.
L. lat. 100 .

Caudalis truncated. The height of the body is $3 \frac{1}{3}$ in the total length, the length of the head $3 \frac{1}{2}$; the diameter of the eye is $4 \frac{1}{2}$ in the latter. The upper maxillary bone reaches to the level of the posterior margin of the eye. Præoperculum serrated behind, with about three spinous teeth at the angle; sub- and interoperculum entire. The fourth dorsal spine and the third of the anal fin longest; the ventrals rather longer than the pectorals, not reaching to the vent. Brownish olive (in spirits); head, body, and the soft parts of the dorsal and anal fins punctulated with brown. The soft portions of the vertical fins and the ventrals with a broad black margin.

\section{a. China. Presented by Mr. Recves.}

Description.-In habit similar to S. marginalis. The height of the body is $3 \frac{1}{3}$ in the total length, the length of the head $3 \frac{1}{2}$. The scales extend on the upper surface beyond the nostrils, but the præorbital and the upper maxillary are naked. The space between the eyes is rather flat, and less than the diameter of the eye; the extent of the snout is equal to the latter, and $4 \frac{1}{2}$ in the length of the head. The nostrils are lateral ; the posterior opening larger, oval. The cleft of the mouth is wide, the upper maxillary reaching to the level of the posterior margin of the cye. The posterior limb of the procoperculum descends obliquely backwards, is finely serrated, and has a slight emargination above the angle, and about three stronger spinous tecth at the angle. Sub- and interoperculum entire. The spines 
of the operculum are rather indistinct, especially the upper and lower; the former is more distant from the middle one.

The spinous portion of the dorsalis is longer and not much lower than the soft. All the spines are of moderate length. and strength : the first is not quite half as long as the second, the fourth longest; the posterior ones gradually become shorter, the last being about five-sixths of the fourth. The membrane between the spines is moderately notehed, without emitting appendages. The soft portion has a slightly rounded upper margin, the tenth ray being about onètenth longer than the longest spine. All the fin is nearly free, like the others, and not protected by an eneroachment of the integument. Caudalis truncated. The soft part of the analis is rather higher than the dorsal, and rounded ; the second spine is nnt mueh stronger, and rather shorter, than the third. The pectoralis is rounded, and composed of eighteen rays; it is a little shorter than the ventral. The ventralis is supported by a spine of more than half the length of the fir, and does not reach the vent; its root falls vertically beneath that of the peetoral.

The canine teeth are small, and there is a small, conspicnous canine tooth on each side of the vomer. The scales are very small.

The ground-colour is now brownish olive, lighter on the belly; the head and body are covered with brown speeks, of the size of a seale, and extending on the base of the soft portions of the dorsal and anal fins; these and the caudal fin have a broad black margin. The ventrals are nearly entirely brownish blaek, the colour becoming deeper on the hinder margin. The pectorals are not coloured.

Length of the specimen $6^{\prime \prime}$

\section{Serranus rupestris.}

Cuv.\& Val. ix. p. 437.

$$
\text { D. } \frac{11}{16} \text {. A. } \frac{3}{10} \text {. Cæc. pylor. } 17 \text {. }
$$

Caudalis truncated. Præoperculum finely serrated, slightly emarginate above the angle. Dirty yellowish, with large, rounded, unequal spots of red colour on the baek, on the base of the dorsal fin, and on the ventrals, and of violet colour on the sides and on the head; pectoral fins with a broad yellow margin; the vertical fins with a narrow black and white edge. ( Val.)

St. Domingo.

\section{Serranus flavo-cæruleus.}

Holocentrus flavo-cæruleus, Lacép. iv. p. 366.

gyminosus, Lacép. iii..pl. 27. f. 2 , iv. p. 372.

Bodianus macrocephalus, Lacto. iii. pl. 20. f. 2, iv. pp. 293, 295.

Serranus borbonicus, Quoy \& Gaim. Voy. Freyc. Poiss. pl. 57 . f. 2. flavo-cæruleus, Cuv. \& Val. ii. p. 297 ; Bennett, Fishes of Ceylon, pl. 19 ; Peters, Wregm. Arch. 1855, p. 236.

$$
\text { D. } \frac{11}{16-17^{\circ}} \text { A. } \frac{3}{8(10)^{\circ}} \text {. }
$$

Caudalis slightly emarginate. Præoperculum with strongcr den- 
tieulations on the angle. Blackish brown; tail and all the fins yellow.

Coast. of Mozambique; Isle de France; Ceylon.

a. Large specimen : stuffed. Isle de France.

b. Adult: stuffed. Isle de France.

c. Adult. Mauritius. Presented by the Zoological Society.

d. Bad skin. Ceylon. Presented by Dr. Kelaart.

e. Large specimen: not good state: has been in chloride of zine. Sine patria. From the Haslar Collection.- Tail and root of the eaudal fin black; anal fin with ten soft rays.

\section{Serranus spiniger. (Plate $X$. fig. B.)}

$$
\text { D. } \frac{11}{16^{\circ}} \text { A. } \frac{3}{8} \text {. L. lat. } 90 \text {. }
$$

Caudalis truncated. The height of the body is $3 \frac{1}{2}$ in the total length, the length of the head $3 \frac{1}{3}$. Præoperculum rounded, with coarser denticulations at the angle. The seeond dorsal spine nearly twice as long as any of the others.

a. Adult. Sine patria. Old Collection.

Description.-The form of the body is eompressed, oblong, its greatest height comprised $3 \frac{1}{2}$ in the total length ; the length of the head is $3 \frac{1}{3}$ in the same; the upper surface of the head is rounded, convex, entirely eovered with minute seales, which extend on the proorlbital, cheeks, all the opercles, the lower jaw, and on a part of the maxillary. The diameter of the eye is $5 \frac{1}{2}$ in the length of the head, larger than the distance between the eyes, and two-thirds of the extent of the snout. 'The two openings of the nostril are small, round, equal, and near together. The cleft of the mouth is wide, the upper maxillary bone reaching nearly to the posterior margin of the orbit. The lower jaw is very prominent; the lips thick and fleshy. The preoperculum is rounded throughout, finely serrated behind, and with several coarse denticulations at the angle; the sub-and interopereulum exhibit a fine serrature on a part of their inferior margin. Operenlum with three conspienous spines: the upper smallest and shortest, nearly concealed by the scales; the middle long and prominent; the lower of half the size; the upper and middle spines are rather nearer together than the lower and middie ones.

The soft portion of the dorsalis is much higher, but shorter than the spinous. The latter shows a peculiarity that is not found in any of the other Servani: the first and shortest spine is followed by the second, which far exeeds the others, and even the rays, in length and strength; it is half as long as the body is high, and nearly twice as long as the third; all the following spines are nearly equal. The upper margin of the soft portion is rounded, the middle rays being rather longer than the others. 'The cundulis appears truneated; but by stretching it out as far as possible, the posterior margin becomes slightly convex. The front part of the base of the onalis is protected by a thick eneroachment of the sealy integmment; its soft portion resembles that of the dorsal in height and form; the spines 
are thick, the first not half the length of the second, and both the others are nearly equal in length. The pectorulis is rounder, composed of from eighteen to nineteen rays, and extends as far backward. as the ventral-that is, not entirely to the vent. The spine of the ventralis reaches beyond the half of the length of the fin. The canines are strong, and there are no large lateral teeth.

The specimen is rather discoloured, and the body appear's now to be of a uniform brownish colour. The soft part of the dorsal, the caudal, and the pectoral fins are of a yellowish-white colour. I camnot decide whether this is natural, or merely the effect of having been exposed to the light.

Length of the specimen $10^{\prime \prime}$.

\section{Serranus ura.}

? Serranus ura, Cur. \& V Val. ii. p. 332.

? _-_ ara, Kaun. Japon. p. 9.

? — ura, Richardson, Ann. \& Mag. Nat. Mist. 1842, ix. p. 24.

$$
\text { D. } \frac{11}{17} \text {. A. } \frac{3}{8} \text {. }
$$

Caudalis rounded; pectoralis far distant from the anal fin. The length of the head is $3 \frac{1}{2}$ in the total, the diameter of the eye about one-fifth of the length of the head. Præoperculum equally and very finely serrated; the third and fourth dorsal spines longest, one-third of the length of the head; the third spine of the anal fin longel and more slender than the second. Dried speeimen greyish brown; brown-spotted all over, the spots of moderate size, each covering: about four scales.

a. Large specimen : stuffed. St. Helena. From General Hardwicke's Collection.

Valenciennes' description contains so few precise characters, that if is impossible, without direet comparison of the specimens, to decide whether that in the British Museum Collection really belongs to the above species; it agrees with his description of ura, but so also do many other species. Moreover, Valeneiennes' specimen is said to be from Japan, whilst the other is from the Atlantic; but there mily be a mistake in one or the other. Therefore I refer our fish for the present to $S$. ura, not being inclined to found a new species upon a single stuffed specimen.

\section{Serranus melanurus.}

Bodianus melanurus, Geoffr. Deser. Eg. pl. 21. f. 1; Is. Geoffr. Poiss. d Eg. p. 205.

$$
\text { D. } \frac{11}{17} . \quad \text { A. } \frac{3}{9} \text {. }
$$

Caudalis truncated. Præopereulum with three or four strong spinous teeth at the angle; sub- and interoperenlum rather strongly denticulated. Coloration uniform; the soft part of the dorsalis, the caudal and anal fins with ferruginous spots.

Suez. 


\section{Serranus gilberti.}

Percis no. 15, Klein, Hist. Pisc. v. p. 43. t. 8. f. 3.

Serranus gilberti, Richardson, Arin. Nat. Iist. 1842, p. 19, and Ichth. China, p. 230.

- megachir, Richardson, Ichth. China, p. 230.

— pardalis, Bleeker, Perc. p. 37.
D. $\frac{11}{16-17}$.
A. $\frac{3}{8-9}$.
L. lat. 75-80.

Caudalis rounded. The length of the head is $3 \frac{1}{2}$ in the total; the diameter of the eye $4 \frac{2}{3}$ in the length of the head, larger than the distance between the eyes, but equal to the distance of the eye from the end of the snout. Pectoralis very large, nearly equal to the length of the head, and just reaching to the front end of the anal fin; the maxillary bone reaches beyond the hinder level of the eye. Præoperculum finely serrated, with stronger denticulations at the angle; sub- and interoperculum entire. Brownish, all parts with large, rounded, dark-brown spots; behind the maxillary bone a black streak.

- China Seas; Batavia; Sumbawa; Amboyna; Torres Straits; North Australia.

$a, b$. Adult: skins. China. From Mr. Warwick's Collection.

c. Adult. China.

d. Adult: stuffed. China. Presented by J. R. Reeres, Esq.

e. Adult. Amboyna. From Mr. Frank's Collection.

$f$. Young. Amboyna. From Mr. Frank's Collection.

g. Adult stuffed. Australia.

h. Adult: skin. Port Essington.

Fishes which have been skinned often beeome stretched, and more elongate than they are in nature; on the other hand, the fins shrink together and become shorter, especially the soft ones; thus the distance between the end of the pectoral fins and the analis appears to be greater. This was the case with specimens named by Dr. Richardson S. gilberti, which name has the priority. In speeimens which decidedly belong to Dr. Richardson's S. megachir, I do not find the number of the soft dorsal rays to be fifteen, but always sixteen, or even seventeen.

\section{Serranus nebulosus.}

Cuv. \& Val. ii. p. 313 ; Bleeker, Perc. p. 34 (not Richardson).

$$
\text { D. } \frac{11}{17} . \quad \Lambda \cdot \frac{9}{8} \text {. L. lat. } 75 \text {. }
$$

Caudal fin rounded. Subopereulum entire, interoperculum slightly denticulated; angle of the præoperculum with rather strong teeth, rectangular. Length of the head more than one-third of the total; eye of moderate size, its diameter one-fifth of the length of the head. Brownish, darker marbled; fins without spots or streaks.

Javanese Sea. 


\section{Serranus bontoides.}

Bleeker, Amboinu, vi. p. 405.

$$
\text { D. } \frac{11}{16-17} \text {. A. } \frac{3}{8} \text {. L. lat. } 80 \text {. }
$$

Caudalis rounded. The diameter of the eye one-fourth of the length of the head; the upper maxillary bone reaching to below the posterior half of the eye. Prxoperculum serrated, with rather stronger denticulations at the augle; sub- and interoperoulum entire; the hinder nine dorsal spines nearly equal in length; the second anal spine longest. Brownish, with scattered darker spots on the head and body; the dorsal fin only with a few brown spots; the soft part of the dorsalis; the caudal and pectoral fins with a yellow margin. $(B l$.

Sea of Amboyna.

\section{Serranus macrospilos.}

Bleeker, Batjan, iii. p. 499.

$$
\text { D. } \frac{11}{16-17^{\circ}} \text { A. } \frac{3}{8} \text {. L. lat. } 85 \text {. }
$$

Caudalis rounded. The diameter of the eye about one-fourth of the length of the head; the upper maxillary bone reaching beyond the posterior margin of the eye. Præoperenlum serrated, with stronger denticulations at the angle; sub- and interoperculum entire; the fourth and fifth dorsal spines not much longer than the following ones; the second anal spine longest, half the height of the body. Brownish green, with large blackish spots, distant from one another, seven between the operculum and caudal fin; dorsal fin with two rather irregular series of large brown spots, about seven in the basal series; pectoral and ventral fins black, the former yellow-edged; anal fin with a black spot and yellow-edged; caudal fin orange-coloured, on the anterior half with three large round black spots, on the posterior half blackish with a yellow margin. $(B l$.

Sea of Batjan.

\section{Serranus areolatus.}

Perca areolata, Forsk. p. 42.

- tauvina (not Forsk.), Geoffr. Descrade l'Eg. pl. 20. f. 1.

Serranus tauvinus, Geoffr. Poiss. d Eg. p. 201.

areolatus (japonicus), Fauna Japon. p. 8; Cuv.\& Val. ii. p. 350 ;

Richardson, Ichth. China, p. 232; Peters, Wiegm. Arch. 1855, p. 235.

$$
\text { D. } \frac{11}{17} \text {. A. } \frac{3}{8} \text {. }
$$

Caudalis truncated. Length of the head $3 \frac{2}{3}$ in the total. Præoperculum very finely serrated, with strong denticulations at the angle; pectoralis very distant from the anal fin. Dried specimens greyish brown, covered all over with numerous small brown spots.

Red Sea ; Coast of Mozambique ; Sea of Japan.

a. Adult: stuffed. Red Sea. Presented by J. Burton, Esq.

b. Half-grown: stuffed. Red Sca. 


\section{Serranus awoara.}

Temm. \& Schleg. Faun. Japon. p. 9. pl. 3. f. 2 ; Richarlson, Ichthyol. Clina, p. 231.

$$
\text { D. } \frac{11}{16-18} \cdot A \cdot \frac{3}{8} \text {. }
$$

Caudalis rounded. Præopereulum with the angle rather produced, more strongly dentieulated than the upper part of the margin. The third, fourth, fifth and sixth spines longest, the seeond not much shorter. Brownish olive; head and body covered with small round yellow spots; fins with a broad yellow edge.

Japanese and Chinese Seas.

a. Adult: stuffed: not good state. China. Presented by J. R. Reeves, Esq.

\section{Serranus geographicus.}

Serranus geographicus, (Kuhl \& von Hass.) Cur. \& Val. ii. p. 322.

$$
\text { D. } \frac{11}{17^{\circ}} \text { A. } \frac{3}{10} \text {. }
$$

Caudalis rounded. Brown, darker marbled. Dorsal fin olive; the spinous part with a large triangular spot at the base of each spine, above with a brown edge; the soft part with two longitudinal brown streaks beneath, and with large brown spots above; analis orange-coloured, with irregular brown strealss; the other fins brown-spotted. ( $V u l$.

Java.

\section{Serranus reticularis.}

Serranus reticularis, (Kuhl \& von Hass.) Cuv. \& Val. ii. p. 323.

$$
\text { D. } \frac{11}{17}, \quad \text { A. } \frac{3}{9} \text {. }
$$

Caudalis rounded. Brownish, with small blackish-brown halfmoon-like spots; head immaeulate; fins with numerous blue points. ( $r$ ral. $)$

Java.

\section{Serranus gaimardi.}

Serranus gaimardi, Blecker, Bataria, p. 455; (? Cuv. \&. Val. vi. p. 520 ; Quoy \& Gaim. Ioy. Astrol. Poiss. p. 656. pl. 3. f. 3.)

$$
\text { D. } \frac{11}{17} \text {. A. } \frac{3}{8} \text {. L. lat. } 90 \text {. }
$$

Caudalis with rather convex posterior margin. The length of the head $3 \frac{3}{1}$ in the total, the diameter of the eye one-fifth of the length of the head; muzzle covered with scales; the upper maxillary bone reaching beyond the posterior margin of the eye. Iracopereulum serrated, with stronger denticulations at the angle; sub-and interoperculum entire; seales eiliated. The third dorsal spine and the second anal longest. Brownish, with seattered brown spots, round on the head, and obleng on the posterior part of the body; caudal fin hlack-spotted behind and with a yellow edgo; dorsal and anal fins near the tips of the rays with from six to ten round black spots, 
the former having a yellow edge, the latter a black one; ventral and pectoral fins with seattered blackish spots. $(B l$. $)$

Sea of Batavia. (New Guinea.)

\section{Serranus chlorostigma.}

Cuv. \& Val. ii. p. 352.

$$
\text { D. } \frac{11}{17} \text {. A. } \frac{3}{9} \text {. }
$$

Caudalis truncated. Præoperculum finely serrated, with five or six rather stronger teeth at the angle; sub- and interoperculum with some denticulations. Whitish, entirely covered with small olivo spots; spinous part of the dorsal fin edged with black, candalis with white.

Seychelles.

120. Serranus cylindricus. (Plate XI. fig. A.)
B. 7. D. $\frac{11}{17}$.
A. $\frac{3}{8}$.
L. lat. 100.

Body elongate, rounded, rather cylindrical; the height $4 \frac{1}{3}$ in the total length, the length of the head $3 \frac{2}{3}$; the breadth equal to three-quarters of the height. Caudalis rounded. Præoperculum rounded, with fine denticulations behind; the upper maxillary bone reaching beyond the posterior margin of the eye. Covered with more or less regular hexagonal brown spots, separated from each other by white lines.

\section{a. Adult. Madagascar. Presented by Dr. J. E. Gray.}

Description. - The form of the body is more elongate and cylindrical than in any other species of Serranus, and might be compared with that of a Blennius. The height is contained $4 \frac{1}{3}$ in the total length, and is only one-fourth more than the breadth. 'The head has a conical form, its length being contained $3 \frac{2}{3}$ in the total. Between the vertex and the neck is a slight concavity, as between the eyes, the distance of which is about $\frac{3}{4}$ ths of the diameter of the eye; the latter is $4 \frac{1}{2}$ in the length of the head, and nearly equal to the distance between the eye and the end of the snont; the nostrils are near together. The upper maxillary bone reaches a little behind the posterior margin of the eye. All the head is eorered with minute scales, except the thick and fleshy lips. Lower jaw longest. The præoperculum is rounded throughout, finely serrated behind, and with some rather stronger denticulations at the angle; its lower limb, the sub- and interoperculum are entire; operculum with three spines, the two lower of which are prominent between the seales, the upper (smallest) being hidden by them; it terminates in a very long triangular membranaceous flap.

The margins of the spinous and soft portions of the dorsalis are slightly convex, both being nearly equal in height; the former has a not much longer base than the soft; the first spine is only one-half the length of the second, the second three-quarters of the third; the fourth, fifth and sixth are longest; the following diminish incon- 
spicuously in length. Ali are strong, with a deeply notched membrane between, and each with a membranaceous appendage' behind at the tip. The first ray is one-fourth longer than the last spine; the rays beeome gradually longer towards the middle of the fin, and again shorter towards behind. The caudalis has a moderately rounded posterior margin. The analis commences a little behind the eommencement of the soft dorsal ; the third spine is rather longer, but not quite so strong as the second; the inferior margin is slightly convex, the last two rays being shorter; the distance of the anus from the anal fin is nearly equal to the length of the seeond anal spine. The pectoralis is rounded, composed of 18 rays, and reaches as far as the ventral - that is, not even to the anus. 'The ventralis has also a convex margin, the second ray being longest; the spine is rather slender, and extends beyond the half of the fin.

'The canine teeth are not very developed, but those of the villiform band are relatively strong, as well as those of the vomer and palatine bones.

The whole fish; except the fins and belly, is eovered with more or less regular, large hexagonal spots of brown colour, separated from each other by straight white lines; five or six of these spots along the base of the dorsal and the back of the tail are larger and of a deeper colour. All the fins exhibit rounded, scattered, large brown spots, and a narrow yellowish-white edge: cren the membranaceons appendages of the spines are of the latter colour. There are a few brown spots only on the belly; the ventrals have a darker hue; there are indistinct spots on the gill-membrane.

Length of the specimen 8 inches.

\section{Serranus labriformis.}

Jenyns, Zool. of the Beagle, Fishes, p. 8. pl. 3.

$$
\text { D. } \frac{11}{17} \text {. A. } \frac{3}{8} \text {. }
$$

External appearance labroid; scales beneath the lateral line ciliated, above and on the belly smooth. Caudalis with a rather convex posterior margin. Length of the head one-third of the total; diamoter of the eye not quite one-sixth of the length of the head, about equalling the distance between them. Preopereulum with obsolete denticulations; the fourth dorsal spine a little the longest. Brown, variegated with greyish, black, and white; the vertical fins with a reddish edge. (Jen.)

Chatham Island (Galapagos Archipelago).

$\eta$. With eighteen or nineteen rays.

\section{Serranus altivelis.}

Cur. \& Val. ii. p. 324. p1. 25; Richards. Ichth. China, p. 230; Bleeker, Perc. p. 33 ; Cantor, Catal. p. 10.

$$
\text { D. } \frac{11}{18-19} \cdot A \cdot \frac{3}{9-10} \text {. }
$$

Caudalis rounded, dorsal and anal fins much elevated; upper profile 
of the head concave. Præoperculum finely and equally serrated. Yellowish, all parts with distant round black spots edged with white. Javanese and Chinese Seas; Sea of Pinang; Port Essington.

a. Large specimen. East Indies.

b. Adult. China. Prasented by General Hardwicke.

c. Young: very bad state. Port Essington. From the Haslar Collection.

\section{Serranus inermis.}

Cuv. \& Val.ix. p. 436; Poey, Memorias Cuba, 1851, p. 54. lam. 4. f.2.

D. $\frac{11}{19}$. A. $\frac{3}{10}$. $\quad$ L. lat. 90 . Cæc. pylor. 20 . Vert. 10/14.

Body elevated. Caudalis truncated, with rounded angles. Præoperculum with excessively fine serrature, denticulations of the angle rather stronger; pectoral fins as long as the head, one-fourth of the total length. Brown, with large white blotches; the vertical fins spotted with white, the pectoral and ventral fins with olive.

Caribbean Sea.

a. Adult. Cuba. Presented by the Koological Society.

b. Adult. West Indies. Presented by the Zoological Society.

\section{Serranus quoyanus.}

Cuv. \& Val. vi. p. 519.

$$
\text { D. } \frac{11}{18} \text { A. } \frac{3}{8} \text {. }
$$

Caudalis ruunded. 'The diameter of the eye is $4 \frac{2}{3}$ in the length of the head; the height is one-fourth of the total length, the length of the head $3 \frac{1}{2}$ in the latter; the maxillary bone reaching to behind the centre of the eye. Præoperculum strongly serrated, with strong denticulations at the angle; sub- and interoperculum entire. The pectoral fins reaching beyond the ventrals, nearly to the anus. Brownish, all the parts with large dark brown spots; the groundcolour of the ventrals and pectorals blackish.

Molucca Sea.

a. Half-grown. Amboyna. From Mr. Frank's Collection.

b. Adult. Celebes. From Mr. Frank's Collection.

\section{Serranus olfax.}

Jenyns, Zool. of the Beagle, Fishes, p. 9. pl. 4.

$$
\text { D. } \frac{11}{18} \text {. A. } \frac{3}{11} \text {. }
$$

Candalis truncated or very slightly emarginate. The length of the head is contained $3 \frac{1}{2}^{\star}$ in the total; the diameter of the eye is one-seventh the length of the head, larger than the distance between them. Præoperculum with a slight sinuosity just above the angle, very obsoletely denticulated. The second dorsal spine longest, not quite equalling half the height. Coloration uniform, mottled with brown. (Jen.)

Chatham Island (Galapagos Archipelago). 


\section{$\theta$. With nineteen or twenty rays.}

\section{Serranus dermopterus.}

Temm. \& Schleg. Faun. Japon. p. 10.

$$
\text { D. } \frac{11}{19-20} \text {. A. } \frac{3}{9} \text {. }
$$

A somewhat aberrant species. Caudalis rounded; dorsal and anal fins very high, the former with an entire upper edge; all enclosed for the greater part in a thick membrane covered with scales. Head small, muzzle short, scales very small. Præoperculum finely serrated, with some eoarser dentieulatious at the angle. Opereulum with three spines. Uniform brownish.

Japanese Sea.

3. Body with longitudinal bands.

\section{Serranus formosus.}

Russell, t. 129 (not good).

Scirena formosa, Shew, Zool. Misc. p. 23. t. 1007.

Serranus formosus, Cuv. \& Val. ii. I ${ }^{21} 1$; Richards. Ichth. China, p. 2.33; Bleeker, Pcrc. p. 31.

$$
\text { D. } \frac{9}{16} \text {. A. } \frac{3}{8} \text {. L. lat. } 75 \text {. }
$$

Caudalis rounded. Length of the head not quite one-third of the total; diameter of the eye $6 \frac{1}{2}$ in the length of the head. Præopereulum without stronger denticulations at the angle; suboperculum with some denticulations; interopereulum entire. In life yellowish red, witl numerous blne lines, oblique on the head, horizontal on the sides; analis black-edged.

Coast of Coromandel; Madras; China Seas; Batavia.

a. Adult. China.

b. Adult: bad skin. India. Presented by J. E. J. Boileau, Esq.

c. ?Adult: stuffed. Isle de France.

\section{Serranus latifasciatus.}

Temm. \&. Schleg. Faun. Japon. p. 6.

$$
\text { D. } \frac{11}{12} \text {. A. } \frac{3}{8} \text {. }
$$

Caudalis with a rather convex posterior margin. Præopereulum with denticulations on the lower part of tho hinder limb, and with three strong spinous teeth at the angle; maxillary bone reaching as far beyond the posterior level of eye as the diameter is long. The first dorsal spine half as long as the second; the others of nearly equal length. Brown (in a dried state), with two broad, lighter, black-edged longitudinal bands; dorsal and candal fins with brown spots, the other ones immaculate. (Schleg.)

Japanese Seas.

\section{Serranus morrhua.}

Cur. \&. Val. ix. p. 434.

$$
\text { D. } \frac{11}{13} . \Lambda \cdot \frac{3}{8} \text {. }
$$

Caudalis rounded. Brownish, with four darker curved longi- 
tudinal bands; cheeks with four oblique streaks from the eye to the margin of the præopereulum; a large brown spot on the occiput. ( $\mathrm{Val}$. )

Isle de France.

\section{Serranus biguttatus.}

Cur. \& Val. vi. p. 507.

$$
\text { D. } \frac{11}{12} \text {. A. } \frac{3}{8} \text {. }
$$

Baek brownish, belly yellowish; a brown line from the ere to the base of the tail; root of the pectoral fins brown. T3ack with two pearl-eoloured spots, one beneath the eighth dorsal spine, thin other beneath the fifth ray. $(V a l$.

Sea of Trincomalce.

\section{Serranus pœcilonotus.}

Temm. \&.Schleg. Faun. Japon. p. 6. pl. 4 A. f. 1; Bleek. Verhand. Batav. Genootsch. xxvi. p. 61.
D. $\frac{11}{14-15}$.
A. $\frac{3}{8}$.
L. lat. 85-90.

Caudalis rounded; proopereulum finely serrated, with two or three spinous teeth at the angle. Four white bands on each side: the first half-moon-like, surrounding the spinous part of the dorsal fin; the seeond parallel to the first, ruining from the shoulder to tho middle of the soft part; the third lateral, united with that of the other side above the eyes; the fourth, from the eye to the peetoral fins and along the sides. Back of the tail with two white spots.

Japanese Seas.

\section{Serranus lemniscatus.}

Cuv. \& Val. ii. p. 240.

$$
\text { D. } \frac{10}{15} \text {. A. } \frac{3}{8} \text {. }
$$

Body three times as long as broad. A brown band from the eye to the caudal fin, another obsolete one beneath. ( $/ \mathrm{al}$. )

Crylon.

\section{Serranus urophthalmus.}

Bleeker, Batav. p. 310.
D. $\frac{11}{15}$.
A. $\frac{3}{8}$.
L. lat. 100.

Caudalis rounded. The height of the body is $4 \frac{1}{5}$ in the total length, the length of the head $3 \frac{1}{6}$, the diameter of the eye $4 \frac{1}{2}-4 \frac{3}{5}$ in the length of the head; head pointed; the upper maxillary bone reaching beyond the hinder margin of the eye. Præoperculum serrated, with a stronger spinous tooth at the angle; sub- and interoperculum denticulated; the third and fourth dossal spines and the second of the anal fin longest. Red (in life), with eight alternating blue and brownish longitudinal bands, oblique on the head; on each side of the muzzle a black spot, another at the root of the eaudal fin; fins immaculate. (Bl.)

Sca of Batoe. 


\section{Serranus lineatus.}

Cuv. \& Val. ii. p. 312.
D. $\frac{11}{18}$
A. $\frac{3}{9}$.

Caudalis rounded. Præoperculum with two or three stronger spinous teeth on the angle. Brown, with four or five blackish (in life, blue) longitudinal bands, sometimes disappearing after death.

Pondicherry; China.

a. Adult. China. Presented by Sir J. Richardson.

\section{Serranus amboinensis.}

Bleeker, Amb. \& Cer. p. 258.
D. $\frac{11}{17-19}$.
A. $\frac{3}{8}$.
L. lat. 100.

Caudalis rounded; the diameter of the eye is $4 \frac{1}{2}$ in the length of the head. Præoperculum deeply serrated, with three stronger denticulations at the angle; sub- and interoperculum with a few denticulations; the third, fourth and fifth dorsal spines and the second anal spine longest. Brownish; head with numerous brown specks; body with from ten to twclve more or less serpentine deep-brown longitudinal stripes; fins brown, not spotted.

Sea of Amboyna.

a. Adult: skin. Ceylon. Presented by E. F. Kelaart, M.D.

\section{PLECTROPOMA.}

Plectropoma, Cuv. Règne Anim.; Cuv. \&. Val. ii. p. 387.

Seven branchiostegals. Teeth villiform, with canines in both jaws; teeth on the palatine bones, tongue smooth. One dorsal, formed by a series of spines and rays. Opereulum with two or three acute points; præopereulum not notched behind, with spinous teeth at the lower limb, directed forwards. Scales small.

All the seas of the Tropical regions.

\section{Plectropoma maculatưn.}

Bodianus maculatus, Bioch, t. 228; Lacép. iv. pp. 280, 293.

Plectropoma punctatum, Quoy \& Gaimard, Voy. Freycinet, Zool. Poiss. p. 318. t. 45. f. 1.

- maculatum, Cuv. \& Val. ii. p. 393 ; Bleeker, Perc. p. 39, and Java, p. 418.

? Plectropoma (niaculatum) areolatum, Rüpp. Atl. pp. 110, 143 (index), and N.W. Fische, p. 90.
D. $\frac{8-8-7-7}{10-11-11-12}$.
A. $\frac{3-3-2}{7-8-8}$.
L. lat. 110. Vert. 10/14,

Præopereulum excecdingly finely serrated behind, and with three spinous teeth below; sub- and interoperculum entirc. Caudalis truncate in younger specimens, in older ones emarginate. Red: 
head, body, and vertical fins with blue spots, those of the head and of the front part of body oblong, elliptical, arranged in irregular longitudinal rows, the other ones eircular and smaller. In spec1mens from the Red Sea all the spots are circular and of equal size.

Red Sea; Seas of Batavia, Siugapore, Macassar, and Halmaheira.

a. Large specimen: stuffed. Red Scas.

\section{Plectropoma leopardinum.}

Holocentrus leopardus, Lacép. iv. pp. 332, 337.

Plectropoma leopardinum, Cuv. \& Val. ii. p. 392. pl. 36 (not good); Faun. Japon. Poiss. p. 12; Blceker, Java, p. 420.

- leopardus, Richardson, Ichthyol. China, p. 230.

_ cyanostigma, Bleeker, Topogr. Batav. in Nat. Gen. Arch. Ned. Ind.

- maculati var. b, Blecker, Perc. p. 40.
D. $\frac{8-8-7-7}{10-11-11-12}$.
A. $\frac{3-3-2-2}{7-8-8-9}$. L. lat. 120 .

Præoperculum exeeedingly finely serrated behind, and with five spinous teeth beneath, the three lowest of which are close together; suboperculum and interoperculum entire. Caudalis slightly emarginate. Brownish red: head, body, vertical fins, and base of the pectorals with numerous, very small, round blue spots, much smaller than the interspace between; caudalis with a yellow posterior edge.

Red Sea; Javanese and Japanese Seus ; Australia ; Louisiade Archipelago.

a. Large specimen: stuffed. Louisiade Arehipelago. Voyage of the Rattlesnake.

\section{Plectropoma oligacanthus.}

Bleeker, Java, ii. 1854, p. 422.
D. $\frac{6-7}{12}$.
A. $\frac{3}{8}$.
L. lat. 120 .

Præoperculum scarcely denticulated behind, and with three or four spinous teeth below; sub- and interoperculum entire. Candalis slightly emarginate. Red with five or seven oblique blue streaks from the eye to the sub-and inter-operculum; two or four other streaks from the eye to the snout; the anterior part of body with blue streaks; the posterior and caudal fin with numerous elliptical and round blue spots; the soft part of the dorsal fin, ventrals, and analis with oblique blue streaks; peetoral fins with an orangecoloured edge. $(B l$.

Sea of Batavia.

\section{Plectropoma melanoleucum.}

Renard, i. pl. 22. f. 120 ; Valentyn, f. 497 (bad).

Bodianus melanoleucus, Lacép. iv. pp. 283, 297.

— cyclostoma, Lncép. iii. pl. 20. f. 1, iv. pp. 282, 295. 
Labrus lævis, Lacip. iii. pl. 23. f. 2. pp. 431, 479.

Plectropoma melanoleucum, Cuv. \& Val. ii. p. 388; Peters, Wiegm. Arch. 1855, p. 238.

$$
\text { D. } \frac{8}{11} \text {. A. } \frac{2}{8} \text {. }
$$

Præopereulum with entire posterior margin, and with four or five spinous tecth below; caudalis truncated. Grey, with five black cross-bands.

Isle de France; Ibo (Mozambique).

\section{Plectropoma nigrorubrum.}

Cuv. \& Val. ii. p. 402; Quoy \& Gaim. Voy. Astrol. Poiss. p. 0ir9. pl. 4. f. 1 .
D. $\frac{10}{17-18}$.
A. $\frac{3}{8}$. Cæe. pylor. 8 .

Præopereulum finely serrated behind, and with two equal and strong spinous teeth below, one of which is placed at the angle. Caudalis truncated. Reddish yellow, with five black cross-bands.

King George's Sound.

a. Adult: stuffed. Sine patria.

b. Half-grown: stuffed. Sine patria.

\section{Plectropoma annulatum. (Plate XI. fig. B.)}

D. $\frac{10}{18}$. L. $\frac{3}{7}$. L. lat. 50. L. transv. 7/20.

Præopereulum finely serrated behind, and with three spinous teeth below, one of which is placed at the angle. Caudalis rounded. Red (?), with six black cross-bands, occupying the whole depth of the body and tail; sides of the head and nape with three black bands, obliquely descending forwards.

Hab. —?

a. Adult. From the Haslar Collection.

Description of the specimen.-The form of the body is rather elevated, its greatest depth being somewhat more than one-third of the total length; the length of the head (opercular spine ineluded) equals the depth of the body. The snout is moderately pointed and slightly longer than the diameter of the eye. The eleft of the mouth is wide and oblique, the upper mixillary extending nearly to below the centre of the eye. The snout is nearly scaleless, the upper maxillary and the mandibula exhibiting minute and rudimentary scales only; one-half of the præorbital covered with distinct. and small scales. The eye is situated high up the side; the bony margin of the orbit is projecting, especially on the upper half, so that the space of the forehead between the eyes appears concare; the diameter of the eye is $4 \frac{1}{3}$ in the length of the head, and much larger than the distance between the eyes.

All the other parts of the skull are thiekly covered with scales; the prooperculum has the posterior limb finely serruted, one short and obtuse spine at the angle, and two longer ones of equal size at 
the lower limb; the lower limb and the angle form one continuous curve. The operculum has two very prominent spines, the lower of which is smaller.

The dorsal fin is rather low, with a noteh before the soft portion; the scales of the body are continued on the lower half of this fin and of the others, and it is difficult to distinguish the real base of the fin. The first spine is above the base of the longest spine of the operculum, and equals in length the last spine; the second is twice as long as the first; the fourth is the longest, and $3 \frac{1}{2}$ in the greatest depth of the body. The membrane between the spines appears to be deeply notched. The length of the base of the soft portion is one-third shorter than that of the spinous, and has the upper margin slightly convex; it is rather lower than the spinous, begins above the origin of the anal, and terminates so near the caudal, that the distance between these two fins is rather less than one-fourth of the depth of the body. The caudal fin is slightly rounded, and oneseventh only of the total length. The first spine of the $a n a_{e}^{7}$ fin is short, one-half the length of the second; the second is very thick, but shorter than the first ray, one-third of the depth of the body; the third spine is slender, and shorter than the preceding; the soft portion is slightly rounded, and its distance from the caudal is onethird of the depth of the body. The pectoral is well dereloped; its base is entirely hidden by scales; it is rounded, and extends to the level of the vent, its length being $4 \frac{1}{2}$ in the total. The ventrals are much shorter than the pectorals, rather more than one-half; they are inserted a little before the pectorals, and their spine is threefifths of their entire length.

The scales are of moderate size, finely etenoid ; those above the peetoral are largest, not much longer than high, and one covering about one-tourth of the eye. The lateral line runs in the upper third of the height of the body, and follows exactly the curve of the back.

The teeth are in villiform bands, with a pair of strong eanines in both jaws; there is another canine tooth in the middle of the side of the lower jaw. The vomerine teeth are in a narrow band, rectangularly bent; the palatine teeth in a band not broader than that of the vomer.

The ground-colour is now pure yellowish, and has been probably red or rose-coloured. The bauds are deep black: two (on each side) descend from the nape to the sides of the head; the anterior from the middle of the distance between the dorsal and the eyes to the upper posterior angle of the orbit; the other from the origin of the dorsal over the suprascapula to the middle of the hinder margin of the orbit; there is a black spot besides between the eyes; a third band, incomplete, on the opereulum. The other bands are broader and vertieal, and the first four extend on the dorsal fin : the first from between the third and fifth dorsal spines to behind the base of the peetoral; the second from between the seventh and ninth dorsal spines to the middle of the belly; the third from between the fourth and sixth dorsal rays to the anal spines; the fourth, rather eurved, from between the twelfth and fourteenth dorsal rays to the end of 
the anal; finally, there are two other bands, much narrower than the anterior ones, on the tail. The fins are otherwise immaeulate.

The native sea of this species is probably a part of the Pacific.

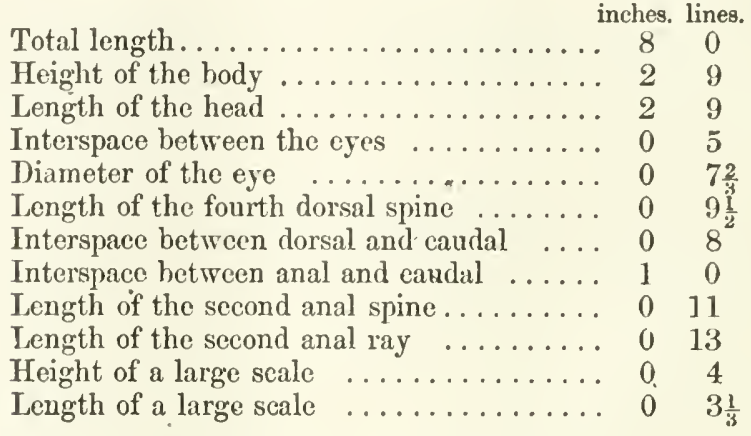

\section{Plectropoma semicinctum.}

Cuv. \& V'al. ix. p. 442; Gay, Chile, Zool. ii. p. 153, Ictiol. pl. 2. f. 1.

$$
\text { D. } \frac{10}{18-20^{\circ}} \quad \text { A: } \frac{3}{7-8^{\circ}} \text {. L. lat. } 45 \text {. }
$$

Prooperculum finely serrated behind, and with three equal and strong spinous teeth below, one of which is placed at the angle. Caudalis truncated. Red, with eight brown cross-bands, lost on the sides. The sides of the head with more or less distinet, irregular, brownish streaks.

San Juan. Fernandez (Chili); Australia.

a. Adult: skin. Australia. Purchased of Mr. Warwick.

$b-d$. Half-grown: skins. Australia. Purehased of Mr. Warwick. e. Half-grown: skin. Swan River.

f. Half-grown. Sine patria. From the Haslar Collection.

\section{Plectropoma susuki.}

Cur. \& Val. ii. p. 404; Faun. Japon. p. 11. pl. 4 (upper figure); Rechardson, Ichthyol. China, p. 2:30.

$$
\text { D. } \frac{11}{14} \text {. A. } \frac{3}{9} \text {. }
$$

Præopereulum with fine denticulations behind, coarser at the angle; a single spinous tooth below. Caudalis rounded. Brownish grey, with eight or nine darker cross-bands.

Chinese and Japanese Seas.

\section{Plectropoma dentex.}

Cuv. \& Val. ii. p. 394; Quoy \& Gaim. Astrol. p. 660. pl. 4. f. 2; Richardson, Lrebus \&. I'error, p. 117. pl. 57. f. 3-5.
D. $\frac{10}{18}$.
A. $\frac{3}{8}$. Cæc. pylor. 7.

Prxoperculum with a fow inconspienons denticulations bèhind, 
and three or four small spinous teeth below. Caudalis rounded. Olive, marbled with blackish; black spots on the sides of the head and on the snout.

King George's Sound.

a. Adult: stuffed. King George's Sound.

\section{Plectropoma cyanostigma. (Plate XII.)}
D. $\frac{13}{15}$.
A. $\frac{3}{8}$.
L. lat. 100.

Præoperculum with three spines beneath, the anterior of which is the strongest. Caudalis rounded; the seeond anal spine longest, curved. Brownish (in a dricd state); head and body covered with round blackish spots, blue in the eentre, and each eovering about six seales.

Australian Seas.

$a, b$. Adult: skins. Australia. Voyage of H.M.S. Fly.

c, d. Adult: skins. Australia. Purchased of Mr. Warwick.

c. Adult. Port Jackson. Purchased of Mr. Gould.

f. Adult: skin. New Holland. From Mr. Gould's Collection.

Description.-Body oblong; its height is comprised four times in the total length, the length of the lead $3 \frac{1}{2}$. The head above is covered with scales to the nostrils,- the whole snout, the præorbital, the maxillary, and mandibulary being naked. The eye forms onesixth of the length of the head, and is situated above at the side, interfering with the outline of the erown. The distance oetween t!: $\mathrm{e}$ eyes is one-third smaller than their diameter; the præorbital broadas broad as the diameter of the eye is long The upper maxillary does not reach to the vertical from the centre of the eye. The præopereulum has a rounded angle; the denticulations along the posterior limb are coarse and distant from one another, beeoming gradually larger at the anglc. The anterior spine of the lower limb is at least twice as long as the posterior, which is situated very near the angle. The sub- and interopereulum are entire. The operculum is provided with three spines, the upper of which is broadest, and distant from the middle; the latter is rather slender and projecting; the third is immediately beneath.

Both the portions of the dorsal fin are nearly equal in height, and have a rounded upper margin ; the spinous portion is $1 \frac{1}{2}$ as long as the soft; the first spine is rather more than half the length of the second; the fourth, fifth, and sixth are longest; the others gradually bccome shorter, the twelfth being rather shorter than the second; the thirteenth apparently belongs to the soft portion, being, again, a little longer; the first ray is one-third longer than the last spine. The caudalis is rounded. The soft portion of the analis is rounded, and rather higher than the dorsal; the spines are very strong, especially the second, which is slightly curved, and not much shorter than the longest of the dorsal fin. The pectoralis is rounded, longer than the ventral, and extends to the vent; it is composed of eighteen rays. 
The ventralis is small, and supported by a spine half the length of the fin.

There are no prominent canine teeth, but there is a series of large teeth in each jaw in front and on the side.

The ground-colour in the dried specimens is brownish--perhaps brownish red in life; the head and body are eovered all over with round blackish spots with a bluish centre, each covering about six seales. All the fins appear now of a uniform blackish-brown eolour, but there seem to have been similar spots on the pectoral.

Length of the largest specimen 16 inches.

\section{Plectropoma cinctum. (Plate XIII. fig. A.)}

$$
\text { D. } \frac{13}{15} \text {. A. } \frac{3}{9} \text {. L. lat. } 100 \text {. }
$$

The height of the body is $3 \frac{1}{3}$ in the total length, and the length of the head is one-third of the latter. Præoperculum strongly serrated, with three large spinous teeth at the lower limb, the anterior of which is the strongest. Caudalis rather rounded. Reddish brown, with six dark-brown eross-bands encireling the body and tail; sides of the head with two bands of the same colour from the eye to the opercles; fins black, and whitish-edged.

a. Fine specimen. Norfolk Islands. From the Haslar Collection.

Description.-The form of the body is oblong, similar to that of the Pereh; its height is comprised $3 \frac{1}{3}$ in the total length. The head is rather elongate, its length being one-third of the total. The snout is elongate, as in Mesoprion, twice the diameter of the eye; the upper surface of the head narrow, the distance between the eyes smaller than their diameter; the scales extend only to the nostrils,- the whole snout, præorbital, and upper maxillarybone being naked. The eye is rather small, only one-sixth of the length of the head; the nostrils, separated into a smaller round posterior opening and into an oval anterior one, are situated in front of the upper angle of the eye. The proorbital is broad, eren broader than the hinder end of the maxillary bone, which reaches to below the centre of the eye. The præoperculum is provided with rather strong and distant denticulations, increasing in size towards the angle, and with three very strong spinous teeth at the lower limb, the anterior of which is the strongest; the angle of the præoperculum is rounded; the sub-and interopereulum are entire. The operculum has three spines, the upper of which is very remote from the others; the middle is the longest, projecting immediately above the lower one. Suprascapula conspicuously erenulated.

The spinous portion of the dorsalis is much lower and longer than the soft. The spines are strong: the seeond one-third longer than the first, the third one-third longer than the second; the fifth to the eighth longest, the ninth to the fourteenth gradually becoming shorter; finally, the fifteenth a little longer than the preceding, and apparently belonging to the soft portion; this portion is nearly 
twice as high as the preceding lowest part of the spinons dorsal, and has an entirely rounded upper margin. The caudalis is rounded. The soft part of the analis is partly enveloped by a thick encroachment of the scaly integument, and forms an oblong flap with a rounded inferior edge ; the second spine is exceedingly thick, and even longer than the longest dorsal spine, also somewhat curved; the third spine is not quite twice the size of the second. The pectoralis extends rather farther than the ventral, to the third cross-band; it is composed of eighteen rays, rounded, and enveloped in a thick membrane. The ventralis, rather short, does not extend to the vent; it is rounded, with a thick membrane between the rays, and has a spine half the length of the fin.

There are three pairs of canines in each jaw, of rather small size; the vomerine and palatine teeth stand in very narrow series.

The ground-colour is a reddish brown, darker on the back. The dark-brown cross-bands and the interspaces of the ground-colour are nearly of the same breadth; the first passes from in front of the dorsal to the gill-opening above the operculum; the second from the interspace between the fourth and sixth dorsal spines vertically to the belly; the third from the twelfth to the fourteenth; the fourth from the middle of the soft dorsal fin to the middle of the anal; the fifth from the end of the dorsal round the tail; the sixth, narrow and indistinct, round the root of the caudal. The second to the fifth bands extend also more or less on the fins. On the side of the head a dark-brown streak runs from the back edge of the eye to the suprascapula, and a second oblique one from beneath the eye to the angle of the præoperculum; a brown streak behind the maxillary. The opercles and soft fins are indistinctly dotted with brown. All the fins, except the spinous dorsal, have a blackish-brown white-edged margin.

Length of the specimen $10^{\prime \prime}$.

\section{Plectropoma serratum.}

Cuv. \& Val. ii. p. 399; Quoy \& Gaim. Voy. Astrol. Poiss. p. 662. pl. 2. f. 1; Dumont d'Urville, Voy. au Pôle Sud, Poiss. pl. 3. f. 1.

$$
\text { 1). } \frac{13}{16} \text {. A. } \frac{3}{9} \text {. Cæc. pylor. } 8 \text {. }
$$

Præoperculum strongly serrated behind, and with two large spinous teeth below, the anterior of which is the strongest. Caudalis truncated. Brown: an oblique blackish band from the eye to the angle of the præoperculum, and some black spots on the sides of the body.

King George's Sound.

\section{Plectropoma aculeatum.}

Cuv. \& Val. vi. p. 523.

$$
\text { D. } \frac{13}{14} \text {. A. } \frac{3}{8} \text {. }
$$

Posterior limb of the præoperculum with coarse denticulations, gradually becoming larger towards the angle, the horizontal limb 
with three very strong spinous teeth; suboperculum with three acute spines at the lower angle. Caudalis truncated. Brown, with small, scattered blackish spots on the back and the dorsal fin. ( $V a l$.

Banc des Aiguilles.

\section{Plectropoma brasilianum.}

Plectropoma brasilianum, Cuv. \& Val. ii. p. 397.

? Plectropoma patachonica, Jenyns, Zool. Beagle, Fishes, p. 11.
D. $\frac{12}{15-16}$.
A. $\frac{3}{7-8}$.
[D. $\frac{13}{16}$.
A. $\frac{3}{7}(C u v$.$) .] Cæc. pylor. 9$.

Prooperculum finely serrated behind, and with four spinous teeth below. Caudalis truncated. Greyish brown, with irregular reddish bands.

Coast of Brazil.

The specimens described by Jenyns exhibit only three spinous teeth at the horizontal limb of the præoperculum.

a. Adult: stuffed. Sine patria.

$b$, c. Half-grown: stuffed. Sine patria.

\section{Plectropoma chloropterum.}

Cuv. \& Val. ii. p. 398; Poey, Memor. Cuba, 1851, p. 73. lam. 9. f. 3. D. $\frac{11}{18}$. A. $\frac{3}{9}$. L. lat. 70 . Cæc. pylor. 8 .

Præoperculum finely and equally serrated behind, and with two spinous teeth below, the anterior of which is the largest. Caudalis rounded. Olive, marbled with brownish black; throat white-spotted.

Caribbean Sea.

\section{Plectropoma pictum.}

Tschudi, Fauna Peruana, Ichthyol. p. 5.
D. $\frac{11}{17}$.
A. $\frac{3}{9}$.

This species appears to be different from the preceding ( $P$. chloropterum), although closely allied, according to the descriptions referred to.

Operculum with three spines; præoperculum serrated behind, and with two spinous teeth beneath, the anterior of which is the strongest, the other situated at the angle; fins and snout scaly. Caudalis rounded; the fourth dorsal spine longest; the third of the anal fin rather shorter than the second; pectorals extending beyond the front cnd of the anal fin. Silvery white, with rose-coloured markings. (Tschudi.)

Coasts of Chili and Peru.

\section{Plectropoma monacanthus.}

Muill. \& Trosch. in Schomb. Hist. Barb. p. 665.
D. $\frac{11}{18-19}$.
A. $\frac{3}{9}$.

A single strong spine in front of the angle of the preoperctum. 
Brownish, with darker spots on the sides, and some rounded spots of a lighter colour on the belly, opercles, and cheeks.

In shallow water along the coast of Barbadoes; Falkland Islands.

a. Adult: stuffed. Falkland Islands. Presented by W. E. Wright, Esq.

$b$ Adult: stuffed. West Indies. Purchased of Mr. Scrivener.

c. Adult: skin. West Indies. Purchased of Mr. Scrivener.

\section{Plectropoma macrophthalmos.}

Tschudi, Faun. Peruana, Ichthyol. p. 6

$$
\text { D. } \frac{10}{10} \text {. A. } \frac{3}{9} \text {. }
$$

Præoperculum scrrated behind, with several spinous teeth beneath. Caudalis?; the third to sixth dorsal spines longest; the third of the anal fin longer than the second. Uniform greyish. (Tschudi.)

Coast of Chili (Lurin, Callao).

\section{Plectropoma paytense.}

Lesson, Voy. Coq. Zool. p. 233.

$$
\text { D. } \frac{10}{12} \text {. A. } \frac{3}{7} \text {. }
$$

Caudalis forked. Reddish grey, with five large yellow spots on the side.

Payta.

\section{Plectropoma hispanum.}

Cuv. \& Val. ii. p. 386; Poєy, Memor. Cuba, 1851, p. 72. lam. 4. f. 1.
D. $\frac{8}{12-13}$.
A. $\frac{3}{7}$.
Vert. 10/14.
Cæc. pylor. 8.

Præoperculum finely serrated behind, and with a single spinous tooth below; suboperculum denticulated. Rose-coloured, with yellow streaks.

Martinique; Cuba.

\section{Plectropoma pnella*.}

Cuv. \& Val. ii. p. 405. pl. 37 ; Ramon de la Sagra, Hist. Cuba, Poiss. p. 18; Poey, Memor. Cuba, 1851, p. 62. lam. 9. f. 2.

D. $\frac{10}{14-15}$. A. $\frac{3}{7}$. L. lat. 60 . L. transv. 8/20. Cæc. pylor. 5. Vert. 10/14.

The height of the body is only $2 \frac{1}{2}$ in the total length. Præoperculum finely serrated behind, rather coarser denticulated below; sub- and interoperculum with exceedingly fine denticulations. Violet, with five or six black cross-bands, the middle of which is

* Plectropoma vitulinum (Poey, Memor. Cuba, p. 68) is closely allied to P. puella. 
broadest, spanning from the fourth dorsal spine to the tenth; the soft part of dorsalis with fine darker streaks.

Caribbean Sea.

a. Adult: skin. Jamaica. From Dr. Parnell's Collection.

b.. Adult: stuffed. America. Presented by Dr. Parnell.

c. Fine specimen. S. America. Presented by Sir R. Schomburgk.

d. Fine specimen. Sine patria. Presented by the Zoological Society.

e. Fine specimen. (Canton?) Presented by the Zoological Society.

f. Adult. From the Haslar Collection.

\section{Plectropoma indigo.}

Poey, MLemor. Cuba, 1851, p. 69. lam. 3. f. 1.

$$
\text { D. } \frac{10}{14} \text {. A. } \frac{3}{6} \text {. }
$$

Allied to Pl. puella." Præoperculum finely serrated behind, with rather small spinous teeth beneath. Blue, with five bluish erossbands, the middle of which is broadest; ventrals black; caudalis emarginate. (Poey.)

Cuba.

\section{Plectropoma bovinum.}

Poey, Memor. Cuba, 1851, p. 69.

$$
\text { D. } \frac{10}{15} \text {. A. } \frac{3}{7} \text {. Cæc. pylor. } 6 .
$$

Proopereulum fincly serrated behind, with rather small spinous teeth beneath. Dark blue, with eight lighter eross-bauds. Caudalis emarginate. (Poey.)

Cuba.

\section{Plectropoma gummigutta.}

Poey, Memor. C'uba, 1851, p. 70. lam. 3. f. 2.

$$
\text { D. } \frac{10}{15} \text {. A. } \frac{3}{7} \text {. }
$$

Præoperculum serrated behind, and with rather stronger denticulations beneath. Caudalis emarginate. Yellowish, with two black, blue-edged spots before the cye; muzzle blue. (Poey.)

Cuba.

\section{Plectropoma gutta-varium.}

Plectropoma gutta-varium, Poey, l. c. pp. 70, 411.

- melanorhina, Guichen. I'viss. in Rumon. de la Sagra, Mist. Cuba, p. 18. pl. 1. f. 1 .

$$
\text { D. } \frac{10}{1+-15} \text {. A. } \frac{3}{7} \text {. }
$$

Praoperculum serrated behind, and with rather stronger denticulations beneath. Cindulis cmarginate. The anterior parts of the body yellow, the posterior hlack; fins yellow; a black, blue-edged spot in front of the eye.

Cuba. 


\section{Plectropoma chlorurum.}

Cur. \&. Val. ii. p. $406^{*}$

D. $\frac{10}{15}$. A. $\frac{3}{7}$. Cæc. pylor. 4 .

Præoperculum finely serrated bchind, with three rather stronger denticulations at the angle, and with six at the horizontal limb. Uniform blackish brown; caudal and pectoral fins yellow, the other ones black.

Martinique.

\section{Plectropoma unicolor.}

Seba, iii. 27. 10.

Holocentrus unicolor, $B l$. Schn. p. 322.

Plectropoma ephippium, Cuv.\&Val. ii. p. 408.

D. $\frac{10}{15}$. A. $\frac{3}{7}$.

Muzzle pointed; præoperculum finely serrated behind, and with rather stronger denticulations below. Caudalis emarginate. Brownish : a black cross-band on the tail, a black spot in front of the eye, a narrow violet undulated line from the eye to the angle of the præoperculum; each scale on the breast with a small whitish speck in the centre.

East Indies?

a. Adult: stuffed. Sine patria.-Of uniform brown colour.

\section{TRACHYPOMA + .}

Seven branchiostegals. Tecth in villiform bands; without canine teeth; teeth on the palatine bones; tongne smooth. One dorsal, with twelve spines; the anal with three. Operculum with moderate points; præoperculum with spinous teeth at the lower limb, directed forward. Scales small. The number of pyloric appendages increased (13).

Pacific.

\section{Trachypoma macracanthus. (Plate XIII. fig. B.)}

D. $\frac{12}{14}$. A. $\frac{3}{6}$. L. lat. 65 . Car. pylor. 13 .

Similar to Plectropoma cyanostigma. The height of the body is $3 \frac{1}{2}$ in the total length; the length of the head is one-third of the same. Posterior limb of præoperculum strongly denticulated; the inferior with three strong spinous teeth, the anterior of which is the largest; sub- and interoperculum entire. Caudalis rounded. Brownish (in spirits), covered all over with very small whitish, durkcr-edged specks.

$a, b$. Norfolk Islands. From the Haslar Collection.

$c, d$. Norfolk Islands. From the Haslar Collection.

* Plectropoma nigricans (Poey, Memor. Cuba, 1851, p. 71.) and Plectropoma accensum (Poey, l.c. p. 72), both from Cuba, if not the same, are closely alliet.

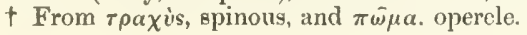


Description - In habit similar to the Perch The height of the body is eomprised $3 \frac{1}{2}$ in the total length, the length of the head is one-third. The head above, in the occipital region, is lather broad and rounded, between the eyes it is mueh narrower (the distance of the eyes being only two-thirds of their diameter), and longitudinally grooved. The scales extend to the nostrils, which, forming on each side two round openings, are situated entirely on the upper surface of the head. The præorbital, the snout, and the jaws are naked. The eye is $3 \frac{2}{3}$ in the length of the head, and the extent of the snout is rather shorter than its diameter. The upper maxillary reaches to below the centre of the eye. The præopereulum exhibits rather a coarse serrature at the posterior limb, some strong teeth at the angle, which is rounded, and three recurved spines at the lower limb, the anterior of which is the strongest and very long. The sub- and interoperculum are entire. The operculum is provided with three conspicuous spines, remote from one another, and the middle one most projecting. The suprascapula with two or three spinous teeth.

The soft portion of the dorsalis is rather higher, and one-third shorter, than the spinous. The spines become longer to the fourth, which is the longest, together with the fifth and sixth, and then gradually diminish in size to the last, which still somewhat exceeds the second spine. The soft portion has a rounded superior margin, the anterior rays being one-third longer than the last spine. Caudalis rounded. The analis is distinguished by the very long and strong second spine; it is longer than any of the dorsal spines, and exceeds even half the height of the body; the first spine is rather more than one-half the length of the third. The six rays form together a very short fin with a rounded margin; none of the rays exceed the second spine in length. The pectoralis, rounded, and composed of 16 rays, extends as far as the ventral--that is, a little beyond the vent. The ventralis, of moderate size and form, is supported by a spine more than half the length of the fin.

There is not the slightest vestige of a eanine tooth in any of the specimens; the vomerine teeth are arranged in a triangular group, those on the palatine bones in narrow bands.

The coloration appears now to be brownish olive, being covered all over with round whitish (in life probably blue), dark-edged specks of the size of a scale.

Length of the largest specimen $7^{\prime \prime}$.

\section{POLYPRION.}

Polyprion, Cuv. Règne Anim. ; Cuv. \& Val. ii. p. 21.

Seven branchiostegals. All the teeth villiform; without canines; teeth on the palatine bones and on the tongue. One dorsal, with eleven snises; the anal fin with three. Opercles denticulated; a strong, rough longitudinal ridge on the operculum. Scales small.

Mediterranean, and the European part of the Atlantic. 


\section{Polyprion cernium.}

Amphibrion americanus, Bl. Schn. p. 205. t. 47.

Epinephelus oxygeneios, Bl. Schn. p. 301.

Scorpæna massiliensis, Risso, Ichthyol. Nice, p. 184 (not Lacép.).

Sciæna aquila, Rosenthal, Ichthyotom. Tafeln, pl. 16. f. 1.

Polyprion cernium, Valenc. Mém. du Mus. xi. p. 265; Cuv. \& Val. iii. p. 21. pl. 42, viii. p. 475; Yarrell, Brit. Fishes, i. p. 19; Cuv. Règne Anim. Ml. pl. 9. f. 1.

Serranus (Polyprium) Couchii, Yarrell, Brit. Fishes, i. p. 12.

Stone-Basse, Couch, Linn. Trans. xiv. p. 81.
D. $\frac{11}{11-12}$.
A. $\frac{3}{8-9}$.
Vert. 13/13.
Cæc. pylor. 2.

The height of the body equal to the length of the head, and onethird of the total. Uniform brown; caudalis rounded, with a whitish edge.

Mediterranean; Madeira ; coasts of Portugal, France, and England.

a. Large spceimen: stuffed. Plymouth. Mr. Yarrell's Collection.

b. Adult. Mediterranean.

c. Adult: stuffed. Sine patria. Mr. Yarrell's Collection (Polyprion couchii).

d. Adult: head, dried.

\section{POGONOPERCA*.}

A barbel at the lower jaw. Seven branchiostegals. All the teeth villiform; without canines; teeth on vomer and palatine bones. Dorsal deeply notched; the first with seven, the anal with three spines. Operculum spiniferous; præoperculum denticulated. Scales minute, imbedded in the skin.

\section{Pogonoperca ocellata. (PLATB XIV fig. $\mathbb{A}$ )}

$$
\text { D. } 7 \mid \frac{1}{12} \text {. A. } \frac{3}{8} \text {. }
$$

Barbel about as long as the diameter of the eye. Brownish, covered all over with small round white dots; three or four large brown blotches on the back (in dried state).

a. Adult: stuffed. Hab. - ?

Description of the specimen.-The height of the body is one-fourth of the total length, the length of the head is $3 \frac{1}{3}$ in the same. The upper surface of the head is short and narrow, the interspace between the eyes being one-ninth only of the length of the head. The snout is short, the cleft of the mouth oblique, the lower jaw prominent. There is a broad and well-developed barbel at the symphysis of the mandibulæ; it is rather longer than the diameter of the eye, and coloured like the body. The intermaxillary does not reach to the end of the maxillary, and is furnished with a broad band of villiform teeth, corresponding to a similar band in the lower jaw ; the vomerine

\footnotetext{
* From $\pi \dot{\omega} \gamma \omega \nu$, beard, and $\pi \dot{\varepsilon} \rho \kappa \eta$, perch.
} 
teeth are arranged at a right angle; the band of palatine teeth is short and narrow. The upper maxillary is styliform at its upper end only, and soon becomes broad, but is scarcely broader at its lower end thap in the middlo; it appears to reach behind the middle of the eye-perhaps to the posterior margin of the orbit. The eye is placed high up the side of the head, interfering with the upper outline of the head, and is of moderate size, its diameter being $5 \frac{1}{3}$ in the length of the head. Opereulum with three spines: the middle is the largest, flat, and much projecting; the upper is similar, but smaller; the lower is more distant, very small, and nearly hidden by the skin. The præopereulum is rounded, and armed behind with coarse, irregular, obtuse spinous teeth; the sub- and interoperculum appear to be entire. The specimen is so prepared that the branchiostegals may be seen; there are on one side distinctly seven, but on the other I count six only.

The spinous dorsal is connected with the soft by a distinct membrane; its base is much longer than that of the soft-nearly as long as the body is high. The spines are strong; the third is the longest, about half the length of the base of the spinous fin. There are seven spines-an eighth apparently belonging to the soft dorsal. The first spine is the shortest, and equal to the eighth; the second and fourth are not much lower than the third. The soft dorsal has been rounded, and is rather higher than the spinous. The eaudal rounded. The anal has three spines in front, the second of which is strongest and rather curved, but searcely longer than the third. Pectoral and ventral fins rounded; the base of the spine of the latter falis just below the root of the former.

The seales must have been very small and thin, and imbedded in the skin, as in the Tench. The coloration is reddish brown on the back, lighter beneath ; all the parts, except the upper portion of the spinous dorsal, are eovered with small, round, yollowish-white spots, each of which, on the body, may have corresponded in life to a scale. There is a large brown bloteh in front of the dorsal, between the occiput and the opereulum; a second smaller one extends below the fourth to the sixth dorsal spine; a third below the middle of the soft dorsal; a fourth on the back of the tail.

inches. lines.

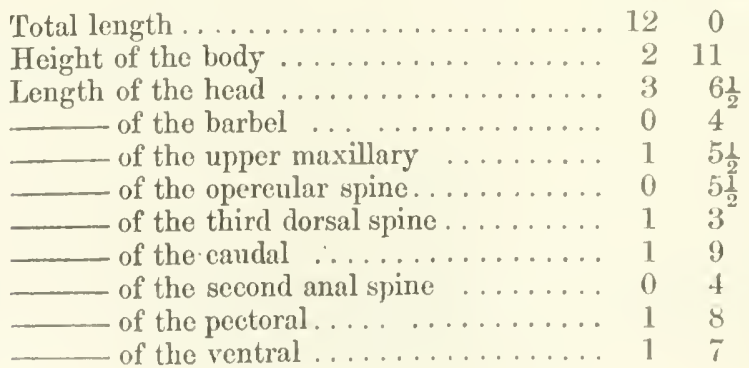




\section{GRAMMISTES.}

Grammistes, (Artedi) C'ur. Riyme Anim.; Cur. 8. Val. p. 201.

Seven branchiostegals. All tho teet: villiform; without canines; teeth on the palatine bones; tongue smooth. 'Two dorsals; the first with seren, the anal fin without conspienous spines. Operculum and preopereulum spiniferous, without serratures. Seales minute, enveloped in the epidernis.

Seas of the Indian region.

\section{Grammistes orientalis.}

Grammistes sebre, siba, 1ii. 27. 5 .

— orientalis, Bl. Schn. Syst. Posth. p. 189; Cur. \& V'al. ii. p. 203. pl. 27; Blecker, Amboina, iii. p. 15.

Perca bilineata, Thunb. Nor. Act. $11 \% / m$. xiij. p. 142. t. 5.

Scisena vittata, Lacép. iv. p. 32:33.

Perca triacanthus, Lacép. pp. 3918, 424.

- pentaeanthus, Laci(p). pp. 392, 424.

$$
\text { D. } 7 \mid \frac{1}{13} . \quad \Lambda, \frac{0}{8} \text {. }
$$

Body oblong, compressed; enudal rounded. Proopereulum with three spines. 'lendril rudimentary. Black or blackish brown; generally with six or seren white longitudinal bands.

Isle de France; Wast Indian Seas; Australia.

a. Mdult. Mauritius. Presented by the Zoological Socicty.

b. Adult: stufled. Mauritius.

c. Adult. Philippines.

d. Half-grown: stuffed. Indian Ocean. Presented by Sir $A$. Smith.

e. Half-grown. Australia. Presented by J. Macgillivray, Esi.

\section{Grammistes punctatus.}

Cuv. \&. Vul. vi. p. 504.

$$
\text { D. } 7 \mid \frac{1}{9} . \quad \Lambda \cdot \frac{0}{8} .
$$

Tendril developed. Propopereulum with three spines. Greyish brown with small white points.

Hab.

\section{RHYPTICUS.}

Rypticus, Cur. Riyme Anim.; Cur. \& Vul. iii. p. 60.

Sunectiens, Vulene. Porss. Voy. de la Vémus, p. :305.

Seven branchiostegals. All the teeth villiform, without eanines; teeth on the palatine bones; tongue smootl. Seales minute, enveloped in the epidermis. The spinous dorsit little developed, with the number of the spines variable; spines of the anal fin none, or small. Opereulum and propopereulum spiniferous. Air-bladder. simple. Pyloric appendages in small number.

Warmer parts of the Atlantic: Galapagos Archipelago. 


\section{Rhypticus saponaceus.}

Parra, p. 51. pl. 54. f. 2.

Anthias saponaceus, $B l$. Schn. p. 310.

Rypticus saponaceus, Cuv. \& Val. iii. p. 63.
D. $\frac{3}{25}$.
A. $\frac{1}{17}$.
Cæc. pylor. 6-7.
Vert. 10/14.

One continuous dorsal. The length of the bead equals the height of the body, and rather more than one-fourth of the total length. Dorsalis gradually becoming higher behind; pectoral rounded, moderate; ventral small. Brown.

Coasts of Tropical America; Cape of Good Hope; St. Helena; Cape Verde.

a. Adult : stuffed. Cape of Good Hope. Presented by Sir A. Smith. b. Adult: stuffed. St. Helena. Presented by Gen. Hardwicke.

e, $d$. Adult: stuffed. W. Indies. From Mr. Scrivener's Collection. e. Adult. St. Vincent's. Presented by the Lords of the Admira'ty. $f-h$. Adult and half-grown: skins. Jamaica. From Dr. Parnell's Collection.

i. Adult. America. Presented by the Zoological Society.

$k$. Half-grown: skeleton. From the Haslar Collection.

Skeleton.-Tho form of the skull deviates in many respects from that of the Serrani. The supraoccipital crest is low, and does not extend beyond the supraoceipital bone. The portion of the skull formed by the parietal and frontal bones is very compressed, smooth, without ridges, and eylindrically rounded; the space between the eyes is still narrower, with a groove in front for receiving the posterior processes of the intermaxillary. The præorbital has an entire, rounded, lower margin, tapering behind; the suborbital arch is very narrow, but supported at the inner side by a long and broad plate, which renders this arch very firm, and supports the eye from beneath; this plate occupies about one-third of the circle of the orbit. The maxillary bone gradually widens behind, and has a rather concave posterior and a convex anterior margin. There is a large open spave between the dentary and articulary bones of the mandibula. The præoperculum is narrow, crescent-shaped, without any prominent angle, and with two equal, flat, and triangular spinous teeth at its upper half; there is another smaller and obtuse tooth above these larger ones. The sub- and interoperculum ure entire. The area of the operculum is hardly larger than the eye; it is provided behind with three prominent spines, the middle of which is the longest, and the continuation of a strong ridge ${ }_{2}$ visible at the inner surface of the operculum; the two upper spines are nearer together, and the uppermost is situated at the upper angle of the opercle.

There are ten abdominal and fourtees caudal vertebræ. The neural spines of the first seven vertebræ are strong, compressed, and the more recumbent the more posteriorly situated; the posterior ones are also shorter. The ribs are shart, but thicker than in Serranus. There is only one rudimentary aual spine, and eonsequently the interhæmal is very feeble and slender, attached to the eleventh 
hæmal spine. The pubio bone is as feeble as the ventral fin itself; it is composed on each side of two narrow laminæ, forming together a channel.

All the teeth form rather broad villiform bands; in both the jaws they extend to the posterior extremity of the bone; those of the vomer are arranged in a triangular patch with emarginate hinder side.

\section{Rhypticus arenatus,}

Cuv. \& Val. iii. p. 65. pl. 45.

$$
\text { D. } \frac{3}{26} \text {. A. } \frac{0}{14} \text {. }
$$

One continuous dorsal. Greyish brown, punctulated with brown. Coast of Brazil ; Jamaica.

a. Half-grown. Jamaica. From Dr. Parnell's Collection.

b, c. Half-grown: skins. Trinidad. Yresented by J. B. Richardson, Esq.

\section{Rhypticus maculatus.}

Ë̈lbr. Ichthyol. S. Carol. p. 39. pl. 6. f. 2.
D. 2 | 25 . A. $\frac{0}{15}$. Cæc. pylor. 4.

The two dorsal spines separated from the soft portion. Olivebrown with whitish spots. (Holbr.)

Cape Romain (coast of S. Carolina).

\section{Rhypticus bicolor.}

Smecticus bicolor, Valenc. l. ¿. p. 307. pl. 2. f. 2.

$$
\text { D. } 10 \mid 21 \text {. A. } \frac{2}{15} \text {. }
$$

Crimson, marbled with lighter; all the fins black.

Galapagos Archipelago.

\section{AULACOCEPHALUS.}

Aulacocephalus, Temm. \& Schleg. Faun. Japon. p. 15.

Seven branchiostegals. All the teeth villiform; without canines; palatines?; tongue?. One dorsal, with nine spines, the anal fin with three. Operculum with three points; præoperculum strongly serrated at the lower limb. Scales small.

Indian Ocean.

\section{Aulacocephalus schlegelii.}

Aulacocephalus, sp., Faun. Japon. p. 15. pl. 5. f. 2.

$$
\text { D. } \frac{9}{13} \text {. A. } \frac{3}{10} \text {. }
$$

The height of the body is $3 \frac{3}{2}$ in the total length, the length of the bead is more than one-third of it. Sub- and interoperculum denticulated; suprascapula pointed. Violet; on each side of the back 
a broad yellow band, running from the muzzle through the eye along the dorsal fin to the upper part of the dorsal fin.

Coasts of the Mauritius and Japanese Seas.

$a, b$. Adult and half-grown: stuffed. Isle de Franec. Presented by Dr. Janvier.

\section{DIPLOPRION.}

Diploprion, (Kuhl \& van Hassclt) Cur. \& Val. ii. p. 137.

Seren branehiostegals. All the teeth villiform; without eanines; teeth on the palatine bones; tongue smooth. Two dorsals, the first with eight, the anal fin with two spines. Operculum spiniferous, præoperenlum with double denticulated limb. Seales small.

Seas of the Indian region.

\section{Diploprion bifasciatum.}

Diploprion bifasciatum, (Kulhl \& van Hasselt) Cur. \& Val. ii. p. 137. pl. 21; Fatn. Japone p. 2. pl. 2. A ; Rinhards. Ichthyol. China, p. 222; Bleck. in Verhand. Batar. Genotsch. xxri. p. 59, and Natunerk. Tyelschr. Nederl. Tud. vi. 1854, p. 207.

D. 8 15. A. $\frac{2}{12}$. Vert. 12/13. Cæe. pylor. 3.

Body $2 \frac{1}{2}$ as long as high, compressed ; the first dorsal fin half as high as trunk; rentrals long, pointed. Yellowish, with two broad black cross-bands.

Japanese, Chinese, and Jaranese Seas; Moluecas.

$a, b$. Adult. China. Presented by J. R. Reeres, Esq.

c. Adult: stuffed. China. Presented by J. R. Reeves, Esq.

d. Half-grown. China. Presented by J. R. Reeres, Esq. e-h. Adult. China.

$i, k$. Half-grown. Hong Kong. From the Haslar Collection.

1. Large specimen. Japan. Purchased of Mr. Frank.

m. Adult: stuffed. Japan. From Mrr. Frank's Collection.

n. Adult. Molucea Islands. From Mr. Frank's Colleetion.

o. Half-grown: stuffed. India.

$p-s$. Half-grown: not good state. India.

\section{MYRIODON.}

Centropristes, sp., Cur. \& V Val. iii. p. 48.

Myriodon, Brisout de Buerneville, Reer. Zool. 1847, p. 133.

Seven branchiostegals. All the teeth minute, rilliform; teeth on the palatine bones; tongue smooth. One dorsal, with twelve or thirteen spines, the anal fin with three. Opereulum spiniferous; præoperenlum denticulated, with spinous teeth at the lower limb, diructed forward. Seales moderate. The number of pyloric appendages small (none?).

Seas of the Australian region. 


\section{Myriodon waigiensis.}

Scorpæna waigiensi3, Quoy \& Gaim. Voy. Freyc. Zool. p. 324.pl. 58.f. 1. Centropristes scorpænoides, Cuv. \& Val. iii. p. 48; Richards. Ann.\& Mag. Nat. Hist. 1842, vol. ix. p. 120.

Myriodon scorpænoïdes, Bris. de Barnev. Rev. Zool. 1847, p. 130; Bleeker, Rionw. p. 480.

D. $\frac{12-13}{9-12}$. A. $\frac{3}{5}$. L. lat. 42 . L. transv. 8/17. Vert. 9/16.

The height of the body is one-third of the total length and equal to the length of the head; the diameter of the eye is one-third of the latter. On each side between the two nasal openings a short membranaceous appendage. Præoperculum with three or four spinous teeth beneath, directed forward; operculum with a single spine. Caudalis very slightly emarginate; the second spine of the anal very long and strong. Greyish, marbled with grey and brown.

Riouw; Waigiou; Port Essington.

a. Adult. Port Essington. Presented by J. Gould, Esq.

b. Adult : injured. Port Essington. From the Haslar Collection.

c. Adult : stuffed. Port Essington.

d. Young: dried. Freycinet's Harbour. Voyage of H.M.S. Herald.

e. Half-grown. Australia. Presented by Sir J. Richardson.

f. Adult: skeleton. Australia. From the Haslar Collection.

g. Adult. Purchased of Mr. Brandt.

A good description of the skeleton is given by Sir J. Richardson, l.c. p. 125 .

\section{GENYOROGE *.}

Diacope, sp., Cuv. Règne Anim.; Cuv. \& Val. ii. p. 410; Rüpp. Atlas, p. 70.

Mesoprion, sp., Bleeker.

Genyoroge, Cantor, Catal. p. 12.

Seven branchiostegals. Teeth villiform, with canines in both jaws; teeth on the palatine bones; tongue smooth. One dorsal with ten or eleven, rarely with more spines; the anal fin with three. Operculum with two or three points; abbve the angle of præoperculum a deep notch, as deep as broad, receiving a more or less spinous knob of the interoperculum. Scales moderate.

From the Red Sea through all the scas of the Indian region extending into the Pacific.

* 1. Diacope duodecim-lineata, Cuv. \& Val. vi. p. 529.-Isle de France.

2. - rufolineata, Cuv. \& Val. vi. p. 531.-New Guinea.

3. - axillaris, Cuv. \& Val. vi. p. 532,-East Indies.

4. —- flavipes, Cuv. \& Val. vi. p. 534.-Vanicolo.

5. — analis, Cuv. \& Val. vi. p. 534.--Isle de France.

6. - _ aurantiaca, Cuv. \& Val. vi. p. 536.-Vanicolo.

7. -- sanguirea, Cuv. \& Val. ii. p. 437.-Red Sea.

8. … vitianus, Hombr. \& Jacq. Voy. au Pôle Sud, Poiss: p. 37. pl. 2. f. 2. -Polynesia. 


\section{Genyoroge nigra.}

Sciæna nigra, Forskal, Deser. Anim. p. 47.

Lutjanus niger, $B l$. Schn. p. 326.

Dircope nigra, Cuv. \& Val. ii. p. 431; Rüpp. N. W. Fische, p. 93. t. 24 . f. 1 .
D. $\frac{19}{13-15}$.
A. $\frac{3}{10-11}$.
L. lat. $45-50$.

The height of the body is more than one-third of the total length; the length of the head is $3 \frac{2}{3}$ in the same; the upper profile of the head is very convex, forming a quarter of a eircle. Præoperculum serrated, with stronger denticulations at tho angle; the prominence of the interoperculum like a spine, directed forwards. Pectoral fins long, reaching to the front end of the anal; caudal truncated. Uniform black.

Red Sea.

a. Adult: stuffed. Rod Sea.

\section{Genyoroge macolor.}

Macolor, Renard, i. pl. 9. f. 60, ii. pl. 7. f. 30 ; Valent. iii. p. 348. pl. 1. f. 1 .

Diacope macolor, Cuv. \& Val. ii. p. 415, Less. Mtem. Soc. Hist. Nat. iv. p. 409, and Voy. Coq. Zool. ii. p. 230. pl. 22. f. 2.

Mesoprion macolor, Bleek. Celeb. iii. p. 752.
D. $\frac{10}{14^{\circ}}$
A. $\frac{3}{10}$.
Cæc. pylor. 4.

Præoperculum indistinctly serrated. Caudalis truncated; pectoral and ventral fins very long, reaching far beyond the front end of the anal. Black, belly lighter; a series of three white spots along the base of dorsal fin, two other spots below; a white band along the sides; head with two white cross-bands; fins black; caudal with white tips, and anal with a white posterior margin.

New Guinea; Amboynu; Celebes.

a. Adult. Molucea Sea. Purehased of Mr. Frank.

$b$, c. Adult. Amboyna. Purchased of Mr. Frank.

d. Half-grown. Amboyna. Purchased of Mr. Sterens.

\section{Genyoroge sebæ.}

Seba, iii. 27. 2 ; Russell, pl. 99.

Diacope sebæ, Cur. \& Tral, ii. p. 411.

- siamensis, Cuv. \& Val. vi. p. 524.

Mesoprion sebæ, Blecker, Perc. p. 45.

D. $\frac{11}{16}$. A. $\frac{3}{9-11}$. L. lat. 40 . Cæc. pylor. 4 (5 Cuv.). Vert. 10/14.

Head one-third of the total length, equal to the hoight of the body; the diameter of the eye is $4 \frac{1}{2}$ in the length of the head; the vertical and horizontal margins of the prooperculum serrated; caudal fin emarginate. Yellowish, with three broad blackish (reddish-violet) cross-bands.

Coast of Pondicherry ; Seas of Java, Amboyna, Waigiou ; Louisiade Archipelago; Coast of Mozambique. 
a. Adult. India. Presented by Sir J. Richardson.

b. Adult: stuffed. Louisiade Archipelago (15 fathoms). Voyage of the Rattlesnake.

c. Adult: skeleton. Amboyna. From Mr. Frank's Collection.

d. Adult: stuffed. Mozambique. Presented by T. Thompson, Esq.

Skeleton.-The skull is disting'uished not only by the development of all the bones situated in a vertical direetion, as we find usual in Genyoroge, but by much more developed nuciferous channels than in $G$. bengalensis, offering a further example of how little importance is the generie character drawn from this modification of the bones. The occipital crest is excecdingly high, with a rounded superior angle, and extends far between the orbits; in front it is separated into two laminæ, which, parting from each other in $G$. bengalensis, are close together in this species. There are two other ridges on ach side of this crest, both arising from above the orbit: the interior, parallel to the occipital crest, articulates with one of the processes of the suprascapula, and terminates behind in a prominent spinous point; the exterior muciferous ridge descends in an oblique direction and articulates with the other process of the supraseapula. The space between the eyes is very uneven on account of ridges and cavities. 'The præurbital bone is large, as large as the area of the eye, trapezoidal, and partly excavated by flat and low muciferous eavities; the suborbital arch muciferous, but otherwise as in $G$. bengalensis. The maxillary bone short, not longer than the prieorbital, gradually widening behind, with a nearly straight-lined upper edge and a rather concave one beneath. The opereulum has only one very short point, forming the end of an interior low erest; there is only a rounded prominence at the place where another point is generally found; it is produced by an emargination beneath. The prooperculun is minutely serrated abore and partly in the noteh, the denticulations being coarser, and radiating at the angle and the inferior limb; the sub- and interoperculum are entire; the knob of the latter is an obtuse point directed upward. The coracoid bone as in $G$. bengalensis.

Of the entire system of muciferous channels, that pair running along the upper surface of the skull is most developed; it is formed by the turbinal, entirely modified into a tube, and by the principal frontal bones. This channel has three openings: in front, the anterior opening of the turbinal; secondly, an opening formed by a turbinal and frontal bone together; finally, a third in the frontal bone alone, above the anterior margin of eye ; this channel is blind behind and does not communicate with the second, as in Acerina cernua. The second arises from above the josterior margin of the orbit, and soon separates into two stems: one of them, the scapular stem, follows the exterior ridge on the parietals, and being eurved upwards and backwards, passes into the supraseapula and the upper suprascapular process, where it is lost: the other, the suborbital stem, tollows the suborbital arch and expands on the preorbital; its openings are small and irregular. The third, or rather the fourth 
channel, runs along the inner part of the præoperculum, is in communication with the scapular stem, and passes beneath on the mandibula; there are several small openings on the præoperculum, but not so regular as those on the mandibula, where we find distinctly three: an entrance-opening behind on the articulary, a second between the angular and dentary, a third on the dentary, and, besides, a few rery small irregular nnes in front. Thus we have here, with slight modifications, and in a rather less developed degree, the same muciferous system as in Acerina cernua, or, in fact, in all the Percoids, but in a more or less rudimentary state.

The length of the abdominal vertebral column is to that of the caudal as 11:17. The first interhæmal spine is trihedral, of moderate size, and attached to the eleventh hæmal; its length is eq alal to that of the second vertebra to the ninth.

There are two rather small eanines on each side of the upper jaw the villiform band reaches to the end of the bone, and has sereral stronger teeth in the outer row. In the lower jaw the villiform band does not extend on the sides of the bone, there being only a single series of stronger teeth, continued also on the front of the jaw. Separate eanines cannot be distinguished. The band on the vomer forms a rather obtuse angle; that on the palatine bones is short and narrow.

\section{Genyoroge bengalensis.}

Renard, Poiss. i. t. 20. f. 110 ; Valentyn, Ind. iii. f. 25.

Sciæna kasmira, Forskal, p. 46.

Holocentrus bengalensis, Bloch, t. 246. f. 2 ; Bl. Schn. p. 316

- quinquelinearis, Bloch, t. 239.

Grammistes kasmira, Bl. Schn. p. 189.

Labrus octolineatus, Lacép. iv. p. 478. pl. 22. f. 1.

- Kasmira, Lacép iii. p. 483.

Perca polyzonias, Forst. Anim. cur. Licht. p. 225.

Diacope octolineata, Cur. \& Val. ii. p. 418, vi. p. 526; Faun. Japon. p. 12. pl. 6. f. 2 ; Richards. Ichthyol. China, p. 229.

- decemlineata, Cur. \& Val. vi. p. 528.

Mesoprion etaape, Less. Voy. Coq. Zool. p. 229.

- octolineatus, Bleeker, Perc. p. 40.

The length of the head is equal to the height of body, and $3 \frac{1}{2}$ in the total; the diameter of the eye is $3 \frac{1}{2}$ in the length of the head. The vertical and the horizontal margins of the præoperculum denticulated. Caudal fin emarginate. Yellowish ; on each side four or five blue longitudinal bands.

Red Sea; Isle de France; East Indian Seas; Polynesıa.

$a, b$. Adult. China.

c. Adult : skeleton. India.

$d, e$. Adult. India. Old Collection.

f. Half-grown: had state. India. From Mr. Frank's Collection.

g. Fine specir on. Feejec Islands. Voyage of the Herald.

$h$. Adult . stuffed. Louisiade Arehipelago; Chaumont Island. Voyage of the Rattlesnake. 
i. Adult: stuffed. Louisiade Archipelago (in 15 fathons ; sand and shells). Voyage of the Rattlesnake.

l. Arult: stufled. Louisiade Arehipelago. I'resented by the Lords of the Admiralty.

l, m. Half-grown: stuffed. Louisiarle Arehipelago. Presented by the Lords of the Armiralty.

$n-p$. Half-grown. Amboyna. Jurchased of Mr. Frank.

\%. $\Lambda$ rlult: stuffed Isle de lirance.

$r$ Half-grown : stuffed. Hed Sea. From the Frankfort Museum.

Sheleton.-The external appearance of the species of Gemyorore exlibiting a more elevated form than the Serrami, we find all the bones situated in a vertical direction, higher, and more devoloped. The horizontal part of the occipital crest is as broad as the vertical, bifid in front, and extending between the orbits. There are two other ridges on each side of this crest, wuch as may be found more or less developed in the Serrani: the interior, parallel to the oecipital erest, arises above the middle of the orbit, articulates with one of the proresses of the supraseapula, and terminates on the paroccipital bone, with a point dirceted backwards; tho exterior ridge arises from above the suborbital arch, deseends in an oblique direction, and artieulates with the other process of the suprascapula. The space between the orbits is neither eoncave nor convex, uncr('n, with several low ridges and grooves; the procorbital bone is large, trapezoidal, and broader than the space between the orbits; the suborlital areh is very narrow, and provided at its inner side with a broad, thin, concave plate for supporting the eyeball from bencath (as in Serramus). The maxillary bone gradually widens behind, with a rather convex superior margin and a rather concave inferior one. The operculum with an upper entirely rounded point, and with a lower moderate, acute spine; the præoperculum is minutely serrated above the notch, the denticulations becoming coarser at the angle and at the lower limb; sub- and interopereulum entire; the knoh of the latter is a ture spine, direeted upwards. The coracoid bone is formed, as usual, of two bones; but they are here very broad, the lower terminating in a point. The first interhomal spine is strong. equal to the length of the second vertebra to the eighth, and is fixed to the hæmal of the tenth. There is a pair of strong eanines on each side of the upper jaw; those of the lower jaw are very small; the teeth of the exterior series in the uandibula gradually hecome larger on the midlle of the dental bone, and again decrease in length behind ; the series of vomerine terth forms an obtuse angle.

\section{Genyoroge cæruleovittata.}

Diacope cæruleovittata, Cuv. \& Vul. vi. p. 5.30.

$$
\text { D. } \frac{11}{13} \text {. A. } \frac{3}{9} \text {. }
$$

Eight blue longitudinal bands on each sirle. Hye very large. ( I'rl.) Isle de France. 


\section{Genyoroge viridis.}

Diacope viridis, Valenc. Voy. Vénus, Zool. p. 303. pl. 1. f. 2.
D. $\frac{11}{14}$.
A. $\frac{3}{9}$.
L. lat. 55 .

Greenish, with four straight, dark green longitudinal bands. ( $\mathrm{Val}$.) Galapagos Archipelago.

\section{Genyoroge octovittatan.}

Diacope octovittata, Cuv. \& Val. vi. p. 528.
D. $\frac{12}{13}$.
A. $\frac{3}{3}$. Vert. 11/14.

On each side four broad (blue?) longitudinal bands; dorsal fin with a broad white margin.

Isle de France.

a. Adult: skeleton. Isle de France. From Mr. Gerrard's Collection.

The comparison of the skeleton of this species with that of $G$. bengalensis proves the real difference of both species. The general structure of the skeleton is much the same; but, besides the difference in the number of the fins and of the vertebro, the frontal benes are much broader, especially behind, where they form a conspicuous flat vault: the distance between the orbits is larger than one-half of the horizontal diameter of the osseous orbit, the same distance in $G$. bengalensis being smaller than one-half of that diameter. The first interhæmal spine is equal to the length of the second to the soventh vertebra, and is attached to the twelfth and thirteenth.

\section{Genyoroge rosea.}

Diacope rosea, Cuv. \& Val. vi. p. 537.

$$
\text { D. } \frac{13}{12} \text {. A. } \frac{3}{8} \text {. }
$$

Rose-coloured (in life); dorsal orange, with blue spots ; anal and ventral fins blue. ( $\mathrm{Val}$.)

Sea of Ulea (Caroline Islands).

\section{Genyoroge gibba.}

Sciæna gibba, Forsk. p. 46.

Lutjanus gibbus, $B l$. Schn. p. 326.

Diacope coccinea, (Ehrenb.) Cuv. \& Val. ii. p. 437 ; Riipp. N. W. Fische, p. 91. t. 23. f. 2 ; Peters, Wiegm. Archic', 1855, p. 238.

- gibba, Cuv. \& Val. ii. p. 438.

$$
\text { D. } \frac{10}{14} \text {. A. } \frac{3}{8-9} \text {. }
$$

The length of the head is $3 \frac{1}{2}$ in the total, and the height of the body $2 \frac{3}{4}$ in the same. The upper prefile of the head gibbous above the eyes; muzzle elongate, pointed. Pectorals pointed, hardly reaching to the front end of the anal; caudal notched. Uniform reddish rose-coloured, with two rather irregular yellow streaks passing from the muzzle below the eye to the pectorals; dorsal, anal, and ventral fins with white pesterior edges.

Red Sea ; Coast of Mozambique. 


\section{Genyoroge notata.}

Russell, pl. 98.

Diacope notata, Cuv. \& Val. ii. p. 422.

Genyoroge notata, Cantor, Catal. p. 12.

$$
\text { D. } \frac{10}{14} \text {. A. } \frac{3}{8} \text {. }
$$

Back reddish brown; a black blotch on the lateral line (according to Valeneiennes, above the lateral line); from the orbit, above the lateral line, three obliquely ascending orange lines, of whieh the lowest reaches to the middle of the base of the dorsal rays; beneath the lateral line three or four similar parallel lines, of which the uppermost divides the black spot; the rest nearly straight from the operculum towards the tail.-Young: head above and back brownish; stripes of the body brown. (Cantor.)

Sea of Pinang; Bay of Bengal.

Mesoprion mssellii, Bleeker, seems ta be a different species, belonging to the group with a superficial notch at the vertical margin of the prooperculum.

\section{Genyoroge marginata.}

Diacope marginata, Cuv. \& Val. ii. p. 425; Peters, Wiegm. Archiv, 1855, p. 238.

- xanthopus, Cuv.\& Val. iii. p. 495.

Mesoprion marginatus, Bleeker, Amboinn, ii. p. 554.

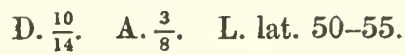

Uniform yellowish (in a dried state); dorsal, anal, and eaudal fins with a black and whitish edge. The height of the body is $3 \frac{1}{3}$ in the total length, the length of the head $3 \frac{2}{5}$; the diameter of the eye is one-fourth of the length of the head. Pectoral fins pointed, long, reaching to the spinous part of the anal fin. Caudalis notehed.

Louisiade Archipelago; Amboyna; Ceylon; Coast of Mozambique.

$a, b$. Adult: skin. Ceylon. Presented by the Zoologieal Society.

c. Half-grown. Amboyna. Purchased of Mr. Stevens.

d. Young. Amboyna. Purehased of Mr. Frank.

$e, f$. Half-grown: stuffed. Louisiade Archipelago. Presented by the Lords of the Admiralty.

$g, h$. Half-grown. From the Collection of the Zoological Society.

\section{Genyoroge bottonensis.}

Holocentrus boutton, Lacép. iv. pp. 331, 367.

Diacope bottonensis, Cuv. \& Val. i. p. 434, vi. p. 535.

Mesoprion bottonensis, Bleeker, Natuurk. Tydsehr. Nederl Indie, ii. p. 170.

jauthinurus, Bleeker, l.c. vi. p. 52.
D. $\frac{10}{14-15}$.
A. $\frac{3}{8}$.
L. lat. 65 .

The height of the body equals the length of the head, and is $3 \frac{1}{8}$ in the 
total; the diameter of the eye one-fourth of the length of the head. Denticulations of the lower margin of the prxoperculum rather stronere than those of the posterior; caudalis notched ; pectoral fins reaching to the base of the anal; the third, fourth and fifth dorsal spines longest; the second anal spine longer and stronger than the third. Red: brownish red on the back, with numerous oblique darker bands abore the lateral line; fins immaeulate.

Sumatra; Amboyna; New Guinea.

a. Adult. Amboyna. From Mr. Frank's Collection.

b. Half-grown. Amboyna. From Mr. Frank's Collection as Mesoprion annularis.

c, d. Half-grown and young. Amboyna. From Mr. Frank's Collection.

\section{Genyoroge rivulata.}

Diacope rivulata, Cuv. \& I Ul. ii. p. 414. pl. 38 ; Rüpp. N. W. Fische, p. 94.

? Diacope alboguttata, Cuv. \& Val. vii. p. 445.
D. $\frac{10}{14-16}$.
A. $\frac{3}{8-9}$.
L. lat. 54 .
Cicc. pylor. 5.

The length of the head is $3 \frac{2}{3}$ in the total, the height of the borly $3 \frac{1}{3}$ only. Caudal fin very slightly emarginate. Brownish, retienlated with blue on the opereles; each scale with a light centre and a darker base and edge; a white spot above the lateral line, opposite to the front end of the anal fin, more or less visible in dried specimens; fins blackish, with darker edges.

Red Sea; Coasts of Coromandel and Malabar; Chinese and Javanese Seas.

a. Adult. China.

b. Adult: stuffed. China. Purchased of Mr. Warwick.

c. Adult: stuffed. China. Presented by J. R. Reeres, Esq.

d. Half-grown. Amboyna. Purchased from Mr. Frank as Mesoprion quadripunctatus.

e. Adult: stuffed. Rel Sea. From the Frankfort Museum.

\section{Genyoroge cæruleopunctata.}

Russell, i. p. 75. pl. 96.

Diacope caruleopunctata, Cuv. \&. Vul. ii. p. 424.

Mesoprion cierulcopunctatus, Blecker, Natuurk. Tydschr. Nederl. Indie, 1851, p. 169.
D. $\frac{10}{15}$.
A. $\frac{3}{8}$.
L. lat. $45-50$.

The height of the body is $2 \frac{3}{4}$ or 3 in the total length, the length of the head $3 \frac{1}{4}$ in the same; the diameter of the eye $3 \frac{1}{2}-4 \frac{1}{2}$ in the length of the head. Caudalis scarcely emarginato; the third, fourth and fifth dorsal spines longest; the second anal spine strongest and longest; the first ray of the ventrals rather clongate. Brownish red, with blue streaks on the forehead, the checks, and opereles; a black ring on the lateral line, below the front part of the soft dorsal fin ; fins immaculate. ( $B l$. .)

Coast of Coromandel : Sea of Padang (Sumatra). 
15. Genyoroge melanura.

Diacope melanura, Rüpp. N. W. Fische, p. 92. t. 23. f. 1.
D. $\frac{10}{14}$.
A. $\frac{3}{8-9}$.
L. lat. 60.
Crec. pylor. 4 .

The height of the body is $3 \frac{1}{4}$ in the total length, and equal to the length of the head. P'roopercuhum serrated, with stronger denticulations helow the noteli. Upper profile of the head straight. l'ectoral fins pointed, reaching nearly to the front end of the anal; caudalis notched. The third, fourth and fifth dorsal spines longest; the second of the anal fin longer and stronger tham the third. Uniform crimson; dorsal, candal, and anal fins white-edged; basal part of the candal of black colour (disappearing in dried specimens).

Red Sea.

a. Adult: stuffed. Red Sea. From the Frankfort Museum.

\section{Genyoroge amboinensis.}

Mesoprion amboinensis, Bleeker, Amb. \& Cer. p. 259.

$$
\text { D. } \frac{11}{13} . \quad \text { A. } \frac{3}{8} \text {. L. lat. } 55 \text {. }
$$

The height of the body is $3 \frac{1}{4}$ in the total length, the length of the head $3 \frac{1}{3}-3 \frac{1}{4}$ in the same; the diameter of the eyce is $3 \frac{1}{2}$ in the length of the head. Caudalis slightly emarginate; the middle dorsal spines longest; the second anal spine longest, longer than the rays. Rose-coloured: back witb oblique red streaks, sides with fire or six yellow longitudinal stripes; fins yellow; a black blotch immediately above the lateral line.

Sea of Amboyna.

\section{$a, o$. Half-grown. Amboyna. Purchased of $\mathrm{Mr}$. Frank.}

Blocker (l.c.) describes the above species with eleven spines of the dorsal fin, and the following with ten; in subsequent memoirs he unites them, without explaining his reasons for it. If there is no mistake in the numbers given, both species must be different, as we have never found any variation in the number of the dorsal spines either in Gemyoroge or in Mesoprion. Not having specimens of both the species, I am unable to decide the question, and give the dịagnosis of $M$. melimospilos.

\section{Genyoroge melanospilos.}

Mesoprion melanospilos, Bleeker, Celebes, iii. p. 750.

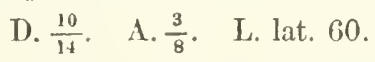

The height of the body is $3 \frac{1}{2}$ in the total length, and equal to the length of the head; the diameter of the eye is $3 \frac{1}{2}$ in the latter. Upper maxillary bone reaching to below the middle of the eye ; the notch of the pricoperculum very deep, and apparently bifid; the fifth spine of the dorsal fin and the second of the anal longret; candalis 
notched. The black lateral bloteh between the lateral line and the anterior dorsal rays; the spinous part of the dorsal fin black-edged: a black spot above the base of the pectoral fins. $(B l$.

Sea of Bulueomba (Celebes).

\section{Genyoroge fulva.}

Perea fulva, Forster, MSS.

Holocentrus fulvus, Bl. Schn. p. 318.

Diacope fulva, Cuv. \& Val. ii. p. 435.

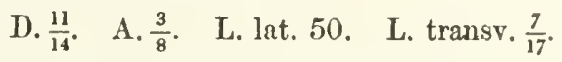

The height of the body is equal to the length of the head, and $3 \frac{1}{2}$ un the total; the diameter of the eye is $4 \frac{1}{2}$ in the length of the head, and equal to two-thirds of the distance between the eye and the end of the muzzle ; the upper maxillary hone reaches nearly to the level of the anterior margin of the eye; the prooperculnm exhibits fine denticulations above the notch, coarser ones beneath. Caudalis very slightly coneave behind. The fourth dorsal spine and the second of the anal fin longest and strongest; pectorals scarcely reaching the front end of the anal. Uniform yellowisl red; caudalis white-edged.

Sea of Otaheiti.

a. Adult : bleached. Otaheiti. Old Collection.-Forster's original specimen.

\section{Genyoroge civis.}

Diacope civis, Cuv. \& Val. vii. p. 444.

$$
\text { D. } \frac{11}{16} \text {. A. } \frac{3}{8} \text {. }
$$

The length of the head is one-third of the total, and equal to the height of the body. Uniform brownish red, with $a$ brown spot on the soft parts of the dorsal and anal fins, and two brown streaks on the caudal. ( $V a l$.

Seychelles.

\section{MESOPRION*.}

Mesoprion, C'uv. Rène Anim.; Cuv. \& Val. ii. p. 439.

Diacope, sp., Rüppell, Atlas, p. 70.

Mesoprion, sp., Blecker.

Seven branchiostegals. Teeth villiform, with canines in both jaws; teeth on the palatine bones. One dorsal, mostly with ten or eleven, rarely with nine or twelve spines, the anal fin with three. Opereulum generally with two or three, rarely with one indistinct point; præopereulum with fine serrature, without or with a very open notch. Scales moderate.

All the seas of the Tropical regions.

* 1. Mesoprion aurolineatus, Cuv. \& Val. iii. p. 496.-Ceylon.

2. Mesoprion richardi, $C u$ \& $V$ al. ii. p. H8.-Caribbean Sea.

3. Mesoprion tæniops, Cuv. \& Val. vi. p. 543.-Celcbes (rivers).

4. Mcsoprion cyanopterus, Cuv. \& Val. ii. p. 472.-Brazil. 


\section{Synopsis of the Species.}

I. Preoperculum finely or moderately denticulated.

A. Coloration uniform, or with indistinct oblique and longitudinal streaks.

1. Ten dorsal spines.

a. Without a large black lateral blotch.

a. Caudal fin deeply forked.
1. M. microchir,
2. M. chrysurus.

B. Caudal fin trumcated, or slightly notched.

aa. Ground-colomr olive, with a yellow, green, or browu shado.
3. M. sparus,
8. MI. bitæniatus,
4. M. dentatus,
9. M. waigriensis,
5. M. carponotatus,
10. M. chrysotænia,
13. M. gembra,
14. M. cynodon,
6. M. bohar,
11. M. argentimaculatus,
7. M. caudalis,
12. M. lineatus,
15. M. griseus,
16. M. buccanella,
17. M. aya.

$b b$. Ground-colour red.

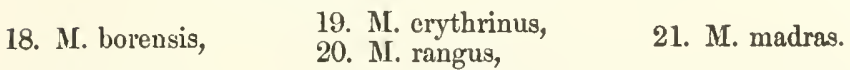

b. With a large black lateral blotch.

22. M. johnii,

23. M. fuscescens,

24. M. fulviflamma,

25. M. uninotatus,

26. M. mahogoni,

2. Eleven dorsal spines.

28. M. annularis, 30. M. erythropterus,

29. M. malabaricus, 31. M. lineolatus,

32. M. timoriensis,

3. Twelve dorsal spines.

34. M. dodecacanthus, 35. M. dodecacanthoides, 36. M. aurorubens.

5. Mesoprion pargus, Cuv. \& Val. ii. p. 473.-Porto-Rico.

6. Mesoprion flavipinnis, Cuv. \& Val. ii. p. 475.-Pondicherry.

7. Mesoprion rubellus, Cuv. \& Val. ii. p. 475.-Pondicherry; Red Sea

8. Sillaoo, Russell, pl. 100.-Mesoprion sillaoo, Cuv.\& Val. ii. p. 476.-East Indies.

9. Mesoprion fulgens, Cuv. \& Val. vi. p. 539.-Coast of Groea.

10. Lutjanus lutjanus, $B l$. t. 245.-Mesoprion lutjanus, $C u v$. \& Val. ii. p. 479. -East Indies.

11. Chirtah, Russell, i. pl. 93.-Mesoprion chirtah, Cuv. \& Val. ii. p. 488.Bay of Bengal.

12. Karooi, Russell, ii. pl. 125.-Mesoprion carui, Cuv. \& Val. ii. p. 489 ; Cantor, Catal. p. 16.-Bay of Bengal.

13. Lutjanus albo-aureus, Lacép. iv. pl. 7.f. 1.-Mesoprion albo-aureus, Cuv. \& Val. ii. p. 489.

14. Perca lunulata, Mungo Park, Trans. Linn. Soc. iii. p. 35. pl.6.-Lutjanus lunulatus, $B l$. Schn. p. 329 ; Lacép. iv. p. 213.-Mesoprion lunulatus, Cuv.\& Val. ii. p. 477.-Sumatra.

15. Mesoprion olivaceus, Cuv. \& Val. ii. p. 478.-Waigiou.

16. Mesoprion erythrognathus, Cuv. \& Val . vii. p. 447.-Seychelles.

17. Mesoprion? emeryii, Richards. Ic. Pisc. p. 7. pl. 3. f. 2.-Australia.

18. Mesoprion elongatus, Hombr. \& Jacq. Voy. au Pôle Sud, Poiss. p. 38. pl. 2. f. 3.-Hab.

19. Mesoprion argenteus, Hombr. \& Jacq. l.c. p. 39. pl. 2. f. t.-Hab. —?

20. Mesoprión caudanotatus, Poey, Memor. Cuba, 1851, p. 440 lam. 3. f. 3.Cuba. 
B. With a more or less broad, distinet, blackish lateral bund.

37. M. vitta, 38. M. bleekeri, 39. M. enneacunthus.

C. Witl permanent blackish cross-bands.

40. II. semicinctus.

D. With several distinct longitudinal bands.

41. II. quinquelineatus, 42. M. sobra, 43. M. decursatus.

II. Species with anomalously armed preoperculum.
44. M. retrospinis,
45. M. pomacanthus.

I. Prooperculum moderately or finely denticulated.

A. Coloration uniform, or with indistinct oblique and longitudinal strectis.

\section{Ten dorsal spines.}

a. Without a large black lateral blotch.

a. Caudal fin deeply forlied.

\section{Mesoprion microchir.}

Blecker, Amboyna, iv. p. 332.
D. $\frac{10}{10-11}$.
A. $\frac{3}{7-8}$.
L. lat. 50 .

The height of the body is $5 \frac{1}{2}$ in the total length, the length of the head four times; the diameter of the eye is $3 \frac{\mathrm{I}}{2}$ in the latter; the upper profile of the head convex. The lower jaw rather prominent, the upper maxillary bone reaching to below the anterlor half of the eyc. Prxopereulum not notched. Cundalis decply forked; the dorsal spines slender, the middle ones nearly equal in length, higher than the rays; the third anal spine longest. Yellowish olive; the dorsal fin brown-spotted at the base, and above brown-edged, tho other fins immaculate. $(B l$.

Sea of Amboyna.

\section{Mesoprion chrysurus. Guv.}

Rabirubbia, Parra, pı. 22. f. 1.

Colas, Duhamel, P'éches, iv. cap. 5. p. 6.t. pl. 12. f. 1.

Acara pitamba, Margr. p. 155.

Sparus chrysurus, $1 \%$. t. 262 ; Lacép. iv. p. 115.

Grammistes clirysurua, Bl. Schn. p. 187.

Anthias rabirubbia, 31. Schn. p. 309.

Sparus semiluna, Lacép. iv. 1p. 141, 142. pl. 3. f. 1.

Mesoprion chrysurus, Cux. $y^{\circ}$ Val. ii. p. 459; Guichcn. Pois.s. in Ramon de la Sagra, II ist. Cuba, p. 24.

- anrovittatus, Spix, Fiscle Brosil. pl. 66.
D. $\frac{10}{13}$.
A. $\frac{3}{9}$.
L. lat. 55-6n.
L. transv. 9/18 Vert. 10/14.

The height of the body is equal to the length of the head, and one-fourth of the total. Camblis deply forked, with the upper Johe longest; pectorals raching to the origin of the anal. Prox- 
operculum very indistinctly emarginate; interopereulum without knob. Greenish olive, with oblique streaks above the lateral line, and some shining golden longitudinal bands on the sides. No lateral blotch, nor a spot in the axil.

Caribbean Sea; Coast of Brazil.

a. Fine specimen. West Indies. From the Haslar Collection.Head above with small round violet spots.

b. Half-grown. Puerto Cabello. Purchased of Mr. Brandt.

$c, d$. Adult : skins. Jamaica. From Dr. Parnell's Collection.

e, f. Half-grown : skins. Jamaica. From Dr. Pamell's Collection.

g. Half-grown: skin. Jamaica. Purchased of Mr. Cuming.

h. Skin: not good state. Trinidad. Presented by J. B. Richardson, Esq.

i-n. Half-grown : skin. West Indies. Purchased of Mr. Scrivener.

o. Skeleton. From the Collection of the Zoological Society.

p. Half-grown. From the Haslar Collection.-Spotted like specimen $a$.

Skeleton.-The skeleton of this species deviates more from those of M. uninotatus and griseus than these species from each other. The maxillary bone gradually widens from the base to its extremity, and has the posterior margin nearly straight and the anterior concave. The posterior processes of the maxillary bones are of moderate length, about one-half the length of the bones themselves; each of these is armed in front with three canines, of nearly equal and of moderate size. There is a series of short conical teeth along all the outer margin, accompanied by a posterior villiform band. The mandibulary is furnished with an outer series of conical teeth, gradually becoming smaller in the posterior portion of the jaw; there are some villiform teeth besides, near the symphysis. The vomerine teeth are arranged in an anchor-shaped villiform band, occupying more than half the length of the bone. The palatine teeth form a band, five times as long as broad, and not extending on the pterygoid. The turbinal bones are well developed, elongate, and slightly divergent; they leave between them a triangular groove to receive the processes of the intermaxillary bones. A short triangular portion of the ethmoid is visible between the branches of the occipital crest, which in this specics is rather elevated, to its anterior extremity, and extends along all the suture of the frontal bones. The lateral crests are relatively much less developed, and the interior arises from the middle of the space between the occipital crest and the upper margin of the orbit. The præorbital is large, irregularly quadrangular, and smooth; the remainder of the infraorbital bones are narrow, and form the base for a large concave plate reaching into the interior of the orbit.

The operculum has two obtuse points, with a notch between; a ridge on the interior surface of the operculum corresponds to the lower of the points; the sub-and interoperculum are entire. . The limbs of the præoperculum have a rather oblique direction towards each other; the angle is rounded, and furnished with obtuse denticulations. The posterior limb has an exceedingly fine serrature, $\mathrm{cx}-$ 
tending into the noteh, which is scarcely conspicuous. The inferior limb is entire. Supraseapula scarcely denticulated. The glossohyal is oblong, of nearly equal width posteriorly and anteriorly, and covered with exceedingly fine villiform tceth; the urohyal terminates posteriorly in two points, the lower of which is elongate; there is a semicircular notch between. The basal portion of the skull is slightly swollen, and there is a deep and broad longitudinal groove behind the condyle of the basioccipital.

There are ten abdominal and fourteen caudal vertebræ, the length of the former portion of the column being to that of the caudal as $1: 1.55$. The first interhæmal spine is not strong, and equal to the length of the first six rertebre together ; it is attached to the hæmal spines of the eleventh and twelfth vertebrx.

$\beta$. Caudal fin truncated, or slightly notched.

$a a$. Ground-colour olive, with a yellow, green, or brown shado.

\section{Mesoprion sparus.}

Diacope sparus, Temm. \&. Schleg. F'azn. Japon. Poiss. p. 14.

$$
\text { D. } \frac{10}{10} \text {. A. } \frac{3}{8} \text {. }
$$

Physiognomy sparoid. The upper maxillary bone reaching to below the middle of the eye. Præoperculum with exceedingly fine deuticulations, and a slight notch behind; suprascapula denticulated. Caudalis notched; the second anal spine shorter, but stronger, than the third. Uniform brownish. (Schleg.)

Sea of Japan.

\section{Mesoprion dentatus.}

Apsilus dentatis, Guichen. in Ramon de la Sagra, Hist. Cuba, Porss. p. 29. pl. 1. f. 2 .
D. $\frac{10}{10} .4 \cdot \frac{9}{8}$.
L. Lat. 60 .
L. transv, $10 / 18$

The upper maxillary reaches scarcely beyond the anterior margin of the eye. Prooperculum with a very slight noteh, with the posierior limb exceedingly finely serrated, and with eonspicuous denticulations beneath. Dorsalis nearly even, candalis forked; the second anal spine shorter, but not stronger, than the third. Coloration uniform. Jamaica.

$a, b$. Adult: skins. Jamaica. From Dr. Parnell's Collection. c. Half-grown: skin. Jamaica. From Dr. P'arnell's Collection.

Description.-This species is very remarkable for its being an intermediate form between species of Centropristis, Anthias, and Mesoprion. I place it in the latter genus on account of the preopercular noteh, which, slight as it is, nevertheless is present, and followed by more conspicuous denticulations of the angle. Otherwise this species has much similarity to Centropristis atrarius, Anthias macrophethalmus, aid Mesoprion aurombens in general habit, and in the small number 
of the rays of the rertical fins. The preceding species, Mesoprion sparus, appears to be closely allied to the fish of the present description; and it is a very remarkable fact in the geographical distribution of fishes, that we find several species, described by Schlegel in the 'Fauna Japonica,' represented in the Atlantic by others, not or scarcely different,- - viz., among the Serranina, Anthias oculatus, Serranus tsirimenara and margaritiferus, Mesuprion sparus and dentatus.

The height of the body is $3 \frac{1}{3}$ or $3 \frac{1}{2}$ in the tatal length, the length of the head four times. The eye is situated in the niddle of the length of the head, in which its diameter is contained $4 \frac{1}{3}$; the interspace between the eyes equals the diameter. The snout is $1 \frac{1}{2}$ as long as the eye is wide; the cleft of the mouth moderate, stightly oblique, with the lower jaw rather prominent. The upper maxillary reaches to, or slightly beyond the vertical from the anterior margin of the orbit. The front head. the snout, and the præorbital are completely scaleless.

The præoperculum has a naked margin, broadest at the angle; the remainder is scaly, there being seven rows of scales between the eye and the lower limb of the præoperculum. The posterior limb is slightly curved, and furnished with an exceedingly fine serrature; there is a very slight notch immediately above the angle; the angle and the lower limb form one curvature, with distinct denticulations. The operculum is nearly twice as high as wide, with the base naked, as in many fishes; it is covered with seren oblique rows of scales. and terminates posteriorly in two obtuse points with a notch between. The suboperculum has two or three rows of scales, one of which extends over all its length. The interoperculum is elongate, crescent-shaped, with two series of small scales.

The origin of the dorsal fin corresponds to the 6th scale of the lateral line, the end to the $39 \mathrm{th}$, the origin of the soft portion to the 26 th-consequently the base of the spinous is much longer than that of the soft. The upper margin is slightly undulating, the fourth and fifth spines and the fifth ray being equal in length, and $2 \frac{1}{2}$ in the total ; the last dorsal spine is one-fourth shorter. All the spines are slender and equal in strength. The dorsal fin is entirely scaleless. The caudal fin is moderately forked, the middle ray being half the length of the longest; small scales cover about one-half of the fin. The origin of the anal fin corresponds to the vertical from the 28th scale of the lateral fin, the end to that from the 41st. The spines are feeble; the first is une-half the length of the second, the second twothirds the length of the third; the third is three-quarters the length of the first ray, which equals the ninth dorsal spine; the last ray is slightly elongate and prominent beyond the margin of the fin. The pectoral fin is elongate, pointed, and extends backwards to the first or second ray of the anal fin; a short triangular patch at the base is scaly. The ventral fin is similer and extends to the vent.

The lateral line follows the outhne of the back, and is formed by scales rather smaller than the others.

The lateral series of teeth in the jaws contain larger.ones than 
those of the villiform bands, and there are two or three canines of moderate size on each side, above and beneath. The romerine teeth form a triangular jatch, with an anterior obtuse angle. The palatine band is cuneiform, narrow

The eoloration is now uniform greyish, the seales of the back haring a darker margin; the dorsal, anal, and rentral fins blackish.

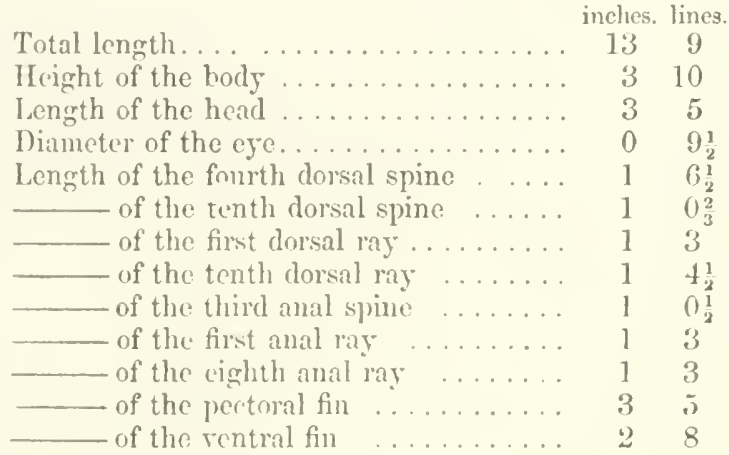

\section{Mesoprion carponotatus.}

Richardson, Amm. \& Mag. Nut. Itist. 1842, rol. ix. p. 28.

$$
\text { D. } \frac{10}{15} \text {. A. } \frac{3}{10} \text {. L. lat. } 63 \text {. }
$$

External appearance sparoid. 'The length of the head is $3 \frac{2}{3}$ in the total length, and equial to the height of the body; the diameter "If the eye is $4 \frac{1}{3}$ in the length of the lead. Proopenculum with a few scarecly visible denticulations, slightly emurginate; opereulum rounded, as in Sparus, with a shallow re-entering are; supuseapula entire. C'andalis truneated : the point of the pectoral fin falls short of the anus. The fourth dorsal spine longest, the second and third of the anal fin nearly equal. Colorition uniform, with a black spot at the root of the peetorial fin.

North Australian Coast.

a. Adult. Port Essington. From Mr. Gilbert's Collection.

\section{(j. Mesoprion bohar.}

Sciena bohar, Forsk. p. 46.

Sparus lepisurus, Lacep. iii. pl. 15. f. 2.

Lutjanus bohar, 131. Schn. p. 325 .

biacope hohar, Cuv. S. Ful, ii. p. 433: Rupp. Atl. Fische, p. 73, and N. II. Fisshe, p. 10:3.

J basope quadriguttata, Cur. \& Vul. ii. p. 427, vi. p. 533.

$$
\text { 1). } \frac{10}{16} \cdot A \cdot \frac{3}{9} \text {. Vert. } 10 / 14
$$

The height of tho body is $3 \frac{3}{1}$ in the total length, the length of the head $: 3 \frac{1}{4}$. Interoperenlum with a distinet knob, propoperenlum 
slightly notched. Caudalis notched; pectorals not fully reaching to the anal. Brownish ; in immature specimens two whitish blotches on each side of the back, disappearing after death.

From the Red Sea along the eastern coast of Africa; (East Indies).

Diacope quadriguttata, Cnv., after having been united by Rüppell with Diac. bohar, and acknowledged by Valenciennes as the young animal of the latter, is now again separated by Bleeker (Natuurk. Tydschr. Nederl. Indie, ii. p. 233). The descriptions of D. bohar are not sufficient to enable us to decide, without specimens from the Red Sea and the East Indies, whether there are really two different species or not. Blecker, in his description, mentions the præoperculum as bcing deeply notched.

a. Half-grown: not good state. Madagascar. Presented by Dr. J. E. Gray.

\section{Mesoprion caudalis.}

Cuv. \&. Val. vi. p. 537.

$$
\text { D. } \frac{10}{13}, \quad \text { A. } \frac{3}{7} \text {. }
$$

Caudalis slightly rounded ; præoperculum with a very conspicuous notch, and stronger denticulations beneath. Yellowish olive, with violet longitudinal streaks abore and beneath the lateral line; caudal fin with a large, triangular, violet, yellowish-edged bloteh ; the spinous part of the dorsal fin blackish; the other fins yellowish. ( $V a l$.

Vanicolo Islands.

\section{Mesoprion bitæniatus.}

Diacope bitæniata, Cuv. \& Val. vi. p. 536; Quoy \& Gaim. Voy. Astrol. Poiss. p. 664. pl. 5. f. 2.

$$
\text { D. } \frac{10}{12} \text {. A. } \frac{3}{7} \text {. }
$$

Caudalis slightly emarginate. Yellowish, with oblique streaks above the lateral line, and longitudinal beneath; two red bands across the cheek, and a black one across the middle of the caudal fin.

Celebes.

\section{Mesoprion waigiensis.}

Diacope waigiensis, Quoy \& Gaim. Voy. Freyc. Zool. p. 307. immaculata, Cuv. \& Val. ii. p. 430 *.
D. $\frac{10}{14}$.
A. $\frac{3}{9}$.
L. lat. 75 .

The height of the body is $3 \frac{2}{3}$ in the total length, and equal to the length of the head; the diameter of the eje is $4 \frac{2}{3}$ in the latter. Præoperculum very finely serrated; notch conspicuous, knob rather indistinct. Caudalis emarginate; pectoral distant from anal fin ; the third and fourth dorsal spines longest; the second of the anal

* Cuvier quotes this species as Diacope immaculata, Quoy \& Gaim.; but this name was given by himself, instead of the true denomination mentioned above. 
stronger, but not longer, than the third. Uniform olive (in il died state), with' indistinet oblique streaks above the lateral line, and longitudinal ones beneath ; base of the pectoral with a narrow black spot.

Sea of Waigion ; Port Essington.

a. Adult: stuffed. Port lissington.

There is a tooth near the symphysis of the intermaxillary bunes, stronger than those of the velvet-like banil; then, more at the side, but in front of the muzzle, a very strong and long canine; then a series of nine or ten smaller ones, gradually becoming smaller behind; at the inside of these canines is the band of relvet-like teeth. In the exterior series of the lower jaw are four canines in front and at the side; and then follow two lixger ones, but smaller than the fang of the upper jaw.

\section{Mesoprion chrysotænia.}

Blecker, Natuurk. Tydsclir. Nederl. Indie, ii. 1851, p. 170, and Art. Soc. Sc. Indo-Nederl. i. p. 40.

$$
\text { D. } \frac{10}{15} \text {. A. } \frac{3}{9} \text {. L. lat. } 65 \text {. }
$$

1ue beight of the body is $3 \frac{1}{4}$ in the total lengtl, the length of the head $3 \frac{2}{5}$; the diameter of the eye is one-fourth of the latter ; the uppor profile of the head straight-lined. Supraseapula and preoperculum serrated, the latter with a conspienous noteh behind. Caudalis emarginate; the third and fourth dorsal spines lomgest. Bluish green (in life), with seven or eight shining golden, broad, longitudinal bands; a black spot above the base of the peetoral fins: fins immaculate.

Sea of Batavia.

a. Half-grown. From the Haslar Collection.

\section{Mesoprion argentimaculatus.}

Srixna argentimaculata, F'orsk. p. 50.

Perea aromtata, Bi. Silin. p. Eg.

Labrus argentatus, Lacép). pp. 426, 467.

I lacope argentimaculata, ('u1. \&) I Tul. ii. p. 432; Rïp). Allus Fische, p. 71. t. 19. f. 1.

$$
\text { I) } \frac{10}{13^{\circ}} \text { A. } \frac{3}{8} \text {. Cxe. pylor. } 4 \text {. }
$$

The height of the horly is :3? in the total length, and cipual to the length of the head. The mper maxillary bone reaching to the level of the postcrior margin of the eye; a slight notch of the pracoperculum always conspicuons: knob of the interopereulum sometimes

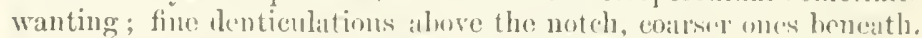
Caudalis truncated, pertorals not filly leachiner to the anal. Givenish; cach scale lightor at the erlge. sometimes white. (Kiijys.)

Red ina. 


\section{Mesoprion lineatus.}

Diacope lineata, Quoy \& Gain. Voy. Freyc. Zool. p. 309.

striata, Cuv. \& Val. ii. p. 430.

Mesoprion striatus, Bleek. Perc. p. 44.

—_ janthinuropterus, Bleek. Celebes, iii. p. 751.

$$
\text { D. } \frac{10}{13} \text {. A. } \frac{3}{8} \text {. L. lat. } 50 \text {. }
$$

The height of the body is $3 \frac{1}{2}$ in the total length, and equal to the length of the head; the diameter of the eye is one-fifth of the latter; the notch of the præoperculum is very slight. Caudalis emarginate, the fourth and fifth dorsal spines longest. Olive, with oblique redbrown streaks above the lateral line, and with longitudinal lines of the same colour on the opercles and sides of the body; no lateral bloteh; dorsal and caudal fins blackish, the spinous part of the former with a black edge; pectorals yellow; anal and ventral fins rose-eoloured.

Waigiou; Molucca Sea ; Sea of Java.

\section{Mesoprion gembra.}

Russell, pl. 95 .

Alphestes sambra, Bl. Schr. Syst. Posth. p. 236. t. 51.

Mesoprion yapilli, Cuv. \& Val. ii. p. 483.

- gembra, Cuv. \& Val. ii. p. 485 ; Cantor, Catal. p. 15.

— immaculatus, Cur. \& Val. ii. p. 474 ; Bleck. Perc. p. 45.

— gembra, Bleek. Sumatra, ii. p. 246 (young).

$$
\text { D. } \frac{10}{13-14} \text {. A. } \frac{3}{8} \text {. L. lat. } 46 .
$$

The height of the body is $3 \frac{1}{2}$ in the total length, the length of the head $3 \frac{1}{3}$; the diameter of the eye is $4 \frac{1}{3}$ in the latter. The upper profile of the head is slightly eoneave; the jaws are equal in front, the upper maxillary bone reaching to below the anterior half of the eye. Suprascapula and præopereulum finely serrated, the latter slightly emarginate. Caudalis truneated, pectorals distant from the anal; the third, fourth, and fiftl dorsal spines longest; the second of the anal fin not much longer, but stronger, than the third. Uniform dark olive, each scale with a brown base; dorsal, anal, and ventral fins olive, along the middle lighter, the former with a blaek edge as far as the spinous part; young specimens with nine or ten darker eross-bands.

Bay of Bengal; Molucca Sea.

a. Large specimen: bleaehed. India. Old Collection.

b. Large speeimen: stuffed.

c. Adult. Sumatra. From Mr. Frank's Collection.

d-g. Half-grown. Amboyna; Borneo. From Mr. Frank's Collection.

h. Half-grown. Amboyna. From Mr. Frank's Collection.

i. Adult. Amboyna. From Mr. Frank's Collection.

$k$. Half-grown : stuffed.

l. Young. 
Sir John Richardsun mentions a dried speeimen of this fish, in the Collection of the British Museun, procured by Mr. Gilbert at Port Essington (No.21), and he deseribes it under the name of $M$. yapilli, in the Ann. S. May. Nat. Kist. 1842, p. 26. I am not able to find this fish in the Collection.

\section{Mesoprion cynodon.}

Caballerote, Jocu, Parru, pl. 25. f. 1, 2.

Anthias caballerote, Bl. Schn. p. 310.

- jocu, Bl. Silth. p. 310.

Mesoprion eynodon, Cue. \& 'T 'ul. ii. p. 465.

— analis, Cur. \&) Vul. ii. p. 452 (not Custelnau, Anim. nouv, ou rares de I Amér. du Sud, Poiss. p. 4).

- litura, Cuc. \& $I^{\prime}$ m. ii. p. 467 .
D. $\frac{10}{14}$.
A. $\frac{3}{8}$.
L. lat. $43-46$.
L. transr. 9/16.

The height of the body is 3 to $3 \frac{1}{5}$ in the total length, the length of the head $3 \frac{2}{5}$; the diameter of the eye is $4 \frac{1}{2}$ in the latter, and $1 \frac{2}{3}$ in the length of the snout; jaws equal in front. Preoperenlum with a distinet noteh, but the knob of the interopereulum very inconspicuous; supraseapula serrated. Caudalis slightly emarginate; peetorals scarcely reaching to the origin of the anal; the fourth dorsal spine longest. Olive (in spirits), each seale with a darker base; a bluish-white, darker-edged streak from the pracorbital below the eye across the opereles. Canines large.

Atlantic Coasts of Tropical America.

a. Adult. South America. Presented by Sir R. Schombuirgk.

b.c. Adult: not good state. South America. Purcliased of Mr. Brandt.

d. Half-grown: very bad state. West Indies.

e. Adult,: skin. Jamaica. From 1)r. Parnell's Collection.

f. Adult. From the Haslar Collection.

g. Young. St. Domingo. J'urehased of Mr. Cuming.

This species may be readily distinguished from the following by its smaller seales; there are nine or even ten longitudinal series of scales between the lateral line and the dorsal fin, whilst $M$. griseus has six or seven only. The other characters are less eonspicuous in young and half-grown individuals, - riz., the greater height of the body in $M$. cmorlon, and the greater length of the snout in 11 . grisens. From Cuvier's description alone it would be impossible to determine the species, as the greater part of the species of Mesoprion, as in many utler genera, are either insufficiently deseribed, or form nominal species only, founded on the most trivial characters.

\section{Mesoprion griseus.}

Mesoprion griscus, ('ur. \&. Ial. ii. p. 469:? Guichen. in Ramon de lu Strygro, Hist. Culu, l'oiss. p. 21;."

- Glaveseris, C'ur. \&. Vil. ii. 1. 172. 
Mesoprion linea, Cuv. \& Val. ii. p. 468.

- jocu, Cuv. \& Val. ii. p. 466.

— goreensis, Cuv. \& Val. vi. p. 540.
D. $\frac{10}{14(15)}$.
A. $\frac{3}{8}$.
L. lat. 40-45.
L. transv. $\frac{6-7}{15}$.
Vert. 10/14.

The height of the body is $3 \frac{1}{3}$ to $3 \frac{3}{4}$ in the total length, and equal to the length of the head; the diameter of the eje is about $4 \frac{1}{2}$ in the latter, and (in adult specimens) one-half the length of the snout; jaws cqual. Præoperculum very slightly emarginate at its posterior limb, interoperculum without knob. Caudalis slightly emarginate; pectorals not reaching to the origin of the anal; canines very large. Olive (in spirits), each scale with a darker base; a bluishwhite, darker-edged line from the præorbital below the eye across the opercles; the line is sometimes interrupted, forming a serics of small spots, sometimes not visible. Young and half-grown specimens often with alternating lighter and darker cross-bars, or with the dorsal and caudal fins black-edged, and the formor with a series of irregular dark spots.

Atlantic Coasts of Tropical America; West Coast of Africa.

a. Large specimen. West Indies. Purehased of Mr. Frank.

$b-d$. Half-grown. West Indies.

e. Half-grown. West Indies. Purchased of Mr. Brandt.

$f-h$. Half-grown. West Indies.

i, k. Adult: stuffed. West Indies. Purchased of Mr. Scrivener.

l. Half-grown : stuffed. West Indies. Purchased of Mr. Serivener. m. Fine specimen. Cuba. From the Collection of the Zoological Society.

n. Adult: skeleton. Cuba. From the Collection of the Zoological Society.

o. Adult: stuffed. Cuba. From the Collection of the Zoological Society.

$p-t$. Adult and half-grown : skins. Jamaica. From Dr. Parnell's Collection.

u. Half-grown : skin. Jamaica. Purchased of Mr. Cuming.

v. Adult. South America. Presented by Sir R. Schomburgk.

w. Half-grown. British Guiana. Presented by Sir R. Schomburgk.

$x, y$. Adult: not good state. Puerto Cabello. Purchased of Mr. Brandt.

z. Adult. From the Haslar Collection.

$a, \beta$. Adult : stuffed.

In specimens which have not attained to maturity, the soft portion of the dorsal and anal fins is more elevated. I give the deseription of specimen $w$.

Description of the specimen.-The body is compressed and rather short, the distance between the dorsal and caudal fins bei $192 \frac{1}{2}$ in the length of the head. The head is compressed; the interspace between the eyes not broader than the vertical diameter of the cye. The cleft of the mouth is nearly horizontal, and rather wide; the upper maxillary reaches somewhat beyond the vertical, from the an- 
terior margin of the eye. The check is sealy; there are seven rows of seales between the eye and the lower limb of the prooperenlum, the row nearest the eve being formed by very large seales, as in most of these fishes. The posterıor limb of the prxoperculum is exceedingly finely serrated, and has a slight noteh above the angle; the denticulations of the angle are stronger. The opereulum is triangular, its width being $1 \frac{1}{3}$ in its height; it has posteriorly two short and very obtuse lobes, separated from each other by a noteh; the lower is the more prominent.

The base of the rertical fins is eorered with small seales. The origin of the dorsal fin corresponds to the rertical from the th seale of the lateral line, the end to that of the 3\%th, the origin of the soft portion to that of the $22 \mathrm{nd}$. The upper margins of both portions are convex, separated by a notch. The spines are of moderate strength, and, as in many other Acanthopterygii, alternately stronger and more feeble*; the fourth is the longest, $2 \frac{1}{2}$ in the length of the liead; the last spine is much shorter than the first ray. Among the rays, the eighth and ninth are longest-rather longer than one-half the length of the head. The caudalis is slightly cmarginate. The anal spines are moderately strong; the second is rather longer, but not stronger than the third; the soft portion is mueh more elerated, and has a rounded margin, the fourth ray being longest, and equal in height to the ninth dorsal ray : the origin of the fin eorresponds to the vertical from the 25th seale of the lateral line, the end to that from the 33rd. The pectoral and ventral fins are equal in length, the former extending backwards to the vent only, the latter nearly to the origin of the anal.

The seales are of moderate size; one of the largest, taken from the side, below the lateral line, covers nearly one-half the eye.

In both jaws there are larger teeth in the external row of the villiform bands; the upper jaw is armed with one pair of canines, of moderate size; no eanines in the lower jaw. The vomerine teeth form a broad triangular pateh, with a produeed anterior angle. The palatine teeth in euneiform bands.

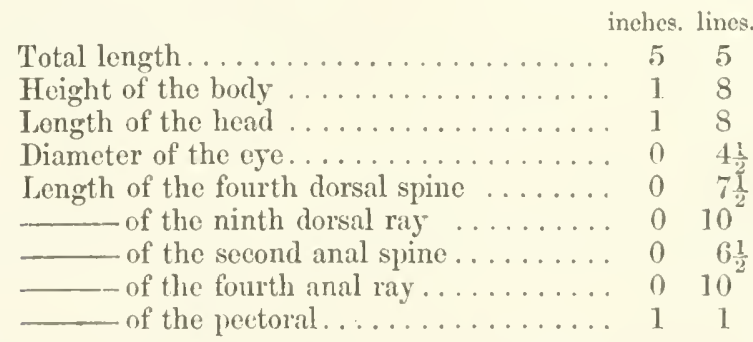

There are four other specimens in the Collection of the British

* In faet, the spines are always equally strong, each being on one side broader and on the other narrower; so that, if riewed from the left side, the third, fifth, seventh, \&e., appear to be broadest; if riewed from the right, the fourth, sixth, eighth, \&e. 
Museum, from the west coast of Africa; they represent one or two nominal species of Valenciemmes ( $M$. gorcensis, and probably $M$. fulgens); the females have a considerably more elevated body than the males.

$\gamma, \delta$. Adult : male. River Niger. From Mr. Fraser's Collection.

є. Adult : female. River Niger. From Mr. Frascr's Collection.

$\zeta$. Adult : female. Coast of Africa. From the Haslar Collection.

$\eta$. Half-grown. Fernando Po. From Mr. Fraser's Collection.

Sheleton.-The maxillary bone gradually widens from the base to its extremity, and has the posterior margin convex and the anterior concave. The posterior processes of the intermaxillary bones are of moderate length, about two-thirds the length of the bones themselves; these are armed with a pair of very strong canines, between which are two other pairs of smaller ones; there is a series of short conical teeth along all the outer margin; the remainder of the teeth form a villiform band. The mandibulary is furnished with an outer series of conical teeth; those standing in front of the jaw and in the middle of the side of the dentary are the largest and canine-like; the villiform band of mandibulary teeth does not extend on the lateral portion of the dentary. The vomerine teeth are arranged in an anchorshaped villiform band, which extends backwards to the middle of the bone. The palatine teeth form a broad band, three times as long as broad, which does not extend on the pterygoid. The turbinal bones are strong, elongate, and being very dirergent, they leave between them a triangular groore, to reccive the processes of the intermaxillaries. The anterior portions of the frontal bones also diverge, and leave between them a space, filled up by an elongate portion of the ethmoid, which in this and other species of Mesoprion forms part of the upper surface of the slinll. The space betweon the orbits is rather narrow and flat, with some gruoves and openings of the rudimentary system of muciferous channels. The portion of the upper surface of the skull, behind the orbits, is distinguished by high crests, leaving between them very deep longitudinal grooves. The median erest is that of the supraoceipital bone, which, strong, but moderately elevated, slightly bifurcates in front, and extends on the frontal bones to above the middle of the orbit. Two other crests arise from the orbit, the inner of which runs (nearly parallel with that of the occipital bone) to the articulation of the superior piece of the suprascapula; the oriter crest descends downwards in a slight curve, and terminates at the junction of the suprascapula, opereulum, and praoperculum. The groove between the two outer crests is triangular, and a large opening leads in to the occipital region. The præorbital is large, irregularly quadrangular, and smooth ; the remainder of the infraorbital bones are narrow, and form the base for a large concave plate reaching into the interior of the orbit.

The opereulum has neither spine nor noteh; the sub- and interoperculum entire. The limbs of the præopereulum have a very oblique direction towards each other; the angle is rounded, and armed with strong spinous teeth; the posterior limb is minutely serrated in all 
its length and in the open noteh above the angle; the inferior limb is entire. Suprascapula obtusely dentieulated. The glossohyal is oblong, and covered with fine villiform teeth; the nrohyal terminates posteriorly in two elongate points, with a semicirenlar notch between.

There are ten abdominal and fourteen eaudal vertebre, the length of the former portion of the eolumn being to that of the caudal as $1: 1 \cdot 4$. The first interhamal spine is strong, dagger-shaped, with a longitudinal groove on each side, and equal to the length of the second vertebra to the eighth.

\section{Mesoprion buccanella.}

Mesoprion buccanella, Cur. \& Val. ii. p. 455; Guichen. in Ramon de la Sagra, Hist. Cuba, Poiss. p. 23.
D. $\frac{10}{14}$.
A. $\frac{3}{8}$.
L. lat. 54 .
L. transs. 8/17.

The height of the body is $3 \frac{1}{3}$ in the total length, and nearly equal to the length of the head; the diameter of the eye is one-fourth of the latter, and $1 \frac{1}{2}$ in the length of the snout; the upper profile of the head oblique, straight, the lower nearly horizontal. Supraseapula and præoperculum serrated, the latter with a slight notch; knob of interopereulum flat, conspieuous. Caudalis emarginate, pectorals just reaching the anal. The fourth and fifth dorsal spines longest; the second and third of the anal fin nearly equal in length. Uniform yelluwish olive (in a dried state), with indistinct oblique streaks above the lateral line, and with longitudinal ones beneath; base of the pectoral deep black.

Caribbean Sea.

a. Fine specimen. Cuba. From the Collection of the Zoologieal Socicty.

b-e. Adult: skins. Jamaica. From Dr. Parnell's Collection.

$f, g$. Adult : stuffed. West Indies. From Mr. Serivener's Colleetion. $h$. Half-grown: stuffed. West Indies. From Mr. Serivener's Collection.

i. Adult: stuffed. America.

\section{Mesoprion aya.}

Acaraaya, Margrave, pp. 107, 168.

Bodianus aya, Bl. t. 227 ; Lacép. iv. pp. $286,287$.

- ruber, Bl. Schn. p. 330.

Mesoprion aya, C'm. \& Val. ii. p. 457 ; Guichen. in Ramon de la Sagra, Hist. Cuba, I'viss. p. 24.
D. $\frac{10}{14}$.
A. $\frac{3}{8}$.
L. lat. 65.
L. transv. $10 / 22$.

The length of the head is nearly equal to the height of the body, and $3 \frac{3}{5}$ in the total ; the diameter of the eyo is $4 \frac{1}{2}$ or $4 \frac{3}{1}$ in the length of the head, and $1 \frac{3}{5}$ in that of the snout. Jaws equal in front; the upper maxillary reaches slightly beyond the vertieal from the front 
margin of the orbit. Propocreulum with a distinct noteh, interopereulum with a slight and flat knob. The fourth and fifth dorsal spines longest, longer than the soft rays. Caudalis slightly emarginate; pectoral fin extending to the origin of the anal fin. Coloration uniform, without black blotch ; caudalis with a narrow black margin.

Caribhean Sea.

a, b. Adult : skins. Jamaica. From I)r. Parnell's Colleetion.

c. Half-grown : skin. Jamaica. From Dr. Parnell's Collection.

d. Fine specimen. South America. l'resented by Sir R. Scliomburgk.

$b b$. Ground-colour red.

18. Mesoprion borensis.

Diacope borensis, Cuv. \& Val. ii. p. 436 (not Richards.).

—— tiea, Less. Voy. Dup. p. 231. pl. 23 (opercles bad).
D. $\frac{10}{14}$.
A. $\frac{3}{9}$

The height of the body is $2 \frac{3}{4}$ in the total length, the length of the head $3 \frac{1}{3}$; the upper profile of the snout very slightly concave. Notch of præoperculum and knob of interoperculum very conspicuous. Caudalis slightly notched; pectorals reaching to the front end of the anal. Red: the dorsal and caudal fins with a violet shade. (Less.)

Island of. Borabora.

This species belongs perhaps to the genus Genyoroge; according to the figure quoted, the third anal spine is much longer than the second.

\section{Mesoprion erythrinus.}

Diacope erythrina, Rïpp. N. W. Fische, p. 92. t. 23 . f. 3.

$$
\text { D. } \frac{10}{14} \text {. A. } \frac{3}{9} \text {. }
$$

The height of the body is one-third of the total length, the length of the head one-fourth; the outline of the forehead gibbous, prominent above that of the snout. Prxoperculum with a very slight notch, interoperculum without knob. Lower jaw longest. Caudalis truncated, pectoral not quite reaching to the anal fin. Uniform red. (Rüpp.)

According to the figure given by Dr. Riippell, this speeies would be easily distinguished by the very small size of the cye, its diameter being about one-seventh of the length of the head; but this is not mentioned in the description.

Red Sea.

\section{Mesoprion rangus.}

Rangoo, Russell, pl. 94.

Mesoprion rangus, Cuv.\& Val. ii. p. 482 ; Cantor, Catal. p. 14.

$$
\text { D. } \frac{10}{13-15} \text {. A. } \frac{3}{8} \text {. }
$$

The height of the body is $3 \frac{1}{2}$ in the total length, and equal to the 
length of the head. Præoperculum serrated, slightly emarginate, and with stronger denticulations at the angle. Caudalis truncated. Uniform cherry-red.

Seas of Java and Ceylon; Coast of Coromandel ; Malayan P'eninsula. a. Skin, twenty inches long. Ceylon. Collected by E. F. Kelaart, M.D.

\section{Mesoprion madras.}

Cuv. \& Val. vii. p. $446 ;$ Blecker, Perc. p. 44.
D. $\frac{10}{13}$.
A. $\frac{3}{8}$.
I. lat. 55 .

The height of the body is $3 \frac{3}{4}$ in the total length, the length of the head $3 \frac{1}{6}$; the diameter of the eye is $3 \frac{1}{2}$ in the latter. Præopereulum serrated, not notehed. Candalis truncated, the fourth dorsal spine longest, all being slender. Reddish, with reddish-brown longitudinal streaks; fins yellow. $(B I$.)

Seychelles; Batavia.

b. With a large black later'al blotch.

22. Mesoprion johnii.

Renard, Poiss. i. t. 31. f. 172; Russell, t. 97.

Anthias johnii, Bloch, t. 318.

Sparus tranquebaricus, Shaix, Zool. iv. p. 471.

? Coius catus, Buch. Ham. Gang. Fish. p. 90. pl. 38. f. 30.

Mesoprion unimaculatus, Quoy \& Gaim. Zool. Froyc. p. 304; Cur. \&. $V$ al. ii. p. 441 ; Bleeker, Perc. p. 42 ; Richards. Ichth. China, p. 229; Quoy \& Gaim. Voy. de l'Astrol. Poiss. p. 665. pl. 5. f. 3.

__ johnii, Cuv. \&. Val. ii. p. 443 ; Cantor, Catal. p. 13.
D. $\frac{10}{14}$.
A. $\frac{3}{8}$.
L. lat. 48 .

The height of the body is $3 \frac{1}{2}$ in the total length, and nearly equal to the length of the head. Notel of præopereulum and knob of interopereulum conspicuous; præopereulum with finer denticulations above, and with coarser ones beneath the noteh; the upper maxillary bone reaching to below the anterior half of the eye. Caudalis slightly emarginate, pectorals not reaching to the front end of the anal fin; the third, fourth and fifth dorsal spines longest; the second of tho anal stronger than the third, but nearly equal in length. Yellowish olive (in a dried state), with indistinct oblique streaks above the lateral line and longitudinal ones beneath; a large oval black spot on the lateral line, extending over the seales of about the 23rd-28th transverse lines.

Indian Ocean ; China Sea ; Malay Arehipelago ; Coast of Australia ; Pacific.

a. Half-grown : not good state. From the Haslar Collection.

b. Half-grown, Old Collection.

$c, d$. Young. From the Collection of the Zoological Society.

e. Adult : stuffor : not good state. Sine patria. Old Collection. 
f. Half-grown : skin : not good state, Port Essington. Presented by the Earl of Derby.

g. Young: not good state. N.W. Australia. Presented by Sir Richardson.

h. Half-grown: stuffed. Pacific. Voyage of the Rattlesnake.

i. Half-grown: skin. China. From Mr. Warwick's Collection.

$k, l$. Adult. China.

m-o. Young. Madras. Presented by J. C. Jerdon, Esq.

p. Young. Maeassar. From Mr. Frank's Collection.

q. Half-grown: stuffed. Cape Sea. Presented by Sir A. Smith.

$r$. Adult : stuffed.

\section{Mesoprion fuscescens.}

Mesoprion fuscescens, Cur.\& Val. vi. p. 538; Bleeker, Batjan, ii. p. 197. - hoteen, Richards. Ichthyol. China, p. 229.
D. $\frac{10}{13}$.
A. $\frac{3}{8}$.
L. lat. 50 .

The height of the body is $3 \frac{1}{2}$ in the total length, and equal to the length of the head; the diameter of the eye is $4 \frac{1}{2}$ in the latter; the upper profile of the head is straight, of the neck slightly concave. Jaws nearly equal, the upper maxillary bone reaching to below the anterior half of the eye. Præopcreulum serrated, with a conspicuous notch behind and with stronger denticulations beneath. Caudalis emarginate; the fifth dorsal spine longest; the second and third anal spines nearly equal in length. Olive, each scale darker at the base : a large black bloteh on the lateral line, below the middle of the soft dorsal fin; pectorals with a brownish spot at the base.

Fresh waters of Celebes and Batjan.

I refer to this species both the specimens upon which Dr. Richardson founded the species $M$. hoteen, as all the details of Bleeker's description of $M$. fuscescens may be applied to them.

a. Adult: stuffed. China. Presented by J. R. Reeves, Esq.

b. Half-grown : stuffed. China. Presented by J. R. Reeves, Esq.

\section{Mesoprion fulviflamma.}

Sciæna fulviflamma, Forsk. p. 45.

Perca fulviflamma, Bl. Schneid. p. 28.

Centropomus hober, Lacép. iv. p. 255.

Diacope flulviflamma, Cuv. Règne Anim.; Rïpp. Atl. Fische, p. 72. t. 19. f. 2, and N.W. Fische, p. 94 ; Cuv. \& Val. ii. p. 423.

Mesoprion monostigma, Cuv. \& Val. ii. p. 446 (not Bleek.). - fulviflamma, Bleek. Amb. ii. p. 553.

$$
\text { D. } \frac{10}{13} \text {. A. } \frac{3}{8} \text {. L. lat. } 50 \text {. Cæe. pylor. } 5 \text {. }
$$

The height of the body is $3 \frac{2}{3}$ in the total length, and the length of the head $3 \frac{1}{2}$; the diameter of the eye one-fourth of the length of the head. Jaws equal, the upper maxillary bone reaching nearly to below the middle of the eye. Præoperculum indistinctly notehed, the denticulations becoming gradually stronger at the angle : no knob on 
the interopereulum. Caudalis tmineated, pectorals not reaching to the anal fin; the third, fourth and fifth dorsal spines, and the second and third anal spines nearly equal in length and strength. Yellowish olive, with oblique streaks above the lateral line and with longitudinal ones beneath; a black lateral blotch on seales of the 22nd-30th transverse lines.

Red Sea; Seychelles; Seas of Java, Amboyna, and China.

a. Adult. Amboyna. From Mr. Frank's Collection.

b. Half-grown. Amboyna and Ceram. From the Collection of Madame Ida Pfeiffer.

c. Young. Amboyna. Purchased of Mr. Frank.

d. Young. China. Presented by J. R. Reeres, Esq.

e. Young. From the Collection of the Zoological Society.

\section{Mesoprion uninotatus.}

? Sparus vermicularis, Bl. Schn. p. 275.

? Salpa purpurascens variegata, Catcsb. pl. 17. f. 1.

? Sparus synagris, L. Gm. p. $1275 ; B l . ~ S c h n$. p. 274.

Dipterodon plumieri, Lacép. iv. p. 167.

Mesoprion uninotatus, Cur. \&- Val. ii. p. 479; Spix, Fische Brasil. pl. 65; Castelnau, Anim. nouv. ou rares de l'Amór. du Sud, Poiss. p. 4 ; Guichen. in Ramon de la Sagra, Mist. Cuba, Poiss. p. 21.
D. $\frac{10}{12}$.
A. $\frac{3}{8}$.
L. lat. 47 .
L. transw. 8/16.
Vert. 10/14.

The height of the body is $3 \frac{1}{2}$ in the total length, and equal to the length of the head; the upper profile of the head straight, obliquely deseending, the lower nearly horizontal. Præopereulum serrated, with a very conspicuous noteh ; interøpereulum without knob. Caudalis slightly emarginate, pectorals just reaching to the front end of the anal fin. Bluish green, with shining golden longitudinal bands; a black lateral bloteh.

Caribbean Sea; Coast of Brazil.

$a, b$. Half-grown. Puerto Cabello. Purehased of Mr. Brandt.

c. Fine specimen. Cuba. From the Collection of the Zoologieal Society.

$d, e$. Adult and half-grown. St. Domingo. Purehased of Mr. Cuming. $f-h$. Adult: skins. Jamaica. From Dr. Parnell's Collection.

$i, k$. Half-grown: skins. Januaiea. From Dr. Parnell's Collection. 7. Adult: stuffed. West Indies. From Mr. Serivener's Collection. m. Half-grown: stuffed. West Indies. From Mr. Serivener's Collection.

n. Half-grown: stuffed: not good state. Bahia.

o. Adult: skeleton. West Indies. From the Haslar Collection.

p. Adult. From the Haslar Collection.

Skeleton.-The skeleton of this species differs in the following details from that of Mesoprion griseus. The eanines of the upper jaw are of moderate size, and there is one other pair only between them : the outer series of the lower jaw is formed hy conical tecth, of nearly 
equal size. The band of the vomerine teeth also is anchor-shaped, but the peduncle is much shorter, oceupying the anterior third oniy of the bone. The palatine band tapers anteriorly and posteriorly. The grooves and ridges between the orbits are more developed, and the occipital crest reaches nearly to the level of the anterior margin of the eye. The outer erest, from the orbit to the præoperculum, is transformed into a muciferous channel. The operculum has a slight noteh posteriorly, but no prominent point. The posterior edge of the pharyngo-branchials is fringed and denticulated, which peculiarity is not found in M.griseus. The basal portion of the skull is swollen and rounded, as in many Pristipomatidee and Scicenidee, whilst that part is rather compressed in $M$. griseus.

There are ten abdominal and fourteen caudal vertebræ, the length of the former portion of the column being to that of the caudal as 1:1.54. The first interhæmal spine is of moderate strength, and equal to the length of the first seven vertebræ together.

\section{Mesoprion mahogoni.}

Cur. \& Val. ii. p. 447 .

$$
\text { D. } \frac{10}{12} \text {. A. } \frac{3}{8} \text {. }
$$

The length of the head is one-third of the total, the dianıeter of the eye $3 \frac{1}{2}$ in the length of the head; the lower profile of the muzzle as much bent upwards as the upper is downwards. Caudalis notehed. Uniform brown, with a large black lateral bloteh. (Cuv.)

Sea of Martinique.

\section{Mesoprion vivanus.}

? Cuv. \&. Val. ii. p. 154 (bad deseription).
D. $\frac{10}{13}$.
A. $\frac{3}{8}$.
L. lat. 60 .
L. transv, 10/20.

The height of the body equals the length of the head, and is $3 \frac{1}{4}$ in the total. The diameter of the eye is one-sixth (in young individuals one-fifth) of the length of the head, and $2 \frac{1}{5}$ (in young $1 \frac{2}{3}$ ) in that of the snout. The upper maxillary reaches to the vertical from the anterior margin of the orbit. Præoperculum with an indjstinct notch; interoperculum without knob. The third, fourth, and fifth dorsal spines longest, very much shorter than the longest dorsal and anal rays; the soft dorsal and anal fins elevated; caudal emarginate; pectoral reaching to the anal fin. Coloration uniform, in young individuals with some indistinet cross-bars; no black spot at the base of the pectoral; a black bloteh on the lateral line.

Atlantic coasts of Tropical America.

a. 16" long: skin. Jamaica. From Dr. Parnell's Collection.

b. Adult: skin. Jamaica. From Dr. Parnell's Collection.

c. Half-grown. Bahia. Purchased of M. Parzudaki.

d. Half-grown. Bahia. Purchased of M. Parzudaki. 
2. Eleven dorsal spines.

\section{Mesoprion annularis.}

Mesoprion annularis, Cuv. \&. Val. ii. p. 484, iii. p. 497; Richardson, Ichth. China, p. 229 ; Bueeker, Perc. p. 47; Cantor, Catal. p. 14.

Diacope anmularis, Riipp. Atl. Fische, p. 74, and N. W. Fische, p. 91. t. 24. f. 2 ; , Quoy \&. Gaim. Voy. Astrol. Poiss. p. 666. pl. 5. f. 4.

- metallicus, Bleck. Tupogr. Batav.

Mesopiion sanguineus, Bleck. Perc. p. 48.

$$
\text { D. } \frac{11}{13-15} \text {. A. } \frac{3}{8-9} \text {. L. lat. 56-60. }
$$

The height of the body is $2 \frac{3}{4}$ in the total length, the length of the head $3 \frac{1}{3}$; the diameter of the eye is one-fourth of the latter. Noteh and knob of the opereles indistinet, in young specimens more distinct. Caudalis truncated; peetoral reaching to the front end of the anal; the fourth, fifth, and sixth dorsal spincs longest; the sceond of the anal fin much stronger than the third. Red: a blackish streak from the first dorsal spine to the cye; back of the tail with a black whiteedged spot; streak and spot sometimes indistinct.

Indian Ocean: Red Sea; Chinese and Japanese Seas.

a. Adult: stuffed: not good state. China. Presented by J. R. Reeves, Esq.

$b$, c. Adult and young. From the Haslar Collection.

d. Adult.

e. Adult. From the Haslar Collection.

$f$. Adult. Australian Seas. From Mr. Dring's Collection.

g. Half-grown. China. Presented by J. R. Reeves, Esq.

h. Young. China. Presented by Captain Sir E. Belcher.

$i$ Young. From the Collection of the College of Surgeons.

$k$. Young. From the Haslar Collection.

Specimens $h$. and $i$. have alternate blackish and lighter longitudinal bands below the lateral line.

\section{Mesoprion malabaricus.}

? Sparus malabaricus, Bl. Schn. p. 278.

? Mesoprion malabaricus, Cur: \& Val. ii. p. 480.

Mesoprion malabaricus, Bleek. Sumatra, iii. p. 3.

$$
\text { D. } \frac{11}{14} \text {. A. } \frac{3}{8} \text {. L. lat. } 52 \text {. }
$$

The height of the body is not quite one-third of the total length. and rather longer than the head: the diameter of the cye is onethird of the length of the head; the upper profile of the head slightly coneave. Jaws nearly equal in front; the upper maxillary bone reaches beyond the anterior half of the eye. Preopereulum serrater and slightly emarginate, with stronger denticulations at the angle. Caudalis truneated; the fouth, fifth, and sixth dorsal spines rather longer than the posterior ones; the second of the anal longest and strongest. Rose-colomred (in life), with oblique streaks ahove the lateral line and with longitudinal ones beneath; a violet longitudinal band on the bate along the base of the dorsal fin; a 
reddish-violet spot on the back of the tail; dorsal and caudal fins with a black edge; spines of the anal and ventral fins white.

Sea of Padang (Sumatra).

u. Half-grown. East Indies. Purchased of Mr. Frank.

Perhaps a variety of the former species.

\section{Mesoprion erythropterus.}

Lutjanus erythropterus, Bloch, t. 249.

Mesoprion erythropterus, Cuv. \&. Val. ii. p. 478; Bleeker, Perc. p. 47. —_ xanthopterygius, Bleek. Perc. p. 46.
D. $\frac{11}{12-13}$.
A. $\frac{3}{8}$.
L. lat. 45 .

The height of the body is rather more than one-fourth of the total length, the length of the head $3 \frac{1}{2}$ in the same length; the diameter of the eye is one-third of the length of the head. Prxoperculum not or very slightly emarginate. Caudalis truncated; the dorsal spines slender, the third and fourth longest. Uniform yellowish; fins purplish. $(B l$.

Sea of Bataria; Sumbawa.

\section{Mesoprion lineolatus.}

Diacope lineolata, Rüpp. Atl. Fische, p. 76. t. 19. f. 3 (Bleek. Perc. p. 46, different).
D. $\frac{11}{12}$.
A. $\frac{3}{8}$.
L. lat. 52.
Cæc. pylor. 4.

The height of the body is one-fourth of the total length; the lengtl of the head is $3 \frac{1}{3}$ in the same; the diameter of the eye is a little more than one-third of the length of the head, and not much larger than the distance between the ejes: The lower jaw slightly prominent; the upper maxillary bone reaches to below the middle of the eye. Præoperculum finely serrated and very slightly emarginate behind; knob of interoperculum none. Caudalis truncated, pectoral distant from the anal; dorsal spines moderate, the third, fourth, and fifth longest; the second of the anal fin longer and stronger than the third. Greenish olive, with oblique darker streaks above the lateral line, and with longitudinal beneath.

Red Sea; Amboyna.

a. Adult. Red Sea.

b. Half-grown. Amboyna. From Mr. Frank's Collection.

\section{Mesoprion timoriensis.}

Diacope timoriensis, Quoy \& Gaim. Voy. du Freyc. Zool. p. 306. pl. 57. f. 1.

Calvetii, Cuv. \& Val. ii. p. 429 ; Faun. Japon. p. 14.

$$
\text { D. } \frac{11}{14} \text {. A. } \frac{3}{8} \text {. }
$$

The height of the body is not quite one-third of the total length ; 
the length of the head is $3 \frac{1}{2}$ in the same. Jaws nearly equal in front. Prxoperculum with a conspienous notch. Caudalis truncated, peetorals reaching to the middle of the anal. Uniform red.

Sea of 'Timor; Japan.

\section{Mesoprion isodon.}

Mesoprion isoodon, Cux. \& V Val. ix. p. 443.
D. $\frac{11}{15}$.
A. $\frac{3}{7}$.
L. lat. 50 .

'The height of the body is $3 \frac{1}{2}$ in the total length, and equal to the length of the head. Caudalis trumeated. Uniform brownish. Three strong canine tecth in the upper jaw. ( $V^{T} a l$. )

St. Domingo.

3. Twelve dorsal spines.

\section{Mesoprion dodecacanthus.}

Blectier, Amboina, iii. p. 101.
1). $\frac{12}{13}$.
A. $\frac{3}{8}$.
L. lat. 46.

The height of the body is $3 \frac{1}{4}$ in the total length, and equal to the length of the head; the diameter of the eye is not fully one-third of the latter. Jaws equal in front, the mper maxillary bone reaching to below the middle of the eye. I'reopereulum serrated, slightly emarginate. The spinous part of the dorsal fin much lower than the soft; the first dorsal spine shortest, the others nearly equal in length ; the second of the anal longest. Caudalis truncated. Rosecoloured (in life), with oblique brownish streaks; a brown spot on the back of the tail and at the baso of the peetoral; the dorsal and caudal fins black-edged; anal fin with a white anterior edge, and with the anterior rays decp violet. (Bl.)

Sia of Amboyna.

\section{Mesoprion dodecacanthoides.}

Blecker, Amboine, v. p. 489.

$$
\text { D. } \frac{12}{13} \text {. A. } \frac{3}{8} \text {. L. lat. } 46 \text {. }
$$

Tho height of the body is $3 \frac{1}{2}$ in the total length, and equal to the length of the lead; the diameter of the eye is not fully one-third of the latter. Jaws nearly equal in front, the upper maxillary bone reaching to below the antrior half of the eye. I'raeperenlum not or very slightly emarginate, serrated, with stronger denticulations heneath and at the angle. 'The spinous part of the dorsal fin higher than the soft; the fourth spine to the serenth equal in length and higher than the others; the seeond of the anal fin longest. Cindalis very slightly emarginate. liose-coloured (in life), with seren ublique 
brownish streaks; a brownish spot on the back of the tail; fins yellow.

Sea of Amboyna. Madras.

a. Half-grown: not good state. Madras. Presented by J. C. Jerdon, Esq.

\section{Mesoprion aurorubens.}

Centropristes aurorubens, Cuv. \& Val. iii. p. 45.

D. $\frac{12}{11}$. A. $\frac{3}{8}$. L. lat. 54 . L. transv. 8/19. Cæc. pylor. 4.

Vert. 10/14.

Vomerine teeth in a broad quadrangular patch, with the anterior sides shortest $(\diamond)$. Præoperculum with a very indistinct noteh, more conspicuous in young individuals. Dorsal fin even, caudal fin notehed; the third anal spine longest. Coloration uniform.

Atlantic coasts of Tropical America.

$a, b$. Adult: skins. Jamaica. From Dr. Parnell's Collection.

c. Half-grown: skin. Jamaica. Purchased of Mr. Ouming.

This fish has been placed in the genus Centropristis, but it is much nearer to Mesoprion, with which it agrees in the structure of the prapereulum; it may, however, be the type of a peculiar genus distinguished by an arrangement of the vomerine teeth which is scarcely to be found in other species of Mesoprion, and an increased number of dorsal spines. The canines are very small.

B. With a more or less broad, distinct, blackish lateral band.

\section{Mesoprion vitta.}

Serranus vitta, Quoy \& Gaim. Voy. de Freyc. Zool. Poiss. pl. 58. f. 3. p. 315 ; Richardson, Ichth. China, p. 234.

? Serranus vitta, Cuv. \& Val. ii. p. 239, vi. p. 505.

Diacope vitta, Schleg. \& Temm. Faun. Japon. p. 13. pl. 6. f. 1.

? Mlesoprion vitta, Bleeker, Perc. p. 44.

Mesoprion phaiotæniatus, Bleeker, Perc. p. 43.

$$
\text { D. } \frac{10}{13-14} \text {. A. } \frac{3}{8} \text {. L. lat. } 55-62 \text {. }
$$

The height of the body is $3 \frac{1}{2}$ in the total length, and nearly equal to the lengtl of the head; the diameter of the eye is one-fourth of the latter; the upper profile of the head is very slightly concave; noteh of præoperculum and knob of interopereulum conspicuous. Jaws nearly equal in front; the upper maxillary bone reaches not quite to below the middle of the eye. Caudalis truncated or very slightly emarginate; pectoral not reaching to the front end of the anal; the dorsal spines are rather slender, the third and fourth longest; the second and third of the anal fin are nearly equal in length, the second stronger. Olive (in spirits), with conspicuous oblique streaks above the lateral line and with longitudinal ones beneath; a broader blackish band from the eye to the back of the caudal fin; dorsal and 
caudal fins blackish, the others yellowish; no black spot at the base of the pectoral.

Japanese, Clinese, and Javanese Scas; Amboyna ; Louisiade Archipclago; Island of Waigiou ; north coast of Australia.

a. Half-grown: skin. Chinese Seas. Purchased of Mr. Warwick.

b. Young: not good state. Hong Kong. From the Haslar Collection.

c. Adult. Amboyna. From Mr. Frank's Collection.

d. Young. Amboyna. Purchased of Mr. Frank.

e. Half-grown. Molucca Sea. From Mr. Frank's Collection.

$f$. Half-grown: stuffed. Louisiade Archipelago. Presented by the Lords of the Admiralty.

g. Half-grown: stuffed. Louisiade Axchipelago. Voyage of tho Rattlesnakc.

h. Half-grown: stuffed. Louisiade Archipelago. (15 fathoms.) Voyage of the Rattlesnake.

i. Half-grown : stuffed. Louisiade Archipelago (Chaumont Isiand). Voyage of the Rattlesnake.

k. Adult: stuffed. Port Essington. Collected by Macgillivray. $l, m$. Young. From the Haslar Collection.

n. Adult: stuffed.

Cuv. and Val. quote for their description the species of Quoy and Gaimard, but give eleven spincs for the dorsal fin. The description and figure in the 'Zoologic de la Voyage, par L. de Freycinet,' perfectly agree with each other, as well as with the species of the 'Fauna Japonica' and with our specimens. 'The number given in the ' Hist. Nat. des Poissons' appears to be wrong.

\section{Mesoprion bleekeri.}

Mesoprion lineolatus, Blecker, Perc. p. 46. (Diacope lineolata, Rüpp). different.)

$$
\text { D. } \frac{11}{12} \text {. A. } \frac{3}{8} \text {. L. lat. } 60 \text {. }
$$

The height of the body is $4 \frac{1}{3}$ in the total length, and the length of the head is $3 \frac{1}{2}$; the diameter of the eye is one-fourth of the latter. Muzzle rather narrow, with the lower profile as mueh ascending as the upper is descending. Jaws equal in front, the upper maxillary bono reaching to below the anterior half of the eye. Præoperculum scrrated, with rather prominent and stronger denticulated angle; suprascapula serrated. Caudalis truncated; pectoral small, short, not reaching beyond the end of the ventral ; the third, fourth, and fifth dorsal spines longest, all being slender; the second of the anal rather thinner and shorter than the third. Yellowish olive, with a blackish longitudinal band from the eye to the caudal fin.

Sea of Batavia; Amboyna.

a. Adult. Amboyna. From Mr. Frank's Collection.

b. Half-grown. Amboyna. From Mr. Frank's Collection.

c. Young. Amboyna. From Mr. Frank's Collection. 


\section{Mesoprion enneacanthus.}

Bleeker, Perc. p. 40.
D. $\frac{9}{13}$.
A. $\frac{3}{8}$.
L. lat. 50 .

The height of the body is $3 \frac{3}{4}$ in the total length, and the length of the head $3 \frac{1}{2}$. Præopereulum serrated, with a slight notch behind; operculum with a single flat spine. Caudalis forked; the second and third dorsal spines longest, the first longer than the last. Oblique streaks above the lateral line; a blackish band from the eye to the caudal. No lateral blotch. $(B l$.

Sea of Batavia.

C. With permanent blackish cross-bands.

\section{Mesoprion semicinctus.}

Lutjanus semicinetus, Quoy \& Gaim. Voy. Freyc. Zool. p. 303.

Mesoprion semicinetus, Cuv. \&. Val. ii. p. 485 ; Bleeker, Amboina, iv. p. 331.

$$
\text { D. } \frac{10}{13} \text {. A. } \frac{3}{8} \text {. L. lat. } 50 \text {. }
$$

The length of the head is $3 \frac{1}{4}$ in the total, and nearly equal to the height of the body; the diameter of the eye is one-fourth of the length of the head; the upper profile of the head straight-lined. Jaws equal in front, the upper maxillary bone reaching to below the anterior half of the eye. Præoperculum slightly emarginate, with stronger denticulations at the angle. Caudalis slightly emarginate; the spinous and soft parts of the dorsal fin equal in height; the fourth and fifth spines and the second of the anal longest. Olive, with nine blackish cross-bands; tail behind with a large round black spot; the spinous part of the dorsal fin brown-edged.

Seas of Waigiou, Rauwack, and Amboyna.

D. With several distinct longitudinal bands.

\section{MIesoprion quinquelineatus.}

Russell, ii. pl. 110.

Mesoprion quinquelineatus, Cav. \& Val. ii. p. 445.

? Diacope cæruleolineata, Rüpp. $N$. W. Fische, p. 93. t. 24 . f. 3.

$$
\text { D. } \frac{10}{14} \text {. A. } \frac{3}{8} \text {. }
$$

Yellowish grey, with five narrow blue longitudinal lines and a lateral blotch of the same colour; fins with an orange-coloured edge. (Red Sea); Javanese Sea.
a. Adult. Sine patria.
D. $\frac{10}{14}$.
A. $\frac{3}{9}$.
L. lat. 80 .

\section{Mesoprion sobra.}

Cuv. \& Val. ii. p. 453; Guichen. in Ramon de la Sagra, Hist. Cuba, Poiss. p. 22.
D. $\frac{10}{14}$.
A. $\frac{3}{8}$.

The height of the body is $3 \frac{1}{2}$ in the total length, and equal to the 
length of the head; the upper profile of the head is straight, obliquely descending, the lower nearly horizontal. Præoperculum scrrated, not notched; interoperculum with a protuberance. Caudalis notched; pectorals not reaching to the anal fin. Yellowish olive, with about fourteen blue longitudinal streaks; three blue streaks on the ehecks, and a white one on the suborbital; a black lateral blotch.

Caribbean Sea.

a. Half-grown. West Indies.

b. Half-grown. West Indies.

c. Half-grown. West Indies.

$d-f$. Young. West Indies.

\section{Mesoprion decussatus.}

C'ur. \&. Val. ii. p. 487; Bleeker, Perc. p. 43.
D. $\frac{10}{13}$.
A. $\frac{3}{8}$.
L. lat. 55.

The height of the body is $3 \frac{1}{2}$ in the total length, the length of the head $3 \frac{1}{3}$; the diameter of the eye is $4 \frac{1}{3}$ in the latter. Jaws equal in front, the upper maxillary bone reaching to below the anterior half of the eye. The notch and the knob of the opereles indistinet. Caudalis slightly emarginate; pectoral just reaching to the front end of the anal; the third to sixth dorsal spines longest; the second and third of the anal fin nearly equal. Silvery white (in spirits), with five straight brown longitudinal bands, the three upper of which are crossed by six or seven vertieal ones.

Sea of Java; Philippines.

a. Adult. Philippines.

b. Adult. India.

c. $3 \frac{3{ }^{\prime \prime}}{4}$ long. Amboyna. From Mr. Frank's Collection as Mesoprion chrysotænia. Young (?); with a large lateral bloteh.

II. Species with anomalously armed præoperculum.

\section{Mesoprion retrospinis.}

Cur. \& Val. vi. p. 541.
D. $\frac{10}{14}$.
A. $\frac{3}{8}$.

The length of the head is $3 \frac{1}{3}$ in the total; the diameter of the eye one-seventh of the length of the head. Prooperculum without notch, and with four or five rather strong teeth beneath; interoperculum without knob. Caudalis truncated. Uniform yellowish olive. ( $\mathrm{Val}$.)

West Indies.

\section{Mesoprion pomacanthus.}

Blerker", Amboina, vi. p. 407.
D. $\frac{10}{13}$.
A. $\frac{3}{8}$.
L. lat. 50 .

'I'he height of the body is $3 \frac{1}{2}$ in the total length, and equal to the 
length of the head; the diameter of the eye is one-third of the latter. The upper maxillary bone reaching to below the anterior half of the eye. Præoperculum serrated, not notched, and with a very long spinous tooth at the angle, reaching to the gill-opening. The second dorsal spine longest. Caudalis slightly emarginate. Yellow, with two or three blue longitudinal bands. $(B l$.

Sea of Amboyna.

\section{GLAUCOSOMA.}

Glaucosona, Temm. \& Schleg. Faun. Japon. Poiss. p. 62; Richards. Voy. Ereb. \& Terr. Fishes, p. 27.

Seven, occasionally eight branchiostegals. All the teeth villiform, without canines; teeth on the palatines. One dorsal, with eight spines, the anal fin with three. Operculum with two flat points; præoperculum crenulated. Scales moderate; head entirely covered with scales.

From the Japanese Sea to the Australian coasts.

\section{Glaucosoma burgeri.}

Glaucosoma, sp., Fuun. Japon. p. 62. pl. 67.

— bügeri, Richards. Toy. of Ereb. \& Terror, Fishes, p. 27.

- hebraïeum, Richards. l. c. p. 27. pl. 17.
D. $\frac{8}{11}$.
A. $\frac{3}{9}$.
L. lat. 48 .
L. transv. $\frac{10}{20}$.

The height of the body is $3 \frac{1}{2}$ in the total length, and nearly equal to the length of the head; the diameter of the eye is nearly onefifth of the latter. The upper maxillary bone reaches to beneath the posterior third of the eye; the whole snout densely scaly ; operculum with two flat thin obtuse tıps; suprascapula not visible. Caudalis truncated, with slightly convex angles; the first rays of the dorsal fin longest. Back more or less distinctly marbled with black.

Sea of Japan; Houtman's Abrolhos, south-western coast of Australia.

Temminck and Schlegel described and figured a Japanese fish from a drawing of Bürger, considering it the type of a new genus, Glaucosoma. Sir John Richardson afterwards discovered, in the Collection of the British Museum, two similar, stuffed specimens from Australia; he thought them to be different from the Japanese one, and gave to the latter the specific appellation of bürgeri, to the former that of hebraïcum. There can be no doubt of their specific difference if we compare the figures only, the first dorsal rays of the one being much elongate, those of the other having the same length as the middle ones. But on comparing the trpical specimens of $G$. hebraïcum with the figure of $G$. bürgeri, I could not convince myself of the real existence of two species. They agree perfectly with that figure in the form of the head and of the hody, and in the number of the spines and rays. The first dorsal rays are broken-a very common occurrence, owing to the bad practice of preserving fishes in a dried or stuffed 
state; and if they were at all elongate, they appear to be much less so than in the figure in the Iehthyology of the Erebus and Terror.' On the other hand, an apparently ineomplete drawing, made from a single fish, like that in the 'Fauna Japonica,' does not afford suffieient authority as to the form of the single rays. With regard to the different coloration, the larger specimen of the two in the British Museum is nearly uniform, although much darker than the figure of the Japanese fish; the other exhibits very distinctly the variegated coloration given by Sir J. Richardson. Thus, not having other materials than Sir John Richardson had, I do not think myself justified in separating the following speeimens from the speeies of the 'Fauna Japoniea.' $a, b$. Large specimens: stuffed. Houtman's Abrolhos. (Jew-fish.)

\section{Third Group. PENTACERATINA.}

\section{PENTACEROS.}

Pentaceros, Cuv. \& Val. iii. p. 30.

Seven branehiostegals. Body high, triangular. All the teeth villiform; teeth on the vomer; palatines? One dorsal with ten, twelve, or fourteen, the anal fin with four or five spines; all the spines strong. Operculum rounded; præopereulum dentieulated. Sicales rather small, sometimes osseous, strongly adherent; head above without soft integuments.

Cape Sea; Pacific.

\section{Pentaceros richardsonii.}

Smith, Illustr. S. Afr. Fishes, pl. 21 (ventral spine much too feeble).

$$
\text { D. } \frac{14}{10} . \quad \text { A. } \frac{4}{8} \text {. }
$$

The height of the body is $2 \frac{3}{4}$ in the total length, the length of the head $3 \frac{2}{3}$; all the bones of the skull without soft integuments; scales rather small, ciliated. Ventral spino very long and strong. The triangular space between the ventrals and the throat much narrower than long. Coloration uniform brown.

Cape Point.

a. Original specimen of Sir A. Smith's deseription.

\section{Pentaceros capensis.}

Cur. \&. I'ul. iii. p. 30. pl. 43.

$$
\text { D. } \frac{12}{12} \text {. A. } \frac{5}{7} \text {. C'xe. pylor. } 9 \text {. }
$$

The height of the borly is one-lialf of the total length, the length of the head one-third. Ventral spine very thick and strong. The 
triangular space between the ventrals and the throat much narrower than long. Yellowish, marbled with brown.

Cape of Good Hope.

\section{Pentaceros decacanthus. (Plate XV. fig. A.)}

$$
\text { D. } \frac{10}{13} \text {. A. } \frac{4}{8} \text {. }
$$

The height of the body is one-half of the total length, the length of the head not quite one-third. Ventral spine very thick and strong. The triangular space between the ventrals and the throat as broad as long. Yellowish, marbled with brown.

a. Has been dried. Pacific. Voyage of the Herald.

Description of the specimen.-In general appearance this species much resembles the preceding, but it is still higher, and the much greater breadth of the breast gives a very good distinctive character. The outline of the lower profile is horizontal from the jaws to the anus; behind the vent it suddenly rises to near the caudal fin; the upper profile is very eurved, but does not descend so far behind as in front. The eye is placed high up the sides, without interfering with the upper profile; above its middle a spinous process projects from the frontal bone, and there are, besides, several very small spines in front of the larger one. The diameter of the eye is nearly one-third of the length of the head, and equals the interspace between the eyes. All the upper surface of the head appears to be bony, without being covered by a soft skin; it is striated, the streaks radiating from a centre above each eye. The nostrils are elose together, one before the other, and placed immediately in front of the upper angle of the eye: the anterior is very small, ovate; the posterior larger, round. The snout is rather shorter than the diameter of the eye; the eleft of the mouth is very oblique ; the lower jaw prominent. Both the jaws are armed with bands of fine villiform teeth: a small pateh of vomerine teeth is distinetly visible, but I am unable to see further to the palatine bones. The upper maxillary does not appear to reach the front edge of the orbit, and may be partly hidden beneath the anterior suborbital bone; this is large, and armed with several strong denticulations below, and with very small ones at its orbital margin; the remainder of the infraorbital areh is not dentieulated. There is a rhomboidal bone with a prominent longitudinal ridge on the occiput. All the bones of the humeral areh and the opereles are strongly striated. The seapulary has a prominent ridge terminating in a spine. The opereulum is entire and has a waving margin ; the præopereulum has a rounded angle and is dentieulated throughout, the spinous teeth being stronger beneath. Cheeks sealy. The gillopening is wide; but I eannot count the branchiostegals on account of the eondition of the specimen.

The peetorals are inserted at the lower third of the height of the body; they are pointed, and appear to reach to the vent. The ventrals are very remote from each other; their spine arises just 
behind and below the root of the pectoral ; it is rery strong and long, two-thirds of the length of the head, flattened, sharp outside, and striated; the first ray is the longest, scarcely longer than the spine

The dorsal fin commences above the humeral; it has ten strong spines, longitudinally striated; the third and fourth are longest, their length being $3 \frac{1}{2}$ in the height of the body. The membrane between the spines extends to the upper third. The length of the base of the soft portion is more than one-half of that of the spinous. The rays are broken off.

The origin of the anal fin falls below the end of the dorsal. The first spine is scarcely shorter than the second, which is shortest; the two others are shorter, but nearly equal in length.

Candal rounded?

The seales are osseous, very adherent, not striated, each with three or four prominences behind; those of the breast are largest; the fins are entirely scaleless. The lateral line eommences behind the scapulary spine, and is very curved on the trunk, like the back.

The ground-colour now is yellowish, largely marbled with brownish. The spinous portion of the dorsal and the rentrals are brown; the other fins yellowish.

\begin{tabular}{|c|c|c|}
\hline & & \\
\hline Total length....... & & 1 \\
\hline Height of the body . . . & $\ldots \ldots \ldots \ldots$ & 0 \\
\hline Isength of the head $\ldots \ldots \ldots$ & $\ldots \ldots \ldots \ldots$ & 0 \\
\hline - of third dorsal spine & $\ldots \ldots \ldots \ldots$ & 0 \\
\hline - of second anal spine & $\ldots \ldots \ldots$ & 0 \\
\hline $\begin{array}{l}\text { - of rentral spine } \ldots \text {. } \\
\text { Interspace between the rentr }\end{array}$ & & 0 \\
\hline Interspace between the rentr & als.......... & 0 \\
\hline
\end{tabular}

\section{OREOSOMA.}

Oreosoma, Cue. \& V Val. iv. p. 515.

Seven branchiostegals. Body high. All the teeth villiform ; teeth on the jaws, romer, and palatine bones. Two dorsils, the first with fire spines; anal long, without spines. Opercles not serrated nor armed; operculum with two ridges, terminating in flat angles. No true scales, but with large, conical, bony protuberanes, symmetrically arranged.

Atlantic.

\section{Oreoscma atlanticum.}

Cur. \&. I Fal. iv. p. 515. pl. 99.

$$
\text { D. } \frac{5}{29} \text {. A. } 26, \quad \text { V. } 1 / 5 \text {. }
$$

With 25 or 26 large, conical, bony protuherances, four of which are on the back. (Cur.)

Atlantic. 


\section{Fourth Group. PRIACANTHINA.}

\section{PRIACANTHUS*.}

Priacanthus, Cuv. \& Val. iii. p. 96.

Six branchiostegals. All the teeth villiform, without canines; teeth on the palatine bones; tongue smooth. One dorsal, with ten spines; the anal fin with three. Opereulum with an indistinct point; præoperculum serrated, with a more or less prominent, flat, crenulated angle. Seales small, rough; snout covered with ctenoid seales. Lower jaw with prominent chin; eye large.

Seas of the tropical regions (Australian Seas?).

\section{Priacanthus macrophthalmus.}

Priacanthus macrophthalmus, Cuv. \& V al. iii. p. 97 (not Bloch); Stamius in Miiller's Archiv, 1848, p. 399 (on the swim-bladder).

_ arenatus, Cuv. \&. Tul. iii. p. 101.

_ fulgens, Lowe, Trans. Zool. Soc. ii. p. 174.

D. $\frac{10}{13-14}$. A. $\frac{3}{14-15}$. L. lat. 80-85. Vert. 9/13. Cæc. pylor. 5.

The height of the body is $3 \frac{1}{3}$ in the total length, the length of the head is rather more than one-fourth of the latter; the diameter of the eye is $2 \frac{2}{3}$ in the length of the head. The posterior opening of the nostril is a long slit, three times as long as broad; the maxillary bone reaching a little beyond the anterior margin of the eye. Angle of the proopereulum obtuse, with a short flat spine in the male; operculum with two short spines; sub-and interopereulum entire. Caudalis truneated; the dorsal and anal spines gradually becoming longer behind, the first ones with a rough surface; the length of the second dorsal spine is $1 \frac{2}{3}$ in that of the last; the ventral fins reaching beyond the front end of the anal, the pectorals much shorter. Uniform red; fins with a blackish edge.

Caribbean Sea; Coast of Brazil; Madeira.

a. Fine specimen : male. Cuba. Presented by the Zoological Society. $b-e$. Adult and half-grown: skins. Jamaica. From Dr. Parnell's Collection.

$f-h$. Half-grown: male. W. Indies.

i. Fine specimen: female. Madeira. Presented by the Rev. R. T. Lowe (=Priacanthus fulgens, Lowe).

* 1. Labrus cruentatus, Lacêp. iii. p. 522. pl. 2. f. 3.-Priacanthus cruentatus, Cuv. \& Val. iii. p. 102.-Atlantic.

2. Priacanthus argenteus, Cuv. \& Val. iii. p. 109 ; Renard, i. pl. 12. f. 72.-East Indies.

3. Priacanthus macropterus, Cuv. \& I al. vii. p. 471; Quoy \& Gaim. Itoy. dr l'Astrol. pl. 7. f. 4.-St. Helena.

4. Priacanthus fax, Cuv, \& Val. vii. p. 473.-Seychelles. 
k. Adult: stuffed. W. Indies.

l. Adult: skin. W. Indies. From Mr. Serivener's Collection.

m. Half-grown: stuffed. W. Indies. From Mr. Serivener's Collection.

n. Half-grown: stuffed. Atlantic.

\section{Priacanthus boops.}

Perca boops, Forster.

Anthias boops, Bl. Schn. p. 308.

Priacanthus boops, Cur. \& Val. iii. p. 103; Barker-Webb \& Berthelot, Hist Nat. Iles Canaries, Ichthyol. p. 12. pl. 3. f. 2; Peters, Wiegm. Arch. 1855 , p. 238.

- macropus, Quoy \& Gaim. Voy. de l'Astrol. 'Zool. iii. p. 668. pl.7. f. 1.

$$
\text { D. } \frac{10}{12} \cdot \quad \text { A. } \frac{3}{13} \text {. L. lat. } 70 \text {. }
$$

The height of the body is equal to the length of the head and $3 \frac{2}{3}$ in the total; the diameter of the eye is nearly one-third of the length of the head. The posterior opening of the nostril is a long broad cavity, nearly three times as long as broad; the maxillary bone reaching a little beyond the anterior margin of the orbit. Angle of præoperculum obtuse, with a very distinet, serrated, triangular, flat spine; opereulum with two short spines; sub-and interopereulum minutely serrated. Caudalis truneated; all the spines and rays of the dorsal and anal fins with a striated or rough surface; the length of the seeond dorsal spine is $2 \frac{1}{2}$ in that of the last. Rose-coloured; the vertical fins with a blackish edge.

St. Helena ; coast of MLzambique.

a. Large specimen: stuffed. St. Helena. Presented by General Hardwicke.

b. Adult: stuffed. St. Helena. Presented by General Hardwicke. c. Adult. Sine patria.

Valencieunes deseribes (rol. vii. p. 469) a speeies procured by Quoy and Gaimard on the royage of the 'Astrolabe,' naming it Priacanthus macropus, on account of the elongated ventral fins, which are one-third of the total length. This eharacter alone would prove its specific difference from $P^{\prime}$ r. boops. But there is another fish, figured by Quoy and Gaimard, which they state to be the same as the fish of Valeneiennes, aud having the rentral fins of moderate length. There ean be no doubt that the specimens in the British Museum, or the Perca boops of Forster, are identical with that figure; but I cannot venture to bring the fish of Valenciennes into the synonymy of Pr. boops.

\section{Priacanthus bonariensis.}

C'uv. \&; I'cl. iii. p. 105.

$$
\text { D. } \frac{10}{13^{\circ}} \text { A. } \frac{3}{13} \text {. L. lat. } 80 \text {. }
$$

The height of the borly is $2 \frac{3}{4}$ in the total length, the length of the head $3 \frac{2}{3}$; the diameter of the eye is nearly one-third of the latter. 
The posterior opening of the nostrils is a long, broad, ear-shaped eavity, narrowest in the middle. The angle of the prænperculum is obtuse, with a more or less cylindrieal spine of moderate length ; operculum with two short spines, a third larger one above, belonging to the scapular bone; sub- and interoperculum minutely serrated. Caudalis truneated; all the spines and rays of the dorsal and anal fins with a striated or rongh surface; the length of the second dorsal spine is nearly three times in that of the last; ventral fins very long, extending to the third soft ray of the anal. Rose-coloured; dorsal and ventral fins nearly entirely black; anal and caudal fins with a broad black margin; pectorals yellowish.

Atlantic shores of South America.

a. Adult. S. America. Presented by Sir R. Schomburgk.

b. Young. Sine patria.

\section{Priacanthus japonicus.}

Priacanthus japonicus, (Langsdorf) Cuv. \& Val. iii. p. 106. pl. 50 ; Faum. Japon. p. 20 (not Bleek.).

$$
\text { D. } \frac{10}{12-13^{\circ}} \text { A. } \frac{3}{12-13} \text {. L. lat. } 70 \text {. }
$$

The height of the body is nearly three times in the total length, the length of the head $3 \frac{1}{3}$; the diameter of the eye is two-fifths of the latter. The posterior opening of the nostrils is long, broad, ear-shaped, wider above than beneath. The angle of the præoperculum obtuse, with an acute, not serrated, triangular spine; operculum with two small spines, a third larger one above, belonging to the scapular bone; sub- and interoperculum minutely serrated. Caudalis truncated; all the spines and rays of the dorsal and anal fins with a striated or rough surface; the last dorsal spine is $2 \frac{1}{3}$ as long as the second, and much longer than the diameter of the eye; ventrals very long, extending beyond the third soft ray of the anal. Rose-coloured; the spinous dorsal and the ventrals black.

Cape Seas; Chinese and Japanese Seas.

a. Adult: stuffed. Cape Seas. Presented by Sir A. Smith.

b. Skin, in spirits. Japan.

c. Skin, in spirits. Japan.

d. Skin, in spirits. Japan.

e. Skin, in spirits. Japan. From Mr. Frank's Collection.

f. Young. China Sea. Presented by Captain Sir Edward Beleher.

This fish is probably only a clmmatal variety of Pr. bonariensis.

\section{Priacanthus niphonius.}

Cuv. \& Val. iii. p. 107; Faun. Japon. Poiss. p. 21. pl. 7 a. f. 1, 2.

$$
\text { D. } \frac{10}{11-12} \text {. A. } \frac{3}{10-11} \text {. L. lat. } 50 \text {. }
$$

The height of the body is $2 \frac{2}{3}$ in the total length, the length of 
the head $3 \frac{1}{3}$; the diameter of the eye is $2 \frac{1}{3}$ in the latter. The posterior opening of the nostrils is long, wide, situated on the upper part of the head, semilunar, with the convexity turned forwards. The angle of the præoperculum obtuse, with a cery indistinet spine; operculum with two inconspicuous spines; sub-and interopereulum and scapular bones serrated. Caudalis truneated; all the spines and rays of the dorsal and anal fins rough or striated; the second and the last dorsal spines nearly equal in length, the fifth longest; the ventrals reach to the anus. Rose-coloured; fins immaculate; the rentrals more or less blackish.

Japanese Sea.

a. Skin, in spirits. Japan.

$b$, c. Adult: stuffed. Japan. From Mr. Frank's Collection.

\section{Priacanthus blochii.}

Anthias macrophthalmus, Bl. vi. p. 115, t. 319 ; Bl. Schn. p. 304. Priacanthus japonicus, Bleeker, Natuurk. Tydschr. Ncderl. Indie, ii. p. 171 (not C'uv. \&. Tal.).

- blochii, Bleek. l. c. ir. p. 456.

$$
\text { D. } \frac{10}{13-14} \text {. A. } \frac{3}{14-15^{\circ}} \text { L. lat. } 70 .
$$

The height of the body is equal to the length of the head, and $3 \frac{1}{2}$ in the total; the diameter of the eye is two-fifths of the length of the head. The posterior opening of the nostrils is a long, narrow, elliptical slit. The angle of the præoperculum is rather obtuse, with a slightly projecting, flat, triangular spine; opereulum with two small spines; sub- and interopereulum entire. Caudalis truncated; all the spines and rays of the dorsal and anal fins rough; the last dorsal spine longest, equal to the diameter of the eye, and rather more than twice the length of the second; the ventral fins extending beyond the front end of the anal. Rose-eoloured; the rertical and ventral fins with black margins.

Sea of Amboyna; Sumatra.

a. Adult. Moluecas. From Mr. Frank's Collection as Pr. macrophthatmus.

b. Half-grown. Amboyna. From Mr. Frank's Collection.

c. Young. Amboyna. From Mr. Frank's Collection.

\section{Priacanthus benmebari.}

Temm. \&. Schleg. Fanm. Jupon. p. 19. pl.7. f. 1; Krusenstern, p. 53. f. 2 ; Richardson, Ichthyol. China and Jupun, p. 237.

$$
\text { D. } \frac{10}{13} \text {. A. } \frac{3}{14} \text {. I. lat. } 75-80 \text {. }
$$

The height of the body is $3 \frac{1}{2}$ in the total length, the length of the head $3 \frac{2}{3}$; the diameter of the efe is $2 \frac{3}{1}$ in the latter. 'The posterior opening of the nostril elliptical, ahout $2 \frac{1}{2}$ as long as broad. 
The angle of the præoperculum slightly obtuse, with a flat, rather elongate, serrated spine; opereulum with two very small spines; sub- and interoperculum with excessively fine denticulations. Caudalis truneated; dorsal and anal spines very slender, neither rough nor striated; the last of the dorsal fin hardly longer than the eighth and ninth, and $1 \frac{1}{2}$ as long as the second; the ventral fins reaching to the anal, but shorter than that fin. Red; dorsal, anal, and ventral fins paler, with round yellow spots.

Japanese Seas.

a. Adult: stuffed. Japan. From the Lefden Museum.

\section{Priacanthus hamruhr.}

Sciæna hamruhr, Forsk. p. 45.

Anthias hamruhr, Bl. Schn. p. 307.

Lutjanus hamruhr, Lacćp. iv. p. 209.

Priacanthus hamruhr, Cuv.\& Val. iii. p. 104; Rïpp. N. W. Fische, p. 95.
D. $\frac{10}{12-15}$.
A. $\frac{3}{15}$.
L. lat. 85 .
Vert. $9 / 13$.

Allied to $\mathrm{Pr}$. benmebari.

The height of the body is nearly equal to the length of the head, and rather more than one-fourth of the total; the diameter of the eye is nearly one-third of the length of the head. The posterior opening of the nostrils is a very long slit, four times as long as broad. The angle of the præoperculum obtuse, with a prominent keel instead of a free spine; operculum obtusely serrated, with a very small spine; sub- and interoperculum?. Caudalis more or less emarginate; all the anal and dorsal spines slender, smooth; the rays of the anal fin rough, those of the dorsal smooth; the last dorsal spine is $1 \frac{2}{3}$ as long as the second, the ventrals extending to the front end of the anal. Rose-coloured; fins immaculate, the vertical fins with a blackish margin.

Red Sea.

a. Adult: stuffed. Red Sea. From the Frankfort Museum.

\section{Priacanthus carolinus.}

Cuv. \& Val. iii. p. 105; Less. Voy. Coq. Zool. Poiss. p. 224 ; Bleeker, Banda, i. p. 235.

$$
\text { D. } \frac{10}{12-13} \text {. A. } \frac{3}{13-14} \text {. L. lat. } 85 \text {. }
$$

The height of the body is $3 \frac{1}{3}$ in the total length, the length of the head $3 \frac{3}{4}$; the diameter of the eye is two-fifths of the latter. The angle of the præoperculum obtuse, with a serrated spine of moderate length; operculum with a single small spine; sub- and interoperculum entire; the last dorsal spine equal to the diameter of the eye. Caudalis truncated; the ventral fins reaching beyond the first anal spine. Rose-coloured; the caudal and the soft portions of the dorsal and anal fins with numerous black dots. (Bl.)

Island of Oualand (Carolines); Banda Neira. 


\section{Priacanthus schmittii.}

Bleeker, Sumatra, i. p. 572.
D. $\frac{10}{12}$.
A. $\frac{3}{12-13}$.
L. lat. 65 .

The height of the body is $3 \frac{1}{2}$ in the total length, the length of the head $3 \frac{1}{3}$; the diameter of the eye is three-serenths of the latter. The angle of the præoperculum obtuse, with a serrated spine of moderate length; operculum with two small spines. Caudalis truneated; the last dorsal spine shorter than the diameter of the eye; the ventral fins not extending to the anal fin. Rose-coloured; fins immaeulate; the ventrals reddish violet, with a white spot on the membrane connecting the fifth ray with the belly. $(B l$.

Sea of Padang.

\section{Priacanthus holocentrum.}

Bleeker, Perc. p. 48.

$$
\text { D. } \frac{10}{13} \text {. A. } \frac{3}{14} \text {. L. lat. } 65 \text {. }
$$

Allied to Pr. tayenus.

The height of the body is equal to the length of the head, and $3 \frac{1}{2}$ in the total; the diameter of the eye is $2 \frac{1}{3}$ in the length of the head. Præopereulum with a very long serrated spine, extending beyond the posterior limb of the operculum; operculum with two small spines. Caudalis truncated; the second spine of the dorsal is two-thirds of the last, which is the longest; the rentrals reach to the front end of the anal fin. Rose-coloured; dorsal and anal fins black-edged; ventrals with black spots; the membrane between the ventrals and the belly with a black spot.

Bataria; Sumatra.

a. Half-grown. Sumatra. (Named Priacanthus pocilopterus ?)

b. Half-grown : dried. This speeimen perfectly agrees with the other one, but is said to have been procured from the London market (?).

\section{Priacanthus macracanthus.}

Priacanthus macracanthus, Cur. \&.Val. iii. p. 108; Less. Voy. Coq. Zool. Poiss. p. 225; Bleck. Perc. p. 48.

— fax, Bleek. Topogr. Batar.

$$
\text { D. } \frac{10}{14} \text {. A. } \frac{3}{15} \text {. L. lat. } 90 \text {. }
$$

The height of the body is equal to the length of the head, and $3 \frac{1}{2}$ in the total length; the diameter of the eye is $2 \frac{1}{3}$ in the length of the head. Pracoperculum with a long, flat, serrated spine, extending beyond the hinder margin of the interopereulum; opereulum with two small spines. Caudalis truncated. Uniform rose-coloured; peetoral and ventril fius yellowish.

Amboyna; Batavia; Jiłuan.

a. Skin, in spirits. Jrpran. 
13. Priacanthus dubius.

Temm. \& Schleg. Faun. Japon. Poiss. p. 19.
D. $\frac{10}{14}$.
A. $\frac{3}{16}$.

Caudalis forked. The height of the body is more than one-third of the total length. Angle of the præoperculum obtuse, and with a short, flat, serrated spine. Ventral fins elongate, extending to the third anal spine; fins immaculate; the dorsal and anal with a blackish margin ; the ventrals blackish, with a black spot at the base. (Schleg.) Japanese Sea.

\section{Priacanthus tayenus.}

Priacanthus tayenus, Richards. Ichth. of the Seas of China, p. 237.
D. $\frac{9-10}{12}$.
A. $\frac{3}{12-13}$.
L. lat. 75.

Caudalis forked, with lengthened tips. The height of the body is one-fourth of the total length; the diameter of the eye nearly one-half of the length of the head, or twice as large as its distance from the end of the snout. The spine of the præoperculum long and serrated. All the dorsal and anal spines are feeble and slender; the second of the dorsal fin is two-thirds of the last, which is the longest; the ventral fins reach only to the anus. Rose-coloured; the ventrals with the eonnecting membrane brown-spotted.

Chinese Sea.

a. Adult. Canton. Presented by J. R. Reeves, Esq.

\section{Priacanthus speculum.}

Cuv. \& Val. vii. p. 471 ; R̀gne Anim. Ill. Poiss. pl. 11. f. 1.

$$
\text { D. } \frac{10}{14} \text {. A. } \frac{3}{15} \text {. }
$$

Caudalis forked. The height of the body is equal to the length of the head, and one-fourth of the total; the diameter of the eye is $2 \frac{2}{3}$ in the length of the head, and equal to its distance from the end of the snout. Præoperculum with a very obsolete spine; the length of the anal fin is one-half of the height of the body. Red: anal edged with blackish; rentrals violet. $(\mathrm{Val}$.

Seychelles. 


\section{Fifth Group. A POGONINA.}

\section{AMBASSIS *}

Chanda, sp., Buch. Ilam. Fish. of Gunges, p. 103.

Ambassis, (Commers.) Cur. \& Val. ii. p. 175.

Bogoda (and Ambassis), Bleek. Nalez. Ichth. Faun. Beng. en Hindost. p. 89.

Six branchiostegals. Teeth villiform, without conspicuously larger canines; teeth on the palatine bones. Two dorsals, the first with seren, the anal fin with three spines; a recumbent spine in front of the dorsal, pointing forwards. Operculum without a prominent spine; the lower limb of the præopereulum with a double denticulated edge $\uparrow$. Seales large, deciduous.

Small fishes, living in the fresh and brackish waters and in the seas of the Indian Region; North Australia; Dalmatia.

A. Species with the anal fin of moderate length (9-11 rays).

\section{Ambassis robustus.}
D. $7 \mid \frac{1}{10}$.
A. $\frac{3}{9}$.
L. lat. 46 .
L. $\operatorname{transi} \cdot \frac{7}{16-17}$.

The height of the body is rather more than twice in the total length (without eaudal fin); the second spine of the anterior dorsal almost four times in the same length; the third spine of the anal fin smaller and shorter than the second. Lateral line with a rather strongly eurved arch beneath the fourth spine of the dorsal fin. Coloration (in spirits) uniform.

Bormeo.

a. Adult.

Prof. Peters, of Berlin, has kindly informed me that a specimen of this species, which is apparently undeseribed, exists in the Berlin Museum. It was sent by Prof. Schlegel, who gave to it the name of A. robustus, and marked it as coming from Borneo. In the Berlin specimen the second anal spine is as long as the head, and one-third of the total length, whilst it is shorter in that in the British Museum Collection.

* 1. Chanda lata, Buch. Ham. p. 1it. pl. 21. f. 39; Cuv. \& Val. ii. p. 184: Bleck. Verl. Bat. Gen. xxr. tab. 1. f. 1.-Ganges.

2. Chanda baculis, Buch. Ham. p. 11; Cuv. \& Val. ii. p. 187.-Ganges.

3. Ambassis barlovi, Syles, Trans. Zool. Soc. i. p. 350. t. 60. f. 1 (bad).

4. Priopis argyrozona, (Kuhl \& v. Hess.) Cuv. \& $V^{2} a l$. vi. p. 503. Known from a drawing only: it may be placed for the present among the doubtful species of Ambassis, to which it is allied, though it may be the type of a separate genus.-Java.

t Sir J. Richardson is wrong in describing "both the anterior and the posterior edges of the proporenlar limb denticilated." (Ichthyology. p. 275.) 


\section{Ambassis commersonii.}

Sciæna safgha, Forsk. Descr. Anim. p. 53.

Centropomus ambassis, Lacép. iv. p. 273.

Lutjanus gymnocephalus, Lacép. iv. p. 216, iii. pl. 23. f. 3.

Ambassis commersonii, Cuv. \& Val. ii. p. 176. pl. 25 ; Rüpp. N.W. Fische, p. 89.

Ambassis nalua, Bleek. Perc. p. 30 ; Batav. p. 453.
B. 6 .
D. $7 \mid \frac{1}{9-10}$.
A. $\frac{3}{9}$.
L. lat. 30-33. Vert. 9/15.

The height of the body is $2 \frac{1}{2}$ in the total length (without caudal fin); the second spine of the first dorsal is $3 \frac{1}{3}$ in the same length. The second and third spines of the analis are equal in size and length, or the third is rather longer; lateral line slightly curved. Coloration of body uniform.

Red Sea; Isle de France; East Indian Seas; Shores of Northern Australia (not yet found in the Chinese Seas).

Cuvier quotes (p. 176) among the synonyma Chanda nalua, Buch., which is afterwards (p. 182) described as a separate species.

a. Adult: skeleton. India. From the Haslar Collection.

b, $c$. Half-grown. India.

d. Half-grown: not good state. India.

$e, f$. Half-grown. India. Presented by W. Masters, Esq.

g. Fine specimen. Purchased of Mr. Frank.

h. Half-grown. Amboyna. From Madame Ida Pfeiffer's Collection.

$i$. Half-growu. Philippines. From Mr. Cuming's Collection.

$k$. Adult. Java. From Mr. Frank's Collection.

l. Adult. Java.

m. Adult. Port Essington. From the Haslar Collection.

n. Adult. N. Australian Exped. Presented by Dr. J. R. Elsey.

o. Adult. Australia. Presented by the Earl of Derby.

Skeleton.-The skull, compared with that of species of Apogon, exhibits the capsula cerebri, although rounded, only slightly prominent, forming the base of a very high crest, which, triangular and pointed behind, reaches to the middle of the interspace between the orbits; it is supported by two bony spines, one of which is small, arising from the paroccipital and directed horizontally backwards; the other, much longer and stronger, arises from the middle of the suture between paroccipital and frontals, and passes in an oblique direction to the upper posterior angle of the erest. There is a groove and a ridge between the orbital part of the frontals, as in Apogon; the groove is, again, bifid behind, and there is another small elevated ridge along each posterior branch of the groove. The præoperculum exhibits also a double edge, an exterior and an interior; the lower branches of both are serrated in this species, and there is a strong spinous tooth at the angle of the interior edge. The præorbital is strongly serrated. There is no spine, or only a very feeble one, supporting the operculum. The intermaxillary and dentary bones are armed with teeth along their entire length; those of the vomer and of the palatine bones are situated in single series, 
the former forming an obtuse angle. There are nine abdominal and fifteen caudal vertebræ. According to the rule that the strongest dermoneural or dorsal spines are supported by the strongest interneurals, we find in this species the two anterior interneural bones of the dorsal fin and the two anterior of the anal very strong-the former corresponding to the neural spines (processus spinosi) of the second and third abdominal vertebræ, the latter to those of the first and second of the caudal portion.

\section{Ambassis urotænia.}

Bleek. Amb. \& Cer. p. 257.

$$
\text { D. } 7 \mid \frac{1}{9-10} \text {. A. } \frac{3}{9-10} \text {. }
$$

The height of the body is $2 \frac{1}{2}$ in the total length (without candal fin); the second spine of the first dorsal is $4 \frac{1}{2}$ in the same length; the third anal spine longest, shorter than the second of the dorsal fin. Yellowish, with a silvery lateral band; the first dorsal blackish between the second and third spines; each lobe of the caudal fin with a broad blackish longitudinal band. (Bl.)

Seas of Amboyna and Wahai.

\section{Ambassis kopsii.}

Bleek. Singapore, ii. p. 253.
B. 6 .
D. $7 \mid \frac{1}{10-11}$.
A. $\frac{3}{8-9}$.
L. lat. 27-28.

The height of the body is nearly one-half of the total length (without caudal fin). Orbit with a small spine, directed backwards, at the posterior upper angle; suboperculum cntire, interoperculum slightly denticulated. Lateral line continuous; the second anal spine rather longer than the third, but shorter than the second of the dorsal fin. Yellowish, body and rertical fins minutely dotted with brown; the spinous dorsal with a rather broad black superior edge. $(B l$.

Sea of Singapore.

\section{Ambassis apogonoides.}

Bleeker, Borneo, iv. p. 200.
B. 6 .
D. $7 \mid \frac{1}{10-11}$.
A. $\frac{3}{9-10}$.
L. lat. 32.

Head pointed, as in Apogon. The height of the body is $3 \frac{1}{4}$ in the total length (caudal included), the length of the head $3 \frac{1}{2}$ in the same length; the diameter of the eye $3 \frac{1}{3}$ in the length of the head; the upper profile of the head concave; the upper maxillary bone reaching to below the middle of the eye. Denticulations of the præorbital and præoperculum very small, inconspicuous; the second dorsal spine longest, one-seventh of the total length, and half the height of the body; the first ray of the ventral fin rather elongate; the second and 
third 'anal spines nearly equal, almost as long as the second of the dorsal fin. Caudalis deeply forked. Yellowish; the first dorsal blackish at the tip. $(B l$.

Rivers of Borneo.

\section{Ambassis batjanensis.}

Bleeker, Batjan, ii. p. 196.
D. $7 \mid \frac{1}{9-10}$.
A. $\frac{3}{9-10}$.
L. lat. 28.
L. transv. $\frac{2}{7}$.

The height of the body is $2 \frac{1}{2}$ in the total length (without caudal fin). Præorbital entire ; inferior limb and angle of the præoperculum denticulated; the length of the dorsal spine is five times in the total ; the third spine of the analis longer than the second. Shining yellowish, with a bluish longitudinal streak ; root of the caudal fin more or less violet.

Fresh waters of Batjan; Amboyna.

a. Adult. Amboyna. From Mr. Frank's Collection.

\section{Ambassis dussumieri.}

Ambassis dussumieri, Cuv. \& Val. ii. p. 181, vi. p. 503, ix. p. 431; Bleeker, Perc. p. 30; Quoy \& Gaim. Voy. Astrol. Poiss. p. 650. pl. 1. f. 3.

Chanda dussumieri, Cantor, Catal. p. 6.

$$
\text { D. } 7 \mid \frac{1}{9-10} \text {. A. } \frac{3}{9} \text {. }
$$

The height of the body is more than three times in the total length (without caudal fin); the second spine of the first dorsal onefifth of the same length; the diameter of the eye is nearly one-third of the length of the head; lateral line interrupted. Coloration of body uniform.

Malabar; Sea of Pinang; Javanese and Chinese Seas; Celebes; Amboyna; Isle de France; Seychelles.

a. Half-grown China.

b. Half-grown. China.

c. Half-grown. China.

\section{Ambassis thermalis.}

Cuv. \& Val. iii. p. 493.

$$
\text { D. } 7 \mid \frac{1}{9} \text {. A. } \frac{3}{9} \text {. }
$$

The height of the body is not fully three times in the total length (without caudal fin). Greenish, with a silvery lateral band; on each lobe of the caudal fin a blackish longitudinal streak. (Les éeailles sont grandes et fortes.-Cuv.)

Warm springs of Cania (Ceylon).

\section{Ambassis nalua.}

Ambassis nalua, Cuv. \& Val. ii. p. 182. 
Chandá nalua, Ham. Buch. Gung. Fish. p. 107. t. 6. f. 36 ; Cantor, Catal. p. 6.

$$
\text { D. } 7 \mid \frac{1}{10-11} \cdot \quad A \cdot \frac{9}{9-10} .
$$

The height of the body is one-half of the total length (without eandal.fin); the seeond spine of the first dorsal is one-fourth of the same length ; no spinous teeth on the hinder part of the orbit (?); interoperculum entire (?). Coloration of body uniform.

A rather donbtful'species.

Jaranese Seas; Sca of Pinang; Rirers of Lower Bengal.

\section{Ambassis interrupta.}

Bleeker, Ceram, ii. p. 696.

$$
\text { D. } 7 \mid \frac{1}{9-10} . \quad \text { A. } \frac{3}{9-10} . \quad \text { L. lat. } 28 \text {. }
$$

The height of the body is one-half of the total length (without caudal fin). Above the eye a small spine, directed backwards ; orbit denticulated beneath; interopereulum dentieulated; the lateral line interrupted beneath the second dorsal fin; the seeond spine of the first dorsal one-third of the total length (without eaudal fin); the third anal spine longest, but much shorter than the second of the dorsal fin. Coloration uniform, with a silvery lateral band; fins yellowish, the interspace between the second and third dorsal spines blackish.

Seas of Bataria and Wahai (Ceram).

\section{Ambassis buruensis.}

Bleeker, Bocroe, p. 396.
D. $7 \mid \frac{1}{8-9}$.
A. $\frac{3}{9-10}$.
L. lat. 28.
L. transr. $\frac{3-4}{7-8}$.

The height of the body is $2 \frac{1}{3}$ in the total length (without caudal fin). Above the eye a small spine, directerl baekwards ; orbit not dentieulated beneath; interopereulum with a small spine at the angle; the lateral line interrupted beneath the front end of the second dorsal; the second spine of the first dorsal is $3 \frac{1}{2}$ in the total length (without eaudal); the third anal spine not much longer than the second, and shorter than the seeond of the dorsal fin. Coloration uniform, with a silvery lateral band; fins yellowish, the interspace between tho second and third dorsal spines blackish. (Bl.).-Closely allied to the preeeding species.

Rivers of Boeroe.

\section{Ambassis wolffii.}

Bleeker, Borneo, i. 13. 9.

$$
\text { D. } 7 \mid \frac{1}{10} \text {. A. } \frac{3}{10} \text {. L. lat. } 36 .
$$

The height of the body is rather more than one-half of the total length (without cauclal fin); the second dorsal spine is nearly onefourth of the same length, and equal to the second of the anal fin: 
several small spinous teeth above the orbit; interoperculum slightly denticulated. Coloration uniform ; tho first dorsal above black. $(B l$. Rivers of Borneo.

\section{Ambassis vachellii.}

Richardson, Ichthyol. China, p. 221.

$$
\text { D. } 7 \mid \frac{1}{9} \text {. A. } \frac{3}{9} \text {. }
$$

The height of the body is $1 \frac{1}{2}$ in the total length, without caudal fin (Rich. states the length of fish 2.50 inches; height of body 1.68 inch); four teeth, reclining backwards on the hinder part of the orbit.

Sea of Canton.

\section{Ambassis macracanthus.}

Bleeker, Perc. p. 30, and Batavia, p. 455.

$$
\text { D. } 7 \mid \frac{1}{9-10} . \quad \text { A. } \frac{3}{9-11} \text {. L. lat. } 29 \text {. }
$$

The height of the body is one-half of the total length (without caudal fin); the second spine of the first dorsal is $2 \frac{1}{2}$ in the same length. Sub- and interoperculum entire; lateral line continuous; the third anal spine longest. Coloration of body uniform; the interspace between the second and third dorsal spines blackish.

Sea of Batavia.

\section{Ambassis macrolepis.}

Bogoda macrolepis, Bleek. Act. Soc. Nederl. ii., Borneo, p. 13.

$$
\text { D. }\left.7\right|_{\frac{1}{10}} \text {. A. } \frac{3}{10} \text {. L. lat. } 70 \text {. }
$$

Præorbital denticulated; the second anal spine longest, not shorter than the second of the dorsal.

River Kapuas (Borneo).

\section{B. Species with the anal fin rather elongate (14-17 rays).}

\section{Ambassis alta.}

Cuv. \& Val. ii. p. 183.

$$
\text { D. } 7 \mid \frac{1}{14} \text {. A. } \frac{3}{14} \text {. }
$$

The height of the body is $2 \frac{1}{2}$ in the total length (caudal fin included); the second spine of the first dorsal is one-half of the height of body. Both the inferior edges of præoperculum and præorbital beautifully serrated.

Bengal.

a-c. Adult. India. Presented by G. R. Waterhouse, Esq.

$d-h$. Half-grown. India. Presented by G. R. Waterhouse, Esq.Body with three darker eross-bands. 


\section{Ambassis ranga.}

Chanda ranga, Buch. Ham. p. 113. pl. 16. f. 38 .

Ambassis ranga, Cuv. \& Val. ii. p. 183.

$$
\text { D. } 7 \mid \frac{1}{12} \text {. A. } \frac{3}{15} \text {. }
$$

The height of the body is $2 \frac{1}{3}$ in the total length (caudal fin included); the first spine of the second dorsal denticulated.

Mouth of the Ganges.

\section{Ambassis oblonga.}

Chanda nama, Buch. Ham. Fish. Gang. p. 109. pl. 39. f. 39. phula, Buch. Ham. l.c. p. 111.

Ambassis nama et phula, Cuv. \& Val. ii. pp. 185, 186.

- oblonga, Cuv.\& Val. ii. p. 185.

Bogoda nama, pt., Bleeker, Nalez. Ichthyol. Fanna Beng. en Hindost. p. 89. tab. 1. f. 2 .

$$
\text { D. } 7 \mid \frac{1}{15} \text {. A. } \frac{3}{14} \text {. }
$$

The height: of the body is one-fourth of the total length (candal fin included); the second spine of the first dorsal is one-half of the height of the body. Præoperculum and præorbital very slightly serrated. Scales very small.

Fresh waters of Bengal.

a, b. Adult, India. Presented by G. R. Waterhouse, Esq.

\section{Ambassis bogoda.}

Chanda bogoda, Buch. Ham. p. 111.

Ambassis bogoda, Cuv. \& Val. ii. p. 187.

Bogoda nama, pt., Bleek. Nalez. Ichthyol. Fanna Beng, en Hindost. p. 89.

$$
\text { D. } 7 \mid \frac{1}{15} \text {. A. } \frac{3}{17} \text {. }
$$

The height of the body is not fully $2 \frac{1}{2}$ in the total length (without caudal fin); the second spine of the first dorsal is $5 \frac{1}{2}$ in the same length. Scales very small.

Month of the Ganges.

$a, b$. Half-grown. India. Presented by the East India Company.

\section{MICROICHTHYS.}

Microichthys, Rüppell, Verz. der im Mus. Senckenbg. aufgest. Samml. Fische, p. 1.

Seven branchiostegals. All the tecth villiform, without canines; palatines?*; tongue? Two separate dorsals; anal fin with two spines; an acute ridge from the eye extending backwards over the opercles*. Scales large, deciduous; opercles naked. Lateral line commencing under the first rays of the second dorsal.

Mediterranean.

* Sir J. Richardson (Ichthyol. p. 275) misunderstood a part of Rüppell's de. scription. Rüppell says, "Dio Zähne am Gaumen konnten nicht untersucht werden," and "von dem Auge riuckwürts über die schuppenlosen Operkeln eine in eine Spitze auslaufende Leiste." 


\section{Rüppell, l.c.}

\section{Microichthys cnccoi.}

General aspect and the form and position of the fins as in Ambassis; lower jaw prnjecting a little beyond the upper.

Sea of Sicily.

\section{4. $\triangle P O G O N *$}

Apogon, Lacép. iii. p. 411; Cuv. \& Val. ii. p. 142.

Seven branchiostegals. All the teeth villiform, without canines; teeth on the palatine bones; tongue smooth. Two separate dorsals, the first with six or seven, the anal fin with two spines. Operculum spiniferous; præoperculum with a double serrated ridge. Scales large, readily deciduous.

From the Red Sea, through all the Seas of the Indian and Australian region, some species entering the fresh waters; one species found on the coast of Brazil.

\section{Synopsis of the Species.}

A. Apogon with less than ten soft rays in the anal fin, and

1. with six spines in the first dorsal.

a. Body without longitudinal or transverse bands.

a. With a black blotch on each side of the base of the caudal fin.

1. A. imberbis,

2. A. heptastigma,

4. A. thermalis.

3. A. hyalosoma.

B. Without such a black blotch.

5. A. pœcilopterus,

6. A. godini,

7. A. axillaris,

8. A. hypselonotus,

9. A. leptacánthus,

10. A. nigromaculatus.

b. Body with darker transverse bands or oblong transverse spots.

11. A. orbicularis,

i2. A. nematopterus,
13. A. trimaculatus,

14. A. rhodopterus,

15. A. koilomatodon.

c. Body with longitudinal bands.

16. A. margaritophorus, 18. A. amboinensis, 17. A. tæniatus,

19. A. sangiensis,

20. A. ceramensis.

* 1. Apogon latus, (Ehrenb.) Cuv. \& Val. ii. p. 159.-Red Sea.

2. multitæniatus, Cuv.\& Val. l.c.; Rüpp. Atl. p. 47.-Red Sea.

3. - coccineus, Rüpp. N.W. p. 88. t. 22. f. 5.-Red Sea.

4. - ceylonicus, Cuv. \& Val. iii. p. 491.

5. - moluccensis, Val. Nouv. Ann. Mus. Hist. Nat. 1832, p. 54.Amboyna.

6. - guamensis, Val. l.c.-Guam.

7. - novæ hollandiæ, Val. l.c. p. 55. pl. 4. f. 2.-Australia.

8. — lateralis, Val. l.c. p. 58.- Vanicolo.

9. - novem-fasciatus, Faun. Japon. pl. 2. f. 2 ; A. schlegelii, Bleek, Verhand. Batav. Genootsch. xxvi. p. 55.-Japan.

10. - fuscus, Quoy \& Gaim. Voy. Freyc. Zool. p. 345.-Guam. 
2. With seven spines in the first dorsal.

a. Body without longitudinal or transverse bands.

21. A. nigripiunis,

22. A. toniopterus,

23. A. monochrous,
24. A. maculosus,

25. A. enneastigma,

26. A. rüppellii,

27. A. novæ guiner,
28. A. cupreus,

29. A. hoevenii,

30. A. truncatus.

b. Body with darker transverse bands or oblong transverse spots.

31. A. bifasciatus,

32. A. timoriensis,

c. Body with longitudinal bands.

36. A. quadrifasciatus, 40. A. frenatus,

37. A. semilineatus, 41. A. kallopterus,

38. A. chrysopomus, 42. A. fasciatus,

39. A. kalosoma,
43. A. cyanosoma,

44. A. cyanotænia,
34. A. annularis,

35. A. lineatus.

45. A. multitæniatus,

46. A. hartzfeldii,

47. A. chrysotænia,

48. A. victoriæ.

3. With eight spines in the first dorsal.
49. A. melas,
50. A. cantoris.

4. With nine spines in the first dorsal.

51. A. meaco.

B. Apogon with more than ten soft rays in the anal fin.
52. A. lineolatus,
54. A. macropterus,
55. A. bleekeri,
57. A. buruensis,
53. A. fucatus,
56. A. macropteroides,
58. A. zosterophorus.

A. Apogon with less than ten soft rays in the anal tin.

$$
\text { 1. D. 6. } \mid \frac{1}{8 \text { or } 9^{\circ}} \text { A. } \frac{2}{7 \text { or } 8 \text { (in one species } 9)^{\circ}} \text {. }
$$

a. Body without longitudinal or transverso bands.

\section{Apogon imberbis.}

Corvulus, Gesner, p. 1273.

Mullus imberbis sive Rex nullorum, Willughby, p. 286 ; Ray, p. 91.

Trigla, sp. 3, Artedi, Genera, p. 43.

Amia, Gronov. Zooph. p. 80. pl. 9. f. 2 (omitted in his system).

Mullus imberbis, Limn. Syst. Nat. xiii. edit. 1. sp. 1341 ; Shav, Zool. iv. p. 618.

A pogon ruber, Lacép. iii. p. 411; Risso, Ichth. Nice, edit. 1. p. 214.

Dipterodon hexacanthus, Lacép. iv. p. 167, iii. pl. 4. f. 2.

Centropomus auratus, Lacép. iv. p. 273.

- rubens, Spinola, Ann. Mus. Hist. Nat. x. p. 370. pl. 28. f. 2.

Perca pusilla, De la Roche, Ann. Mus. Hist. Nat. xiii. p. 318.

A pogon rex mullorum, Cuv. \& $\mathrm{Val}$. ii. p. 143; Cuv. Rigne Anim. Ill.

pl. 7. f. 2 (not good); Guichen. Explor. Alyer. Poiss. p. 32.

A black blotch on each side of the tail. Bright red or orangecoloured in life, with minute black points; fins not spotted.

Mediterranean; Madeira.

a. Adult. Europe.

b. Adult: skeleton. Europe. 
c-e. Adult. Mediterranean. From Mr. Frank's Collection.

f. Adult. Sicily. Presented by W. Swainson, Esq.

g. Adult: bad state. Madeira. From the Haslar Collection.

Skeleton.-The skull of the species of the genus Apogon is distinguished by the hemispherical prominent capsula cerebri, formed by the parietal and occipital bones and by the hinder part of the frontals ; the latter part is generally provided with two or more small spinous prominences; the orbital part of the frontals is very developed, not flat, but with a deep narrow groove along the median line; this groove is bifid behind, thus separating the orbital part of the frontals from the posterior. In front of the median groove is a high ridge, generally half as long as the diameter of the eye, and bifid behind; this ridge, together with those spinous prominences of the frontals, is for the purpose of keeping the skin suspended above the grooves. Large mucose cavities are formed thereby, communicating with those of the suborbital arch, \&c. The occipital crest is very developed and broad, more or less truncated behind, reaching downwards to the vertebral column, and supported by another, narrower, horizontal one, which arises also from the occipital. Another peculiarity of the skull of Apogon is the internal free ridge of the prooperculum, parallel to the external margin. The operculum is always supported by a strong, straight bony ridge, conspicuous from the outside, but prominent only at the inner surface; it arises near the articulation of the operculum with the epitympanic (os temporcle), and projects sometimes in a small free spine at the hinder angle of the operculum.

In Apogon imberbis the lower outer margin only of the prooperculum is very finely denticulated, the teeth becoming smaller at the angle. The vomerine and palatine teeth are arranged in a single row, the series of the former forming a right angle. There are eleven abdominal and fourteen caudal vertebræ.

\section{Apogon heptastigma.}

Apogon heptastigma, (Ehrenberg) Cuv.\& Val. ii. p. 160.

Two black spots on each side of the tail; brownish red, tins reddish ; five black spots at the base of dorsalis.

Red Sea.

\section{Apogon hyalosoma.}

Apogon thermalis, Blecker, Perc. p. 27 (not Cuv.).

- hyalosoma, Bleeker, Singapore, p. 63, and Amboyna, iv. p. 329.

Caudalis slightly notched. Uniform yellowish, with a black spot at the root of the caudal fin; interspace between the second and third dorsal spines black. Suprascapula, sub-and interopereulum errtire; the upper maxillary bone reaching to below the posterior half of the eye.

Seas of Batavia, Sumbawa, Amboyna, and Sumatra.

a. Adult. Amboyna. From Mr. Frank's Collection. 


\section{Apogon thermalis.}

Cuv. \&. Val, iii. p. 492 (not Bleeker).

A black blotch on cach side of the tail. Uniform yellowish; interspace between the sccond and third spines of the first dorsal fin blackish.

Warm springs of Cania (Ceylon).

The circumstance of this spccies being found in warm springs makes it probable that it is different from the preceding. The original description, like most of Valenciennes's, is too imperfect to determine specimens by it.

\section{Apogon pœcilopterus.}

Apogon pœcilopterus, (Kuhl \& van Hasselt) Cuv. \& Val. ii. p. 154; Cantor, Catal. p. 2.

No black blotch on the tail; sides brown-spotted; a large black spot on the first dorsal fin; the second marbled with brown, and with a brown band at the base. Nine soft rays in the analis.

Jaranese Sea.

\section{Apogon godini.}

Bleeker, Sumatra, iii. p. 496.

No black blotch on the tail; rose-coloured; scales with violet edges ; fins not spotted. Thirty-three scales in the lateral linc. Caudalis emarginate.

Western coast of Sumatra.

\section{Apogon axillaris.}

Valenciennes, Nouv. Ann. Mus. Hist. Nat. 1832, p. 56. pl. 4. f. 3.

Reddish, minutcly punctulated with blackish; a deep black spot at the base of the pectoral fins, which are punctulated with black. Caudalis slightly notched; præorbital entire; præoperculum with a single edge beneath; analis with soven soft rays.

Ascension Island.

\section{Apogon hypselonotus.}

Bleeker, Batoe, p. 309.

Uniform greenish. Caudalis deeply forked; suprascapula, suband interoperculum entire; the sceond dorsal spine longest. L. lat. 23-25. L. transv. 9.

Sea of Batoe.

\section{Apogon leptacanthus.}

Bleeker, Ternate, viii. p. 204.

Coloration uniform. Caudalis notched; the dorsal spines flexible; the second elongate, filiform. L. lat. 24. L. transv. 8-9.

Sea of Ternate. 


\section{Apogon nigromaculatus.}

Hombr. \& Jacquin. Voy. au Pôle Sud, Poiss. p. 32. pl. 1. f. 2.

The height of the body is one-half of the total length (without caudal); the procorbital with three or four notehes beneath. Spines very long and strong; the second dorsai spine longer than one-half the height of the body. Rose-coloured, with small spots of deep blaek; fins immaculate.

New Guinea.

b. Body with darker transverse bands or oblong transverse spots.

\section{Apogon orbicularis.}

Apogon orbieularis, (Kuhl \& van Hasselt) Cuv. \& Val. ii. p. 155, vi. p. 495; Bleek. Amb. \& Cer. p. 254; Quoy \& Gaim. Voy. Astrol. Poiss. p. 648. pl. 1. f. 4; Bleck. Act. Soc. Nederl. i. Amboina, p. 28.

A brown zone round the body from the front part of the first dorsal fin to the anus, posteriorly with large, irregular, dark blotehes; the first dorsal with small brown spots; in the middle of the tail a blaek longitudinal band.

Javanese Seas; Ceram.

\section{Apogon nematopterus.}

Bleck. Act. Soc. Nederl. i., Manado en Macassar, p. 35.

A broad, vertical, blackish zone round the body, occupying the whole space beneath the first dorsal fin, pasteriorly irregularly spotted with brownish. The first and second rays of the second dorsal produced into filaments.

Sea of Manado.

\section{Apogon trimaculatus.}

Cuv. \& Val. ii. p. 156. pl. 22 (not Richards. Ichth. China, p. 221); Less. Voy. Coq. Zool. p. 237.

Analis with nine soft rays. Pectoral fins reaching to the middlo of the anal fin. Red (in life), with three black transverse spots, forming three half-rings and reaching to the middle of the depth of the body : the first corresponding to the front part of the first dorsal, the second to the second dorsal, and the third to the middle of the back of the tail.

Buru (Moluccas).

Four pyloric appendagcs. (Cuv.)

\section{Apogon rhodopterus.}

Bleeker, Singapore, p. 62.

Analis with seven or eight soft rays; pectoral fins not reaching to the analis. Greenish, with two transverse bands, the first placed beneath the front part of the first dorsal, the second beneath the 
posterior part of the seeond; tail with a round black spot (lateral?); the first dorsal black-edged.

Singapore.

\section{Apogon koilomatodon.}

Bleeker, Ternate, p. 4.

Præorbital slightly denticulated; the upper maxillary bone reaching to just below the middle of the eye ; back and sides with darker spots ; two black half-rings eneircling the back, the first eorresponding to the anterior dorsal fin, the second to the hinder part of the posterior.

Ternate (Moluccas).

c. Body with longitudinal bands.

\section{Apogon margaritophorus.}

Bleeker, Batjan, p. 363.

Along the back two blackish-violet and two bright red alternate bands; along the middle of the side a broad orange-coloured band with a row of 12 bluish spots; erown with a yellowish-green mark in the shape of $\mathrm{a} \mathrm{V}$; on each side of the head four bright red longitindinal bands; fins uniform red.

Batjan.

\section{Apogon tæniatus.}

Apogon tæniatus, (Ehrenberg) Cur. \& Val. ii. p. 159; Rïppell, Atlas Fische, p. 48, and N.W. Fische, p. 87.

Brownish, with five lighter longitudinal lines; above the pectoral fins a round brown spot; a blackish spot at the base of the caudalis ; a vertical dark band in the middle of the second dorsal fin.

Djetta (Rerl Sea).

Curier $(l \cdot c$.$) gives the number of rays of the dorsal fins 7 \mid \frac{1}{8}$, but Rüppell (l.c.) twice states it to be $6 \mid \frac{1}{9}$.

\section{Apogon amboinensis.}

Bleeker, Amboina, iv. p. 329.

Yellowish (in life), with two brown longitudinal bands, one muning from above the eye to the side and eurred, the other from the muzzle through the eye to the tail; a round black spot at the root of the raudal fin; fins uniform, the first dorsal blackish in front. Caudalis notched; the upper maxillary bone reaching to behind the middle of the eye; procopereulum with only the posterior margin dentieulated; sub- nnd interopereulum entiro; the sccond spine of the first dorsal longest.

Rivers of Amboyna. 


\section{Apogon sangiensis.}

Bleeker, Sangi, p. 375.

Shining golden; a broad deep brown band from the muzzle through the eye to the operculnm; a round black spot at the root of the caudal fin; anal fin sparingly spotted with blue. Caudalis notched; suprascapula, sub- and interoperculum entire; the third dorsal spine longest. L. lat. 25. L. transv. 9-10.

Sea of Sangi.

\section{Apogon ceramensis.}

Bleeker, Amb. \& Cer. p. 256.

Caudalis notched. Greenish; head sprinkled with darker; a narrow brown streak from the thorax (?) to the tail; a black spot at the root of the caudal fin; the interspace between the second and third dorsal spines black.

Sea of Wahai (Ceram).

$$
\text { 2. D. } 7 \mid \frac{1}{8-10^{\circ}} \text { A. } \frac{2}{8-10} .
$$

$a$. Body without longitudinal or transrerse bands.

\section{Apogon nigripinnis.}

Cuv. \& Val. ii. p. 152; Faun. Japon. Poiss. p. 3.

Analis with eight soft rays; the limbs of the præoperculum denticulated; caudalis rounded. The first dorsal black, at least in its upper half; the second dorsal and the anal fin with a black band along the base, sometimes extending over all the fin; the hinder margin of the caudal and the ventral fins black.

Chinese and Japanese Seas.

a. Adult. China. Presented by Capt. Sir E. Belcher.

b, c. Half-grown. China. Presented by Capt. Sir E. Belcher.

d-f. Young: not good state. China. Presented by Capt. Sir E. Belcher.

$g-i$. Adult: bad state. East Indies. From the Haslar Collection. $k-r$. Half-grown specimens. East Indies. From the Haslar Collection.

s. Half-grown. East Indies. From the Haslar Collection. $t-v$. Young. East Indies. From the Haslar Collection.

\section{Apogon tæniopterus.}

Bennett, Proc. Zool. Soc. iii. 1835, p. 206.

Analis with eight soft rays; the limbs and the inner edge of the oræoperculum and the orbit denticulated; caudalis notched. The first dorsal with oblique black spots between the spines; the second and the anal fin with a black band along the base; each lobe of the 
caudal with a blackish streak; the outer margin of the ventral blackish.

Isle de France.

a. Large specimen. Mauritius. Presented by the Zoological Society. (Type of the species.)

\section{Apogon monochrous.}

Bleeker, Act. Soc. Nederl. i., Manado en Macassar, p. 34.

Analis with eight soft rays. Shining golden, minutely dotted with brown ; fins sometimes rather darker. Bones of the head not serrated, except the outer margin of the præoperculum and the suprascapula. Caudalis notched.

Seas of Manado, Amboyna, and of the Feejee Islands.

a. Adult. Amboyna. Purchased of Mr. Frank.

$b$, c. Adult. East Indies. Purchased of Mr. Frank.

$d, e$. Adult. Feejee Islands. Voyage of H.M.S. Herald.

$f-h$. Half-grown. Feejee Islands. Voyage of H.M.S. Herald.

\section{Apogon maculosus.}

Cuv. \& Val. vi. p. 494.

Brown: on each side four series of darker spots; fins brownspotted; head immaculate.

East Indian Seas.

\section{Apogon enneastigma.}

Rüppell, N.W. Fische, p. 87. t. 22. f. 3.

Reddish, with lighter fins ; the first dorsal with a black front edge; above the pectoral a round black, whitish-edged spot; back with five brown specks along the base of the dorsal fins; another black spot on each side of the tail. D. $\left.7\right|_{\frac{1}{9-10}}$. A. $\frac{2}{8-9}$.

Massaua (Red Sea).

26. Apogon rüppellii. (Plate XV. fig. B.)

Reddish, with lighter fins; a series of seven blackish dots from the occiput along the base of the dorsals, those beneath the fin not being very conspicuous. A sccond series of nine dots àlong, and immediately above the lateral line. There are two or three indistinct dots on the back of the tail. No spot above the base of the pectoral. The first dorsal blackish between the first three spines, the second with somo indistinct brownish spots. A brownish streak from the eye to the angle of the preoperculum. Analis with nine or ten rays.

Australian Seas.

a. Adult. Australia. Presented by the Earl of Derby. $b, c . \Lambda$ dult: stuffed. Victoria. Voyage of H.M.S. Herald. 
Description.-The height of the body is $3 \frac{1}{2}$ to 3 times in the total length, the length of the head $3 \frac{1}{3}$ to $3 \frac{1}{4}$. The diameter of the eye is about one-third of the length of the head, and much longer than the distance between the eyes; the upper maxillary bone reaches a little behind the vertical from the centre of the eye; the outer edge of the præoperculum is minutely serrated and the angle rounded; the inner edge is entire; operculum with a very short spine. D. $7 \mid \frac{1}{9}$; the third and fourth spines are the longest and equal, about half the height of the body ; the spine of the soft dorsal is not much shorter, and the middle rays longer, than the third spine of the first dorsal. Caudalis slightly emarginate, with rounded lobes. A. $\frac{2}{9-10}$; the second spine is three-quarters of the longest of the dorsal; the pectoral fins reach as far backwards as the ventrals. L. lat. 26. L. transv. $\frac{2}{6}$. All the teeth minute, in narrow villiform bands; that of the vomer rectangularly bent. Length 3 inches 9 lines.

\section{Apogon novæ guineæ.}

? Apogon vinosus, Cuv. \& Val. vi. p. 494.

Apogon novæ guineæ, Valenc. Ann. Mus. Hist. Nat. 1832, p. 53. pl. 4.

f. 1; Bleeker, Natuurk. Tydschr. Nederl. Indie, vii. p. 316.

- modestus, Bleeker, l. c. p. 315.

Body and fins yellowish, head sprinkled with brown. Caudalis very slightly notched; suprascapula, sub- and interoperculum entire ; the upper maxillary bone reaching a little behind the middle of the eye; the fourth dorsal spine longest. L. lat. 24-25. L. transv. 8-9.

Sea of Anjer (Java); Bataria; New Guinea.

$a, b$. Large specimens: very bad state. India. From the Haslar Collection.

c. Large specimen : very bad state. Norfollk Island. From the Haslar Collection.

\section{Apogon cupreus.}

Apogon cupreus, (Ehrenberg) Cuv. \& Val. ii. p. 159.

? Apogon chrysosoma, Bleeker, Amb. \& Cer. p. 256.

Caudalis forked. Uniform reddish brown; fins not spotted.

Red Sea.

\section{Apogon hoevenii.}

Bleeker, Amboina, v. p. 483.

Caudalis forked. Red (in life); two obsolete darker streaks below the eye; the first dorsal fin blackish, the interspace between the sixth and seventh spines black.

Amboyna Sea.

\section{Apogon truncatus.}

Bleeker, Java, i. p. 415.

The upper maxillary bone reaching behind the level of the eye; 
eaudalis very slightly notehed. Yellowish, head brown; the upper half of the first dorsal fin black.

Batavia.

b. Body with darker transverse bands or oblong transverse spots.

\section{Apogon bifasciatus.}

Apogon bifasciatus, Riippell, N. W. Fische, p. 86. t. 22. f. 2.

Apogon trimaculatus, (not Cuv.) Richards. Ichthyol. China, p. 221.

Analis with eight soft rays. Whitish, with two brownish halfrings encircling the back, the first corresponding to the anterior spines of the first dorsal, the second to the last rays of the second; on each side of the base of the caudalis a blackish spot*. (Cfr. Apogon trimaculatus, p 233.)

Red Sea; Chinese Seas.

This species has three pyloric appendages.

a. Adult. China. Presented by J. R. Recves, Esq.

b. Adult. Philippines.

c. Young: bad state. Sine patria.

d. Adult. Red Sea.

e. Adult female: skeleton. Red-Sea.

Skeleton.-The bones of the suborbital areh form an open eanal, the edges of which are strongly serrated, with the denticulations directed backwards, execpt in the pracorbital, the edges of which are entire. Both the margins of the pracopereulum strongly serrated, the denticulations of the innor ridgo being coarser, gradually becoming larger at the angle. The suprascapula, sub-and interoperculum are entire. The vomerine teeth are in a single series, forming a right angle. There are ten abdominal and fourteen caudal vertebræ.

\section{Apogon timoriensis.}

Blecker, Natuurk. Tydschr. Nederl. Ind. vi. 1854, p. 207.

Suprascapula denticulated. Shining golden, with two broad, brownish-violet transverse bands, the first beneath the spinous dorsal, the second beneath the soft dorsal, triangular, with the point reaching to tho base of the anal ; the spinous dorsal black at the tip.

Sea of Timor Kupang.

\section{Apogon bandanensis.}

Blecker, Banda, iii. p. 05.

Suprascapula entire. Brownish, with threo broad riolet bands, the first corresponding to the anterior dorsal fin, the second to the posterior, and the third to the middle of tail ; fins not spotted.

Banda Sea.

* Rüppell states in this species nine soft rays of the anal fin; but all the specimens in the British Museum Collection, some of which were sent by $\mathrm{Dr}$. Rüppell himself, exhibit eight only. 


\section{Apogon annularis.}

Rüppell, Atlas, p. 48, and N.W. Fische, p. 85.

Whitish (in spirits), with a broad zone round the base of the caudal fin.

Var. Apogon roseipinnis.

A pogon roseipinnis, Cuv. \& Val. iii. p. 490, vi. p. 553; Bleek. Amb. and Cer. p. 253; Peters, Wiegm, Arch. 1855, p. 234; Quoy \& Gaim. Voy. Astrol. Poiss. p. 649. pl. 1. f. 5.

A series of black spots (a violet band in life) along the base of the analis.

Red Sea; Coast of Mozambique; Indian Ocean.

a. Adult female : skeleton. Amboyna. From Mr. Frank's Collection.

b. Adult. Amboyna. From Mr. Frank's Collection.

c. Adult. Amboyna. From Madame Ida Pfeiffer's Collection.

d. Adult. Amboyna. From Mr. Frank's Colleetion.

e. Adult. Hong Kong. Presented by J. C. Bowring, Esq.

In well-preserved specimens the whole tractus intestinalis exhibited a deep black colour, not produeed by the contents of the stomach and of the intestines, but by a pigment deposited in all its membranes. There are four pylorie appendages, of the same intense black eolour. The other abdominal intestines have the usual colour. The posterior third of the ovarium is united, the two anterior ones separated.

Slceleton.-The very fine, velvet-like vomerine teeth form a rather acute angle; those of the palatine bones are situated in a narrow biserial band. The præorbital bone is rather flat, the others slightly concave, with entire edges: of the edges of the preopereulum only the posterior part of the external margin is minutely serrated. The ridge of the frontal bones is low, the groove not deep, whieh is in accordanee with tho less-developed canalicule mucosi of the other parts of the skull in this species. There are ten abdominal and fourteen caudal vertebræ.

\section{Apogon lineatus.}

Temm. \& Schleg. Faun. Japon. Poiss. p. 3; Bleeker, Verhand. Batav. Genootsch. xxri. p. 54. t. 1. f. 1.

Reddish brown (in spirits), with 8-12 very obsoleto brownish cross-streaks; no blaek spot at the base of the caudal fin.

Japanese Sea.

c. Body with longitudinal bands.

\section{Apogon quadrifasciatus.}

Valenciennes, ii. p. 153; Bleeker, Perc. p. 28; Cantor, Cutal. p. 3; Peters, Wiegm. Arch. 1855, p. 234.

Caudalis notched. Whitish (in spirits), on each side two parallel 
brown longitudinal bands; fins yellowish; the upper half of the anterior dorsal more or less intense black.

Javanese and Chinese Seas; Feojee Islands; Coast of Mozambique.

a. Adult female: skeleton. India. Presented by the Zoological Socicty.

b. Adult. Feejee Islands. Presented by the Lords of the Admiralty.

c. Adult. China.

d. Half-grown. China. Presented by Capt. Sir E. Belcher.

e. Young: very bad state. Australia. Presented by J. Macgillivray, Esq.

f. Adult. From Mr. Frank's Collection.

Ovaria nearly entirely united, above with two lobes.

Skeleton.-The hinder half of the suborbital arch represents a closed canal; the posterior margin of the præoperculum and the hinder part of the inferior are minutely serrated; suprascapula, sub- and interoperculum entire. There are eleven abdominal and fourteen caudal vertebræ.

\section{Apogon semilineatus.}

Temm.\& Schleg. Faun. Japon. Poiss. p. 4. pl. 2. f. 3 (head of male); Bleek. Verh. Batav. Genootsch. xxvi. p. 55. t. 1. f. 2.

Caudalis forked. Brownish; a black longitudinal streak from the muzzle above the eye to the middle of the tail, another from the muzzlo through the eye to the point of the operculum. Tip of the first dorsal fin black.

Japanese Sea.

\section{Apogon chrysopomus.}

Bleeker, Celebes, v. p. 239.

Above violet (in life beneath yellowish); a brown longitudinal band from the forehead above the lateral line to the back of the tail; opercles pearl-coloured, with five or six red spots; a black spot at the root of the caudal fin; fins immaculate; the first dorsal fin blackish above. Caudalis notched; sub- and interoperculum entire; suprascapula denticulated; the third dorsal spine longest. L. Iat. 25. L. transv. 8-9.

Sea of Macassar.

\section{Apogon kalosoma.}

Bleeker, Banka, p. 448.

Reddish yellow, with two brown longitudinal bands, the upper of which is eurved towards the back, tho lower being straight and united with the former on the tail ; there are moreover about fourteen serpentine brown longitudinal stripes on the back and the sides; a round black spot on the root of the caudal fin ; the first dorsal fin blackish in front; the second and the anal fin with a black band along the base. L. lat. 36. L. transv. 15. Caudalis notehed.

Sea of Banka. 


\section{Apogon frenatus.}

A pogon frenatus, Valenc. Nouv. Ann. Mus. Hist. Nat. 1832, p. 57. pl. 4. f. 4; Bleeker, Act. Soc. Nederl. i., Amboina, p. 25. vittiger, Bennett in Proc. Zool. Soc. 1833, p. 32. melanorhynchos, Bleeker, $A m b . \&$ Cer. p. 255, and l. c. p. 26.

Reddish brown, with a black longitudinal band from the muzzle along the middle of the side; a black spot on the base of the caudal fiu; the first dorsal black in front; the second and the anal with a black longitudinal band at the base; caudal notched.

Mauritius ; Ceram; Amboyna; Feejee Islands; Guam ; Now Guinea.

a. Half-grown. Feejee Islands. Voyage of the Herald.

\section{Apogon kallopterus.}

Bleeker, Act. Soc. Nederl. i., Manado en Macassar, p. 33.

Rose-coloured, with a violet shade; a violet band, above and beneath margined with white, from the eye to the caudal fin; a brown band round the muzzle to the eyes; a blackish spot on the base of the caudal fin; the spinous dorsal fin blackish brown, with four subvertical yellow streaks; the soft dorsal with four brown and four pearl-coloured spots, forming two longitudinal series; the anal with a brown band along the base; ventral fins with a white outer margin. L. lat. 26-27. Caudal deeply forked.

Sea of Manado.

\section{Apogon fasciatus.}

Mullus fasciatus, White, Newo South Wales, p. 268. f. 1.

A pogon novem-fasciatus, Cuv. \& Val. ii. p. 154; Bleeker, Timor, i. p. 163 ; Peters, Wiegm. Arch. 1855, p. 234.

fasciatus, Quoy \& Gaim. Voy. Freyc. Zool. p. 344.

- balinensis, Bleeker, Perc. p. 28, and Verhand. Batav. Genootsch. xxii., Bali, p. 5 .

— aroubiensis, Hombr. \& Jacquin. Voy. au Póle Sud, Poiss. p. 31. pl. 1. f. 1 .

- endeka-tænia, Bleeker, Banka, p. 449.

Caudalis notched. On each side four or five brown longitudinal bands, and one along the middle of the back; a large round black spot at the root of the caudal fin; the second dorsal and the anal with a blackish band along the base. L. lat. 25-26. L. transv. 8-9.

Feejee Islands; Australian and Molucca Seas; Coast of Mozambique.

a. Adult. India. From the Haslar Collection.

b. Young: very bad state. Amboyna.

c. Adult. Amboyna. From Madame Ida Pfeiffer's Collection.

$d-f$. Half-grown. Feejee Islands. Presented by the Lords of the Admiralty.

g. Adult: skin. Port Jackson. Presented by F. Strange.

h. Adult:'skin. Port Jackson. From Mr. Gould's Collection.

i. Half-grown: not good state. New Holland. 
$k$, l. Adult: skin. Australia. Voyage of H.M.S. Fly. m. Adult: stuffed. Australia. From Mr. Warwick's Collection. n. Half-grown. East Indies. From Mr. Frank's Collection.

\section{Apogon cyanosoma.}

\section{Bleeker, Solor, p. 71.}

Blue (in life), with six golden longitudinal bands; fins red, immaeulate. Caudalis slightly notched; the upper maxillary bone reaching to behind the middle of the eye; præoperculum with the posterior and inferior edges denticulated; sub- and interopereulum entire. L. lat. 23. L. transw. 8.

Sea of Lawajong (Solor)

\section{Apogon cyanotænia.}

\section{Bleeker, Solor, p. 71.}

Rose-coloured (in life) ; back with four or five brown longitudinal stripes; sides with two orange-coloured bands; head with blue longitudinal streaks; fins immaculate, a black spot at the root of the caudal fin. Candalis notched; the upper maxillary bone reaching to behind the middle of the eye; præoperculum with denticulated inferior and posterior margins; sub- and interopereulum entire. L. lat. 25. L. transv. 8-9.

Sea of Lawajong (Solor).

\section{Apogon multitæniatus.}

Bleeker, Perc. p. 28 (? Cuv. \& Val. ii. p. 159).

Caudalis notehed; purple-coloured (in life), with 10-13 brown longitudinal streaks on each side; fins not spotted.

Bima (Sumbara Island).

\section{Apogon hartzfeldii.}

Bleker, Natuurk. Tydschr. Nederl. Indie, iii. 1852, p. 254, and vi. p. 482.

Caudalis slightly notehed. Rose-coloured (in life); a large round black bloteh on the base of the caudal fin; on each side of the back, near the dorsal line, a light-blue longitudinal band; the second dorsal fin and the analis with a brown band along the base.

Sea of Amboyna.

a. Adult. Amboyna. From Mr. Frank's Collection.

\section{Apogon chrysotænia.}

Bleeker, Natuurk. Tydschr. Nederl. Indie, 185̃1, p. 168.

L. lat. 25. I. transv. 9. The third dorsal spine longest. Caudalis notched. Greyish brown, with two deep olive longitudinal bands on the back and three golden ones on the side. 'The spinous dorsal fin violet, the others red. (Blecker.)

Batavia. 
48. Apogon victoriæ. (Plate XV. fig. C.)

Yellowish olive (in a dried state), with four darker longitudinal bands on each side; root of the pectoral deep black; pectoral yellow. All the outer edge of the præopereulum denticulated, the mner entire. $a$, b. Adult: dried. Victoria (Australia). Voyage of H.M.S. Herald.

Description. - The height of the body is $3 \frac{1}{3}$ in the total length, the length of the head $3 \frac{3}{4}$; the diameter of the eje is less than onethird of the length of the head, and much longer than the distance between the eyes. The lower jaw slightly projects beyond the upper; the upper maxillary bone rcaches beyond the vertical from the centre of the eye; the outer margin of the præopereulum is finely serrated posteriorly and inferiorly, the interior ridge being entire. D. $7 \mid \frac{1}{9}$; the first spine is minute; the second rather longer than one-half of the third; the third is very strong, and about $1 \frac{1}{4}$ in the length of the head. The spine of the second dorsal fin is not much shorter than the soft portion, one-half the length of the head. Caudalis notehed. A. $\frac{2}{8}$; the second spine is rather shorter than that of the soft dorsal; the pectoral reaches slightly beyond the origin of the anal fin; the ventral spine is very strong, eompressed, and equal to the second of the anal fin. I. lat. 24. L. transv. $2 / 6-7$. The present colour is a yellowish olive, with four darker, rather indistinet bands, broader than the interspaces of the ground-colour between: the first from the nape, above the lateral line, along the back of the tail; the second from the eye to the middle of the root of the caudal fin; the third from the axil along the lower side of the tail; the fourth on the side of the belly. The pectoral is yellow, with the basal part deep black; the other fins without distinet colour.

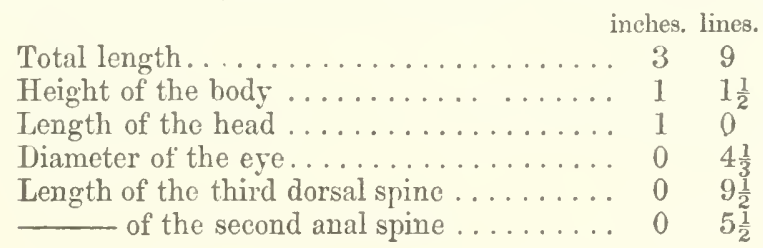

3. With eight spines in the first dorsal.

\section{Apogon inelas.}

Bleeker, Perc. p. 29, and Act. Soc. Nederl. i., Amboina, p. 27.

Caudalis notched. Entirely uniform brownish black; the seeond dorsal fin with a large round blne spot in the middle of the base.

Bima (Sumbava Island); Celebes: Amboyna.

\section{Apogon cantoris.}

Bleeker, Riouto, p. 479.

I. lat. 24. I. transv. 9. Caudal fin slightly notched. Greenish, i 2 
punctulated with brown, with two indistinct brownish cross-bands; a black spot at the middle of the base of the soft dorsal fin.

Riouw.

4. With nine spines in the first dorsal.

\section{Apogon meaco.}

Sparus meaco, Lacip. iv. pp. 54 \& 160.

Apogon meaco, Cuv. \& Val. ii. p. 161.

Caudal fin rounded; six white bands and a brown spot on the tail; fins brown-spotted.

Hab. - ?

B. Apogon with more than ten soft rays in the analis. (The first dorsal fin with six spines.)

\section{Apogon lineolatus.}

Renard, fol. 40. p. 204.

Apogon lineolatus, (Ehrenb.) Cuv. \& Val. ii. p. 160; Rüppell, Atlas, Fische, p. 47. t. 12. f. 1, and N.W. Fische, p. 85.

Anal with fourteen soft rays; whitish (in spirits), with twelvo blackish transverse lines; a black blotch on the tail.

Red Sea.

\section{Apogon fucatus.}

Cantor, Catal. p. 4.

Anal with sixteen soft rays; eaudal slightly forked. The upper maxillary bone nearly reaching to the front of the anterior margin of the orbit. The lower part of the front edge of the second dorsal spine is armed with three blunt teeth, vertically situated; the second, third and fourth spines are of nearly equal length. From the lower part of the orbit to the muzzle a gamboge oblique line; at the base of the caudal a large round black spot; fins not spotted. (Cant.)

Sea of Pinang.

Cantor states that this species has no pyloric appendages.

\section{Apogon macropterus.}

A pogon macropterus, (Kuhl \& van Hasselt) Cuv. \& Val. ii. p. 160.

? Apogon ceylonicus, Cuv. \& Val. iii. p. 491.

Anal with thirteen soft rays. Whitish (in spirits); on each scale a vertical line, formed by minute brown points; fins not spotted. (Cuv.)

Javanese Sea.

It will be diffieult to determine specimens belonging to this species, the description of Cuvier being very imperfect. But the following species, referred by Bleeker to $A$. macropterus, appears to be distinct, 
as Bleeker himself supposes. His specimens exhibit a black spot at the root of the caudal fin, which is not mentioned by Cuvier; and at least one additional soft ray in the anal fin.

\section{Apogon bleekeri.}

Apogon macropterus, Bleeker, Natuurk. Tydschr. Nederl. Indie, 1851, p. 168.

? A pogon argenteus, Valenc. Nouv. Ann. Mus. Hist. Nat. 1832, p. 60.

Anal with fourteen to seventeen soft rays; caudal slightly forked; the upper maxillary bone reaching to below the middle of the eye. I. lat. 23. The second dorsal spine longest, the first not much shorter. Uniform yellowish; a round black spot at the root of the caudal fin. Bataria; Padang; Amboyna.

a. Half-grown: not good state. Amboyna. From Mr. Frank's Collection.

\section{Apogon macropteroides.}

Bleeker, Banka, ii. p. 724.

Anal with sixteen or seventeen soft rays; caudal notched; the upper maxillary bone reaching to below the middle of the eye. L. lat. 23. The second dorsal spine longest, nearly twice as long as the first. Reddish yellow (in life), with about twenty-three red transverse streaks; head and body punctulated with brown, the points on the sides of the head larger; at the root of the caudal fin the points are crowded, and form a blackish spot; fins immaculate.

Sea of Lepar.

\section{Apogon burnensis.}

Bleeker, Boeroe, p. 394.

Caudal forked; anal with twelve or thirteen soft rays; the second and third dorsal spines longest. Yellowish, shining golden, with two brown longitudinal bands; a blackish spot at the root of the caudal fin. $(B l$.)

Sea of Boeroe.

\section{Apogon zosterophorus.}

Bleeker, Act. Soc. Nederl. i., Manado en Macassar, p. 36.

Caudal notched; anal with fifteen soft rays. Shining golden; a broad brownish band obliquely descending forwards from the whole base of the second dorsal to the belly; a blackish band round the snout to the eyes; a black spot at the root of the caudal fin.

Sea of Manado.

\section{APOGONICHTHYS.}

Apogonichthys, Bleeker, Floris, p. 321, and Verhand. Batav. Genootsch. xxvi. p. 56.

Closely allied to Apogon. Seven branchiostegals. All the teeth 
Filliform, without canines; tceth on the palasine bones; tongue smooth. Two separate dorsals, the first with six or seven, the anal fin with two spines. Opereulum spiniferous; prooperculum with a double ridge, but both entire. Scales large, readily deciduous.

From the Red Sea tlirough the seas of the Indian and Australian region. [Sea of Bahia.]

\section{Apogonichthys gracilis.}

Bleeker, Ternate, rii. p. $3 \pi 1$.

Caudal notched; anal with eleven or twelre soft rays; the first dorsal spine longest. Shining golden, with a brown streak from the muzzle througli the ere to the operculum; root of the caudal fin with a brown spot; each lobe of the caudal with a brown longitudinal band.

Sea of Ternate.

\section{Apogonichthys auritus.}

Apogon auritus, Cur. \& I ' al. rii. p. 443.

punctulatus, Riippell, N. W. Fische, p. 88. t. 22. f. 4 (not Bleek.). ? Apogon variegatus, Tulenc. Noux. Ann. Mus. i. p. 55.

Caudal truncated. Uniform brown; a round, black, white-edged spot ou the operculum. L. lat. 20. L. transv. 7-8.

Isle de France; Red Sea.

\section{Apogonichthys polystigma.}

Apogon punctulatus, Blecker, Nut. Tydschr. Nederl. Indie, iii. p. 696 (not Rüpp.).

A pogonichtlys polystigma, Blecker, l.c. ri. p. 484.

Brownish, fins red; operculum with a large blue, lighter-edged spot below; two oblique brown bands from the eye to the prooperculum, each scale with a blackish spot at the basc. The upper maxillary bone reaching a little beyond the posterior margin of the eye; the second and third dorsal spines longest. L. lat. 26. L. transv. 9-10.

Sea of Ceram; Sumatra.

\section{Apogonichthys amblyuropterus.}

Apogon amblyuropterus, Bleeker, Ceram, ii. p. 695.

None of the opercular bones denticulated; caudalis rounded. Red (in life), sparingly sprinkled with brown; the first dorsal and the rentrul fins rearly entirely brown, the others yellow; the second dorsal aud the anal with three red longitudinal bands, the candal with three undulated red cross-hands. I. lat. 20. L. transv. 8.

Sea of Wahai (Ceram). 


\section{Apogonichthys glaga.}

Apogon glagn, Bleeker, Perc. p. 29.

Apogonichthys glaga, Bleek. Verh. Batav. Genootsch. xxvi. p. 57.

Rose-coloured (in life), head minutely dotted with brown; the spinous dorsal violet-black in its upper half, the soft dorsal with light blue spots and a broad blackish upper edge; caudal fin black-edged. Seren spines in the first dorsal. Cauclalis truncated, with rounded angles. I. lat. 23. L. transv. 8-9.

Javanese and Japanese Sers; Singapore.

\section{Apogonichthys carinatus.}

Apogon carinatus, Cuv. \& Val. ii. p. 157 ; Faun. Jupon. Poiss. p. 3. Apogonichthys carinatus, Bleeker, Floris, p. 321, and Verh. Batav. Genootsch. xxvi. p. 56. pl. 1. f. 3.

Ten soft rays in the anal fin; uniform whitish (in spirits); the four hinder rays of the second dorsal black.

Japanese and Chinese Seas.

\section{Apogonichthys perdix.}

Bleeker, Floris, p. 321.

Orange-coloured in life, marbled with brownish ; cheeks and opercles brown; the first dorsal fin violct, the other fins orange, with all the rays brown-spotted. Caudalis rounded; the third and fourth dorsal spines longest. L. lat. 20. L. transv. 8-9.

Sea of Floris.

\section{Apogonichthys aprion.}

Apogon aprion, Richards. Ann. Nat. Hist. 1842, vol. ix. p. 16.

Caudal rounded. The first dorsal with six spines*; præoperculum not serrated; a small cluster of teeth on the tongue. L. lat. 40. L. transv. 5/13. Brownish, with about eight blackish cross-bauds on the back; top of the first dorsal deep black.

Coasts of North Australia.

a. Adult. Port Essington. Presented by J. Gould, Esq.

b. Adult: stuffed. Port Essington. Presented by J. Grould. Esq.

c. Adult: stuffed. Australia.

d. Adult: skin. Port Essington. From Mr. Gilbert's Collection.

e. Adult: skin. King's River, near Victoria (Port Essington).

\section{Apogonichthys americanus.}

Apogon americanum, Castelnau, Anim. nouv. ou rarcs Amér. du Sud, Poiss. p. 3. pl. 3. f. 2.

Caudalis forked; analis with eight soft rays. Uniform reddish olive. (Casteln.)

Coast of Bahia.

* The number fire, stated by Dr. Richardson, is anomalous in one of the specimens; the others have six. 
PERCID $\%$.

I refer this fish for the present to Apogonichthys, as there is no mention of a serrature of the præoperculum in the description. The figure also exhibits an entiro limb of this bone.

\section{CHILODIPTERUS.}

Cheilodipterus, Lacép. iii. p. 539 ; Cuv. \& Val. ii. p. 162.

Seren branchiostegals. Villiform teeth with the addition of canines, generally in both jaws; teeth on the palatine bones. Two dorsals, separated by an interspace, the first with six, the anal fin with two spines. Operculum without points, præoperculum with an interior ridge and generally with doublo serrature. Scales large, deciduous.

From the Red Sea through the Indian Ocean into the Pacific.

\section{Chilodipterus octovittatus.}

Cheilodipterus lineatus, Lacép. iii. p. 543. pl. 34. f. 1.

Centropomus macrodon, Lacép. iv. p. 273.

Cheilodipterus octovittatus, Cur. \& Val. ii. p. 163.

- heptazona, Bleek. Perc. p. 29.

Candalis notched. Whitish, with eight black longitudinal bands on each side; a black blotch on each side of the base of the caudal fin.

Red Sea; Indian Ocean.

a. Adult. Mauritius. From the Collection of the Zoologieal Society.

b. Adult. Amboyna. From Mr. Frank's Collection.

c. Adult. India. Presented by the Zoological Society.

\section{Chilodipterus lineatus.}

Perca lineata, Forskal, Descrint. Anim. p. 42. no. 43; Rïpp. N. W. Fische, p. 89.

- arabica, Linn. Syst. Nat. i. p. 1312.

Centropomus arabicus, Lacép. iv ، pp. 250, 255.

Cheilodiptèrus arabicus, Cuv. \& Val. ii. p. 165. pl. 23.

Caudalis notched. On each side 14-16 black longitudinal lines; a black blotch on each side of the base of the candal fin.

Red Sea.

a. Adult. Red Sea.

b. Adult. Madagascar. Presentod by Dr. J. E. Gray.

\section{Chilodipterus quinquelineatus.}

Cheilodipterus quinquelineatus, Cuv. \& Val. ii. p. $167 ; R \ddot{i p p} . \Lambda$. W. Fische, p. 89 ; Lesson, Zool. Voy. Duperr. ii. p. 237 ; Bleeker, Amb. \&. Cer. p. 252.

A pogon noremstriatus, Rüpp. N. W. Fische, p. 85. t. 22. f. 1.

Caudalis notched, with ten hlack longitudinal bands-four on 
each side, one along the middle of back, and one on the belly; a black spot on the tail with yellow centre; the first lorsal fin black in front.

Society Islands; Amboyna; Red Sea.

a. Half-grown. Amboyna. From Mr. Frank's Collection.

\section{Chilodipterus apogonoides.}

Bleeker, Act. Soc. Nederl. i., Manado en Macassar, p. 37.

Caudalis forked. The interior ridge of the præoperculum not serrated; an outer series of larger teeth in the upper jaw, two small canines in the lower. Rose-coloured; a brownish band round the muzzle; top of the spinous dorsal blackish. (Bl.)

Sea of Manado.

\section{Chilodipterus amblyuropterus.}

Bleeker, Boeroe, p. 395.

Caudalis rounded; sub- and interoperculum entire; with numorous blackish longitudinal streaks; fins immaculate. (Bl.)

Sea of Boeroe.

\section{SCOMBROPS.}

Scombrops, Temm. \& Schleg. Faun. Japom p. 118.

Eye large. Seven branchiostegals; in the upper jaw two long canine teeth, in the lower a series of eanine-like teeth; teeth on the palatine bones. Two dorsals, the first with eight, the anal fin with three spines. No denticulations on tho bones of the skull; operculum with two very feeble points. Scales moderate, very thin, smooth. Pancreatic cæca in increased number.

Japanese Sea.

\section{Scombrops chilodipteroides.}

Scombrops, sp., Temm. \& Schleg. l.c. pl. 63. f. 2.

- chellodipteroides, Blcek. Verhand. Bat. Genootsch. xxv. Jap. p. 9, and xxvi. Jap. p. 58.

D. $8 \mid \frac{2}{13}$. A. $\frac{3}{12}$. L. lat. 55-60. L. transv. $\frac{5-6}{12-14}$. Cæc. pylor. 15.

Spines of the fins very feeble; lower jaw longest; caudalis forked; coloration uniform.

Japanese Sea.

a. Japan.

\section{POMATOMUS.}

Pomatomus, (not Lacép.) Risso, Ichthyol. Nice, p. 387 ; Cuv. \& Val. ii. p. 171.

Eye very large. Seven branchiostegals. All the teeth villiform. 
without canines : no teeth on the palatine bones. Two dorsals, separated by an interspace, the first with seren, the anal fin with two spines. No denticulations on the edges of the bones of the skull; operculum with two rery feeble points, præoperculum with prominent rounded and striated angle. Scales moderate, slightly adherent. Pancreatic exea in considerable number.

Mediterranean.

\section{Pomatomus telescopium.}

Risso, Ichthyol. Nice, p. 301. pl. 9. f. 31; Cuv. \& Val. ii. p. 171. pl. 24, vi. p. 4955 ; Lowe, Trans. Zool. Soc. ii. p. 173; Guichen. Explor. Scient. Algér. Poiss. p. 32; Barker-Webb \&. Berthel. IIist. Nat. Iles Canar. Ichthyol. pl. 1.

$$
\begin{array}{llll}
\text { D. } 7 \mid \frac{1}{10} . & \text { A. } \frac{2}{9} \text {. } & \text { L. lat. } 40 . \quad \text { Cæc. pylor. } 22 .
\end{array}
$$

Height of the body rather more than one-fourth of the total length ; eye very large, one-third of the length of the head; caudalis forked. Coloration uniform.

Mediterranean; Canarian Islands.

a. Young. Sicily.

\section{ACROPOMA.}

Acropoma, I'emm. \& Schleg. Faun. Jupon. Poiss. p. 31.

Seren branchiostegals. Teeth villiform, with eanines in both the jaws; teeth on the palatine bones. Two dorsals, the first with seven (eight) spines, the anal fin with three. Operculum produced into a long denticulated point, procoperculum entire. Anus nearer the root of the rentrals than the origin of the anal. Scales moderate, Jecidnous, minutely ciliated.

Japanese Sea.

\section{Acropoma japonicum.}

Acropoma, sp., Temm. \& Schleg. l.c. pl. 12. f. 2, 3.

$$
\text { D. } 7(8) \mid \frac{1}{10} \text {. A. } \frac{3}{7} \text {. }
$$

Spines of tho fins slender; lower jaw longest; caudalis forked. Coloration uniform.

Japanese Sea. 


\section{Sixth Group. GRYSTINA.}

\section{OLIGORUS*}

Grystes, sp., Cuv.\& Val. iii. p. 58.

Seven branchiostegals. All the teeth villiform, without canines; teeth on the palatine bones; tongue smooth. One dorsal, with eleven spines, the anal fin with three. Operculum with one point, præoperculum with a single smooth or obtusely denticulated ridge. Seales small. The number of the pyloric appendages small (3).

Rivers of Australia.

\section{Oligorus macquariensis.}

Grystes brisbanii, Less. Voy. Coq. Zool. ii. p. 227.

Grystes macquariensis, Cur. \& V Val. iii. p. 58; Richards. Ereb.\&. Terr. Fishes, p. 118. pl. 53. f. $8,9$.

- peelii, Mitchell, Exped. Austr. pl. 6. f. 1.
B. 7.
D. $\frac{11}{14}$.
A. $\frac{3}{12}$.
Cæc. pylor. 3.

The height of the body is $4 \frac{3}{4}$ in the total length, the length of the head $3 \frac{1}{2}$; the diameter of the eye is one-seventh of the latter. Præoperculum, suprascapula, and præorbital entire; opereulum with one small spine. Pectoral and ventral fins short, caudalis rounded; the fifth dorsal spine longest; the second and third of the anal nearly equal in length. Brownish grey, with irregular darker spots.

Rivers of Australia.

$a, b$. Adult: stuffed. Australia. Presented by the Earl of Derby.

\section{Oligorus gigas.}

Centropristis gigas, Owen, Osteol. Catal. i. p. 51.
B. 7 .
D. $\frac{11}{12}$.
A. $\frac{3}{8}$.
Vert. $13 / 14$.

Præoperculum obtusely serrated.

New Zealand.

This species, established by Prof. Owen from a skeleton in the Collection of the College of Surgeons, can scarcely be referred to Centropristis, even if that genus be technically taken in the extent of the characters given by Cuvier, because there are no canine teeth at all. Cuvier combined very heterogeneous fishes in that genus, and, inconsistently enough, separated many others which exhibit all its characters. At present it is quite impossible to retain it with the definition of Cuvier. The skeleton of the fish in question much rescmbles that of some species of Serranus; bnt we cannot, on

* ỏiros, few, and wosos, guard; formed according to pylorus, from $\pi \dot{v} \lambda \eta$, gate, and inos s. oipos. 
account of the absence of the canine teeth, refer it to that genus. 'Therefore; although not having a skeleton of Oligoms macquariensis, I think it nevertheless best to combine both fishes, on aecount of the similarity in the structure of their teeth, of their branchiostegals, and of their fins, as well as in their general habit, size, and native country.

\section{GRYSTES*}

Grystes, sp., Cuv. \& Val. iii. p. 54.

Six or seven branchiostegals. All the teeth villiform, without canines; teeth on the palatine bones; tongue smooth. One dorsal, with ten spines, the anal fin with three. Operculum with two points, præoperculum with a single smooth-edged ridge. Scales moderate. The number of the pyloric appendages increased. Airbladder simple, slightly notched behind.

Rivers of the United States.

\section{Grystes salmonoides.}

Labrus salmoides, Lacép. iv. pp. 716, 717. pl. 5. f. 2.

Cichla variabilis, Lesueur, Journ. Acad. Nat. Sc. Philad.

Grystes salmoides, Cuv. \& Val. iii. p. 54. pl. 45; Règne Anim. IIl. Poiss. pl. 9 a. f. 2 ; Dekay, New York Fauna, Fishes, pl. 69. f. 223 (cop.) ; Holbr. Ichth. S. Carol. p. 25. pl. 4. f. 2 (dorsal wrong).

Micropterus, Cuv. \& Val. v. p. 9 (founded on a mutilated specimen).
B. 6-7.
D. ${ }_{13-14}^{10}$
A. $\frac{3}{11-12}$.
L. lat. 90.
Cæc. pylor. 14 and more.

The height of the body is nearly one-fourth of the total length, the length of the head is eontained $3 \frac{1}{2}$ therein. Lower jaw prominent. Præoperculum and suprascapula entire, operculum with two spines; præorbital without or with some slight dentieulations; pectoral and ventral fins short; the fourth dorsal spine longest; the second of the anal much shorter than the third; caudalis slightly notched. Uniform greenish brown, with a black spot at the posterior angle of the operculum. Young with many indistinct longitudinal streaks.

Fresh waters of the United States.

$a-h$. Adult and half-grown : skins. Lake Erie. From Dr. Parnell's Collection.

\section{ARRIPIS.}

Centropristes, sp., Cuv. \& Val. iii. p. 50, vii. p. 451 ; Richardson, Voy. Ereb. \& Terr. Fishes, pp. 29, 117.

Arripis, Jenyns, Zool. Beagle, Fishcs, p. 14.

Homodon, Brisout de Barneville, Rev. Zool. 1847, p. 133.

Seven branchiostegals. All the tceth eard-like or villiform, with-

* 1. Grystes nuecensis, Baird \& Girard, Proc. Acad. Nat. Sc. Phitad. 1854, p. 25.

2. Grystes fasciatus, Eoff in Ninth Smithson. Report, p. 289.-Ohio. 
out any canines; teeth on the palatine bones; tongue smooth. One dorsal, with nine slender spines; the anal fin with three. Operculum spiniferous; præoperculum denticulated. Scales moderate. Number of the pyloric appendages increased (17-50)

Seas of the Australian region.

\section{Arripis georgianus.}

Centropristes georgianus, Cuv. \& Val. vii. p. 451 ; Richardson, Ereb. \&. Terr. Fishes, p. 117. pl. 54. f. 3-6.

Arripis georgianus, Jenyns, Zool. Beagle, p. 14.

$$
\text { D. } \frac{9}{14} \text {. A. } \frac{3}{10} \text {. L. lat. } 55 \text {. Cæc. pylor. } 17 .
$$

The height of the body is $4 \frac{1}{2}$ in the total length, and the length of the head nearly four times; the diameter of the eye is one-third of the length of the head; præoperculum finely serrated, operculum with two spines. The fourth dorsal spine longest. In a dried state greenish or jellowish olive, each scale punctulated with darker in the centre or at the edges.

South-eastern and south-western coasts of Australia; Norfolk Island; Port Jackson; King George's Sound.

$a-c$. Adult: skins. Holdfast Bay; South Australia.

d. Adult : skin : not good state. Houtman's Abrolhos._- 'Herring' of the Colonists.

e, f. Half-grown: skins: not in a good state. Hobson's Bay; Port Philip. Voyage of H.M.S. Fly.

g. Adult: skin. Port Jackson. Presented by Mr. J. Strange.

$h$. Half-grown: skin: not in a good state. Port Jackson. From Mr. Gould's Collection.

\section{Arripis salar.}

Centropristes salar, Richardson, Zool. Trans. iii. p. 78, and Voy. Zool. Ereb. \& Terr. Fishes, p. 29. pl. 20. f. 4-6.

- tasmanicus, Hombr. \&. Jacq. in Dumont d'Urville, Voy. au Pôle Sud, Poiss. p. 40. pl. 4. f. 1.

D. $\frac{9}{16-17}$. A. $\frac{3}{10}$. L. lat. 48-52. I. transv. 6/12. Cæc. pylor. ea 50 . Vert. 10/15.

The height of the body is one-fourth of the total length, and equal to the longth of the head; the diameter of the eye is one-fifth of the latter. Præoperculum serrated behind and beneath; sub- and interoperculum with scales. The fourth dorsal spine longest; the third of the anal rather longer than the second. Back with darker spots.

Bay of Islands (New Zealand) ; Port Arthur (Van Diemen's Land) ; Australia; Raoul Island; Norfolk Islands.

a. Fine specimen. Raoul Island. Presented by the Lords of the Admiralty. 
$b-d$. Half-grown. Norfolk Island. From the Haslar Collection. e. Adult malc: skeleton. Australia. From the Haslar Collection. $f-h$. Adult: bad state. Australia. From the Haslar Collection. i. Half-grown. Australia. Presented by J. B. Jukes, Esq.

k. Adult: stuffed. Australia.

l. Adult: not good state. Australia. Presented by Sir J. Richardson. $m$. Half-grown. Australia. Presented by the Earl of Derby. $n-q$. Adult: not good state. Port Arthur. From the Haslar Collection.

$r$. Adult: not good state. Port Arthur. From the Haslar Collection.

$s-w$. Adult : very bad state. Port Arthur. Presented by Sir John Richardson.

The swim-bladder is simple, provided with thin membranes; testiculi two and separate; pseudobranchix large.

Skeleton.-The upper surface of the skull is broad, flat, rather depressed in the middle; the occipital crest is feeble, and does not extend on to the upper surface of the skull; one low, thin and muciferous ridge passes from the orbit to the upper end of the præoperculum. Preorbital very small, triangular, with spinous teeth at the lower margin. Suborbital arch narrow, with a concare plate at the inner side for supporting the eyeball; upper maxillary with a rather slender basal style, and widening behind; there is an additional bone situated along its upper margin. There is no free space between the articulary and dentary bone. The operculum terminates behind in two very fecble, flat, thin points, separated from each other by a noteh; the upper is shorter and rounded. The præoperculum is striated, each stria terminating in a fine tooth; the serrature extends over both the limbs, and is coarser beneath ; the sub- and interoperculum have the margins entire and rounded; suprascapula searcely and very indistinctly denticulated, humeral entire; the lower coraeoid styliform. There is no free space between both halves of the pubic bone.

The length of the abdominal vertebral column is to that of the caudal as $12: 19$; the ribs are rather long and slender; the first interhæmal is compressed, feeble and flexible, and attached to the hæmals of the twelfth, thirteenth, and fourtcenth vertebræ.

The teeth, being rather strong and separate, form a card-like band in the upper jaw. The others are villiform, and reach, in both the jaws, to the extremities of the bones. The group of the vomerine teeth forms nearly an isosceles triangle; palatine band rather broad; those of the pharyngo-branchial villiform.

\section{Arripis truttaceus.}

Perca trutta, Cur. \& Val. ii. p. 54. Centropristes (?) truttaceus, Cur. \& Val. iii. p. 50.

$$
\text { D. } \frac{9}{18} \text {. A. } \frac{3}{9} \text {. }
$$

The height of the body is one-fourth of the total length, and equal 
to the length of the head; the diameter of the eye is one-sixth of the latter. Denticulations of the præoperculum visible on the inferior limb only ; operculun with two feeble spines; sub- and interoperculum without scales. The fourth dorsal spine longest. Coloration uniform. (Cuv.)

Port Western (New Holland).

\section{HURO.}

Huro, Cuv. \& Val. ii.p. 124; Richards. Faun. Bor. Amer. Fishes, p. 4.

Six branchiostegals. All the teeth villiform, without canines; palatine bones?; tongue? Two dorsals, the first with six, the anal fin with three spines. No denticulations on the bones of the head; operculum with two flat obtuse points. Scales moderate.

Lake Huron.

\section{Huro nigricans.}

Cuv. Règne Anim.; Cuv. \& I'al. ii. p. 124. pl. 17 ; Ruchards. Faun. Bor. Amer. Fishes, p. 4; Dekay, Nevo York Fauna, Fishes, p. 15. pl. 69. f. 224 (cop.).
D. $6 \mid \frac{2}{10 ?}$.
A. $\frac{3}{11}$.
L. lat. 60-65.

Height of the body equal to one-third of the total length, excluding the caudal; cleft of the mouth obliquely running upwards towards the plane of the forehead. Caudal slightly notched. Coloration uniform.

Lake Huron. (Black Bass.)

\section{PERCILIA.}

Percilia, Girard, Proc. Acad. Nat. Sc. Philad. vii. 1854, p. 197, and U.S. Naval Astron. Exped. to the Southern Hemisph. Zool. p. 235.

Five or six branchiostegals. Maxillary teeth small, conical, without canines; palatine teeth none. Two dorsals, united at the base only; the first with nine spines, the anal with three. Operculum without any spines; a few minute spines along the limb of the præoperculum. Scales moderate.

Rio de Maypu.

\section{Percilia gillissii.}

Girard, l. c. pl. 29. f. 5-9.
D. $9 \mid 11$.
A. $\frac{3}{8}$.
L. lat. $3 \bar{j}$.

Snout short and rounded; the upper maxillary reaching to the vertical from the anterior margin of the eye. Light reddish or reddish brown, maculated with black. (Gir.)

Rio de Maypu. 


\section{CENTRARCHUS*}

Centrarchus, Cur. Rène Anim. ; Cu». \& Val. iii. p. 84.

Pomoxis, (Rafin.) Holbr. Ichth. S. Carol. p. 36.

Six branchiostegals. All the teeth villiform, without eanines; teeth on the palatine bones and on the tongue. One dorsal; the anal fin generally with more than three spines. Operculum with two flat points, præoperculum entire or scarcely denticulated. Scales moderate. Air-bladder notched behind. Pyloric appendages in moderate number.

Fresh waters of the Nearetic region; one species from Cuba.

\section{Centrarchus æneus.}

Cichla ænea, J.e Sueur, Journ. Ac. Nat. Sc. Philad. 1822, p. 214. pl. 12 ; Kirtland, Zool. Ohio, pp. 168, 191.

Centrarchus æneus, Cuv. \& Val. iii. p. 84; Richards. Faun. Bor. Amer. Fish. p. 18. pl. 75; Kirtland, Bost. Journ. iv. p. 239. pl. 11; f. 1; ? Dekay, New York Fauna, Fishes, p. 27. pl. 2. f. 4.

Centrarchus pentacanthus, Cuv. \& Val. iii. p. 88.

D. $\frac{10-11}{10-11}$. A. $\frac{5-6}{10-11}$. L. lat. 39-40. L. transv. 19-20. Vert. 14/18. Cæc. pylor. 7 .

The height of the body is $2{ }_{4}^{3}$ in the total length, and more than the length of the head; the diameter of the eye is one-fourth of the latter, and rather shorter than the distance between the eyes. Præoperculum and præorbital serrated. Caudalis truncated. Greyish brown, each scale with a dark centre; vertical fins variegated with dark brown; a black spot above the angle of the operculum.

Lakes of North America.

a-c. Adult: skins. Lake Erie. From Dr. Parnell's Collection.

\section{Centrarchus pomotis.}

Baird, in the Ninth Smithson. Report, p. 325.

$$
\text { D. } \frac{11}{12} \text {. A. } \frac{5}{10} \text {. L. transv. 6/12. }
$$

Snout very short, lowor jaw longest; the maxillary bone reaching to the posterior margin of the eye. The length of the head is $3 \frac{1}{2}$ in the total, the diameter of the eye me-fourth of the former. Caudalis rounded; the external soft ray of the ventrals extending as a filiform appendage beyond the other rays, which do not reach the front end of the anal. Greenish olive, with three or four irregnlar longitudinal bands of dull greenish yellow; a dusky spot at the end of the operculum; fins uniform. (Baird.)

New Jersey; New York.

* 1. Centrarchus viridis, Cuv. \& $I^{\prime} a l$. vii. p. 460.-Southern parts of N. America. 


\section{Centrarchus interruptus.}

Centrarchus intermuptus, Girard, Proc. Ac. Nat. Sc. Philad. 1854, p. 129. - maculosus, Ayres, Proc. Californ. Ac. Nat. Mist. 1854, p. 8.

Ambloplites interruptus, Girard, U. S. I'ac. R. R. Ixp. Fishes, p. 10. pl. 2. f. 1-4.

$$
\text { D. } \frac{19}{8-11} \cdot \quad \text { A. } \frac{6-7}{10-9} \text {. }
$$

The length of the hear is about one-third of the total; the diameter of the eye one-fourth of the length of the head. (ireyish brown, with irregular darker transverse bands, intermpted along tho lateral line; the portion of the band above is somewhat alternating with that beneath it; a large black spot above the angle of the oporculum; two dark streaks diverge from the eye backwards. (Gir.)

Rivers of California.

\section{Centrarchus irideus.}

Perca iridea, Bosc.

Labrus sparoides, Lacrp. jii. pl. 24. f. 2.

— iris, Lucep. jv. p. 716. pl. 5. f. 3.

- macropterus, Lacip. jii. pl. 24. f. 1.

Centrarchus irideus, C'uv. \& Val. iii. p. 89; ILollor. Ichth. S. Carol. p. 15. pl. 3. f. 1.

Pparoides, Cuv. \& Val. vii. p. 458 (not pl. 48).
D). $\frac{11-12}{14-13}$.
A. $\frac{8-9}{16}$.

Greenish, with series of black spots; the rays of the vertical fins with alternate black and white spots. Dorsal fin with a dusky spot, bordered with orange near the posterior extremity of the fin (more indistinct in old age).

C'harleston.

\section{Centrarchus hexacanthus.}

Centrarcluus sparoides, Cuv. \& Vul. iii. p. 88. pl. 48.

- hexacanthus, C'uv. \& Val. vii. p. 458; Korthand, Isost. Journ. iii. p. 480. pl. 29. f. 2.

Cichla storeria, Kirtl. Rop. Zool. Ohio, p. 1!s.

l'omotis hexacanthus, Molbr. Jchth. S'. C'arol. p. 36. jul. (6. f. 1.

$$
\text { D. } \frac{7-8}{16-15^{\circ}} \quad \Lambda \cdot \frac{6}{17-18^{\circ}} \text { Crece. pylor. } 8 \text {. }
$$

The form of the head and body is similar to that of $C$. coneus. Prseopereulum with some irregular denticnlations at the angle and at the lower limb. Jiody and vertical fins irregularly spotted with blackish.

Fresh waters of North America.

a-e. Adult, half-grown, and young: skins. Streams leading into Lake Erie. From Dr. Parnell's Collection. $f-h$. Young.

\section{Centrarchus nitidus.}

Pomoxis nitidus, Girard in U.S.I'ac. R.R. Exp. Fishes, p. (3. pl. 2. f. .5-8.

$$
\text { D. } \frac{6}{16} \cdot A \cdot \frac{6}{17} \text {. }
$$

The height of the body is one-third of the trotal lenerth. and moro 
PERCID.E.

than the length of the head. Præopereulum entire. Back and vertical fins irregularly spotted with blackish, on the back grouped together in bands. ( $(i \mathrm{iv}$.)

Houston River, Kentucky.

\section{Centrarchus fasciatus.}

Cichla fasciata, Lesueur, Journ. Ac. Nat. Sc. Philad. ii. p. 216. - ohioensis, minima, Lesucur, l. c. p. 218.

Centrarchus fasciatus, Dekay, New York Fauna, Fishes, p. 28. pl.3. f. 8; Kirtl. Bost. Journ. v. p. 28. pl. 9. f. 1.

$$
\text { D. } \frac{10}{14} \text {. A. } \frac{3}{12} \text {. }
$$

Body gibhous; the height is $3 \frac{1}{3}$ in the total length. Dusky bluish, often with transverse bands.

Lakes of the United States.

\section{Centrarchus obscurus.}

Dekay, New Fork Fama, Fishes, p. 30. pl. 17. f. 47 (in the text 48).

$$
\text { D. } \frac{10}{12} \text {. A. } \frac{3}{12} \text {. }
$$

Bods rather elongate, not gibbous; the height is one-fourth of the total length. Uniform greenish brown. (Dekay.)

Onondaga Creck.

\section{Centrarchus gulosus.}

Pomotis gulosns, Cuv. \& V Val. iii. p. 498.

Centrarehus gulosus, Cuv. \& Val. vii. p. 459.

$$
\text { D. } \frac{10}{9} \cdot \Lambda \cdot \frac{3}{8} \text {. }
$$

Brown, shining golden; a black spot above the angle of the operculum. (Cuv. \& Fal.)

Lake Pont Chartrain; Lakes near New Orleans.

\section{Centrarchus tetracanthus.}

Cuv. s. Val. vii. p. 460.

$$
\text { D. } \frac{15}{10} \cdot 1 \cdot \frac{1}{9} \text {. }
$$

The height of the body is about one-third of the total length. Body and vertical fins spotted with blackish. ( $\mathrm{Val}$.)

Fresh waters of Cuba.

\section{BRYTTUS*}

Bryttus, Cuv. \& Val. vii. p. 461.

Six (five) branchiostegals. All the teeth villiform, without canines;

* 1. Pryttus reticulatus, Cuv. \& V al. rii. p. 463. - North America.

2. Calliurus diaphanus, Girard, U. S. Pacif. R. R. Exp. Fishes, p. 13. pl. 4. f. 1-4.-Texas.

3. Bryttus signifer, Girard, l.c. pl. 7. f. 5-8.-Texas.

4. - humilis, Girard, l.c. pl. 7. f. 9-24.-Arkansas and Texas.

5. Calliurıs microps, Girard, l. c. p. 17. pl. 4. f. 5-8.--Tezas. 
teeth on the palatine, bones*. Onc dorsa, with ten (occasionally with nine) spines, the anal fin with three. Opereulum with a rounded, membranaceous, coloured lobe above the angle; propopereulum entire. Scales moderate.

Fresh waters of the Nearetic region.

\section{Bryttus punctatus.}

Bryttus punctatus, Cur. \&. I $a l$. vii. p. 462. $\longrightarrow$ unicolor, Cuv. \& V Vul. vii. p. 464 .

$$
\text { D. } \frac{10}{16} \text {. A. } \frac{3}{8-9} \text {. L. lat. } 35 \text {. }
$$

The height of the body is one-half of the total length (without caudal fin); the length of the head one-third. Caudalis emarginate, with rounded lobes; the first ray of the ventral pointed. Brownish green, with parallel series of round black spots; cheeks blackspotted. Angle and inferior limb of opereulum blackish. Ventrals black. ( $\mathrm{Val}$.)

Fresh waters of North America.

\section{Bryttus albulus.}

Girard, U.S. Pacif. R. R. Exp. Fishes, p. 19. pl. 6. f. 1-4.

$$
\text { B. 5. D. } \frac{10}{11} \text {. A. } \frac{3}{10} \text {. L. transv. } 6 / 16 \text {. }
$$

The height of the body is $2 \frac{1}{2}$, the length of the head $3 \frac{1}{2}$ in the total length. The upper maxillary reaches to the anterior margin of the orbit. Pale reddish brown, dorsal with a black pateh (not marked in the figure). (Gir.)

Rio Blaneo (Texas).

\section{Bryttus longulus.}

Pomotis longulus, Baird \& Girard, Proc. Acad. Nat. Sc. Plillad. 1853, p. 391, and in Marcy's Farplor. Red River, p. 215. pl. 12.

Bryttus longulus, Buird \&. Givard, l. c. 1854, p. 25.

Calliurus formosus, Girard, U. S. Pucif. R. R. Expod. Fishes, 3. 14. pl. 5. f. 1-4.

longulus, Girard, l. c. p. 16. pl. 5. f. 5-8, pl. 6. f. 5-8.

$$
\text { D. } \frac{10}{11-12} \text {. A. } \frac{3}{8-9} \text {. I. lat. } 52 \text {. }
$$

The height of the body is about three times in the total length, the length of the head $3 \frac{1}{2}$; the upper maxillary does not extend to the vertical from the posterior margin of the eye. Reddish brown; the dorsal and anal with a subcireular large black spot behind; ventrals and the extermal half of the anal yellowish. (B. \& G.)

Red River; fresh waters of Texas and Arkansas.

* Sir J. Richardson probably made a mistake in translating the diagnosis of Cuvier, if he attributes to this genus "a narrow band of villiform terth on the tongue." (Ichthyol. p. 277.) 


\section{Bryttus floridensis.}

Calliurus floridensis, Holbr. Journ. Acad. Nat. Sc. Philad. 1855, p. 53. pl. 6. f. 1.
D. $\frac{10}{10}$.
A. $\frac{3}{10}$.

The height of the body is $2 \frac{2}{3}$ in the total length, the length of the head $3 \frac{1}{2}$. The upper maxillary reaches to the middle of the orbit. Caudalis subtruneated, with rounded angles. Opereular appendage very short. Dusky above, with black spots along the sides; anal and caudal fins dusky; dorsal with a reddish-brown spot at its posterior inferior margin. (Holbr.)

St. John's River (Florida).

This speeies is said to have the tongue armed with a pateh of asperitios.

\section{Bryttus melanops.}

Calliurus melanops, Girard, U. S. Pacif. R. R. Exp. Fishes, p. 11.pl.3.

$$
\text { D. } \frac{10}{10} \text {. A. } \frac{3}{9} \text {. }
$$

The height of the body equals the length of the head, and is about one-third of the total. The upper maxillary reaches to the vertical from the posterior margin of the orbit. Reddish, with a blackish spot at the centre of each scale. (Gir.)

Fresh waters of Texas.

\section{Bryttus murinus.}

Calliurus murinus, Girard, U.S. Pacif. R. R. Exped. Fishes, p. 18. pl. 7. f. 1-4.

$$
\text { D. } \frac{10}{12} \text {. A. } \frac{3}{10} \text {. }
$$

The height of the body equals nearly the length of the head, and is one-third of the total. The upper maxillary does not reach to the vertical from the centre of the eye. Dark blackish brown; the dorsal with a black patch behind. (Gir.)

Fresh waters of Texas.

\section{Bryttus fasciatus.}

Holbr. Journ. Acad. Nat. Sc. Philad. 1855, p. 51. pl. 5. f. 3.

$$
\text { D. } \frac{9}{12} \text {. A. } \frac{3}{11} \text {. }
$$

The height of the body is $2 \frac{1}{2}$ in the total length; the length of the head $3 \frac{1}{2}$. Caudalis rounded. Olive-brown, with dusky vertical bars; below yellowish, with numerous erimson spots. (Holbr.)

St. John's River (Florila).

\section{Bryttus gloriosus.}

Holbrook, l. c. p. 52. pl. 5. f. 4.

$$
\text { I). } \frac{9}{11} \text {. A. } \frac{3}{10} \text {. }
$$

The height of the body is $2 \frac{2}{5}$ in the total length, the length of the 
head $3 \frac{1}{2}$. Caudalis rounded. Olive-brown : head, body, dorsal and anal fins with numerous golden spots; a black blotch at the root of the caudal fin. (Holbr.)

Cooper River; South Carolina; Georgia.

\section{POMOTIS*}

Pomotis, Cuv. Règne Anim.; Cuv. \& Val. iii. p. 90.

Six branchiostegals. All the teeth villiform, without canines; teeth neither on the palatines nor on the tongue. One dorsal, with ten, rarely with nine or eleven spines; the anal fin with three spines. Operculum with a rounded, membranaceous, coloured lobe above the angle; præoperculum entire or minutcly crenulated. Scales moderate. Air-bladder large, subdivided posteriorly into two horns. Pyloric appendages in small number (6-8).

Fresh waters of the Nearctic region.

\section{Pomotis auritus.}

Labrus auritus, L. Gm. p. 1286 ; Bl. Schn. p. 246; Shaw, Zool. iv. p. 482.

Perca gibbosa, Catesby, t. 8. f. 3.

Pomotis vulgaris, Cuv. \& Val. iii. p. 91. pl. 49, vii. p. 465 ; Richards. Faun. Bor. Amer. p. 24. pl. 76 ; Kirtland in Bost. Journ. iii. p. 470. pl. 28. f. 2; Cuv. Règne Anim. Ill. Poiss. pl.10.f.3; Dekay, New York Fauna, Fish. p. 31. pl. 51. f. 166; Holbr.Ichth. S. Carol. p.6. pl.1. f.2.
D. $\frac{10}{11-12}$.
A. $\frac{9}{10}$.
L. lat. 33-34.
L. transv. $\frac{5}{12-14}$.
Vert. 14/16.

Cæc. pylor. 6-8.

The height of the body is $2 \frac{1}{2}$ in the total length, the length of the head $3 \frac{1}{2}$; the diameter of the eye is one-fourth of the latter, or twothirds of the distance between the eyes. Præoperculum slightly serrated; caudal fin slightly notched, with rounded lobes. The length of the third dorsal spine $2 \frac{1}{2}$ or three times in the length of the

* 1. Pomotis tetracanthus, Cuv. \& Val. iii. p. 94.-Buenos Ayres.

2. - ravenelii, Cuv. \& Val. vii. p. 465.-N. America.

3. — holbrookii, Cuv. \& Val. vii. p. 466.-Charleston.

4. — incisor, Cuv. \& Val. vii. p. 466; Holbr. Ichtl. S. Carol. p. 13. pl. 2. f. 1.-New Orleans, S. Carolina.

5. - gibbosus, Cuv. \& Val. vii. p. 467.-Charleston.

6. - solis, Cuv. \& Val. vii. p. 468.--Lake Pont Chartrain.

7. — catesbyi, Cuv.\& Val. vii. p. 469.-Philadelphia.

8. — breviceps, Baird \& Girard, Proc. Ac. Nat. Sci. Philad. 1853, p. 390, and in Marcy's Explor. Red River, Zool. p. 246. pl. 13, and in U.S. Pacif. R. R. Exp. Fish.p. 28.-Red River.

9. Labrus appendix, Mitch. Suppl. Mem. Amer. Monthly Mag. ii. p. 247.Pomotis appendix, Dekay, New York Fauna, p. 32.-N : America.

10. Pomotis nitidus, Kirtl. Bost. Journ. iii. p. 472. pl. 28. f. 1.-Ohio.

11. —- luna, Gir. U. S. Pacif. R. R. Exped. Fish. p. 22. pl. 8. f. 1-4.-U. S.

12. - aquilensis, Baird \& Girard, Proc. Ac. Nat. Sci. Philad. 1853. p. 387, and U. S. Pacif. R. R. Exped. Fish. p. 25. pl. 9. f. 1-4, pl. 10. f. 8-11.-P. nefastus, Baird \& Girard, Proc. Ac. Nat. Sci. Philad. 1854, p. 24.-P. popeii, Girard, U.S. Pacif. R.R.Exp. Fish.p. 26. 
head. Coloration uniforn, with a black lobe at the operculum, and with series of brownish spots between the rays of the vertical fins.

North America.

a. Adult: skin. Lake Eric. From Dr. Parnell's Collection.

b. Adult. New York. From Mr. Brandt's Collection.

$c$, d. Adult. N. America. From Mr. Warwick's Collection.

e. Adult: skin. New Orleans. From Dr. Parnell's Collection.

$f$. Young. New Orleans.

$g, h$. Young.

Var. Uniform blackish brown.

i. Adult: skin. Lake Eric. From Dr. Parnell's Collection.

\section{Pomotis rubricauda.}

Pomotis rubricauda, Storer, Bost. Journ. Nat. Itist. iv. p. 177; Itolbr. Ichth. S. Carol. p. 10. pl. 2. f. 2.

- appendix, Storer, Synops. p. 42.

fillax, Buirel s. Givirerd, Proc. Ac. Nut. Se. Philad. 1854, p. 24, and U.S. P'ucif. R. R. Exp. Fishes, p. 27. pl. 8. f. 9-12, pl. 9. f. 5-12, pl. 10. f. $1-7$.

- convexifrons, Iaird \& Girard, Iroc. Ac. Nut. Sc. Philad. 1854, p. 24.

$$
\text { D. } \frac{10}{11}, \quad \text { A. } \frac{3}{10} \text {. Cæc. pylor. } 7 \text {. }
$$

The height of the body is about $2 \frac{2}{3}$ in the total length, the length of the head (withont appendage) four times. The appendage rery long, one-half of the length of the head (in mature specimens). Præoperenlum rounded, not, or but slightly, serrated at its angle. The spinous portion of the dorsal lower than the soft. The pectoral not reaching so far backwards as the ventral. Caudal fin slightly notehed, with rounded lobes. Above dusky, sides of the opereles and helow red, some blue waring lines on the sides of the head. $\Lambda$ ppendage black, bordered above and below with pale greenish blue. Fins uniform yellowish; dorsal fin sometimes with a darker pateh.

Fresh waters from Massachusetts to Georgia and Texas.

u. Half-grown: skin. From Dr. Parnell's Collection.

\section{Pomotis elongatus.}

IIolbrook in Joum. Acad. Nat. Sc. Ihilud. 1855, p. 47. pl. 5. f. 1.

$$
\text { D. } \frac{10}{12} \text {. A. } \frac{3}{10} \text {. }
$$

The height of the body is 22 in the total length, the length of the head four times. The upper maxillary reaches to the anterior margin of the eye. Operenlar lobe black, of moderate size. .Cindilis cmarginate, with rounded lobes. The soft portion of the dorsal higher than the spinous. Cheeks with pale bluish lines; body dusky ahove, yellow below, with several dark vertical bars on the sides, and a black bloteh on the back of the tail behind the dorsal fin. (//oller.)

St. John's River; Florida. 


\section{Pomotis speciosus.}

Baird \&. Girard, Proc. Ac. Nat. Sc. Philud. 1854, p. 24, and U. S. Pacif. R. R. Exp. Fishes, p. 23. pl. 8. f. 5-8 (not Holbrook).
D. $\frac{10}{11}$.
A. $\frac{3}{11}$.
L. lat. 43.

The length of the head is one-fourth of the total; the diameter of the eye one-fourth of the length of the head. Caudalis cmarginate; pectorals reaching as far backwards as the ventrals. Brownish, with a narrow blackish band parallel to, and near, thc dorsal line; posterior part of the soft dorsal with a large subcireular blackish spot; anal and ventrals blackish; pectorals yellowish.

Fresh waters of the United States. (Texas.)

Some of the specimens in the British Muscum Collection have the spinous dorsal rather elevated, the fifth spine being more than onehalf of the length of the head. Others have the same spine much shorter, contained about $2 \frac{1}{2}$ in the length of the head. These specimens, perhaps, are specifically different, but exhibit the black dorsal spot mentioned in the diagnosis.

a-e. Adult, half-grown, and young: skins. (Lakc Eric?) From Dr. Parnell's Collection.

\section{Pomotis chætodon.}

Baird in the Ninth Smithsom. Report, p. 324.

$$
\text { D. } \frac{10}{11} \text {. A. } \frac{3}{12} \text {. }
$$

The height of the body is more than one-half of the total length; eye large, only one-third of the length of the head. Caudalis subtruncated; the pectorals and rentrals extending beyond the third anal spine. Dirty white, with six black vertical bands; ventrals black in the centre; the dorsal black between the three anterior rays. (Bairel.)

Cedar Swamp Creck, New Jersey.

\section{Pomotis heros.}

Baird S. Girard, Proc. Ac. Nat. Sc. Philad. 1854, p. 25, and U. S. Pucif. R. R. Exp. Fishes, p. 24. pl. 9. f. 13-16.

$$
\text { D. } \frac{10}{12} \cdot A \cdot \frac{3}{11} \text {. }
$$

The length of the head is $3 \frac{1}{2}$ in the total; the rliameter of the eye one-fourth of the former. Pectorals rery long, extending to the second soft ray of the anal fin. Caudalis emarginate; the spinous dorsal elevated. Uniform blackish brown; pectorals yellowish; other fins greyish. (B. \& $G$.)

Texas.

Compare Pomotis machrochir[a, Raf.], Kirtland, Bost, etoum. iii p. 469. pl. 27. f. 3. 


\section{Pomotis microlophys.}

Pomotis speciosus, Holbr. Journ. Ac. Nat. Sc. Philud. 1855, p. 48. pl. 5. f. 2 (not Baird \& Girard).

$$
\text { D. } \frac{10}{10} \text {. A. } \frac{9}{9} \text {. }
$$

The height of the body is $2 \frac{2}{3}$ in the total length, the length of the head four times; the diameter of the eye is one-fourth of the latter. The upper maxillary reaehes nearly to the anterior margin of the eye. Opercular lobe small, blaek, edged with red. Caudalis emarginate, with rounded lobes; the soft dorsal higher than the spinous; the tenth dorsal spine mueh longer than the ninth (aceording to the figure quoted); the pectoral fin extends to the second anal ray, the ventral to the first spine. Brownish olive, with a few reddish-brown spots on the sides; lateral line red: fins immaeulate. (Hollr.)

St. John's River (Florida).

\section{Pomotis marginatus.}

Holbr. l. c. p. 49. pl. 6. f. 2.

$$
\text { D. } \frac{9}{12} \text {. A. } \frac{3}{10} \text {. }
$$

The height of the body is $2 \frac{2}{5}$ in the total length, the length of the head $3 \frac{3}{4}$; snout shorter than the diameter of the eye; the upper maxillary extending to tho orbit. Caudalis slightly emarginate; the peetoral reaches to the rent, the ventral to the origin of the anal. Dusky olive brown, with vertical bars of the same colour; head and body with numerous bluish-green spots; opercular appendix bordered with green. (Holbr.)

St. John's River (Florida).

\section{ANOPLUS.}

Anoplus, Temm. \& Schleg. Faun. Japon. Poiss. p. 17.

Branehiostegals six. The outer teeth of the jaws short, but rather thick; teeth on the vomer; none on the palatine bones. Dorsal deeply notehed, the first portion with ten, the anal with three spines; all the spines very long, strong, and flattened. Caudalis very slightly notehed. Præopereulum very fincly serrated; the other opereles neither serrated nor armed.

Japanese Sea.

\section{Anoplus banjos.}

Banjos, Krusenstern's Reise, pl. 54. f. 1.

Anoplus, sp., Faun. Japon. l. c. pl. 8.

Anoplus banjos, Richards. Ichth. China, 236.

$$
\text { D. } \frac{10}{12} \text {. A. } \frac{3}{7} \text {. L. lat. } 66 \text {. }
$$

The third dorsal spine two-thirds of the height of the body; the soft dorsal with a deep-blaek spot at the upper extremity. $a, b$. Adult : stuffed. Japan. From the Leyden Museum. 


\section{ODONTONECTES.}

Cæsio, sp., Cuv. \& Val. vi. p. 442.

Six branchiostegals. Villiform tecth in the jaws, on the vomer and the palatine bones; an outer semes of larger teeth in the jaws; canines very small. One dorsal, with ten spines, and with the basal half scaly; the anal fin with three spines. Opereular points indistinct; the angle of the præoperculum very slightly serrated. Scales moderate, without visible serrature. Cleft of the mouth oblique, the lower jaw longest; eye moderate. Pyloric appendages in small number; air-bladder with two narrow processes in front to the base of the skull.

East Indian Seas.

This fish cannot be referred to Ccesio, having distinct bands of palatine and vomerine teeth; nor to Cuvier's family of Moenidce, not having the mouth more protractile than the greater part of the Percidce. It is very probable that Ccesio lunaris, and some other similar species which I have had no opportunity of examining, should also be referred to this genus.

\section{Odontonectes erythrogaster.}

Renard, i. 32.174

Cæsio erythrogaster, (Kuhl\& van Hass.) Cuv.\& $V a l$. vi.p. 442.pl.166 ; Bleek. Verh. Batav. Genootsch. xxiii. Manid. p. 9.
B. 6 .
D. $\frac{10}{15}$.
A. $\frac{3}{11}$.
L. lat. 53.
L. transv. $7 / 13$.
Vert. $10 / 14$. Cæe. pylor. 5 .

The height of the body is $3 \frac{1}{2}$ in the total length, the length of the head four times; the snout is equal to the diameter of the eye, and about one-fourth of the length of the head. The upper maxillary reaches scarcely beyond the vertical from the anterior margin of the eye ; the angle of the præoperculum rounded and very finely serrated. The basal half of the dorsal and anal fins scaly; all the spines slender and flexible; the fourth of the dorsal longest; dorsal continuous; caudalis deeply forked; the second and third anal spines nearly equal. Above bluish green ; belly rose-coloured.

East Indian Seas.

a. Adult. Amboyna. Purchased of Mr. Frank.

b. Adult : skeleton. Amboyna. Purchased of Mr. Frank.

c. Adult: not good state. Molucea Sea. Purchased of Mr. Frank.

d. Adult. From the Haslar Collection.

e. Adult. From the Haslar Collection.

f. Adult.

g. Adult. From Mr. Brandt's Collection.

Skeleton.-The skull of this species is distinguished by the exceedingly high erest, which extends from the foramen occipitale to the anterior end of the frontal bones; it is triangular, and supported by a bony ridge arising from the supraoccipital bone and 
aseending in an oblique direction. There are, besides, the two usual lateral ridges, moderately dereloped. The basal portion of the skull is not globose or swollen. 'The jaw-bones are rather fecble; the maxillary is styliform in its basal half, and widens at the opposite extremity, so that the posterior and anterior margins are equally and slightly coneare. The articulary processes of the intermaxillary bones are shorter than the bones themselves, and are received in a slight groore of the extremity of the occipital crest. The muciferous ehannel of the lower jaw is little developed, like those of the other parts of the skull. The præorbital is falciform, and has no denticnlation whatever; the suborbital arch is narrow, with an interior ridge reaching into the orbit. The præopereulum is indistinctly serrated at the angle only; the posterior edge is nearly rertical, the inferior and the angle slightly rounded. The opereulum has a slight ridge at the inner side, terminating in an obtuse point; the sub- and interopereulum are narrow and slightly curved. The coracoid, the ulna, and the radius are remarkably broad, the pubie bones rather narrow and very elongate.

The teeth are very small, and arranged in a single series in the upper and lower jaws. The band of vomerine teeth is bent at an obtuse angle, and narrow, like that of the palatine bones.

There are ten abdominal and fourteen eaudal vertebrx, the length of the former portion of the rertebral column being to that of the caudal as $1: 1 \cdot 6$. The neural and hxmal spines are slender; the first interhemal is attached to the hrmals of the eleventh and twelfth rertebrix by a slender and styliform portion, and forms a broad semicirenlar plate, to which the anal spines are joined.

\section{DULES*.}

Dules, Cuw. \&. I'al. iii. p. 111.

Six branehiostegals. All the tecth villiform, without eanines; tecth on the palatine bones. One dorsail, with ten spines, the anal fin with three. Opereulum with two or threc points, prxoperenlum serrated. Seales moderate, minutely serrated; chin not very prominent: cyes moderate.

Seas between the Tropies, some species entering into the rirers.

\section{Dules auriga.}

Cuv. \& $V$ al. iii.p. 112. pl. 51; Dekay, Nerc Tork Funa, Fishes, p. 34. pl. 10. f. 54 ; Jen!ms, Zool. of the Beagle, Fishes, p. 16.

$$
\text { D. } \frac{10}{13} . \Lambda \cdot \frac{3}{7} \text {. Vert. } 10 / 14 \text {. }
$$

'The third dorsal spine very elongate, filiform, half the length of

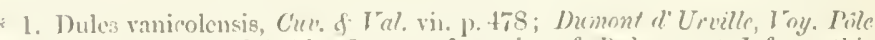
Sind, I'siss. p. 12. pl. :3. f. '2 (the figures of species of Dules, quoter from this work, rlo not appear to be very eorrectly executed with regard to their coloration) 
the total. Candalis truneated. Opereulum with three spines. Yellowish grey, with two or three darker cross-bands.

This tish much resembles the genus Centropristis.

Coast of Brazil (and of North America?).

«. Adult. Bahia. Purchased of M. Parzudaki.

\section{Dules flaviventris.}

Cur. \& Fal. iii. p. 113.

$$
\text { D. } \frac{10}{12} \text {. A. } \frac{3}{7} \text {. }
$$

No elongate dorsal spine. Caudalis truncated. Opereulum with three spines. Brownish, with a large yellow space on the belly, and with two round black spots on each side, at the base of the caudal fin. $(C u v$.)

Coast of Brazil.

I suppose that this species belongs to Centropristis.

\section{Dules caudavittatus.}

Holocentrus caudavittatus, Lacép. iv. pp. 332, 367.

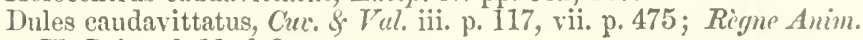
III. Poiss. pl. 11. f. 2.

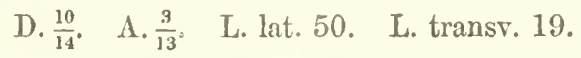

In habit very similar to $D$. teniums. Caudal fin with two black cross-bands, the posterior of which forms a black edge; the soft dorsal fin without black. ( $\mathrm{Cuv}, \& \cdot \mathrm{F}$ al. $)$

Isle de Franee.

\section{Dules tæniurus.}

Cuv. \& Val, iii. p. 114; Blecker, Perc. p. 49.
D. $\frac{10}{10}$. A. $\frac{3}{11}$.
L. lat. 50-55.
L. transv. 6/12.

The height of the body is $3 \frac{2}{3}$ in the total length, the length of the head $4 \frac{1}{4}$; the diameter of the eye is one-third of the latter. Operculum with two spines. Candalis deeply notched; the fourth and fifth dorsal spines longest, the tenth shorter than the following ray; the spinous and the soft portion of the dorsal nearly equal in height and in length; the second anal spine stronger, but shorter than the third. Above steel-blue; each lobe of the eaudal brown, with an oblique white band; both bands convergent posteriorly; the soft dorsal anteriorly and above with a brownish margin.

Chinese and Javanese Seas.

Blecker (7.c.) mentions only forty seales in a longitudinal line, as is the case in $D$. marginatus.

a. Fine specimen. Chinese Sea. Presented by Capt. Sir E. Beleher.

b. Adult. Chinese Sea. Presented by. Capt. Sir F. Belcher.

c. Adult. Chimese Sca. Presented by Capt. Sir 1. Belcher. 


\section{Dules fuscus.}

Cuv. \& Val. iii. p. 118; Peters, Wiegm. Arch. 1855, p. 238.

$$
\text { D. } \frac{10}{11} \text {. A. } \frac{3}{10} \text {. }
$$

In habit similar to D. taniurus. Brown; the dorsal fin uniform brown; caudalis with some indistinct blackish longitudinal lines; analis with a series of black spots along the base. (Cuv.)

Isle de France; Island of Anjoana (Mozambique).

\section{Dules marginatus.}

Cuv. \& Val. iii. p. 116. pl. 52, vii. p. 474; Dumont d'Urille, Voy. Pôle Sud, Poiss. p. 41. pl. 3. f. 3 ; Bleeker, Sumatra, i. p. 573.

D. $\frac{10}{11}$. A. $\frac{3}{11-12}$. L. lat. 40-45. L. taansv. 5/8. Cæc. pylor. 8.

In habit similar to D.tceniurus. - The fourth and fifth dorsal spines longest, the tenth as long as the following ray; the second anal spine stronger, but shorter than the third. Greyish above; caudal fin with two black cross-bands, the posterior of which forms a black edge ; the soft dorsal fin anteriorly and above with a black band.

Sea of Java. Amboyna. Vanicolo. Feejee Islands.

a. Adult. Java.

b. Adult. Amboyna. From Mr. Frank's Collection.

c. Adult. Amboyna. From the Collection of Madame I. Pfeiffer.

d. Adult. Amboyna. Purchased of Mr. Stevens.

$e-g$. Adult and half-grown. Feejee Islands. Presented by the Lords of the Admiralty.

h. Adult. Feejee Islands. From Mr. Maegillivray's Collection. $i, k$. Adult: stuffed.

\section{Dules rupestris.}

Centropomus rupestris, Lacép. iv. pp. 252, 273.

Dules rupestris, Cuv. \& Val. iii. p. 119, vii. p. 477; ? Bleek. Natuurk. Tydschr. Ned. Indie, vi. p. 209.

- maculatus, Cuv. \& Val. vii. p. 475 ; Bleek. Amboina, iv. p. 333.
D. $\frac{10}{10-11}$.
A. $\frac{3}{10-11}$.
L. lat. 40-42.
L. transv. 4/8. Vert. 11/15.

\section{Cxc. pylor. 7 .}

The height of the body is $3 \frac{1}{2}-3 \frac{2}{3}$ in the total length, and the length of the head $4 \frac{1}{3}-4 \frac{2}{5}$; the diameter of the eyes equal to, or less than, the distance between them. Opereulum with two spines. Caudalis truncated, or slightly emarginate; the fourth and fifth dorsal spines longest, the spinous portion of the dorsal sometimes higher, sometimes rather lower than the soft. Brownish grey above, each scale with a deep-black spot in the centre; the vertical fins brown-spotted, and edged with blackish.

Eresh waters of Isle de Franee, of Celebes and Amboyna, of the Feejee Islands, and of the Island of Ovalau.

a. Large specimen. Feejec Islands. Vojage of the Herald. 
b. Large specimen : skeleton. Feejee Islands. Voyage of the Herald. c-e. Adult and half-grown. Island of Ooalau (fresh waters). Voyage of the Herald.

$f$. Adult. Island of Ooalau (fresh waters). Voyage of the Herald. $g-i$. Adult. Amboyna. Purchased of Mr. Frank.

$k$. Adult. Isle de France. Presented by the Zoological Society.

l. Adult. From the Collection of the Zoological Society.

Skeleton.-This genus, or at least this species of the genus, is justly considered to be a true Percoid, the bones of the skull offering all the characters of the family, although somewhat modified in form. The upper part of the skull is broad, flat, slightly rounded on the sides, rough, but without any prominent ridges. The occipital crest is well developed, pointed behind, but does not extend on to the upper surface of the skull; the nasals are narrow, cylindrical, tubiform. The præorbital is small, only one-third as broad as the distance between the eyes, and minutely serrated on the posterior third of the lower margin; the suborbital arch is feeble, rather narrow, and there is no interior plate for supporting the eyeball. The upper maxillary is rather slender, widening behind, and with a slightly convex upper edge and a concave one beneath. The operculum has two very acute spines, the terminations of two ridges at its interior surface. The lower spine is much longer, and obliquely rirected downwards. The præoperculum is entire behind, nearly right-angular, and has a minutely serrated inferior margin. The suboperculum is distinguished by a deep notch in the lower limb, in front of which it shows an exceedingly fine serrature. The interoperculum has a rounded inferior margin, with some denticulations so fine as to be hardly visible. The suprascapula and humerus are finely serrated ; the lower coracoid narrow, styliform.

The length of the abdominal vertebral column is to that of the caudal as $11: 15$; the first interhæmal spine is not very strong, equal to the length of the third to the eighth vertebra, and attached to the twelfth hæmal spine.

The dentition is very complete : there are villiform bands in both the jaws, reaching to the extremities of the bones; on the vomer in a broad band, forming a right angle; on the palatine and pterygoid bones in narrow separate bands; and, finally, in an oval patch on the entopterygoid. The teeth on the pharyngo-branchial or upper pharyngeal bone are remarkably strong and rasp-like.

\section{Dules guamensis.}

Cuv. \& Val. vii. p. 474; Dumont d' Urville, Voy. Pôle Sud, Poiss. p. 42. pl. 3. f. 1 .

$$
\text { D. } \frac{10}{10} \text {. A. } \frac{3}{10} \text {. }
$$

In habit similar to $D$. tceniurus. Fins immaculate, each lobe of the caudal black at the tip. ( $V a l$.

Sea of Guam. 
9. Dules malo.

Dules malo, Cur. \& Vul. vii. p. 479; Dumont t Urville, l.c. p. 43. pl. 3. f. 4 .

mato, Less. Voy. Coq. Zool. ii. p. 223.

lenciscus, Jonyns, Zool. of the Beagle, Fishes, p. 17.

$$
\text { D. } \frac{10}{11} \text {. A. } \frac{3}{11-12} \text {. }
$$

The height of the body is one-third of the total length (withont candal fin); the diameter of the eye is larger than one-third of the length of the head, or than the distanee between the eyes. Silvery white, brownish on the back; the dorsal, anal, and ventral fins brown-spotted.

River Matarai (Otaiti).

\section{Dules bennetti.}

Perca argentea, Bennett, Fishes of Ceylon, pl. 22.

Dules benuetti, (Bleeker) Peters, Wiegm. Arch. 1855, p. 238.
B. 5? (Bennett).
D. $\frac{10}{9}$.
1. $\frac{3}{10}$.
L. lat. 50.
L. transs. 6/12.

Catzdalis forked. Uniform silvery ; a black streak along the middle of the caudal, and on each lobe two oblique black transverse bands, confluent into an oval; all the other fins immaculate. (Benn.)

Sea of Ceylon (Bennett). Fresh waters of Mozambique (Peters).

a. Adult. Presented by Sir A. Smith.-The soft dorsal fin with a black tip. Perhaps a rariety of D. teniurus.

\section{Dules ambiguus.}

Datnia ambigua, Richardson, Foy. Ereb. \& Terr. Fishes, p. 25. pl. 19.

$$
\text { D. } \frac{10}{11} \text {. A. } \frac{3}{9} \text {. L. lat. } 85 \text {. }
$$

The spines of the fins.rery strong; the snout rather elongate, much longer than the eye; propopereulum with spinous teeth at the inferior limb, directed forwards. Coloration uniform.

Western Australia.

a. Adult: bad state; has been in chloride of zinc. From the Haslar Collection.

b, c. Adult: stuffed. West Australia. Presented by Captain Sir G. Grey. 
Before we proceed to the family of the Pristipomatida, which contain fishes with the habit and many of the characters of the Pereicle, and which enter into a nearly continuous series with our last genera (Odontonectes, Dules), we are obliged to interealate a fish, which we dare not remove very far from Pomotis, Centrarchus, and Bryttusfishes with a similar structure of the vertical fins, and inhabitants of the fresh waters of the same geographical region. The extraordinary position of the vent, before the ventrals (as oecurs again in Amblyopsis), and the number of the rays of the ventrals demand the formation of a separate family for this fish.

\section{Fam. 4. APHREDODERIDÆ.}

Form of the body ohlong; eyes lateral ; eleft of the mouth extending on to the sides of the muzzle; vent jugular, before the ventrals. Villiform teeth in both the jaws and on the palate. Six branchiostegals. Some of the bones of the skull armed. Scales ctenoid. Ventral fins thoracic, with more than five soft rays. One single dorsal, with the spinous portion little developed. Cæca pylorica in moderate number. Air-bladder simple.

Fresh waters of North America.

One genus.

\section{APHREDODERUS.}

Aphredoderus, (Lesucur) Cuv. \&. Val. ix. p. 445; Dekay, Newo York Fauna, Fishes, p. 35.

Cleft of the mouth slightly oblique, with the lower jaw Iongest; eye moderate. Villiform teeth in both the jaws, on the vomer and on the palatine bones. Six branchiostegals. Infraorbital and praopereulum with spinous teeth. Seales moderate, ctenoid. Dorsal with three, anal with two spines. Caudalis rounded. Pseudobranchiæ?

Fresh waters of North America.

\section{Aphredoderus sayanus.}

Scolopsis sayanus, Gilliams, Journ. Ac. Nat. Sc. Philad. iv. p. 81. pl. 3. Aphredoderus gibbosus, (Lesueur) Cuv. \& Val. ix. p. 448. pl. 278.

- sayanus, Dckay, New York Fauna, Fishes, p. 35. pl. 21. f. 62; Baird, Ninth Smithsonian Report, p. 326.
D. $\frac{3}{11}$.
A. $\frac{2}{7}$.
L. lat. $45-50$.
Cæc. pylor. 12.

The height of the body is $4 \frac{1}{3}$ in the total length, of which the head is one-fourth; the diameter of the eye is less than the distance from the end of the snout, and two-thirds of the distance between the eyes. The maxillary bone extends beyond the vertical from the anterior margin of the eye ; the distance of the anus from the snout is equal to one-fifth of the total length; caudalis rounded. Greenish olive; a vertical spot beneath the eye.

Harrowgate, near Philadelphia; Lake Pont Chartrain. Many streams on the Atlantic coast.

a. Adult: skin. United States. Hrom Dr. Parnell's Collection. 


\section{Fam. 5. PRISTIPOMATIDA.}

Percoidei pt., Sciænoidei pt., Sparoidei pt., et Mænides, Cuv. Rigne Anim.; Mïller, Berl. Abhandl. 1844, p. 201.

Percidæ pt., et Sciænidæ pt., Owen, Lect. Comp. Anat. Vert. i. p. 49.

Theraponidæ pt., Sciænidæ pt., Sparidæ pt., et Mænides, Richards.

Body compressed and oblong, covered with scales, the serrature of which is sometimes exceedingly fine and sometimes wanting. Lateral line continuous, not continued on the caudal fin*. Mouth in front of the snout, with lateral eleft. Eye lateral, of moderate sizc. Five, six, or seven branchiostegals $\uparrow$. Teeth in villiform bands, with pointed and conical canines in some of the genera; no molars or trenchant teeth in the jaws, generally no teeth on the palate; jaws toothless in two of the genera. No barbels. Cheek not cuirased. One dorsal fin, formed by a spinous and soft portion of nearly equal development, the former of which either contains strong spines or is continuous with the latter; anal similarly developed as the soft dorsal; the lower rays of the pectorals branched; ventrals thoracic, with one spine and five soft rays. The bones of the head with a rudimentary or moderately developed mueiferous system. Stomach cæcal; pyloric appendages in small or moderate number $\neq$. Air-bladder present, more or less simple. Pseudobranchix well devcloped $\$$.

Carnivorous fishes, without molar or trenchant teeth, inhabiting the seas of the temperate and tropical regions; a few entering fresh waters.

The fishes united by the above characters into a family form a rery natural group, in their external structure as well as in their internal organization. A few of the members continue to havo romerine toeth, like Percidae; but they are either deciduous or absent in species closest allied to them. At the end of the family there are some fishes with a more cylindrical habit, and Erytherichthys has some resemblance to the Scombrida. There is a South American freshwater fish, Polycentrus, and Hyperoglyphe from Australia, which disturb the harmony of the characters of this family ; but not knowing a better place for them, I thought it best to leave them where they were placed by their first discoverers.

\section{Synopsis of the Genera.}

1. Anal fin with three spines.

A. Air-bladder separated by a contraction into an anterior and posterior portion.

All the teeth villiform and conical

1. TherApoN.

Teeth of the outer row with a small lobe on caeh side

2. HeLOTES.

* In Polycentrus absent.

+ In Chatopterus four. t Except in Hyperoglyphe.

$\$$ In Polycentrus hidden. 
B. Air-bladder not contracted.

1. Teeth in the jaws.

a. Mouth moderately protractile.

* Prcoperculum serrated.

Seven branchiostegals. A central groove behind the symphysis of the lower jaw. The vertical fins not scaly, or at the base only. Teeth of the jaws villiform ............

Seven (?) brancbiostegals. A central gtoove'behind the symphysis of the lower jaw. In each jaw an external series of very stout and conical teeth

4. Pristipoma

\section{Conodon.}

Seven branchiostegals. A central groove behind the symphysis of the lower jaw. The soft portions of the vertical fins scaly to their margin
6. Hemulon.';
7. Hapalogenys.

Six or seren branchiostegals. Lower jaw with pores, but without central groove. The upper profile of the head parabolic

\section{8} n branchiostegals. 'The spinous dorsal very low, scarcely
continuous with the soft, with eight spines .................

Six branchiostegals. Body elevated; the upper profile of the head concave ..........................................

Five branchinstegals. Præorbital with a spine directed backwards

\section{HYPEROGLYPHE.}

10. LOBOTES.

13. Scolopsis.

Five or six branehiostegals. Prreorbital not armed. Caudalis deeply forked .........................................

Seren branchiostegals. Lower jaw without pores. Dorsal fin
with ton spines

14. Heteroonathodon.

17. Pristipomoiden.

\section{- Praoperculam entire.}

Canine teeth; distance between the eye and the angle of the mouth great; more than three series of scales between the eye and the angle of the præoperculum. Dorsal scaleless

\section{Dentex.}

Canine teeth; distance between the eye and the angle of the mouth great. Three series of scales between the eye and the angle of the præoperculum. Dorsal scaleless .........

Canine teeth; distance between the eye and the angle of the mouth small. More than three series of scales between the eye and the angle of the proopereulum. Dorsal scaleless ...................................................

Four branchiostegals. Canine teeth none ....................

Seren oranchiostegals. Canine teeth none ......................

Dorsal scaly along the base
18. Pentapus.
19. Ciletopterus.
20. Aphareus.
23. CAsio.

\section{b. Mouth very protractile.}

Spines of the fins very stout; twelve in the dorsal fin 11. Datniordes.

Dorsal $\frac{9}{10} ;$ anal $\frac{3}{7(-9)}$ 12. Gerres.

Spines of the fins feeble. Dorsal scaleless. Vomerine teeth... 21. Mana.

Spines of the fins very feeble. Dorsal scaleless. Vomerine teeth none

22. SMARIS. 
Spines of the fins very strong 3. Macquaria.

Spines of the fins fecble 24. ERYTIRICHTHYs.

II. Anal fin with more than three spines.

Anal fin with five spines

25. Pentaprion.

Anal fin with thirteen spines. No lateral line.

26. Polycentaus.

\section{THERAPON*.}

Therapon, Cuv. Regne Anim.; Cuv. \& Val. iii. p. 125.

Datnia, Cuv. \& V $V_{a l}$. iii. p. 138.

Pelates, Cuv. Rène Anim.; Cuv. \& Val. iii. p. 145.

Six branchiostegals. Eyo of moderate size. Teeth villiform in both the jaws, deciduous on the romer and the palatine bones. Operculum spiniferous; præopereulum serrated. Dorsal more or less notched, with twrelve spines (in Th. caudovittatus with thirtcen); anal with three. Seales moderate. Air-bladder with two divisions, an anterior and posterior, separated from each other by a contraction. Cæca pylorica in moderate number.

From the Red Sea to the Cape of Good Hope through the Indian Ocean to the coasts of Australia. Several speeies entering rivers.

\section{Therapon theraps.}

Therapon theraps, Cuv. \& Val. iii. p. 129. pl. 53; Blecker, Perc. p. 50; Richards. Ann. \& Mag. Nat. IIist. 1842, vol. ix. p. 126; Rüpp. Neue Wirb. Fische, p. 95.
D. $\frac{12}{10}$.
A. $\frac{3}{8}$.
L. lat. 55. Vert. 10/15.

The height of the body is $3 \frac{1}{3}$ in the total length ; the length of the head four times. The snout is $1 \frac{1}{3}$ the interspace between the eyes. Præopereulum rounded, serrated, with moderate spinous teeth at the angle; opereulum with two spines, the lower of which is elongate and strong. Greenish grey, with three straight brown longitudinal bands, the inferior of whieh extends from the head to the tail ; the spinous portion of the dorsal fin blackish between the third and seventh spines; two or three blackish bands obliquely erossing each lobe of the eandal.

All the Indian Seas; Chinese Sea; False Bay : entering rivers.

a. Adult. India.

b. Half-grown. India.

c. Many half-grown and young specimens. East Indies.

* 1. Therapon rubricatus, Richards. Ann. \& Mag. N. H. 1842, vol. ix. p. 127. - N. W. const of Australia.

2. - mierolepis, Rüppell, Verz. Fische des Senekenberg. Mus. p. 4.Indian Ocean.

3. - Douzetianus, Hombr. \& Jacquin. Voy. Póle Sud, Zool. iii., Poiss. p. 43. pl. 4. f. 2.-Hab. —? 
$d-f$. Young. India. From the Haslar Colleetion.

g. Half-grown. Singapore.

$h, i$. Young. Malacea.

$k$. Half-gromn. China.

l. Half-grown. China Seas. Presented by Capt. Sir E. Beleher.

m. Half-grown. China Seas. Presented by Capt. Sir E. Beleher.

n. Adult: stuffed. China Seas. Presented by J. R. Reeves, Esq.

o. Hialf-grown. China Seas.

p. Adult : skin. False Bay. Voyage of H.MI.S. Fly.

$q-u$. Young. From the Haslar Colleetion.

? Var.

$v$. Half-grown. Philippines.

\section{Therapon obscurus.,}

Cuv. \& Val. iii. p. 135; Cantor, Catal. p. 20.

$$
\text { D. } \frac{12}{10-11} \text {. A. } \frac{3}{8} \text {. Cæe. pylor. } 7 \text {. }
$$

The height of the body is nearly equal to the length of the head, and contained $3 \frac{1}{4}$ in the total. Snout as in Th. theraps. Teeth of the vomer and the palatine bones distinct. Præopereulum equally serrated; operenlum with two spines, the lower of which is the longest. The dorsal fin deeply notched, the caudal emarginate. Pale blackish silvery, with two broad, longitudinal lighter bands; the spinous portion of the dorsal fin blackish between the third and seventh spines; the caudal fin with two oblique black bands on each lobe.

Sea of Pinang.

The fish described by Bleeker (Perc. p. 51) under the name of $T h$. obscurus cannot belong to this species.

\section{Therapon squalidus.}

Cuv. \& Val. iii. p. 136.

\section{D. $\frac{12}{10}$. A. $\frac{3}{8}$. Cæe. pylor. 13 .}

Very similar to Th. obscurus. The height of the body is nearly equal to the length of the head, and contained about $3 \frac{1}{3}$ in the total. Snout as in Th. theraps. Præopereulum angular, equally serrated; operculum with two spines, the lower of which is the longest. The dorsal fin is deeply notehed, the eaudal emarginate. Pale bluish silvery, with two broad silvery longitudinal bands; the spinous portion of the dorsal fin with a large blackish spot; the eandal fin with two narrow oblique black bands on each lobe. (Cuv.)

Indian Ocean.

Therapon transversus, Cuv. and Val. iii. p. 137, with indistinct cross-bars and eleven pylorie appendages, may prove to be identical with the former. 


\section{Therapon virgatus.}

Datnia virgata, Cuv. \& Val. vii. p. 480.

$$
\text { D. } \frac{12}{12} \text {. A. } \frac{3}{8} \text {. }
$$

Very similar to Th. obscums. No teeth on the palate; the spinous tecth of the præoperculum and the opereular spine very strong. Three longitudinal bands; each lobe of the eaudal with two oblique streaks; the spinous dorsal with a blackish bloteh, the soft portion and the anal with two brown spots. ( $\mathrm{Val}$.)

Bay of Bengal.

\section{Therapon ellipticus.}

Datnia elliptica, Rich. Voy. Ereb. \& Terr. Fishes, p. 118. pl. 52. f.4-8.

$$
\text { D. } \frac{12}{11-13} \text {. A. } \frac{3}{8} \text {. L. lat. } 85 \text {. L. transv. } 17 / 31 \text {. }
$$

The height of the body is $3 \frac{2}{3}$ in the total length, the length of the head $4 \frac{1}{3}$. The snout moderately pointed. No teeth on the vomer or palate. Præoperculum serrated posteriorly and inferiorly, with the angle scaleless; præorbital serrated; two opercular spines, the lower of which is the broader and longer. Dorsal fin nearly even; caudalis emarrinate. Uniform.

Rivers of Western Australia,

a. 17"long: stuffed. Australia.-Type of the species.

b. Adult: skin. River Namoi (Australia).

\section{Therapon cancellatus.}

Datnia cancellata, Cuv. \& Val. iii. p. 144; Bleeker, Celebes, vii. p. 438.

$$
\text { B, 6. D. } \frac{12}{10} \text {. A. } \frac{3}{8} \text {. L. lat. } 50 \text {. }
$$

The height of the body is $3 \frac{1}{2}$ in the total length, the length of the head $3 \frac{5}{6}$; the diameter of the eye is $3 \frac{1}{2}-3 \frac{2}{3}$ in the latter. The upper maxillary reaches nearly to the anterior margin of the eye. Snout scarcely longer than the diameter of the eye. The angle of the præoperculum with spinous teeth; operculum with two spines, the lower of which is much the longer. The fourth dorsal spine less than one-half of the depth of the body, and equal to the second of the anal fin. Caudal scarcely emarginate, with a pointed upper lobo and a rounded lower one. Above greenish, with brownish crossbands on the back; three brownish longitudinal bands below the lateral line, the lower of which is formed by spots. The spinous dorsal with a black margin; the anal and ventral fins with a large blackish basal blotch.

Seas of Java and Celobes.

\section{Therapon cinereus.}

? Therapon cinereus, Cuv. \& Val. iii. p. 138.
D. $\frac{12}{10}$.
A. $\frac{3}{8}$.
L. lat. 55 .
L. transv. 11/18.

The height of the body is $3 \frac{1}{3}$ in the total length, the length of 
the head $3 \frac{2}{3}$. The interspace between the eyes equals nearly the liameter of the eye; the snout is a little longer. Præoperculum rounded, with moderate denticulations, gradually becoming larger towards the angle. Operculum with two spines, the lower of which is very long and strong. Spines of moderate strength; the fourth of the dorsal more than one-half the length of the head, and the twelfth much longer than the preceding. The third spine of the anal longer than the second. Caudalis scarcely emarginate. Cheeks with five or six series of scales. Coloration uniform; a black blotch between the third and sixth spines.

India.

a. Adult. India. Old Collection, with the name of Perca argentea.

8. Therapon unicolor. (Plate XVI. fig. A.)
D. $\frac{12}{10}$.
A. $\frac{3}{8}$.
L. lat. 50 .
L. transv. 9/20.

The height of the body is four times in the total length, the length of the head $4 \frac{1}{2}$; the interspace between the eyes is more than their diameter, and the snout is still longer. Præoperculum rounded, finely serrated; præorbital and coracoid indistinctly denticulated. Operculum with two spines, the lower of which is slightly pointed. Spines of the dorsal rather feeble; the sixth is the longest, and $3 \frac{3}{4}$ in the length of the head. Caudal truncated, with rounded angles Cheeks with small scales, forming many series. Greyish, each scate with darker margin.

Fresh waters of New South Wales.

$a-d$. Adult: skins. Head of Mosquito Creek, near Darling Downs. $e-k$. Adult : skins. Gwydir River.

Description.-The height of the body is one-fourth of the total length. The head is slightly compressed, its width between the orbits being one-fourth of its length, which is $3 \frac{1}{2}$ in the total. The upper surface of the head is flat and entirely scaleless. The snout is of moderate length, the upper maxillary reaching beyond the anterior margin of the eje. The præorbital is quadrangular, not much narrower posteriorly than anteriorly; it has the lower edge indistinctly denticulated. The eye is situated high up the sides, rather small, taking one-sixth of the length of the head. The scales of the cheeks are small, and arranged in about nine series between the orbit and the angle of the præoperculum. The naked margin of the præoperculum is narrow, the angle rounded; the posterior limb finely serrated, and longer than the lower, which is entire. The scales of the opercles are intermediate in size between those of the cheek and of the body. The operculum has two points, with a notch between; the upper is very obtuse, the lower spinous and rather prominent. The sub- and interoperculum do not show any denticulation; the suprascapula is not visible, whilst the coracoid is very broad, scaly, and denticulated at its posterior margin.

The spines of the dorsal fin are feehle and rather low : the first is 
one-half of the second ; the sixth is the longest, $3 \frac{3}{4}$ in the length of the head; the twelfth longer than the eleventh. The soft portion of the dorsal is more elevated and rounded; the distance between the dorsal and caudal fins is less than the height of the tail below the end of the dorsal. The caudal is rather short, truncated, and has the angles rounded. The origin of the anal falls somewhat behind the vertical from the origin of the soft dorsal, whilst the ends of both corrospond to each other; the spines are moderately strong; the first is one-half of the second, which is stronger, but not longer than the third; the soft portion is lower than the corresponding dorsal fin. The pectorals are rounded, very short, and $8 \frac{1}{2}$ in the total length. The ventrals are inserted immediately behind the pectorals, and rather longer, their length being one-seventh of the total.

The scales are of moderate size, miuutely eiliated; those of the belly are very small. The lateral line is nearly straight, slightly bent downwards beneath the soft dorsal.

The teeth form villiform bands, with an outer series of stronger ones; there are no teeth on the palate.

The fishes are now uniform greyish, silvery shining; each scale has the margin darker.

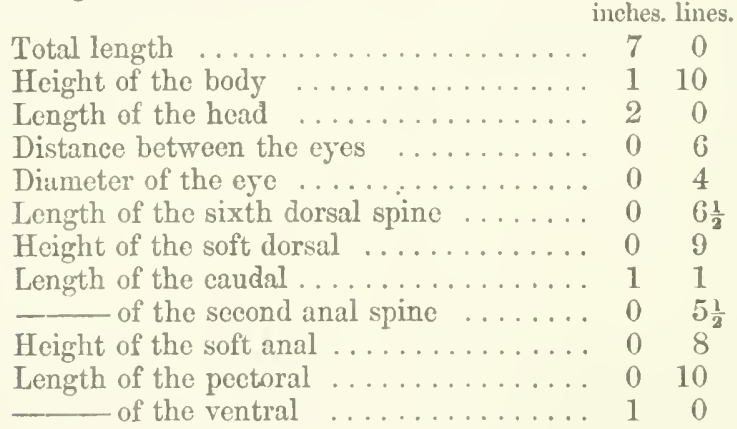

\section{Therapon servus.}

Sciæna jarbua, Forskal, Descr. Anim. p. 50; Shav, Zool. iv. p. 541. Holocentmis servus, Bloch, t. 238. f. 1 .

- jarbua, Lacép. iv. pp. 318, 355.

Grammistes servus, Bl. Schn. p. 185.

Therapon timoriensis, Quoy \& Gaim. Voy. Freyc. Poiss. p. 341.

— servus, Cuv. 8; Val. iii. p. 125, vii. p. 479 ; Bleeker, Perc. p. 50;

Richardson, Ann. \& Mag. Nat. Hist. 1842, vol. ix. p. 126; Rüpp. N. Wirb. Fische, p. 95.

Pterapon trivittatus, Gray, Ind. Zool. pl. . f. 1.
D. $11 *: \frac{1}{10}$.
A. $\frac{3}{8}$.
L. lat. 80 .
Vert. 10/15.

The height of the body is nearly equal to the length of the head, and is contrined $3 \frac{3}{4}$ in the total length. The snout is a little longer than the interspace between the eyes is broad. Prxoperculum

* The first spine is minute and scarcely visible in young specimens. 
rounded, serrated, with strong spinous teeth at the angle; operculum with two spines, the lower of which is elongate and strong. Greenish grey, witb three curved, brown, longitudinal bands, tho convexity of which is towards the belly; the inferior extends from the head to the tail; the spinous portion of the dorsal fin blackish between the fourth and seventh spines; two blackish bands obliquely erossing each lobe of the eaudal.

From the Red Sea along the Eastern Coasts of Africa through all the Indian Seas to the North Coast of Australia; ontering fresh waters.

a. Adult and half-grown: stuffed. Port Essington (fresh water). $b, c$. Adult: stuffed. Cape York. Voyage of the Rattlesnake. $d-f$. Fine specimens. Amboyna. From Mr. Frank's Collection.

g. Adult. Moluceas. From the Leyden Museum.

h. Adult. Moluceas.

i. Adult. China. Presented by J. R. Reeres, Esq.

$k$. Adult: skeleton. China.

l. Adult: stuffed. China. Presented by J. R. Reeves, Esq.

$m$. Half-grown. China. Presented by Capt. Sir Edward Belcher. n. Half-grown : skin. China. From Mr. Warwick's Collection. o, p. Young. China. Presented by Capt. Sir Edward Belcher.

q, r. Half-grown: not good state. Madras. Presented by J. C. Jerdon, Esq.

$s, t$. Half-grown: not good state. Madras. Presented by J. C. Jerdon, Esq.

$u, v$. Young. Fresh water of Point de Galle (Ceylon). Presented by Sir A. Smith.

$w$. Adult: stuffed. Red Sea.

$x, y$. Half-grown: stuffed. Cape Seas. Presented by Sir A. Smith.

z. Half-grown. India. With the name of Perca cincta.

a. Half-grown. India. With the name of Perca cincta.

$\beta$. Half-grown. India. Presented by G. R. Waterhouse, Esq

$\gamma$. Half-grown. India.

$\delta$. Young: not good state. India.

$\epsilon-\theta$. Young. India.

،. Young. India. From the Haslar Collection.

к. Half-grown : stuffed. (Nepal?) Presented by B.H.Hodgson, Esq.

Skeleton.-The skeleton of Therapon differs in nothing particularly from that of the Percine type, and does not yet show those developed grooves on the skull of the true Scicenidce. The upper surface of the skull is continued, in a straight line, into the occipital crest, which, well developed, exhibits a strong and thick ridge. The frontal bones are flat and broad, without sharp ridges, tapering from the anterior angle of the orbit, and truncated in front. The præorbital is bruad, irregularly quadrangular, with the lower margin denticulated; the remainder of the infraorbital arch is very narrow ; the bone next to the præorbital has at its inner side a broad plate, joining the entopterygoid and supporting the eyeball from beneath. The maxillary is moderately widened behind; the intermaxillaryhas a 
broad band of villiform teeth in front, and several larger ones in its external series; the villiform band is very narrow on the lateral parts of the bone. The villiform band of the mandibula is much narrower; but there is an extcrnal series of teeth, rather larger and more numerous than in the upper jaw. There is a very narrow transverse band of excecdingly fine teeth on the vomer. The pharyngeal bones are separated from each other, the upper as well as the lower ones; they are armed with villiform teeth.

'ithe opereulum is distinguished by a very long and strong spinous process, longer than its grcatest width; there is another small one above. Suboperculum narrow, with a small notch to receive a limb of the coraeoid; not serrated. Interoperculum shorter and broader, with the lower limb distinctly serrated. The axes of the two limbs of the præoperculum form a very obtuse angle; they are represented by a thick ridge, from which striæ radiate, terminating in strong spines; there are about fifteen spines round the edges of the bone, two of which (at the angle) are strongest; those of the lower limb are very feeble. 'The suprascapula and the eoracoid are distinctly denticulated, and the latter exhibits flat strix besides. The pubic bones are shaped as in the Percina; namely, each is formed by three plates, the internal thinnest, broadest, and closcly joined to that of the other side. The two other plates, situated in one plane vertical to the third, are low.

There are ten abdominal and fifteen eaudal vertebræ. The fourth has a broad process, to which the air-bladder is fixed. The second rib is remarkably broad in its upper half. The first interhæmal is of moderate strength, equal to the length of the second vertebra to the serenth, and is fixed to the hremals of the eleventh and twelftin.

\section{Therapon trivittatus.}

Russell, ii. pl. 126.

Coius trivittatus, Buch. Ham. pp. 92, 370.

Therapon puta, Cuv.\& Val, iii. p. 13I ; Bleck. Perc. p. 50 ; Cur. Rdgne Anim. Ill. Poiss. pl. 12. f. 2.

- trivittatus, Cant. Catal. p. 19.

D. $\frac{12}{10}$. A. $\frac{3}{9}$. L. lat. 90-100. Cæc. pylor. 7. Vert. 10/15.

The height of the body is $3 \frac{3}{4}-4 \frac{1}{4}$ in the total length, the length of the head $4 \frac{1}{4}$. The snont is $1 \frac{1}{3}$ the interspace between the eyes. Præoperculum serrated, with very long spinous teeth at the angle; operculum witl two spines, the lower of which is elongate and strong. Greenish grey, with three straight brown longitudinal bands, the inferior of which extends from the eye to the tail; the spinous portion of the dorsal fin blackish between the third and eighth spincs; two blackish bands obliquely erossing each lobe of the caudal.

Indian Seas.

a. Arult: skeleton. India. From Mr. Frank's Collection.

b. Adult. C'eylon. From Mr. Cuming's Collection. 
c. Young. Singapore.

d. Adult. Moluccas.

e. Adult. Purchased of M. Parzudaki.

$f$. Air-bladder of specimen $a$.

Skeleton.-The general structure being the same as in Th. servus, I only give descriptions of those parts which show the specific difference. The breadth of the frontal bones between the eyes is narrower; these bones do not taper in front, but show a sinuous lateral margin from the angle of the orbit. The teeth in the external series of the intermaxillary are scarcely larger than those of the villiform band behind, and very numerous; the lower jaw has no larger teeth whatever. Vomer edentulous. Suboperculum without notch, interoperculum not denticulated. The angle of the præopcrculum is still more obtuse; the axis of the lower limb is prolonged into a long spine, not much smaller than that of the oporculum; there are two smaller spines above this long one, dirccted upwards, and two below, directed backwards; all the lower limb is finely serrated. The fourth vertebra shows the same peculiarity as in the preceding species; but not the second rib, which is like the succeeding ones.

\section{Therapon ghebul.}

Therapon ghebul, (Ehrenberg) Cuv. \& Val. iii. p. 133; Bleeker, Perc. p. 51 .

$$
\text { D. } \frac{12}{10} \text {. A. } \frac{3}{10(\text { Cuv. } 9)} \text {. L. lat. 90-100. }
$$

The height of the body is equal to the length of the head and $4 \frac{1}{4}-4 \frac{1}{3}$ in the total. Snout as in Th. trivittatus. Præoperculum serrated, with long spinous teeth at the angle; operculum with two spines, the upper of which is short, the lower moderately long. Greenish, with four straight brown longitudinal bands, the third of which extends from the muzzle to the tail; the spinous portion of the dorsal fin blackish between the third and eighth spines; two blackish cross-bands obliquely crossing each lobe of the caudal.

Red Sea; Javanese Sea.

\section{Therapon oxyrhynchus.}

Temm. \& Schleg. Faun. Japon. p. 16. pl. 6. f. 3; Ruchards. Ichthyol. China, p. 239; Bleek. Verhand. Batav. Genootsch. xxvi. p. 64.
D $\frac{12}{10}$.
A. $\frac{3}{8}$.
L. lat. 55-60.
L. transv. 15/25. Vert. 10/15.

The height of the body is equal to the length of the head (opercular spine included) and $3 \frac{1}{2}$ in the total; the snout is nearly twice as long as the interspace between the eyes is broad. Præoperculum rounded, with long spinous teeth behind, longest at the angle, smallest at the.lower margin. Operculum with two spines, the lower of which is elongate. Greenish grey, with four brown longitudinal bands, the third running from the snout through the 
eye to the root of tail; the dorsal fin with two brown bands, ono along the base, the other along the upper margin of the spinous portion.

Japanese and Chinese Seas.

a. Skin, in spirits. Japan. From Mr. Frank's Collection.

b. Adult: stuffed. Japan.

c. Adult. China.

d. Adult. China.

e. Adult. India. From the Haslar Collection.

$f$. Adult (has becn dried). India. Presented by the Zoologieal Society.

g. Adult: skeleton: not good state. India. Prescnted by the Zoological Society.

Skeleton.-This species has the same dentition of the jaws as $T h$. trivittatus. The romer has a prominent transverse ridge, but I cannot find any teeth. The angle of the pricoperculuin is as obtuse as in Th. trivittatus, but the spinous teeth of the posterior limb and of the angle are more numerous and more equal; there are about nine above the longest at the angle, more or less directed upwards; then follow several smaller ones; and the greater part of the lower limb shows a fine serrature. The other parts of the skeleton are very much like Th. trivittatus.

\section{Therapon quadrilineatus.}

Iolocentrus quadrilineatus, Bloch, t. 238. f. 2.

Therapon quadrilineatus, Cuv. \&. Val. iii. p. 134; Bleeker, Perc. p. 51 ; Richards. Ichth. China, p. 239.

—_ xanthurus, Cuv. \& V Val. iii. p. 130.

$$
\text { D. } \frac{12}{(9) 10^{\circ}} \quad \Lambda . \frac{3}{10} \text {. L. lat. } 65 .
$$

The height of the body is equal to the length of the head, and one-fourth of the total. Snout as in Th. trivittatus. Præoperculum serrated, with stronger teeth at the angle; opereulum with two moderate spines, nearly equal in length. Dorsal fin not very deeply notehed. Candal truncated, with rounded angles. Greyish, with four straight, brown, longitudinal bands; the spinous portion of the dorsal fin black-edged, and with a blackish spot botween the third and serenth spines; caudal fin immaculate.

Javarıese and Chinese Seas.

\section{Therapon cuvieri.}

Pristipoma sexlineatum, Quoy \& Gaim. Voy. Frcyc. Poiss. p. 320.

Pelates sexlineatus, quadrilineatus, et quinquelineatus, Cuv.\& Val. iii. p. 14f.pl. 55; Less. Voy. Coq. Zool. ii. p. 223; Cuv. R̀gne Anim. Ill. Poiss. pl. 12. f. 1.

Therapon cuvieri, Bleck. Nat. Tydschr. Nederl. Indie, vi. p. 211.

D. $\frac{12}{10}$. A. $\frac{3}{10}$. I. lat. 66 . I. trans $8.12 / 23$. Cæc. pylor. 6 .

The height of the body is $3 \frac{1}{2}$ in the total length, the length of 
the head $4 \frac{1}{4}$; the diameter of the eye is nearly five times in the length of the head, and $1 \frac{3}{4}$ in that of the snout. Præoperculum finely and equally serrated throughout; opercular spines very feeble. No vomerine or palatine teeth. Dorsal scarcely notched, with slender spines; the fifth and sixth are longest, their length being $2 \frac{1}{2}$ in the depth of the body; the last two spines much longer than the first two; anal spines feeble. Caudal very slightly notched. Four, five, or six longitudinal bands; fins immaculate.

Coasts of Australia; Sea of Timor.

a. Half-grown: skin. N. S. Wales.

b. Half-grown: skin. Port Jackson. From Mr. Goull's Collection.

c. Adult. Sydney. From the Haslar Collection.

d. Adult. Sydney. From the Haslar Collection.

e. Adult: skin. Port Essington. From Mr. Macgillivray's Collection.

f. Adult. Australia. From the Haslar Collection.

g. Adult. Australia. From the Haslar Collection.

$h$. Adult. Australia. From Mr. Gould's Collection.

i. Adult: stuffed. Australia. From Mr. Warwick's Collection.

\section{Therapon argenteus.}

Datnia argentea, Cuv. \& V al. iii. 139. pl. 54; Bleeker, Perc. p. 52.

Mesopristes macracanthus, Bleeker, Topogr. Butav.

Datnia cancellatoides, Bleek. Sumatra, i. p. 5 (young with longitudinal bands).

Cuvier quotes tò this species Coius datnia, Ham. Buch. Gang. Fish. p. 88. pl. 9. f. 29, creating for this species the generic name of Datnia. By comparing Buchanan's figure of the fish, and still more his description, one may easily sce that this is quite a different fish. Hamilton's figure has thirty-three scales in the lateral line ; Cuvier's fish has nearly sixty. Ham. Buch. describes the posterior teeth as "blunt and crowded together; the palate is smooth, and has behind the teeth a short membranous veil; above each ventral fin is a lung scale-like appendant." Neither such_a membranous veil nor such an appendix is to be found in Cuvier's fish; and this species of Ham. Buch. is identical with Sparus hasta, Schneid., or Chrysophrys longispinis, Cuv. \& Val., Chrysophrys hasta, m.
B. 6 . D. $\frac{12}{10}$.
A. $\frac{3}{8}$.
L. lat. 56 .
L. transv. 25. Cæc. pylor. 11.

The height of the body is more than one-third of the total length, the length of the head nearly one-fourth; the diameter of the eyc is $3 \frac{1}{2}$ in the latter. The upper maxillary does not reach to the anterior margin of the eye; snout much longer than the diameter of the eye. Suprascapulary and coracoid serrated; operculum with two spines, the lower of which is the longer. The fourth and fifth dorsal spines longest, longer than half the height of the body; the second anal spine still stronger and longer. Caudal slightly notched. Seales 
very fincly serrated. Silvery, darker on the back; the spinous dorsal with a narrow black edge; the soft anal with a blackish blotch.

Capo Sca; Indian Ocean; Molucca Sea.

a. Adult. Amboyna. From Mr. Frank's Collection.

b. Half-grown. Amboyna. From Mr. Frank's Collection.

c. Adult. India.

$d$ Adult: stuffed: not good state. Cape Seas.

\section{Therapon caudovittatus.}

Datnia caudavittata, Richards. Voy. of the Erebus and Terror, Fishes, p. 24. pl. 18. f. 3-5.
D. $\frac{13}{9}$.
A. $\frac{3}{8}$.
L. lat. 46.

Snout rather longer than the diameter of the eye; præoperculum rounded, finely and equally denticulated. Opercular spines flat and rather short. Dorsal scarcely notehed: the last spines as long as the first rays; the fourth, fifth and sixth dorsal spines lnngest, half as high as the body, slender; the second anal spine rather stronger than the third. Spotted with greyish brown: each lobe of the caudal with one broad deep-black band.

Rivers of Australia.

a. Adult. Antarctic Expedition. Presented by the Lords of the Admiralty.

$b, c . \cdot F i n e$ specimens : stuffed. Victoria. Voyage of H.M.S. Herald.

d, e. Adult: stuffed. Cape York. Voyage of the Rattlesnake.

$f-h$. Adult: skins: not good state. Harvey River (fresh watcr), Western Australia.

h. Adult: not good state. From the Haslar Collection.

The contraction of the air-bladder in this species is as conspicuous as in any other Therapon; it has been overlooked by SirJ.Richardson, who describes the air-bladder as undivided, and separates $T h$. cuuclovittatus from this genus.

\section{HELOTES.}

Helotes, Cuv. Regne Anim; Cuv. \& Val. iii. p. 149.

Six branchiostegals. Eye of moderate size. Cleft of the mouth rather small; jaws nearly equal. 'Teeth: none on tho vomer or the palatine benes; those of the outer rows with a small lobe on each side. Operculum with feeble spines; preopereulum dentieulated. Dorsal not deeply notched, with twelve spines, anal with three. Scales small, ctenoid. $\Lambda$ ir-bladder separater by a contraction into an anterior and posterior portion. Caea pylorica iи moderate mumber.

From the Molucea Sen to Australia. 


\section{Helotes sexlineatus.}

Therapon sexlineatus, Quoy \& Gaim. Voy. Freyc. Poiss. pl. 60. f. 1.

Helotes sexlineatus, Cuv. \& Val. iii. p. 149. pl. 56 ; Bleek. Natuurk. Tydschr. Nederl. Ind. 1851, p. 171; Cuv. Regne Anim. Ill. Poiss. pl. 12 . f. 3 .
D. $\frac{12}{10}$. A. $\frac{3}{10}$.
L. lat. 110.
L. transv. 35.
Cæe. pylor. 15.

\section{Vert. 10/15.}

The height of the body equals the length of the head, and is $4 \frac{1}{2}$ in the total. Teeth with distinct lobes. Opereulum with two short spines, the lower of which is somewhat prominent; præoperculum rounded, denticulated. The fifth and sixth dorsal spines longest. Six blackishbrown longitudinal bands on each side.

Australian Coasts.

\section{Helotes octolineatus.}

Jenyns, Zool. Beagle, Fishes, p. 18.

$$
\text { D. } \frac{12}{9} \text { A. A. } \frac{3}{7} \text {. }
$$

The height of the body is nearly equal to the length of the head, and $4 \frac{1}{2}$ in the total. Jaws equal. Teeth distinctly three-pointed. Operculum with two spines, the lower of which is prominent. Eight blackish-brown longitudinal bands on each side. (Jen.)

King George's Sound (S. W. Coast of Australia).

\section{Helotes polytænia.}

Bleeker, Halmaheira, p. 53.
D. $\frac{12}{10}$.
A. $\frac{3}{10}$.
L. lat. 75.
L. $\operatorname{transv} \cdot \frac{14}{24}$.

The height of the body is four times in the total length, the length of the head $4 \frac{1}{2}$; the diameter of the eye is $3 \frac{1}{2} \cdot$ in the latter. Teeth with rather indistinct lateral lobes. Operculum with two flat, short spines; præoperculum rounded nearly throughout, denticulated. The fifth and sixth dorsal spines longest, half as high as the body, the two posterior ones much longer than the two anterior. A black blotch above the lateral line near the nape; (ton or twelve) brown longitudinal bands on the sides.

Sea of Halmaheira.

a. Adult.-It is not without doubt that I refor this specimen to the above species, as it has six longitudinal bands only, and a black blotch on the dorsal. In other points it agrees with Bleeker's description.

\section{MACQUARIA.}

Macquaria, Cuv. \& Val. v. p. 377.

Form of the body oblong, compressed; eye moderate; cleft of the mouth nearly horizontal, with the jaws equal. One dorsal, with 
eleven spines, anal fin with three; all the spines strong. No teeth in the jaws or on the palate. Branchiostegals five. Both limbs of the prapereulum serrated; opereulum with two points. Seales moderate, etenoid. Lir-bladder simple; pyloric appendages in moderate number.

Freshwater fish from Australia.

\section{Macquaria australasica.}

Cuv. \& Val. l.c. pl. 131 ; Less. Voy. Coq. Zool. ii. p. 194. pl. 14. f. 1. D. $\frac{11}{11}$. A. $\frac{3}{8}$. L. lat. 65-66. Coce. pylor. 8.

Externally very similar to Dules ambiguus. Snout scaleless. The fourth and fifth dorsal spines longest; the second of the anal fin mueh longer and stronger than the third. Uniform brownish.

Macquarie River.

\section{PRISTIPOMA*.}

Pristipoma, Cuv. Règne Anim.; Cuv. \&. Vul. v. p. 243.

Form of the body obloug, compressed. Eye moderate. Cleft of the mouth horizontal, not rery wide, with the jaws nearly equal; a central groove below the ehint. One dorsal, with eleven to fourteen spines, the anal with three; rertical fins not sealy, or with scales on the basal portions only. Villiform teeth in both the jaws, without canines; none on the palate. Brinchiostegals seven. Preopereulum serrated; opereulum with very indistinet points. Seales moderate, ctenoid. I'seudobranchix. Air-bladder simple; pyloric appendages in small number.

All the Tropical Seas, extending into the Japanese Seas and the Mediterranean.

\section{Pristipoma cavifrons.}

? Intjanus luteus, $B l$. taf. 247 .

? Grammistes hepatus, Bl. Schn. p. 187.

Diagramma cavifions, Cuv. \& Val. v. p. 290. pl. 123.
B. 7 .
1). $\frac{13}{13}$.
A. $\frac{3}{9}$.
L. lat. 50. Vert. 10/16.

The height of the body is one-third of the total length, the length of the head one-fourth. Snout short, eleft of the mouth small. The upper margin of the orbits is elevated, and renders the space between concave. Proopereulum serrated throughout. Dorsal fin notehed,

* 1. Pristipoma rangii, Cuv. \& Val. ix. p. 484.-Cape Verde.

2. - jubelini, Cuv. \& V al. v. p. 250.-Cape Verde; Scnegal.

3. Russell, pl. 132.-Pristipoma guoraka, Cuv. \& Val. v. p. 256, cop. in Bélang. Voy. p. 363 ; Cant. Catal. p. 73.

4. Pristipoma? chloronotum, Richards. Ichth. China, p. 228.-Canton.

5. - ? gallinaecum, Richards. Ichth. Chine, p. 22:2.-Canton.

6. - ? grammopocilum, Richards. Ichth. China, p. 228.-Canton.

7. - loucurum, Cuv. \& Val. ix. p. 488.--Seychilles.

Cfr. Pristipoma cavifrons. 
with long and strong spines. Caudalis emarginate; the second anal spine very strong, and much longer than the third. Coloration uniform.

Atlantic coasts of Tropical America.

a. Adult: skin. +West Indies. Purchased of Mr. Scrivener.

This species is said to have no groove below the chin, and has been placed in Diagramma by Cuvier, but it is closely allied to the following species.

\section{Pristipoma serrula.}

Cuv. \& Val. จ. p. 272 ; Ramon de la Sagra, Hist. Cuba, Poiss. p. 70.

$$
\text { D. } \frac{12}{13} \text {. A. } \frac{3}{9} \text {. }
$$

The height of the body is one-third of the total length; the snout short, not longer than the width of the eye. Dorsal fin very deeply notched, with feeble spines; the second and third anal spines equal in length. Back with four or five yellow longitudinal lines. (Cuv.)

Martinique.

Pristipoma auratum, Cuv. \& Val. l.c., with uniform coloration, may be only a variety of the above species.

\section{Pristipoma melanopterum.}

Pristipoma melanopterum, Cuv. \& Val. v. p. 273.

? Pristipoma bilineatum, Cuv. \& Val. v. p. 271. pl. 122.
D. $\frac{12}{17-18(15)}$.
A. $\frac{3}{8-9}$.
L. lat. 50 .
L. transv. 9/14.

The height of the body is $2 \frac{2}{3}$ in the total length, the length of the head $3 \frac{2}{3}$. The snout is obtuse, rather shorter than the diameter of the eye, which is one-third of the length of the head. The cleft of the mouth is narrow, the upper maxillary reaching to the vertical from the front margin of the eye. Præoperculum with the posterior limb very slightly emarginate, and with rather "stronger denticulations at the angle. The dorsal fin deeply notched, with strong spines; the third longest, one-half the length of the head. Caudalis emarginate; the second anal spine exceedingly strong, and much longer than the third of the dorsal fin. Vertical fins scaly on one-half their height. On each side two parallel brown bands, one above the lateral line, the other from the eye to a round spot at the root of the caudal; the fins blackish. Coloration in old age uniform, with blackish fins.

Coasts of Tropical America.

a. Fine specimen. Rio Janeiro. Presented by A. Fry, Esq.

b. Adult: skin. Jamaica. From Dr. Parnell's Collection.

I should without any hesitation consider $P$. bilineatum as the younger state of $P$. melanopterum, if Cuvier had not stated fifteen soft rays in the dorsal fin of the former. On the other hand, specimen $a$, which is not full-grown, has seventeen rays, and the exact coloration given by Cuvier of $P$. bilineatum. 
Likewise Pristipoma bicolor (Castelnan, Anim. nour, ou rares, Amér. Sud, p. 8. pl. 2. f. 2) may prove to be a valiety only of the abovo species, or tho type of the species itself, but with the coloration made from life.

\section{Pristipoma virginicum. =}

Margrace, p. 152 (Acara pinima), and p. 148 (Guatucupa juba). Sparus virginicus, Lim, \{Gmel. p. $1278 ;$ Bl. Schn. p. 274.

vittatus, $13 l$. taf. 263 . f. 2 (not taf. 275).

Ferea juba, $13 l$. taf. 308. i. 2 (very bad).

Grammistes mauritii, Bl. Schn. p. 185.

- juba, Bl. schn. p. 181.

Lutjanus vircinicus, Lacép. iv. pp. 197, 199.

Sparus jub, Lacép. iv. pp. 43, 138.

Pristiponia rodo, Cur. \& Val, v. p. 274.
D. $\frac{12}{15-17}$.
A. $\frac{3}{10}$.
L. lat. 56 .
L. transv. $14 / 16$.

The profile of the head and nape very steep. The height of the body is $2 \frac{1}{2}$ in the total length, the length of the head four times. The cleft of the mouth is small, the upper maxillary not extending to the anterior margin of the orbit. The portions of the dorsal fin scarcely separated by a slight noteh; the spines stout, the longest shorter than the second of the anal, which is onc-hall the length of the head. Caudalis deeply notched. An oblique brown band from the nape through the eye to the angle of the mouth; another, more vertical, from the origin of the dorsal to the root of the pectoral; behind this cross-hand six parallel bluish longitudinal bands.

Atlantic coasts of 'Tropical America.

a, b. $13^{\prime \prime}$ long: skins. Jamaica. From Dr. Parnell's Collection. c. Adult: skin. Jamaica. From Dr. Parnell's Collection.

d. Adult. S. America. Presented by Sir R. Schomburgk.

e. Half-grown. From the Collection of the Zoological Society.

$f, g$. Half-grown. From the Collection of the Zoological Society.

h. Adult. From the Haslar Collection.

$i$. Half-grown. From the Haslar Collection.

$k, l$. $\Lambda$ dult: stufferl.

$m, n$. Adult: stuffed. Old Collection.

\section{Pristipoma surinamense.}

Lutjanus surinamensis, Bloch, taf. 258.

IIolocentrus gihbosus, Lacím. iv. pp. 344, 391.

l'ristipoma surinamense, C'u. \& V Itl. v. p. 273.

$$
\text { D) } \frac{14}{16}, \quad \text { A. } \frac{3}{7} \text {. }
$$

The height of the body is one-third of the total length. The snout is short, not longer thin the width of the eye. Dorsal fin notehed; the fourth spine longest; the second anal spine strong. Caudalis somewhat rounded. Body with irregular blackish erossbars.

\section{Surinaun.}




\section{Pristipoma nigrum.}

Pristipoma nigrum, (Mertens) Cuv. \&. Val.v. p. 258; Cant. Catal. p. 74.
B. 7 .
D. $\frac{14}{16}$.
A. $\frac{3}{7}$.

The height of the body is three times, in the total length, tho length of the head $3 \frac{3}{4}$; eye one-third of the latter. Blackish brown. Sea of Pinang; Manilla.

\section{Pristipoma hasta.}

Lutjanus hasta, Bloch, taf. 246. f. 1 ; Bl.Schn.p.324; Lacép.iv. p. 229. Labrus commersoni, Lacép. iii. pp. 431, 477. pl. 23. f. 1; Shaw, Zool. iv. p. 493.

Lutjanus microstoma, Lacép. iii. pl. 34. f. 2, iv. pp. 181, 216.

Pristipoma kakaan, Cuv. \& Val.v. p. 244; Rüpp. N.IV. Fische, p. 123. t. 20. f. 1; Richardson, Ichth. China, p. 227; Bleek. Verh. Bat. Genootsch. xxii. p. 3.

- commersonii, Cuv. \& Val. v. p. 252 ; Cant. Catal. p. 72.

— hasta, Cuv. \& Val. v. p. 247, cop. in Bélanger, Voy. Ind: Orient. p. 362 ; Bleek. l. c. xxiii. Scian. p. 20.

chrysobalion, (Kuhl \& v. Hasselt) Cuv. \& Val. v. p. 248.

D. $11 \mid \frac{1}{14}$. A. $\frac{3}{7-8}$. I. lat. 47. L. transv. 6/10. Cæc. pylor. 6 .

The height of the body is 3 to $3 \frac{1}{2}$ in the total; the length of the head is sometimes equal to that height, sometimes less; the snout is a little longer than the width of the eye, the diameter of which is $4 \frac{1}{3}$ in the length of the hear. Jaws equal; the upper maxillary reaches to the level of the anterior margin of the orbit. The posterior limb of the præoperculum emarginate, its angle rounded, produced and denticulated. The fourth dorsal spine longest, longer than half the length of the head; the dorsal fins separated by a more or less deep notch. Caudalis truncated; the second anal spine very strong, but shorter than the longest of the dorsal fin*; pectoral pointed, elongate, its length being $3 \frac{1}{2}$ in the total. Back and upper part of the sides with brown spots, more or less regularly arranged, sometimes forming longitudinal series, sometimes cross-bars; both the dorsal fins with two or three series of round brown spots.

From the Red Sea along the east coast of Africa through all the Indian Seas to the northern shores of Australia.

a. Adult: stuffed. Red Sea. From the Frankfort Museum.

b. Adult. India. Purchased of Mrr. Frank.

c. Adult: skin. India. Presented by B. H. Hodgson, Esq.

d. Half-grown : not good state. India. From the Haslar Collection.

e. Adult. China.

$f$. Adult. China.

g. Adult: not good state. China.

h. Adult: stuffed. China. Presented by J. R. Reeves, Esq.

i. Half-grown. China. Presented by J. R. Reeves, Esq.

$k$. Half-grown. China.

* In young specimens the anal spine is as long as the fourth of the dorsal fin. 
1. Half-grown. China.

$m, n$. Young. China.

o. Half-grown. I'hilippine Islands.

$p$. Half-grown. Moluecas.

q. Half-grown. Moluecas. Purchased of Mr. Frank.

$r$. Half-grown. Amboyna. Purchased of Mr. Frank.

s. Half-grown. Ceram. Purchased of Mr. Frank.

t. Half-grown. Sumatra. Purchased of Mr. Frank.

u. 20"long: stuffed. Cape York (69 fathoms). Voyage of the Rattlesnake.

v. Half-grown: bad state. North Australia. Presented br Dr. J. R. Elsey.

\section{Pristipoma nageb.}

Rüppell, N. W. Fische, p. 124. taf. 30. f. 2; ? Richardson, Ichth. China, p. 227 ; Bleek. l.c. xxiii. Scian. p. 21.

$$
\text { D. } 11 \mid \frac{1}{14} \text {. A. } \frac{3}{8} \text {. (L. lat. } 40, \text { Bleek.) }
$$

The height of the body is nearly equal to the length of the head, and $3 \frac{1}{3}$ in the total. The snout is elongate, compressed; præoperculum slightly emarginate; dorsal fin deeply notehed, with the spines of moderate strength, the fourth the longest. Caudalis truneated; the second anal spine longer and stronger than the third, but shorter than the highest of the dorsal. Silvery, with eight vertical bands, each formed by one or two scries of blackish spots. Dorsalis with brownish spots.

Red Sea; Sunda Sea.

\section{Pristipoma punctulatum.}

Rïpp. N. W. Fische, p. 121. taf. 30. f. 3.

$$
\text { D. } \frac{12}{15} \text {. A. } \frac{3}{8} \text {. }
$$

The height of the body is $2 \frac{3}{4}$ in the total length, the length of the head nearly four times. The snout and the eleft of the mouth are short; præopereulum slightly emarginate posteriorly. The dorsal and anal fins are low; the former is slightly notched, and has the third spine longest, which is one-third only of the height of the body; the second anal spine is still shorter, but very strong; the third mueh shorter and thinner. Caudalis truncated; peetoral elongate, $3 \frac{1}{3}$ in the total length. Back and sides with blackish dots, forming undulating longitudinal lines; dorsal fin with longitudinal series of blackish spots.

Red Sea.

a. Fourteen inches long: stuffed. Isle de France. From Dr. Janvier's Collection.-This speeimen agrees very well with the above description, taken from fishes of the Red Sea; but the second anal spine is rather longer than the third of the dorsal, and exceedingly strong. There are forty-eight transverse rows of scales, cight longitudinal ones above the lateral line, and sixteen below. 


\section{Pristipona dussumieri.}

C'ur. \&. Vul. v. p. 259.
D. $\frac{12}{14}$.
A. $\frac{3}{7}$.
L. lat. 46.
I. transv. 6/12.

The height of the body is nearly equal to the length of the head, and $3 \frac{1}{3}$ in the total. The snout is scarcely longer than the diameter of the eye, which is nearly one-fourth of the length of the head. The eleft of the mouth is rather narrow, the upper maxillary searcely reaching to the vertical from the front margin of the orbit. Præoperculum with the posterior limb slightly emarginate, and with the angle not projecting. The dorsal fin notched, with strong spines; the fourth the longest, $2 \frac{1}{4}$ in the length of the head. Caudalis truncated. The second anal spine is exceedingly strong, mueh longer than the third, and at least as long as the longest of the dorsal. The length of the peetoral is one-fourth of the total.

Coast of Coromandel.

a. Adult: bleached. Old Collection, as Perca corvina.

b. Adult: bleached. Old Collection, as Perca corvina.

c. Adult: stuffed: not good state.

\section{Pristipoma argenteum.}

Sciæua argentea, Forsk. p. 51 (not Gmelin).

Pomadasis argenteus, Lacép. iv. p. 516.

Pristiponia argenteun, Cur. \&. Val. v. p. $249 ;$ Rüpp. N. W. Fische, p. 123.
D. $\frac{12-13}{13-15}$.
A. $\frac{3}{7-9}$.
L. lat. 56 .
L. transv. $8 / 15$.

The height of the body is $3 \frac{1}{3}$ in the total length, the length of the head $3 \frac{1}{2}$; the diameter of the eye is $1 \frac{2}{3}$ in the length of the snout, and $4 \frac{1}{2}$ in that of the head. The snout is elongate, the eleft of the mouth rather small, the upper maxillary not extending to the front margin of the orbit. The præoperculum slightly sinuous behind. The dorsal fin deeply notched, with spines of moderate strength; the fourth longest, $2 \frac{1}{2}$ in the length of the head. Caudalis with rather elongate lobes, but nearly truncated when stretched ont. The second anal spine not much stronger and scareely longer than the third, shorter than the highest of the dorsal fin. Pectoral nearly one-fourth of the total length. Silvery, the upper two-thirds with brownish dots. Dorsal.fin with a series of brownish spots along its base.

Red Sea.

a. Adult. From the Haslar Collection.

b. Adult: not good state. Coast of Africa. From the Haslar Collection.

c. Young.

$d, e$. Young: stuffed: bad state.

The specimens in the British Museum Collection are of unknown o 2 
origin, and I doubt whether they came from the Red Sea; but they agree very well with $P$. argenteum, as far as the characters are given in the deseriptions quoted.

\section{Pristipoma argyreum.}

Pristipoma argyreum, Bleek. Verh. Bat. Gen. xxiii. Scian. p. 22. ? Pristipoma argyreum, Cuv. \& I $a$ al. ix. p. 485.
D. $\frac{12-13}{13}$.
A. $\frac{3}{7}$.
L. lat. 40.

The height of the body is $3 \frac{1}{3}$ to $3 \frac{1}{2}$ in the total length, and equal to the length of the head. The snout is much shorter than the eye, which is one-third of the length of the eye. Prropereulum slightly emarginate behind, with fine denticulations. The third and fourth dorsal spines longest, one-half of the height of the body. Caudalis truneated; the sceond anal spine one-seventh of the total length. Uniform silvery; opereulum with an olive spot.

Coast of Coromandel; Sumatra; Batavia.

\section{Pristipoma pihloo.}

Richardson, Ichth. China, p. 227.

$$
\text { D. } \frac{11}{14} \text {. A. } \frac{3}{8} \text {. }
$$

Proopereulum with the posterior edge emarginate. The second anal spine longer and stronger than the third. A row of seven roundish dark spots or short transverse bars along the back above the lateral line. (Richardson.)

Canton.

The speeimen on which this species was founded by Sir John Riehardson appears to have been mislaid.

\section{Pristipoma paikeeli.}

l'aikeeli, Russell, pl. 121.

Pristipoma paikeeli, C'uv. \& Val. v. p. 259; Cant. Catal. p. 74; Blcek. Verh. Bat. Gen. xxiii. Scicen. p. 20.

$$
\text { B. 7. D. } \frac{12}{15} \text {. A. } \frac{3}{9} \text {. L. lat. 55-60. }
$$

The height of the boay is three times in the total length, the length of the head $3 \frac{1}{2}$. Caudalis emarginate. Silvery brownish white; on the back and sides as far as the peetoral fin, six brown parallel longitudinal bands edged with black; all the fins, except the pectoral, minutely dotted with brown; the spinous dorsal blackedged; the upper half of the soft dorsal and the posterior margin of the eaudal blackish. Membrane of the soft dorsal, of the eaudal, anal, and ventral fins partially-covered with minute scales.

Madras; Vizagaputam: Sea of Pinang. 


\section{Pristipoma maculatum.}

Anthias maculatus, $B l$. tab. 326، f. 2; Bl. Schn. p. 306.

Lutjanus maculatus, Lacép. iv. p. 239.

Caripe, Russell, pl. 124.

Pristipoma caripa, Cuv.\& Val. v. p. 261 ; Cant. Catal. p. $75 ;$ Rüpp. N. W. Fische, p. $124 ;$ Bleek. l. c. p. 21.

$$
\text { D. } 11 \mid \frac{1}{13-14} \text {. A. } \frac{3}{7} \text {. L. lat. } 47 \text {. }
$$

The height of the body is $3 \frac{1}{4}$ in the total length, the length of the head $3 \frac{1}{2}$; the snout is not longer than the diameter of the eye, and $3 \frac{2}{3}$ in the length of the head. The jaws are equal in front; the upper maxillary reaches to the vertical from the anterior margin of the eye. The posterior limb of the præoperculum is conspicuously emarginate, and finely denticulated like the angle. The dorsal fin is deeply notched; the spines are strong; the fourth is the longest, half the length of the head. Caudalis slightly emarginate; the second anal spine, stronger and longer than the third, is not quite so long as the longest of the dorsal. Pectoral elongate, one-fourth of the total length. A black cross-band before the dorsal fin; six large blotches on each side of the back, either forming two longitudinal rows or three cross-bands. The spinous dorsal blackish, with a series of whitish spots along the base; the soft dorsal with two series of brown spots.

From the coast of Coromandel to New Guinea; Red Sea.

a. Half-grown: stuffed. Torres Strait. Voyage of the Rattlesnake.

b. Half-grown. Amboyna. Purchased of Mr. Frank.

\section{Pristipoma auritum.}

Cuv. \& Val. v. p. 263; Cant. Catal. p. 76.
B. 7 .
D. $\frac{12(11)}{14}$.
A. $\frac{3}{7-8}$.

The length of the opercle little less than one-half of that of the head; it projects backwards above the anterior half of the pectoral. Mouth small. The fourth dorsal spine longest, and equal to the second of the anal. Caudal fin covered almost throughout with minute rough scales; the membrane of the ventrals scaly. The spinous dorsal with numerous brownish spots, forming three to six oblique series; the upper margin black. 'The soft dorsal with some smaller rounded spots.

Siam ; Sea of Pinang.

\section{Pristipoma therapon.}

Bleeker, Jaca, i. p. 100, and Verh. Bat. Gen. xxiii. Scian. p. 22.

$$
\text { D. } \frac{12}{14} \text {. A. } \frac{3}{7} \text {. L. lat. } 40 \text {. }
$$

The height of the body is $3 \frac{1}{2}$ in the total length; the diameter of 
the eye is one-third of the length of the head, the snout rather shorter. Præoperculum with the posterior limb very slightly emarginate. 'The fourth spine of the dorsal longest, $1 \frac{1}{2}$ in the height of the body; the seeond of the anal one-sixth of the total length. Uniform; a large brown blotch on the anterior part of the dorsal fin. $(B l$.

Sea of Batavia.

18. Pristipoma terribile. (P'LATK XIV.)

D. $12 \mid \frac{1}{12}$. A. $\frac{3}{7}$. I. lat. 46 . I. transv. $8 / 19$.

'The height of the body is three times in the total length, the length of the head $3 \frac{1}{2}$; the snout is rather pointed and longer than the diameter of the eye, which is $3 \frac{3}{4}$ in the length of the head. The upper jaw is rather longer than the lower; the maxillary extends nearly to the vertical from the anterior margin of the orbit. The posterior limb of the preoperculum is emarginate and serrated, and the angle produced backwards, rounded, and armed with stronger spinons teeth. Dorsal fin deeply notehed; all the spines very strong and long: the fourth of the dorsal is the longest, and more than onehalf of the length of the head. Caudalis truncated; the second anal spine exceedingly long, five-sixths of the length of the head; the length of the pectoral is one-fifth of the total. Coloration uniform; the first dorsal with a black edge.

«. Sine patria.

Deseription of the specimen.-This species is intermediate between $P$. hasta and $P$. crocro. It resembles $T$ herapon argenteus in general habit and in the strength of its spines, which are relatively stronger than in any other species of Pristipoma. The body is rather compressed and elevated, its greatest depth, below the fourth dorsal spine, being one-third of the total length. The upper profile descends abruptly from its highest point to the nape, where it is slightly concave; from thence to the snout it is straight. The upper surface is moderately broad, the distance between the eyes being less than the width of the orbit. The snout is rather pointer, with the upper jaw slightly overlapping the lower. The teeth form villiform bands without canines or other larger teeth. On the chin there is the usual central groove and some indistinet lateral pores. The praoperculum approaches in form that of $P$. hasta, being conspicuously emarginate, with the angle produced backwards, and armed with much stronger spinous teeth than those of the posterior limb. The scales extend to the margin of the bone, and are smaller than those of the opereulum. The opereulum has a noteh behind, between two feeble and obtuse points. The suprascapula is serrated.

The origin of the dorsal fin fills in front of the vertical from the base of the pectoral, and its end before that of the anal; the base of the spinous portion is more than twice as long as that of the soft. 'The syanes are exceclingly strong, on one side broarlir tham on the of here: 
the first is small; the second one-half the length of the third; the third three-fourths of the fourth, which is the longest, half as high as the body. The following decrease in length to the twelfth; the thirteenth, which must be considered as part of the soft portion, is longer than the two preceding spines, and equal to the tenth. The soft portion has a rounded margin, the second, third and fourth rays being the longest, and equal in height to the sixth spine; they are twice as long as the last, which is the shortest. The spinous portion, as well as the soft, can be received into a scaly sheath. The caudal fin is truncated, and scaly at the base only: one of its longest rays is one-fifth of the total length. The distance between the eaudal and anal fins equals the base of the latter; the origin and end of the anal fin fall vertically behind the origin and the end of the soft dorsal. The first spine is one-half the length of the third, and is excavated posteriorly. The second is exceedingly long, equal to the height of the body above it, and broader on the left side than on the right. The third is broader on the right side, two-thirds of the length of the former, and shorter than the first ray. The margin of the soft portion of the anal fin is very slightly' emarginate. The pectoral fin is rather pointed, and of moderate length, one-fifth of the total. The root of the ventral fin is situated immediately behind that of the pectoral ; the first ray is one-third longer than the strong adjacent spine, and produced into a short filament which extends to the vent.

The scales are of moderate size, slightly crenated, quadrangular, rather longer than high; one of the largest covers about one-fifth of the eye. The lateral line is curved, and parallel to the profile of the back.

The specimen is now uniform silvery, with the spinons dorsal black-edged; this part of the fin appears to have been blackish.

A supposition as to the origin of the specimon cannot be given with any certainty, on account of its affinity to neotropical species, as well as to palæotropical; but there is more probability of its being found in a part of the East Indian Seas, or of the Pacific.

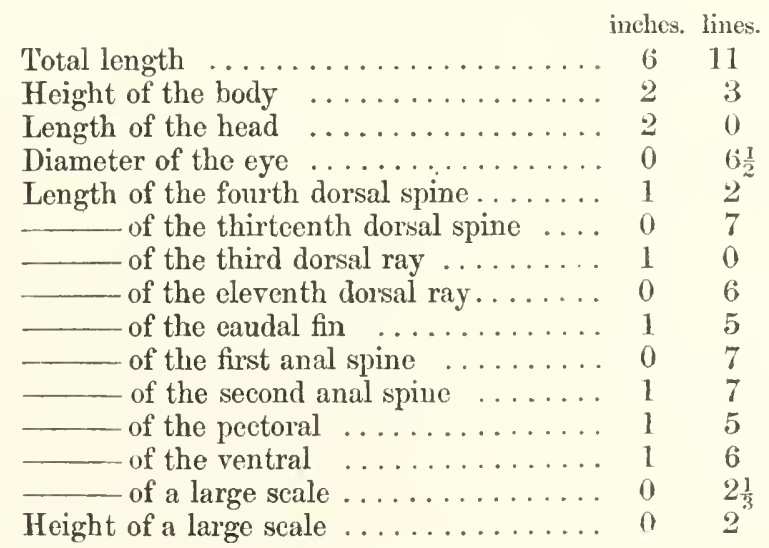




\section{Pristipoma crocro.}

Cur. \& Val. v. p. 264.
D. $12 \mid \frac{1}{11}$.
A. $\frac{3}{7}$.
L. lat. 50-56.
L. $\operatorname{transv} \cdot \frac{8}{19}$.
Vert. 11/15.

The height of the body is four times in the total length, the length of the head $3 \frac{3}{4}$. 'The snont is elongate and rather pointed; the diameter of the eye is $4 \frac{1}{2}$ in the length of the head, and $1 \frac{1}{2}$ in that of the snout. The upper jaw is rather longer than the lower; the maxillary extends to the vertical from the anterior margin of the orbit. The posterior limb of the propoperculum rery slightly emarginate, serrated, the angle not prominent, romded, and with stronger dentieulations. The dorsal fin deeply notehed, all the spines strong; the fifth dorsal spine longest, nearly one-half as long as the head. C'tudalis truneated; the second anal spine exceedingly strong, nearly two-thirds of the length of the head; pectoral rather short, one-sixth of the total. Coloration uniform; the first dorsal blackish, the pectoral yellowish, the other fins greyish.

Atlantic coasts of Tropical America.

a. Fine speeimen. S. Domingo. From Mr. Cuming's Collection.

b. 14" long: skin. Jamaica. From Dr. Parnell's Collection.

c. Adult: skin: Jametica. From Dr. Parnell's Collection.

d. Arlult.

e. Half-grown.

f. Half-grown: skeleton. Old Collection.

g. Fine specimen. From the Collection of the Zoological Society.It agrees with the other specimens in all the characters, except in having the dorsal spines, and especially the anal spine, shorter.

Sheleton.-The most superficial comparison of the skeleton of this fish with that of a species of Therapon (e.\%. Th. servus) shows the close affinity of those genera, and the crror of Cuvier, who united Pristipoma, \&c., with the Scionida. The upper surface of the skull is nearly even between the orbits, there being two pairs of foramina only, one close together in the middle of the frontal bones, the other more distant from each other, near the anterior extremity of those bones: these foramina lead into narrow muciferous channels in the interior of the bone. The oceipital crest is raised above the level of the skull, and moderately elevated; it extends as far as the occipital. On each sicle of this erest there is another, much lower, running to the point where the supraseapular bone is suspended. The turbinal bones are clongate, concare, forming a half-channel. The intermaxillary is stout and rather short, the upper posterior process being more than one-half of the length of the bone; the anterior portion of each process is broad, the posterior styliform; its posterior margin is S-shaped, without a prominent process. The maxillary is ruther narrow, with the posterior margin deeply notehed. The lower part of the mandibulary is transformed into a wide mucierous channel, with four grooves, separated from one another by narrow transverse ridges. The infraorbital ring is very narrow, except the 
praorbital: there is no interior plate to support the eyeball from beneath. The præorbital is triangular, with the lower side curred, and has three or four cavities or wide openings of its muciferous channel. The operculum is very irregularly shaped, and posteriorly armed with two points of nearly equal size, separated from each other by a dcep notch ; the lower is more acute: there is no ridge on the interior side of the bone. Sub- and interoperculum without any denticulation. The prooperculum is very strongly built and armed ; there are three strong but short spinous teeth at the angle, and fifteen smaller ones along the posterior margin; the upper of these teeth are directed upwards; the lower margin is slightly convex and entire. It has four wide openings of the muciferous channel; two larger ones on the lower limb, and two smaller oncs above the angle. The suprascapula is strongly, the coracoid bone not serrated.

The vomer is anteriorly broad, rounded, along its middle shightly concave, without any teeth. The teeth in the jaws are placed in broad villiform bands, the lateral ones being scarcely larger than the remainder. The pharyngeal teeth are short, cardiform.

There are eleven abdominal and fifteen caudal vertebræ; the length of the former portion of the column being to that of the caudal as $1: 1 \cdot 5$. There are several spurious interneural spines (interneurals without corresponding dorsal spine) in front of the dorsal fin, and each of these interneurals terminates above in a small hook, directed forwards, as is the case in many other fishes. The first interhæmal is very strong, with deep longitudinal grooves; its length equals that of the first eight vertebræ.

\section{Pristipoma coro.}

Seba, iii. 27. 14.

Coro-colo, Margr. p. 177.

Scitena coro, Bl. pl. 307 . f. 2 ; Bl. Schn. p. 81.

Pristipoma coro, Cuv. \& Val. v. p. 266 ; Cuv. Règne Anim. Ill. Poiss. pl. 30. f. 2.
D. $11 / \frac{1}{13}$.
A. $\frac{3}{7}$.
L. lat. 50 .
L. $\operatorname{transv} \cdot \frac{6}{12}$.

The height of the body is $3 \frac{1}{2}$ in the total length, the length of the head $3 \frac{2}{3}$; the diameter of the eye is one-fourth of the latter; the snout is rather longer, with the lower jaw longest, and with the eleft of the mouth moderate, the upper maxillary reaching somewhat beyond the vertical from the anterior margin of the eye. The posterior limb of the præoperculum obliquely descending backwards, with pointed, distant, spinous teeth; two strong spinous tceth at the angle. Dorsalis deeply notched, with rather strong and long spines; the fourth longest, rather more than one-half the length of the head. Candalis truncated; the second anal spine exceedingly strong, and even longer than the fourth of the dorsal. Body with about eight. brownish cross-bands.

Atlantic coasts of Tropical America.
$a, b$. Adult.
S. Domingo.
Purchased of Mr. Cuming. 


\section{Pristipoma catharinæ.}

Cur. \&.Val. v. p. 269 ; Less. Voy. Coq. Zool. ii. p. 201.

$$
\text { D. } 11 \mid \frac{1}{14^{\circ}} \text { A. A. } \frac{3}{10} \text {. }
$$

The height of the body is one-third of the total length. The mouth is small. Præoperculum with rather stronger denticulations at the angle. The dorsal fin notehed, with strong and long spines, the twelfth being longer than the two preeeding ones. Caudalis emarginate; the second anal spine strong, longer than the third, which equals in length the first ray. Ventral fins longer than peetorals, with a long spine. Coloration uniform; the fins brown, except the pectorals. (Cuv.)

Coast of Brazil.

\section{Pristipoma rogerii.}

Cur. \& Val. v. p. 254.

$$
\text { 3. 7. D. } \frac{12}{15} \text {. A. } \frac{3}{10} \text {. Cæc. pylor. } 5 .
$$

The præopereulum with the posterior margin vertical, and with the angle rounded; the fourth and fifth dorsal spines longest, onethird of the greatest depth of the body. The anal spines very strong; the third rather longer than the second, and nearly one-third the depth of the body. Uniform silvery; along the base of the spinous dorsal brown and white spots; on the soft portion brown spots only. (Cuv.)

Senegal.

A rather doubtful species, and perhaps identical with the following.

\section{Pristipoma bennettii.}

Pristipoma bennettii, Love, Trans. Zool. Soc. ii. p. 176; Valenc. in Burker-Webb, Hist. Nat. Iles Canar. Ichth. p. 26; Guichen. Poiss. in Explor. Algér. p. 44.

Pristipoma ronchus, Valenc. l.c. p. 25. pl. 7. f. 2 ; Guichen. l.c.
D. $\frac{12-13}{16}$.
A. $\frac{3}{11-12}$.
L. lat. 50-55.
L. $\operatorname{transv} \cdot \frac{8}{15}$. Caec. pylor. 8 .

$$
\text { Vert. } 10 / 16 \text {. }
$$

The height of the body nearly equals the length of the head, and is $3 \frac{2}{3}$ in the total ; the diameter of the eye is one-fourth of the latter, and $1 \frac{2}{5}$ in the length of the snout. The eleft of the mouth is moderate, the upper maxillary not reaching to the vertical from the front margin of the orbit. Prxopereulum with the posterior limb very slightly emarginate, and with rather coarser dentieulations at the angle. Dorsalis notched, and with the spines of moderate strength ; the fourth is the longest, and $2 \frac{1}{3}$ in the length of the head. Caudalis emarginate; the seeond anal spine stronger, but not longer than the third, and rather shorter than the highest of the dorsal; the length of the pectoral is $4 \frac{1}{3}$ in the total. Coloration uniform; sometimes a greenish-black spot above the angle of the opereulum.

Coast of Algiers; Canary Islands; St. Vincent's. 
a. Fine specimen. St. Vincent's. From Mr. Macgillivray's Collection.

$b-d$. Young. St. Vincent's. Voyage of H.M.S. Plumper.

e. Fine specimen. Madeira. From the Haslar Collection.

$f$. Adult. Madeira. Presented by the Rev. R. T. Lowe.

\%. Adult. From the Haslar Collection.

$h$. Adult : skeleton. From the Haslar Collection.

Skeleton.-The system of muciferous channels is rather more developed than in other species of Pristipoma: the two pairs of foramina on the frontal bones are wide, and lead into spacious channels; the turbinal bones are elongate, and transformed into half-canals. The occipital erest is elevated, triangular, and does not extend over the frontal bones. Of the two lateral crests, the interior is short, without free processes posteriorly, and the exterior is wide and muciferous, communicating with channels of the suprascapula and the preoperculum.

The maxillary is very irregularly formed, broadest near its base; it is joined by one process to the palatine bone, by a second to the intermaxillary, and by a third to the vomer. The posterior process of the intermaxillary is longer than the descending, toothed branch of the bone; the anterior portion of each process is broad, the posterior styliform; the descending branch is rather narrow, without any prominence. The lower part of the mandibulary is transformed into a wide muciferous channel, with four grooves, separated from one another by delicate transverse ridges. The præorbital is triangular, with the lower side curved, and has four or five wide openings. The remainder of the infraorbital ring is very narrow, muciferous, and without an interior plate to support the eyeball from beneath.

The opereulum has two obtuse and flat points posteriorly, with a deep groove between; there is no longitudinal ridge on its inner surface. The præoperculum is very strongly built; its serrature begins near the upper extremity, the teeth becoming gradually coarser at the angle, and disappearing at the lower limb. The posterior teeth are horizontally directed backwards. There are four wide openings, separated from one another by narrow ridges: two larger ones on the lower limb, one on the angle, and one on the posterior limb. The suprascapula is obtusely denticulated, the coracoid entire.

The lower part of the brain-capsule is slightly swollen, and there is an elongate opening before the oceipital joint. The anterior portion of the basisphenoid has a narrow sharp ridge above and below. The head of the vomer is broad, rounded, and slightly concave at its lower surface.

The teeth in the jaws form broad villiform bands, with an onter series of stronger ones. The pharyngeal teeth are stout, conical, and placed in elongate triangular patches below, and in rounded ones above.

There are ten abdominal and sixteen caudal vertebre, the length of the former portion of the vertebral column being to that of the latter as $1: 1 . \overline{5}$. There are three spurious intemneural spines in 
front of the dorsal fin, each terminating in a small hook, directed forwards. The first interhæmal is very strong, with two divergent anterior ridges, leaving a deep groove between them; it is attached to the eleventh vertebra, and its length equals that of the first seven vertebræ.

\section{Pristipoma conceptionis.}

Cur. \& Val. v. p. 268, ix. p. 486 ; Less. Voy. Coq. Zool. ii. p. 200; Gay, Hist. Chil. Zool. ii. p. 195, Atl. Ictiol. lam. 4. f. 2.

$$
\text { D. } \frac{13}{14} \text {. A. } \frac{3}{13} \text {. L. lat. } 60 \text {. }
$$

The length of the head is rather less than the height of the body, which is one-fourth of the total. Prxoperculum slightly serrated; dorsal and anal fins low; dorsal notehed; the spines feeble. Coloration uniform.

Coast of Chili.

\section{Pristipoma stridens.}

Sciæna stridens, Forsk. p. 50.

Pristipoma simmena, Cur. \&. Val. v. p. 260.

- stridens, Rïpp. N.W. Fische, p. 122. taf. 31. f. 1.
D. $11 \mid \frac{1}{13-15}$.
A. $\frac{3}{7-8}$.
L. lat. 62 .
Cæc. pylor. (5) 6 .

The height of the body is nearly equal to the length of the head, and somewhat less than one-fourth of the total. The snout is of moderate extent, longer than the diameter of the eye, which is onefourth of the length of the head. The upper jaw is rather longer than the lower; the maxillary extends nearly to the vertical from the anterior margin of the orbit. The posterior limb of the præopereulum very slightly emarginate, serrated ; the angle not prominent, rounded, and with rather stronger denticulations. The dorsal fin deeply notehed; the spines slender, but scarcely flexible; the fifth dorsal spine longest, one-half the length of the head. Caudalis emarginate; the seeond anal spine not strong, and shorter than the third. On each side two to six brownish-black longitudinal bands; if two, one from the eye to the root of the caudal, the other above the lateral line.

Red Sea.

a. Adult. Red Sea.

\section{Pristipoma lineatum.}

? Pristipoma rubrum, Cuv. \& Val. v. p. 283.

Pristipoma lineatum, Cuv. \& $\mathrm{Val}$. v. p. 287.
D. $\frac{12}{14}$.
A. $\frac{3}{10}$.
L. lat. 56.
L. $\operatorname{transv} \cdot \frac{8}{16}$.
Cæc. pylor, 5.

Vert. 11/15.

'The height of the body is $3 \frac{1}{4}$ in the total length, the length of the head $3 \frac{1}{3}$. The profile of the nape is convex, abruptly descending. The snout is high, and $1 \frac{1}{4}$ the width of the eye, the diameter of 
which is $4 \frac{1}{3}$ in the length of the hearl. The sleft of the mouth is moderate, the upper maxillary reaching exactly to the vertical from the anterior margin of the orbit. 'The posterior margin of the præopereulum is slightly oblique in a backward directiou, and finely dentienlated. The dorsal fin scarcely notehed; the spincs moderate: the fourth longest, and rather shorter than one-half the length of the head. Caudalis emarginate; the seeond anal spine is stronger than the third, but not longer, and seareely one-half the lengtl of the fourth dorsal spine. The pectoral fins rather longer than the ventrals. Indistinct oblique streaks above the lateral bine; a dark band on the upper half of the opereulum ; a whitish band along the base of the dorsal fin ; the soft portion with or without brownish spots.

Coast of Brazil.

a. Fine specimen. Rio Janeiro. Presented by A. Fry, Lisq.

\section{Pristipoma fasciatum.}

C'u. \&. Tal. v. p. 285, cop. by Dekay, New York Funna, Fishes, p. 87.

$$
\text { D. } \frac{12}{16} \text {. A. } \frac{3}{13} \text {. L. lat. } 75 \text {. Cxe. pylor. } 6 \text {. }
$$

The height of the body is nearly equal to the length of the head, and $3 \frac{1}{2}$ in the total. The snout is compressed, produced, with the jaws nearly equal, and with the cleft of the mouth rather small. The diameter of the eye is one-fifth of the length of the head, and less than one-half the extent of the snout. The dorsal fin is nearly even; all the spines ratler slender. Candalis emarginate; the third anal spine somewhat thimner and longer than the second. The sides of the body clouded with darker, in the form of more or less regular cross-bars; a dark streak on the upper half of the operenlum, extending on the sides. The dorsal fin with two, posteriorly with three longitudinal series of rounded brown spots.

Coast of the Southern States of North America.

a. Fine specimen. New Orleans. Purchased of Mr. Cuming.

Cuvier mentions his specimens as coming from New York; but it is not confirmed by any of the American naturalists ; and I trink this to be a more southern speeies. Homulon fulvomaculutum of Holbrook appears to be closely allied, but specifically different.

\section{Pristipoma fulvomaculatum.}

Labrus fulvomaculatus, Mitch. Trans. Lit. \& Phil. Soc. Nev York, i. p. 406.

Hremulon fulvomaculatum, Dekay, New York Fauna, Fishes, p. 84. pl. 7. f. 21 ; Holbr. Ichthyol. S. Carol. p. 156. pl. 22 . f. 2.

$$
\text { D. } \frac{11}{15} \text {. A. } \frac{3}{12} \text {. Caec. pylor. } 6 \text {. }
$$

The height of the body is $3 \frac{1}{3}$ in the total length, the length of the head $3 \frac{1}{2}$. The upper maxillary does not extend to the vertical 
from the front margin of the orbit. Præopereulum with the posterior limb very slightly emarginate. Spines of the fins slender; the third of the dorsal fin longest. Caudalis emarginate. Sides of the head and body and the vertical fins with numerous yellow spots ; those above the lateral line arranged in irregular oblique series, those below it in horizontal rows. (Holhr.)

Coast from Georgia to Virginia.

\section{Pristipoma viridense.}

Cuv. \& Val.v. p. 287 ; Barker-Webb\& Berthelot, Hist. Nat. Mes Canar. Ichthyol. p. 26.

D. $\frac{13}{15}$. A. $\frac{3}{7}$. L. lat. 80 . L. transv. 12/28. Vert. 11/15.

The height of the body is nearly equal to the length of the head, and $3 \frac{3}{4}$ in the total; the diameter of the eye is $3 \frac{2}{3}$ in the length of the head. Dorsal fin continuous, with the spines of moderate strength; the seeond anal spine strong, scarcely longer than the third. Caudalis truncated. Coloration uniform brown; dorsal fin with a more or less distinet black margin.

North-west Coast of Africa; Caribbean Sea.

a. Fine specimen. Madeira. Presented by the Rev. R. T. Lowe.

b. Fine specimen. St. Vincent's. Presented by the Lords of the Admiralty.

c. Large specimen: not good state. From the Haslar Collection.

\section{Pristipoma suillum.}

Cur: \&. Val. ix. p. 482.

$$
\text { D. } \frac{12}{15} \text {. A. } \frac{3}{9} \text {. L. lat. } 55 \text {. }
$$

The height of the body is nearly four times in the total length, the length of the head $3 \frac{3}{5}$; the diameter of the eye is one-sixth of the latter, and much shorter than the long and pointed snout; the eye occupies the middle of the length of the head. The præopereulum with a deep sinuosity above the angle, and finely serrated. Dorsal and anal spines rather feeble; eaudalis forked; peetoral one-fifth of the total length. Body with streaks formed by greenish spots, oblique above the lateral line, straight beneath; dorsalis with a series of large greenish spots. ( $\mathrm{Val}$.)

Cape Verde.

\section{Pristipoma peroteti.}

Pristipoma perotaei, Cur. \& Val. v. p. 254.
D. $\frac{11}{17}$.
A. $\frac{3}{10}$.
L. lat. 55.
L. transv. 26 .

Coloration uniform. (Cuv.)

Senegal. 
32. Pristipoma octolineatum.

Cur. Wal. ix. p. 487; Guirhen. Poiss. in Faxplor. Algér. p. 44. pl. 2.

$$
\text { D. } \frac{13}{14} \text {. A. } \frac{3}{7} \text {. }
$$

The height of the body equals the length of the head, and is onefourth of the total; the diameter of the eye is rather less than onethird of the length of the head. Præopereulum with strong dentienlations. Dorsal fin even, caudal scarcely emarginate. On each side four blue longitudinal streaks.

Cape Verde; Coast of Algiers.

\section{Pristipoma cantharinum.}

Jenyjs, Zool. Beagle, Fishes, p. 49. pl. 10.

$$
\text { D. } \frac{12}{15-16^{\circ}} \text {. A. } \frac{3}{12} \text {. L. lat. } 70 \text {. }
$$

The height of the body is $3 \frac{3}{4}$ in the total length, the length of the head four times; the diameter of the eye is one-fifth of the latter ; the snont produced, twice as long, with the jaws cqual in front. The upper maxillary does not reach to the vertical from the anterior margin of the orbit. Præoperculum reetangular, with the angle slightly rounded, and the ascending limb straight and fincly denticulated. The dorsal fin is scarcely notched, the longest (fourth) spine being $2 \frac{1}{2}$ in the length of the head. The eaudal forked; the second anal spine stoutest, but rather shorter than the third, and scarcely one-half of the length of the longest of the dorsal fin; the pectorals are $5 \frac{1}{2}$ in the total length. Uniform bluish grey.

Galapagos Arehipelago.

a. Bleacherl: $7 \frac{1}{2}$ "long.

\section{Pristipoma japonicum.}

Cuv. \&.Vul. v. p. 288 ; Fuun.Jupon. Poiss. p. 60. pl. 26. f. 2 ; Richards. Ichth. China, p. 228.
D. $\frac{14-15}{16}$.
A. $\frac{3}{7}$.
L. lat. 89.
Cæc. pylor. 8 .
Vert. 11/16.

The height of the body is $3 \frac{4}{5}$ in the total length, the length of the head 4 or $4 \frac{1}{3}$. The snout is short, scarcely longer than the diameter of the eye, with the lower jaw longest; the upper maxillary reaches to the front margin of the orbit. Præoperculum finely serrated throughout, with the posterior limb slightly emarginate, and the angle rounded. Dorsalis not notched; the spines of moderate strength. Caudalis slightly emarginate; the anal spines nearly equal. Coloration uniform.

Chinese and Japanese Seas.

a. Fine speeimen. China.

b. Adult: stuffed. China Sea. Presented by J. R. Reeves, Esq.

c. Adult: skeleton. China Sea. Presented by J. R. Reeves, Esq.

Pseudobranchiæ well developed. Air-bladder large, simple. 
Skeleton.-In this species the system of mueiforous channels is still less developed than in Pristipoma crocro. The occipital crest is very elevated, and extends to the anterior extremity of the frontal bones; the lateral erests, between the orbit and suprascapula, are relatively as high. At the anterior end of each frontal bone there is a wide oral opening continued into the channel-shaped turbinal bone. The bones of the jaws are rather fceble: the length of the posterior processes of the intermaxillaries is about one-half of that of the entire bone; a projecting semicireular process at the posterior margin. The maxillary bone is eoncare posteriorly, and has the lower posterior angle produced. The mandibulary bone has four or five grooves beneath; they are shallow, very small in front, and separated from one another by broad bony interspaces: the anterior part of the romer is angular and slightly swollen, as in fishes with a toothed romer. The præorbital is broad, triangular, with some small irregular cavities; the remainder of the infraorbital arch is very narrow, without an interior plate for supporting the eyeball from beneath. The opereulum has two very obtuse points, distant and separated from each other by a deep and wide noteh ; the sub- and interoperculum are not denticulated, and have the lower margins slightly rounded; the limbs of the præoperculum have a vertical direction towards each other, but the angle at which they mect is rounded. The posterior limb is decply serrated, the inferior very indistinctly; the tecth above the angle are the strongest and spinous. The muciferous channel of the præoperculum has four narrow openings.

There are eleven abdominal and sixtcen caudal vertebrce, the length of the former portion of the vertebral column being to that of the latter as $1: 1 \cdot 5$. The neural spines are slightly inclined backwards ; the hremals of the first four caudal vertebrie are lengthened, and broad at their lower extremity, to receive the interhæmals. The first interhæmal is strong, and as long as the first seven vertebræ together.

The dentition is composed of villiform bands only, the pharyngeal teeth being rather stronger than those of the jaws.

\section{CONODON.}

Conodon, Cuv. \& Val, v. p. 156.

Body oblong; muzzle with the jaws nearly equal in front. Two dorsals, united by a low membrane; the first with eleven strong spines; three strong anal spines. In each of the jaws an external series of very stout, short, conical teeth. Præoperculum denticulated. Scales moderate. Pseudobranchia? Air-bladder with two. very short horms in front.

C'aribbean Sea.

\section{Conodon plumieri.}

Sciæna plumieri, Bloch, vi. p. 66. taf. 306.

Perca plumieri, Bl. Schn. p. 85; Cuv. \& Val. ii. p. 51. 
Centropomus plumieri, Lacép. iv. p. 268.

Chilodipterus chrysopterus, Lacép. iii. p. 542. pl. $33 *$. f. 1.

Conodon antillanus, Cuv. \& Val. v. p. I56.

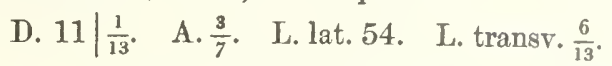

The second anal spine one-half of the length of the head. The upper maxillary reaches to the anterior margin of the eye. Præoperculum with denticulations posteriorly and inferiorly, equal in size, and with two spinous teeth at the angle. Caudalis truncated. Body with eight cross-bands.

Caribbean Sea.

a. Adult: skin. Jamaica. From Dr. Parnell's Collection.

b. Half-grown: skin. Jamaica. From Dr. Parnell's Collection.

c. Adult: stuffed: not good state.

d. Adult: stuffed. Old Collection.

e. Adult: skin : not good state.

The lighter (yellowish) longitudinal bands disappear in the preserved fish.

\section{HAMULON†.}

Diabasis, Desm., Benn.

Hæmulon, Cuv. Regne Anm.; Cuv. \&. Val. v. p. 223.

Form of the body oblong, compressed. Eye moderate. Cleft of the mouth horizontul, generally wide, with the jaws equal. A central groove below the chin. One dorsal, with twelve or thirteen spines, the anal with three; the soft portions of the rertical fins scaly to their margins. Villiform teeth in both the jaws, without canines; none on the palate. Branchiostegals seven. Præoperculum serrated; operculum with very indistinct points. Scales moderate, ctenoid. Pseudobranchiæ. Air-bladder simple; pyloric appendages in small number.

Atlantic coasts of Tropical America.

\section{Hæmulon formosum.}

Catesby, ii. p. 6. pl. 6. f. 1; Duham. Pêches, il. p. 62. pl. 11. f. 2.

Perca formosa, Linn. Syst. Nat. i. p. 488.

Labrus plumieri, Lacép. iii. p. 480. pl. 2. f. 2.

Hæmulon formosum, Cuv. \& Val. v. p. 230; Casteln. Anim. nouv. ou rares Amér. du Sud, Poiss. p. 10.
D. $\frac{12}{16^{\circ}}$.
A. $\frac{3}{9}$.
L. lat. 50.
L. transv. $\frac{4-5}{18}$.

The height of the body equals the length of the head, and is $3 \frac{1}{3}$ in the total; the diameter of the eye is four times in the length of the head and $1 \frac{2}{3}$ in that of the snout; the snout is elongate, compressed; the cleft of the mouth wide; the upper maxillary reaches to below

* Cuvier erroneously quotes pl. 23.

† 1. Hæmulon arcuatum, Cuv.\& Val, ix. p. 481 ; Holbr. Ichth. S. Carol. pl. 17. -f. 2.-S. Carolina.

2. Diabasis obliquatus, Benn. Zool. Journ. v. p. 90.-Jamaica. 
the middle of the eye. The eleventh and twelfth dorsal spines are nearly equal in length. Caudalis forked. The side of the head with eleven or twelve bluish, waving longitudinal streaks, edged with brownish, and not extending on the trunk.

Atlantic coasts of Tropical America.

a. Half-grown. From the Collection of the Zoological Society. $b$, c. Fine specimens. Pernambuce. Presented by J. P. Smith, Esq. d,e. Adult: skins. Jamaica. From Dr. Parnell's Collection. $f, g$. Adult: stuffed.

\section{Hæmulon elegans.}

Anthias formosus, Bl. taf. $323 ; B l$. Schn. p. 305.

Hæmulon elegans, Cuv. \& Val. v. p. 227; Cuv. Rigne Anim. Ill. Poiss. pl. 30. f. 1 .
D. $\frac{12}{16}$.
A. $\frac{3}{9}$.
L. lat. 50.
L. transv. $8 / 16$.

The height of the body equals the length of the head, and is $3 \frac{1}{3}$ in the total; the diameter of the eye is $1 \frac{1}{2}$ in the length of the snout and $3 \frac{1}{2}$ in that of the head. The snout is compressed, elongate; the cleft of the mouth wide; the upper maxillary rcaches to below the middle of the eye. The elerenth and twelfth dorsal spines are nearly equal in length; caudalis forked. Sides of the head and of the body with seven or eight waring, light-blue longitudinal bands, edged with brownish.

Caribbean Sea.

a. Adult.

b. Half-grown : bleached. Old Collection.

c-e. Adult and half-grown: skins. Jamaica. From Dr. Parnell's Collection.

$f$. Young.

$g, h$. Half-grown. From the Haslar Collection.

i. Adult. From the Haslar Collection.

$k-n$. Adult: stuffed.

o. Adult : stuffed. Old Collection.

\section{Hæmulon microphthalmum. (Plate XVII.)}
D. $\frac{12}{16}$.
A. $\frac{3}{8}$.
I. lat. 55.

The height of the body equals the length of the head, and is $3 \frac{2}{5}$ in the total. The eye is small, its diameter being one-sixth of the length of the hearl, and contained $2 \frac{1}{2}$ in the length of the snout. The eleft of the mouth is rather wide, but the upper maxillary does not reach to the vertical from the anterior margin of the eye. Præoperculum with the posterior limb very slightly emarginate, finely and equally scrrated. Dorsal fin not decply notehed, with the spines of moderatestrength; the fourth is the longest, and $2 \frac{1}{3}$ in the length of the head; catulal forked. 'T'he second anal spine very strong, longer than the third, two-thirds of the fourth dorsal spine. Yertical 
fins covered with very thin scales and transparent. Coloration uniform olive (in a dried state).

Coast of America.

\section{a. Adult: stuffed. America.}

Description of the specimen.-This species much resembles $H$. elegans, formosum, canna, \&c., but may be readily distinguished by its small eye, uniform coloration, and by the transparent scales, which cover the vertical fins. The length of the head and the height of the body are nearly equal, and $3 \frac{2}{5}$ in the total length. The crown is very convex and elevated, much broader than the diameter of the eye, and covered with scales to the nostrils. The eye is nearer the posterior margin of the præoperculum than the end of the muzzle, and relatively smaller than in other species, its diameter being onesixth only of the length of the head. The præoperculum is finely and equally serrated at both its limbs; the posterior limb is very slightly emarginate, the angle and the inferior limb are rounded. The scales reach to the margin. The suprascapula is serrated.

The base of the spinous portion of the dorsal fin is longer than that of the soft. The spines are of moderate strength, on one side broad, on the other with a longitudinal ridge: the first is one-half as high as the second, the second is rather more than one-half of the third; the fourth is a little longer than the third; the following spines gradually decrease in height to the eleventh and twelfth, which are equal. The soft dorsal has the superior margin slightly curved, the middle rays being longest, and about equal to the ninth dorsal spine: this part of the fin is covered with transparent scales nearly to its margin. The distance between the dorsal and caudal fins is equal to the width between the last ten dorsal rays. The caudal.fin is moderately forked, the lobes being $4 \frac{1}{2}$ in the total length: transparent scales cover two-thirds of the fin. The distance between the caudal and anal fins equals the width between the last thirteen dorsal rays. The origin of the anal fin falls below the fourth dorsal ray, its end below the twelfth. The first spine is small; the second extremely thick and striated, equal in length to the eighth of the dorsal; the third is shorter and less strong, on the right side flat, on the left with a longitudinal ridge. The first ray is equal to, or rather shorter than, the second spine, and covered with transparent scales, like the whole fin. The pectoral is pointed; but the extremity being broken off, I am not able to state the relative length of the fin. The length of the ventral is $6 \frac{2}{3}$ in the total; its base falls immediately behind that of the pectoral; the spine is moderately strong, and two-thirds of the length of the fin.

The scales eovering the head are much smaller than those of the body, especially those of the nape; they are very finely ciliated. The scales of the lateral line are small, one-third the size of one of the adjacent series.

The teeth are in broad villiform bands, with rather stronger ones in the outer series; those which are placed on the side of the lower jaw are the strongest. 
The colour is now entirely uniform, each scale having a darker margin.

\begin{tabular}{|c|c|c|}
\hline & inches. & lines. \\
\hline Total length...... & 14 & 0 \\
\hline Height of the body $\ldots \ldots \ldots \ldots \ldots \ldots$ & 4 & 1 \\
\hline Length of the head $\ldots \ldots \ldots \ldots \ldots$ & 4 & 0 \\
\hline —_ of the diameter of the eye ...... & 0 & $7 \frac{1}{2}$ \\
\hline _ of the fourth dorsal spine $\ldots . .$. & 1 & $7 \frac{1}{2}$ \\
\hline - - of the elerenth dorsal spine .... & 9 & 0 \\
\hline - of the seventh dorsal ray $\ldots \ldots$ & 12 & 0 \\
\hline - of the second anal spine........ & 1 & $1 \frac{1}{2}$ \\
\hline
\end{tabular}

4. Hæmulon macrostoma. (Prate XVIII.)
D. $11 / \frac{1}{16}$.
A. $\frac{3}{8}$.
L. lat. 55-58.
L. transv. 10/17.

The height of the body equals the length of the head, and is $3 \frac{1}{8}$ in the total. The snout is elongate and compressed, and rather more than twice the diameter of the eye, which is $5 \frac{1}{3}$ in the length of the head. The eleft of the mouth is very wide, the upper maxillary nearly reaching to the vertical from the anterior margin of the eye. Præopereulum with the posterior limb nearly vertical, and with obtuse denticulations, which become stronger at the angle, but disappear with age. Dorsal fin deeply notched, with strong spines, the fourth being the longest, $2 \frac{1}{2}$ in the length of the head, and the last being considerably longer than the eleventh. Caudalis forked; the second anal spine very strong, searcely longer than the following, and equal in length to the sixth of the dorsal. The length of the pectoral is $4 \frac{2}{7}$ in the total. Five blackish (in a dried state) longitudinal bands, one being very distinct from the eye to the eaudal fin, the others more or less indistinct and interrupted.

Jamaica.

$a-c$. Adult and half-grown : skins. Jamaica. From Dr. Parnell's Collection.

Description.- This fish belongs to the group with the cleft of the mouth wide, and with the rertieal fins thickly enveloped by seales, and is closely allied to $H$. elegans, canna, \&e. The body is rather elevated, its greatest depth being below the origin of the dorsal fin, and contained $3 \frac{1}{8}$ in the total length. The length of the head is equal to that height. The mouth is nearly horizontal. The maxillary and intermaxillary may be nearly entirely concealed below the præorbital, the greatest width of which is one-half more than that of the orbit; it is covered with scales, like the eheeks and the præopereulum. The space between the eyes is convex, larger than the width of the orbit, and scaly nearly to the nostrils, which are situated immediately before the eyes. The eye is nearer the posterior margin of the opereulum than the end of the snout. The suprascapula is scarcely to be distinguished from the scales; it is ineonspicuously serrated.

The dorsal fin begins abore the base of the pectoral and terminates 
a little behind the anal ; the base of the spinous portion is one-half longer than that of the soft; both portions are separated by a deep notch. The spines are strong: the first is two-fifths of the second; the second three-quarters of the third; the fourth is the longest, and $2 \frac{1}{2}$ in the length of the head; the fifth equals the third, and the following gradually deerease in height to the eleventh; the twelfth is longer than the preceding, and it belongs apparently to the soft dorsal, being closely attached to the adjacent ray. The soft portion is so thickly enveloped by scales, that it is difficult to distinguish the single rays. The upper margin is slightly rounded, the third, fourth, and fifth of the rays being the longest, and equal in height to the second spine, whilst the last measures not half that height. The caudal fin is moderately forked, and thickly covered by minute scales to its margins. The origin of the anal fin falls below the third or the fourth dorsal ray: the soft portion is higher than the spinous, entirely enveloped by scales, and has a rather eoncave margin. The first spine is very small; the second very strong, striated, equal in length to the sixth dorsal spine, or one-third of the length of the head; the third is rather shorter and not so stout as the other; on one side it is flat and striated, on the other longitudinally grooved. The pectoral fin is pointed, and contained $4 \frac{2}{7}$ in the total length; it extends to the vertical from the vent; there are some seales at its base. The base of the ventral falls below that of the pectoral; and being much shorter than that fin, it does not reach to the vent, and is one-sixth of the total length; a series of small scales follows each of the rays, covering their base and the interspaces between them nearly to the end of the fin. The rentral spine slightly exceeds one-half of the length of the adjacent ray.

The scales are of moderate size, ctenoid, and arranged in rather. irregular series; those of the lateral line are small, and their number is variable, and would not indicate the number of the transverse series of scales. An oblique stripe of very small scales descends upwards and forwards from the suprascapula to the nape.

The teeth form in both the jaws broad villiform bands, but the outer series eontains large conical teeth, which are as strong in the lower jaw as in the upper. In one of the specimens, one of the upper pharyngeal bones is preserved; it is armed with powerful teeth, which, at the outer part of the bone, are strong and curved, and towards the middle conical and pointed; on the inner portion of the bone the teeth are obtuse and broad, and assume the character of molars.

The ground-colour is now greyish; there is a distinct, straight, blaekish band from the middle of the eye to the upper half of the tail. Above this band are two or three others, and below "it a fourth, much less distinct, and in two of the specimens interrupted. The ventrals are blackish.

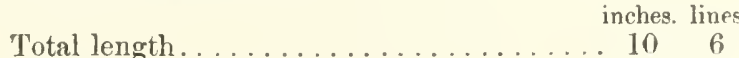

Height of the body ............... 40

Length of the head ............... 4 n

Diameter of the eye $\ldots \ldots \ldots \ldots \ldots \ldots$. 0 


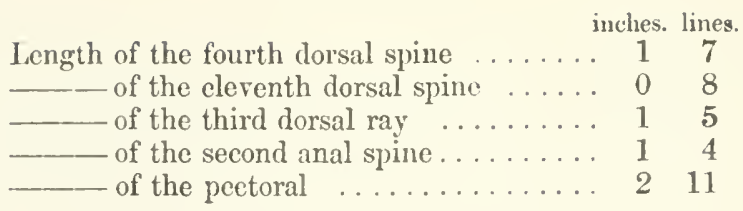

\section{Hæmulon chromis}

Perca chromis, Broussonet.

Hæmulon canna, Agass. in Spix, Pisc.Bras. p. 130. pl. 69 (not C.\&.V.). - chromis, Cuv. \& Val. v. p. 242.
D. $\frac{12}{17-18}$.
A. $\frac{3}{8}$.
I. lat. 43 .
L. transv. 6/16.

The height of the body is $3 \frac{1}{3}$ in the total length, the length of the head $3 \frac{2}{5}$; the diameter of the eye is $1 \frac{1}{3}$ in the length of the snout, and $3 \frac{3}{4}$ in that of the head. The eleft of the month is rather wide, the upper maxillary reaching a little beyond the front margin of the eye. The præoperculum is finely and equally denticulated, with the posterior limb slightly emarginate. The dorsal fin deeply notehed, with the spines of moderate strength; the fourth is the longest, $2 \frac{1}{2}$ in the length of the head. Candalis forked, and enveloped by scales nearly to its extremities; the sceond anal spine much stronger, but searcely longer than the third, $2 \frac{4}{5}$ in the length of the head; ventral and pectoral fins covered with scales. Each scale with a darker centre, the spots forming more or less distinct oblique streaks. A hlaekish-brown spot, concealed by the angle of the præoperculum. Fins brownish.

Atlantic coasts of 'Tropical America.

«. Adult. Bahia. Purchased of M. Parzudaki.

b. Adult: not good state. Bahia. Purchased of M. Parzudaki.

c. Fine specimen. Cuba. From the Collection of the Zoological Society.

d. Adult: skin. Jamaica. From Dr. Parncll's Collection.

e. Half-grown: skin. Jamaica. From Dr. Parnell's Collection.

f. Half-grown. Gulf of Mexico. From the Haslar Collection.

\%. Large specimen: not good state. South America. Presented by Sir R. Schomburgk.

h. Adult: not good state. S. America. Purchased of Mr. Brandt. i. Adult. Old Collection, as Perea chromis.

k. Adult: not good state. Old Collection.

The fish described by Agassiz (l.c.) agrees much better with $H$. chromis than with $I f$. camna, Cuv. The number of the soft rays of the dorsal fin, the extent of the upper maxillary, and the less distinct oblique streaks, are the characters by which $H$. chromis may be distinguished from $I I$. canna.

\section{Hæmulon schrankii.}

Agers. in Spix, Pisc. Bras. p. 131. tab. 69 a.

$$
\text { D. } \frac{12}{18} \text {. A. } \frac{3}{10} \text {. }
$$

The height of the borly is nearly equal to the length of the head, 
and $3 \frac{1}{2}$ in the total. The cleft of the mouth is rather wide, the upper maxillary reaching nearly to below the eentre of the eye. The dorsal fin notehed, with the spines of moderate strength, and with the fourth longest. Candalis forked, but the basal half only scaly; the pectoral and ventral fins without any seales. Coloration immaculate. (Ag.)

Coast of Brazil.

\section{Hæmulon canna.}

Cuv. \&. Val. v. p. 233; ? Castelnau, Anim. nouv. ou rares de l'Amér. du Sud, Poiss. p. 11 (not Agass.).
D. $\frac{12}{16}$.
A. $\frac{3}{8}$.
L. lat. 48.
L. transv. $5 / 13$.

The height of the body equals the length of the head, and is $3 \frac{2}{5}$ in the total. The snout is elongate and compressed, and nearly twice the width of the eye, the diameter of which is $5 \frac{1}{2}$ in the length of the head. The cleft of the mouth is wide, but the upper maxillary does not reach the vertical from the front margin of the eye. Præopereulum with the posterior limb nearly vertical, and with rather stronger denticulations at the angle. Dorsal fin notched, with strong spines, the fourth spine longest, $2 \frac{1}{2}$ in the length of the head; the eaudal forked. The second anal spine very strong, rather longer than the third, but not quite so long as the fourth spine of the dorsal (in young specimens rather longer). The length of the pectoral is $4 \frac{1}{2}$ in the total. Oblique black bands descend from the back along the series of the scales; dorsal, caudal, anal, and ventral fins blackish.

Coasts of Tropical America.

$a-d$. Adult and half-grown: skins. Jamaica. From Dr. Parnell's Collection.

e. Adult. Guatemala. Purehased of Mr. Frank.

f. Half-grown. Purerto Cabello. Purchased of Mr. Brandt.

\section{Hæmulon album.}

Cuv. \& Val. v. p. 241.
D. $\frac{12}{16}$.
A. $\frac{3}{8}$.
L. lat. 50.
L. transv. $7 / 16$.

The height of the body is $3 \frac{1}{4}$ in the total length, the length of the head $3 \frac{1}{2}$; the diameter of the eye is one-sixth of the latter, and $2 \frac{2}{3}$ in the length of the snout; the eleft of the mouth is wide, but the upper maxillary does not reach to the vertical from the front margin of the orbit. Præoperculum finely and equally serrated, with the posterior limb nearly vertical. The dorsal fin seareely notched; spines moderately strong, the fourth longest, $2 \frac{1}{3}$ in the length of the head. Caudalis forked. The second and third anal spines nearly equal in length and strength, rather longer than one-half of the fourth dorsal spine. Coloration uniform (in a dried state); no black spot behind the angle of præopereulum.

Caribbean Sea.

a. Seventeen inches long: skin. Jamaica. From Dr. Parnell's Collection. 


\section{Hæmulon xanthopterum.}

Hamulon bonariense, Cuv. \& I $a l . v$. p. 234.

— xanthopterum, Cur. \&. I $u l$. v. p. $2: 34$.

— heterodon, Cuv. \& Vul. v. p. 2:35, pl, 121.
D. $11 \mid \frac{1}{14-15}$.
A. $\frac{3}{8}$.
L. lat. 50 .
Vert. 11/15.

The height of the body is 3 or $3 \frac{1}{3}$ in the total length, the length of the head $3 \frac{1}{2}$ or $3 \frac{2}{3}$. The snout rather pointed, of moderate length, rather longer than the diameter of the eye, which is $3 \frac{1}{2}$ in the length of the head. The upper maxillary does not fully extend to the vertieal from the centre of the ortit. The posterior limb of the preoperculum is slightly emarginate and minutely dentieulated; the angle with rather stronger spinous teeth. 'The dorsal fin is notehed; the spincs are moderately strong; the fourth the longest, exaetly one-half the length of the head. The soft dorsal, the eaudal, and anal fins are thickly enveloped by scales. Candalis forked; the second anal spine is stronger and longer than the third, and rather longer than the longest of the dorsal. The pectoral fins are turned upwards. The lateral scales between the pectoral fin and the lateral line are conspicuously much laryer than the remuinder. Coloration uniform, with oblique bands beneath the lateral line; a deep-black spot is eoneealed by the angle of the præoperculum.

Atlantic eoasts of 'Tropieal Ameriea.

a, b. Adult. West Indies.

c. Adult : skeleton. West Indies.

d. Fine specimen. From the Haslar Collection.

$e-l$. Adult: stuffed. West Indies. Purchased of Mr. Scrivener.

$m$. Adult: stuffed. Martinique.

$n-y$. Adult an ' half-grown: skins. Jamaica. From Dr. Parnell's Collection.

z. Half-grown: skin. Trinidad. P'resented by J. B. Richardson, Esq.

a. Half-grown. Puerto Cibello. P'urehased of Mr. Brandt.

13. Half-grown. Old Colleetion, as Perct chromis.

$\gamma$. Half-grown: stuffed. From Mr. Yarrell's Collection.

Peritoneum black.

Sleleton.-The system of mueiferous channels is more developed than in Pristipoma, but much less than in the true Scicnida. 'There are four very distinet openings on the upper part of the skull, between the eyes; the posterior and smaller pair elose together; the anterior more distant from each other, and close behind the turbinal bone, which, more strongly developed than usual, forms a solid halfchannel. Between these openings there is a deep longitudinal grove, widening between the turbinal bones to receive the proeesses of the intermaxillaries. 'The oecipital crest is very prominent, the horizontal portion being wider than the vertieal, and extending on the frontal bones; the lateral erests are relatively less developed, but very distinet, and the outer one is transformerl into a muciferous chammel, commencing with an clongate opening above the posterior part of 
the orbit. The basisphenoid is distinguished by a very deep longitudinal groove, arising from the condyloid process of the basioccipital. - The intermaxillaries are furnished with very elongate posterior processes, much longer than the bone itself. Cuvier might have placed this species in his family of Manides with greater propriety than several species of Casio. The maxillary bone, as in most of the species of Hamulon and Pristipoma, is broadest near its base, where it is hidden below the large præorbital, the free part being narrow, and nearly of equal width to the posterior extremity. The anterior part of the vomer is slightly swollen and rounded. The mandibulary has four wide cavities below, separated from one another by delicate transverse bones. The operculum has no prominent point, and is irregularly quadrangular, the posterior side being slightly emarginate. The præoperculum has the strongest denticulations at the angle, the posterior margin slightly concave and the inferior convex; its muciferous channel has four wide openings with thin bones between, as in the mandibular channel. The præorbital is very large, triangular, with the inferior side curved; three or four muciferous cavities of considerable width. Suprascapula with some denticulations.

The exterior row of the maxillary teeth, as well as of the mandibulary, contains several larger conical teeth, and there is also a large tooth at the posterior extremity of the row.

There are eleven abdominal and fifteen caudal vertebro, the length of the former portion of the column being to that of the latter as $1: 1 \cdot 44$. The first interhæmal is strong, and equals the length of the first eight vertebræ together.

\section{Hæmulon caudimacula.}

Cuv. \& Val. v. p. 236.

$$
\text { D. } \frac{12}{16} \text {. A. } \frac{3}{7} \text {. }
$$

Candalis forked. Brownish oblique streaks on the back and sides; a black spot on each side $o_{2}^{e}$ the root of the caudal fin; ventral and anal fins blackish. (Cuv.)

Coast of Brazil.

\section{Hæmulon chrysopterum.}

Catesby, Hist. Nat. Carol. ii. p. 2. pl. 2. f. 1.

Perca chrysoptera, Linn. Syst. Nat. i. p. 488; Linn. Gm. p. 1314.

Lutjanus chrysopterus, Lacép. iv. pp. 186, 226.

Hæmulon chrysopteron, Cuv. \& Val. v. p. 240; Dekay, Nero York Zool. iv. p. 85. pl. 7. f. 22; Holbr. Ichth. S. Carol. p. 120. pl. 17. f. 1.

$$
\text { D. } \frac{13-14}{15-14} \text {. A. } \frac{3}{8} \text {. L. lat. } 53 \text {. L. transv. 6/13. }
$$

The height of the body is $3 \frac{4}{5}$. in the total length, the length of the head $3 \frac{1}{2}$; the diameter of the eye is $3 \frac{1}{2}$ in the length of the head, and $1 \frac{1}{3}$ in that of the snout. The cleft of the mouth is wide, the upper maxillary reaching nearly to the vertical from the centre of the eye. The præoperculum with the posterior limb slightly emarginate, and with rather stronger denticulations at the angle. The dorsal fin notched; spines slender, flexible; the fourth longest, $2 \frac{1}{2}$ 
in the length of the head. Caudal fin deeply forked; the second anal spinc stronger, but scarcely longer than the third, and much shorter than the fourth of the dorsal. Scales of the pectoral region not larger than the others. Coloration uniform (in spirits), without a black spot behind the angle of the præoperculum.

Atlantic coasts of Tropical America; S. Carolina.

a. Adult. West Indies.

b. Adult: stuffed. West Indies.

$r-h$. Adult: skins. Jamaica. From Dr. Parnell's Collection.

i. Adult: skin. Trinidad. Presented by J. B. Richardson, Esq.

k. Adult: stuffed: not good state. Bahia.

12. Hæmulon chrysargyreum. (Plate XVI. fig. B.)
D. $11 \mid \frac{1}{13}$.
A. $\frac{3}{9}$.
L. lat. 50 .
L. transv. 9/12.

'The height of the body is $3 \frac{1}{2}$ in the total length, the length of the head nearly four times. The snout is of moderate length and rather shorter than the diameter of the eyc, which is one-third of the length of the head. The cleft of the mouth is moderate, the maxillary searcely reaching beyond the rertical from the anterior margin of the eyc. I'roopereulum with the posterior limb nearly vertical and fincly serrated, the denticulations becoming rather stronger at the angle. Dorsal fin deeply notehed, with slender spines, the fourth being the longest and more than one-half of the length of the head. Caudalis deeply forked. The seeond anal spine rather slender, nearly equal to the following, and one-third the length of the liead. Silvery, with five golden parallel longitudinal bands on each side, and a sixth medial one from the crown to the origin of the dor'sal; the spinous dorsal blackish.

Caribbean Sea.

a. Adult: stuffed. West Indies. I'urchased of Mr. Scrivener.

b. Fine specimen. Trinidad. Presented by J. B. Richardson, Esq.

Description.-The upper profile descends in a gentle curre from the fourth dorsal spine to the end of the snout. The body is not very elevated, its greatest depth being $3 \frac{1}{2}$ in the total length. The head forms nearly one-fourth of the same length, and has the crown rather concare and covered with small scales to the nostrils. The distance between the eyes is less than the width of the orbit. The eleft of the mouth is nearly horizontal, with the jaws equal; the upper maxillary reaches to, or seareely beyond, the anterior margin of the orbit; it is nearly entirely hidden beneath the præorbital, the greatest width of which is three-quarters of the diameter of the eye ; the posterior portion of the prieorbital is sealy. The eyc is rather large, one-third of the length of the head, and neaver the end of the snout than of the opereulum. The posterior limb of the preoperculum is very slightly cmarginate, or nearly vertical, and finely serrated ; the angle is rounderl, and armed with rather eoarser denticulations. The operculum has a slight noteh posteriorly; the suprascapulit is hidden by the seales and minutely serrated. 
The dorsal fin begins above the base of the pectoral, and terminates above, or a little behind, the end of the anal; the base of the spinous portion is one-half longer than that of the soft; both portions are separated by a deep noteh. The spines are slender, but not flexible; the first is two-fifths of the length of the second, the second threefifths of the third, the third rather shorter than the fifth; the fourth longest, one-half of the height of the body. The following spines gradually decrease in height to the eleventh; the twelfth is longer than the preeeding, and it belongs apparently to the soft dorsal, being elosely attached to the adjacent ray. The soft dorsal is covered with transparent scales from the base to the upper margin, which is nearly straight and obliquely descending backwards; this portion of the fin is much lower than the spinous. The distance between the dorsal and caudal fins is shorter than the base of the soft dorsal. The caudalis is deeply forked, the upper lobe (which is rather longer than the lower) being $4 \frac{2}{3}$ in the total length, and three times as long as one of the middle and shortest rays. Series of small scalcs extend over one-half of the lobes. The distance between the caudal and anal fins equals the length of the base of the soft dorsal. The origin of the anal falls below the second dorsal ray, the end a little before the vertical from the end of the dorsal. The first spine is small; the second and third are nearly equal, and rather stronger than the dorsal spines, the eighth of which they equal in length. The soft portion of the fin has the margin slightly emarginate, and is thickly covered with minute scales; it is higher than the soft dorsal, the first ray being nearly one-half of the length of the head. The pectoral fin is slightly pointed, scaly at the base only, and nearly onesixth of the total length. The ventral is much shorter; its base falls immediately behind that of the pectoral; the spinc is two-thirds the length of the first ray; there is a narrow series of minute scales along the outer side of each ray.

The scales are of moderate size, one of the largest covering onesixth of the eye; they are finely serrated, and rather higher than long.

The teeth form villiform bands, with the outer series of the upper jaw containing rathcr larger ones.

The colours are beautifully preserved in the specimen from Trinidad. The ground-colour is silvery, with a greyish-green hue on the back. A narrow golden longitudinal streak descends from the origin of the dorsal to the centre of the crown. There are on each side five golden, parallel, longitudinal bands, not much narrower than the intermediate stripes of the ground-colour : the first from the snout above the eye to the middle of the base of the soft dorsal; the second from the upper margin of the orbit crossing the lateral line to the end of the dorsal ; the third from the posterior margin of the orbit along the middle of the body; the fourth from the inferior margin of the orbit across the base of the pectoral to the base of the lower caudal lobe; the fifth from the inferior margin of the præorbital to the end of the anal. The upper part of the iris and the inside of the mouth are red. The dorsal and caudal fins blackish; the spinous portion of the 
former is of deeper black on the marginal half; the anal and ventral fins citrine; peetoral colourless, with the axil blackish. All these colours are changed into a uniform yellowish in dried specimens.

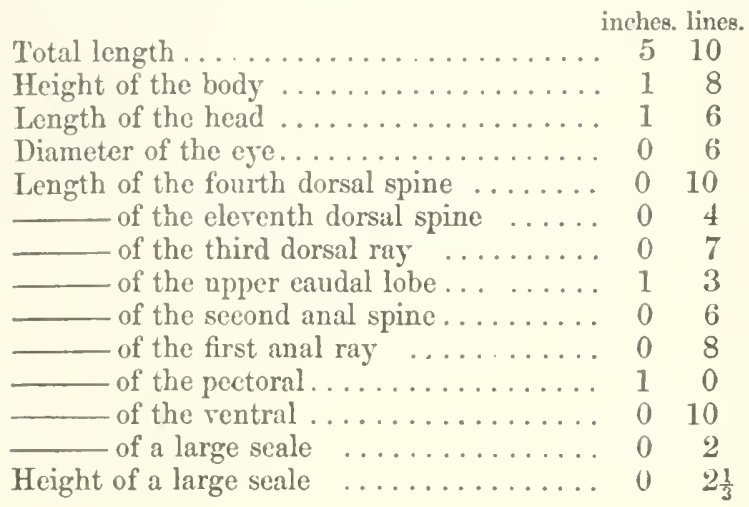

\section{Hæmulon quadrilineatum.}

? Capeuna, Margr. p. 155 (fig. p. 163).

Grammistes trivittatus, Bl. Schn. p. 188.

Serranus capeuna, Licht. Berl. Abhandl. 1820, p. 288.

Hæmulon quadrilineatum, Cuv. \& Val. v. p. 238. pl. 120

$$
\text { D. } \frac{13}{14} \text {. A. } \frac{3}{8} \text {. }
$$

The height of the body equals the length of the head, and is somewhat less than one-fourth of the total. The upper maxillary reaches to the front margin of the orbit. The dorsal spines not rery strong; caudalis forked; the sccond anal spine stronger and longer than the third. Two brown bands along nearly all the side of the body-one above, the other along the lateral line; a short brown streak between the upper band and the spinous dorsal, another along the side of the head above the orbit; two broad golden longitudinal bands from the eye and muzzle beneath the lateral line; dorsal and caudal fins greyish brown. (Cuv.)

S. Domingo.

\section{Hæmulon aurolineatum.}

Cuv. \&. Val. v. p. 237; Casteln. Anim. nout. on rares Ankér. du Sud, Poiss. p. 11.
D. $\frac{13}{15}$.
A. $\frac{3}{8}$.
L. lat. 54 .
L. transs. $7 / 16$.

The height of the body is $3 \frac{1}{3}$ in the total length, the length of the head $3 \frac{2}{3}$; the diameter of the eye is $1 \frac{1}{3}$ in the length of the snout, and $3 \frac{1}{2}$ in that of the head. The eleft of the mouth is wide, the upper maxillary reaching to below the centre of the eye. Preoperculum with the posterior limb vertical, and with rather stronger denticulations at the angle. The dorsal fin with a noteh; the spines rather slender; the fourth longest, rather less than one-half the 
length of the head. Caudalis deeply forked; the second anal spine rather longer and stronger than the third, but much shorter than the fourth of the dorsal. On each side two brown longitudinal bands, one from the vertex to the end of the dorsal, the other beneath the lateral line from the eye to the middle of the tail; a large brown spot on each side of the base of the caudal.

Atlantic coasts of Tropical America.

a. Fine specimen. Pernambuco. Presented by J. P. G. Smith, Esq.

$b$. Adult. From the Haslar Collection.

\section{HAPALOGENYS.}

Hapalogenys, Richards. Ann. \& Mag. Nat. Hist. 1844, xiii. p. 463, and Ichthyol. Sulph. p. 84.

Pogonias, sp., Temm. \& Schleg. Faun. Japon. Poiss. p. 59.

Form of the body compressed, elevated. Eye moderate. Cleft of the mouth horizontal. Mandibula inferiorly with several pores, hidden by crowded, barbel-like papillæ. Præoperculum serrated; operculum with short spines. Six branchiostegals. One dorsal, with eleven spines, the anal with three; all the spines very strong. Caudal convex. Scales ctenoid, of moderate size. Air-bladder simple. Pyloric appendages in small number. Pseudobranchiæ. The lower pharyngeal bones separated.

Chinese and Japanese Seas.

\section{Hapalogenys nigripinnis.}

Pogonias nigripinnis, Temm. \& Schleg. Faun. Japon. Poiss. p. 59. pl. 25 (not good).

Hapalogenys nitens, Richards. Ann.\& Mag. Nat. Hist. 1844, xiii. p. 463, and Ichthyol. Sulph. p. 84. pl. 43. f. $1,2$.

? Hapalogenys maculatus, Richards. Ichth. China, p. 225.

B. 6. D. $\frac{11}{15-16}$. A. $\frac{3}{9-10^{\circ}}$. L. lat. 65. L. transv. 11/25. Cæc. pylor. 4 .

The fourth dorsal spine longest, nearly one-half the length of the head; the second anal spine rather more than one-half of the fourth of the dorsal fin. Coloration uniform reddish grey; fins blackish.

Chinese Seas.

a. Adult: stuffed. Purchased of Mr. Frank.

b. Half-grown. China. Presented by J. R. Reeres, Esq.

Sir John Richardson mentions, in his 'Report on the Ichthyology of the Seas of China and Japan', four specimens in the British Museum Collection-types of four species of Hapalogenys :-

1. The typical specimen of $H$. analis.

2. A specimen in spirits ( $4 \frac{1}{2}{ }^{\prime \prime}$ long), representing $H$. nitens. This is, without any doubt, the original of the figure in the "Voyage of the Sulphur.'

3. A specimen of $H$.maculatus. There is no such specimen in the 
Collection. Having established the species from the figure of Reeves, he has probably, by some mistake, referred tho second specimen to this species. Not trusting in species established from figures, I consider $H$. maculatus as a very doubtful species-if not merely a young individual of $H$. nitens.

4. This specimen ( $9^{\prime \prime}$ long) is stated to have been received "from Berlin as Pogonias melanopterus, out of Bürger's Collection." In fact it has been purchased with that name, of Mr. Frank, who received it from the Lcyden Museum. Doubtless it is one of the specimens on which $P$. nigripinnis of the 'Fauna Japonica' was founded, and is of great value, because it proves that the figure given in that work is rery faulty, representing the upper profile of the head much too concave, the dorsal spines too slender, the barbels too long, and the coloration too dark; consequently the figure is of no use for determining the species. But, moreover, that specimen proves the unmistakeable identity of Pogonias nigripinnis and of Hapalogenys nitens; and I am surprised that Sir J. Richardson did not arrive at the same result, having seen both the specimens. The figure in the 'Ichthyology of the Sulphur' is a perfectly true representation of the species.

\section{Hapalogenys mucronatus.}

Pristipoma mucronatum, Eydoux \& Souleyet, Voy. de la Bonite, Zool. p. 161. pl. 2. f. 1 (1841).

Hapalogenys analis, Richaids. l. c., \& Ichth. Sulph. p. 85. pl. 43. f. 2.
B. 6 .
D. $\frac{11}{15}$.
A. $\frac{3}{9}$.
L. lat. 55 .
L. transv. 11/23.

The third dorsal spine and the second of the anal exceedingly long and strong, the former three-quarters of the length of the head; the anal spine two-thirds of that of the dorsal. Body with dark cross-bands*; the soft dorsal and the caudal black-edged.

China Seas.

a. Stuffed. China. Presented by J. R. Reeves, Esq.

\section{DIAGRAMMA.}

Diagramma, Cuv. Regne Anim.; Cuv. \& Val. v. p. 290.

Plectorhynchus, (Lacêp.) Cantor, Catal. p. 77.

Form of the body compressed, oblong, with the upper profile of the head parabolic. Cleft of the mouth small, horizontal. Eyc moderate. Præoperculum serrated; suborbitals without any spines. Six or seven branchiostegals. No canine teeth. Four or six pores under the mandibula, but no larger groove. One dorsal, with nine to fourteen spines; three anal spines. Caudal not forked. Scales ctenoid, rather small, in the first species moderate. Swim-bladder simple; pyloric appendages in small number.

From the Red Sea through all the East Indian Neas to the Pacific. Une species in the Mediterranean.

* They are not more visible in the speeimen in the Britislı Museun Collection. 


\section{Diagramma gibbosum.}

Diagramma gibbosus, (Hombr. \& Jacq.) Grichèn. Voy. Pôle Sud, Poiss. p. 46. pl. 5. f. 2.

$$
\text { D. } \frac{13}{18} \text {. A. } \frac{3}{8} \text {. }
$$

The height of the body is $2 \frac{1}{2}$ in the total length, the length of the head nearly four times. The distance of the eaudal fin from the dorsal is longer than the height of the tail beneath the end of the dorsal (according to the figure). Dorsal fin notched, with strong spines; caudalis subtruncated; the second anal spine much longer and stronger than the third; the fourth dorsal spine longest. Uniform greenish. (Guichen.)

Samoa (Polynesia?).

\section{Diagramma crassispinum.}

Rüppell, N. W. Fische, p. 125. taf. 30. f. 4.

$$
\text { D. } \frac{14}{16-17} \text {. A. } \frac{3}{7} \text {. }
$$

The height of the body is $2 \frac{3}{4}$ in the total length, the length of the head $3 \frac{3}{4}$; the distance between the dorsal and caudal fins is much longer than the height of the tail below the end of the dorsal (according to the figure). Dorsal fin notched, with strong spines; the fourth dorsal spine longest, $2 \frac{1}{5}$ in the height of the body; the second anal spine mueh longer and stronger than the third. Caudalis truncated. Uniform blackish; fins black. (Riipp.)

Red Sea.

3. Diagramma affine. (Plate XIX. fig. A.)

? Diagramma crassispinum, Bleek. Verh. Batav. Genootsch. xxiii. Scian. p. 26 (not Rüpp.).
D. $\frac{14}{16}$.
A. $\frac{3}{7}$.
L. lat. 45 .
L. transv. 9/16.

The height of the body is $2 \frac{1}{2}$ in the total length, the length of the head $3 \frac{2}{5}$; the distance between the dorsal and eaudal fins is less than the height of the tail below the end of the dorsal. Dorsal fin notched, with strong spines, the fourth of which is the strongest, $2 \frac{1}{3}$ in the height of the body; the second anal spine much longer and stronger than the third. Caudalis slightly convex. Uniform brownish; the dorsal, anal, and ventral fins black.

Coasts of N.W. Australia; East Indian Archipelago.

a. Adult: very bad state. N.W. Australia. Presented by Sir J. Richardson.

b. Adult. From the Haslar Collection.

c. Adult. From the Haslar Collection.

d. Adult: deformed. Moluceas. Purchased of Mr. Frank.

e. Fine specimen. Purchased of Mr. Frank.

f. Half-grown. Amboyna. Purchased of Mr. Frank.

g. Half-grown. Madras. Presented by J. C. Jerdon, Esq.

h. Fine specimen. China. Presented by Capt. Sir E. Belcher.

Description.-This species is elosely allied to D. crassispinum, 
Rüpp., from which, however, it must be distinguished, on account of its shorter and higher tail. One might also suppose it to be identical with Pristipoma nigrum, of which we find a bad description by Cuvier in the Hist. Nat. des Poissons: but our fish, having no central groore beneath the chin, cannot be referred to Pristipoma. The form of the body is very compressed and elevated, its greatest depth being $2 \frac{1}{2}$ in the total length. The upper profile is nearly straight along the base of the spinous dorsal, but it descends steeply along that of the soft, and still more from the origin of the dorsal to the snout. The lower profile is nearly straight between the snout and the anal fin. The length of the head is $3 \frac{2}{5}$ in the total; it is very compressed, the distance between the eyes being one-half only of the width of the orbit. The snout is short, but elevated; the eleft of the mouth horizontal, rather narrow, the upper maxillary extending to the rertical from the anterior margin of the orbit; all the snout scaleless. The nostrils are situated immediately before the eye; they are rather distant from each other, and nearly equal in width. The diameter of the eye is $3 \frac{1}{3}$ in the length of the head, and longer than the greatest width of the præorbital. The præoperculum is distinctly serrated, and eovered with seales to the margin; its posterior limb is nearly vertical and twice as long as the inferior: the angle is rounded. The operculum has a erescent-shaped noteh between two obtuse points. The suprascapula is serrated.

The dorsalis begins above the suprascapula and terminates a little behind the anal; the length of the base of the spinous dorsal is nearly twice as long as that of the soft. The spines are strong, and broader on one side than on the other: the first is two-fifths of the length of the second, the second three-fifths of the third; the fourth is the longest, and $2 \frac{1}{3}$ in the height of the body ; the following decrease in length to the tiirteenth, the last being a little longer than the preceding, and about equal to the second. The soft dorsal has a roundod upper margin, the middle rays being the highest, but rather shortel than the fourth dorsal spine. All the fin is scaleless, and moves in a scaly sheatl. The distanee between the dorsal and caudal fins is nearly one-half the length of the base of the soft dorsal, and less than the height of the tail below the end of that fin. The caudal fin is slightly rounded, sealy at the base, and its length $5 \frac{3}{4}$ in the total. The distance between the eaudal and anal fins equals the length of the base of the latter. The origin of the anal fin falls rertically below the fourth dorsal spine, and its end a little before that of the dorsal; the spines are very strong: the first is one-third of the length of the second, the second is $2 \frac{1}{2}$ in the height of the body; the third is one-third shorter than the former, and broader on the right side than on the left. The soft portion is shorter than the spinous, and the whole fin moves in a scaly sheath. The pectoral is rounded, and shorter than the ventral, the length of which is $4 \frac{2}{3}$ in the total; it reaches to the vent, and its base is situated posteriorly to that of the pectoral.

The scales are of moderate size, one of the largest corering about one-fourth of the eye: they are finely ciliated, and about as high as 
long. Those above the lateral line are rather smaller than those below it, therefore the number of transverse series of scales below that line is less (45). The curvature of the lateral line follows that of the back.

The coloration is uniform brownish, the breast white; all the fins, exeept the pectorals and the caudal, are black. The caudal and the margin of the soft dorsal and anal are white (in spirits).

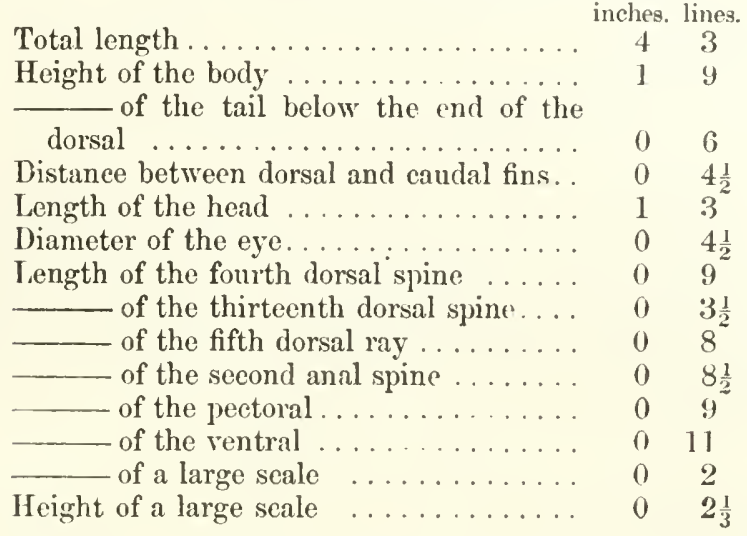

\section{Diagramma griseum.}

Cir. \&. Val. v. p. 306.

$$
\text { D. } \frac{12}{21} \text {. A. } \frac{3}{7} \text {. Vert. } 10 / 16 \text {. }
$$

The height of the body is one-third of the total length, the length of the head one-fourth. Candalis truneated; the second anal spine strong. Uniform greyish. (Cuv.)

Coast of Malabar.

\section{Diagramma pertusum.}

Perea pertusa, Thunberg, Nya Handl. Stockh. 1798, xiv. p. 198. pl. 7. f. 1 (sec. Bloch)

Lutjanus pertusus, Bl. Schn. p. 328.

Diagramma thunbergii, Cur. \& Val. v. p. 308.

$$
\text { D. } \frac{10}{21} \text {. A. } \frac{3}{6}
$$

Uniform brownish (in a dried state).

Japanese Sea.

\section{Diagramma mediterraneum.}

Guichen. Explor. Algér. Rept. et Poiss. p. 45. pl. 3.

D $\frac{12}{17}$. A. $\frac{3}{9}$

The height of the body is three times in the total length, the length of the head $3 \frac{3}{4}$; the diameter of the eye is one-third of the latter. Dorsalis nearly even, caudalis forked. Uniform greyish; fins blackish hrown. (Guich.)

Coast of Algiers. 


\section{Diagramma centurio.}

Cuv. \& I'al. v. p. 308.
D. $\frac{10}{26}$.
A. $\frac{3}{7}$.

Brownish grey; neek, back, dorsal and caudal fins dotted with brown. (Cuv.)

Seychelles.

\section{Diagramma shotaf.}

Sciæna shotaf, Forsk. p. 51.

Diagramma shotaf, Rüpp. Atl. Fische, p. 126, and N. W. Fische, p. 125; ? Cuv. \& Val. v. p. 305.

$$
\text { D. } \frac{14}{19-20} \text {. A. } \frac{3}{7} \text {. }
$$

The height of the body is one-third of the total length, the iength of the head one-fourth. The height of the soft dorsal is one-half of the greatest depth of the body. Caudalis truncated; the second anal spine longer and thicker than the third. Grey, with blackish fins, and two light-blue streaks from the eye on the præoperculum.

Red Sea.

\section{Diagramma fœtela.}

Sciæna foetela, Forsk. p. 51 .

Diagramma flavo-maculatum, (Ekrenb.) Cur. \& I'al. v. p. 304; Rüpp. Atl. Fische, p. 127.

— foetela, Cur. \& V Vul. v. p. 305 (adult); Rüpp. N. W. Fische, n. 125.

$$
\text { D. } \frac{12}{23} \text {. A. } \frac{3}{8} \text {. }
$$

The height of the body is one-third of the total length, the length of the head nearly one-fourth. Along the back two series of rounded yellowish spots; across the opereles sereral yellowish longitudinal bands, continued on the body, but interrupted, and forming spots on the posterior half; the dorsal fin with a yellowish margir and two series of yellowish spots; caudal and anal fns spotted with yellow. Uniform with age.

Red Sea.

\section{Diagramma gaterina.}

Sciæna gaterina, Forsk. p. 50.

Renard, fol. 3. f. 17 .

Holocentrus gaterina, Lacép. iv. p. 347.

Diagramma gaterina, Cur. \&. Val. v. p. 301. pl.125; Rüpp. Atl. Fische, taf. 32. f. 1 .
B. T. D. $\frac{13}{19-20}$.
A. $\frac{3}{7}$.
I. lat. 80 .
L. transv. 12/25. Vert. 11/16.

The height of the body is one-third of the total length, the length of the head nearly one-fourth. The third spine of the dorsal fin and the following four or five nearly equal in height. Caudalis truncated; the second anal spine stronger, but not much longer, than the third. Body and vertical fins with numerous blackish-hrown spots.

Red Sea. 
a. Adult. Red Sea. From the Senckenberg Museum.

b. Adult: stuffed.

The fish mentioned by Sir J. Richardson (Ichthyol. China, p. 227) eannot belong to this species, its numbers being-D. $\frac{14}{15}$. A. $\frac{3}{7}$.

\section{Diagramma pardalis.}

Diagramma pardalis, (Kuhl \& v. Hasselt) Cuv. \&. Val. v. p. 300.
D. $\frac{12}{18}$.
A. $\frac{3}{8}$.
L. lat. 80 .
I. transv. $12 / 22$.

'The height of the body is three times in the total length, the length of the head $3 \frac{2}{3}$; the diameter of the eye is $4 \frac{1}{2}$ in the length of the head, and one-half of that of the snout. The upper maxillary does not extend to the vertical from the front margin of the orbit. Præoperculum with the posterior limb rertical, and the angle rounded, finely and equally serrated. The dorsal fin cannot be entirely concealed in a scaly sheath; it is deeply notshed, with the middle part of the soft portion elevated; the spines are moderate, the fourth the longest, and $2 \frac{1}{2}$ in the length of the head. Caudalis emarginate; the second and third anal spines nearly equal in length, but the former stronger. Head, body, and vertical fins covered with numerous round brown spots; the spinous dorsal edged with deep black; pectoral and ventral fins blackish, the former dotted with brown.

Javanese Sea.

a. Large specimen $\left(15^{\prime \prime}\right)$.

b. Large specimen: not good state: has been in chloride of zinc. Purchased of Mr. Frank.

c. Half-grown: stuffed: bad state.

\section{Diagramma punctatum.}

Diagranima punctatum, (Ehrenb.) Cuv. \& Val. v. p. 302 ; Faun. Japon. Poiss. p. 60; Rüpp. Atl. Fische, p. 126. taf. 32. f. 2, and N. W. Fische, p. 125; Quoy \& Gaim. Voy. Astrol. Poiss.pl. 12. f. 2.p. 699*; Cuv. Regne Anim. Ill. Poiss. pl. 30. f. 3 ; Bleeker, I'erh. Batav. Genootsch. xxiii. Scian. p. 25 (not synonymy).

Holocentrus radjabou, Lacép. iv. pp. 335, 374.

Diagramma cinerascens, Cur. \& Val. v. p. 307 (adult); Rüpp. Atl. p. 127.
B. 7 .
D. $\frac{10}{22-23}$.
A. $\frac{3}{7}$.
L. lat. 85. Vert. 12/15.

The height of the body is $3 \frac{1}{2}$ in the total length, the length of the head $4 \frac{1}{5}$. The width of the eye is scarcely longer than the extent of the snout, and $3 \frac{1}{2}$ in the length of the head. The upper maxillary extends to the vertical from the front margin of the orbit. Præoperculum with the posterior limb vertical, and the angle rounded, finely and equally serrated. The dorsal fin moves in a high scaly sheath, and is even or slightly notched; the spines are moderate, the second and third the longest, half the length of the head. Cau-

* These naturalists give the following numbers: B. 5. D. $\frac{10}{14}$ A. $\frac{3}{7}$, \&e. (!) 
dulis truncated; the sceond and third anal spines nearly equally strong, the latter ratler longer. Body and vertical fins with numerous brown spots, disippearing with age; the dorsal and anal fins with a black margin. Sonctimes light longitudinal streaks at the side of the hearl.

Red Sea ; Trineomalee; Seas of Java and Vanicolo; Sea of China.

a. Arlult: stuffed. Red Sea. From the Senckenberg Musenm.

b. Adult: skin. Ceylon. Presented by E. F. Kelaart, M.D.

c. Adult. China.

d. Adult. China.

$e, f$. Half-grown. From the IIaslar Collcetion.

g. Half-grown: stuffed. From the ('ollection of the Zoological Society.

h. Adult: skeleton. From the Haslar Collection.

The air-bleulder has been deseribed* as simple, but a closer examination has shown me that there are several slender horns in front and on the sides of the anterior quarter. 'Their number differs in different iudividuals from five to eight. They are rather short, and, reaching between the muscles of the ablominal cavity, have here the very peculiar purpose of fixing the air-bladder; they decrease in length postcriorly, and are hollow.

Skeleton.-The maxillary bone scarcely widens at its posterior extremity, but it has the inferior angle produced ; the intermaxillary is a littlo shorter, and has a flat proninence posteriorky, and a drep noteh between this prominence and the process ; its posterior process is broader and stronger than tho bone itself, and of about the sane length, but does not extend to the level of the orbit. The vomer. has anteriorly an angular transverse ridge, as in species with a toothed vomer; its posterior portion is longitudinally grooved. 'I'lue mandibula is elevated, but short, its length slightly exceeding the width of the orbit; the muciferons channel, which is eontained in the lower part of the bone, is nearly entirely closed by the bone, there being two or three small openings only, as is the case with rearly all the rest of the system of muciferous channels. The curlinal bones are very elongate, tubuliform, with a long slit posteriorly and a small opening in front; there is a wide interspaco between these bones to receive the posterior processes of the intermaxillaries. 'The freo margin of tho palatine bone has nearly a vertical direction; the pterygoid reaches to the mandibulary joint, and teminates in a small prominent knob. 'The pre-, meso-, and epitympanic form together an oblong plate, with a central impression and a wide opening between the pre- and epitynipanie.

The occipital erest is very elevated, its horizontal portion being nearly threo times as wide as the vertical, and extending to tho level of the anterior margin of the orbit. 'There are, besidos, two similar erests on each sido from the orbit to the scapulary; they are very developed, the outer being lower and muciferous, and the inner continued into tho upper ordital edgo, which is likewise elevated. Thore are two pairs of openings of molemte width at the anterior extre- 


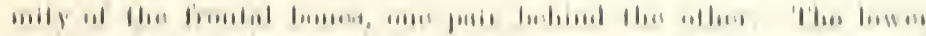

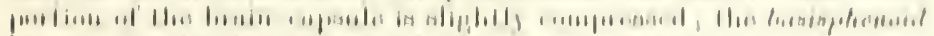

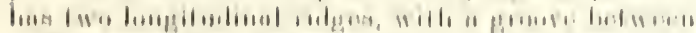

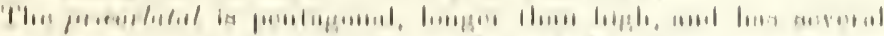

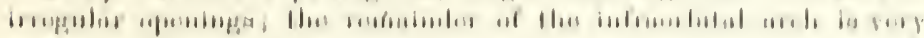
11111111.

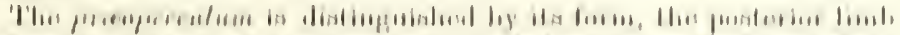

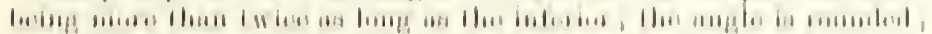

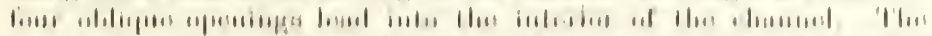

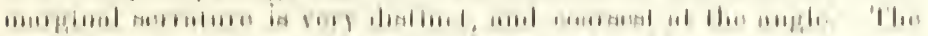

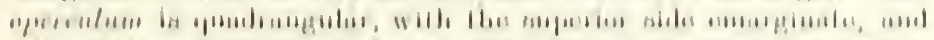

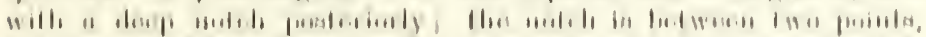

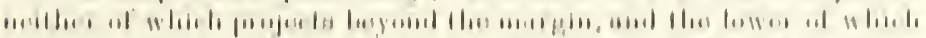

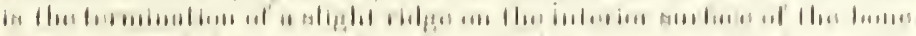

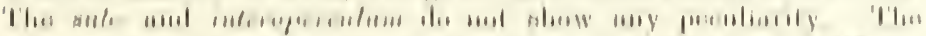

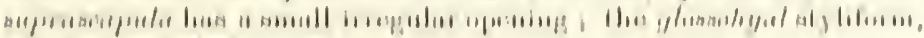

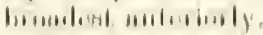

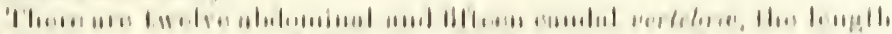

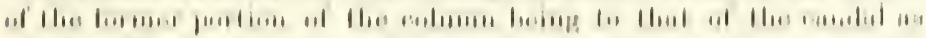

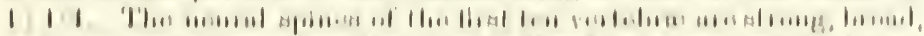

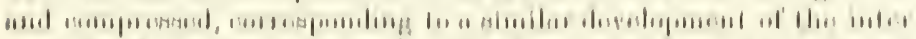

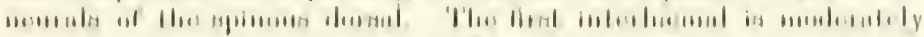

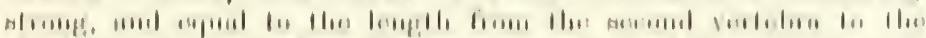

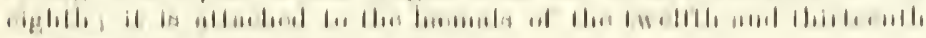
1.11,11110

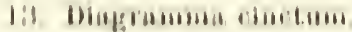

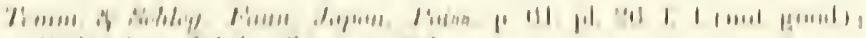

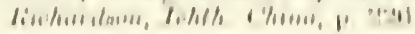

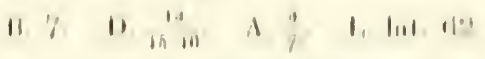

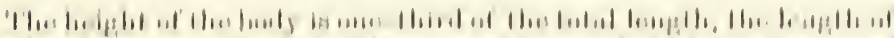

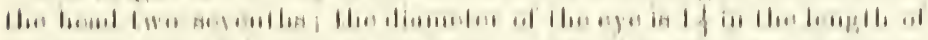

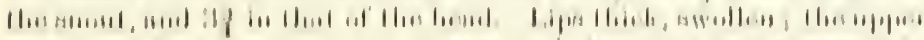

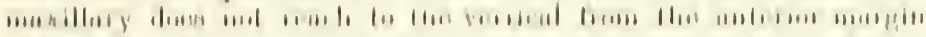

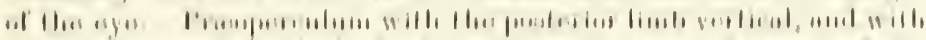

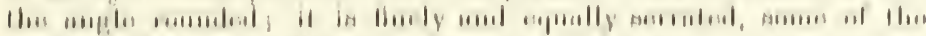

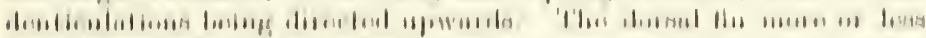

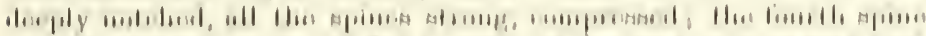

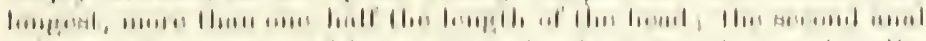

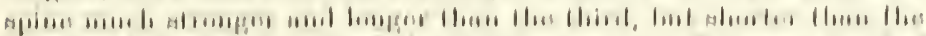

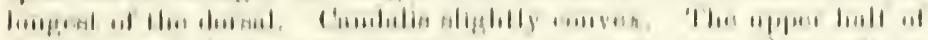

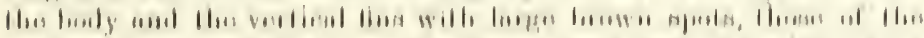

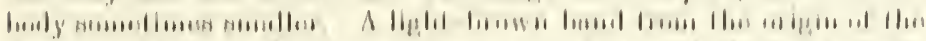

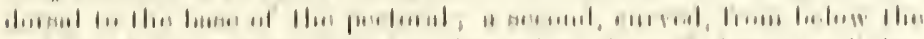

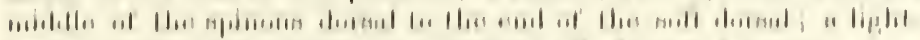

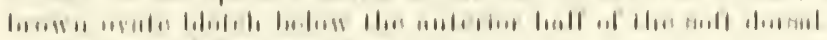

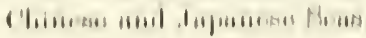

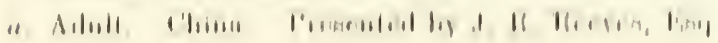


b. Adult: stuffed. China. Presented by J. R. Reeves, Esq.

c. Adult. China.

d. Half-grown. China.

e. Adult: skeleton. China.

f. Adult: stuffed. Japan. Purchased of Mr. Frank.

g. Adult: skin. Nepal? Presented by B. H. Hodgson, Esq.

\section{Diagramma chætodonoides.}

Plectorhynchus chætodonoides, Lacép. iii. p. 135, ii. pl. 13. f. 2.

Lutjanus chætodonoides, Lacép. iv. pp. 195, 243.

Chætodon plectorhynchus, Shaw, Zool. iv. p. 356. pl. 49.

Diagramma plectorhynchus, Cuv. \& Vul.v. p. 294 ; Bleek.Verh. Batav. Genootsch. xxiii. Scicen. p. 24.

$$
\text { B. 7. D. } \frac{12}{19} \text {. A. } \frac{3}{7-8} \text {. Cæc. pylor. } 12 \text {. }
$$

The height of the body is $2 \frac{1}{2}$ in the total length. The dorsal spines of moderate length and strength, the second of the anal fin rather long and strong. Brownish black, with nine white blotehes on each side, each with a blackish centre. The soft dorsal and the anal white, with black spots; the spinous dorsal blackish, with a whitish margin; pectoral and ventral fins black.

Sea of Batavia.

Cuvier considers a fish in the Collection of the Leyden Muscum as a variety of this species: it has a whitish ground-colour, the back marbled with blackish; a whitish spot in front of the ventral tins, another behind the pectoral, a third, round, above the anal, and a fourth, square, occupying the tail ; the vertical fins black-spotted.

\section{Diagramma pica.}

Seba, iii. 26. 31 .

Diagramma pica, Cuv. \& Val. v. p. 297.

$$
\text { D. } \frac{12}{21} \text {. A. } \frac{3}{7} \text {. L. lat. } 85 \text {. }
$$

The height of the body is $3 \frac{1}{2}$ in the total length ; the dorsal spines one-fourth of the height of the body. Three large white spots on each side, one across the muzzle, one across the neck, and a third near the end of the spinous dorsal; belly and lower parts of the sides white, notched by the black coloration of the back. Dorsal fil black, above the white spot white; candal white, with irregular black bands and spots. (Cuv.)

Sea of Otaheiti.

\section{Diagramma orientale.}

Anthias orientalis, Bloch, taf. 326. f. $3 ; \mathrm{Bl}$. Schn. p. 306.

Lutjanus aurantius, Lacép. iv. p. 239.

Serranus orientalis, Cur. \& Val. ii. p. 318. 
Diagramma orientale, Cuv. \&. Val. v. p. 299. pl. 124; Bleeker. Verh. Bat. Gen. xxiii. Scian. p. 23.

- sibbaldii, Benn. Proc. Zool. Soc. 1832, p. 182.

$$
\text { D. } \frac{13}{17-18} \text {. A. } \frac{3}{8} \text {. L. lat. } 65 \text {. }
$$

The height of the body is $3 \frac{1}{2}$ in the total length, the length of the head $4 \frac{1}{2}$. Dorsal fin notched; spines moderate, the second anal spine stronger and longer than the third. A white spot across the muzzle, another across the neck, a third near the end of the spinous dorsal, a fourth round the tail; belly of white colour, extending on several parts of the side of the body; dorsal fin black, above the white spots white. Candal white, with a black longitudinal streak, and with blackish margins.

Seas of Ceylon and Bali.

a. Half-grown. Ceylon. From the Collection of the Zoological Society. Type of Diagramma sibbaldii.

\section{Diagramma pictum.}

Seba, iii. 26. 32 (very bad).

Perca picta, Thunb. Nya Handl. xiii. p. 141. pl. 5.

Grammistes pictus, $B l$. Schn. p. 190.

Lutjanus pictus, Lacép. v. pp. 687, 688.

Diagramma pictum, Cuv. \& Val. v. p. 315 ; Faun. Japon. Poiss. p. 62 ; Richardson, Ichth. China, p. 227.

Plectorhynchus balteatus, Cant. Catal. p. 78.
D. $\frac{9-10}{23}$.
A. $\frac{3}{6}$.
L. lat. ca. 95 .
Cæc. pylor. 5 .

The height of the body is $3 \frac{1}{3}$ in the total length, the length of the head $4 \frac{1}{3}$; the diameter of the eye is $3 \frac{2}{3}$ in the latter. The dorsal fin is slightly notched, and has the second spine elevated, $\frac{2}{3}$ or $\frac{3}{4}$ of the greatest depth of the body. Caudalis convex. The second anal spine stronger and a little longer than the third. Belly yellowish; back and sides brown, with four (in varieties with less or more) white longitudinal bands. The first from the muzzle along the median line of the crown, bifurcating on the neck into two bands, one on each side; the lateral part runs to the anterior part of the soft dorsal, sending upwards a vertical portion to the first three dorsal spines. The second band, broader, from the nostril above the eye to the back of the tail, continued on the last rays of the dorsal, as well as on the upper part of the caudal. The third from the lower margin of the orbit to the lower part of the caudal. The fourth, indistinct from the yellowish coloration of the belly, from the snout to behind the anal fin. The spinous dorsal black, between the first three spines white; the soft portion with a broad white longitudinal band, and with the posterior rays white. The caudal with a broad black median band, and with two oblique ones of the same colour on each lobe; the anterior half of the anal black, the remainder white; pectoral colourless, ventral black in the outer half.

Coast of Pondicherry; Seas of Pinang, Java, and Amboyna; Chinese and Japanese Seas. 
a. Half-grown. China. Presented by Sir J. Richardson.

b. Half-grown. Japan. I'urchased of Mr. Frank.

c. Half-grown. Amboyna. Purchased of Mr. Frank.

d. Half-grown.

e. Young. From the Haslar Collection.

$f, y$. Half-grown: dried: not good state.

There can be no doubt that the fish described by Dr. Cantor as Plectorhynchus balteatus belongs to the typical form of Diagramma pictum. He appears to have been misled by his specimens exhibiting twenty-three rays of the dorsal, and the length of the second dorsal spine being contained 3 in the depth of the body, which is really more in aceordance with Cuvier's description of Diagramma balteatum. But, on the other hand, the coloration is exactly the same as in $D$. pictum, and differing from $D$. balteatum; and Cuvier does not mention anything about the height of the dorsal spines of $D$. pictum. In fact, the height of these spines appears to vary very much; and I fully believe that $D$. balteatum is a varicty of $D$. pictum, so that Dr. Cantor's mistake appears to be of no great consequenee.

Var. A.

h, i. Adult. Madras. Presented by J. C. Jerdon, Esq.

I consider these two specimens as a variety of $D$. pictum. The form of the body is the same, the second anal spine three-fifths of the height of the borly. Six white longitudinal bands on each side: the first as in the typieal specimens; the seeond (additional) narrow and short from the crown of the head, lost on the anterior third of the body; the third like the second in the type; the fourth (additional) from the mirldle of the eye to the root of the caudal; the fifth and sixth like the third and fourth in the type. On the dorsal the white band of the soft portion is continued on the spinous; the membrane between the first three spines white; on the other fins the black colour predominates; pectorals colourless. These specimens hare nine dorsal spines.

Var. B. Diagrama balteatum.

Diagramma balteatum, (Fuhl \&. v. Hass.) Cuv. \& Val. v. p. 316.

$$
\text { D. } \frac{10}{23} \text {. A. } \frac{3}{7} \text {. }
$$

The height of the body is $3 \frac{1}{3}$ in the total length, the length of the head $4 \frac{1}{3}$. The dorsal fin is slightly notehed, and the second spine is $\frac{3}{4}$ as high as the body. Caudalis convex. Belly yellowish; back and sides brown, with a white spot beneath the first three dorsal spines. One white band from abore the eye to the upper half of the caudal; the remainder of the eaudal black. Dorsal black, with a white longitudinal band along the middle, and with the posterior part white.

Sea of Java.

$k, l$. Half-grown. China or Borneo? Presented by Sir Eiward Beleher. 


\section{Diagramma pœcilopterum.}

Diagramma poecilopterum, Cuv. \& Val. v. p. 314 ; Faun. Japon. Poiss. p. 61 .

$$
\text { D. } \frac{9}{23} \text {. A. } \frac{3}{5} \text {. }
$$

White, with six or seven black longitudinal bands, alternately complete and interrupted; dorsal and caudal with round or irregular black spots; anal and ventrals black.

Coast of Pondicherry; Trineomalee; Molucea Sea ; Japanese Sea.

\section{Diagramma lessonii.}

Cuv. \& Val. v. p. 313 ; Less. Voy. Coq. Zool. ii. p. 199. pl. 24 (bad); Bleek. Batar. p. 463.
B. 6.
D. $\frac{12(-13)}{19}$.
A. $\frac{3}{7}$
L. lat. 90 .

The height of the body is $3 \frac{1}{4}$ in the total length, the length of the head $4 \frac{1}{4}$; the diameter of the eye is $3 \frac{1}{4}$ in the latter. Dorsalis even, the third, fourth and fifth spines longest; $2 \frac{1}{2}$ in the length of the head. Caudalis truneated; the second anal spine longer and stronger than the third. Baek and sides blackish brown, with five whito longitudinal bands (on the head six); belly whitish. All the bands meet those of the other side on the erown and muzzle: the first from the nape to the first dorsal rays; the second from the erown to the middle of the base of the soft dorsal ; the third from the upper margin of the orbit to the back of the tail; the fourth from the lower posterior angle of the orbit to the middle of the root of the eaudal; the fifth from the lower margin of the orbit to the lower part of the tail ; the sixth on the head only, from the snout to the base of the pectoral. The spinous dorsal blackish brown, with a serrated, white, broad longitudinal band, continuing near and along the upper margin of the soft dorsal, but narrower. The soft dorsal yellowish, with a brownish-black narrow edge, besides the white band and large round brown spots; dorsal and anal largely spotted with brown; peetoral not coloured; ventral with the outer half brown.

Waigiou ; Amboyna.

a. Fine speeimen. Amboyna. Purchased of Mr. Frank.

\section{Diagramma blochii.}

Anthias diagramma, $B l$. tab. 320 .

Gramnistes diagramma, $\mathrm{Bl}$. Schn. p. 184.

Sparus diagramma, Shaw, Zool, iv. p. 440. pl. 65.

Diagramma blochii, Cuv. \&. Val. v. p. 312.

Plectorhynchus blochii, Cantor, Catal. p. 77.

$$
\text { B. } 6 . \quad \text { D. } \frac{10}{23} \text {. A. } \frac{3}{7} \text {. }
$$

The seeond, third and fourth dorsal spines equal or even slightly execed one-half of the height of the body ; the seeond and third anal spines equal the length of the tenth dorsal spine, and slightly exeeed one-third of the height of the body. Yellow : from between the cyes 
a longitudinal brown band following the back, continuing above the base of the soft dorsal fin; a second from the muzzle above the orbit, dividing in two portions, which again unite above the middle of the pectoral fin, and continue straight to the posterior part of the soft dorsal; a third, the broadest, from the eye straight to the root of the caudal; a fourth, under and parallel to the latter; a fifth and sixth, of lighter brown, from the muzzle to the posterior part of the abdomen; a seventh, similar, from the gill-opening to the posterior part of the root of the caudal fin. The margin of the dorsal black; between the root of the third and fourth dorsal spines a black spot; from the point of the second to the base of the eighth spine, a broad oblique black band, continuing straight to the middle of the soft dorsal, where it unites with the first band of the body, and thus continues to the posterior part of the fin; eaudal orange, with scattered irregular black spots; anal and ventral greyish, posterior part black; pectorals orange, with a black band across the root, the centre, and the point. ( Cant.)

Seas of Ceylon and Pinang.

?a. Adult: skin : not good state. East Indies.

\section{Diagramma albovittatum.}

Rïppell, N. W. Fische, p. 125. taf. 31. f. 2 ; Bleek. Act. Soc. Sc. IndoNederl. i. Man. en Makass. p. 46.
B. 6 .
D. $\frac{13}{18}$.
A. $\frac{2}{6-7}$.
L. lat. 75-80.

The height of the body is $3 \frac{1}{2}$ in the total length, the length of the head four times. Dorsal fin nearly even, caudal slightly rounded. Brown, with three white bands on each side: the first from the vertex along the base of the spinous dorsal to the last dorsal spine; the seeond from above the eye to the back of the tail; the third from below the eye to the inferior side of the tail. Fins yellowish; the soft dorsal with two brown longitudinal bands; the caudal fin with a median band, and two oblique ones on each lobe, all of a brown colour.

Red Sea; Sea of Manado.

\section{Diagramma lineatum.}

Sebu, iii. 27. 18; Bem. Ceyl. Fish. p. 13. f. 13.

Perca diagramma, L. Gm. p. 1319.

lineata, L. Gim. p. 1319.

Sciana lineata, I. Mres. Ad. Frid. t. 31. f. 4.

- abu mgaterin, Forsk. p. 51.

Grammistes lineatus, I3l. Schn. p. 186.

Diagramma lineatum, Cuv. \& Vul.v. p. 309 ; Bleek. Amboinu, iii. p. 22.

$$
\text { B. 6. D. } \frac{12}{20} \text {. A. } \frac{3}{7} \text {. L. lat. } 75 \text {. }
$$

'The height of the body is $3 \frac{1}{2}$ in the total length, the length of the head $4 \frac{1}{2}$. The fourth dorsal spine longest, about half the depth of the body; caudalis rounded; the second anul spine longer than the 
third. Brown, with six yellowish longitudinal bands : the first along the middle of the neck and occiput; the second from the eye to the middle of the base of the soft dorsal; the third, broader, from the eye to the back of the tail, and continuing on the caudal ; the fourth from the eye to the root of the caudal; the fifth from the snout to the lower pant of the caudal; the sixth from the mouth to the anal. Fins yellow; the anal and dorsal fins with a basal and marginal black band, the basal of the latter widening posteriorly, and extending to the top of the soft portion; caudal fin with a median black band, and with two other oblique ones on each lobe; pectoral with three spots, ventral with one large brown spot.

\section{Diagramma radja}

Bleeker, Amboina, iv. p. 366.
B. 6.
D. $\frac{13}{19}$.
A. $\frac{3}{7}$.
L. lat. 75 .

The height of the body is $3 \frac{1}{2}$ in the total length, the length of the head $4 \frac{1}{3}$; the diameter of the eye is $3 \frac{1}{4}$ in the latter; the fourth and fifth dorsal spines longest, one-third of the height of the body. Caudalis rounded; the second anal spine longer than the third. Yellow, with eight or nine black longitudinal bands, the fourth of which runs from the eye to the caudal. The spinous dorsal with a basal and with a marginal black band, continued on the soft portion; the caudal with a median longitudinal band, and with four or five oblique streaks above and beneath; the anal with some blackish spots; pectoral with a blackish spot at the base; ventral immaculate. $(B l$.

Sea of Amboyna.

Seba, iii. 27. 17.

\section{Diagramma sebæ.}

Diagramma sebæ, Bleek. Verh. Batav. Genootsch. xxiii. Scian. p. 24.
D. $\frac{13}{18}$.
A. $\frac{3}{7}$.
L. lat. 80 .

The height of the body is $3 \frac{2}{3}$ in the total length, the length of the head four times; the diameter of the eye is $3-3 \frac{1}{2}$ in the latter. The second, third and fourth dorsal spines are the longest, and $2 \frac{2}{3}$ or three times in the height of the body, the last is the shortest; the second spine of the anal tin longest, and one-third of the height of the body. Caudalis truncated. Yellowish, with seven brown longitudinal bands; the vertical fins black-edged and spotted with blackish ; pectoral and ventral fins yellow, the former with a red spot at the base. $(B l$.

Sea of Batavia and Banda Neira.

\section{Diagramma goldmanni.}

Blecker, Ternate, ii. p. 602.
B. 6 .
D. $\frac{12}{19}$.
A. $\frac{3}{7}$.
L. lat. $65-70$.

The height of the body is $3 \frac{2}{5}$ in the total length, the length of the 
head $4 \frac{1}{4}$; the diameter of the eye is about one-third of the latter ; the third and fourth dorsal spines longest, nearly one-third of the height of the body. Caudalis truncated; the seeond anal spine searcely longer than the third. Yellow, with ten or eleven blackishbrown oblique longitudinal bands edged with blue: the first from the middle of the nape to the base of the fourth dorsal spine; the second and third from above the head to the base of the spinous dorsal; the fourth, fifth and sixth from the eye to the base of the soft dorsal ; the seventh from below the eye to the end of the dorsal ; the eighth from below the eye to the eaudal; the ninth from the mouth to the eaudal; the tenth along the belly. Dorsal fin above black-edged, and with a series of round black spots. Caudal and anal fins without bands, with a few large blaek spots; pectoral and ventral fins immaculate, above the base of the former a large sanguineous spot. $(B l$.

Sea of Temate.

\section{Diagramma hæmatochir.}

Blecker in Natuurk. Tydschr. Nederl. Indie, 1854, p. 175.

$$
\text { B. } 6 \text {. D. } \frac{12}{20} \text {. A. } \frac{3}{7} \text {. L. lat. } 80 \text {. }
$$

The height of the body is $3 \frac{3}{4}$ in the total length, the length of the head $4 \frac{1}{2}$; the diameter of the eye is one-fourth of the latter: the third and fourth dorsal spines longest, nearly one-third of the height of the body. Caudalis truneated. Yellowish; the snout brownish, with two white, eurved eross-bands between the eyes; on each side about seventeen oblique blackish-brown bands: one along the middle of the neck, eight from the head to the baek, and the others from the side of the belly to the baek; no bands below the eye. The vertieal fins black-edged; the spinous dorsal with one series of, blackishbrown spots, the soft with two ; eaudalis with numerous, analis with searee spots. A large sanguineous spot above the base of the pectoral fin. ( $B l$.)

Sea of Ternate.

\section{Diagramma polytænia.}

Blecker, Celebes, iii. p. 755 (not Solor, p. 68).

$$
\text { B. } 6 . \quad \text { J) } \frac{12}{22} \text {. A. } \frac{3}{7} \text {. L. lat. } 100 \text {. }
$$

The height of the body is $3 \frac{1}{2}$ in the total length, the length of the head $4 \frac{1}{5}$; the diameter of the eye is $3 \frac{2}{3}$ in the latter; the third, fourth and fifth dorsal spines longest, one-third of the height of the body. Caudalis truneated; the seeond anal spine longer than the third. Yellow, with nine bluish-white longitudinal bands edged with black, the four upper ones terminating at the base of the lorsal, the four next at the caudal, the lowest near the amus. (Bl.)

Sea of Macassar. (Port lissington.)

a. ? Adult: skin: not good state. Port lissingrton. Presented by the Earl of Derhy. 


\section{Diagramma polytænioides.}

Diagramma polytenia, Bleck. Nutuurk. Tydsehr. Nederl. Indie, r. p. 68 (not l. c. iii. p. 755).

__ polytienioides, Bleek. l.c. vi. p. 377 .
B. 6 .
D. $\frac{12}{21}$.
A. $\frac{3}{7}$.
L. lat. 85 .

The height of the body is $3 \frac{2}{3}$ in the total length, the length of the head $4 \frac{2}{3}$; the diameter of the eye is $3 \frac{1}{2}$ or $3 \frac{2}{3}$ in the latter. The fourth dorsal spine longest, rather longer than one-thind of the height of the body; the second anal spine longer than the third. Yellow, with nine bluish-white longitudinal bands edged with brown; the three upper ones runuing from the crown to the base of the dorsal fin; the fourth, fifth and sixth from the side of the head to the caudal fin; the seventh and eighth from the head to the anal; the ninth from the head to the belly. The caudal brownish violet, with nine or ten obliquo bluish-white streaks; the other fins yellow: the pectorals with three brownish eross-bars; the anal with two or three white oblique bands; the soft portion of the dorsal with three brown longitudinal bands.

Sea of Solor ; Amboyna.

a. Fine specimen. Amboyna. l'urehased of Mr. Frank.

b. Adult. Amboyna. Purchased of Mr. Frank.-I consider this specimen as a variety of $D$. polytemioides. It has six white longitudinal bands only, but the same numbers of the fins, the same spinous dorsal fin of nearly uniform yellow, and two crossbars on the pectorals.

\section{Diagramma chrysotænia.}

Blecker, Celebes, viii. p. 303.

$$
\text { J. 6. D. } \frac{13}{20} \cdot \text { A. } \frac{3}{7} \text {. L. lat. } 65 \text {. }
$$

The height of the body is $3 \frac{2}{5}$ in the total length, the length of the head one-fourth; the diameter of the eye is one-third. of the length of the hear. Caudalis subtruncated; the second anal spine longer and stronger than the third. Above bluish; on each side eight orange-coloured longitudinal bands: the first from the neck along the base of the spinous dorsal, continuing on the soft portion of this fin; the second from the forehead, extending on the posterior quarter of the soft dorsal; the third from the snout above the cye and the lateral line to the back of the tail; the fourth from the eye to the upper half of the root of the caudal; the fifth from the eye to the middle of the caudal; the sixth from below the eye to the lower half of the root of the caudal; the seventh from the mouth to the lower margin of the caudal; the eighth from the mouth to the base of the anal. A median yellow band from the snout to the origin of the dorsal. The dorsal and caudal fins brown-edged; the spinous portion of the former with two, the soft with three yellow longitudinal bands; the other fins yellow. (Bl.)

Sea of Macassar. 


\section{Diagramma reticulatum.}
D. $\frac{13}{21-22}$.
A. $\frac{3}{7}$.
L. lat. 85 .
I. transv. 1:3/25.

The height of the body is $3 \frac{1}{4}$ in the total length, the length of the lead four times. Caudalis trumeated; tho second anal spine is stronger, but scarcely longer than the third. Brownish grey (in a dried state), reticulated with durker waved lines; three longitudinal bands on the opereles.

Chinese Seas.

a. Adult: stufled. China. Presented by J. R. Reeves, Esq.

b. Adult: stufled. Chinu. Purchased of Mr. Warwick.

Description.-I'he greatest depth of the body is above the pectoral fins, where it is contained $3 \frac{1}{4}$ in the total length; the upper profile descends parabolically from the fifth dorsal spine to the mouth. The cleft of the mouth is horizontal and rather small, the upper maxillary not extending to the anterior margin of tho orbit. 'The snout is mueh longer than the dimmeter of the eye, which is one-fourth of the length of tho head. The lips are thick and Heshy. 'The scales above extend to between the nostrils, laterally on the posterior portion of the proorbital. 'The scales of the eheek are very small, and cover the propoperculum to its margin. The prosopereulum is distinetly and equally serrated, and has the angle and the inferior limb rounded. The operculum has two obtuso points, with a slight noteh between. Supraseapula serrated.

'The dorsal fin begins above the supraseapula, and ends above the middle of the distunee between the anal and caudal fins; the length of its spinons portion is rather more than thit of the soft, and the distance from the caudul fin equals that between the first and fifth dorsal spines. The upper margin is continuous and slightly waved. The spines are of modernte strength, on one side broader. The first spino is threo-fifths of the length of the second, the seeond threequarters of the third, the third rather shorer than the fourth, fifth and sixth, which aro the longest, and about $3 \frac{1}{1}$ in the height of the body. 'The posterior spines gradually deerease in length, the last being about equul to the second. The first ray is longer than the preceding spine; the following rays become gruduuly longer to the tenth, which, together with the following threo or four, form the highest portion of the fin, cren higher than the longest spine; the posterior rnys decreaso again in length, and form a rouncted angle of the fin. The spinous portion moves in a sealy shenth, which becomes deeper and more conspicuous from the seventh spine: the soft portion is covered with senles for lalf its hright.

'The caudal fin is truncraterl ; one of its longest rays is one-fittl of the total length. Minute seales extend between the rays to one-half of the length of the fin. 'The origin of the and fiu fulls vertienlly below the fifth ray of the dorsil, and the end below the fourteenth: the length of its base is rnther more than one-half of its distanee from the eauchl. 'The first spine is small; the second strong, and equal to the longest ray of the dorsal: the third is rather shorter and mueh thimer. 'The first thee rays exceed the spoines in length, 
and form, with the other shorter ones, a rounded margin. One-half of the fin is thickly covered with scales. The pectoral is slightly rounded, and its length $6 \frac{1}{3}$ in the total. The ventral is rather shorter; its base falls immediately behind that of the peetoral; the spine is moderate, about two-thirds the length of the fin. Both the latter fins are far distant from the vent.

The scales are rather small, etenoid; the lateral line is very slightly curved.

The teeth of the jaws are in villiform bands, the outer row containing rather larger ones.

The coloration is now brownish grey, with darker stripes, waved and anastomosing; the stripes have a more longitudinal direction on the anterior part of the body, and a more oblique one in the middle and posteriorly. There are three indistinct bands across the operculum.

\begin{tabular}{|c|c|c|}
\hline \multicolumn{3}{|c|}{ inches. lines. } \\
\hline Total length ..... & 11 & 2 \\
\hline Height of the body. . & 3 & 5 \\
\hline Length of the head $\ldots \ldots \ldots \ldots \ldots$ & 2 & 9 \\
\hline - of the fourth dorsal spine ....... & 1 & $0 \frac{1}{2}$ \\
\hline - of the thirteenth dorsal spine .... & 0 & 9 \\
\hline - of the eleventh dorsal ray....... & 1 & $2 \frac{1}{2}$ \\
\hline - of the longest caudal ray ....... & 2 & $2^{2}$ \\
\hline - of the second anal spine $\ldots \ldots \ldots$ & 1 & 2 \\
\hline Distance between eaudal and dorsal fins .. & 1 & 0 \\
\hline - between anal and caudal fins .. & 2 & 0 \\
\hline
\end{tabular}

31. Diagramma nitidum. (Plate XIX. fig. B.)

D. $\frac{12}{20}$. A. $\frac{3}{7}$. L. lat. 95 . L. transv. $20 / 25$.

The height of the body is $3 \frac{1}{5}$ in the total length, the length of the head four times. Caudalis truncated. The second anal spine stronger, but seareely longer, than the third. Reddish brown' (in spirits), with six bluish, darker-edged, parallel, longitudinal bands : the first from the nape to the origin of the soft dorsal; the seeond from abnve the eye to the posterior third of the soft dorsal; the third from the eye on, and above, the lateral line to the baek of the tail; the fourth from the eye below the lateral line to the middle of the tail; the fifth from below the eye to the inferior part of the caudal; the sixth from the mouth over the root of the pectoral to the end of the anal fin.

a. Australia. Presented by the Earl of Derby.

Description of the specimen.-The greatest depth of the body is above the pectoral fins, where it is contained $3 \frac{1}{5}$ in the total length ; the upper profile descends parabolically from the third dorsal spine to the mouth. The cleft of the mouth is horizontal and small, the upper maxillary not extending to the anterior margin of the orbit. The diameter of the eye is one-third of the length of the head, and 
more than the extent of the snout (perhaps in younger individuals only). There are three pairs of minute pores near the symphysis of the lower jaw. The scales above extend to between the nostrils, laterally nearly over all the præorbital. The scales of the check are not much smaller than those of the opereulum, and cover the præoperculum to its margin. The preopereulum is distinctly and equally serrated, and has the angle and the inferior limb rounded; its posterior limb descends in a slightly oblique direction forwards. The operculum has two obtuse points with a slight notch between. Suprascapula serrated.

The dorsal fin begins above the base of the pectoral, and the vertical from its posterior end falls nearer to the anal than to the eaudal; the length of its spinous portion is rather longer than that of the soft, and the distance from the caudal fin equals that between the first and sixth dorsal spines. The upper margin is continuous and slightly waved. The spines are of moderate strength, on one side broader. The first spine is one-half the length of the second, the seeond three-fifths of the third, the third rather shorter than the next four, which are the longest, and about $3 \frac{1}{3}$ in the height of the body. The posterior spines scarcely decrease in height, the last being equal to the third. The first ray is rather longer than the preceding spine, and the following gradually become higher to the tenth, which forms the highest point of the fin-higher than the spinous dorsal; from thence they decrease again, forming a rounded angle of the fin. The spinous portion moves in a scaly sheath, which becomes deeper and more conspicuous from the fourth spine; the soft portion is covered with seales for half its height.

The caudal fin is truncated; one of its longest rays is one-fifth of the total length. Ninute scales extend between the rays to one-half of the length of the fin. The origin of the anal fin falls vertically below the sixth ray of the dorsal, and the end below the elerenth: the length of its base is one-half of the distanee from the caudal. The first spine is small; the second strong, and equal to the longest ray of the dorsal; the third is rather shorter and moroslender. The first three rays exceed the spines in length, and form, with the other shorter ones, a rounded margin. One-half of the fin is thickly eovered with seales. The pectoral is slightly rounded, and its length is onesixth of the total; the ventrul has the same length, and cxtends to the vent. Its base falls immediately behind that of the pectoral. The spine is moderate, about two-thirds of the length of the fin.

The scales are small, ctenoid. The lateral line is slightly curred.

The teeth of the jaws stand in rilliform bands, the outer row containing rather larger ones.

To the description of the colours given above, must be added, that the fins appear to be immaculate, and that the lower portion of the side of the head is silvery shining.

Total length inches. lines.

Ileight of the body 46

lingth of the head

15

12 
Diameter of the eye ........... (1) ;

Length of the fifth dorsal spine....... () is

\begin{tabular}{|c|c|}
\hline 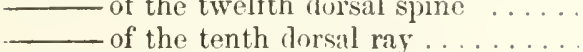 & 0 \\
\hline - of the longest candal ray ....... & \\
\hline - of the seeond anal spine & \\
\hline Distance between dorsal and candal fins & \\
\hline
\end{tabular}

\section{HYPEROGLYPHE*}

Diagramma, sp., Richerds. Erad. \&. Terr. Fishes, ]. 20.

Body oblong, compressed. Eye moderate. Snout blunt; cleft of the mouth obliepe, with the upjer jaw longer. Two dorsals, seareely united, the first much lower than the second, with eight short spines; anal fin with very feeble spines. l'ieorlbit:l and prooperculum serrated; opereulum spiniferous. Seven branchiostegals. Jaws with the tecth in villiform bands, without canines. lioof of the mouth with a deep longitudinal groove. Scales small, eycloid. (Pharyngeal bones separated from each other.) Air-bladder simple; pylorie appendages in great number.

Coasts of Australia.

\section{Hyperoglyphe porosa.}

Diagramma porosa, Richards. Erab. \&. Terr. Fishes, p. 20, f. 5, 6.

$$
\text { 3. 7. D. } 8 \mid \frac{1}{20} \text {. A. } \frac{3}{16} \text {. L. lat. } 95-100 \text {. }
$$

the upper maxillary reaches to below the niddle of the eye ; both limbs of the præoperculum ciliated. Caudalis slightly cmarginate. Uniform brown (in spirits); the soft dorsal and anal fins with two series of dark-brown spots.

Coasts of Australia.

a. $5 \frac{1}{2}$ "long. From the Haslar Collection.

\section{LOBOTES†.}

Lobotes, Cur. Règne Anim.; Cur. \&. I'al. v. p. 318.

Form of the body and of the vertieal fins rather elevated. Ey rather small. Snont blunt, with the lower jaw longer and the eleft of the mouth oblique. One dorsal, with twelve spines, the anal tin with three. Candalis rounded. No canines (inferior pharyngeal bones separated). I'ropopereulum denticulated; opereulum with ol)-

* From irme $\rho$, above. and $\gamma \lambda \eta \phi \dot{y}$, groore.

† 1. Lobotes citrinus. Rivhards. Ichth. China. p. 237 .

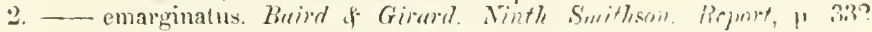
(Cniterl States). does mot appene to bolongr in this gomens 
tuse points. Scales moderate, ctenoid. Branchiostegals six. Airbladder simple; pyloric appendages few. Pseudobranchiæ developed. Atlantic Cnasts of America. Indian Seas.

\section{Lobotes auctorum.}

Holocentrus surinamensis, $B l$. taf. $243 ; B l$. Schn. p. 316.

Bodianus triurus, Mitch. Trans. Lit. \& Phil. Soc. New York, i. p. 418. pl. 3. f. 10.

Lobotes surinamensis, Cuv. \&.Val.v.p. 319 ; Lekay, New York Fauna, Fishes, p. 88. pl. 18. f. 49 ; Holbr. Ichth. S. Carol. p. 159. pl. 23. f. 2.

Lobotes erate, Cur. \& Val. v. p. 322 ; Bleek. Verh. Bat. Genootsch. xxii. p. 4, and xxrii. Scicen. p. 26 ; Cant. Catal. p. 80 ; Cuv. Règne Anim. Ill. Poiss. pl, 31. f. 1 .

__ farkharii, Cur. \& Val. v. p. 324.

- somnolentus, Cuv. \&. Val. v. p. 324.

_- incurvus, Richards. Ichth. Chin. p. 237.

D. $\frac{12}{15-16}$. A. $\frac{3}{11}$. L. lat. 45 . Cxc. pylor. 3. Vert. 13/11.

Caudal fin rounded; the soft dorsal and anal fins rather elevated; nape concave; eye small. Uniform brownish, yellowish, or blackish; caudal fin sometimes with a lighter edge.

Atlantic coasts of America from New York to the coast of $\mathrm{Su}$ rinam; Caribbean Sea. Ceylon; Bay of Bengal; Sunda, Molucca, and Chinese Seas.

As in all fishes which attain to a considerable size, the individuals of this species are subjected to some modifications of several external characters; for instance, of the denticulations of the præoperculum, of the colours, and of the height of the fins. I eannot find any determinable difference between specimens from the old and new world. Lobotes incurvus is founded on a half-grown specimen, with the vertical fins scarcely longer than usual.

a. 22" long: stuffed. North $\Lambda$ merica. Purchased of Mr. Warwick.

b. Half-grown. Cuba. From the Collection of the Zoological Society. c, d. Adult and half-grown: skins. Jamaica. From J)r. Parnell's Collection.

e. 22" long: stuffed. Calcutta. Presented by E. Blyth, Esq.

f. Half-grown: stuffed. China. Presented by J. R. Reeves, Esq.

-Original specimen of Lolotes incurvus.

g. Half-grown : stuffed. India. Purchased of Mr. Warwick.

h. Half-grown: stuffed.

\section{DATNIOIDES.}

Datnioides, Blecker, Naturk. Tydschr. Nederl. Indie, 1853, v. p. 440.

Body elevated. Eye moderate. Intermaxillaries very protractile, their posterior processes extending to the occiput. One dorsal fin, with a deep notch and twelvo spines; the anal fin with three; all the spines very stout; caudalis rounded. Praoperculum serrated, opereulum with short spines. Seales moderate or rather small, 
etenoid. Six branchiostegals. Pseudobranchiæ. (The lower pharyngeal bones separated.) Air-bladder simple.

East Indian rivers.

\section{Datnioides polota.}

Coius polota, Buch. Ham. pp. 95, 370. pl. 38. f. 31 ; Faun. Japon. Poiss p. 17 ; Richards. Ichth. Sulph. p. 83.

binotatus, Gray, Ind. Zool. Pisc. pl. 2. f. 2 ; Faun. Japon. I'ouss. p. 17 ; Richards. Ichth. Sulph. p. 83.

Datnia polota, Cantor, Catal. p. 16.

Lobotes hexazona, Bleek. Natuurk. Tyds. Ned. Ind. i. p. 9, ii. p. 165.

Datnioides polota, Bleek. l.c. v. p. 441.
B. 6 .
D. $\frac{12}{13}$.
A. $\frac{3}{8-9}$.
L. lat. 70 .

Greenish, with eight blackish cross-bands.

Estuaries of the Ganges; rivers of Borneo and Sumatra.

a. Adult. Borneo.

$b-h$. Half-grown and young. India.

i. Young. India. Presented by W. Masters, Esq.

\section{Datnioides microlepis.}

Blecker, Rorneo, vii. p. 442.
B. 6 .
D. $\frac{12}{15}$.
A. $\frac{3}{9}$.
L. lat. 75-80.

Red, with eight black cross-bands.

River Kapuas (Borneo).

\section{GERRES*}

Gerres, Cuv. Regne Anim.; Cuv. \& Val. vi. p. 446.

Catochænum, Cant. Catal. p. 55.

Form of the body compressed, oblong or elevated. Mouth very protractile, and descending when thrust out. Eye rather large. Præoperculum generally entire. Six branchiostegals. No canine teeth. Dorsalis deeply notched, with the formula $\frac{9}{10}$; analis $\frac{3}{7(-9)}$. Caudal forked. Seales moderate, minutely or not ciliated. Air-bladder simple; pyloric appendages in small number. Pseudobranchiæ.

All the tropical seas, entering fresh waters. One species from the coast of North America.

* 1. Gerres bilobus, Cuv. \& Val. vi. p. 466.-Cape Verde.

2. - peruvianus, Cuv. \& Val. vi. p. $167 ;$ Less. Voy. Coq. Zool. Poiss. p. 180.-Coast of Peru.

3. — richii, Cuv. \&. Val. vi. p. 469.-East Indies?

4. Smaris lineatus, Humboldt, Observ. Zool. p. 185. pl. 46. f. 1.-Gerres lineatus, Cuv. \& Val. vi. p. 470.-Acapulco.

5. Gerres limbatus, Cuv. \& Val. vi. p. 476.-Catochænum limbatum, Cant. Catal. p. 55.-East Indies.

6. — lucidus, Cuv. \& Val. vi. p. 477.-Pondicherry.

7. - waigiensis, Quoy \& Gaim. Voy. Freyc. Zool. p. 292.-Waigiou.

8. Eucinostomus argenteus, Baird \& Gir. Ninth Smithson. Report, p. 345, probably should be referred to this genus. The species being the most northern, is highly interesting; but the description given does not distinguish it from East Indian species.-Coast of New Jersey. 


\section{Gerres plumieri.}

('ur. s) lal. vi. p. 452. pl. l6it.
D. $\frac{9}{10}$
A. $\frac{3}{7-8}$.
L. lat. $: 3 \%$.
L. transv. 6/11. Vert. 10/14.

The height of tne body is $2 \frac{1}{5}$ in the total length (withont eaudal fin). P'reorbital scrrated; the secont dorsal and anal spines exceedingly strong and long: the former slightly longer, nearly as long as the head. Silvery, with more or less distinct longitudinal stripes corresponding to the series of seales; dorsal generally blackish.

Atlantic coasts of Tropical Ameriea.

a. Fine specimen. S. Domingo. Purchased of Mr. Cuming.

b. Skeleton. S. Domingo. Purchased of Mr. Cuming.

c. Fine specimen. Central America. From M. Sallés Collection.

d. Adult. Guatemala. Purchased of Mr. Frank.

e. Adult. Pernambuco. Presented by J. P. G. Smitl, Esq.

f. Adult. Bahia. Purchased of M. Parzurlaki.

y, h. Half-growri and young: skins. South Americal. From 1)ı. Parnell's collecetion.

Air-bladder simple.

Sleteton.-The skull of Gorres exhibits several peruliarities ly which it may be distinguished from any other: they are-the high, triangular oceipital erest, with a deep groove in front, to receive two very elongate processes of the intermaxillary bones, the peeuliar shape of the jaws, and the broad and strong pulie bones. The maxillary bone has a somewhat irregular form, is slightly curved, and has a broak shallow groove along its upper and posterior margin. The front part of the intermaxillary bones is broad and slightly excavated, not unlike the upper jaw of sone Tortoises: the posterior processes are resy slender, flexible, and extend baekwards into a groove of the occipital erest situated on the posterior half of the frontal bones; the descending branch of the intermaxillary also is rather irregularly formed and bent. The mandibula has the inferine margin slightly concare; the front part of the dentary is rather flat and horizontal, whilst the posterior part, together with the adjacent portion of the articulary, forms a high and elevated ridge. The turbinal boncs are very clongate, imegularly bent, and transformed into a half-channel. The pratorlital is triangular, broalest anteriorly, and with the inferior margin distinetly serrated; the infraorbital areh, like the posterior part of the proorbital, is narrow, and without an interior plate. The head of the vomer forms an angular prominenee, but without any teeth; the palatine bones are deeply groored. The posterior margin of the prapopereulum is nearly straight and minutely serrated: the angle is rounded, and armed with equal and coarse rontienlations; the lower margin is straight and very distinetly serrated. The operenlum is twice as deep as long, five-sided, with the posterior side slightly emarginate, and without prominent points ; its inferiol angle is rejy arute. 'The sub- and interoper'ulum ar' very thin; their inferior margins are mitire. and form together a vers 
strong curvature. 'The upper surfiace of the skull is furmished with a very high and strong triangular crest, sharply pointed above, and supported by two pairs of short and low ridges, one before the other. The occipital crest bifureates anteriorly, forming the posterior end of a longitudinal groove, in which the processes of the intermaxillaries move, as in a sheath. The base of the skull is rather compressed. The humeral arch does not exhibit any peenliarity. The pubie bones form a very strong and broad triangular plate, and have the exterior ridges mueh developed.

There are ten abdominal and fourteen eandal vertebre, the length of the former portion of the vertebral eolumn being to that of the caudal as $1: 1 \cdot 3$. The ribs are moderately strong, and have a longitudinal groove anteriorly and posteriorly ; the first rib is short, bent backwards, and has a short prominence at its outer curvature. The neural spines of the posterior abdominal vertebræ gradually become longer, and are furmished with a flat, transparent posterior ridge. The interneural spines of the spinous dorsal have a similar ridge anteriorly and posteriorly; and these ridges are so broad, that they do not leave a frce space between them. The interneural belonging to the seeond dorsal spine is exceedingly strong, and nearly equals the first interhremal ; it is intercalated between the seeond and third neural spines. The first interhæmal, to which are joined the first and second anal spines, is trihedral, exeeedingly strong, and attaehed to the hæmals of the tenth and eleventh vertebræ; its length equals that of the second vertebra to the ninth.

\section{Gerres poeti.}

Cuv. \&.Val. vi. p. 468; Bleek. Verh. Bat. Genootsch, xxiii. Manid. p. 11.

$$
\text { D. } \frac{9}{10} \text {. A. } \frac{3}{7} \text {. }
$$

'The diameter of the eye is $2 \frac{1}{2}$ in the length of the head. Spines of the fins extremely strong and broad; the lesıth of the third dorsal spine is $2 \frac{1}{2}$ in the depth of the body, and its width is onc-ninth of its own length. The second anal spine is rather shorter than the third, and one-third of the depth of the body ; its width is one-fifth of its own length. Uniform silvery; dorsal above black-cidged.

Coast of Mahé (entering the rivers); Sunda Sea.

\section{Gerres rhomoens.}

Sloane, Jamaica, ii. pl. 253. f. 1.

Gerres brasilianus, Cuc. \& T'al. vi. p. 458.

_ rhombeus, Cuv. \&. Val. vi. p. 459.
D. $\frac{9}{10}$.
A. $\frac{2-3}{9-8}$.
I. Iat. 38 .
L. transv. 6/11.
$9 / 15$.

The height of the body is one-half of the total length (without catulal fin). Preorbital entire; præopereulum distinctly, interoper"ulum fincly serrated. 'Tlie spines moderate; the second of the dorsal two-thirds the length of the head, in young inclivirluals as long as 
the head; the second of the anal three-fourths of the second of the dorsal. Silvery; dorsal with a blackish margin.

Atlantic coasts of 'Tropical America.

a. Fine specimen. Cuba. Presented by the Zoological Society.

$b-f$. Adult and half-grown: skins. Jamaica. From Dr. Parnell's Collection.

\%. Ailult: not good state. Puerto Capello. l'urehased of Mr. Brandt. h. Adult: not good state. South America. I'urehased of Mr. Brandt. i-1. Adult: not good state. South America. Purehased of Mr. Brandt. m. Half-grown. South America. Presented by Sir R. Sehomburgk. n. Adult: skcleton. From the Haslar Collection.

o. Adult: skeleton. From the Collection of the Zoological Society. p. Half-grown. From the Haslar Colleetion.

\%. Young.

Slicleton.-I have had skeletons of the fish prepared with two amal spincs as well as with three, and having found them exactly alike, I am fully eonvineed that the form with two anal spines is merely aecidental in sose individuals, and that $G$. rhombeus of Cuvier must be considered as a nominal species. I have, however, preferred the name of $G$. rhombeus to that of $G$. brasiliensis.

The skeleton differs from that of G.plumieri in several points. The maxillary bone is very irregularly shaped, and exhibits a thick protuberanee in the middle of its onter surfiee; thrs is, howerer, more conspienous in very old specimens. The intermaxillaries and the mandibula are very much like those of $G$. plumicri. The proorthital has the maxillary margiu coneave and entire; its posterior part is rather hroaler than the remainder of the infraorbital areh. The hearl of the romer is rather flat, withont a distinct prominence ; the palatine bones exlibit a slight groove. Both the margins of the preoperenlum are straight; the angle is rounded, and like the inferior limb armed with a very distinet and equal serrature; the posterior limb is cntire. The remainder of the opereular apparatus as in G. plumieri. The occipital crest extends further forwards than in G. plumieri, the anterior groove being situated above the anterior portion of the frontal bones; there is, besides, this peeuliarity in G. rhombers, that the groove mentioned communieates with the orbitul carity by a pair of large oval holes.

There are nine alsdominal and fifteen caudal vertebre; the length of the former portion of the vertebral eolumn being to that of the caudal as $1: 1 \cdot 8$. The ribs are rather fecble, with a posterior and anterior longitudinal groove; the first three ribs are very slender, short, and without a promiuent knob. The nenral spines beeome gralually louger to the thirteenth vertebra, and are furnished with a more or less distinct, tlat, transparent, posterior ridge. The interneural spines do not differ from those of $G$. plumieri, execpt that of the second dorsal spine, which, like that spine itself, is not quite so strong. The first interhamal is exceedingly strong, and has in front a rery hroad aud emarginate ridge: its length equals that of the first nine vertebræ. 


\section{Gerres zebra.}

Müll. \&. Trosch. in Schomburgh's Barbad. p. 668.

$$
\text { D. } \frac{9}{10} \text {. A. } \frac{3}{7} \text {. }
$$

Silvery: steel-blue above; five or seven vertical bands. The height of the body is a third of its length, and contains two and a half times the length of the second and third spine in the dorsal fin, and three times of the second spine in the anal fin. (M. \& T.)

Coast and freshwater ponds of Barbadoes.

\section{Gerres subfasciatus.}

Cuv. \& Val. vi. p. 477.

$$
\text { D. } \frac{9}{10} \text {. A. } \frac{3}{7} \text {. }
$$

The height of the body is one-third of the total length; the snout is rather shorter than the diameter of the eye. Spines of the fins slender; the third of the dorsal fin is one-half of the height of the body, its width being less than one-twelfth of its own length. The second anal spine stronger, but rather shorter than the third, and about one-fifth of the height of the body. Silvery, with six or seven indistinet vertical bands.

Port .Jackson.

$a, b$. Adult: bad state. From the Haslar Collection. $c-e$. Half-grown: bad state. From the Haslar Collection.

\section{Gerres ovatus. (Plate XX. fig. A.)}
D. $\frac{9}{10-11}$.
A. $\frac{3}{7}$.
L. lat. 36 .
L. transv. 5/10.

The height of the body is $2 \frac{1}{4}$ in the total length (without caudal fin); the diameter of the eye is one-third of the length of the head, longer than the snout, and equal to the distance between the eyes. The groove for the processes of the intermaxillary bones is short, and does not extend beyond the vertical from the anterior margin of the eye ; there are no scales between that groove and the orbit. The spines of the dorsal slender and flexible; the seeond and third longest, and $2 \frac{1}{2}$ in the height of the body; the third of the anal fin longest, shorter than the first ray, and nearly one-fourth of the height of the body. Coloration uniform; dorsalis black-edged.

Coast of Australia.

a. Adult. Australia. Presented by the Earl of Derby.

b. Adult. Australia. From Mr. Macgillivray's Collection.

Description.-The body is elevated, ovate, its greatest depth being above the ventral fin, where it is contained $2 \frac{1}{4}$ in the total length (without eaudal fin), or three times when this fin is included. The upper profile anteriorly descends abruptly from the origin of the dorsal, the lower ascends from the base of the mandibula; both uneet at a not very acute angle. Posteriorly, along the base of the anal, the 
lower protile ancends more sulkenly than the mpled descends. The

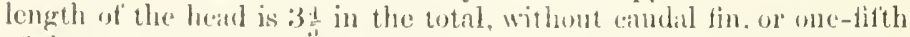
of the sime tength, that fin included. 'The smout is shorter than the diameter of the eye, the upper maxillaly extending to the anterior milgin of the orbit. 'The groove for the processes of the intermitillary' hone's is slort, quadrangular, with a pesterior and anterior angle and two lateral ones; it does not extend beyond the vertical from the anterion maren of the eye, and is antirely sculcless, as is the interspace between this sroove and the ahit. The upper surface of the heal is avered with laige suals's, to letween the anterior part of the distance hetween the eyes. 'The mostrils are placed high up the sedes, nearer the eye than the end of the smout; they are rather furminent, with the posterior opening wider. The precorbital is cutirely scaleless: antoriorly broad, it is narrowest between the masillary and the orloit. The scales of the cheeks are rither smaller than those of the body, and extend on the mandihula, there forming al narrow stripe immorliatoly lielind the nuxillary. The proeperenlum has a rertical posterior margin ; the angle and the inferior limb are lounded, without any denticulations; the seales of the ehecks do not catend orer its limbs. The operenlum is irregularly quadrangular; its postrior side is emarginate; the inforior stright, slightly ascending bitckialls. The sub-and interoperenlum are, like the opereulum, covered witn dechluons scules; their inferion mangins are convex.

The dorat fin is not very deeply notehed ; the length of the base of the spinous portion is shorter than of the soft, and its distance frone the caurlat is one-fifth only of that from the end of the snout; its origin is above the batse of the pretoral, and jis end a little before the rertical form the end of the anal fill. The spmes are slender, ancl the anterior ones flexilile: the first is minute; the seeond and thime ane the highest, and :! in the depth of the body; the fourth, fifth and sixth decrease in length, the last four being nearly ergual, and onc-half' of the third. 'The first ray is higher than the preceling subia, the other rays not differing very much from it in height, and finming together a slightly convex margin, with the membrane butwen derpy notched. There are eleven soft rays in one specimen,

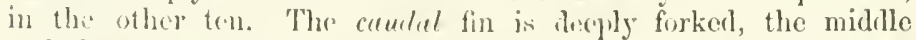
and shortest ring heing $3 \frac{1}{3}$ in the lenerth of one of the outer and lomerest bays; the upper lobe is scarcely longer than the lower, and one-fomth of the total length; small, thin, and decilnoms seales cximd wer the basal third of each bolie. The origin of the anul fin falls below the sixth dorsil ray, amel is and a little behind that of tho donsil ; the length of its lows is more than its distance from the candal, and expats five-cighthe of the longth of the head; it moves, like the dorsal, in a saly sheath. The anterior spine is minute; the seend stronger than the stontest of the dorsal; the third is moro slender, lut lonower than the seenul, and abont onefouth of the heright of the bolly. The first ray is renther longer than the prowling spouc, and the follow ing rays diminish in loneth, so as lo fintur a comeare materin of the fin.

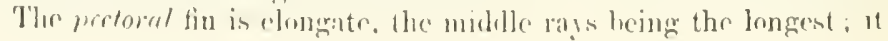


does not fully extend to the origin of the amal, and is $3 \frac{3}{5}$ in the total length; its base is entirely scaleless. The base of the ventral is at some distance behind that of the peetoral, and falls below the fourth dorial spine; it does not extend to the vent, and is $6 \frac{2}{3}$ in the total length; it is composed of one straight spine, two-thirds of the adjacent ray, and of five rays, the last of which is split into two branches to its base.

The scales are very thin, not ciliated, searcely higher than long; one of the largest covers one-half of the eyo. There is an execedingly long squamose flap at the exterior base of the ventral. The lateril line is slightly curved.

The teeth are minute, in villiform bands.

The back is reddish olive, with some reflecting longitudinal streaks ; the sides and the belly are silvery. The dorsal fin has a broad blackish margin, the other fins are colourless.

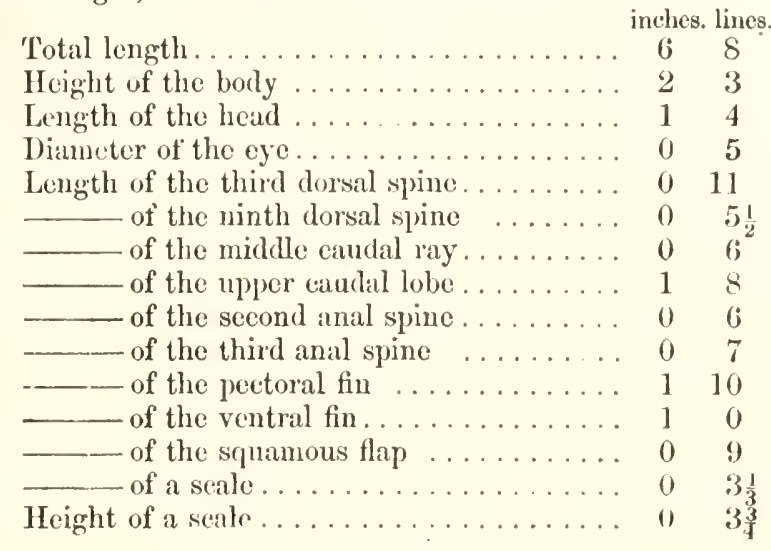

\section{Gerres abbreviatus.}

Blecker, Jiva, i. p. 103, and Verh. Iiatav. Genootsch. xxiii. Manid. p. 11.

$$
\text { D. } \frac{9}{10} \text {. A. } \frac{3}{7} \text {. L. lat. } 33 \text {. I. transv. 5/10. }
$$

The height of the body is $2 \frac{2}{3}$ in the total length; the dianeter of the eye is one-third of the length of the head. l'reorbital and pratoperculum entire. The second spine of the dorsal fin more than one-half of the heiglit of the body, and neirly copual to the length of the head. The second and third anal spines strong, and rather longer than the rays, one-thind of the height of the body. Coloration uniform; dorsil black-edged.

Seas of Batavia and Amboyna.

Adult. Amboyna. Purchased of Mr. Frank.

\section{Gerres filamentosus.}

Russull, i p. 52. pl. ris

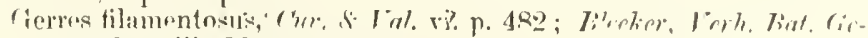
nootsrh. xxiii. Mernid. N.. 11. 
Gerres punctatus, Bleeker, Topoyr. Batav. (not Cuv.).

Catochænum filamentosum, Cant. Catal. p. 56.
D. $\frac{9}{10}$. A. $\frac{3}{7}$.
L. lat. 45 .
L. transv. 6/12.

The height of the body is $2 \frac{1}{3}$ in the total length (without caudal fin). The spines of moderate strength ; the second of the anal produced into a filament, which sometimes extends to the caudal.

Sea of Pinang; Sunda and Molucea Sea; New Guinea.

a. Adult: not good state. Molucea Sea. Purchased of Mr. Frank.

b. Adult: not good state. Molucea Sea. Purchased of Mr. Frank.

c. Adult: stuffed. Cape York (in 68 fathoms). Voyage of the Rattlesnake.

\section{Gerres punctatus.}

Cuv. \& Val. vi. p. 480.

$$
\text { D. } \frac{9}{10} \text {. A. } \frac{3}{8} \text {. }
$$

The height of the body is $3 \frac{1}{2}$ in the total length. The second dorsal spine prolonged into a short filament, and sometimes as long as three-quarters of the height of the body. Silvery; dorsal with a narrow black margin, each ray with a brown point at the base. Young individuals with indistinct cross-bands.

Coast of Pondicherry; Sea of China.

Gerres macracanthus (Bleeker, Natuurk. Tydschr. Nederl. Ind. 1854 , vi. p. 195) may be founded on older individuals of the above

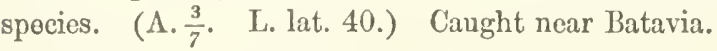

a. Adult. Old Collection, as Sparus edentulus.

$b, c$. Young. China. Presented by J. R. Reeves, Esq.

d. Half-grown. Philippine Islands.

e. Half-grown. Presented by G. R. Waterhouse, Esq.

\section{Gerres gula.}

Cuv. \& Val. vi. p. 464; Jenyns, Zool. Beagle, Fishes, p. 58.
D. $\frac{9}{10}$.
A. $\frac{3}{7}$.
L. lat. 45.
L. transv. $4 / 9$.
Vert. 9/15.

The height of the body is $2 \frac{3}{4}$ in the total length (without caudal fin). Proorbital and præoperculum entire, the latter with the angle slightly rounded. The groove for the processes of the intermaxillaries extends nearly to the vertical from the centre of the eye; a transverse stripe of seales covers a part of the groove, separating from it the posterior third*. The snout is shorter than the diameter of the eye, and equal to the space between the eyes. The spines of the fins of moderate strength; the second and third of the dorsal half as long as tho head, but twice as long as the second of the anal. Silvery: dorsal fin minutely dotted with brown; the dots more crowded at the top of the dorsal.

Atlantic coasts of Tropical America.

* Space between the eycs with a fovea in the middle (Jenyns, l.c.) 
a. Adult. Bahia. Purchased of M. Parzudaki.

b. Adult. Bahia. Purchased of M. Parzudaki.

c. Adult: skeleton. Bahia. Purchased of M. Parzudaki.

d. Half-grown. S. Domingo. Purchased of Mr. Cuming.

$e, f$. Young. Jamaica. From Mr. Gosse's Collection.

g. Adult. From the Haslar Collection.

$h$. Young.

$i, k$. Half-grown and young: skins.

Skeleton.-The very remarkable form of the first interhæmal spine has been mentioned by Cuvier. He states the number of the caudal vertebræ to be thirteen; but I have found fifteen, as in other speeies of Gerres. The length of the abdominat portion of the vertebral column is to that of the eaudal as $1: 1 \cdot 6$.

\section{Gerres nigri. (Plate XX. fig. B.)}
D. $\frac{9}{10}$.
A. $\frac{3}{8}$.
L. lat. 42.
L. transv. 5/11.

The height of the body is $2 \frac{3}{5}$ in the total length (without caudal fin); the diameter of the eye is about one-third of the length of the head, rather longer than the snout, and equal to the distanee between the eyes. The groove for the processes of the intermaxillary bones is elongate, triangular, reaching nearly to the vertical from the ecntre of the eye, and is entirely scaleless. Spines of the fins rather slender; the second of the dorsal is $2 \frac{1}{5}$ in the height of the body, and nearly twice as long as the third of the anal, which is rather longer, but less stout, than the preceding. Silvery, with indistinct longitudinal stripes above the lateral line; the vertical fins blackish; dorsal black-edged.

Mouth of the River Niger.

a. Adult. River Niger. From Mr. Fraser's Collection.

b. Half-grown. Coast of Africa. From the Haslar Collection.

Description.-The body is moderately elevated, its greatest depth being below the origin of the dorsal, where it is contained $2 \frac{1}{5}$ in the total length, without caudal fin, or $3 \frac{1}{6}$ in the same length, the caudal included. The upper profile anteriorly and posteriorly descends as mueh as the lower aseends, and they meet in front at an acute angle. The length of the head is $3 \frac{2}{5}$ in the total, without caudal fin. The snout is rather shorter than the diameter of the eye, the upper maxillary extending to the anterior margin of the eye. The groove for the processes of the intermaxillary bones is elongate, triangular, with a somewhat rounded posterior angle, and widening anteriorly. The scales of the upper surface of the skull do not extend over that groove, forming a stripe between the groove and the orbit, and terminating behind the nostrils, which are situated high up the sides, nearly halfway between the orbit and the end of the snout. The præorbital is entirely scaleless: anteriorly broad, it is narrowest between the maxillary and the orbit. "The seales of the cheeks are smaller than those of the body, and extend in a narrow stripe on the mandibula, immediately behind the maxillary. The pracoperculum is 
rounued, without any denticulations whatever; the seales of the cheels do not cxtend on its limbs. The opereulum is irregularly quadringular; its posterior side is emarginate, the inferior straight, obliquely ascending backwards. 'The sub-and interoperculum are covered with deciduous scales, like the operculum; their inferior margin is slightly convex.

The dorsal fin is not very deeply notched; the length of the base of the spinous portion is shorter than of the soft, and its distance from the caudal is one-third only of that from the end of the snout; its origin is above the base of the ventral, its end a little before the vertical from the end of the anal fin. The spines are rather slender, but not flexible: the first is minute; the second the highest, and $2 \frac{1}{5}$ in the height of the body; the third is a little, the fifth and sixth considerably shorter; the last three are nearly equal in length, and $2 \frac{3}{5}$ in the length of the second. The first ray equals the sixth spine; the other rays not differing very much in height, and forming a slightly convex margin, with the membrane between deeply notehed. The caudal fin is deeply forked, the middle and shortest ray being one-fifth only of the length of one of the outer and longest rays; the lobes are equal, and one-fourth of the total length: small, thin, and deciduous seales extend over the basal third of each lobe. The origin of the anal fin falls beneath the third ray of the dorsal, its end a little behind that of the dorsal. The length of its base is more than its distance from the eaudal, and exactly equals the distance between the anterior margin of the eye and the hinder end of the opereulum; it mores like the dorsal in a scaly sheath. 'The anterior' spine is minute; the second rather stronger than the strongest of the dorsal; the third is more slender, but longer than the second, it is more than half of the second dorsal spine, and about one-sixth of the height of the body. The first ray is rather longer than the last spine, and the following rays diminish in length, so as to form a concave margin of the fin.

The pectoral fin is elongate, the middle rays being the longest; it reaches beyond the origin of the anal fin, and is one-fourth of the total length. The base of the ventral fin falls behind that of the pectoral ; it does not extend to the vent, and is one-suventh only of the total length; it is composed of one slightly eurved spine, threefourths of the adjacent ray, and of tive rays, the last of which, as in all the species of Gerres, is split into two branches to its base, so that there is an appearance of the fin having six soft rays.

The scales are deciduons, not ciliated. higher than long: one of the largest covers one-third of the eye. There is an exceedingly long squamous flap at the exterior base of the ventral. The lateral line is very slightly eurved.

The teeth are minute, in villiform bands.

The back is reldish olive, with some reflecting longitudinal streaks ; the sides and the belly are silvery. The vertical fins are blackish; the dorsal fin with a black edge. In the younger of the sjecimens the blackish colour of the dorsal fin forms two longitulinal series of s.] $\mathrm{nts}$. 


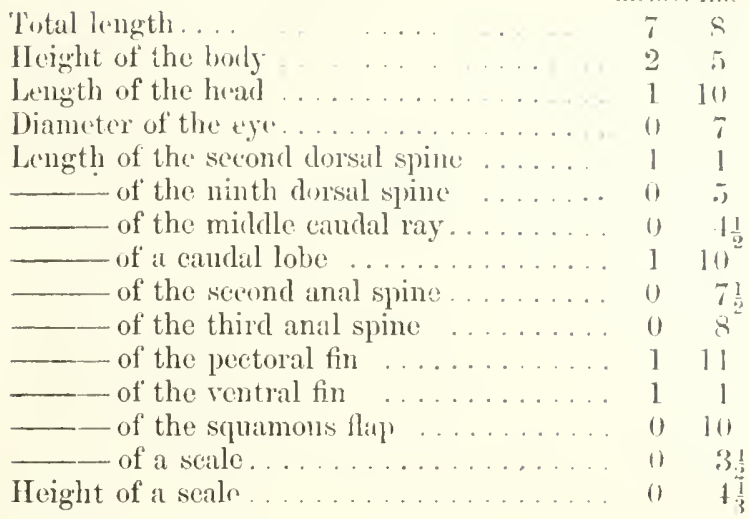

\section{Gerres squamipimis. (I'Lte XXI.)}

\section{D. $\frac{9}{10}$. A. $\frac{3}{7}$. L. lat. $4: 3-44$. L. tramsr. 5/13.}

The height of the borly is $2 \frac{1}{2}$ in the total length (without caudal fin); the diameter of the cye is 33 in the longth of the hade rather. shorter than the snont, but erpal to the distance between the eyes. 'The groove for the processes of the intermaxillary hones is loroal, triangular, entirely scaleless, and does not reach to the rertical from the centre of the eyc. The dorsal spines are rather slemler and slightly eompressen; the second is $1 \frac{3}{5}$ in the length of the hoad. The second anal spine is rather strong, stronger and a little longer than the third: its length is $1 \frac{2}{5}$ in that of the loead: caurlal fin deeply forked, entircly covered with scales; the length of a lobe is nearly $3 \frac{1}{2}$ in the total. Uniform silvery; the maremin of the dorsal fin blackish.

Caribbean Sea.

«-l. Adult: skins. famaica. From Dr. Parnell's Collection.

e. Half-grown: skin. Jamaica. From Dr. Parnell's Collection.

f. Adult: not good state. Guatemala. Purehased of Mr. Frank.

Description.-The body is moderately clevated, its greatest d'pt]. being below the anterior part of the spinons dorsal, where it is contained $2 \frac{1}{2}$ in the total length, without caudul fin, or $3 \frac{1}{2}$ in the same length, the caudal included. The mper profile, anteriorly and nosteriorly, descends as much as the lower ascends, and they mect at an acute angle in front. The length of the head is $3 \frac{1}{3}$ in thr total, without caudal fin. The snout is rather longer than the diameter of the eye, and the upper maxillary extends slightly beyond the anterior margin of the eye; the part of the maxillary which is not hidd. $n$ by the proorbital is rather elongate. ovate. The gronre for the processes of the intermaxillary bones is mather broul, trimgular, widening anteriorly, with a romeled posterior angle, whirls is situated in the vertical from the anteriur third of the orbit. The 
scales of the upper surface of the skull do not extend over that groore, forming a stripe between the groove and the orbit, and terminating a little behind the nostrils, which are situated high up the sides, close to the orbit, and remote from the end of the snout. The proorbital is entirely scaleless, and without any denticulations; anteriorly broad, it is narrowest between the maxillary and the orbit; its maxillary margin is semilunate. The scales of the cheeks are rather smaller than those of the body, and extend on that part of the mandibula which is situated immediately behind the maxillary; they are arranged in four series on the præoperculum and in two on the mandibula. The angle and the inferior margin of the præoperculum form one curve: a narrow space along this curve is scaleless; it is about as wide as one of the scales of the eheek. The opereulum is irregularly quadrangular, with the posterior side slightly omarginate; the inferior is straight, obliquely ascending backwards. The sub- and interopereulum are covered with deciduous seales, like the operculum; their inferior margins form one conrexity.

The dorsal fin is not very deeply notched; the length of the base of the spinous portion is two-thirds of that of the soft, and the distance of the dorsal from the caudal is not quite one-third of that from the end of the snout; its origin is a little behind the vertical from the base of the ventrals, whilst the extremities of the dorsal and anal fins correspond to each other. The spines are rather slender: the first is rery short; the seeond the highest and somewhat flexible, its length being $1 \frac{2}{5}$ in that of the head, and $2 \frac{1}{5}$ in the height of the body; the third is rather shorter; and the following gradually decrease in length to the last, which is oue-half of the second. The first ray nearly equals the sixth spine. The caudal fin is entirely and densely curered with minute scales, and deeply forked, the middle and shortest ray being one-fifth only of the outer and longest rays; the upper lobe is rather longer than the lower, and nearly $3 \frac{1}{2}$ in the total length. The origin of the anal fin falls beneath the fifth ray of the dorsal, whilst the extremities of both fins correspond to each other; the length of its base is rather more than its distance from the caudal, and rather less than the distance between the anterior margin of the eye and the hinder end of the operculum; it moves, like the dorsal, in a deep sealy sheath. The first spine is very short; the second strong, its length being $1 \frac{2}{5}$ in that of the head, and $3 \frac{1}{4}$ in the height of the body; the third is rather shorter, and half as stout as the second. The first ray has about the length of the second spine, whilst the following rays diminish in length, so as to form a concare margin of the fin.

The pectoral fin is rather elongate, the middle rays being the longest; it reaches nearly to the origin of the anal fin, and is $3 \frac{3}{4}$ in the total length. The base of the ventral fin falls behind that of the pectoral; it is partly eovered with stripes of minute scales; it does not reach to the rent, and is $6 \frac{1}{3}$ in the total length; it is composed of one spine, slightly eurved, and three-fourths of the adjacent ray, and of five rays, the last of which, as in all the species of Gerres, is split into two branches to its base. 
The scales are not ciliated, higher than long; one of the largest covers one-third of the eye. There is an exceedingly long squamous flap at the exterior base of the ventral. The lateral line is very slightly curved.

The teeth are minute, in villiform bands.

The colour is uniform silvery, with shining longitudinal stripes; the upper half of the spinous dorsal is greyish.

\begin{tabular}{|c|c|}
\hline Totgl lenoth & 1.1. \\
\hline Height of the body & 3 \\
\hline Length of the head & 2 \\
\hline Diameter of the eye......... & 0 \\
\hline Length of the second dorsal spine & 1 \\
\hline of the ninth dorsal spine & 0 \\
\hline - of a caudal lobe ....... & 3 \\
\hline - of the seeond anal spine. & 1 \\
\hline - of the third anal spine & \\
\hline - of the peetoral fin ... & \\
\hline - of the ventral fin & 1 \\
\hline ht of a seale ...... & 0 \\
\hline
\end{tabular}

\section{Gerres japonicus.}

Bleeker, Japan, p. 404, and Verh. Bat. Gen. xxri. Japan, tab. 5. f. 2.

$$
\text { D. } \frac{9}{10}, \quad \text { A. } \frac{3}{7} \text {. L. lat. } 40 \text {. }
$$

The height of the body is $2 \frac{2}{3}$ in the total length (without eaudal fin); the diameter of the eye is one-third of the length of the head. Præorbital and præopereulum entire. Spines of the fins slender; the seeond of the dorsal fin one-half of the depth of the body; the seeond of the anal longer than the third, or than one-half of the seeond dorsal spine; the caudal lobes are $4 \frac{2}{3}$ or $4 \frac{3}{4}$ in the total length. The spinous dorsal above black; caudal fin with a broad blackish margin.

Seas of Japan and China.

a. Half-grown: not good state. China. Presented by J. R. Reeves, Esq.

\section{Gerres acinaces.}

Bleeker, Natuurk. Tydschr. Nederl. Indie, 1854, vi. p. 194.

$$
\text { D. } \frac{9}{10} \text {. A. } \frac{3}{7} \text {. I. lat. } 40-45 \text {. }
$$

The height of the body is about $3 \frac{3}{4}$ in the total length; the diameter of the eye is $3 \frac{1}{2}$ in the length of the head. The second dorsal spine longer than one-half of the height of the body, but mueh shorter than the head; the seeond of the anal longer than the third and than the rays, nearly one-half of the length of the head. Silvery ; caudalis brown-edged posteriorly. (Bl.)

Sea of Batavia. 
Thus species appeass to be rery similar to Groes squamipinnis; but the latter has the caudal fin so thickly covered with seales, that I do not believe that lilreker would have omitted so conspiruons a character if it were also present in $G$. acinaces.

\section{Gerres kapas.}

Biecker, Rionne, p. 4 .8.

$$
\text { D. } \frac{9}{10} \text {. A. } \frac{3}{7} \text {. L. lat. } 32 \text {. }
$$

The height of the body is $3 \frac{1}{5}-3 \frac{1}{2}$ in the total length. The spines of the fins slendel"; the second and third of the dorsal fin one-half of the height of the body ; tle sceond and third of the anal not longer than the rays, and contained three or four times in the height of the body. Silvery : above greyish; the spinous dorsal black-clged. (BI.)

Sea of Bataria.

\section{Gerres aprion.}

Cur. \&. Vul. vi. p. 4 4il.

D. $\frac{9}{10}$. A. $\frac{3}{7}$. L. lat. 45 . I. transv. 6/10. Cae. pylor. 3.

The height of the body is one-third of the total length (without caudal fin). Præorbital and proepereulum entire, the latter with the angle slightly rounded. The groove for the processes of the intermaxillaries extends to the vertical frem the centre of the eye, is elongate, and entirely free of seales. The snout is slightly longer' than the diameter of the eye, which exceeds the width of the head between the eyes. The spines of the fins moderate; the second of the dorsal is longer than one-half of the length of the head, and nearly twice as long as the second of the anal. Silvery: a decpblack spot at the top of the dorsal fin; the upper part of the snout blackish brown.

Atlantic coasts of Tropical America.

a. Fine specimen. S. Dumingo. Purchased of Mr. Cuming.

b. Half-grown. S. Domingo. Purchased of Mr. Cuming.

$c-h$. Adult, half-grown, and young: skins. Jamaica. From Dr. Parnell's Collection.

i-l. Adult: bad state. West Indies.

m. Half-grown: skin: bad state. West Indies. Pureliased of Mr. Scrivener.

n. Adult. South America. I'resented by Lord Stuart.

o. Aault. South America. l'resented by Lord Stuart.

p. Half-grown.

\%. Half-grown.

r. Half-grown.

s. Adult: skin.

\section{Gerres oyena.}

Labrus oyena, Forsk. p. 35: BI. Srhn. 1. 24is: Tarrip. iii. p. 463. Sparus erythrurus, Bl. 1ab. 261 (very bad).

Cichla erythrura, J3I. Sichn. p. 33836. 
Sparus britannus, Laeép. iv. pp. 132, 134.

Labrus longirostris, Lacip. iii. p. 467. pl. 19. f. 1.

Smaris oyena, Rïp. Atl. p. 11. tat. 3. f. 2.

Gerres oyena, Cur. \& V Tal. vi. 1. 472; ? Jenyns, Zool. Berogle, Fishes, p. 59 ; Bleck. Terh. Bat. Gen. xxiii. Mrenid. p. 12.

- oblongus, Bleek. Topoyr. Butar. (not Cur.).

? Gerres equula, Temm. S- Schleg. Fann. Japon. Poiss. p. 76. pl. 40. f. 1 (not good); Bleck. Verhand. Batar. Genontsch. xxri. p. 92.

D. $\frac{9}{10}$. A. $\frac{3}{7}$. L. lat. 35-38. Cæc. pylor. 3. Vert. 10/14.

The height of the body is $2 \frac{3}{4}$ in the total length (without caudal fin). Preorbital and prooperculum entire, the latter with the angle slightly rounded. The snout is slightly longer than the diameter of the eye, which is onc-third of the length of the head. The spines of the fins moderate; the second of the dorsal is one-half of the height of the body, and at least twice as long as the second of the anal. Uniform silvery.

Red Sea; Isle de France; Sunda Sea (Japanese Sea?).

a. Adult: bad state. Old Collection.

b, c. Half-grown: bad state. From the Haslar Collection.

\section{Gerres macrosoma.}

Blecker, Gilolo, p. 56

$$
\text { D. } \frac{9}{10} \text {. A. } \frac{3}{7} \text {. I. lat. } 42 \text {. }
$$

The height of the body is four times in the total length (one-third without eandal), the length of the head $4 \frac{2}{3}$ to $4 \frac{3}{5}$; the diameter of the eye is one-third of the latter, and rather shorter than the snont; the interspace between the eyes is rather less than the width of the orbit. The groove for the processes of the intermaxillary bones is entirely scaleless, and does not extend to the rertical from the eentre of the eye. The spines of the fins are slender; the second of the dorsal $1 \frac{3}{4}$ in the height of the body; the second of the anal shorter than the third. Silvery: each spine and ray of the dorsal with a brown basal spot; the spinous portion black-edged.

Seas of Gilolo and Amboyna.

a. Half-grown. Amboyna. Purchased of Mr. Frank.

\section{Gerres argyreus.}

Sciæua argyrea, Forster.

Cichla argyrea, Bl. Schn. p. 344.

Gerres waigiensis, Quoy \& Gaim. Voy. Freyc. Zool. p. 292

- argyreus, Cuv. \& Tal. vi. p. 478.

$$
\text { D. } \frac{9}{10} \text {. A. } \frac{3}{7} \text {. L. lat. } 45 \text {. }
$$

The height of the body is scarcely more than the length of the head, and one-third of the total (without eandal fin); the diameter of the eye is one-third of the length of the head, and rather longer 
than the snout, the extent of which equals the distance between the eyes. The groove for the processes of the intermaxillary bones is entirely scaleless, and does not extend to the vertical from the eentre of the eye. The spines of the fins are slender; the second of the dorsal is one-half of the height of the body, and more than twice the length of the seeond anal spine, which is rather stronger, but not longer. than the third. Silvery; top of the dorsal blackish.

Red Sea; Seas of Waigiou, Strong, and Tanna; Port Jackson.

a. Adult. From the Haslar Collection.

b. Adult. From the Haslar Collection.

$c, d$, Adult: skins: not good state. Port Jackson. Purchased of J. Gould, Esq.

\section{Gerres oblongus.}

Cur. \& Fal. vi. p. 479.

$$
\text { D. } \frac{9}{10} \cdot \text { A. } \frac{3}{7} \text {. }
$$

The height of the body is less than one-fourth of the total length. Spines of the fins slender. Silvery, with five or six indistinct brownish vertical bands. Lateral line nearly straight. (Cu .)

Sea of Ceylon.

\section{SCOLOPSIS *}

Scolopsides, Cuv. Règne Anim.; Cuv. \& Val. v. p. 327.

Form of the body oblong. Eye moderate. Snout moderate. with the cleft of the mouth nearly horizontal and the jaws equal. One dorsal; the number of the fins-D. $\frac{10}{9(8)}$. A. $\frac{3}{7(6)}$; eaudalis more or less forked. Infraorbital areh with a spine directed backwards. Preoperculum generally distinetly d'entieulated; opereulum with an indistinct spine. Seales moderately etenoid. Five branchiostegals. Pseudobranchia. Air-bladder simple; pyloric appendages few.

From the Red Sea through the Indian Oeean into the Pacific.

\section{Scolopsis japonicus.}

Anthias japonicus, Bloch, taf. 325. f. $2 ; B l$. Schn. p. 307.

Lutjanus japonieus, Lacép. iv. p. 31.

Kurite, Russell, pl. 106.

Scolopsis kate, C'ur. \& Val. v. p. 329.

- kurite, Rüpp. Atl. Fische, p. 9. taf. 2. f. 3; Cur. \& Val. v. p. 331.

Scolopsides rüppelii, Cuv. \& Val. v. p. 332 ; Richardson, Ichth. China, p. 236.
D. $\frac{10}{9}$.
A. $\frac{3}{7}$.
L. lat. 41-44.
L. transv. $\frac{5}{16}$.

The height of the body is nearly one-third of the total length, the length of the head one-fourth ; the diameter of the eye is about one-

* 1. Scolopsides pomotis, Richardson, Ichth. China, p. 237.

2. - taniopterus, Cur. \& I Fal. v. p. 345; Bleek. Verh. Bat. Gen. xxiii. Scian. p. 29.-Batavia 
third of the latter, and longer than the snout. The infraorbital ring with two prominent spines; the anterior spiniferous plate rather clevated, and denticulated beneath the spine; prooperenlum with a slight notch above the angle. The spines of the fins strong; the second of the anal fin longer and rather stronger than the third, nearly one-half of the length of the head. Candalis slightly forked. Coloration uniform.

Red Sea; Coast of Pondicherry; Chinese Sea.

a. Adult: stuffed. China. Presented by J. R. Reeves, liso. b, c. Adult: skins. Ceylon. Collected by E. F. Kelatart, M.D.

The notice given by Sir J. Riehardson (l.c.) is taken from specimen $a_{0}$; it shows the two infraorbital spines, one of which is directed backwards, the other forwards, as conspienomsly as in any species of Scolopsis. Therefore the statement of Sir J. Richardson, "two suborbitar teeth pointing backwards, one under the other and more slender, none pointing forwards," is erroneous.

\section{Scolopsis margaritifer.}

C'ue. S. Vul. v. p. 337; Blecker, Terhand. Buter. Genootsch. xxiii. Scicen. p. 30.
D. $\frac{10}{9}$.
A. $\frac{3}{7}$.
L. lat. 40 .
L. transv. 4/15.

The height of the body is $3 \frac{1}{5}-3 \frac{1}{3}$ in the total length, the length of the head $4 \frac{1}{3}-4 \frac{1}{2}$; the diameter of the eye is $2 \frac{3}{4}$ in the latter, longer than the snout, and equal to the distance between the eyes. Pracorbital half as wide as the orbit, with a very long and strong spine, and some denticulations beneath; the second (third) infraorbital texminating posteriorly in a small point, above the tip of the large spine. Præoperculum with strong and short spinous teeth, each of which has a small hook at the base; the angle projecting backwards, strongly armed. The spines of the fins moderate; the second of the anal stronger, but rather shorter than the third, which is $2 \frac{2}{3}$ in the length of the head. Caudalis forked, the upper lobe longest. Grecnish olive, each scale with a pearl-coloured base. The marginal half of the dorsal violet.

Sea of Batavia; Waigiou.

«. Fine specimen. From the Haslar Collection.

\section{Scolopsis ciliatus.}

Holocentrus ciliatus, Lacép. iv. pp. 333, 371.

Lycogenis argyrosoma, Kuhl \& van Hasselt.

Scolopsides lycogenis, Cuv. \& Val. v. p. 346. pl. 127.
B. 5. D. $\frac{10}{8-9}$.
A. $\frac{3}{7}$.
L. lat. 41.
L. transv. 4/15. Cac. pylor. 5.
Vert. $10 / 14$.

The height of the body is $3 \frac{1}{2}$ in the total length, the length of the head $4 \frac{1}{2}$; the snout is rather shorter than the diameter of the eye, 
which is one-third of the length of the head, and equal to the interspace between the eyes. The upper maxillary armed with a prominent serrated longitudinal ridge, and extending to the vertical from the front margin of the eye; the infraorbital arch with two prominent spines of nearly equal size. I'rxopereulum with stronger spinous teeth at the angle, but the angle not prominent. Operculum with a conspicuous spine. Spines of the fins slender; the third of the anal fin longer than the sceond. Caudalis emarginate. A shining white longiturlinal band between the lateral line and the middle of the dorsal fin.

Seas of Java, Amboyna, New Guinea, and Vanicolo.

c. Adult. Amboyna. Purchased of Mr. Frank.

b. Adult. Amboyna. From Madame Ida Pfeiffer's Collection.

\section{Scolopsis auratus.}

Perea aurata, Mungo Purk, Trans. Linn. Soc. iii. p. 35.

Anthias vosmeri, $3 l$. tab. $321 ; 3 l$. Schn. p. 304.

Lutjanus vosmeri, Lacép. iv. p. 213.

- aureovittatus, Lncép. iv. j. 216.

I'omacentrus emeadactylus, Lacép. iv. pn. 505, 508.

Scolopsides vosmeri, Cuv. of Val. v. p. 333 ; Bleck. Verh, Bat. Genoutsch. xxili. Scicen. p. 27.

Scolopsis aurata, Cant. Catal. p. 81.

$$
\text { D. } \frac{10}{9} . \quad A \cdot \frac{3}{7} \text {. }
$$

The height of the body is $2 \frac{1}{2}$ in the total length, the length of the head about four times; the diameter of the eye is one-third of the latter. The infraorbital arch with two prominent spines, and the anterior spiniferous plate denticulated beneath the spine; a part of the propereular teeth bent outwards, and most of them with a minute spine at the base, pointing downwards; the second anal spine longest and strongest, the first half its length. A silvery longitudinal band beneath the lateral line, terminating opposite the soft dorsal fin.

Seas of Jara, Sumatra, and Pinang.

\section{Scolopsis torquatus.}

Cur. \& Vul. v. p. 335; Bleck. Vcrh. Butuv. Genootsch. xxiii. p. 28.

$$
\text { D. } \frac{10}{9} \text {. A. } \frac{3}{7} \text {. L. lat. 41-42. L. transv. } 4 / 15 \text {. }
$$

Body rather elevated; snout short; pracorbital spine strong; angle of proopereulum projecting; the spines of the fins rather strong; the second of the anal fin longer than the third. $\Lambda$ broad yellowish cross-band from the nape over the operculum.

Sea of Batavia; Molucea Sea.

a. Fine specimen. Moluceas (as Scolopsides collaris).

b. Adult. India. 


\section{Scolopsis bilineatus.}

Anthias bilineatus, Bloch, taf. 325. f. 1; Bl. Schn. p. 306.

Lutjanus ellipticus, Lacép. iv. p. 213.

Scolopsides bilineatus, Cux. \& Val. v. p. 336; Bleck. Verh. But. Genootsch. xxiii. Scicen. p. 28.
D. $\frac{10}{9}$.
A. $\frac{3}{7}$.
L. lat. 46 .
L. transv. 4/15.

The snout is short, shorter than the diameter of the eye; the interspace between the eyes exeecls the diameter. Præopereulum notched abore the angle. A yellowish band, edged with brown, aseends from the angle of the mouth in a slight curve upwards to the origin of the soft dorsal; a yellowisl bloteh on the back, below the posterior two-thirds of the soft dorsal. A yellow line from the origin of the dorsal to the middle of the forehead; another, parallel, above the eye; a third through the eye, joining that of the other side on the muzzle. Dorsal fin white, with a broad black streak on the marginal half of the soft portion; anal black in its anterior lialf, white in its posterior.

Seas of Amboyna and Celebes.

a. Adult. Amboyna. Purehased of Mr. Frank.

b. Half-grown. Celebes.

c. Adult. Old Collection, as Perca frenata.

\section{Scolopsis bimaculatus.}

Scolopsis bimaculatus, Rïpm. At7. Fische, p. 8. pl. 2. f. 2, and $N$. W. Fische, p. 126; Cur. \&. Vul. v. p. 340.

Scolopsides treniatus, (Ehrenb.) C'ur. of Val. l. c.

- inermis, Rich. Ichth. Chink, p. 236 (not Schlcy.).

$$
\text { D. } \frac{10}{9} \text {. A. } \frac{3}{7} \text {. L. lat. } 47 \text {. L. transv. } 4 / 15 \text {. }
$$

The height of the body is $3 \frac{1}{3}$ in the total length, the length of the head four times. The diameter of the eye is one-third of the length of the head, and rather longer than the snout, or the interspace between the eyes. Infraorbital arch with one strong spine; the spiniferous plate rather elevated, with several denticulations beneath the spine. Præopereulum with the angle projecting. Spines of the fins rather slender; the third of the anal fin somewhat longer and not thinner than the second. Caudalis slightly forked. Rose-eoloured, with a large oblong blackish blotch in the middle of the total length

Red Sca; Ceylon; Chinese Scas.

a. Adult: stuffed. China Seas. Presented by J. R. Reeves, Esq.

b. Fine specimen.

\section{Scolopsis inermis.}

Temm. 8. Schleg. Funn. Japon. Poiss. p. 03. pl. 28. f. 1; Bleck. T'orh. Butav. Genootsch. xxvi. p. 83,- Richurds. Ichth. Chinu, 1) 236, belongs to Sc. bimaculatus.]

$$
\text { D. } \frac{10}{9} \cdot \Lambda \cdot \frac{3}{7} \text {. L. lat. } 30 \text {. }
$$

The height of the body is $3 \frac{2}{5}$ to $3 \frac{3}{5}$ in the cotal length, the length 
of the head $3 \frac{2}{3}$ to 4 ; the diameter of the eye is a little less than one-third of the latter. The præorbital is only half as high as the eye, and has a short spine and some denticulations beneath. Præoperculum with the angle rounded, slightly denticulated. The anal spines strong, the second and third nearly equal; candalis scarcely emarginate. Coloration uniform.

Japanese Sea.

\section{Scolopsis monogramma.}

Scolopsides monogramma, (Kuhl \&. r. Hass.) Cux. \& Val. v. p. 338 ; Cur. Rène Anim. Ill. Poiss. pl. 31. f. 3; Bleek. Verh. Batav. Gen. xxiii. Scian. p. 29 (not synonymy).
D. $\frac{10}{9}$.
A. $\frac{3}{7}$.
L. lat. 46 .
L. transv. 4/16.

The height of the body is $3 \frac{3}{5}$ in the total length, the length of the head $4 \frac{2}{5}$; the diameter of the eye is nearly one-third of the length of the head, and rather longer than the snout, or the distance between the eyes. Præorbital two-thirds as high as the eye, with a flat strong spine and some dentieulations beneath; præoperculum distinctly serrated at the angle and at the posterior limb, which is slightly emarginate. The spines of the fins moderate; the third of the anal fin a little longer than the second. Caudalis emarginate. Coloration uniform (in spirits).

Sea of Java; Molucca Sea.

a. Adult. Moluccas.

6. Adult. Amboyna. Purchased of Mr. Frank.

\section{Scolopsis phæops.}

Scolopsides phrops, Bennot, Proc. Committ. Zool. Soc. i. p. 165.
D. $\frac{10}{9}$.
A. $\frac{3}{7}$.
L. lat. 44.
L. transv. 5/17.

The height of the body is three times in the total length (without caudal fin), the length of the head $3 \frac{1}{3}$; the snout is rather longer than the diameter of the eye, which is $3 \frac{3}{5}$ in the lengtl of the herd. The præorbital is in the middle half as wide as the orbit, and armed with a flat strong spine and seçeral spinous tecth; præoperculum with strong spinous teeth, and with a notch above the projecting angle. Caudalis deeply forked, with both lobes produced into filaments. A silvery streak from the muzale across the proorbital to the eye; another from the prieorbital spine to the angle of the praopereulum. A light yellowish longitudinal band from over the eye, abore and parallel to the lateral line, to the end of the dorsal.

Isle de France.

1. Fine specimen. Isle de Franee. From the Collection of the Zoological Society.-Type of the species.

Description of the specimen.-This speeies is rather elongated, the greatest depth of the body being one-third of the total length (without caudal fin). The head is rather broad and flat above, covered with scales nearly to the nostrils; all the snout is scaleless. The distance hetween the eyes is more than the width of the orbit or the extent 
of the snout. The cleft of the mouth is slightly oblique, moderate, the maxillary not reaching to the vertical from the anterior margin of the orbit. The procorbital is broadest between the eye and the top of the snout; it is eomposed, as in all the species of Scolopsis, of two pieces, the posterior of which is the spiniferous; its width in the middle, or in the suture between the two pieces, is one-half of that of the orbit. The spine is strong, flat, and pointed; and there are five spinous teeth besides, much smaller than the spine, but similar in shape: there is no spine pointing forwards. The præoperculum is scaly to its posterior margin, but part of its inferior limb is naked. There are six series of seales between the orbit and the angle of the præopereulum. The posterior limb descends obliquely forwards, and is armed with about twelve rather distant spinous teeth, the middle of which are strongest; the ang.e is rounded and projecting, and amed with about eight spinous teeth, more feeble than the strongest ones of the limb; the inferior limb is smooth, without teeth, and as long as the posterior. The operculum has a short and prominent spine, and is eovered with seales of moderate size; even its basal margin is scaly. The supraseapula is finely serrated, and it ean searcely be distinguished from the surrounding scales.

The dorsal fin begins before the vertieal from the base of the pectoral, and terminates a little behind the anal. 'The length of the base of the soft dor'sal is $1 \frac{3}{4}$ in that of the spinous. The spines ate moderate, not flexible: the first is two-thirds of the second; the seeond is rather shorter than the following four, which are the longest, and one-third of the height of the body. The soft dorsal is rather higher, the sixth and seventh rays being the longest. 'The distance between the dorsal and caudal fins equals the height of the tail beneath the end of the dorsal. The caulal is deeply forked, each lobe being produced into a filament, the length of which equals that of the first dorsal ray; the upper lobe is slightly longer than the lower. The fin is nearly scaleless. The distance between the caudal and anal fins equals the height of the tail above the end of the latter. The anal fin begins beneath the second dorsal ray, and terminates a little before the dorsalis. The spines are rather stronger than those of the dorsal, and on one side broader than on the other : the first is nearly one-half of the second; the second three-quarters of the third, which is three times as long as the head. The margin of the soft portion is slightly rounded, the posterior rays gradually becoming shorter: the first ray is $2 \frac{1}{4}$ in the length of the head. The pectoral fin is slightly pointed, scaly at the base only, and does not reach to the vent. 'The base of the ventral fin falls behind that of the peetoral; it is shorter, and also does not reach to the vent; the spine is two-thirds of the first ray.

The scales are of moderate size, finely erenated; much higher than long, and firmly adherent; one of the largest eovers one-fifth of the eye.

The ground-colour is now greenish olive: the fins are colmurless, The bands as deseribed abore. 
inches. lines,

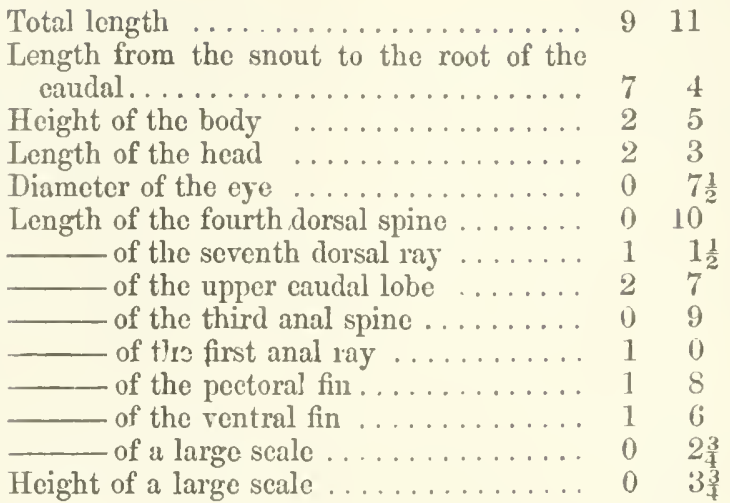

\section{Scolopsis temporalis.}

Scolopsides temporalis, Cur. \& Val. v. p. 341.
D. $\frac{10}{8-9}$.
A. $\frac{3}{7}$.
L. lat. 47 .
L. transv. 6/17.

The snout is as long as the diameter of the eye; the procorbital two-thirds as high as the eye, with a flat spine and some denticulations beneath; the præopereulum with the posterior limb oblique and coarsely denticulated, and with the angle projecting backwards. The spines of the fins rather slender; the second anal spine shorter and not thicker than the third. Caudalis deeply forked, with the lobes produced into filaments, the upper being the longest. The first ray of the rentrals produced into a short filament. Upper part of the head, between the scaly crown and the tip of the snout, violet, with three cross-bands of yellowish colour (in a dried state); the upper band continued behind the eye, and forming there a violet ring with yellowish centre. Body and fins uniform.

Seas of Waigiou, Vanicolo, and New Guinea; Louisiade Archipelago. a, b. Adult: stuffed. Louisiade Archipelago (in 15 fathoms). Voyage of the Rattlesnake.

\section{Scolopsis personatus.}

Cuv. \&. Val. v. p. 344 ; Bleck. Sumatra, i. p. 575.
D. $\frac{10}{9}$.
A. $\frac{3}{7}$.
L. lat. 50 .

The height of the body is $3 \frac{3}{4}$ in the total length, the length of the head four times; the diameter of the eye is $3 \frac{1}{3}$ in the latter. The procorbital is half as wide as the eye, and denticulated beneath the spine: the snout is searely longer than the diancter of the eye. l'reoperenlum with the angle rounded, and the posterior limb slightly emarginate, strongly denticulated. 'The third anal spine longest. 
Caudal fin deeply forked, with the lobes pointed; the first ray of the ventral fins produeed into a short filament. Snout above violet, with a bluish band (in life) between the eyes; a broad yellow band from the eye to the caudal; the soft dorsal with a violet margin behind.

Seas of Java and Sumatra.

\section{Scolopsis frenatus.}

Cuv. \& Val. v. p. 343.

$$
\text { D. } \frac{10}{9} \text { A. } \frac{3}{7} \text {. }
$$

Præoperculum with strong denticulations, some of which aro bifurcate ; the angle projecting backwards. Caudalis deeply forked, with both the lobes produced into filaments. The upper part of the muzzle violet, with a whitish margin in front; a green band from the eye to the third dorsal spine (sometimes disappearing in spirits). Sometimes a blaekish spot on the tail. (Cuv.)

Seyehelles; Isle de France.

\section{Scolopsis cancellatus.}

? Seolopsis lineatus, Quoy \& Gaim. Voy. de l'Astrol. pl. 60. f. 3 (very bad).

Scolopsides cancellatus, Cuv. \& Val. v. p. 351 ; Bleek. Verh. Batav. Genootsch. xxiii. Scicen. p. 28.

$$
\begin{aligned}
& \text { D. } \frac{10}{9} \text {. A. } \frac{3}{7} \text {. L. lat. } 42 \text {. L. transv. 3/12. } \\
& \text { Cæc. pylor. } 6 \text {. Vert. 10/14. }
\end{aligned}
$$

The height of the body is nearly equal to the length of the head, and $3 \frac{2}{3}$ in the total ; the snout is very short, two-thirds of the diameter of the eye, which is $2 \frac{1}{2}$ in the length of the head. The interspace between the eyes is flat, narrowest above the middle of the eyes, and there shorter than the width of the eye; but above the anterior angle of the orbit it widens so much as to equal the diameter mentioned. The upper maxillary extends to the vertical from the front margin of the orbit. The infraorbital arch with one spine only. Præoperculum finely and equally serrated, with a slight noteh above the angle. Spines of the fins moderate; the seeond anal spine rather stronges, but not longer than the third. Back largely marbled with greyish brown; two yellowish longitudinal streaks from the upper half of the eye; a black spot between the first three dorsal spines.

Polynesia ; Sumatra.

a. Half-grown. Sumatra. From the Collection of the Zoological Society.

\section{Scolopsis bleekeri.}

Scolopsides lineatus, Bleeker, Solor, p. 73 (not Rïpp.).

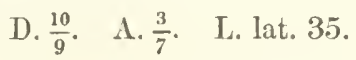

The height of the borly is $3 \frac{1}{2}$ in the total length, the lengtl of the 
head $4 \frac{1}{4}$; the diameter of the eye is $2 \frac{2}{3}$ in the latter, and longer than the snout. The proorbital is one-third as high as the cye, and armed with a strong slender spine and some denticulations beneath. Præoperculum with the posterior limb stronerly serrated and seareely emarginate. Caudalis forked; the second anal spine much longer and stronger than the third, even longer than the soft portion of the fin. Above dark violet; a yellow eross-band between the eyes; three bluish longitudinal bands-the first along the middle of the neck to the dorsal fin, the second from the erown to the base of the soft dorsal, the third from the eye to the end of the dorsal ; a white longitudinal band from the snout, below the eye, to the eaudal. A black spot on the anterior part of the spinous dorsal. (Bl.)

Sea of Solor.

\section{Sc^lopsis ghanam.}

Sciæna ghanam, Forsk. p. 5i:

Holocentrus ghamam, Lucép. iv. p. 347.

Scolopsis Iineatus, Riipp. Atl. Fische, p. 7. pl. 2. f. 1, and N. W. Fische, p. 126.

Seolopsides ghanam, Cur. \&. Val. r. p. 348.
I. $\frac{10}{9}$.
A. $\frac{3}{7}$.
L. lat. 43 .
L. transv. 4/14.
Cæe. pylor. 3.

The height of the body is $3 \frac{2}{3}$ in the total length, the length of the head four times; the diameter of the eye is $3 \frac{2}{5}$ in the latter, and much longer than the snout, or the interspace between the eyes. The infraorbital arch with one flat spine of moderate length; the spiniferous plate slightly dentieulated, and not elerated. Præopercuhum with a noteh above the angle. Spines of the fins slender; the third of the anal longer and not thinner than the second. Caudalis slightly forked. The lateral line angularly eurved below the fourth dorsal spine, and steeply descending behind the end of the dorsal fin. On each side four whitish lines: the first from above the anterior angle of the orbit to the end of the dorsal; the second from the supraseapula above, and following the lateral line to the back of the tail; the third from the posterior upper angle of the orbit below, and following the lateral line, lost on the posterior third of the body ; the fourth, shortest, from the posterior lower angle of the orbit, lost above the base of the pectoral.

Red Sea.

1t. Adult.

l. Adult.

\section{Scolopsis pectinatus.}

Scolopsides pectinatus, (Kuhl \& r. IIass.) Cur. \& Val. v. p. 346 .

$$
\text { D. } \frac{10}{8} . \Lambda \cdot \frac{3}{6} \text {. }
$$

Præorbital narrow, with a very acute spine and without other denticulations; preoperculum with the angle projecting backwards. Yellowish, indistinctly spotted; fins immaculate. (Cuv.)

Sea of Java. 


\section{Scolopsis longulus.}

Richards. Ann. \& Mag. Nat. Hist. ix. 1842, p. 389.
D. $\frac{10}{9}$.
A. $\frac{3}{7}$.
L. lat. 42 .
L. transv. 3/15.

The height of the body is nearly equal to the length of the head, and about one-fourth of the total; the diameter of the eye is rather shorter than the snout, and $3 \frac{3}{4}$ in the length of the head. The præorbital is three-quarters as wide as the eye, and armed with a small spine and some denticulations beneath; præoperculum with the posterior limb very finely serrated, and with the angle rounded. The spines of the fins moderate; the second of the anal shorter than the third. Caudalis emarginate. A yellowish band broadly edged with blackish above and below, from above the pectoral to the root of the caudal; two indistinct blackish lines above the lateral line.

North-west coast of Australia.

a. Adult: skin. Torres Straits. From Mr. Gilbert's Collection.Type of the species.

b. Adult : skin. Port Essington. Presented by the Earl of Derby.

c. Adult : skin. Port Essington.

\section{Scolopsis leucotænia.}

Bleeker, Banka, p. 451.
D. $\frac{10}{9}$.
A. $\frac{3}{7}$.
L. lat. 36 .

The height of the body is $3 \frac{1}{2}$ in the total length, the length of the head four times; the diameter of the eye is $2 \frac{3}{4}$ in the latter, and longer than the snout. The præorbital half as high as the eye, with a single spine, and without denticulations beneath; præopereulum with the posterior limb slightly emarginate and strongly denticulated. Caudalis forked; the seeond anal spine much longer and stronger than the third. A brown band from above the eye to the end of the dorsal fin, a second from the snout to the base of the caudal; a white band between. $(B l$.

Sea of Banka.

\section{Scolopsis leucotænioides.}

Bleeker, Celebes, vii. p. 439.

$$
\text { D. } \frac{10}{9} \text { A. } \frac{3}{7} \text {. L. lat. } 40 \text {. }
$$

The height of the body is equal to the length of the head, and one-fourth of the total; the diameter of the eye is much longer than the snout, twice the distance between the eyes, and $2 \frac{1}{2}$ in the length of the head. The præorbital is one-third as high only as the eye, with a short spine behind, and without any other denticulations. Præopereulum serrated. Caudalis forked; the second and third anal spines nearly equal. A black eurved band from the muzzle, above the eye and the lateral line, to the eaudal fin, anteriorly and posteriorly united with that of the other side; a second black straight 
band from the muzzle, through the eye, to the root of the caudal; a third, very broad white band from the eye to the caudal. $\Lambda$ black bloteh between the first and fourth dorsal spines; a series of brownish spots along the base of the soft dorsal. (Bl.)

Sea of Manado (Celebes).

\section{Scolopsis caninus.}

Cuv. \&. Val. v. p. 354 .
D. $\frac{10}{9}$.
A. $\frac{3}{7}$.

Sereral larger teeth in the jaws. Proorbital with the posterior margin very oblique, entire, and terminating above in a short point; præoperculum with the margin rounded and searcely serrated; spines of the fins slender. A yellowish band from the eye to the caudal fin.

New Guinea.

\section{HETEROGNATHODON*.}

Heterodon, Bleeker, Bydr. Topogr. Batav.

Heterognathodon, Bleeker, Natuurk. Tydschr. Nederl. Ind. i. 1850, p. 100, and Verhand. Batav. Genootsch. xxiii. Scicen. p. 30.

Form of the body oblong; eye-moderate; cleft of the mouth nearly horizontal, with the jaws equal. One dorsal; dorsal with the number $\frac{10}{9}$; anal $\frac{3}{7}$; spines feeble. Candalis more or less decply forked. Canine teeth in both jaws. Infraorbital arch entire; præoperculum serratea ; operculum with a single spine. Five (sometimes six) branchiostegals. Seales moderate, ciliated.

East Indian Seas.

\section{Heterognathodon bifasciatus.}

Bleeker, Verhand. Batur. Genootsch. xxiii. Scien. p. 30.

$$
\text { D. } \frac{10}{9} \text { A. } \frac{3}{7} \text {. L. lat. } 40 \text {. }
$$

The height of the body is one-fifth of the total length, the length of the head one-fourth. The snout is convex, shorter than the diameter of the eye, which is $2 \frac{2}{3}$ in the length of the head. The upper maxillary bones rough; proorbital naked. The third anal spine longest; eaudalis emarginate. Bluish, with two pearl-coloured longitudinal bands; the first between the eye and the end of the dorsal, the seeond from the snout to the caudal. (Bl.)

Sea of Sumbawa.

\section{Heterognathodon hellmuthii.}

Bleelicr, Solor, p. 75.

$$
\text { B. } 6 . \text { D. } \frac{10}{9} \text {. A. } \frac{3}{7} \text {. L. lat. } 50 \text {. }
$$

The height of the body is $4 \frac{3}{4}$ in the total length, the length of the

* 1 suppose that the Lamen guliminde, Russell, ii. pl. 107, is to be refered to this genus. It is identienl with Centhares guliminda, Cuv. \& Val. vi. p. 31. and Spnndyliosoma guliminda, Cantor, Catul. 1. 50.-Las' Ludian Scas. 
head $4 \frac{2}{3}$. The snout is convex, shorter than the diameter of the eye, which is nearly one-third of the length of the head. Prieorbital and margin of the proopereulum scaly; the posterior limb of the præopereulum minutely denticulated. Caudalis forked. A brownish longitudinal band from the eye to the candal fin; above and below the lateral line two series of blue dots. (Bl.)

Sea of Solor.

\section{Heterognathodon xanthopleura.}

Heterodon zonatus, Bleeker, Bydr. Tropogr. Batav.

Heterognathodon xanthopleura, Blecker, Natuurk. Tydsch. Nederl. Indle, i. 1850, p. 101, and Ter. Bat. Genootsch. xxiii. Scian. p. 31.

$$
\text { D. } \frac{10}{9} \text {. A. } \frac{3}{7} \text {. L. lat. } 40 \text {. }
$$

The height of the body equals the length of the head, and is oncfourth of the total; the snout is conieal and rather longer than the diameter of the eye, which is $3 \frac{1}{2}$ in the length of the head. Proorbital naked; propoperculum rery fincly denticulated. The third anal spine longest. Caudalis emarginate. On each side two lighter longitudinal bands; a bluish band from the eye to the operculum.

Seas of Batavia and Amboyna.

a. Adult. Amboyna. Purchased of Mr. Frank.

b. Half-grown. Purchased of Mr. Brandt as Dentex lineretus.

\section{Heterognathodon macrurus.}

Bleeker, Natuurk. Tydschr. Nederl. Ind. i. 1850, p. 101, and Verhand. Batav. Genootsch. xxiii. Scicen. p. 31.

$$
\text { D. } \frac{10}{9} \text {. A. } \frac{3}{7} \text {. L. lat. } 40 \text {. }
$$

The height of the body is $4 \frac{1}{2}$ in the total length, the length of the head five times; the snout is conical, shorter than the diameter of the eye, which is one-third of the length of the head. Proorbital scaly. The third anal spine longest. Caudalis deeply forked. A broad yellowish band from the eye to the caudal fin. (Bl.) .

Sea of Batavia.

\section{Heterognathodon nemurus.}

Bleeker, Celebes, iii. p. 754.

$$
\text { D. } \frac{10}{9} \text {. A. } \frac{3}{7} \text {. L. lat. } 45 \text { (Bleeker } 55 \text { ?). }
$$

The height of the body equals the length of the head, and is $3 \frac{1}{2}$ in the total length (without the caudal); the snout is conical and scarcely longer than the diameter of the eye, which is $3 \frac{2}{3}$ in the length of the head. Præorbital naked, the margin of the præoperculum scaly. Caudalis forked, with the lobes produced into filaments longer than the fin; body with two broad yellow longitudinal bands on each side.

Sea of Macassar.

a. Adult. From the Haslar Collection. 


\section{Heterognathodon microdon.}

Blecker, Batav. p. 464.
B. 5.
D. $\frac{10}{9}$.
A. $\frac{3}{7}$.
I. lat. 48 .

The height of the body is $4 \frac{1}{3}$ in the total length, the length of the head $4 \frac{2}{3}$. The snout is conical, shorter than the diameter of the eye, which is one-third of the length of the head. Præorbital scaleless; margin of preoperculum scaly. Caudalis forked. Rosecoloured; a yellow band from the snout through the eye to the caudal fin.

Seas of Batavia and Amboyna; Louisiade Arehipelago.

a. Adult. Amboyna. Purchased of Mr. Frank.

b. Half-grown : stuffed. Lonisiade Archipelago. Presented by the Lords of the Admiralty.

\section{DENTEX *}

Dentex, sp., Cuv. Règne Anim.; Cuv. \& Iral. vi. p. 212.

Form of the body oblong, rather elevated; eye moderate; cleft of the mouth more or less horizontal, with the jaws nearly equal. One continuous dorsal, with the numbers varying between $\frac{10 \text { and } 13}{10 \text { and } 12}$; in the anal between $\frac{3}{8-9}$; caudalis more or less forked. Gencrally strong canines in both the jaws. Prxorbital entire, broad; distance between the eye and the cleft of the mouth great; procoperculum entire, with more than three series of seales; operculum without prominent spine. Six branchiostegals. Scales moderate, ctenoid. Pseudobranchix. Swim-bladder with a notrh posteriorly. Pyloric appendages in small number.

Mediterranean; Atlantic; Red Sea; Sunda Sea ; Japanese Sea.

\section{Dentex vulgaris.}

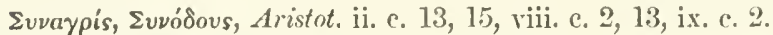

Dentex, Colum. viii. c. 16.

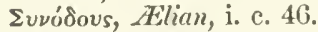

Synagris, Salv. p. 111; Rondel. v. c. 19. p. 150.

Sparus, no. 5, Avtedi, Genera, p. 36.

—, no. 6, Artedi, Symon. p. 59.

* 1. Labrus macrocephalus, Lacép. iii. p. 480. pl. 26. f. 1.-Dentex macrocephalus, Cuv. \& Val. vi. p. 232 ; Cuv. Rigne Anim. Ill. Poiss. pl. 35. f. 2.Hab. - - ? - Probably a species of Payrus.

2. Dentex gobioides, (Solander) Cuv. \& I ül. vi. p. 234.-Otaheiti.

3. Labrus thunbergii, Lacép. iv. p. 467.-Dentex thunbergii, Cuv. \& I'al. vi. p. 237.-Japan.

4. Sparus eynodon, Bloch, taf. 278. - Ciehla eynodon, Bl. Schn. p. 338.Dentex cynodon, Cuv. \& $\mathrm{Val}$. vi. p. 2:39.-1Hab.—?

5. Dentex rivulatus, Benn. Proc. Zool, Soc. iii. p. 91 (not Rüpp.).-Trebizond.

6. - waigiensis, Quoy \& Gaim. I'oy. Freyc. Zool. p. 302.-Appears to be some P'ercoid fish. 
Sparus dentex, L. G'm. p. 1278; Bl. taf. 268 ; Bl. Schn. p. 271 ; Lacép. iv. p. 121 ; Risso, Ichth. Nice, p. 253; De la Roche, Am. Mus. xiii. p. 317.

Duhamel, Péches, ii. e. 2. p. 251.

Cichla dentex, Bl. Schn. p. 337.

Sparus cetti, Risso, Ichth. Nice, p. 256.

Dentex cetti, Risso, Eur. Mérid. iii. p. 256.

—- vulgaris, Cue. \& Val. vi. p. 220. pl. 153; Flem. Brit. Anim. p. 212; Jen. Man. p. 357; Farr. Brit. Fish. i. p. 127; Guichen. Explor. Algér. Poiss. p. 51; Webb \& Berthel. Isles Canar. Poiss. 1. :36.
B. 6 . D. $\frac{10-11}{12-11}$.
A. $\frac{3}{8}$.
L. lat. 60.
L. transv. 7/16. Cxe. pylor. 5. Vert. 10/14.

The height of the body is $3 \frac{1}{2}$ in the total length, the length of the head $3 \frac{3}{4}$; the diameter of the cye is $5 \frac{1}{2}$ in the latter, and $2 \frac{1}{2}$ in that of the snout. The præorbital is very large, its height being nearly twice that of the eye. There are eight series of seales between the præorbital and the anglo of the præopereulum, the limb of which is also partly covered with small, irregnlar scales. In each of the jaws four canine teeth, the outer pair of which is much stronger than the inner one. The spines of the fins are rather slender and flexible; the fourth of the dorsal is the longest, and $2 \frac{1}{2}$ in the length of the head. Caudalis forked. The third anal spine rather longer than the second, and rather shorter than the first ray; the posterior rays of the dorsal and anal fins slightly elongate. Bluish silvery, with some irregular blackish dots on the bark; axil blackish.

Mediterranean; Camary Islands ; Coast of England (orcasional).

a. Adult: skeleton. Adriatic. Purchased of Mr. Frank.

b. Fine specimen. Dalmatia. Purchased of Dr. Heckel.

c. Half-grown. Lisbon. Presented by W. Swainson, Esq.

d, e. Young: stuffed: not good state. Lisbon. Presented by G. Hough, Esq.

f. Adult. Madeira. Presented by the Rev. R. T. Lowe.

g. Young: bad state. Old Collection.

$\hbar$. Adult: bad state. Purchased of Mr. Frank.

Skeleton.-The upper maxillary bone is oblong, flat, with the posterior inferior angle forming a prominence, to which the extremity of the intermaxillary is joined; the intermaxillary tapers little, is rather broad at the base, and has the posterior processes nearly as long as the descending branches, although they do not reach backwards to the vertical from the anterior margin of the orbit. The mandibulary is moderately elongate and elevated, and has a very distinet muciférous channel with four elliptical openings. The head of the vomer is broad, slightly excavated and rounded anteriorly; the palatine bones have a nearly vertical situation. The turbinal bones are very elongate, tubuliform; the preorbital very large, quadrangular; there is a bony plate at the inner side of the infraorbital ring. The lower limb of the præopereulum is only one-half the length of the posterior; both meet at a rather obtuse angle, which, however, is rounded; long slits and openings lead into a channel along the 
interior ridge of the bone. The opereulum is quadrangular, with a slight exterior ridge; the interoperculum rather broader than the subopereulum. The anterior portion of the frontal bones is slightly convex, porons. The occipital crest is strong, and extends on the frontal bones to dbove the eentre of the orbit; the lateral crests also are very dereloped. The basal portion of the brain-capsule is slightly compressed, and the basisphenoid has a quadrangular opening before the occipital foint. The humeral arch and the pubic bones do not show any peculiarity.

There are ten abdominal and fourteen caudai verubrox, the length of the former portion of the vertebral column. being to that of the latter as $1: 1 \cdot 4$. Some of the anterior ribs are broad in their basal portion. The neural and'hæmal spines slender, the interneurals dilated; the first interhæmal is rather fecble, but it has a very distinet anterior ridge.

\section{Dentex argyrozona.}

Cur. \& Val. vi. p. 235; Smith, Ill. S. Afr. Fishes, pl. 19.
D. $\frac{12}{9-10}$.
A. $\frac{3}{8}$.
L. lat. 60 .
L. transv. $\frac{7-8}{16}$.
Caec. pylor. 4.

Vert. 9/13.

The height of the body equals the length of the head, and is $3 \frac{1}{2}$ in the total. The snout exceeds in length the diameter of the eyc. Canines very strong. The præorbital scaleless, nearly as high as the eye; there are eight or mme rows of scales between the procorbital and the margin of the protopereulum, which is also corored with scales for its greater part; the scales above the lateral line searcely smaller than those of the sides. The spines of the fins slender, rather flexible; the fourth of the dorsal longest, and not quite onethird of the length of the head; the second and third anal spines nearly equal. Caudalis emarginate. Red, with silvery longitudinal bands.

Cape Scas.

a. Half-grown: not good state. Cape of Good Hope. From the Haslar Collection.

b. 23" long: stuffed. Cape Seas. From Sir 1. Smith's Collection. c. 29" long: stuffed. Cape Scas. Purchased of Mr. Gould.

d. Adult: stuffed. Cape Seas. From Sir A. Smith's Collection.

e. Adult: skin. False Bay.

f. $29^{\prime \prime}$ long: stuffed.

3. Dentex pranrbitalis. (Plate XXIII. fig. A.)
D. $\frac{12}{10}$.
A.:
L. lat. 60.
L. transs. $10 / 15$.

The height of the body is $3 \frac{1}{2}$ in the total length, the length of the head four times; the diameter of the eye is $2 \frac{1}{2}$ in the length of the snont, and 62 in that of the head. Camines very strong. The praorbital regularly quadrangnlar, sealeless, much higher than wide; the width of the orbit is $2 \frac{1}{2}$ in the height of the proorbital. There 
are eleven or twelve series of scales between the præorbital and the margin of the præoperculum, which is also entirely scaly. The scales on the upper surface of the head entirely cover the space between the eyes; those above the lateral line are considerably smaller than those below. The dorsal spines moderate, not flexible; the fourth is the longest, and $2 \frac{1}{2}$ in the length of the head; the third anal spine rather longer than the second. Caudalis emarginate. Coloration uniform (in a dried state).

Capc Seas.

\section{a. Stuffed. Cape Seas. From Sir A. Smith's Collection.}

Description of the specimen.-The greatest depth of the body is below the origin of the dorsal, where it is contained $3 \frac{1}{2}$ in the total length. The nape of the neck is very convex and gibbous; from thence the upper profile of the head is straight and descends in an oblique line. The head is elevated and strongly compressed, its width between the eyes being $5 \frac{1}{2}$ in its length, which is one-fourth of the total. The head is entirely covered with rather small scales, except the snout; on the upper side the scales extend to the level of the anterior nostril. The posterior processes of the intermaxillaries are rather longer than these bones. The præorbital is very large, elevated, quadrangular, with the posterior margin straight, descending obliquely downwards. The eye is situated high up the sides, but does not interfere with the upper profile; it is rather small, its diameter being $6 \frac{2}{3}$ in the length of the head.

The dorsal spines are of moderate strength, on one side broader and compressed; the first is two-thirds of the second, the second three-quarters of the third; the third rather shorter than the fourth, which appears to be the longest, and $2 \frac{1}{2}$ in the length of the head; the soft dorsal is considerably lower than the spinous. The caudal fin is slightly forked. The posterior edge of the pectoral is slightlemarginate; the fin is pointed, its length being $4 \frac{1}{2}$ in the total, anc reaches nearly to the anal fin: the ventral is much shorter; but $I$ cannot state its exact length, part of the fin being broken off.

The scales are rather small on the head, on the back, and on the breast, much larger on the sides of the body and on the back of the tail. They are minutely ciliated and higher than long. One of the largest covers the eye.

Each of the jaws is armed with a series of pointed conical teeth, becoming smaller posteriorly; there are four canines in front of the upper jaw, six in front of the lower, the outer of which are strong and curved. Behind these larger teeth is a narrow band of small cardiform teeth.

The present colour is a uniform greyish olive.

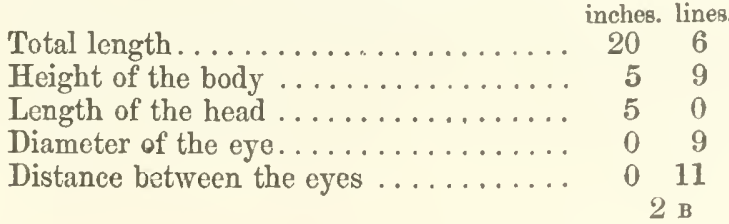




\begin{tabular}{|c|c|}
\hline & inches. lines \\
\hline Length of the fourth dorsal spine & $\begin{array}{ll}2 & 0\end{array}$ \\
\hline - of the pectoral......... & 4 \\
\hline - of the rentral spine $\ldots$. & $1 \quad 10 \frac{1}{2}$ \\
\hline Height of $a$ seale $\ldots \ldots \ldots \ldots \ldots \ldots$ & $\begin{array}{l}0 \\
0\end{array}$ \\
\hline
\end{tabular}

\section{Dentex rupestris.}

Cur. \& Val. vi. p. 231 ; Smith, Ill. S. Afr. Fishes, pl. 14 (not good); Oncen, Osieolog. Catal. i. p. 60.
D. $\frac{11}{11}$.
A. $\frac{3}{8}$.
L. lat. 58.
L. transv. $\frac{11}{17}$.

The height of the body equals the length of the head, and is $3 \frac{1}{2}$ in the total. The snout is twice as long as the diameter of the eye, which is $5 \frac{1}{3}$ in the length of the head. Canines rery strong. The præorbital scaleless, much higher than the eye; there are seventeen rows of scales between the præorbital and the margin of the præopereulum, which is also covered with Ercles for its greater part; the scales above the lateral line are much smaller than those of the sides, similar to those of the head. The spines of the fins moderate, not flexible; the fourth of the dorsal is the longest, and $3 \frac{1}{3}$ in the length of the head; the second and third anal spines nearly equal. Caudalis emarginate. Coloration uniform.

Cape Seas.

a. Adult: stuffed. Cape Seas. From Sir A. Smith's Collection.

\section{Dentex macrophthalmus.}

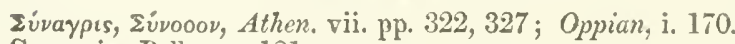

Synagris, Bellon. p. 181.

? Dentalis seu Dentex Bellonii, Gesner, pp. 934, 1119.

Synagris Bellonii, Gesner, p. 934.

Spanes maerophthalmus, Bloch, taf. 272; Risso, Ichth. Nice, p. 250.

Cichla macrophthalme, Bl. Schn. p. 337.

Sparus erythrostoma, Risso, Eur. Mérid. iii. no. 31.

Dentex macrophthalmus, Cuv. \& Val. vi. p. 227; Guichen. Explor Scient. Algér. Poiss. p. 51; Webb \& Berth. l.c. p. 37.

? Dentex maroceanus, Cuv. \& Val. vi. p. 234.

$$
\text { B. } 6 . \quad \text { D. } \frac{12}{10^{\circ}} \text { A. } \frac{3}{8} \text {. L. lat. } 60 \text {. }
$$

The height of the body is $3 \frac{1}{2}$ in the total length, the length of the head 33 ; the diameter of the eye is one-third of the latter, and longer than the distance between the eyes; the preorbital is three times as long as high ; præopereulum with sealy margin; four canines of moderate size in the upper jaw. Dorsal spines moderate; the second of the anal fin longer and stronger than tho third. Caudalis emarginate. Uniform red.

Mediterranean. 
a. Adult: stuffed: not good state.

b, c. Half-grown: stuffed.

d. Adult: skin. Mediterranean. From the Collection of the Zoological Society.

\section{Dentex filosus.}

Dentex filosus, Valenc. in Webb, Iles Canar. Poiss. p. 37 ; Guichen. Explor. Scient. Algér. Poiss. p. 52.

Dentex filamentosus, Valenc. l. .. pl. 6 (not Cuv. \&-Val.).
D. $\frac{12}{10}$.
A. $\frac{3}{8}$.
L. lat. 60 .
L. transv. 8/14.

The height of the body is $3 \frac{1}{2}$ in the total length, the length of the head four times. Nape very convex, elevated. The scales of the upper surface of the skull do not extend to the vertical from the anterior margin of the eye; there are eight series of scales between the præorbital and the angle of the præoperculum. Four canines in each jaw. The third or the third and fourth spines of the dorsal produced into more or less long filaments. Caudalis forked. The first ray of the rentrals sometimes elongate. Reddish, with irregular blackish spots on the back.

Coast of Algiers; Canary Islands ; Cape Seas.

a. Adult: stuffed. Cape Seas. Presented by Sir A. Smith.

\section{Dentex nufar.}

Dentex nufar, (Ehrenb.) Cuv. \&. Val. vi. p. $240 ;$ Rüpp. N. W. Fische, p. 115.
D. $\frac{12}{10}$.
A. $\frac{3}{8}$.
Cæc. pylor. 4.

The third spine of the dorsal fin three-quarters of the height of the body, the fourth and fifth shorter; four canines in each of the jaws. Coloration uniform silvery.

Red Sea.

\section{Dentex hypselosoma.}

Bleeker, Japan, p. 402, and Verh. Bat. Gen. xxvi. Japan, tab. 4. f. 2.
B. 6 .
D. $\frac{12}{10}$.
A. $\frac{3}{8}$.
L. lat. 50 .

The height of the body is $2 \frac{3}{4}$ in the total length, the length of the head $3 \frac{4}{5}$ or 4 ; the diameter of the eye is one-third of the latter, and longer than the snout. The height of the proorbital two-thirda of that of the eye. Four canine teeth above, six below. The scales of the præoperculum are arranged in five series. Dorsal spines rather slender; the fourth longest, nearly one-third of the height of the body. Caudalis emarginate; the second anal spine longest. Rose-coloured; a broad yellow band between the eyes. ( $B l$.)

Sea of Japan. 


\section{Dentex griseus.}

Dentex griseus, Temm. \& Schleq. Faun. Japon. Poiss. p. 72. pl. 36 ; Blecker, Sumatra, iv. p. 80, and Verhand. Batav. Genootseh. xxvi. Jаран, p. 88.

Dentex lethrinoides, Bleek. Java, i. p. 102, and Verh. Bat. Gen. xxiii. Spar. p. 11.

Lobotes microprion, Bleek. Natuurk. Tydschr. Nederl. Ind. ii. p. 174 (young).
B. 6 .
D. $\frac{10}{10}$.
A. $\frac{3}{10}$.
L. lat. 50 .

The height of the body is $2 \frac{1}{2}-3 \frac{1}{2}$ in the total length, the length of the head four times. The snout is rather longer than the eye; the præorbital is large, about half as high as the eye, and scaleless, like the margin of the præoperculum; there are four rows of seales between the præorbital and the angle of the preoperculum. Six canine teeth in the upper jaw. Spines of the fins moderato: the fourth of the dorsal longest, one-third of the height of the body ; the third of the anal fin much longer than the second. Caudalis emarginate. Uniform rose-coloured, the dorsal and anal fins marbled with darker; young specimens with seven brownish cross-bands.

Seas of Japan, Java, and Sumatra.

a. Adult: stuffed: not good state. Japan.

\section{Dentez microdon.}

Blecker, Celebes, i. p. 219.
B. 6 .
D. $\frac{10}{10}$.
A. $\frac{3}{10}$.
I. lat. 50 .

The height of the body is $3 \frac{1}{2}$ in the total length, the length of the head $4 \frac{1}{5}$; the diameter of the eye is one-third of the latter, and equal to the length of the snout. The height of the proorbital is $1 \frac{1}{2}$ in the diameter of the eye; the upper maxillary does not extend to the vertical from the anterior margin of the orbit. No canine teeth. There are four series of scales between the procorbital and the margin of the præoperculum. Dorsal spines slender; the third, fourth, and fifth longest, one-third of the height of the body; the third anal spine longest. Caudalis deeply forked. Greenish; a black streak from the eye to the interopereulum. $(B l$.

Sea of Bulucomba (Celebes).

\section{Dentex rivulatus.}

Rïpp. N. W. Fische, p. 116. taf. 29. f. 2 (not Benn.).

$$
\text { D. } \frac{10}{9} \text {. } \Lambda \cdot \frac{3}{10} \text {. }
$$

The height of the body is three times in the total length, the length of the head $3 \frac{1}{2}$; the eye is one-third of the latter. There are four series of scales on the præoperculum. Canines in both jaws; on the sides a series of conical teeth. Spines of the fins moderate; caudalis forked; the third anal spine longest. Greenish; sides of the head with blue waved lines. (Riipp.)

led Sea. 


\section{Dentex moltidens.}

Cuv.\& Val. vi. p. 238.
D. $\frac{10}{11}$.
A. $\frac{3}{9}$.

Eight or ten canine-like teeth in the outer series of each of the jaws. The last rays of the dorsal and anal fins elongate; the spine of the rentral compressed, very broad, and nearly as long as the rays. Præorbital narrow and elongate. Pectoral very long. Uniform red. ( $V a l$.

Red Sea.

This species, imperfectly described by Valenciennes, perhaps should be referred to Pentapus.

\section{Dentex hasta.}

Cuv. \& Val. vi. p. 255.
B. 6 .
D. $\frac{11}{11}$.
A. $\frac{3}{8}$.

Dorsal spines, and especially those of the anal, strong; prooperculum slightly ciliated, its limb scaleless. Six stout canine tecth in each of the jaws. The height of the body one-third of the total length. Coloration uniform. (Val.)

Coast of Malabar.

\section{SYNAGRIS*.}

Dentex, sp., Cuv. Règne Anım.; Cuv. \& Val. vi. p. 212.

Form of the body rather elongate; eye moderate; cleft of the mouth more or less horizontal, with the jaws nearly equal. One continuous dorsal with the number $\frac{10}{9}$; anal fin $\frac{3}{7(8)}$; spines feeble. Caudalis deeply forked. Canine teeth, at least in the upper jaw. Infraorbital arch entire; præoperculum entire, or with very indistinct serrature, with three series of scales; operculum without prominent spine. Six branchiostegals. Scales moderate, ciliated. Pseudobranchix. Swim-bladder with a notch posteriorly. Pyloric, appendages in small number.

From the Red Sea, through all the East Indian Seas, into the Pacific. [One species from the Surinam coast.]

\section{Synagris furcosus.}

Dentex furcosus, Cuv. \& Val. vi. p. 244.
D. $\frac{10}{9}$.
A. $\frac{3}{7}$.
L. lat. $48-50$.
L. transv. $4 / 14$.

The height of the body equals the length of the head, and is one-

* 1. Dentex marginatus, Cuv. \& Val. vi. p. 245.-East Indies.

2. — tambuloides, Bleek. Batav. p. 465.-Batavia.

3. - tolu, Cuv. \& Val. vi. p. 249 ; Bleek. Verh. Bat. Gen. xxiii. Spar. p. 13.-Bataria.

4. Coryphæna striata, Bloch.-Dentex striatus, Cuv.\& Val. vi. p. 252.Tranquebar.

5. Dentex mesoprion, Bleck. Sumatra, ii. p. 13.-Sumatra.

6. - ruber, Cuu. \& Val. vi. p. 245; Less. Voy. Coq. Zool. Poiss. p. 187. pl. 31. f. 2; Bleek. Verh. Bat. Gen. xxiii. Spar. p. 12.-East Indies. 
fourth of the total ; the diameter of the eye is $3 \frac{2}{3}$ in the latter, and $1 \frac{k}{3}-1 \frac{1}{2}$ in the length of the snout. The pricorbital is higher than the eye; there are three rows of seales between the præorbital and the margin of the præoperculum. Six canine teeth in each of the jaws. The spines of the fins slender, flexible; the fourth, fifth, and sixth of the dorsal fin longest, $2 \frac{2}{3}-2 \frac{1}{3}$ in the length of the head. Caudalis deeply forked, scaly, the upper lobe rather longer; the second and third anal spines very feeble, nearly equal; the posterior rays of the dorsal and anal fins slightly elongate. Coloration uniform.

Coast of Trincomalee; Sea of Amboyna; Louisiade Archipelago; Coasts of Australia.

a. Fine specimen. Amboyna. Purchased of Mr. Frank.

b. Adult: stuffed. Louisiade Archipelago. Presented by the Lords of the Admiralty.

c. Adult: stuffed. Chaumont Island (Louisiade Archipelago), in 17 fathoms. Voyage of the Rattlesnake.

d, e. Adult: skins. Damlay Island.

f. Fine specimen. Australia. Presented by J. Macgillirray, Esq.

g. Fine specimen. Australia. Presented by J. Macgillivray, Esq.

\section{Synagris tæniopterus.}

Dentex tæniopterus, Cuv. \& Val. vi. p. 246; Bleek. Verh. Batav. Genootsch. xxiii. Spar. p. 11.
D. $\frac{10}{9}$.
A. $\frac{3}{7}$.
L. lat. 48 .
L. transv. $4 / 11$.

The height of the body nearly equals the length of the head, and is $3 \frac{2}{3}$ in the total ; the snout is longer than the diameter of the eye, which is one-fourth of the length of the head. The præorbital is as high as the eye; there are three series of scales between the præorbital and the margin of the præoperculum. The spines of the fins slender and flexible; the pasterior of the dorsal fin longest, 23 in the length of the head, and rather shorter than the rays. Caudalis forked. The third anal spine intermediate in length between the second spine and the first ray; the posterior rays of the dorsal and anal fins slightly elongate. Rose-coloured, with yellow longitudinal bands on the body; a yellow band from the base of the first dorsal spine to the top of the last ray.

Coasts of Australia; Molucra Seo

a. Adult: stuffed. N.E. coast of Australia. Voyage of the Rattlesnake.

b. Adult. Molucca Sea.

\section{Synagris mulloides.}

Dentex mulloides, Blecker, Sumatra, i. p. 576.
D. $\frac{10}{9}$.
A. $\frac{3}{7}$.
L. lat. 50 .

The height of the body is five times in the total length, the length of the head $4 \frac{1}{2}$; the diameter of the cye is about one-third of the 
latter, and as long as the snout; the præorbital is only half the height of the eye. Six or eight canine teeth in the upper jaw, none in the lower. There are three series of scales betwcen the præorbital and the angle of the præoperculum. The spines of the fins feeble, flexible; the middle ones of the dorsal fin highest, not quite so high as the body; the third anal spine longèst, but rather shorter than the first ray. Caudalis deeply forked, the upper lobe longer Uniform rose-coloured. ( $B l$.) Sea of Sibogha (Sumatra).

\section{Synagris upeneoides.}

Dentex upeneoides, Bleeker, Banka, ii. p. 725.
B. 6 .
D. $\frac{10}{9}$.
A. $\frac{3}{7}$.
L. lat. 50.

The height of the body is $4 \frac{1}{2}$ in the total length, the length of the head $4 \frac{1}{5}$; the diameter of the eye is one-third of the latter, and as long as the smout. The upper maxillary reaches to the vertieal from the anterior margin of the orbit; the height of the præorbital is $1 \frac{2}{5}$ in the diameter of the eye; there are three series of scales between the præorbital and the margin of the præoperculum. Six canine teeth in the upper jaw, none in the lower. The spines of the fins slender, flexible; the middle ones of the dorsal longest, half the height of the body ; the soft portion of the fin lower than the spinous. Caudalis deeply forked. Rose-coloured; the soft lorsal with a yellow longitudinal band near the upper margin. $(B l$.

Sea of Banka.

\section{Synagris zysron.}

Dentex zysron, Bleeker, Nias, p. 219.
B. 6 .
D. $\frac{10}{9}$.
A. $\frac{3}{7}$.
L. lat. 50 .

The height of the body is five times in the total length, the length of the head $4 \frac{3}{5}$; the snout is shorter than the diameter of the eye, which is one-third of the length of the head; the proorbital is not half as high as the eye. Eight or ten canine teeth in the upper jaw. There are three series of scales between the preorbital and the margin of the præoperculum. Præopereulum with slight dentieulations. Spines of the fins slender, those of the dorsal more than one-half lower than the body. Caudalis deeply forked. The third anal spine intermediate between the second spine and the first ray. Rosecoloured; dorsalis with the upper margin yellow; analis with aiz oblique yellowish longitudinal band. (Bl.)

Sea of Nias.

\section{Synagris ovenii.}

Dentex ovenii, Bleeker, Celebes, v. p. 246.
B. 6 . D. $\frac{10}{9}$.
A. $\frac{3}{7}$.
L. lat. 50.

The height of the body is five times in the total length, the length of the head $4 \frac{1}{5}$; the diameter of the eye is one-third of the latter, and equal to the length of the snout; the height of the præorbital.is 
$1 \frac{3}{5}$ in the diameter of the eye. Six or eight canine tecth in each jaw. Scales of the præoperculum arranged in three series. Dorsal spines slender, about half the height of the body; eaudal fin deeply forked, with the upper lobe longer. The third anal spine longest, much shorter than the soft portion of the fin; the posterior anal ray shortest. Rose-coloured, without any bands. ( $B l$.

Sea of Macassar.

\section{Synagris metopias.}

Dentex metopias, Bleek. Act. Soc. Nederl. ii., Amboma, p. 51.
D. $\frac{10}{9}$.
A. $\frac{3}{7}$.
L. lat. 48-50.

The height of the body is $4 \frac{2}{5}$ in the total length (without caudal fin), the length of the head $3 \frac{3}{5}$; the diameter of the eye is $2 \frac{2}{3}$ in the latter, and much longer than the snout; the height of the præorbital is less than one-half the width of the orbit (above the angle of the mouth); the upper maxillary reaches to below tho anterior half of the eye ; præoperculum with denticulations. The soft portion of the dorsal scarcely higher than the spinous; the first ventral ray produced into a filament; the upper caudal lobe longer than the lower. Uniform rose-coloured. (Bl.)

Sea of Amboyna.

\section{Synagris hexodon.}

Dentex hexodon, Quoy \& Gaim. Voy. Freyc. Poiss. p. 301 ; Cuv.\& Val. vi. p. 243.

$$
\text { D. } \frac{10}{9} \text {. A. } \frac{3}{7} \text {. L. lat. } 45 \text {. }
$$

Scales of the cheeks larger than thase of the body; six canines in each jaw; the dorsal spines feeble, and lower than the soft portion of the fin. Body elongate. Uniform rose-coloured, silvery bencath. (Val.)

A rather doubtful species, from the Sea of Timor.

\section{Synagris peronii.}

Dentex poronii, Cuv. \& Val. vi. p. 245. pl. 154.
D. $\frac{10}{9}$.
A. $\frac{3}{8}$.
L. lat. 65 .

The height of the body equals the length of the head, and is $4 \frac{1}{4}$ in the total length. Caudalis deeply forked, covered with seales. The posterior rays of the dorsal and anal fins not elongate; the third anal spine longer than the second. Rose-coloured. (Val.)

Molucea Sea.

\section{Synagris variabilis.}

Dentex variabilis, (Ehrenbery) Cuv. \& $V$ al. vi. p. 241.

— fasciolatus, (Ehrenberg) Cur. \& Val. vi. p. 242.

$$
\text { D. } \frac{10}{9} \text {. A. } \frac{3}{8} \text {. }
$$

Dorsal fin rather low. Silvery; body and vertical fins marbled with brownish. ( $\mathrm{Fal}$.)

Red Sea. 


\section{Synagris luteus.}

? Coryphæna lutea, Bl. Schn. p. 297. taf. 58. Dentex luteus, Cuv. \& Val. vi. p. 250.
D. $\frac{10}{9}$.
A. $\frac{3}{7}$.
L. lat. 40 .

Teeth nearly equal. ( $V a l$.

Coast of Pondicherry.

\section{Synagris celebicus.}

Dentex celebicus, Bleeker, Celebes, v. p. 245.
B. 6.
D. $\frac{10}{9}$.
A. $\frac{3}{7}$.
L. lat. 50 .

The height of the body is five times in the tctal length, the length of the head $4 \frac{1}{4}$. The snout is seareely shortir than the diameter of the eye, which is onc-third of the length of the head; the upper maxillary reaches to below the anterior half of the eye ; the prieorbital is narrow, its height being $1 \frac{2}{3}$ in the diameter of the eye. Six canine teeth in each jaw. Scales of the præoperculum arranged in three series. The dorsal spines slender, the posterior ones longest, one-half the height of the body; the soft portion of the dorsal searcely higher than the spinous. Caudalis deeply forked; the third anal spine longest, rather shorter than the soft portion of the fin. Rosecoloured, with a yellow lateral band; dorsal and anal fins with two greenish-yellow longitudinal bands, the former with a yellow margin.

Macassar ; Louisiade Archipelago.

a. Adult: stuffed. Louisiade Archipelago (in 30 fathoms). Voyage of the Rattlesnake.

\section{Synagris nematopus.}

Dentex nematopus, Bleeker, Celebes, i. p. 219.

$$
\text { D. } \frac{10}{9} \text {. A. } \frac{3}{7} \text {. L. lat. } 45 \text {. }
$$

The height of the body is $4 \frac{1}{2}$ in the total length, and equals the length of the head; the diameter of the eye is $3 \frac{1}{3}$ in the latter, and equal to the length of the snout. The præorbital is half as high as the eye; there are three series of scales between the præorbital and the margin of the præopereulum. The upper maxillary reaches beyond the vertical from the anterior margin of the eye. Four canines in the upper jaw, none in the lower. Spines of the fins slender ; the posterior ones of the dorsal longer, and $1 \frac{3}{4}$ in the height of the body; the soft portion of the fin higher than the spinous. The pectoral fins rather longer than the head; in adult specimens the first ray of the ventrals produeed into a filament, reaching beyond the origin of the anal fin. The third anal spine intermediate in length between the second spine and the first ray. Caudalis decply forked, the upper lobe being longer. Red, with two yellow bands 
from the head to the caudal fin; dorsal fin with three wared, greenish-yellow longitudinal stripes.

Sea of Bulueomba (Celebes). Louisiade Archipelago.

$a-d$. Adult and half-grown: stuffed. Louisiade Archipelago. Voyage of the Rattlesnake (in 30 fathoms).

\section{Synagris japonicus.}

Sparus japonieus, Bloch, t. 277. f. 1 .

Dentex blochii, Blecker, Natuurk. Tydselr. Nederl. Indie, 1851, p. 176.

$$
\text { B. 6. D. } \frac{10}{9} \text {. A. } \frac{3}{7} \text {. L. lat. } 45 \text {. }
$$

The height of the body is 4 or $3 \frac{3}{4}$ in the total length, and nearly equal to the length of the head; the diameter of the eye is $3-3 \frac{1}{2}$ in the latter, and rather longer than the snout ; the height of the præorbital is about one-half of the diameter of the eye; there are three series of seales between the præorbital and the angle of the præoperculum. Eight or ten canine teeth in the upper jaw, none in the lower. The spines of the fins slender; the posterior ones of the dorsal longer, $2 \frac{2}{3}$ in the height of the body ; the third anal spine intermediate in length between the second spine and the first ray. Caudalis deeply forked, with the upper lobe longer, and sometimes produced into a short filament. Reddish violet, with seven or eight golden longitudinal bands; a ferruginous spot on the operculum; dorsal fin yellow-edged, caudal red. $(B l$.)

Sea of Batavia.

\section{Synagris filamentosus.}

Cantharus filamentosus, Rïpp. Atl. Fische, p. 50. pl. 12. f. 3 (not Dentex filamentosus, Cuv.\& $\mathrm{Val}$.).

Dentex bipunctatus, (Ehrenberg) Cuv. \& Val. vi. p. 247.

— tambulus, Cuv. \& Val. vi. pp. 249, 558 (not Sparts japonicus, Bloch); Rüpp. N. W. Fische, p. 114; Bleck. Verhand. Bat. Genootsch. xxiii. Spar. p. 12.

$$
\text { D. } \frac{10}{9} \text {. A. } \frac{3}{7} \text {. Crec. pylor. } 4 \text {. }
$$

The height of the body is three times in tho total length (without caudal), the length of the head $3 \frac{1}{4}$. The snout is longer than the eye. The posterior spines of the dorsal fin longest, one-third of the height of the body; caudalis deeply forked; in adult specimens (males?) the upper lobe prolonged into a filament nearly as long as the fin, and the ventrals elongate, about one-fourth of the total length. Reddish; two yellow streaks along the belly.

Red Sea; Coast of Pondicherry.

\section{Synagris nemurus.}

Dentex nemurus, Bleet. Act. Soe. Nederl. ii., Amboina, p. 49.

$$
\text { B. } 6 \text {. D. } \frac{10}{9} \text {. A. } \frac{3}{7} \text {. L. lat. } 50 \text {. }
$$

The height of the body is $4 \frac{1}{4}$ in the total length (without caudal 
fin), the length of the head $3 \frac{3}{5}$; the diameter of the eye is $2 \frac{2}{3}$ in the latter, and longer than the snout; the praorbital is not half as high as the orbit (above the angle of the mouth); the upper maxillary bone reaches to below the anterior half of the orbit; præoperculum denticulated, operculum with a conspicuous spine. The first wentral ray produced into a filament; the upper caudal lobe with a filament, which is $3 \frac{2}{5}$ in the length of the body. Rose-coloured; the dorsal fin with a yellow margin; the anal with a series of yellow dots along the base. ( $B l$.

Sea of Amboyna.

\section{Synagris sinensis.}

Sparus sinensis, Lacép. iv. p. 46.

Dentex setigerus, Cuv. \& Val. vi. p. 253 ; Faun. Japon. Poiss. p. 73. pl. 37. f. 1 (not good).

$$
\text { D. } \frac{10}{9} \text {. A. } \frac{3}{8} \text {. L. lat. } 48 \text {. L. trans\$, } 4 / 10 \text {. }
$$

The height of the body is four times in the total length (without caudal), the length of the head $3 \frac{3}{4}$; the diameter of the eye is much shorter than the muzzle, and one-fourth of the length of the head. Præorbital very large, much higher than the eye, and scaleless, like the margin of the præoperculum. Præoperculum minutely ciliated, The spines of the fins slender, those of the dorsal $2 \frac{1}{2}$ in the length of the head; the last rays of the dorsal and anal fins elongate; the upper lobe of the caudal produced into a very long filament. Red, with sï yellow longitudinal banes on each side; dorsal and anal fins with a yellow band along the base and margin; the elongated caudal ray yellow.

Japanese and Chinese Seas.

a. Adult: stuffed : injured. China. Presented by J. R. Reeves, Esq. b. Adult: skin : not good state. China. Presented by J. R. Reeves, Esq.

\section{Synagris nematophorus.}

Dentex nematophorus, Bleeker, Sumatra, iii. p. 500.
B. 6 .
D. $\frac{10}{9}$.
A. $\frac{3}{7}$.
L. lat. 48.

The height of the body is nearly equal to the length of the head, and $4 \frac{1}{3}$ in the total; the diameter of the eye is about one-third of the latter, and longer than the snout. The præorbital is half the height of the eye; there are three series of scales between the præorbital and the angle of the præoperculum; the upper maxillary reaches tu the vertical from the anterior margin of the eye. The first two dorsal spines produced into very long filaments, extending to the caudal fin. Caudalis deeply forked, the upper lobe produced into a filament. Rose-coloured, with three or four yellow longitudinal bands ; dorsal fin yellow-edged, anal with a yellow basal streak. $(B l$. Sea of Padang (Sumatra). 


\section{Synagris macronemus.}

Dentex filamentosus, Cuv. \& $V a l$. vi. p. 254. pl. 155 (not Dentex fila-

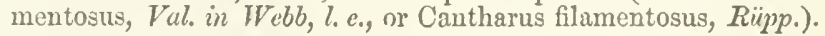
B. 6 .
D. $\frac{10}{9}$.
A. $\frac{3}{7}$.

The height of the body is $3 \frac{3}{4}$ in the total length, the length of the head four times; the first dorsal spine, the upper lobe of the candal, and the first ray of the rentral produced into long flaments. ( $V_{a l}$.)

Surinam.

It is not certain, from the imperfect description of Valenciennes, whether this fish should be referred to Synagris or to Dentex; according to the figure, it has the habit of Synagris, but the scales on the præoperculum are arranged in more than three series, as in Dentex.

\section{PRISTIPOMOIDES.}

Pristipomoides, Bleek. Natuurk. Tydschr. Nederl. Ind. 1852, iii. p. 574.

Form of the body compressed, rather elongate; eye and muzzle moderate, with the lower jaw longest. Seven branchiostegals. 'Two or four canine teeth. Præoperculum denticulated. No pores under the mandibula. One dorsal with ten, the anal with three spines; candal fin deeply forked and entirely scaly. Scales moderate, ctenoid.

Coast of Sumatra.

\section{Pristipomoides typus.}

Pristipomoides typus, Bleek. l.c. p. 575.

Dentex pristipoma, Bleeker, Celebes, v. p. 246.
D. $\frac{10}{10}$.
A. $\frac{3}{7}$.
L. lat. 50 .

The height of the body is $4 \frac{1}{2}$ to $4 \frac{2}{3}$ in the total length, the length of the head $4 \frac{1}{4}$; the snout is not shorter than the eye; the upper maxillary reaches to below the anterior half of the orbit; dorsal fin not notehed, spines slender; the last ray of the dorsal and anal fins elongate. Rose-coloured. ( $B l$.)

Sea of Sibogha (West Sumatra).

\section{PENTAPUS*.}

Pentapus, Cuv. Règne Anim. ; Cuv. \& Val. vi. p. 258.

Leiopsis, Bennett, in Life of Raffles, p. 688.

Form of the body oblong; eye moderate; cleft of the mouth horizontal, with the jaws equal. One continuous dorsal, with tho numbers varying between $\frac{10}{8 \text { and } 10}$; in the anal between $\frac{3}{7 \text { and } 10}$; caudalis deeply forked. Canines small. Procorbital entire, narrow; the distance between the eye and the eleft of the mouth small. Præopereulum entire, with more than three series of seales; opereulum with one feeble spine. Six branchiostegals. Scales moderate,

* 1. Pentapus iris, Cuv. \& V Vul. vi. p. 266.-Anstratia. 
ciliated. Pseudobranchix. Swim-bladder simple. Pylorie appendages in small number.

East Indian and Australian Seas.

\section{Pentapus aurolineatus.}

Sparus aurolineatus, Lacép. iv. p. 132.

Pentapus aurolineatus, Cuv. \&· Vul. vi. pp. 269, 559. pl. 157; Bleekrr, Halmaheira, p. 7.
D. $\frac{10}{10}$.
A. $\frac{3}{9-10}$.
L. lat. $70-75$.
L. transv. 6/17.

The upper maxillary with a crenulated longitudinal ridge; four or five series of scales between the proorbital and the angle of the prieopereulum. The third anal spine longest. Body with more or less distinct longitudinal stripes; a white spot on the back, beneath the end of the dorsal fin.

Isle de France; Molueea Sea; Louisiade Arehipelago.

a-c. Adult: stuffed. Louisiade Archipelago (in 43 to 50 fathoms). Voyage of the Rattlesnake.

d. Adult. Isle de France. From the Colleetion of the Zoologieal Society (Dentex lycogenis, Benn.).

\section{Pentapus vitta.}

Quoy \& Gaim. Voy. Freyc. Uran. Poiss. p. 294. pl. 44. f. 4; Cuv. \& Val. vi. p. 264.
D. $\frac{10}{9}$.
A. $\frac{3}{7-8}$.
L. lat. 60 .
L. transv. 6/20.

The margin of the præopereulum without distinet seales, slightly striated. The height of the body equals the length of the head, and is about one-fourth of the total. The diameter of the eye is shorter' than the snout, and the distance between the eyes one-fourth of the length of the head. Caudalis forked, with acute lobes. The spines of the fins feeble; scales of the præoperculum small, in about six series; the second of the anal one-half of the third. A broad brownish-black band from the snout through the eye to the upper half of the root of the eaudal fin.

Coasts of Australia.

$a, b$. Adult: stuffed. Victoria (Australia). Voyago of H.M.S. Herald.

$c-f$. Adult: skins. Houtman's Abrolhos. From Mr. Gould's Collection.

g. Adult: not good state. 'From the Haslar Colleetion.

\section{Pentapus peronii.}

Cuv. \& Val. vi. p. 268.
D. $\frac{10}{9}$. A. $\frac{3}{7}$.
L. lat. 50 .
Cæe. pylor. 6 .

The margin of the proopereulum scaleless; pectoral very short; a black band from the eye to the eaudal fin. ( $\mathrm{Val}$.

II $a b$. 


\section{Pentapus vittatus.}

Sparus vittatus, Bloch, taf. 275.

Pentapus vittatus, Cuv. \& Val. vi. p. 260.
B. 6 .
D. $\frac{10}{8}$.
A. $\frac{3}{7}$.
L. lat. 32
L. transv. 14-15.

The margin of the præoperculum scaly. The height of the body equals the length of the head, and is one-fourth of the total; the diameter of the eye is rather less than one-third of the length of the head, and equals that of the snout. Caudalis forked. Three blue longitudinal bands from the head along the sides. ( $\mathrm{Val}$.)

East Indies.

\section{Pentapus porosus.}

Cuv. \& Val. vi. p. 267. pl. 156.
D. $\frac{10}{9}$.
A. $\frac{3}{7}$.
L. lat. 50 .

The height of the body equals the length of the head, and is onefourth of the total. The pectoral does not extend to the anal. Body with indistinct oblique streaks. ( $\left.V a l_{\text {. }}\right)$

Hab.

6. Pentapus nubilus.

Pentapodus nubilus, Cantor, Catal. p. 49.

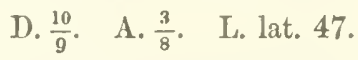

The length of the head, when the muzzle is protracted, is "onethird of that of the body, the caudal not ineluded. The pectoral reaches to the anal. An indistinct blackish oblique band from the nape of the neck to the point of the operculum; a second, similar, in front of the dorsal, terminating beneath the lateral line in a large rounded spot; a few indistinct, blackish, elouded spots along the sides. (Cant.)

Sea of Pinang.

\section{Pentapas unicolor.}

Cuv. \& Val. vi. p. 263.
D. $\frac{10}{8}$.
A. $\frac{3}{7}$.
L. lat. 60 .

The height of the body equals the length of the head, and is about one-fourth of the total. Caudalis forked. Coloration uniform. ( $\mathrm{Fal}_{\text {. }}$ )

East Indies?

\section{Pentapus setosus.}

Cuv. \& Val. vi. p. 270; IBleeker, Natuurk. Tydschr. Nederl. Ind. 1851, p. 175 .

B. 6. D. $\frac{10}{9}$. A. $\frac{3}{7}$. I. lat. 60. Cæc. pylor. 5. Vert. 10/13.

The height of the body equals the length of the head, and is $4 \frac{3}{4}$ in the total; the diameter of the eye is $3 \frac{1}{2}$ in the length of the head. The middle spines of the dorsal longest; the first ray of the ventrals 
produced into a filament, reaching to the anal; the third anal spine intermediate between the second spine and the first ray. The upper lobe of the caudal produced into a long filament. A blue and yellow band from the muzzle through the eye to the operculum; a brown, bluish-edged spot at the root of the caudal; dorsal fin with the upper margin yellow.

Sea of Batavia.

9. Pentapus paradiseus. (PLAte XXIV. fig. A.)
D. $\frac{10}{9}$.
A. $\frac{3}{7}$.
L. lat. 45.
L. transv. 5/16.

The height of the body equals the length of the head, and is onefourth of the total (without caudal filament); the diameter of the eye is $3 \frac{3}{4}$ in the length of the head. The middle spines of the dorsal are the longest. The first ray of the ventral sometimes produced into a short filament, which does not reach to the vent; the third anal spine intermediate between the second spine and the first ray. In male (?) individuals the upper lobe of the caudal produced into a filament, sometimes as long as the body. Muzzle above bluish silvery with two yellow cross-bands, the anterior of which runs to the middle of the eye, crossing the præorbital. A third yellow band from the præorbital, along the inferior margin of the orbit, across the cheek, operculum and suboperculum, to the base of the pectoral. A silvery longitudinal band from the middle of the eye, along the side of the body, below the lateral line, to the upper part of the tail, and convergent with another pearl-coloured band from the origin of the anal: both the latter bands meet at an acute angle in the middle of the base of the caudal fin. Finally, a pearl-coloured band on the back, along the base of the dorsal fin.

Polynesia; Sumatra.

a. $11^{\prime \prime}$ long, filament $3 \frac{1}{2} "$. Old Collection.

b. $6^{\prime \prime}$ long, filament $2^{\prime \prime}$. Sumatra. From the Collection of the Zoological Society.

c, d. $7 \frac{1}{2}$ " long, flament $2 \frac{1}{2}$ ". Australia. Presented by J. Macgillivray, Esq.

e, f. $8^{\prime \prime}$ long, filament 5": stuffed. Moreton Island (12 fathoms). Voyage of the Rattlesnake.

g, h. $6^{\prime \prime}$ long, filament $\frac{1}{2}^{\prime \prime}$ : stuffed. Louisiade Archipelago (30 fathoms). Voyage of the Rattlesnake.

i. $7 \frac{1}{2}$ "long, filament none. Purchased of Mr. Gosse.

k. $7^{\prime \prime}$ long, filament 2". Presented by J. B. Jukes, Esq.

l. $5^{\prime \prime} 4^{\prime \prime \prime}$ long, filament none. From the Haslar Collection.

Description.-This fish forms one of the most beautiful species of the whole family. The coloration, with the exception of the ground-colour, is very well preserved in specimens in spirits, but not so well in dried specimens; this facilitates its distinction from $P$. setosus, to which it is closely allied. It appears, however, from the descriptions of the latter species, that, besides the differences 
in colour, our new species has fewer transwerse rows of seales and a more elevated body. Its greatest depth is above the base of the ventral fins, where it equals the length of the head, and forms onefourth of the total; the height of the body is $3 \frac{1}{5}$ in the total length (the caudal excluded). The head is rather broad above, the distance between the eyes being more than the width of the orbit, and equal to the length of the snout; it is scaly to the level of the nostrils, which, close together, and at some distance from the eye, are situated rather on the upper surface of the head than on its side. The snout is somewhat pointed, with the jaws equal, and with the cleft of the mouth moderate and slightly oblique. The upper maxillary reaches to the vertical from the anterior margin of the orbit. The proorbital is porous, and has a slight notch to receive the extremity of the maxillary bone; here it is narrowest, the distance between the angle of the mouth and the eye being only one-half of the diameter of the latter; it is, like the rest of the snout, entirely scaleless. The præopereulum is not denticulated, exhibiting some slight striæ at the angle; the limbs have a nearly vertical direction towards each other, but the angle is rounded; there is a broad scelcless space above the angle and the lower limb, the remainder of the cheek being covered with seren series of scales of rather small size. The operculum has a semicircular notch behind, but no prominent points. The suprascapula can scarcely be distinguished from the surrounding scales.

The origin of the dorsal fin is above the posterior extremity of the operculum, and its end behind the vertical from the end of tho anal fin. The spines are slender and somewhat flexible: the first is threefifths of the length of the sceond; the second and third are rather shorter than the three following, which are the longest, and $2 \frac{1}{2}$ in the height of the bods; the posterior spine is rather shorter than the rays, which form a slightly convex margin of the fin, and none of which attain the height of the spinous dorsal; the posterior rays are not elongate. The distance between the dorsal and caudal fins equals the height of the tail below the end of the dorsal. The caudal is forked, and partly corered with series of small scales: the upper lobe is longest, and produced in some of the specimens into a filament, which is shorter than the fin in two half-grown specimens, but onethird or three-quarters of the total length in adult ones; a third part of the specimens are destitute of such a filament. I am inclined to believe that this is a sexual difference. The distance between the caudal and anal fins is equal to that between the snout and the posterior margin of the eye. The anal spines are very feeble; the first is one-half the length of the second, the second two-thirds of the third; the third is three-quarters of the first ray. The fin is lower than the soft portion of the dorsal, and has sometimes a rounced margin; sometimes the last ray is rather elongate. The pectoral is slightly pointed, and its length is $1 \frac{1}{3}$ in that of the head. 'The base of the ventral falls behind that of the pectoral ; its first ray is sometimes produeed into a short filament, in other specimens not.

The scales are of moderate size, fincly ciliated, much higher than 
long; one of the largest eovers one-sixth of the eye. The lateral line follows the eurvature of the baek.

There are, besides the villiform bands and the outer series of larger teeth, four eanines of moderate size in front of the upper jaw. The lower jaw is armed with a single pair; they are rather bent outwards, and reeeire the four upper ones between them.

To the eoloration, as given aluove, must be added, that the groundcolour is now a reddish olive (rose-eoloured in life?), and that two of the speeimens exhibit a brownish speck at the root of the eaudal, in the angle formed by the pearl-coloured bands. A similar spot is found in Pentapus setosus.

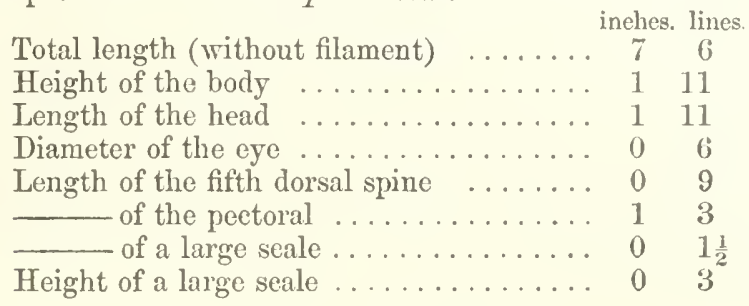

\section{CHETOPTERUS.}

Chætopterus, Temm. \& Schleg. Faun. Japon. Poiss. p. 78.

Form of the body elongate; eye moderate; eleft of the month slightly oblique, with the lower jaw rather longer. One eontinuous dorsal with ten spines, the anal fin with three. Caudalis deeply forked. Canine teeth none; minute teeth on the vomer and the palatine bones. Præorbital and præoperculum entiro. I Four branchiostegals. Seales moderate, eiliated.

Japanese Sea.

\section{Chætopterus dubius.}

Chrtopterus, sp., Temm. \&. Schleg. l.c. pl. 37. f. 2.

Uniform red.
D. $\frac{10}{10}$.
A. $\frac{3}{8}$.
L. lat. 75 .

Japanese Sea.

\section{APHAREUS.}

Aphareus, Cuv.\& Val. vi. p. 485; Rüpp. N. W. Fisshe, p. 121.

Form of the body oblong; eye moderate; the cleft of the mouth slightly oblique, rather wide, with the lower jaw longer. One dorsal, continuous, with the anterior part highest, and with ten or twelve spines; analis $\frac{3}{8}$. All the spines feeble; caudalis deeply forked. No eanines. No teeth on the palate. Præorbital and præopereulum entire. Scales rather small. Seven brançhiostegals. Airbladder simple. A (respiratory) eavity behind the branchiæ, at the interior side of the humerus. Pylorie appendages in small number.

Red Sea; Isle de France. 


\section{Aphareus furcatus.}

Renard, pl. 30. p. 166 ; Valentyn, no. 129.

Labrus furcutus, Lacép. iii. pp. 424, 477. pl. 21. f. 1.

Caranxamorus sacrestinus, tacép. v. p. 682.

Aphareus cærulescens, Cuv. \& Val. vi. p. 487. pl. 167 b.
D. $\frac{10}{11}$.
A. $\frac{3}{8}$.
L. lat. 75 .

The third dorsal spine is the longest. The last ray of the dorsal and anal fins twice as long as the preceding. Uniform brownish blue. (Cuv.)

Isle de France.

\section{Aphareus rutilans.}

Cuv. \& Val. vi. p. 490; Rüpp. l. c. -; ? Bleek. Act. Soc. Nederl. ii., Amboina, p. 52.
D. $\frac{12}{9}$.
A. $\frac{3}{8}$.
Cæc. pylor. 5.

The fourth, fifth, and sixth dorsal spines are the longest; the last ray of the dorsal and anal fins twice as long as the preceding. Uniform rose-coloured.

Red Sea. [Sea of Amboyna.]

Bleeker found ten dorsal spines and eleven rajs in a specimen from Amboyna, which number is given to the other species by Cuvier. In other respects the description agrees better with $A$. rutilans. Bleeker states seventy scales for the lateral line.

\section{MAENA*.}

Mæna, Cuv. Rène Anim. ; Cuv. \& Val. vi. p. 386.

Form of the body compressed, oblong; eye moderate; the mouth very protractile; the posterior processes of the intermaxillaries extending to the occiput. One dorsal, scaleless, with the number $\frac{11}{11}$; the anal $\frac{3}{9}$ : the spines feeble. Caudalis forked. Minute teeth on the vomer. Præoperculum entire. Scales moderate, ciliated. Six branchiostegals. Pseudobranchiæ. Air-bladder posteriorly divided into two lobes. Pyloric appendages in small number.

Mediterranean.

\section{Mæna vulgaris.}

? Maıvis, Aristot. vi. cap. 15, 17, viii. cap. 30, ix. cap. 2.

? Mæna, Plin. ix. cap. 25; Rondel. v. cap. 13. p. 138.

Sparis, sp. 7, Artedi, Genera, p. 36.

Sparus mæna, L. Gm. p. 1271; ? Bl. taf. 270; Bl. Schn. p. 272.

mendola, Lacép. iv. p. 85.

Mæna vulgaris, Cuv. \& Val. vi. p. 390 ; Martens, Reise nach Venedig, ii. p. 424; Guichen. Explor. Scient. Algér. Poiss. p. 55.

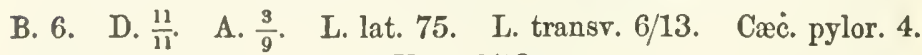
Vert. 9/13.

The height of the body is $3 \frac{1}{2}$ in the total length, the length of the

* 1. Mæna jusculum, Cuv. \& Val. vi. p. 395.-Mediterranean. 
head $4 \frac{1}{4}$; the diameter of the eye is one-fourth of the latter. The height of the dorsal is $2 \frac{1}{2}$ in that of the body. Lead-coloured, with indistinct longitudinal stripes; a black bloteh beneath the lateral line.

Mediterranean.

a. Adult. Sicily. Presented by W. Swainson, Esq.

b-e. Adult and half-grown. Malta. From the Haslar Collection.

$f$. Adult female: not good state. Malta.

g. Adult.

$h, i$. Aäult: stuffed. From Mr. Yarrell's Collection.

$k$. Adult: stuffed.

\section{Mæna vomerina.}

Cuv. \& Val. vi. p. 400. pl. 164.

D. $\frac{11}{11}$. A. $\frac{3}{9}$. L. lat. 60-65. L. transv. 20. Cæe. pylor. 4.

The vomerine teeth are arranged in a small pateh on the anterior part of the bone. The height of the body is $3 \frac{3}{4}$ in the total, the Jength of the head $4 \frac{1}{5}$; the diameter of the eye is one-third of the latter; the spinous dorsal half as high as the body. Coloration uniform. ( $\mathrm{Val}$.)

Malta.

\section{Mæna zebra.}

? Sparus lineatus, Osbeck, Act. Nov. Nat. Curios. iv. 1770, p. 100 * Sparus zebra, Brünn. Pisc. Mass. p. 47; Bl. Schn. p. 279.

- osbeckii, Lacép. iv. pp. 33, 109; Risso, Ichth. Nice, p. 246.

- massiliensis, Lacép. iv. p. 107.

— tricuspidatus, Spinola, Ann. Mus. x. pl. 18.

- gora, Risso, Ichth. Nice, 2nd edit. p. 357.

Mæna osbeckii, Cuv. \& Val. vi. p. 397 ; Guichen. l. c.

D. $\frac{11}{11}$. A. $\frac{3}{9}$. L. lat. 70. L. transv. 20. Cæe. pylor. 4. Vert. 10/13.

The height of the body is three times in the total length, the length of the head $4 \frac{1}{2}$. Greyish blue : head, body, and vertical fins with light-blue spots, those of the cheeks forming radiating series.

Mediterranean.

\section{SMARIS †.}

Smaris, Cuv. Règne Anim.; Cuv. \&. Val. vi. p. 403.

Form of the body oblong or cylindrical; eye moderate or rather large; the mouth very protraetile, the posterior processes of the intermaxillaries extending to the occiput. One dorsal, scaleless, with (nine) eleven and more spines, the anal fin with three; all the

* It is very doubtful whether the fish described by Osbeck is to be referred to this species, which has no lateral blotch, whilst Osbeck says, "Macula nigra utrinque infra lateralem." The fish is called by Osbeck Sp. lineatus, and not radiatus, as Valenciennes erroneously copies from Bonnaterre.

+ 1. Smaris martinicus, Cuv. \& V V l. vi. p. 424.-Martinique. 
spines very feeble; candalis forked. No teeth on the vomer. Præoperculum entire. Scales rather small, ciliated. Six branchiostegals. Pseudobranchiæ. Air-bladder generally forked posteriorly. Pyloric appendages in small number.

Mediterranean ; Atlantic. [Sea of Cevlon.]

\section{Smaris vulgaris.}

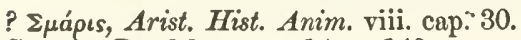

Smaris, Rondel. v. cap. 14. p. 140.

Giaret, Bellon. i. p. 221. fig. in p. 223 \& p. 222.

Mæna candida seu Smaris Rondeletii, Gesner, Aquut. iv. p. 522.

Smaris primus, Johnst. i. cap. 1. p. 55. tab. 20. f. 5.

Sparus, sp. 10, Artedi, Genera, p. 36.

Sparus smaris, L. Syst. Nat. i. p. 468; L. Gm. p. 1271; Bl. Schn. p. 273 ; Risso, Ichth. Nice, p. 238 (not Brïnn.); Lacép. iv. pp. 79, 84.

Smaris smaris, Risso, Hist. Nat. iii. p. 345.

Sparus argenteus, macula, \&c., Brünn. Ichth. Mass. p. 42.

Smaris vulgaris, Cuv. \& Val. vi. p. 407 ; Bonap. Faun. Ital. Pesci, pl. .f. 1.

Smaris gagarella, Cuv. \& Val. vi. p. 420 ; Bonap. l.c.

D. $\frac{11}{11}$ A. $\frac{3}{9}$. L. lat. 70. L. transv. 7/12. Cæc. pylor. 4. Vert. 10/13.

The height of the body equals the length of the head, and is $4 \frac{1}{2}$ in the total; the snout (when closed) is rather longer than the diameter of the eye, which is $3 \frac{1}{2}$ in the length of the head. The dorsal fin not notched, with the posterior rays shortest; the sixth spine is the longest, longer than one-half of the height of the body. A large black lateral spot beneath the lateral line.

Mediterrariean.

a. Fine specimen. Dalmatia.

b, c. Adult. Adriatic. From Mr. Frank's Collection.

d. Adult. Lisbon.

e. Adult : skin. Mediterranean. From tho Collection of the Zoological Society.

\section{Smaris alcedo.}

Smaris, Willughby, iv. cap. 23. p. 43.

Sparus alcedo, Risso, Ichth. Nice, p. 258.

Smaris smaris, mas, Risso, Eur. Mérid. iii. p. 345.

Sciæna gymnodon, Pall. Zoogr. iii. p. 252.

Smaris alcedo, Cuv. \& Val. vi. p. $416 ;$ Bonap. Faun. Ital. pl. . f. 3 ; Guich. Explor. Scient. Algér. Poiss. p. 55.

- chryselis, Cuv. \& Val. vi. p. 419 . pl. 165 ; Bonap. l. c. f. 4; Nordm. in Dcmid. Voy. Russ. Mérid. p. 389.

$$
\text { D. } \frac{11}{11} \text { A. } \frac{3}{9} \text {. Cæc. pylor. } 4 \text {. }
$$

The height of the body is nearly equal to the length of the head, and onc-fourth or one-fifth of the total. The spinous dorsal rather higher than one-half of the depth of the body; the posterior rays 
not shortened. Head and body with irregular blue spots and streaks; vertical fins blue-spotted; a brownish spot between the first two or three dorsal spines.

Mediterranean.

a. Adult: skin. From the Collection of the Zoological Society.

\section{Smaris maurii.}

Bonap. Faun. Ital. Pesci, pl. . f. 3.

$$
\text { D. } \frac{11}{12} \text { A. A. } \frac{3}{9} \text {. }
$$

The height of the body is rather shorter than the length of the head, and about one-fifth of the total. Dorsal fin without notch, with the posterior rays longest, rather higher than one-half the height of the body. No black lateral blotch. (Bonap.)

Mediterranean.

\section{Smaris gracilis.}

Sparus smaris, De la Roche, Ann. Mus. Hist. Nat. xiii. p. 344.

Smaris gracilis, Bonap. Fuun. Ital. pl. . f. 1.

$$
\text { D. } \frac{11}{11} \text { A. } \frac{3}{9} \text {. }
$$

The length of the head is much more than the height of the body, which is one-sixth of the total length. The dorsal without notch, much higher than one-half of the depth of the body; the posterior rays shortest. A black lateral blotch below the lateral line.

Mediterranean.

a. Adult: skin. Mediterranean. From the Collection of the Zoological Society.

\section{Smaris melanurus.}

Cuv. \& Val. vi. p. 422.

D. $\frac{12}{15}$. A. $\frac{3}{15^{\circ}}$. Cæc. pylor. 7. L. lat. 66. L. transv. 8/15.

Lead-coloured, silvery shining; a large black spot at the root of the caudal fin.

Cape Verde.

a-c. Adult. From the Haslar Collection.

6. Smaris balteatus.

Cuv. \& Val. vi. p. 424.
D. $\frac{15}{10}$. A. $\frac{3}{10^{\circ}}$.

Body cylindrical, elongate. Dorsalis deeply notched. Above reddish brown, dotted with white; a silvery band from above the eye to the caudal; beneath silvery. ( $\left.{ }^{\top} \mathrm{a} l.\right)$

('crlon. 


\section{Smaris insidiator.}

Snınris insidiator, Cuv. \& $\dot{V}$ al. vi. p. 414 ; Bonap. Faun. Ital. Pesci, pl. . f. 2.

? Smaris angustatus, Solander, Cur. \& Val. vi. p. 421.-Madeira.

? Smaris royeri, Bowdich, Cuv. \& $\mathrm{Val}$. vi. p. 421.-Madeira.

D. $\frac{13}{9}$. A. $\frac{3}{10}$. L. lat. 90 . L. transv. 4/15. Cæc. pylor. 3.

Body eylindrieal. The height of the borly is one-sixth of tho total length, the length of the liear one-fourth; the diameter of the cye is nearly one-third of the length of the head, and equal to that of the snout. Caudalis notched. No lateral bloteh.

Mediterranean; Madeira.

a. Fine specimen. Madeira. From the Haslar Collection.

b. Fine specimen. Madeira. Pturehased of Mr. Stevens.

c. Adult: bad state. Madeira. From the Haslar Collection.

d. Adult. Bay of Naples. Presented by S. P. Pratt, Esq.

e. Adult.

f. Adult.

\section{CASI0*}

Casio, sp., (Commerson) Cuv. Rigne Anim. ; Cux. \& Val. vi. p. 426.

Form of the body oblong; eye moderate; the eleft of the mouth more or less oblique, with the jaws equal, or the lower slightly longer. One dorsal, continuous, with the anterior part highest, more or less eovered with scalest; the number of the spines varying between nine and thirteen; anal fin $\frac{3}{10-13}$; all the spines very feeble; caudalis decply forked. No teeth on the palate. Prxopereulum entiro, or minutely denticulated. Scales moderate, ciliated. Six or seven branchiostegals. I'sendobranchia. Air-bladder simple. Pylorie appendages in small number.

From the Red Sen through the Indian Ocean into the Pacifie.

\section{Cæsio lunaris.}

Renard, pl. 32. f. 174 .

Casio lunaris, (Ehrenbg.) Cuv. \& Val. vi. p. 441 ; Less. Voy. Coq. Zool. ii. p. 186, Poiss. pl. 34 (faulty); Blecker, Natuurk. Tydschr. Nederl. Inrlie, 1851, p. 167.
D. $\frac{10}{14}$.
A. $\frac{3}{11}$.
L. lat. 55 .
Cace. pylor. 5.

The height of the body is $3 \frac{1}{2}$ in the total length, the length of the head $4 \frac{2}{3}$; the diameter of the eye is $3 \frac{1}{3}$ in the latter; the second

* 1. Cessio tricolor, Cruv of Val. vi. p. 438.-East Indies.

2. Sparus cuning, Bl. taf. 2633. f. 1 ; Lacép. iv. p. 115.-Cichla cuning, Bl. Schn. p. 336.-Cersio cuning, Cuv. of I Fal. vi. p. H4. - Last Indies.

$\uparrow$ Cfr. Caesio grmnopterus, p. :394. 
anal spine longer and stronger than the third. No lateral band; a black spot at the axil; candal lobes with black tips.

Red Sea; Sea of Batavia; New Irelund.

a. Adult: stuffod.

\section{Casio xanthonotus.}

Bleeker, Batav. p. 466.

$$
\text { D. } \frac{10}{15}, \Lambda \cdot \frac{3}{12}, \text { 1. lat. } 60 \text {. }
$$

'The height of the body is four times in the total length, the length of the head $4 \frac{1}{3}$; tho diancter of the eye is $3 \frac{1}{3}$ in tho latter, and longer than the snout. Above yellow, a blue band between the snout and eye; lateral lino brown; baso of the poetorals violet; no band or spot on the caudal. (Bl.)

Sea of Hatavia.

\section{Cæsio pisang.}

Bleeker, Amboina, iii. p. 23.

$$
\text { 1). } \frac{10}{14^{\circ}} \quad \text { A. } \frac{5}{11^{\circ}} \text { I. lat. } 60 \text {. }
$$

The height of the body is $-4 \frac{1}{3}$ in the total length, the length of the head $4 \frac{1}{4}-4 \frac{1}{3}$; the diancter of "the eye is one-third of the latter, and much longer than the suout. Rose-coloured; scules of tho upper parts with a bho busal spot; lateral line brown; lobes of tho candal with black tips.

Soas of Amboyna and Batavia.

a. Fino specimen. Amboynn. Furchased of Mr. lirank.

b. Adult. Amboyna. P'izrehased of Mr. Frank.

c. Hall-grown. Amboyna. l'urchnsed of Mr. Frank.

\section{Cæsio pinjalo.}

Pinjalo typus, Bleck. Byclr. Topoyr. Batav.

Cresio pinjalo, Bleek. Jaca, i. p. 102.

$$
\text { D. } \frac{11}{14} \cdot \Lambda \cdot \frac{3}{10}, \quad \text { 1. lat. } 55 \text {. }
$$

The height of the body is 3 or $3 \frac{1}{2}$ in the total length, the longth of the head forr times; the diamoter of the eye is one-third of the latter. Coloration uniform; dorsal blitek-edged. (Bl.)

Sea of Batavia.

\section{Cæsio maculatus.}

Cuv. \& Val. vi. p. 439.
D. $\frac{10}{15}$.
A. $\frac{3}{13}$.
I. lat. 65.
L. transv. $7 / 14$.

The height of the body equals the length of the head, and is onefourth of the total. A black longitudinal stripe on eneh lohe of the candal; axil black. Greenish, spotted with blue; no laterul band.

Seas of Amboyna, Vanicolo, and China (Madagascar). 
a. Larg: specimen. Madagascar. Presented by Dr. J. E. Gray.

b. Adult. Hong Kong. Presented by J. C. Bowring, Esq.

c. Adult. Amboyna. Purchased of Mr. Frank.

d. Adult. Amboyna. From Madame Ida Pfeiffer's Collection.

\section{Cæsio cærulaureus.}

Cæsio corulaureus, Lacép. iii. p. 86; Cuv. \& Val. vi. p. 434 (cfr. p. 559, and note by Valencicnnes).

? Smaris mauritianus, Quoy \&. Gaim. Ioy. Freyc. Zool. Poiss. p. 290. pl. 44. f. 3.

? Crsio azuraureus, Rüpp. Atl. Fische, p. 130.

?- corulaureus, rar., Cant. Catal. p. 54.

$$
\text { D. } \frac{10}{15} \text {. A. } \frac{3}{13} \text {. }
$$

The height of the body is about one-fifth of the total length. Above bluish, with a golden longitudinal band along the lateral line; along each lobe of the eaudal a blackish band ( $C u v$.

Red Sea; Isle de France; Ceylonese Sea.

It is very doubtful whether the fish deseribed hy Riippell as Casio azuratreus is to be referred to Cuvier's species. It has the formula D. $\frac{10}{13}, A \cdot \frac{3}{11}$, no lateral band, and appears to be higher in comparison with its length. On the other hand, the fish from the Red Sea, described by Cuvier as a variety of $C$. coerulaureus, p. 436, is probably identical with Ccesio striatus of Rüppell. From the extremely delicate structure of the fin-rays, it is very difficult to eount them and to gire the correct.numbers, but which is the more necessary, as we do not yet know to what extent they vary in the speeies of this genus.

\section{Cæsio striatas.}

Crsio striatus, Rüpp. Atl. Fische, p. 131. pl. 34. f. 1 .

? Casio coerulaureus, var., Cuv. \& I Tal. vi. p. 436.
1 B. 6 .
D. $\frac{9}{14}$.
A. $\frac{3}{12}$.
L. lat. 60 .
L. transr. 8/13.

The height of the body is $4 \frac{1}{2}$ in the total length, the length of the head $4 \frac{1}{3}$; the diameter of the eye is $3 \frac{1}{2}$ in the latter, and shorter than the snout. Violet, with four or five blackish longitudinal bands; along each lobe of the caudal a blackish band; abore the axil a black spot.

Red Sea.

a. Fine specimen. Red Sea.

\section{Cæsio chrysozona.}

Cresio chrysozona, (Kuhl \& van IIass.) Cuv. \& Vul. vi. p. 440.
I). $\frac{10}{15}$.
A. $\frac{3}{12}$.
L. lat. 65 .
I. transs. $6 / 16$.

The height of the body is one-fifth of the total length, the length of the head one-fourth; the diameter of the cye is one-fourth of the latter, and nearly equal in length to the snout. $\Lambda$ hroad shining 
golden longitudinal band from the shoulder to the caudal; axil and tips of the caudal blackish.

Molncea Sea.

a. Adult. Moluceas. Purchased of Mr. Frank.

\section{Cæsio argenteus.}

Bodianus argenteus, Bloch, vii. p. 44. taf. 231. f. 2; Bl. Schn. p. 332. Cæsio argenteus, Cuv. \&. Val. vi. p. 437.
D. $\frac{10}{14}$.
A. $\frac{3}{12}$.

The height of the body is about one-fifth of the total length. Uniform silvery, with a black spot above the axil.

East Indies?

\section{Cæsio tile.}

Cuv. \&. Val. vi. p. 428; Less. Voy. Coq. Zool. Poiss. p. 181 ; Cuv. Regne Anim. Ill. Poiss, pl, 36. f. 2.

B. 6. D. $\frac{11}{18}$. A. $\frac{3}{12}$. L. lat. 75. L. transv. 18 or 20 . Cxc. pylor. 5.

The height of the body is five times in the total length, the length of the head $4 \frac{1}{2}$; the diameter of the eye is about one-fourth of the latter, and $1 \frac{1}{2}$ in the distance between the eyes. A blackish band from the shoulder, continued on the upper lobe of the caudal fin; the lower lobe with a longitudinal band of the same colour. Axil black. (Cuv.)

Archipelago of the Caroline Islands.

\section{Cæsio cylindricus. (Plate XXIV. fig. B.)}
B. 7
D. $\frac{13}{17}$.
A. $\frac{3}{13}$.
L. lat. 76 .
L. transv. 6/15.

Body cylindrical; its greatest depth is one-sixth of the total length. The distance between the eyes less than the diameter of the eye. The base only of the soft portions of the vertical fins scaly. Above bluish, each scale of the back with a brownish margin; a brown longitudinal band from the suprascapula, continued on the upper caudal lobe; the lower lobe with a similar band; axil deep black.

Madagascar.

a. Fine specimen. Madagascar. Presented by Dr. J. E. Gray.

Description of the specimen.-The body is elongate, cylindrical, but with the back not broad. The length of the head is $4 \frac{1}{4}$ in the total; above, it is scaly to the vertical from the centre of the eye; the distance between the eyes is less than the width of the orbit, which is nearly one-fourth of the length of the head; the snout is rather longer than the diameter of the eye, and scaleless, like a crescentshaped space behind the eye. The cleft of the mouth is slightly oblique, and of moderate width, the upper maxillary reaching to the anterior margin of the orbit. The jaws are equal, the upper moderately protractile, the processes of the intermaxillaries reaching to above the anterior third of the eye. The teeth of the jaws are very fine; a toothless ridge across the vomer. The nostrils are distant 
from each other; the posterior is situated above the anterior margin of the eye, at the upper surface of the skull; the anterior more on the side of the head, nearer the eye than the extremity of the snout. There are three series of scales on the præoperculum, nearly onehalf of which is scaleless and finely striated; the lower limb is rather longer than the posterior, both meeting at a rounded angle. The operculum is without any spine, and the suprascapula is not serrated. The origin of the dorsal fin is in a vertical line from the base of the ventral, and its end above that of the anal. The spines are extremely feeble; the third is the longest, and one-half of the length of the head; the posterior rays decrease in length to the origin of the soft portion. The caudal fin is deeply forked, with the lobes equal, the length of which is $5 \frac{1}{2}$ in the total. The lower margin of the anal is slightly emarginate, and the spines are rather shorter than the first ray. The base of the rentrals is situated at some distance from that of the pectorals, but, being much shorter, they do not reach quite so far backwards as the pectorals. Their length is $8 \frac{3}{4}$ in the total, that of the pectorals $5 \frac{1}{2}$.

The scales are smooth, not ciliated, scarcely higher than long, and rather small; one of the largest covers about one-eighth of the eye. The lateral line is nearly straight, but slightly bent downwards above the anal fin.

The ground-colour of the back and of the sides is bluish, of the belly silvery; a brown longitudinal band runs from the suprascapula along, and on the tail above, the lateral line to the caudal, on the upper lobe of which it is continued; each scale above this band has a brownish margin. There is a similar band on the lower caudal lobe. The dorsal fin is entirely blackish ; the other fins are colourless, except the base of the upper three pectoral rays, which is black, like the axil.

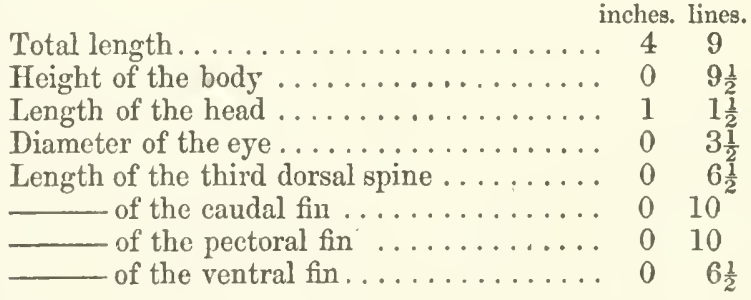

Bleeker refers the following species to Casio, from which, however, it must probably be separated, having the dorsal fin entirely naked, and seven branchiostegals. There are, moreover, extremely minute teeth on the vomer; but these alone, as Bleeker justly observes, could not alter the situation of this species in the system.

\section{Cæsio gymnopterus.}

Bleeker, Ternate, vii. p. 372.
B. 7.
D. $\frac{9}{15}$.
A. $\frac{3}{12}$.
L. lat. 65-70.

Dorsal fin without any scales. The height of the body is one- 
seventh of the total length, the length of the head about one-fourth. The upper maxillary scaleless, reaching to the anterior margin of the eye. Coloration uniform. $(B l$. $)$

Sea of Ternate.

\section{ERYTHRICHTHYS.}

Erythrichthys, Temm. \& Schleg. Faun. Jipon. Poiss. p. 117.

Enmelichthys, Richards. Voy. Ereb. \& Terr. Fishes, p. 47.

Boxaodon, Gay, Hist. Chil. Zool. ii. p. 208.

Dipterygonotus, Bleek. Contr. Ichth. Celebes.

Form of the body elongate; eye moderate; the mouth very protractile, the processes of the intermaxillaries extending to the occiput. Two dorsals, with several isolated spines between; all the spines feeble. Caudalis forked. No teeth in the jaws or in the palate; the lower pharyngeal bones separated from each other, and, like the upper ones, armed with cardiform teeth. Prroperculum entire. Scales rather small, ciliated. Seven or six branchiostegals. Pseudobranchiæ.

Molucea Sea; Sunda Sea; Australian Seas; Pacific.

\section{Erythrichthys schlegelii.}

Erythrichthys, sp., Temm. \& Schleg. Faun. Jupon. Poiss. p. 117. pl. 63. f. 1 .
B. 6 .
D. $10 \mid \frac{2}{10}$.
A. $\frac{3}{10}$.

The angle of the præoperculum is a right one, not rounded. Uniform red.

Japanese Sea.

The figure of this species given in the Fauna Japonica does not show isolated spines between the dorsals; but it is highly probable, from its great similarity to the following species, that such exist.

\section{Erythrichthys nitidus.}

Emmelichthys nitidus, Richards. l.c. pl. 29. f. 7, 8 .
B. 7 .
D. $9|3| \frac{1}{9-10}$.
A. $\frac{3}{10}$.
L. lat. 96.
L. transv. $8 / 20$.

Uniform greyish silvery. The angle of the præoperculum rounded. West Australia; New Zealand.

a. Adult: skin New Zealand. Presented by Mr. Frederic Knap.

b. Adult : skin.

\section{Erythrichthys cyanescens.}

Boxaodon cyanescens, Gay, l.c. p. 209, Atl. Ictiol. lam. 5. f. 1.

Uniform bluish green.

$$
\text { D. } 8|5| 10 \text {. A. } \frac{2(3 ?)}{12} \text {. }
$$

Sea of Valparaiso.

This fish decidedly belongs to the genus Erythrichthys of Schlegel. 
or Emmelichthys of Richardson; but it is difficult to give the distinctive characters of the species, as the description quoted evidently contains many errors: $e . g$. six branchiostegals are stated in the diagnosis of the genus, and seren in the formula attributed to the species; two anal spines are given in the description, and three in the figuro, \&e. The mouth also is said to be little protractile.

\section{Erythrichthys leucogrammicus.}

Dipterygonotus leucogrannmicus, Bleck. Contr. Ichth. Celebes. Emmelichthys leucogrammicus, Bleek. Jura, i. p. 103.

$$
\text { B. 7. D. } 10|4| \frac{1}{9} \text {. A. } \frac{3}{10} \text {. }
$$

Bluish, with three white longitudinal streaks on each side. Sunda and Molucea Seas.

$a, b$. Half-grown. Amboyna. Purchased of Mr. Frank.

$c, d$. Half-grown: not good state. Molucca Sea. Purchased of Mr. Frank.

\section{PENTAPRION.}

Pentaprion, Bleck. Java, i. p. 104, and Verh. Batav. Genootsch. xxiii. Manid. p. 13.

Form of the body compressed, oblong; eje moderate; mouth very protractile, and descending when thrust out. One dorsal, deeply notched, with ten spines, the anal fin with five. Caudalis forked. No teeth on the palate. Seales moderate, not ciliated, deciduous. Six branchiostegals.

Sunda Sea.

Bleeker, l. c.

\section{Pentaprion gerreoides.}

Uniform silvery.

$$
\text { D. } \frac{10}{14} \text {. A. } \frac{5}{12} \text {. }
$$

Sea of Batavia.

\section{POLYCENTRUS.}

Polycentrus, Miill. \& Trosch. in Schomb. Reis. Brit. Guyana, iii. p. 622, and Horce Ichthyol. iii. p. 25.

Six branchiostegals. Præopereulum and proorbital serrated; operculum spiniferous. No lateral line. Dorsal and anal fins with numerous spines. - Pharyngeal bones separated from each other. Pseudobranchiæ hidden.

Essequibo.

\section{Polycentrus schomburgkii.}

Miill. \&. Troseh. 1. c., and Hor. Ichthyol. iii. taf. 5. f. 2.

Brown
B. 6 .
D. $\frac{16}{8}$.
A. $\frac{13}{7}$ V. $1 / 5$.

Essequibo. 


\section{Fam. 6. MULLID E.}

Percoidei, pt., Cuv. Regne Anim.; Cuv. \& Val. Hist. Nat. des Poiss, iii. p. 419 ; Mïll. Berl. Abhandl. 1844, p. 201.

Percidæ, pt., Owen, Lect. on Compar. Anat. p. 49.

Mullidæ, Gray, Syn. Brit. Mus. 1840; Richardson.

Body elongate, slightly compressed, covered with large scales without or with an extremely fine serrature. Profile of the bead more. or less parabolic; hyal apparatus with two long barbels. Lateral lime continuous. Mouth in front of the snout, with the cleft lateral and rather small. Eye lateral, of moderate size. Four branchiostegats; pseudobranchiæ. Dentition feeble, more or less complete. "Two dorsal fins, remote from each other; anal similar to the second dorsal ; ventrals with one spine and five rays. Air-bladder, if present, simple and of variable size; stomach siphonal.

Inhabitants of nearly all the tropical seas, extending in Europe on to the coasts of the temperate region. Some species entering rivers.

\section{Synopsis of the Genera.}

Teeth in both the jaws, on the vomer and the

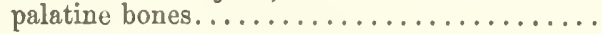

1. UPENEOIDES.

Teeth in both the jaws and on the vomer; none on the palatine bones...................

No teeth in the upper jaw

2. UPENEICHTHYS.

No teeth on the palate; teeth of the jaws in several

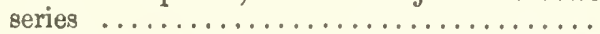

No teeth on the palate; teeth of the jaws in a single series

3. Mulius.

4. Mullomes.

5. UPENEUS.

\section{UPENEOIDES*}

Upeneus, sp., Cuv. \& Val. iii. p. 448.

Upeneoides, Bleeker.

Teeth in both the jaws, on the vomer and palatine bones.

Red Sea; East Indian and Australian Seas.

\section{Upeneoides vittatus,}

Mullus vittatus, Forskal, Faun. Arab. p. 31; L. Gm. Syst. Nat. i. p. 1341 ; Bl. Schn. p. 79 ; Lacép. iii. pp. 382 , 401. pl. 14. f. 1; Shaw, Zool. iv. p. 616. pl. 89.

Russell, pl. 158.

Mullus bandi, Shaw, Zool. iv. p. 615.

* 1. Upéneus tæniopterus, Cuv. \& Val. iii, p. 451.-Ceylon.

2. Mullus subvittatus, Temm. \& Schleg. Faun. Japon. Poiss. p. 30.-Upeneus subvittatus, Rickardson, Ichth. China, p. 219.-Japanese and Chinese Seas. 
Uponeus vittatus et bivittatus, Cuv. \& Val. iii. p. 448, vii. p. 520; Riipp. N. W. Fische, p. 101.

- bitieniatus, Bennett, Proc. Comm. Zool. Soc. 1830-31, p. 59.

Upeneoides bivittatus, Blecker, l'erc. p. 64, and Amboina, vi. p. 411. vittatus, Isleck. Act. Soc. Nederl. ii. Amboinu, p. 43.
D. $8 \mid \frac{1}{8}$.
A. 7.
L. Int. 39 .
L. transv. 3/6.

The length of the head is 41 in the total; the barbels reach to the vorticul from the angle of the prusoporenlum; the height of the spinous dorsal is four-fitths of that of the body. liody with two or three longitudinal bands, shining golden; the spinous dorsal with the top black, and with ono or two blackish bonds; the upper lobe of the caudal with three or four, the lower with two or three oblique black bonds.

From the Red Sea to nearly all the Indiun Soas.

a. Adult. Philippines.

b. Adult: verybad skin. Ceylon! Prosonted by tho\%oological Society.

c. Half-grown. Amboyna. From Mr. Frank's Collection.

d. Ifalf-grown. India. From tho IInslar Collection.

$e, f$. Half-grown : vory bud statc. India.

\section{Upeneoides tragula.}

Upenous tragula, Richardson, Thlh. China, p. 220.

Upeneoides variegatus, Blecker, Pere. p. 64, and Act. Soc. Nerlerl. ii. Amboina, p. 48.
I). $8 \mid \frac{1}{8}$.
A. 7 .
J. lut. 30 .
J. transv. 2/5.

The longth of the head is 43 in the total ; tho barbels do not reach to the verticel from the posterior margin of the proopereulum. The height of the spinous dorsal is three-fuarters of thit of the body. Vomorine teoth in two lateral stripes. Head, body, anal, pectoral, and ventral fins sparingly and irregulurly spotted with brownish; a brown longitudinal band from the snout through the eye to the base of the caudal; dorsil fins lirgely inarhled with blackish; oach lobo of the eaudal with five or six oblique brown cross-bands.

Last Indian Archipelngo; Chinese Sea.

a. Adult. Amboyna. From Mr. Frank's Colloction.

b. Adult. Philippines.

c. Adult: stuffed. Canton. Presented by J. R. Reoves, Esqu.

d. Adult: stuffed. Voynge of II.M.S. Herald.

\section{Upeneoides sulphureas.}

Valent. iii. p. 504. fig. 505; Renard, i. 43. 216.

Upenous sulphureus, Cuv. \& Vil. iii. p. 450.

? Iyponeus vittatus, var., C'ant. C'atul. p. 35.

Upencoides sulphurous, Blecker, Act. Sioc. Nederl. ii. Amboina, p. 45.

$$
\text { 1). } 8 \mid \frac{1}{8} \text {. A. } 7 . \text { I. lint. } 38 .
$$

'The length of the head is $4 \frac{1}{6}-4 \frac{1}{2}$ in the total; the height of tho spinous dorsal is $1 \frac{1}{5}$ or $1 \frac{1}{3}$ in that of the hody. Rose-coloured, with 
five yellow longitudinal bands; belly yellow. The dorsal fins with two or three longitudinal bands, and with the top, black. 'The caudal white-edged, tho upper lobe brownish.

Red Sca; East Indian Archipelago; Chinese Sea.

a. II lif-grown. Red Saa. l'urchased of Mr. Frank.

b. Malf-grown: not good stato. Amboyna. Purchased of Mr. Frank.

c. Half-grown. China. Presented by J. R. Roeves, Esq.

?d. Half-grown : stuffed. Now Hebrides. Voyage of the Hurald.

\section{Upenooides moluccensis.}

Bleeker, Amboina, vi. p. 403.

$$
\text { D. } 7 \mid \frac{1}{8} \text {. A. 8. L. lat. 38-3\%. }
$$

The height of the body is 51 in the total length, the length of the head $4 \frac{3}{5}$; the space botween the orbits is flat. The vomerine teeth form a continuous angular band. 'The barbels do not reach to tho posterior margin of the prooperculum. The height of the spinous dorsal is $1 \frac{1}{4}$ in that of the body. Rose-coloured, with a yellow lateral band; tho eaudal and dorsal fins with alternate yellow and pearl-coloured bands; those of the spinous dorsal horizontul, those of the second dorsal and of the caudal oblique; tho uppor caudal lowe with blackish tip. ( $B l$.)

Sea of Amboyna.

\section{Upeneoides bensasi.}

Mullus bensasi, Termm. \& Schleg. Faun. Japon. Poiss. p. 30. pl. 11. f, 2. Upeneoides bensagi, Jleek. Verh. Batav, Genootseh. xxvi: Japan, p. 71.

$$
\text { D. } 7 \mid \frac{1}{B} \text {. A. 7. I. lat. } 30 \text {. }
$$

The height of the body is 5-5 $\frac{1}{2}$ in the total length, the length of the head $4 \frac{1}{2}-4 \frac{2}{3}$. Vomerine teeth in an angular uninterrupted band. The height of the spinous dorsal not, or searecly less than, that of the body. Rose-coloured: dorsal fins with two or threo deep-red longitudinal bands; tho upper caudal lobo with four oblique decpred bands.

Japanese Sea.

\section{Upeneoides sundaicus.}

Upeneoides vittatus, Blecker, 1'ere. p. 63.

sundaicus, Blecker, Amboina, vi. p. 411, and Act. Soc. Nederl. ii. Amboina, p. 47.

$$
\text { D. } 8 \mid \frac{1}{8} \text {. A. 8. I. lat. } 34-35 \text {. }
$$

The length of the head is 43 to 5 in the total. The barbels reach to the posterior margin of the preoperculum. The spinous dorsal as high, or nearly as high as tho body. Back light violot; a broad brown band from the oye to the caudal. Fins rose-colourod; the soft dorsal with five yellow longitudinal stripes; the upper caudal 
lobe with four or five yellow cross-bands, the lower margined with violet posteriorly.

East Indian Archipelago.

\section{Upeneoides vlamingii.}

Vlaming, no. 123; Renard, i. 5. 31.

Upeneus vlamingii, Cuv. \& Val. iii. p. 452. pl. 71 ; Richardson, Ann. \&. Mag. Nat. Hist. 1842, ix. p. 211.

\section{D. $8 \mid 9 . \quad$ A. 8. Cæc. pylor. ca. 30.}

The height of the body equals the length of the head, and is $3 \frac{2}{3}$ in the total. The barbels reach to the angle of the propereulum. The vomerine teeth are divided into two lateral groups. Red; each scale with a violet speck, forming together longitudinal series; snout and cheeks with oblique violet streaks; the second dorsal and anal fins with longitudinal series of violet speeks. (Cuv.)

Island of Motuaro, Queen Charlotte's Sound. (Rich.)

\section{UPENEICHTHYS.}

Upeneus, sp., Cur. \& Val. iii. p. 455.

Upeneich thys, Bleeker.

Teeth in both the jaws and on the vomer, none on the palatine bones.

Australian Seas, entering rivers.

\section{Upeneichthys porosus.}

Upeneus porosus, Cuv. \& Val. iii. p. 455 ; Less. Voy. Coq. Zool. Poiss. p. 216.
D. $8 \mid 9$.
A. 7 .
L. lat. 28.
L. transv. $2 / 6$.

The barbels reach to the vertical from the extremity of the operculum. Two silvery streaks between the eye and the mouth, the lower continued below and behind the eye.

Seas of Australia, Van J)iemen's Land, and New Zealand: entering rivers.

a. Adult: skin: not good state. Port Jackson. From Mr. Gould's Collection.

b. Half-grown: skin. Australia. From Mr. Gould's Collection. c. Half-grown: skin. Australia. Voyage of.H.Mí.S. Fly.

d. Half-grown. Australia. Presented by the Earl of Derby. $e-g$. Adult: not good state. From the Haslar Collection.

\section{MULLUS.}

Mullus, Linne; Cuv. Règne Anim.; Cuv. \& Val. iii. p. 422.

Teeth in the lower jaw, on the romer and on the palatine bones, none in the upper jaw.

Mediterranean; Coasts of Temperate Europe. 


\section{Mullus barbatus.}

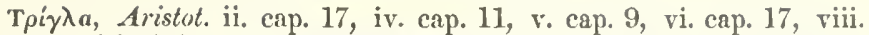
cap. 2 \& 13, ix. cap. 2 \& 37 ; Alian, ii. cap. 41; Athen. vii. pp.324,325.

Mullus, Orid, v. 123; Plin.ix. cap. 17, 18, 51; Martial, x. ep. 30, 31, xi. ep. 50; Colum. viii. cap. 17; Salv. fol. 235; Willughby, p. 285; Ray, p. 90.

Trigla, no. 1, Artedi, Genera, p. 43.

Mullus barbatus, Limn. Syst. Nat. i. p. 495; Bl. taf. 348. f. 2 ; Mart. Reise nach Venedig, ii. p. 426; Cuv. \& Val. iii. p. 442. pl. 70; Yarr. Brit. Fishes, i. p. 36 ; Nordm. in Demid. Voy. Poiss. p. 373.

Mullus ruber, Lacép. iii. p. 385; Shaw, Gen. Zool. iv. p. 611.
B. 4. D. $7 \mid \frac{1}{8}$.
A. $2 / 6$.
L. lat. 40 .
Vert. 10/14.

The upper profile of the snout approaching the vertical line; the upper maxillary reaching beyond the vertical from the anterior wargin of the eye. Red, without yellow stripes.

From the Mediterranean to the South coast of England.

a. Fine specimen. Madeira. Presented by the Rev. R. T. Lowe.

b. Adult: skeleton. Madeira. Presented by Sir A. Smith.

c. Adult: very bad state. Adriatic. From Mr. Frank's Collection.

d. Fourteen inches loug. London market. Purchased.

e. Adult: stuffed. Deronshire.

f. Half-grown. Brighton. Presented by Mr. E. Gerrard.

g. Half-grown: skin. Europe. From Mr. Yarrell's Collection.

For a description of the skeleton see the following species,

\section{Mullus surmuletus.}

Mullus, Plin. ix. cap. 17.

Mullus major, Salv. fol 236; Willughby, p. 285; Ray, p. 91.

Trigla, no. 2, Artedi, Genera, p. 43.

Mullus surmuletus, Linn. Syst. Nat. i. p. 496 ; Bloch, taf. 57 ; Lacḱp. iii. p. 394; Pennant, Brit. Zool. iii. p. 368. pl. 64; Lim. Faun. Suec. ed. Retz. p. 341; Brünn. Pisc. Mass. p. 71; Martens, Reise viach Venedig, ii. p. 427 ; Cuv. \& Val. iii. p. 433; Cuv. Règne Anim. Ill. Poiss. pl. 19. f. 2: Yarrell, Brit. Fishes, i. p. 31 ; Guichen. Explor. Sc. Al.gér. Poiss. p. 8.

barhatus, De la Foche, Ann. Mus. xiii. p. 316; Gronov. Syst. ed. Gray, p. 108*.

B. 4. D. $7 \mid \frac{1}{8}$. A. 2/6. T. lat. 40. Cæc. pylor. 22. Vert. 10/14.

The upper profile of the snout very oblique; the upper maxillary reaching to the vertical from the anterior margin of the eye. Red, with three yellow longitudinal stripes.

From the Mediterranean to the Daltic.

a. Adult: stuffed. Brixham.

$b$, c. Adult. British Channel. London market.

d. Adult and half-grown. Madeira. From the Haslar Collection.

* Gronorius considers $M$. barbatus as the male and M. surmuletus as the female of one and the same species. 
e. Half-grown: skeleton. Mediterranean. From the Haslar Collection.

f. Half-grown. Dalmatia.

g. Half-grown. Dalmatia.

h. Adult: skin : bad state. From Gronovius's Coilection.

Skeleton.-The doubts which I have always entertained on the specifie difference between Mullus barbatus and surmuletus are still more increased by the examination of the skeletons. Both are so much like each other, that they need only one deseription. There is no difference at all between them except in the more abrupt upper profile of the snout in $M$. barbatus. The maxillary is thin, oblong, as broad at the base as at the extremity; the intermaxillary feeble; thin, with the posterior process shorter than the descending branch, which shows a flat prominence on its posterior margin. The mandibulary also is thin, with some pores, and becomes suddenly very narrow near the symphysis. The entopterygoid is well ossified, and extends upwards to the bony plate situated at the inner surface of the infraorbital ring; there is a wide slit between the epi- and pretympanic. The length of the inferior limb of the præoperculum is three-fifths of that of the posterior; both meet at a rounded angle; there is a rudimentary muciferous channel between the margin of the bone and the infer ridge, which is rounded and scarcely elevated. The operculin is irregularly quadrangular, the posterior side being emagqiate. The sub- and interopereulum are thin. IThe præorbital is oblong, twice as long as wide, and very porous; the remainder of the infraorbital ring very narrow. The frontal bones are flat, with some slight ridges and grooves. The oeeipital crest is very feeble, and not more developed than the lateral erests; the interior lateral crest does not extend backwards to the articulation of the suprascapula. The basal portion of the brain-capsule is neither compressed nor rounded, and the basisphenoid has a large opening before the occipital joint. The barbels are fixed to the basihyal; the urohyal is formed by three plates, the two lower of which are rather eonvergent towatds each other. The ulna and radius are dilated, and the openings between them and the humerus are very small. The inner plates of the pubic bones are broad, and joined together in their whole length.

There are ten abdominal and fourteen eaudal vertebræ, the length of the former portion of the vertebral eolumn being to that of the latter as $1: 1 \cdot 4$. The neural, hæmal, interneural and interhæmal spines are very feeble.

\section{MULLOIDES*.}

Upenerls, sp., Cux. \& Val. iii. p. 456.

Mulloides, Bleek. Ceran, ii. p. 697.

* 1. Upeneus martinicus, Cur. \& $V$ ral. iii. p. 483.-Martinique.

2. - parvus, Poey, Memor. Cuba, p. 226.-Cuba.-This fish may belong to another group.

3. - halteatus, Cuv. \& V $V$ l. iii. p. 484.-Cuba.-A very doubtful species.

4. -- mauritianus, Benn. Irnr. Comm. Zool. Soc. i. p. 59.-Mauritius. 
Teeth in both the jaws in several series, but neither on the vomer nor on the palatine bones.

From the Red Sea, through all the Indian Seas, to Polynesia. Atlantic coasts of Tropical America.

\section{Mulloides flavolineatus.}

Mullus flavolineatus, Lacép. iii. p. 406.

- aureovittatus, Shavo, Zool. iv. p. 618.

Upeneus flavolineatus, Cur. \&.Val. iii. p. $456 ;$ Rüpp. N. W. Fische, p. 101. t. 26. f. 1 ; Jenyns, Zool. Beagle, Fishes, p. 24

? Hypeneus flavolineatus, var., Cant. Catal. p. 36.

Mulloides flavolineatus, Bleek. Ceram, ii. p. 697.

D. $\left.7\right|_{\frac{1}{8}}$. A. 8. L. lat. 35-36. L. transt. 2/5-6. Cæc. pylor. 18. Vert. $10 / 14$.

The height of the body is $5 \frac{1}{3}$ in the total length ; the space between the eyes is $1 \frac{1}{2}$ in the length of the snout, and flat; the barbels reach to the vertical from the angle of the præoperculum; the spinous dorsal is nearly as high as the body. A broad citrine band from the eye to the caudal; yellow streaks on the snout; fins immaculate.

From the Red Sea to the Chinese Sea.

a. Adult. Sine patria. From the Haslar Collection.

b. Adult male: skeleton. From the Haslar Collection.

c. Half-grown. China. Presented by Sir J. Richardson.

d. Half-grown. Madagascar. Presented by Dr. J. E. Gray.

e. Intestines of specimen $b$.

The skeleton differs very little from that of Mullus barbatus; the posterior process of the intermaxillary is more elongate, and equals in length the descending branch; the limbs of the præopereulum have a rectangular direction towards each other, the angle itself being slightly rounded. The basal portion of the brain-capsule is rounded; the length of the abdominal portion of the vertebral column is to that of the caudal as $1: 1 \cdot 46$.

\section{Mulloides flavovittatus.}

Upeneus flavovittatus, Poey, Memor. Cuba, p. 224. lam. 17. f. 4.

D. $7 \mid$ 9. A. 7. L. lat. 38-41. L. transv. 3/7. Cæc. pylor. 10-18. Vert. 10/14.

The height of the body is one-fifth of the total length; the space between the eyes is $1 \frac{1}{2}$ in the length of the snout, and flat; the barbels reach to the vertical from the angle of the præoperculum; the spinous dorsal is much lower than the body. A broad citrine band from the eye to the caudal; yellow streaks on the snout; fins immaculate.

Caribbean Sea.

$a-c$. Adult and half-grown: skins. Jamaica. From Dr. Parnell's Collection. 
d. Large specimen. Cuba. From the Collection of the Zoological Society.

Poey attributes a single series of teeth to this species; but I can distinctly distinguish a band of several series of teeth, rather stronger than in the species with villiform bands.

\section{Mulloides vanicolensis.}

Upeneus vanicolensis, Cuv. \& Val. vii. p. 521.

Mulloides ranicolensis, Bleek. Ternate, ii. p. 601.

$$
\text { D. } 7 \mid \frac{1}{8} \text {. A. 8. L. lat. } 35 \text {. }
$$

The height of the body is about one-fifth of the total length; the space between the eycs is very convex; the barbels reach to the posterior margin of the præoperculum. The scapula without spine. The spinous dorsal nearly as high as the body. Coloration uniform.

Seas of Ternate and Vanicolo.

\section{Mulloides zeylonicus.}

Upeneus zeylonicus, Cuv. \& Val. iii. p. 459, vii. p. 520.

$$
\text { D. } 7 \mid \frac{1}{8} \text {. A. } 7 \text {. }
$$

The height of the body is $5 \frac{1}{2}$ in the total length. The barbels do not reach beyond the angle of the præoperculum. Red: the first dorsal brownish yellow, the second with a black line along the base. (Cuv.)

Coasts of Trincomalce and New Guinea.

Air-bladder large.

\section{Mulloides japonicus.}

Mullus japonicus, Houtt. Mém. Harl. xx. p. 334; L. Gm. i. p. 1340 ; $B l$. Sehn. p. 79 .

Upeneus japonicus, Cuv. \& $V$ al. iii. p. 460.

$$
\text { D. } 7 \mid \frac{1}{8} \text {. A. } 7 \text {. }
$$

Scapula with a small spine. Coloration uniform. (Cuv.)

Sea of Japan.

\section{UPENEUS*}

Upeneus, sp., Cur. \& Val. iii. p. 461.

Lpeneus, Blecker.

* 1. Mullus auriflamma, Forsk. p. 30;Bl. Schn. p. 79.-Upeneus auriflamma, Cuv. \& Val. iii. p. 461.

2. - cherserydros, Lacép. iii. p. 406.-Scixna ciliata, Lacép. ir. pp. 308, 312.-Mullus radiatus, Shaw, p. 618.-Upencus cherserydros, Cuv. \& $\checkmark \mathrm{r} u$. iii. p. 470.--Indian Ocean.

3. ¿'peneus cinnabarinus, C'uv. \& V $V^{\prime}$. iii. p. 475.-Ceylon.

4. - fraterculus, Cuv. \& Val. rii. p. 524.-Seychelles.

5. - atherinoides, Cuv. \& Val. vii. p. 526. -Guam.

6. - cyprinoides, Cuv. \& $\mathrm{Val}$. vii. p. 526.-Ile de France.

7. luteus, Cuv. \& Val. vii. p. 521; Bleck. Perc. p. 63.-Indian Occan. 
The teeth in both the jaws form a single serics; palate without any teeth.

From the Red Sea, through all the Indian Seas, to Polynesia. Tropical parts of the Atlantic.

\section{Upeneus barberinus.}

Mullus barberinus, Lacép. iii. p. 406. pl. 13. f. 3.

Upeneus barberinus, Cuv. \& Val. iii. p. 462; Rüpp. N. W. Fische, p. 101.
D. $8 \mid 9$. A. 7 .
L. lat. 29-31.
I. transv. 2/7. Vert. 10/14.

The height of the body is $4 \frac{1}{3}-4 \frac{1}{2}$ in the total length; the distance between the eyes is one-half the length of the snout; the barbels reach slightly beyond the vertical from the angle of the præopereulum. A black band from the eye along the lateral line to below the anterior half of the second dorsal; a round black spot on each side of the root of the eaudal.

Red Sea; East Indian Seas.

a. Fine specimen. Moluccas.

b. Adult: skeleton. Amboyna. From the Collection of Madame Ida Pfeiffer.

c. Young. Amboyna. From the Collection of Madame Ida Pfeiffer.

d. Half-grown. Amboyna. Purehased of Mr. Frank.

e. Adult. India. From Mr. Frank's Collection.

f. Adult. India.

g. Adult. India.

The skeleton differs very distinctly from that of Mullus and of Mulloides flavolineatus. The maxillary is much narrower at the base than at the extremity; the posterior process of the intermaxillary is very short. The frontal bones are concave between the orbits, and there is a longitudinal crest along their meeting margins, extending nearly to the anterior end of the bones and not continued into the occipital crest, which is rather higher than the lateral ones. The angle of the præoperculum is as mueh rounded as in $M$. barbatus; the basal portion of the brain-capsule is neither compressed nor rounded. The length of the abdominal portion of the vertebral column is to that of the caudal as $1: 1 \cdot 7$.

\section{Upeneus macronemus.}

Mullus macronemus, Lacép. iii. pp. 404, 405. pl. 13. f. 2.

- auriflamma, Lackp. iii. p. 400 (not Forsk.).

Upeneus lateristriga, Cuv. \& Val. iii. p. 463; Rüpp. N. W. Fische, p. 101.

$$
\text { D. } 8 \mid 9 . \quad \text { A. } \frac{1}{6} \text {. }
$$

The space between the eyes is somewhat sinuous. The barbels reach to the base of the ventrals ; the last dorsal ray elongate. Rosecoloured: a brown longitudinal band from the nostrils through the eye to below the middle of the second dorsal; a brown spot on each 
side of the tail; the rentral fin, the anterior margin of the first dorsal, the lower half of the second, and the lateral margin of the caudal fin are brown. The anal fin and the upper half of the second dorsal yellowish, with violet longitudinal lines. (Rïpp.)

Red Sea.

\section{Upeneus barberinoides.}

Bleeker, Amboina \&erum, p. 263.

$$
\text { D. } 8 \mid \frac{1}{8} \text {. A. } 8 \text {. L. lat. } 30 \text {. }
$$

The height of the body is $4 \frac{1}{4}-4 \frac{1}{2}$ in the total length, the length of the head about four times. The barbels reach slightly beyond the posterior margin of the prsepereulum. Red : the dorsal scales with a reddish-violet eentre; a lateral brown band from the snout through the eye to below the anterior portion of the soft dorsal; opereles with a large brown spot besides, extending on the side of the body; a blackish spot on the lateral line, corresponding to the extremity of the second dorsal; the soft dorsal with a bluish-black base, and with alternate yellow and blue stripes on its upper half. $(B l$.

Northern coast of Ceram.

\section{Upeneus indicus}

Russell, ii. p. 42. pl. 157.

Mullus indicus, Shaw, Zool. iv. pt. 2. p. 614.

Upeneus russellii, Cur. \&.Val. iii.p.465; Richards. Ichth. China, p. 220; Blecker, Pere. p. 62.

? Upeneus waigiensis, Cue. \& Val. iii. p. 466.
D. $8 \mid 9$.
A. $\frac{1}{7}$.
L. lat. 30 .
L. transv. $3 / 7$.

Interspace between the eyes rather flat; the barbels reach slightly beyond the angle of the prooperculum. $\Lambda$ shining golden spot on the lateral line, disappearing after death; a black blotch on each side of the tail, on the lateral line, between the dorsal and eaudal fins.

East Indian Seas.

a. Thirteen inches long: stuffed. China. Presented by J. R. Recves, Esq.

b. Adult : stuffed. China. Presented by J. R. Reeres, Esq.

\section{Upeneus spilurus.}

Bleeker, Japan, p. 395, and Verhand. Batav. Genootsch. xxvi. Japan, p. 68. tab. 2. f. 2.

$$
\text { D. } 8 \mid \frac{1}{8} . \quad \text { A. } 8 . \quad \text { L. lat. } 28 .
$$

'The height of the body is nearly equal to the length of the head, and $4 \frac{1}{2}$ in the total. Scales ctenoid (?). The spinous dorsal mucl lower than the body. Rose-coloured; a large round black spot above the lateral line, between the second dorsal and eaudal. (Bl.)

Sea of Japan. 


\section{Upeneus pleurospilos.}

Bleeker, Nutuurk. Tydsehr. Nederl. Ind. iv. p. 110, and Verhand. Batav. Genootseh. xxvi. Japan, p. 69.

$$
\text { D. } 8 \mid \frac{1}{8} \text {. A. 8. L. lat. } 30 \text {. }
$$

The height of the body is nearly equal to the length of the head, and $4 \frac{1}{2}$ in the total. The barbels reach to the posterior margin of the opereulum. The spinous dorsal much lower than the body. Rose-coloured: each seale of the back and of the sides with a central reddish-violet spot; a black spot below the lateral line, corresponding to the posterior part of the spinous dorsal; cheeks and snout with bluish stripes; the seeond dorsal with two blue longitudinal bands; the caudal, anal, and ventral fins with yellow bands. $(B l$.

Seas of Japan and Amboyna.

\section{Upeneus brandesii.}

? Upeneus pleurostigma, Benn. Proc. Comm. Zool. Soc. i. p. 59.

Upeneus brandesii, Bleeker, Bunda, i. p. 236.

$$
\text { D. } 8 \mid \frac{1}{8} \text {. A. 8. L. lat. } 30 \text {. }
$$

The height of the body is one-fifth of the total length, the length of the head one-fourth. The barbels reach to the posterior margin of the præopereulum. Red: a large round black spot on the lateral line between the dorsals; the seeond dorsal with a large black basal spot. $(B l$.

Sea of Banda Neira (and of Mauritius?).

\section{Upeneus malabaricus.}

Cuv. \& Val. iii. p. 467 .
D. $8 \mid 9$.
A. 7. I. lat. 3 .
L. transv. $3 / 7$.

The barbels reach beyond the angle of the præoperculum. A large ovate white spot on the lateral line, above the extremity of the pectoral ; a black spot on each side of the root of the tail.

Coast of Malabar; Philippine Islands.

a. Half-grown. Philippines.

\section{Upeneus trifasciatus.}

Mullus bifasciatus, Lacép. iii. p. 404. pl. 14. f. 2.

trifasciatus, Lacép. iii. p. 404. pl. 15. f. 1.

— multifasciatus, Quoy \& Gaim. Voy. Freyc. pl. 59. f. 1.

Upeneus bifasciatus, Cuv. \& Val. iii. p. 468.

_- trifasciatus, Cuv. \& Val. iii. p. 468; Jenyns, Zool. Beagle, Fishes, p. 25 ; Blcek. Banda, i. p. 237.

D. 8 9. A. 7. L. lat. 30. L. transv. 3/7. Vert. 10/14.

The distanee between the eyes is convex, and $1 \frac{2}{3}$ in the length of the snout. A broad black eross-band over the tail, a second from the anterior portion of the soft dorsal; the space between the two 
wands yellow or white; sometimes a third black band from the spinous dorsal. An oblong black spot behind the eye. The basal half of the second dorsal black, the upper half with white longitudinal bands; the anal with blackish longitudinal bands.

From the Indian Ocean to Polynesia.

a. Adult. China. Presented by Sir J. Richardson.

b. Adult. China.

c. Young. Amboyna. Purchased of Mr. Frank.

d. Half-grown. Celebes.

e. Adult: skin: bad state. Ceylon. I'resented by the Zoological Society.

f. Adult : skeleton. India. From Mr. Frank's Collection.

g. Half-grown. India. From Mr. Frank's Collection.

$h$. Half-grown. India. From the Haslar Collection.

i. Half-grown. India. From the Haslar Collection.

$V a r$-Anterior portion of the body black, with two white longitudinal bands, one from the muzzle above the eye to the origin of the soft dorsal ; the second oblique, from the cheek below the eye to the lateral line. A black spot on each side of the tail instead of the caudal band.

$k$. Half-grown. East Indies. From Mr. Frank's Collection.

The skeleton of this speeies is entirely similar to that of $U_{\text {peneus }}$ barberinus: the length of the abdominal portion of the rertebral column is to that of the caudal as $1: 1 \cdot 6$.

\section{Upeneus maculatus.}

Margrave, p. 166, 181.

Nullus maculatus, $B l$. taf. 348 . f. 1 .

Upeneus maculatus, Cux. \& Val. iii. p. 478; Poey, Mern. Cub. p. 223; Casteln. Anim. nouv. ou rares Amér. Sud, p. 6.

D. $8 \mid 9 . \quad$ A. $7 . \quad$ L. lat. 30 . L. transv. $3^{\prime} 6$.

Cæc. pylor. 8-9 (Cuv.; 18, Poey). Vert. 10/14.

The height of the body is $4 \frac{1}{2}$ in the total length; the interspace between the eres one-half of the lengtl of the snout, and flat. Two blaek blotehes on the lateral line, corresponding to the two dorsal fins.

Atlantic coasts of Tropical America.

$\iota-i$. Adult and half-grown: skins. Jamaiea. From Dr. Parnell's Collection.

k. Half-grown.

l. Half-grown. West Indies.

m. Adult: stuffed. West Indies. From Mr. Serivener's Collection.

\section{Upeneus punctatus.}

C'ur. \&. V'al. nii. p. 482.
D. $7 \mid 9 . \quad$ A. 7.

Red, each seale with a lilae centre; on each side of tho snout 
three lilae streaks; on each side of the body four or fire clouded brownish spots. (Cuv.)

Sea of Martinigue.

\section{Upeneus prayensis.}

Cur. \&. Val, iii. p. 485 ; Jcnyns, Zool. Beagle, Fishcs, p. 26.
D. $8 \mid 9$.
A. 7 .
L. lat. 30 .
L. transv. $3 / 6$.

The height of the body is $4 \frac{2}{3}$ in the total length; the distance between the eyes is flat, and one-half of the length of the snout; the barbels reach nearly to the vertical from the opereular spine. Coloration uniform (in spirits), except a small black spot behind the eye, at the upper extremity of the preopereulum, and a blackish longitudinal band on the soft dorsal.

West coast of Africa.

a. Half-grown. River Niger. From Mr. Fraser's Collection.

\section{Upeneus cyclostoma.}

Mullus cyclostomus, Lacćp. iii. p. 401. pl. 19. f. 3 (very bad).

Sciæna heptacanthus, Lacép. iv. pp. 308, 312.

Upeneus cyclostomus, Cuv. S. Val. iii. p. $472 ;$ Rïpp. N. W. Fische, p. 101.

? Upeneus immaculatus, Benn. Proc. Comm. Zool. Soc. i. p. 60.
D. $8: 9$.
A. 7. L. lat. 27-30.
L. transv. 2/7.

The height of the body is $4 \frac{1}{3}$ in the total length; the diameter of the eye is one-fifth of the length of the head, and less than one-half of that of the snout. The snout not pointed; the distance between the eyes is conrex, and $1 \frac{3}{5}$ in the length of the snout. The height of the spinous dorsal is two-thirds of that of the body. The tubes of the lateral line with very short lateral branehes. The barbels reach to, or nearly to, the base of the ventrals. Coloration uniform (in spirits).

From the Red Sea, through the Indian Ocean, to the Indian Arehipelago.

a. Fine speeimen. Moluccas. From the Leyden Museum as Upeneus luteus.

b. Half-grown. Ceram and Amboyna. From Madamo Ida Pfeiffer's Collection.

c. Adult: stuffed. Louisiade Arehipelago. Voyage of the Rattlesnake.

d. Young: stuffed. Louisiade Arehipelago (30 fathoms). Vojage of the Rattlesnake.

e. Half-grown: stuffed. Redsear Bay (S.E. coast of New Guinea; on mud). Vojage of the Rattlesnake.

\section{Upeneus oxycephalus.}

BleeKCP, Act. Soc. Sc. Indo-Nederl. i. Manado en Mrakass. p. 45.

$$
\text { D. } 8 \mid \frac{1}{8} \text {. A. } 8 \text {. L. lat. } 30 .
$$

The height of the body is $4 \frac{1}{2}-4 \frac{3}{5}$ in the total length, the length of 
the head $3 \frac{4}{5}-4$; the space between the orbits eonrex; the greater part of the eye is situated on the posterior half of the length of the head, in which it is contained 5-5 $\frac{1}{3}$ times; the snout is pointed, and longer than twiee the diameter of the eyc. The barbels reach to the base of the ventrals; the height of the spinous dorsal is $1 \frac{2}{3}$ in that of the body. liose-eoloured; two blue stripes on the side of the snout, and two or three other's on the side of the head. The seeond dorsal and the anal bright yellow, with three to five bluish longitudinal bands. $(B l$.)

Sea of Manado (and Ile de France).

a. ? Adult: stuffed. Mauritius. From Dr. Janrier's Collection.

\section{Upeneus chrysopleuron.}

Mullus ehrysopleuron, Tenm. \& Schleg. Finn. Japom. Poiss. p. 29. pl. 12. f. 1.

Upeneus biaculeatus, (Groy) Rich. Ichth. China, p. 219*.

Upeneoides chrysopleuron, Bleek. Verhind. Butav. Genootsch. xxv. Japan, p. 10.

Upeneus chrysopleuron, Bleek. l.c. xxvi. Japan, p. 70.

$$
\text { D. } 8 \mid \frac{1}{8} \text {. A. } 8 \text {. L. lat. } 30 \text {. }
$$

The height of the body is nearly equal to the length of the head, and $4 \frac{1}{2}$ in the total. The length of the snout is twice the diameter of the eye. Crown rather flat; the teeth of the jaws of unequal size. The spinous dorsal much lower than the body. Rose-eoloured, with a broad golden band from the head to the candal, extending on the baek of the tail; snout with bluish streaks; fins immaculate ; it small blackish spot above the axil.

Seas of Japan and China.

a. Adult. China. Presented by J. R. Reeves, Esq.

b. Half-grown. China Presented by J. R. Reeres, Esq.

c. Adult. China.

\&. Adult. China.

e. Adult : stuffed. Presented by J. C. Jerdon, Esq.

$f$. Half-grown. Presented by the Zoologieal Society.

\section{Upeneus jansenii.}

Bleeker, Act. Soc. Sc. Indo-Nederl. i. Man. en Makass. p. 44.

$$
\text { D. } 8 \mid \frac{1}{8} \text {. A. } 8 \text {. L. lat. } 30 \text {, }
$$

The height of the body is about one-fifth of the total length, the length of the head one-fourth; the diameter of the eyo is about one-fourth of the latter, and much more than one-half the extent of the snout. ('rown rather flat. The barbels reach to the posterior

* Sir J. Richardson quotes as the first authority, "Gray, Catal. Brit. Mus." A catalogue containing an account of this fish has ncver been published, to my knowledge. 
margin of the præoperculum. The height of the spinous dorsal is $1 \frac{2}{3}$ in that of the body. Uniform rose-coloured.

Seas of Manado and Amboyna.

(, b. Half-grown. Amboyma. Purchased of Mrr. Frank.

\section{Upeneus dubius.}

Mullus dubius, Temm. \&. Schleg. Fann. Japon. Poiss. p. 30. pl. 11. f. :3.

$$
\text { D. } 7 \mid \frac{1}{8} \text {. A. } \frac{1}{6} \text {. }
$$

Red, with a yellow longitudinal band; dorsal and anal fins with oblique brown longitudinal bands. (Schley.)

sea of Japan.

\section{Upeneus bilineatus.}

Cuv. \& Val. vii. p. 525.

$$
\text { D. } 7 \mid \frac{1}{8} . \quad \text { A. } 7 \text {. }
$$

Snout short, with the upper profile approaching the vertical line, as in Mullus barbatus. Barbels rather short. Back brownish; two yellow stripes along the side of the body; the top of the first dorsal black. ( $V a l$.

Sea of Amboyna.

\section{Upeneus crassilabris.}

Cut. \& Val. vii. p. 523.
D. $8 \mid \frac{1}{8}$.
A. 7 .

The height of the tail is one-half of that of the body. Lips thick. The barbels do not reach to the base of the ventrals. Ventrals very large. The first dorsal violet; the second violet on the base, and with violet stripes on its upper half; anal dotted and obliquely striped with violet; caudal dark-culoured, dotted with white; the three outer rays of the ventral violet; barbels brownish. ( $V a l$.) 


\section{Fam. 7. SPARIDA.}

Sparoidei, pt., ot Squamipinnes, pt., Cuv. Rigne Anim.; Cuv. \& Val. Hist. Nut. des Poiss.; Muiller, Berl. Abhandl. 1844, p. 201.

Sparidæ, pt.; et Chætodontidæ, pt., Richirdson.

Body compressed and oblong, covered with scales, the serrature of which is exceedingly minute, and sometimes wanting. Tail not armed. Lateral line continuous, not continued on the eaudal fin. Mouth in front of the snout, with lateral cleft. Eye lateral, of moderato size. Five, six or seven branchiostegals. Either trenchant teeth in front of the jaws, or lateral series of molar teeth*; generally no teeth on the palate. One dorsal fin, formed by a spinous and soft portion of nearly equal development; anal with threo spines; the lower rays of the pectorals generally bmnched, in one group simple; ventrals thoracic, with one spine and five rays. The bones of the head with a rudimentary muciferous system. Air-bladder present, often bifid posteriorly. Pseudobranchiæ well developed.

Herbi- and carnivorous fishes, inhabiting the seas of tho temperate and tropical regions; a few entering rivers.

\section{Synopsis of the Groups.}

a. Cantharina. More or less broad, trenchant teeth in front of the jaws; no molars or vomerine teeth; the lower pectoral rays branched.-Mostly regetable feeders.

b. Haplodactylina. Trenchant teeth in front; no molars; the lower pectoral rays simplo.-Vegetable feeders.

c. Sargina. Trenchant toeth in front and molar teeth on the sides. - Mostly carnivorous.

d. Pagrina. Conical teeth in front and molars on the sides.-Cardivorous,

e. Pimelepterina. Trenchant teeth in front; teeth on the palate.Carnivorous?

[Appendix: Bormia.]

\section{First Group. CANTHARINA.}

Sparidae with more or less broad, trenchant teeth in front of the jaws ; no molars or vomerine teeth; the lower pectoral rays branched.

* Some species of Lethrinus appear to make an exception, but their teeth are hick, and approach to molars; they are, moreover, readily distinguished by their naked cheok. 


\section{Synopsis of the Genera.}

* Cheeks and opercles scaly; vertical fins without scales.

A band of cardiform teeth in front of both jaws, the outer series containing teeth, which are slightly compressed and lanceolate

1. Cantharus.

A single series of trenchant, notched teeth in both jaws, without a band of other teeth behind.........

A single series of broad lanceolate teeth in both jaws, without any other teeth behind

2. Box.

A single series of broad, trenchant teeth in both jaws, with granular teeth behind and pointed ones on the side

\section{Omlata.}

One or two series of broad, trenchant teeth, and with a band of granulated teeth behind; no pointed lateral teeth

\section{Crenidens.}

* Cheeks and opercles scaly ; vertical fins more or less covered with scales.

A series of broad lanceolate teeth in both jaws, with a band of similar teeth behind, which are less de. veloped. Eleven dorsal spines

\section{Pachimietopon.}

Dorsal fin deeply notched. Ten dorsal spines ......

$A$ recumbent spine before the dorsal fin ..............

7. Dipterodon.

8. Proteracantuus.

** Cheeks scaly, opercles naked.

Scales moderate; fourteen or fifteen dorsal spines...

Scales moderate; twelve dorsal spines.

9. Girella.

Scales small

10. Doydixodon.

11. Tephreops.

*** Oheeks naked.

Scales moderato

12. Grmacrotaphus.

\section{CANTHARUS*.}

Cantharus, Cuv. Regne Anim.; Cuv. \&al. vi. p. 318.

Teeth cardiform or villiform, those of the outer row slightly compressed and lanceolate $\uparrow$; no molar teeth. Cheeks scaly. The dorsal spines (ten or eleven) can be received into a scaly sheath; three anal spines. Scales moderate. Six branchiostegals. Pyloric appendages in small number. Air-bladder with two horns posteriorly.

Mediterraneun ; from the coasts of Great Britain round the Cape to the Seychelles.

\section{Cantharus lineatus.}

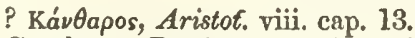

Cantharus, Rondel. v. cap. 4.p. 120; Gesner, p. 178; Aldrov. ii. cap. 20. p. 186 ; Willughby, p. 309 ; Ray, p. 130.

* 1. Cantharus senegalensis, Cuv. \& Val. vi. p. 337.-Cape Verde.

+ This is very conspicuous in mature specimens, and has been overlooked by Cuvier. Therefore I separate these fishes from the Pristipomatida, and do not think that the Indian species are to be referred to this genus. 
Sparus, no. 2, Artedi, Genera, p. 36.

cantharus, L. Gm. p. 1274; Bl. Schn. p. 17 ; Duhumel, Piches, ii. sect. 4. pl. 7. f. 1 .

- lineatus, Montagu, Mem. Wern. Soc. ii. 1815, p. 45l. pl. 23.

- retula, Couch, Trans. Linn. Soc. xiv. p. 79.

- sciandra (Rudolphi), Rosenth. Ichthyot. Tufeln. taf. 14. f. 1.

Pagrus lineatus, Flem. Brat. Anim. p. 211.

Cantharus vulgaris, Cuv. \& Val. vi. p. 319. pl. 160 ; Guichen. Explor. Sc. Algér. Poiss. p. 53.

— griseus, Cuv. S. I al. vi. p. 333; Jen. Brit. Vert.p. $358 ;$ Yarell, Brit. Fishes, p. 130; Lowe, Trans. Zool. Soc. ii. p. 178.

- lineatus, White, Catal. Brit. Fishes, p. 16.

By an examination of several specimens from the Mediterranean and the Canary Islands, as well as from the British Channel, it is evident that the few differenees on which Valenciennes separated the $C$. griseus from $C$. vulguris must have been merely aceidental in the individuals from which the descriptions were taken. In the 'Histoire Naturelle des Iles Canariens, par Webb et Berthelot,' Valenciennes says, that $C$. griseus is not found in those seas, and that the $C$. griseus, Lowe, is to be referred to C. vulgaris. There are speeimens in the British Museum (one was sent by the Rev. R. T. Lowe) which really agree better with $C$.griseus, Val. But other specimens from the British coast have the præorbital as slightly notehed as it is stated to be by Valenciennes in the Mediterranean fish; others from the Mediterranean have six series of præopereular seales, as well as those from the Channel.
D. $\frac{11}{12}$.
A. $\frac{3}{10}$.
L. lat. 68-75.
I. transs. $\frac{9-10}{19}$. Vert. 10/14.

The height of the body is $3-3 \frac{1}{4}$ in the total length, the length of the head $4 \frac{1}{2}$, the diameter of the eye is about one-fourth of the latter (in young and half-grown individuals larger), and equal to, or rather shorter than, the snout. There are six (or seren) series of scales between the præorbital and the præopereular limb; præorbital notched by the maxillary bone. The dorsal spines rather slender and flexible, the fourth, fifth and sixth the highest, and longer than any of the rays. Caudalis emarginate ; the anal spines very much shorter than the rays. Greyish green, with darker longitudinal lines ; fins blackish grey.

a. Adult: stuffed. Polperro.

b. Adult: stuffed. Plymouth. Presented br Lieut. H. F. Spence, R.N.

c. Adult: stuffed. Plymouth.

r, e. Fighteen inches long : skins. Plymouth. Frem Mr. Yarrell's Collection.

f. Half-grown. British Channel.

7. Adult: stuffed. Frith of Forth. From Dr. Parnell's Collection.

h. Adult: stuffed. England. From Mr. Yarrell's Collection.

i. Fine speeimen. Lanzarote. Presented by the Rev. R. T. Lowe.

i. Half-grown : stuffed. Santa Cruz, Teneriffe.

l. Half-grown. From the Haslar Collection.

$m-p$. Adult: stuffed. 
q-s. Half-grown : stuffed.

t. Half-grown : not good state. Mediterranean. Purchased of Mr. Frank.

$u$. Half-grown : skin. Mediterranean. From the Collection of the Zoological Society.

$v$. Half-grown. From the Haslar Collection.

w. Half-grown : bad state. From the Old Collection.

$x$. Adult. From the Old Collection.

$y-\gamma$. Adult: skins. From Mr. Yarrell's Collection.

$\delta$. Half-grown: skin. From Gronov's Collection.

є. Adult: skeleton.

Skeleton.-The maxillary bone is oblong, straight, with a longitudinal ridge, and provided above and behind with a semicircular flat process. The intermaxillary is rather narrow, styliform, with the posterior processes shorter than the descending branches. The manJibula has a narrow cleft between the dentary and articular bones, and several very distinct pores of the muciferous channel. The vomer has a rather irregularly quadrangular and slightly concave head, and terminates in a long tapering tail. The marginal part of the præoperculum is very thin; the length of the inferior limb is twothirds of that of the posterior; both meet at a right angle, which, however, is rounded. The præopercular ridge is rather low, with a narrow muciferous channel. The operculum is irregularly quadrangular, with tae upper side shortest, and the posterior slightly emarginate; therc is a very slight ridge on the inner surface of the bone, descending obliquely downwards, and not terminating in a point; the_surface near the uppèr angle is roughened by pores. The suboperculum is rather shorter and narrower than the interoperculum. The turbinal bones are somewhat elongate, transformed into a muciferous channel, and widened posteriorly. The præorbital is of moderate width, tapering posteriorly, with the anterior margin convex; the remainder of the infraorbital / ring is very narrow. There is an excavated bony plate at its inner side, to support the eyeball from beneath ; this plate articulates with the pterygoid by a rather strong process. The frontals form a high and very convex bony protuberance, pierced by several pairs of pores, whilst the superciliary portion is thin, and without bony excrescences; from that bony protuberance arises the high, triangular, occipital crest, with the upper margin slightly convex. The lateral crests also are well developed. The basal portion of the brain-capsule is slightly compressed. The glosso-hyal rather short, cuneiform, with the anterior extremity thickest. The urohyal is very deeply notched posteriorly, terminating in two processes, the upper of which is flat, in a vertical direction, whilst the lower horizontal one is again forked, and forms two long spines. The pubic bones are elongate, each being formed by three lamellæ of nearly equal development.

There are ten abdominal and fourteen caudal vertebro, the length of the former portion of the vertebral column being to that of the latter as $1: 1 \cdot 34$. The neural spines are of moderate length; those 
of the first caudal vertebræ are the longest, as long as three of the latter together. The interneurals are much dilated; there are three spurious interneurals. The first interhæmal is rather slender, equal to the length of the first six vertebræ.

The teeth form, in both the jaws, broad cardiform bands, and the anterior ones are distinctly compressed and lanceolate.

\section{Cantharus brama.}

Duhamel, Pêches, ii. sect. 4. pl. 4. f. 1.

Sparus brama, Bloch, v. p. 77 (not fig.).

Cantharus brama, Cuv. \& Val. vi. p. 328; Guichen. Explor. Sc. Alger. Poiss. p. 53; Expéd. Sc. Morée, Zool. pl. 17. f. $1 a, b$.

$$
\text { D. } \frac{11}{12}, \quad \Lambda \cdot \frac{3}{10} \text {. }
$$

Very similar to $C$. lineatus; it is said to have the præorbital not notched. ( $\mathrm{Val}$.)

Mediterranean.

\section{Cantharus orbicularis.}

Cuv. \& Val. vi. p. 331; Bonap. Faun. Ital. Pesci, pl.

$$
\text { D. } \frac{11}{12} \text {. A. } \frac{3}{10^{\circ}} \text { L. lat. } 70 \text {. }
$$

The height of the body is $2 \frac{1}{2}$ in the total length; præorbital without notch; the sixth dorsal spine the highest.

Coast of Corsica.

\section{Cantharus emarginatus.}

? Cantharus emarginatus, Cuv. \& Val. vi. p. 338.
D. $\frac{11}{12}$.
A. $\frac{3}{11}$.
L. lat. 80 .
L. transv. 13/21.

The height of the body is one-third of the total length, the length of the head is $4 \frac{1}{4}$ in it ; the diameter of the eye is about one-fourth of the latter, less than the distance between the eyes, and nearly equal to the length of the snout. There are eight series of seales between the præorbital and the præopercular limb; præorbital notched by the maxillary bone, which has a rather sharp longitudinal ridge. Dorsal rather low. Caudalis emarginate, the third anal spine shorter than the dorsal spines. Coloration uniform (in a dried state).

? Cape Seas.

a. Adult: stuffed.

\section{Cantharus blochii.}

Sparus brama, Bloch, taf. 279 (not descr.).

Cantharus blochii, Cav. \&. Val. vi. p. 339.
D. $\frac{10}{12}$.
A. $\frac{3}{10}$.
L. lat. 64 .
L. transv. 9/18.

Vert. 11/13.

The height of the body is $3 \frac{1}{5}$ in the total length, the length of the head $4 \frac{1}{4}$; the diameter of the eyes is $1 \frac{2}{3}$ in the distance between 
them, and about one-fourth of the lengen of the head. The anterior teeth broad, lanceolate. There are about eleven seriess of scales between the præorbital and the præopercular limb, which is covered with scales. The dorsal spines moderate and rather short; the fourth one-third of the length of the head. The anal spines of moderate size. Uniform brownish.

Cape Seas.

a. Adult: stuffed. Cape Seas. Presented by Sir A. Smith.

b. Adult: skin. False Bay.

r. Adult: skin. From Gronor's Collection.

\section{Cantharus grandoculis.}

C'u. \&- Inl. vi. p. 341 ; Cur. Regne Anim. Ill. Poiss. pl. 35. f. 3.

$$
\text { D. } \frac{10}{10} \text {. A. } \frac{3}{10} \text {. }
$$

Nape of the neck slightly concave; the greatest depth of the body is below the posterior dorsal spines, where it is contained three times in the total length. Proorbital without notch. The diameter of the eye is $2 \frac{1}{2}$ in the length of the head. Four scries of scales on the prooperculum. Spines of the fins strong. Gircenish; dorsal spotted with violet; rentrals blackish. ( $V a l$.

Seychelles.

I very much doubt whether the three following species, referred by Valenciennes to Cantharus, really helong to this genus or to this family at all.

\section{Cantharus cæruleus.}

Cuv. \& r ral. vi. p. 342.
D. $\frac{12}{10}$.
A. $\frac{3}{10}$.

Body ovate, obtuse in front; præorbital without notch, caudal forked. The soft portion of the dorsal and anal fins elongato. Blush; a bluish streak from the muzzle to the orbit. ( $\mathrm{Val}$.)

Sea of Guam (Mariannes).

\section{Cantharus maculatus.}

Cur. \& Val. vi. p. 343.

$$
\text { D. } \frac{10}{11} \text {. A. } \frac{3}{11} \text {. }
$$

Body ovate, elongate; snout obtuse; præorbital narrow, without notch. The spinous dorsal low, the soft and the anal fin high; eaudal slightly forked. Red, with three series of irregular, rounded, white spots ; fins brown, the caudal and the margin of the soft dorsal yellow. ( V ral.)

Indian Ocean. 


\section{Cantharus lineolatus.}

C'uv. \& Val: vi. p. 344.
D. $\frac{10}{13}$
A. $\frac{3}{13}$.

Body ovate; præorbital narrow; caudal truncated. Brown, with lighter spots and lineolated with white; fins brown, sparingly spotted with white. ( $V a l$.

Indian Occan.

\section{2. $\mathrm{BOX} *$}

Box (Boops), Cuv. Règne Auim. ; Cur. \& Vul. vi. p. 346.

In both jaws a single anterior series of broad incisors, notehed at the eutting margin; no molars. Cheeks sealy. The dorsal spines (eleven to fifteen) ean be reecivel into a sealy sheath; anal spines three. Seales moderate. Six branchiostegals. Pyloric appendages in small number; air-bladder with two horns posteriorly. Intestinal tractus elongate.

Vegetable feeders. From the Mediterranean; Western eoasts of Europe and Afriea: Caribbean Sea; one species from the East Indies.

\section{Box vulgaris.}

B⿳亠े,, Aristot. ix. cap. 3 ; Oppian, i. p. 5.

Box, Plin. xxxii. cap. 11 ; Bellon. p. 230.

Boops, Rondel. v. c. 11. p. 136 ; Cesner, p. 127 ; Aldrov. ii. c. 41. p. 231 ; Willughby, p. 317 ; Ray, p. 135.

Sparus, no. 6, Artedi, Gen. p. 36.

boops, Linn. Syst. Nat. i. p. 469 ; L. Gm. p. 1274; Brïnn. Pisc. Mass. p. 44; Lacép. iv. pp. 97, 99; Bl. Sehn. p. 273; Risso, Ichth. Niee, p. 242 ; Matens, Reise nach Tenelig, ii. p. 424.

Box vulgaris, Cur. \& Val. vi. p. 348. pl. 161; White, Catal. Brit. Fishes, p." 20 ; Cuv. Règne Anim. Ill. Poiss. pl. 36. f. 1 (not good); Guichenot, Explor. Sc. Alyér. Poiss. p. 54.

Boops canariensis, Ialenc, in Wabb \& Berihel. Ilist. Nat. Iles Crnen: Poiss. p. 30. pl. 10. f. 1.

D. $\frac{14}{14}$. A. $\frac{3}{15}$. L. lat. 75 . L. transv. 6/13. Cre. pylor. 5. Vert. 11/13.

Borly elongate, sounewhat eylindrical; caurlal decply forked. Yellowish olive, with golden longitudinal bands.

Mediterranean; Canary Islands. Oceasionally all the southern coast of England. Caribbean Sea.

a. Arlutt: stufferl. Mediterranean. Purehased of Mr. Mrgent.

b. Half-grown. Dalmatia.

c. Fine specimen. Madeira. From the Haslar Collection.

1. Skeleton. Mardeira. From the Rer, R. T. Lowe's Collectiou.

e. Half-grown: skin : not good state. Sinta Cruz (Teneriffe).

f. Adult. Eishon. l'resented by l'. Hongh, Esclp.

y. Young. Lisbon.

h. Young. lishon.

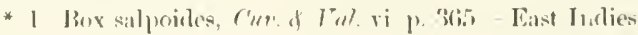


i. Adult: skin : rery bad state Falmouth fish-market. Presented by W. P. Cork, Esq.

h. Adult. Old Collection.

l. Half-grown: bad state.

w. Half-grown: bad state.

и. Half-grown: stuffed. Fron Mr. Iarrell's Collection.

o. Young.

r. Adult: skin. Fron Gronor's Collection.

Var. Carimuca, an species?

q. Fine specimen. St. Vineent's. From Mr. Macgillivray's Collection.
D. $\frac{15}{14}$.
A. $\frac{3}{16^{\circ}}$.
L. lat. 80.
L. transw. S/15.

This specimen differs more from the Mediterranean fish than the Boops canariensis of Valenciennes, having smaller scales above the lateral line; but the wider the range of a species, and the more numcrous it is in individuals, the more eaution is required in separating new forms from it, as after all it may prove to be a climatic or an accidental variety. But the fish is very interesting, as a specimen of Box has not yet been found in the West Indies.

Sleleton.-The oceipital crest and the two lateral erests are thin, feeble, and moderately elevated; the former does not extend on the frontal bones, and the latter emit a flat free process posteriorly. 'The upper surface of the frontal bones is roughened by low irregular ridges and grooves; there is a shallow median groove along the suture of the bones. The turbinal bones are transformed into a rather elongate tube. The posterior process of the intermaxillary is shorter than the deseending branch of the bone; the mandibula is of moderate length, as long as the procorbital. The romer is euneiform, flat. The pricorbital is elongate, slightly tapering posteriorly; the remainder of the infraorbital areh is somewhat narrower, without interior plate. The praperculum has no prominent ridge, or a developed muciferous cavity ; its angular portion is very thin, flexible, broad, produced, with the posterior margin rounded. The operenlum is twice as high as broad, and has a very obtuse posterior point, with a slight notch above. The suboperculum is elongate, and has a nearly vertical situation. The basal portion of the brain-capsule is compressed, and the basisphenoid has a rery wide foramen before the oceipital joint. The urohyal is distinguished by a very deep incisure in its posterior margin. Each pubie bone is formed by three lamellæ of equal extent; their entire length is less than that of the coracoid.

I find one vertebra more than stated by Valenciennes, namely eleven abdominal vertebre and thirteen candal, the length of the former portion of the vertebral colum being to that of the latter as $1: 1 \cdot 07$. The single rertebra are rather elongate; the noural and hromal spines narrow, exeept those of the first four rertebre, which are dilated; the interneural spines are dilated, triangular, but short, and do not extend between the neural spines. The interhomal spines are very feeble, and the first is searcely different from the others. 'The ribs are slender. 


\section{¿. Box salpa.}

$\sum u ́ \lambda \pi \eta$. Arist: iv. c. 8 , v. c. 9,10 , vi. c. 17 , viii. e. 2,13 , ix. c. $3 \vec{\imath}$; Eliun, ix. c. 7. p. 516; Oppian, i. p. (;; Athen. vii. p. 320 .

Salpa, Orid. HIal. v. 121 ; Plin. ix. c. 5t; Bellom. pp. 187, 189; Romel. v. c. 23 . p. 154; Gesner, pp. 832, 979) Aldror. ii. c. 21. p. 189 ; Willughby, p. 316 ; Ray, p. 134.

Sparus, no. 15, Artedi, Gen. p. 38.

— salpa, Lim. Syst. Nat. i. p. 470 ; Brimu. Pisc. Mass. p. 46; J. Gm. p. 1275 ; Bloch, taf. 265 (not good); Bl. Schn. p. 270 ; Lacíp. iv. pp. 97, 101 ; Risso, Ichth. Nice, p. 243.

Cynsedus, Gronor. Zoophyl. no. 216.

Box salpa, Cur. \& Vul.vi.p.357. pl. 162; Webbぬ Berth.l.c. ; Guinh.l.c. Cynredus onias, Gromor. Syst. cd. Gray, p. 55.
1). $\frac{11}{15}$.
A. $\frac{3}{1.1-15}$.
I. lat. 73 .
L. transv. 5/14.
Cace pylor. 4. Vert. $10 / 14$.

Body rather compressed ; caudalis forked. Greenish, with orangecoloured longitudinal bands; a black spot in and abore the axil.

Mediterranean; Canary Islands; Cape Seas?

थ. Adult: skin : not good state. Mediterrancan. From the Collection of the Zoological Nociety.

b. Young. Malta. From the Haslar Collection.

c. Adult. Sicily. I'resented by W. Swainson, Esq.

¿. 13" long. Madeira. From the Haslar Collection.

e. Adult: stuffed. Cape Seas. Purchased of Sir A. Smith.-Axil with a black spot; therefore not identical with $B$. goieensis.

$f$. Adult: bad state. From the Haslar Collection.

\%. Adult: bad state.

h. Adult: stuffed.

i. Adult: skin. From Mr. Yarrell's Collcction.

$k$. Half-grown.

l. Half-grown: stuffed: bad state. From Mr. Yarrell's Collection. m. Large specimen: skeleton. Lanzarote. From the Rev. R. T. Lowe's Collcetion.

n. Intestires of specimen $m$.

o. Half-grown: skin. From Gronov's Collection.

$A$ description of the anatomy of the soft parts has been giren by Valenciennes, to which I may add, that the pyloric appendages are very elongate.

Slicleton.-The occipital crest and the two lateral erests are rather fecble and moderately elevated; the former slightly extends on the frontal bones, and the latter cmit a flat free proeess posteriorly. The upper surface of the frontal bones is slightly convex and roughened by irregular small ridges and holes; there is no central longitudinal grone. The upper portion of the skull is hroad, and therefore the turbinal bones are remote from each other; they are transformed into curved tubes. The intermaxillaries are short and strongly built; their posterior processes are nearly equal in length to the deseending branch. The maxillary bone is short, bent, and very irregularly shaped; its upper portion is fitted in the angle of the intermaxillary and provided with a deep groove for the artieulation with the turbinal bone,- $a$ structure by which we are reminded of that of Givella; 
Pimelepterus, \&c. The mandibulary is stout, elevated, and short, shorter than the procorbital, and relatively much shorter than in $B o x$ vulyaris. 'The vomer has a broad and flat head, and its posterior portion compressed and narrow. The praeorhital has its upper anterior portion rather produced, and its inferior edge slightly emarginate. The infraorbital ring is not much narrower than the posterior part of the præorbital, and has no interior plate. The angle of the præ. operculum is regularly rounded and not produced. The operculum is quadrangular, twice as high as broad; the anterior side is the longest, the superior the shortest; it has no spine at all. The subopcreulum is obliquely situated, and much narrower than the interopereulum. The basal portion of the brain-capsule is very compressed, and the basisphenoid has a wide and elongate foramen before the occipital joint. The glossohyal is vory short, triangular. The urohyal not only has a very deep posterior incisure, but the lower of the two processes formed by that incisure is again deeply forked. The pubic bones are formed by three lamellæ of equal extent, as in Box vulgaris, but they are relatively longer, and not much shorter than the coracoid.

I find one vertebra more than stated by Valenciennes, namely ten abdominal and fourteen caudal vertebræ, the length of the former portion of the vertebral column being to that of the latter as $1: 1 \cdot 18$. The single vertebre are strong; but not distinguished by their length. The neural and hæmal spines are narrow, remote from each other, except those of the first three vertebræ, which are dilated. The interneural spines are rather short, and do not extend very far between the neurals; those of the spinous dorsal are dilated. The interhæmal spines are very feeble; the first is stronger and longer than the others, with a short anterior ridge, and is attached to the hæmal of the eleventh vertebra. The ribs are of moderate strength, and some have epipleural spines.

The incisors are similar to those of Pimelepterus; there are nine on each side of the upper jaw, and twelve on each side of the lower. Each has a free vertical portion and a horizontal one, by which the tooth is anchylosed to the bone. The vertical portion has a shallow outer longitudinal groove, terminating in a notch at the cutting margin; the horizontal portion is compressed, and has a very deep groove for the soft parts of the tooth. The teeth are replaced from time to time by others, which enter their place from the outside of the series, whilst we observe, in other fishes of this family, that the teeth replacing the old ones are developed on the interior side of the cavity of the inouth. The pharyngeal teeth form broad cardiform patches, and are stronger bencath than above.

\section{Box goreensis.}

Cuv. \& Val. vi. p. 364.

$$
\text { D. } \frac{11}{15^{\circ}} \text { A. } \frac{3}{14} \text {. }
$$

Very similar to $B$. salpa, but withnut black at the axil. ( $\mathrm{Val}$.) A rather doubtful species from Cape Verde. 


\section{SCATHARUS.}

Scatharus, Cuv. \&. Val. vi. p. 375.

In both jaws a single series of lanceolate tecth, behind which are no other teeth; no molars. Cheeks scaly. The dorsal spines (eleven) can be received in a sealy sheath; anal spines three. Seales moderate. Six branchiostegals. Pyloric appendages in small number; air-bladder with two short posterior horns.

Mediterranean.

\section{Scatharus græcus.}

Cuv. \& Val. vi. p. 376. pl. 162 ter; Expet. Sc. Morée, Zool. pl. 17. f. $2 a, b$.

\section{D. $\frac{11}{11}$. A. $\frac{3}{10}$. Cace. pylor. 4 .}

The height of the body is one-third of the total length. Coloration uniform.

Mediterranean.

\section{OBLATA.}

Oblata, sp., Cuv. Rèrgne Anim.; Cur. \& Val. vi. p. 366.

In both jaws a series of broad incisors in front, notehed at the cutting margin, behind which is a band of granular teeth* ; on the sides a series of small pointed teeth; no molars. Cheeks scaly. The dorsal spines (eleven) ean be reenived in a sealy sheath; anal spine. three. Seales moderate. Six branchiostegals. Pyloric appendages in small number; air-bladder with two horns posteriorly.

Mediterranean.

\section{Oblata melanura.}

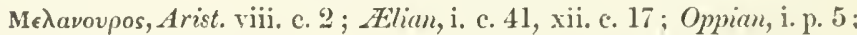
Athen. vii. p. 313.

Melanurus, Orid. IIal. v. 112; Plin. xxxii. c. 11; Bellon. pp. 270, 271; Rondel. v. c. 6. p. 126; Salv. f. 181, 182; Aldror. i. c. 13. p. 64; Gesner, pp. 540,638; Willughby, p. 310; Ray, p. 131.

Sparus, no. 14, Artedi, Genera, p. 37.

— melamurns, Linn. Syst. Net. i. p. 468 ; Brïun. Pisc. Mass. p. 41 ; L. Gm. p. $1271 ; B l . S c h$; p. 273. oblada, Lacép. iv. p. 76 ; Risso, Iehth. Nice, p. 237.

Oblata molmeura, Cuv. \&. Val. vi. p. 366. pl. 16: b; Guichenot, Ixplor. Sc. Algér. Poiss. p. 54.

D. $\frac{11}{14}$. A. $\frac{3}{13}$. L. lat. 65. L. transv. $\frac{7-8}{16}$. Caec. 1ylor. 6. Vert. 10/14.

The lower jaw rather prominent; a large black bloteh across the back of the tail, extending on the sides.

Mediterrancan; Madeira; Canary Islands.

a. Adult: skin. Mediterranean. From the Collection of tho Zoological Socicty.

* The teeth behind the incisors are not villiform, as stated hy Curer, but granular, as in Crenidens, to which genus Oblate is closcly allicd. 
b. Adult. Mediterranean. Purchased of Mr. Frank.

c. Many young specimens. Malta. From the Haslar Collection.

d. Fine specimen. Madeira. From the Rev. R. 'T. Lowe's Collection.

e. Adult. Lanzarote. From the Rev. R. 'T. Lowe's Collection.

f. Adult male: skeleton. Madeira. From the IIaslar Collection.

g. Adult. From Mr. Yarrell's Collection.

$h$, i. Half-grown: bad state.

$k$. Half-grown: stuffed: not good state. From Mr. Yarrell's Collection.

l. Intestines of specimen $f$.

Skeleton.-The occipital crest is very elevated, triangular, and extends anteriorly to a trallsverse protuberance of the frontal bones between the eyes; the lateral crests are moderately developed, and terminate posteriorly in a short free process. The frontal bones have a very rough surface with many larger and smaller pores and a broad impression in front: The intermaxillaries are moderately developed, and have the posterior processes shorter than the descending branches. The maxillary is slightly curved, and not much broader at its free extremity than at its base. The mandibula is longer than the preorbital, with a free interspace between the dentary and articular bones. The turbinal bone is transformed into a lalfchannel. The præorbital is porous, and tapers slightly at its posterior extremity; the other infraorbital bones form a very narrow ring, with a narrow interior plate for supporting the eyeball from beneath. The anterior portion of the vomer is flat and broad. The system of muciferous channels is more developed in this species than in Box: there is a prooperenlar channel with rery distinct openings; the limbs of the pracopereulum are inconspicuously striated, and the striæ do not terminate in denticulations; the inferior limb is shorter than the posterior. The operculum is $1 \frac{1}{2}$ as high as broad, and irregularly quadrangular; the upper side is oblique. There is a ridge at the inside of the bone, running towards the posterior angle, and not terminating in a prominent spine. The sub-and interopcreulum are very thin, and the former is situated in a very obligue direetion. The basisphenoid has a very wide opening before the occipital joint, and ascends in a curve from the brain-capsule to the nasal vertebra. The glossohyal is elongate, styliform; the urohyal triangular, elevated, and without posterior notch. Each pubic bone is formed by threo lamella of nearly equal development, as in $B o x$; it is of moderate length and much shorter than the coracoid.

There are ten abdominal and fourteen candal vertebre, the length of the former portion of the vertebral colum being to that of the latter as 1:1.4. The neural and hxmal spines are slender; tho longest are those belonging to the eighth vertebra to the fifteenth. The hremal spines are much longer than the neurals. The interneurals of the spinous dorsal are dilated, and not shorter than the neurals. The first interhæmal is slender and has a narrow ridge anteriorly; it is attached to the eleventh rertebra. The rib; are moderately strong, and some of them beur epipleurul spiness. 
The eight anterior teeth of the upper jaw and the ten anterior of the lower are compressed, but without horizontal proeess. All the lateral teeth are conical and pointed There are some granular teeth behind the incisors, irregularly arranged. The pharyngeal tecth are eardiform, the upper ones strongest.

\section{CRENIDENS.}

Crenidens, Cuv. \& Val. vi. p. 377.

In both jaws one or two series of broad tecth, with the cutting margin erenulated; a band of granulated teeth belind those series; no pointed lateral teeth. Cheeks and opereles scaly. The spines of the dorsal (eleven) can be received in a groove; three anal spines; dorsal and anal fins not scaly. Scales of moderate size. Five branchiostegals. Pyloric appendages in small number; air-bladder simple.

A vegetable feeder from the eastern coasts of Africa.

\section{Crenidens forskalii.}

Sparus crenidens, Forskal, Descript. Anim. p. xv.

Crenidens forskalii, Cuv. \& Val. vi. p. 377. pl. 162 quater; Rüppell, N. W. Fische, p. 120 ; Peters, Wiegm. Archiv, 1855, p. 243.

D. $\frac{11}{11}$ A. $\frac{3}{9}$. L. lat. 55 . L. transv. 5/13. Cæe. pylor. 3 . Vert. $10 / 15$.

The height of the body is one-third of the total length. Three series of seales on the cheeks. Coloration uniform.

Red Sea; Coast of Mozambique.

a. Adult: stuffed. Red Sea. From Dr. Rüppell's Collection.

\section{PACHYMETOPON.}

A series of trenchant incisors in front of both the jaws, behind which is a band of similar teeth, but less doveloped, and replacing the former. No molars; no teeth on the palate. Dorsal and anal fins partly, caudal entirely hidden by scales. Dorsal without noteh and with eleven spines. Scales moderate. Cheek sealy.

$\mathrm{Hab}$.

1. Pachymetopon graude. (Plıte XXVI:

D. $\frac{11}{11}$. A. $\frac{3}{10}$. $\quad$ L. lat. 88 . L. transv. $11 / 22$.

$\Lambda$ large and conrex transverse protuberanee between the eyes. Hab. ㄴ?

a. Adult: stuffed. From the Collection of the Zoologieal Soeiety.

Description of the specimen.- The form of the body describes a regular oval, the lower profilo being considerably curved. 'The profile 
of the neck is strongly eurved, and passes into a very prominent rounded protuberance between the eyes. The greatest height of the body is above the root of the ventrals, and one-third in the total length; the head is rather short, one-fifth of the total length, and distinguished by the convex prominence across the forchead. The width between the eyes is $2 \frac{1}{5}$ in the length of the head. The snout is elevated, short, and obtuse, with the eleft of the mouth rather small, the uppor maxillary reaehing to the vertical from the posterior nostril. The posterior portion of the mandibula is sealy. The præorbital is rather longer than wide, and naked, like the upper part of the skull. The eye is of moderate size, and eontained $4 \frac{1}{5}$ in the length of the head, or $1 \frac{1}{2}$ in that of the snout. The nostrils are situated before the upper angle of the orbit, and rather remote from each other; the posterior is an elongate slit, the anterior more rounded. The eheek is eovered with six series of seales, but a broad marginal space of the præopereulum is sealeless; the posterior margin of the præopereulum is straight, slightly oblique; the angle is rounded and minutely serrated; the inferior margin convex, and about half as long as the posterior. The other opereles are covered with seales, without any spines or denticulations. The supraseapula is mueh larger than a seale, and indistinetly striated; a series of scales, similarly striated, ascends from the supraseapula to the neek.

The distanee of the oeciput from the dorsal fin nearly equals that from the end of the snout. The fin is continuous, and its soft portion is enveloped in a sealy coat to one-half of its height. Its origin falls vertically above the root of the pectoral, and its end above the sixty-third seale of the lateral line. The spines are moderate; the fifth is one of the highest, and about $2 \frac{1}{5}$ in the length of the head. The soft dorsal nearly equals the same height. The distance between the eaudal and dorsal fins nearly equals the height of the tail beneath the dorsal fin. The caudal fin is densely eovered and entirely hidden by minute seales; it is emarginate, with the lobes pointed, one of the middle rays being rather less than one-half of the length of a lobe. The anal fin is scaly to the same extent as the soft dorsal; its origin falls vertically rather behind that of the soft portion of the dorsal; the spines are rather strong; the first is one-half of the length of the seeond; the second rather stronger, but not longer than the third, and about two-thirds the length of the longest dorsal spine. The rays appear to he equal to one another, and to those of the dorsal fin. The pectoral fin is $3 \frac{2}{3}$ in the total length, and reaehes to the origin of the anal; the fifth ray exeeeds the others in length; the basal portion of the fin is densely eovered with seales. The root of the ventral falls entirely behind that of the peetoral; the fin has a moderately strong spine, about two-thirds of the length of the adjacent ray, and reaches nearly to the vent.

The seales are of moderate size, not ciliated, higher than long; one of the largest eovers one-half of the eye.

The teeth forming the outer series are triangular, broad, with pointed extremities, sixtcen in the upper jaw and twenty-two in the 
lower. The other teeth, behind this series, are arranged in a broad band, similarly but less developed, with the eutting margin not yet pointed.

The coloration is now a uniform greyish; but the fish appears to have been red in life, with the dorsal, anal, and ventral fins blackish

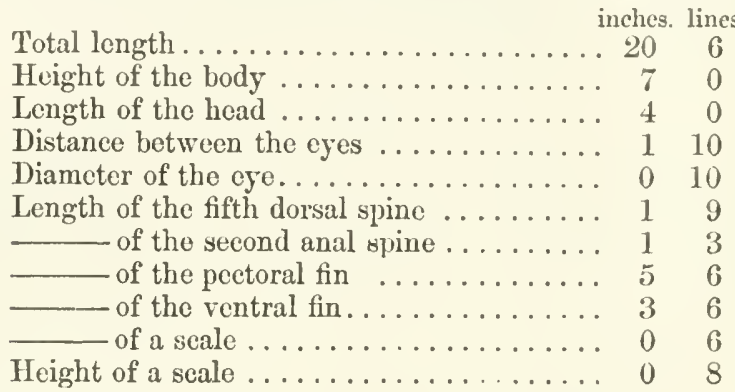

\section{DIPTERODON.}

Dipterodon, Cuv. \& Val. vii. p. 274.

A series of trenchant incisors in both jaws; no molars; no teeth on the vomer or the palatines. Cheek sealy. Minute seales corer the greater part of the soft portions of the rertieal fins. Dorsal deeply notehed, with ten spines, nine of which form the spinous portion; three anal spines. Proopereulum denticulated. Scales small. Six branchiostegals. Air-bladder simple.

Cape Seas.

\section{Dipterodon capensis.}

Coracinus, Gronov. Zoophyl. no. 226.

Dipterodon capensis, Cuv. \& Vul. vii. p. 276. pl. 188.

Coracinus aper, Gronov. Syst. ed. Gray, p. 57.
D. $9 \mid \frac{1}{17-18}$.
A. $\frac{3}{13-14}$.
L. lat. 75. Vert. 10/15.

The height of the body is $2 \frac{2}{3}$ in the total length. Uniform dark brown.

Cape Seas.

a. Adult: stuffed. Cape Scas. Procured from Sir A. Smith.

b. Adult.

c. Half-grown: stuffed. Cape Seas. Procured from Sir 1. Smith. d. Adult: skin. From Gronov's Collection.

\section{PROTERACANTHUS.}

Crenidens (Cirella), sp., Cant. Catal. p. 52.

In both jaws one or two series of flat trienspid teeth, behind which is a hiud of similar tecth, replacing the former. No molars. Checks and opereles scaly. A reeumbent spine before the dorsal; 
ten dorsal and three anal spines; the soft portions of the dorsal and anal scaly at the buse. Seales of moderate size. Five branchiostegals.

Sea of Pinang; Malayan Peninsula.

\section{Proteracanthus sarissophorus.}

Crenidens̃ sarissophorus, Cant. Catal. p. 52. pl. 1.

Girella sarissophorus, Bleek. Singup. pp. 63, 64.

$$
\text { D. } \frac{10}{15} \text {. A. } \frac{3}{14} \text {. }
$$

The height of the body is $2 \frac{3}{4}$ in the total length; caudal truneated; the fourth dorsal spine (the reeumbent spine not included) very strong and elongate, overlapping the suceeding five spines : the first ventral ray produced into a filament. Coloration uniform brownish. (Cant.)

Sea of Pinang; Malayan Peninsula.

\section{GIRELIA*}

Girella, Gray, Mhustr. Ind. 'Zool.

Melanichthys, Temm. \&- Schleg. Fann. Japon. Poiss. p. 75.

Crenidens, sp., Richardson.

In both jaws series of flat and generally trieuspid teeth, behind which is a band of similar teeth, but less developed, and replacing the former. No molars; [in one species a short series of palatine teeth.] Cheeks sealy; opereles naked, exeept the upper angle of the opereulum. The dorsal spines (fourteen or fifteen) can be received into a rather incomplete groove. Seales of moderite size. Six branehiostegals. Pyloric appendages in great number; airbladder divided into two posterior horns.

Chinese, Japanese, and Australian Seas.

\section{Girella punctata.}

Girella punctata, Gruy, Ill. Ind. Zool. pl. 98. f. 3, 4.

Melanichthys, Tenım. \&. Schleg. Faum. Japon. Poiss. p. 75. pl. 39.

Crenidens punctatus, Richardson, Ichth. China, p. 242.

- melanichthys, Richardson, Ichth. China, p. 243.
D. $\frac{14-15}{13-14}$.
A. $\frac{3}{12-13}$.
L. lat. 52-66.
L. trausv. $\frac{7-9}{17-21}$.

The length of the head is about $4 \frac{1}{2}$ in the total length; dorsal tin of moderate height, the longest ray rather longer than the last spine; the incisors three-pointed, moderately broad, imbricate, the upper in three, the lower in two series. Uniform brownish.

Chinese and Japanese Seas.

a. $9^{\prime \prime}$ long: skin. China Seas, Purehased of.Mr. Warwick.

b. 14" long: stuffed. China. Presented by J. R. Reeves, Esq.

-Type of Givella punctata: rather deformed by stuffing. $c-f$. Adult: stuffed. Japan. Purchased of Mr. Frank.

* 1. Crenidens leoninus, Richardson, Ichth. China, p. 242.-China Scas 


\section{Girella tricuspidata.}

Box tricuspidatus, Quoy s. Gaim. Voy. Freyc. Zool. p. 29t.

Oblata tricuspidata, Cuv. \&. Val. vi. p. 372.

Crenidens triglyphus, Richardson, Voy. Ereb. \&. Terr., Fishes, p. 36. pl. 25 . f. 2.
1). $\frac{15}{11-12}$.
A. $\frac{3}{11-12}$.
L. lat. 50 .
L. transv. 10/20*. Vert. 11/16.

The length of the head is $4 \frac{2}{3}$ in the total length; dorsal fin moderately high, the spinous portion lower than the soft; the incisors three-pointed, moderately broad, imbricate, in several series in the upper, in two in the lower jaw. Uniform brownish.

Australian Scas.

a. Adult: had state. Sydney. From the Haslar Collection.

b. Thirteen inches long: stuffed. Australia. Purchased of Mr. Warwick.

c. Young. Australia. Purchased of $\mathrm{Mr}$. Gould.

$d-g$. Half-grown. From the Haslar Collection.

h. Skeleton. From the Haslar Collection.

i. Half-grown: bad state. From the Haslar Collection.

$k$. Intestines of specimen $h$.

The peritoneum is of an intensely black colour; the stomach horseshoe-like bent; the pyloric appendages are exceedingly numerous, thin, and many of them bifid or trifid; the intestines make five complete convolutions, and are $1 \frac{2}{3}$ as long as the whole fish; the airblacler is pesteriorly divided into two large horns, situated between the museles of the tail and the hæmal spines belonging to the anal fin.

Skeleton.-The oecipital crest is elevated, triangular, and does not extend on the frontal bones. The frontal bones are broad, and furnished with two low elongate protuberances, which diverge between the eyes, each terminating in two erests, lateral to that of the oceipital, and moderately developed; the nasal (ethmoid) bone is not concealed by the frontal bones, and projects considerably before them. The anterior portion of the intermaxillaries is strong and thick; their posterior processes equal in length the descending branches. The maxillary is fecble, with a broad free extremity. The mandibula is short, elevated, and about as long as the proorbital. The head of the vomer is triangular and slightly excarated. The turbinal bone is very elongate and tubiform, the præorbital rhombic, the suborbital arch narrow, with a broad interior plate for supporting the cyeball from beneath. The horizontal limb of the proopereulum is much shorter than the vertical; both are minutely serrated; the angle rounded; there are small openings from the numciferous channel of the bonc. The pperculum is $1 \frac{1}{2}$ as high as wide, quadrangular, with the upper side horizontal, and the posterior slightly emarginate; it is provirled at its inner surface with a bony oblique ridge, terminating in a free prominent spine. The sub-

* The series of small scales on the bach and on the belly are ineluded in these numibers. 
and interoperculum are obliquely situated; the former tapers posteriorly, and is produced into an elongate point. The basal portion of the brain-eipsule is not compressed; the basisphenoid has a narrow opening before the occipital joint. The urohyal is elevated, triangular, with the postcrior side cmarginate. Each pubic bone is formed by three lamella, the inferior of which is the broadest, and the two exterior ones strongest; it is elongate, and nearly as long as the coracoid.

There are eleren abdominal and sixteen eaudal vertebre, the length of the former portion of the vertebral column being to that of the latter as $1: 1 \cdot 4$. The single vertebra are rather short. The first interhamal spine is of moderate strength, and evidently composed of two. Some of the ribs have epipleural spines.

\section{Girella simplex.}

Crenidrus simplex, Richardson, Voy. Erebus \& Teror, Fishes, p. 25.

$$
\text { D. } \frac{15-14}{12-13} \text {. A. } \frac{3}{12} \text {. L. lat. } 55 \text {. L. transs. 11/20. }
$$

The leugth of the head is one-fifth of the total length; dorsal fin of morlclate height, the spinous portion about as high as the soft; the incisors with the cutting margin entire, morlerately broad, imbrieate, above and below in two or three irregular series. Uniform brownish (in a dried state).

Australian Seas.

a. Adult. Sydncy. Purchased of Mr. Brandt.

b. Adult: stuffed. Port Jackson. Purchased of Mr. Gould. Type of the speeies.

c. Adult: stuffed. Moore's Bay. Purehased of Mr. Warwiek.

This species is distinguished by a short series of teeth on the anterior portion of the palatine bones.

\section{Girella zonata. (PLATE XXVII.)}

$$
\text { D. } \frac{14}{14} \text { A. } \frac{3}{11} \text {. L. lat. } 49 \text {. L. transv. } 9 / 17 \text {. }
$$

In both jaws a pluriserial band of nurrow tricuspid teeth, scparated from a posterior band of similar teeth, which are less developed, by a groove. Brown (in spirits), with a vertieal lighter zone across the middle of the body; the vertical fins and the ventrals blaekisl.

Australian Scas?

a. Fine speeimen. From the Haslar Collection.

Description of the specimen.--The anterior part of the trunk is slightly elevated, its greatest height being above the base of the ventral fins, where it is one-third of the total length. The head is rather short and thick, the distance between the eyes being onethird of the length of the head, which is $4 \frac{1}{3}$ in the total. The snotst 
is obtuse and broad; the upper maxillary (which, when the mouth is closed, is entirely hidden) reaches to the vertical from the anterior margin of the eye. The pracorbital is higher than long, and entirely scaleless. The eye is situated near the upper protile of the head, without interfering with it ; it is of moderate size, its diameter being $4 \frac{3}{5}$ in the length of the head. The cheeks are covered with very small seales extending nearly to the prwopereular margin, which exhibits some minute serrature at the angle. 'Tlic operculum is sealy on its upper angle only; the remainder is naked, like the sub- and interopereulum. 'The subopereulum is narrow, and tapers very much posteriorly; its lower margin is nearly straight; the interopereulum is broader and eresecnt-shaped. The supraseapula is not visible externally.

The dorsul fin begins vertically above the root of the pectorals, and ends in the vertical from the 35 th seale of the lateral line. Streaks of minute seales ascend between the spines and rays to about one-half of the height of the fin. The spines are of morlerate size; they gradually become longer to the sixth, the serenth to the fourteenth being nearly equal in length, about $2 \frac{1}{3}$ in the length of the head; the anterior rays are rather more elerated, but the posterior ones decrease again, and the last is about one-third of the length of the head. The distance between the dorsal and caudal fins exactly equals that between the end of the snout and the procopereular margin, or the depth of the tail beneath the end of the dorsal. 'The caudal fin is nearly sealeless, emarginate, with acute lobes; one of the middle rays is about two-thirds of the upper lobe. 'The anal fin begins a little behind the soft portion of the dorsal, and ends a little before it; its base is sealy, and streaks of minute seales extend on between the rays to about one-third of the depth of the fin; the lower marin is rery convex. The spines are rather strong; the first is one-half the length of the seennd; the sceond three-quarters of the thirl, the free portion of which is $2 \frac{1}{3}$ in the length of the head: the tollowing rays become longer to the fourth, fifth, and sixth, which are ahout two-thirds of the length of the head; and the last ray is onelaalf only of the sixth. 'The pectoral fins are scaly in their basal third ; they have a romeled posterior margin, and are of moderate length, not rxtending to the rent. 'The root of the ventrels is placed at some distance behind the fertical from the base of the pectorals; they extend to the rent, and are composed of one spine and five rays, the former of which is about one-half the length of the first ray. There is no elongate seale at the hase of these fins.

the scules are ristinctly ciliated, and rather longer than high, their hasal portion being much larger than the free. Many beautifully aranged fine streaks radiate from the centre to the basal margiu. One of the largest covers one-half of the ere.

both jaws are furnisherl in front with a transwerse hand of delicate, tricuspid, narrow terth, arranged in thee or four series. Inother (posterior) band of teeth is seplarated from the former by a greove; this band eontains teeth, hy which the anterior one's mat he replaced: thry are therefore in a less deroloped rondition, having 
rather the appearance of setiform or villiform teeth, with the notehes at the eutting margin searcely visible. There are no palatine tecth whatever.

The colour is now a dark nut-brown, with a lighter vertical band, descending from the middle of the spinous dorsal to the belly, and oceupying three series of seales. The dorsal, anal, and ventral fins are blackish.

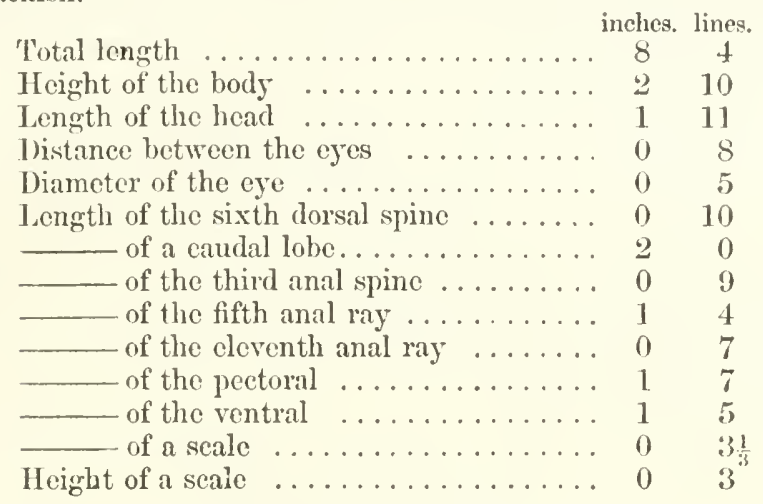

\section{DOYDIXODON.}

Doydixodon, Falenc. in Voy. Féms, v. p. 318.

In both jaws series of flat teeth, bchind which is a hand of similar tecth, less developed and replacing the former. No molars: 110 teeth on the palate. Cheeks scaly; opeleles naked. Dorsal and anal fins sealy at the base; twelve dorsal spines; the soft portions elevated. Scales of moderate size. Five branchiostegals.

Galapagos Archipelago.

\section{Doydixodon freminvillei.}

Falenc. l. c. p. 323. pl. .).

$$
\text { D. } \frac{12 *}{20} \cdot \Lambda \cdot \frac{3}{15} \cdot \text { L. lat. } 40-45 \text {. }
$$

Uniform browrish.

Galapagos Archipclago.

\section{TEPHREOPS.}

Crenickens, sp., Richurds. Voy. Ercb. s. Terr., Fishes, p. 69.

In both jaws series of flat, trieuspid teeth, behind which is a band of similar teeth, less developed and replacing the fornier. No molars. Cheoks scaly; opereles naked, except the uprer angle of the operculum. Fourteen dorsal spines. Seales very small.

Australian Seas.

* The figure cloes not agree witli these numbers. 


\section{Tephræops richardsoni.}

Crenidens tephræops, Richards. Voy. Ercb. \& Terr, Fishes, p. 69. pl. 41. f. 1 .

$$
\text { D. } \frac{14}{13} . \quad \text { A. } \frac{3}{11} \text {. }
$$

In front of the jaws a single series of tricuspid teeth, separated from the broad posterior band of smaller ones by a groove; anal fin rather elevated, the secoud ray being four-fifths of the length of the head. Uniform blackish.

King George's Sound.

a. Eleren inches long: stuffed. King George's Sound.-Type of the speeies.

\section{Tephræops zebra.}

Crenidens zebra, Richards. l. c. p. 70.

Nine blackish-brown bars descending from the back.

Known from a drawing only.

King George's Sound.

\section{GYMNOCROTAPHUS*}

In both jaws a series of broad, lanceolate incisors, behind which is a band of eardiform teeth. No molars. Checks naked. Operces sealy. Six branehiostegals. Ten dorsal spines. The rertical fins partly eovered with seales. Seales of moderate size.

Cape Seas.

\section{Gymnocrotaphus curvidens. (Plate XXII.)}
B. 6 .
D. $\frac{10}{12}$.
A. $\frac{3}{10}$.
L. lat. 65 .
L. transt. $6 / 18$.

The height of the body is about one-third of the total length. Cape Seas.

a. Thirteen inches long: stuffed. Cape Seas. Presented by Sir A. Smith.

Description of the specimen.-The fish is somewhat similar to Canthares in gencral appearance. The borly is rather elevated, its greatest height above the ventrals being nearly one-third of the total length. The length of the head is one-fourth of the total. The space between the eyes is rather convex and broad, its width being $2 \frac{3}{5}$ in the length of the head. All the snout, the eheck, and the proopereulum are completely naked, and the seales of the neck do not extend on between the eyes. The snout is of moderate length. The eye is situated high up the sides, and its diameter is $5 \frac{1}{5}$ in the length of the head. The nostrils are before the npper angle of the

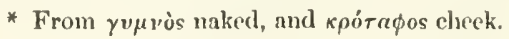


eye and rather remote from each other; the procorbital is a little higher than long. The angle of the praoperculum is rounded; its limbs are directed towards each other at a rather obtuse angle; it has no denticulations whatever. The other opereles are entirely covered with scales, and have no armature. The suprascapula is very large, and there is a series of similar seales between-it and the nape of the neck.

The distance of the oceiput from the origin of the dorsul fin is much less than frem the end of the snout; the former falls vertically above the root of the ventrals, and its end above the forty-sixth scale of the lateral line. The last two spines and the soft dorsal are enreloped in scales, which ascend to one-half the height of the fin: The spines are of moderate strength and rather short; the first is the shortest, whilst the third to the last are nearly equal and $3 \frac{3}{4}$ in the length of the head. The soft dorsal is higher, quadrangular. The distance between the dorsal and caudal fins is much less than the depth of the tail beneath the end of the dorsal fin. The greater part of the caudal is covered with small scales; it is slightly emarginate, with rounded lobes. The anal fin is opposite to the soft dorsal, to which it is very similar, though somewhat lower. The spines are not stronger than those of the dorsal; the third is the longest, rather shorter than the longest dorsal spine or than the first anal ray. The pectoral is pointed, and one-fourth of the total length; the portion nearest to the base is sealy. The base of the ventrals falls behind that of the pectorals; their length is $6 \frac{4}{5}$ in the total; the spine is of moderate strength, and three-fifths of the length of the adjacent ray.

The scales are of moderate size, minutely eiliated, higher than long; one of the largest eovers rather more than one-half of the orbit.

There is a series of broad, lanceolate, curved incisors in cach of the jaws-in the upper one twelve, in the lower fourteen; there is also a broad band of eardiform teeth behind these ineisors. Neither the vomer nor the palatine bones appear to have any teeth.

Colour uniform brownish grey (in a dried state).

inches. lines.

Total length.................. 13 (3

Height of the body . . . . . . . . . . . . 4 4

Longth of the head .............. 33

Diameter of the cye.............. 0 7 $7 \frac{1}{2}$

Distance between the eyes ........... 13

Length of the fourth dorsal spine ....... $0010 \frac{1}{2}$

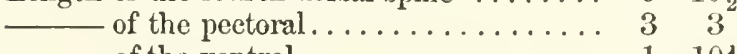

— of the ventral . . . . . . . . . . . .

Heiglit of a seale . . . . . . . . . . . . . 000 


\section{Second Group. HAPLODACTYLINA.}

Sparida with eutting teeth in front; no molars; the lower peetoral rays simple, not branched.

One genus.

\section{HAPLODACTYLUS.}

Aplodactylus, Cuv. \&. Val. viii. p. 476.

In both jaws series of flat and generally trieuspid teeth, behind which is a band of small cardiform teeth; no molars; vomerine teeth. Cheeks and opereles sealy. Two elongate dorsal fins, the first with fifteen or sixteen spines; anal short; the lower peetoral rays simple. Seales very small. Six or five branehiostegals. Pyloric appendages in small number; air-bladder simple.

Western coasts of South America; Port Arthur (Australia).

Vegetable feeders.

\section{Haplodactylus punccatus.}

Aplodactylus punctatus, Cuv. \& Val. viii. p. 477. pl. 242; Jeryns, Zool. of the Beagle, Fishes, p. 15 ; Cony, Hist. Chil. Zool. ii. p. 156.

Aplodactylus reginæ, (Valenc.) Gay, IIist. Chil. Zool. ii. p. 158. lam. 1. fig. 2.
D. $16 \mid 21$.
A. $\frac{3}{8}$. Cæe. pylor. 2.

Ineisors trieuspid; six simple pectoral rays. Brownish red, dotted all over with black.

Coasts of Chile.

a. Fine specimen. S. America. From Mr. Bridges' Collection.

\section{Haplodactylus vermiculatus.}

Gay, Hist. Chil. Zool. ii. p. 159. lam. 1. f. 1.

$$
\text { D. } 15 \mid \frac{1}{20} \text {. A. } \frac{3}{8} \text {. }
$$

Incisors tricuspid. Brownish grey, lighter beneath, rermiculated with brown; fins brown-spotted. (Gay.)

Sea of Valparaiso.

\section{Haplodactylus guttatus.}

Gay, l.c. p. 160.

$$
\text { D. } 15 \mid \frac{1}{19-20} \text {. A. } \frac{3}{7} \text {. }
$$

Yellowish, dotted all over with white. (Gay.)

Cuast of Chile. 


\section{Haplodactylus arctidens.}

Richards. Proc. Zool. Suc. 1839, p. 96, and Trans. Zool. Soc. iii. p. 81.

D. $16 \mid \frac{1}{18}$. A $\frac{3}{7}$. Caec. pylor. 4. Vert. 16/18(?).

Incisors laneeolate, without distinet lobes in old age. Six simple pectoral rays. Uniform brownish.

a. Twenty-three inches long: stuffed. Port Arthur. Presented by Sir J. Richardson.-Type of the species.

5. Haplodactylus lophodon. (PL.st: XXill. fiłg. B.)

$$
\text { B. 5. D. } 17 / 20 \text {. A. } \frac{3}{6} \text {. J. lat. } 78
$$

Each incisor with a terminal lobe and two lateral lobes (on each side). Six simple pectoral rays. brown: opereulum with a black spot behind; caudal and anal variegated with lighter.

Coast of New South Wales.

a. Adult. Sydney. Presented by the College of Surgeons.

b. Young. New South Wales. Presented by Dr. G. Benneti.

Deseription of the specimen. - The greatest height of the body is $3 \frac{3}{5}$ in the total length, and is below the sixth dorsal spine; the npper profile of the head and the nape of the neck is rather concave. 'The head is small, its length being one-fifth of the total; its upper surface between the orbits is flat. The snout is olstuse and rounded, not longer than the diameter of the eye, which is more than tho distance between the eyes, and one-fourth of the length of the head. The cleft of the mouth is narrow, horizontal, situated at the lower part of the snout, which eonsiderably projects above it; the mouth is very little protractile, and the upper maxillary does not reach to the anterior margin of the orbit. The nostrils are rather remote from each other, and the anterior is furnished with a short membranaceors appendage. The limbs of the prooperculum are flexible and skinny, and meet at a rounded angle; the opereulum terminates posteriorly in a point, separated from another shorter one by a decp semicireular notch; the sub- and interoperculum are narrow. The opercles and eheeks are covered with minute seales, the other parts of the head being naked.

The dorsal fin begins in the vertical from the extremity of the operculum ; the spinous portion has the upper margin convex, and is continued by the soft one, although the latter is eunsiderably elevated above the posterior spines; its upper margin is nearly straight, obliquely descending. The first spine is one-half the length of the second, the seeond one-half of the third; the following inerease in length to the sixth, which is nearly one-half of the length of the head. The posterior spines gradually become shorter to the sixtecnth and seventeenth, which are equal in length to each other and to the second spine. The second and third rays are the longest, rather longer than the sixth spine, the following gradually becoming shorter. There is a pad along all the base of the fin, covered with smatl scales and 
hiding the basal portion of the fin. The distance between the dorsal and caudal fins is $8 \frac{3}{4}$ in the total length, and much more than the height of the tail below the extremity of the dorsal. The caudal fin is slightly emarginate, with the lobes rather rounded; its length is nearly one-sixth of the total. Stripes of minute and transparent scales extend over the greater half of the interspaces between the rays. The anal is very short, the length of its base being $2 \frac{1}{2}$ in its distance from the caudal ; its origin falls vertically below the second dorsal ray, and its end below the eleventh. The first spine is onehalf the length of the second, the sceond is one-half of the third, the third two-thirds of the second and third rays, which are the longest, and about $1 \frac{1}{3}$ in the length of the head; the base of the fin is sealy. The pectoral fin is rounded, and equals the head in length. The six lower lays are simple, not distinguished from the others in length or in thickness. The ventrals are shorter and do not reach to the rent; they are inserted below the middle of the pectoral: their spine is two-thirds of the total length of the fin.

The scales are small, longer than high, not ciliated at their outer margin; one of the largest covers one-fifth of the eye.

The teeth are placed in a band in the upper jaw and in a single series in the lower; they are compressed and rather elongate, with a lobe at the extremity and with two on each side. There are no vomerine or palatine teeth.

The ground-colour is brown; body and tail with indistinct and intermpted darker longitudinal stripes; a darker vertical spot below the eye; the noteh of the opereulum black, white-edged anteriorly ; the peetoral and ventral fins are blackish, the caudal and anal fins variegated with lighter.

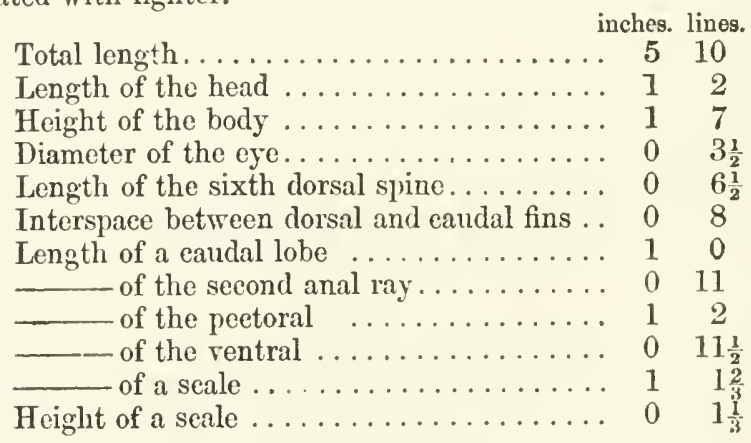

\section{Third Group. SARGINA.}

Sparida with entting teeth in front of the jaws and molars on the sides.

$$
\text { Synopsis of the Genera. }
$$

Molar teeth in several series............... 14. Sargus.

Nolar teeth in a single series $\ldots \ldots \ldots \ldots \ldots \ldots \ldots$ 15. Cirarax. 


\section{SARGUS*.}

Sargus, (Klein) Cuv. Rìnne Anim.; Cuv. \&. Ful. vi. p. 9.

A single front-row of eutting teeth and several side-rows of rounded molar teeth in both the jaws. Cheeks scaly. The spines of the dorsal (ten to thirteen) may be received in a groove; three anal spines. Opereles not armed. Scales of moderate size. Five or six branchiostegals. Pyloric appendages in small number; air-bladder sometimes notched anteriorly and posteriorly.

Mediterranean; warmer parts of the Atlantic; shores of the United States; eastern shores of Africa.

\section{Sargus vulgaris.}

Sargus, Gesner, Aquat. p. 825; Aldrov. pp. 174, 176; Salvian. f. 179; Bellon. p. 244.

Sparus sargus, Brüm, p. 38. no. 52.

putazzo, Risso, Eur. Mérid. iii. p. 352.

Sargus vulgaris, Geoffr. Descr. Ey. pl. 18. f. 2.

___ salviani, Cuv. \& Val. vi. p. 28; Guichenot, Explor. Se. Algér.

Poiss. p. 47; Webu \& Berthelot, Hist. Nat. Iles Cunur., Poiss. p. 28.

D. $\frac{11-12}{15-14}$. A. $\frac{9}{14^{\circ}}$ L. lat. 55 . L. transv. 6/14. Cace. pylor. 4.

Vert. 10/14.

Incisors moderately broad, implanted obliquely. The molars of tho upper jaw form two distinet series only. The dianeter of the eye is four times or $4 \frac{1}{2}$ in the length of the head, $1 \frac{1}{2}$ or $1 \frac{2}{3}$ in that of the snout, and $1 \frac{1}{2}$ in the distance between the eyes. The crown of the head is slightly convex, and there is a small protuberance above the upper anterior angle of the orbit. The preorbital is broad, and covers entirely the maxillary bone. The pectoral fins extend to, or slightly beyond, the origin of the soft portion of the anal fin, and the ventrals to the vent; the second anal spine is rather longer, but not stronger, than the third, and $3 \frac{1}{3}$ in the length of the head. Golden oliveyellow, sometimes silvery, with narrow, slightly warv, golden-yellow longitudinal stripes : a broad black band from the nape to the shoulder and axil; a broad black blotch across the back of the tail.

Mediterranean.

a. Adult: skin: not good state. Mediterranean. From the Collection of the Zoologieal Soeiety.

$b-e$. Young and half-grown. Malta. Frou the Haslar Collection. $f$. Half-grown : skin. Malta. From Mr. Yarrell's Collection.

$g, h$. Very fine specimens. Lanzarote. Presented by the Rev. R. T. Lowe.

$i, k$. Adult: stuffed. Santa Cruz (Teneriffe).

1. Adult. Madeira. From the Haslar Colleetion.

m. Adult: bad state. Purehased of Mr. Frank.

n, o. Half-grown: bad stac. From the Haslar Collection.

1). Adult: not good state: stuffed.

There is a specimen in the British Museum which so remarkably

* 1. Sargus ascensionis, Cuv. \& V ral, vi. p. 61.-Ascension. 
differs in the number of the fins, that I considered it as the type of a new species for a long while, to which I intended to give the name of Sergus auricularis; but having this single specimon only, I prefer to give a full description of it, as after all it may prove to be merely an aceidental variety.

\%. Adult. From the Haslar Collection.

$$
\text { D. } \frac{13}{12} \text {. 1. } \frac{3}{13} \text {. J. lat. } 56 \text {. L. transv. } 6 / 14 \text {. }
$$

Description of the specimen.-The body is rather elevated, its greatest depth, below the fifth dorsal spine, heing $2 \frac{1}{5}$ in the total length. The profile of the mape forms a not very strong curve, and is continued into that of the heal, which deseends to the snout in a straight line; the distance between the occiput and the end of the snout equals that between the oeciput and the origin of the dorsal fin. The head is compressed, and forms one-fourth of the total length; the distince between the eyes is one-third of the length of the head. The snout is rather pointed and of moderate length, the upper maxillary reaching nearly to the vertical from the anterior margin of the orbit. The pracorbital is $1 \frac{1}{2}$ as long as high, and eovers entirely the maxillary bone. The eye is of moderate size, and situated much nearer to the upper vertical than to the inferior limb of the præoperculum. The nostrils are placed near the upper angle of the orbit; the posterior is an elongate slit, the anterior is round. There are four series of scales between the præorbital and the limb of the pracopereulum, which also is partly covered with a single series of deciduous scales. The posterior margin of the pricoperculum deseends forwards in a straight and slightly oblique line ; the angle is rounded ; the inferior margin straight and oblique. The operculum has no , listinet spine, and is eovered with seales, like the sub-and interoperculum. 'I'he suprascapula is scale-like, without strix or denticulations; lout there is a curved series of scales, ascending from the supraseapula to the nape, which cxhibit very distinct strix.

The dorsal fin begins above the root of the rentrals and extends to the vertical from the forty-first seale of the lateral line, its distunce from the eaudal fin being $2 \frac{1}{4}$ in the length of the head. The spines are rather strong, compressed, and broader on one side; the first is one-half the length of the second; the fourth, fifth, and sixth are longest, and $2 \frac{1}{2}$ in the length of the head; the following gradually decrease in length to the last, which is $3 \frac{3}{5}$ in the length of the bead. The soft rays are nearly equal in length to one another and to tho last spine. The caudal fin is forked, one of the middle rays being nearly one-third the length of the upper lobe, which is rather longer than the lower. The origin of the anal fin fills vertically below the end of the spinous dorsal, and its end immerliately behind that of the soft clorsal; it is rather higher than the opposite fin, the posterior rays, however, gradually becoming shorter. 'The spincs are rather stout; the first is two-fifth the length of the second, the second slightly exereds the third, and is one-thind of the length of the head. 'The sixth pectorel ray is longest, reaching to the origin of the soft 
anal. The base of the ventials fills entirely behind that of the pectorals; they are of moderate length and reaching nearly to the vent; the spine is three-quarter's of the length of the adjacent ray. There is an elongate pointed scale inserted at the base of the ventral.

'The scales are minutcly eiliated, higher than wide; one of the largest covers one-third of the eye.

The incisor's are moderately broad, little narrower than in S. rondeletii; they are obliquely implanted, eight in each of the jaws. The molars are arranged in two series; but there are several intercalated between the two series of the upper jaw, giving the appearance of a third series; the postorior ones of the inner series are the largest.

The fish is silvery, with a blackish band from the nape aeross the shoulder and the posterior edge of the gill-opening; another broad blackish band on the tail, behind the dorsal; the axil and the ventral fins are blackish, the latter with a narrow white outor edge.

\begin{tabular}{|c|c|}
\hline Total longth . . . . . . . & 8 \\
\hline Height of the body . . . . . . . . . . . & 3 \\
\hline Length of the head $\ldots \ldots \ldots \ldots \ldots \ldots$ & 2 \\
\hline Distance between the eyes .......... & 0 \\
\hline ___ between the dorsal and caudal fins & 1 \\
\hline Diameter of the eye $\ldots \ldots \ldots \ldots \ldots$ & 0 \\
\hline Length of the fifth dorsal spine . . . . . . & 0 \\
\hline of the thirteenth dorsal spinc... & 0 \\
\hline of the pectoral............. & 2 \\
\hline - of the ventral ............ & 1 \\
\hline - of the second anal spine ........ & 0 \\
\hline - of a scale .............. & 0 \\
\hline [eight of a seale . . . . . . . . . . & 0 \\
\hline
\end{tabular}

Skeleton.-The jaw-bones, armed with several series of broad molar teeth, are of a stronger and more solid structure than in any other fish of the preceding families. The intermaxillaries have their posterior proeesses rather elongate, the groove in which they move extending to the vertical from the anterior margin of the orbit. The portions for the ineisors and for the posterior molars are slightly swollen and separated from each other by a slight noteh. The maxillary has the lower extremity bent forwards to support the functions of the intermaxillary, by which it is received in a groove. This strueture is widely different from that of the fishes of the preceding families, where both the bones are very loosely eonneeted with each other; only some species of Dentex approach to it. The maxillary is piereed by an opening above the middle. The mandibulary is short, elevated, and thick; there is no free space between the artieular and dentary bones; its muciferous channels are very rudimentary, with small openings. The head of the vomer forms a semicireular plate, its posterior portion being very narrow, with a small groove behind the head. The lowel limb of the procopereulum is one-third shorter than the posterior; both meet at a rather obtuse angle, which, however. is rounder. '?ho interion 
ridge is strong, rounded, not prominent, whth a narrow muciferous channel behind. 'The opereulum is irregularly quadrangular, half as wide as high, with the posterior and superior sides shortest and very slightly emarginate. There is a ridge on its inner surface, obliquely desecnding downwards. The interopereulum is longer and broader than the subopereulum. The turbinal bone is elongate and rather widened posteriorly; the præorbital rhombie, with the anterior margin membranaceous and much wider than the remainder of the infraorbital ring. There is a bony plate at the inner side to support the eyeball from beneath. The frontal bones, between the orbits, are slightly convex, with several low ridges and pores, radiating from the anteriur extremity of the vecipital erest. The oceipital erest is very high, strong, triangular, with the upper margin slightly convex, and extends to above the centre of the orbit. The lateral crests also are well developed, though very much lower than the median one. The basal portion of the brain-capsule is compressed, the basioccipital having a very wide quadrangular foramen behind the oceipital joint. The large free space between the coracoid and radius is triangular, widest above, and not twice as long as broad. Each of the pubie bones is formed by three lamellæ of nearly equal derelopment.

There are ten abdominal and fourteen eaudal vertebre, the length of the former portion of the vertebral eolumn being to that of the latter as $1: 1 \cdot 4$. There are three spurious interneural spines, each with a small process above, directed forwards, as in many Aeanthopterygian fishes; the process of the first is rather longer than the others. The first interhæmal has an anterior ridge, and is strong and elongate, its length equalling that of the second vertebra to the eighth.

There are eight rather narrow incisors in both the jaws, with a group of granular teeth behind. The immature teeth, destined to replace those which are in use, make their apprearance on the outer side of the bone. The molars are arranged in two series in both the jaws; sometimes several smaller ones extend further backwards at the inner side of these series, and give the sppearanee of a thiird.

\section{Sargus rondeletii.}

Sápyos, Aristot. viii. c. 2, ix. c. 5; Alian, i. c. 23, 26, xiii. c. 2; Oppian, iv. 599, 308-403; Ather. vii. 313, 321.

Sargus, Ocid. Hal. v. 106 ; Mlin. ix. c. 17, 51, 59; Bellon. Aquat. p. 242 ; Rondel. v. e. 5. p. 122 ; Salv. f. 178; Gesn. Aquat. p. 828; Gronot. Zoophyl. 1. 63. no. 219.

Sparus sargus, L. Gm. p. 1270; 137. taf. 264; Bl. Schn. p. 270; Lacćp. iv. pp. 27, 77; Risso, Ichth. Nice, p. 236 .

— variegatus, (Bomnat.) Lacíp. iv. p. 107.

Silngus raucus, Geoffr. Descr. Eg. Pviss. pl. 18. f. 1.

_ rondeletii, Chit. \&.Val. vi. p. 14. pl. 141; Guichenot, Explor. Sc. Alyér. Poiss. p. 46; Webb \&-Berthel. Mist. Nat. Mes Canar. P'oiss. p. 28.
1). $\frac{11-12}{12-15}$.
A. $\frac{3}{13-14}$.
L. lat. 65.
I. transv. 8/16.
Cace. pylor. 5. Vert. $10 / 14$.

Incisors rather broad, implanted obliquely. Three series of molars above, two bencath. Thr dimeter of the cye is $4 \frac{1}{3}$ in the length of 
the head and $1 \frac{1}{2}$ in that of the snout, which equals the distance between the eyes; the erown of the head is convex, and there is a protuberance above the upper anterior angle of the orbit ; the præorbital does not entirely cover the maxillary bone. The pectoal fins extend to the origin of the anal, and the ventrals nearly to the vent. The second anal spine is rather stronger and longer than the third, and $3 \frac{1}{3}$ (in younger individuals $2 \frac{3}{4}$ ) in the length of the head. Silvery or shining golden, with numerous narrow longitudinal dusky stripes ( 8 or 9 above and 15 or 16 below the lateral line), and with four or five narrow blackish eross-bands, the first between the origin of the dorsal and the axil ; a broad black eross-band on the back of the tail.

Mediterranean; Canary Islands; Madeira.

a. Fine speeimen. Madeira. From the Haslar Collection.

b. Fine specimen. Madeira. Presented by the Rev. R. T. Lowe.

c. Fine specimen. Madeira. Purehased of Mr. Stevens.

d. Adult: skeleton. Lanzarote. Presented by the Rev. R. T. Lowe. $e, f$. Adult: stuffed. Santa Cruz (Teneriffe). Presented by J. Gould, Esq.

g. Adult: stuffed. Santa Cruz (Teneriffe).

h. Adult: stuffed. Lisbon. Presented by G. Hough, Esq.

$i$. Adult: skin. From Mr. Yarrell's Collection.

$k, l$. Half-grown: bad state. From the Haslar Collection.

Skeleton.-The skeleton is very similar to that of the preceding species; there are, however, the following differences. The foramen of the maxillary is much smaller, and situated more towards the upper extremity of the bone. The occipital crest has the upper margin straight. The large free space between the coracoid and the radius is triangular and elongate, three times as long as broad. There are ten abdominal and fourteen caudal vertebræ, the length of the former portion of the vertebral column being to that of the caudal as $1: 1 \cdot 24$. Valenciennes attributes nine abdominal vertebræ to this and the preceding species,- I have found ten in both. Further, he says, "le premier interépineux porte à sa partie supérieure une épine osseuse, courte, mais très-grosse, dont la pointe est dirigée vers la tête du poisson; en avant de cet interépineux en sont trois sans rayons." This is incorrect; the first true interneural has no spine directed forwards, but that spine belongs to the third spurious interneural $(i . e$. to the third interneural without corresponding dermoneural). But, in fact, all the three spurious interneurals have such a spine directed forwards, as usual in this Order of fishes. The first interhæmal is strong and very elongate, equal to the length of the second vertebra to the ninth.

There are eight rather broad incisors in both the jaws, with a group of granular teeth behind. The molars are arranged in three series above, and in two below; sometimes some smaller teeth extend from that group along the inner side of the constant series, giving the appearance of a fourth (or third in the lower jaw) additional one. The pharyngeal teeth are eardiform, and the upper ones are slightly eompressed, terminating in a small curred hook. 


\section{Sargus capensis}

Simith, Illustr. Zool. S. Afr. Fishes, pl. 23. f. 2.
D. $\frac{12}{1+16}$.
1. $\frac{3}{14-15}$.
I. lat. 72 .
L. transv. 8,15.

Incisors moderately broad, implanted obliquely; three series of molars in the upper jaw, two in the lower. Head rather small, its length being $4 \frac{3}{4}$ in the total length; the distance between the origin of the dorsal fin and the ocriput is much more than that between the occijut and the snont. 'The diameter of the cye is one-fourth of the length of the head, less than the distance between the eyes, and $1 \frac{1}{2}$ in the length of the snont. The pectural fins extend to the vertical from the second soft ray of the anal fin; the second anal spine is rather longer and stronger than the third, and nearly one-third of the length of the head. Uuitorm silvery : a large black bloteh behind the dorsal (in life).

Cape Suas.

a. Adult.

D. $\frac{12}{11}$.

A. $\frac{3}{11}$.

b. Mibult.

D. $\frac{12}{15}$.

A. $\frac{3}{15}$.

c. Adult: stuffed.

D. $\frac{12}{16}$.

A. $\frac{3}{15}$.

Cape Seats.

Presented hy Sir A. Smith.

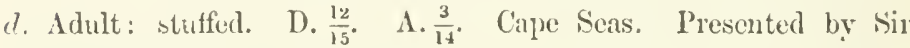
A. Smith.-Type of the species.

Description. - The body is rather elevated, its greatest depth being below the fourth dorsal spine, where it is nearly one-third of the total length. The profile of the nape forms a strong eurve and is eontinued into that of the head, which is straight and descends abruptly to the snout; the distance between the oeciput and the end of the snout is about three-quarters of that between the oceiput and the origin of the dorsal fin. The head is compressed and rather short, its length being $4 \frac{3}{1}$ in the total; the distance between the eyes is one-thirl of the length of the head. 'The snout is of moderate length, the upper maxillary reaching to the vertical from the posterior nostril. The proorbital is $1 \frac{1}{2}$ as long as high, and does not entirely corer the maxillary bone. 'The eyc is of moderate size, situated in the middle of the vertical from the neek to the inferior limb of the propoperculum. The nostrils are placed near the upper angle of tho orbit; the posterior is a very small slit, the anterior more ovate in form. There are five series of seales between the proorlital and the limb of the pracoperculum, which is also covered with a single series of scales. 'The posterior' margin of the preoperculum is rertical, the angle and the inferior margin are curved. 'The opereulnm has an ohtuse spine posteriorly, and is covered with scales, like the suband interopereulum. The supwaseapula is seale-like, without any strix or denticulations: and there is an indistinet curved series of scales, ascending trom the suprascapula to the nape. which exhibit some inconspicunous striae.

The dorsel tin hegins immediately hehind the ventical from the 
brase of tho pectornt, and extentes to that from the fifty-six th senles of the latoral line, its distances from the enulul fin beingr equal to onolailf the length of the heal. 'The npines are mether strongr, compresensed,

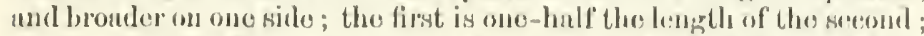
the fourth und fifth are the longest, nenly one-half tho length of the heorl; tho following grudunlly decresuse in longth to the hest, which is $1 \frac{1}{2}$ in the length of tho fonrth. 'The soft mys are nourly arpunt in longth to one another sund to tho last spino. 'Tlos coudal tin is lorked, one of the midello mys being nomly one-third of the mpere lobe, which is rather longer than the lower. The origin of the courl fin filly vertically bolow that of the noft dorsal, nnd its ond immodialely bohinel that of the dorsal; it is searcely lower than the opposito fin, but tho postorior ruys gradually become somowht shorter. 'I'he spinos nre ruther atout; the first is norly one-half tho length of the second; the recond rather longer and stronger thun the thirel, und about onothirel of the length of the hesd. 'Tho pectoral fin has a low very small scules at the bise; the sixth rny rexeseds the othors in length, renching towthe second anal ruy. The base of the vecurals fialls ontirely behind that of the pectomes they are of unoderate lorigth, the first ruy oxtending to the vent; the spine is about throe-funters of the length of that ray. 'I'hom is a long senly flap insortud at thes baso of tho ventrinl.

'Tlue scales nro inintely enlated the oncer murgin, higher than wide; one of the hingest covers one-third of the oyo.

'The incisors uro modentoly lnad, very little numowes thun in S. rondeletii; they nro implnuted in un olslipues diection; theres axo six or oight in the upper juw, and oight or ten in tho lower. 'Tho molars are rathor small, arrunger in throes sories in thos nper juw, and in two in the lower; thero is somotimes another molur at thes inner side of tho series of terth in thes lower jaw.

'The examples nos now uniform silvery, with se shining stresk along

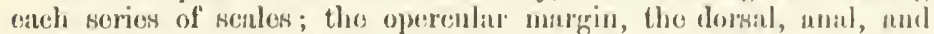
ventral fins aro greyish. Tho black sorsul blotch on tho lateral line, behind the dorsal, has disnpereared.

Total length

Hoight of tho bouly

longth of the head ...............

Distance between the oyes . . . . . . . . - botweon the dersal and tho occiput between the occiput und thes snout

Diameter of the vyo . . . . . . . . . . . .

lengtlı of tho fourth dorsal apino........

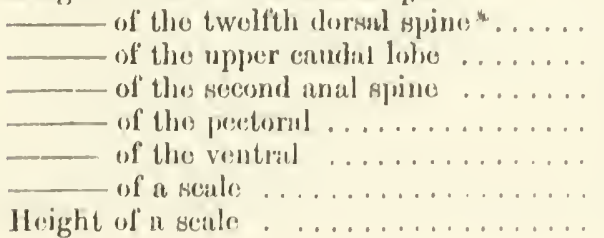

inches. lines.

() 6

is 4

(2)

1) 8

I 11

141

() 6

() 11

() 7

$2 \quad 6$

() $8 \frac{1}{3}$

20

I 7

() $2 \frac{1}{2}$

() $: 13$ 


\section{Sargus vetula.}

Scarus, Rondel. vi. cap. 2. p. 164 ; Willuyhby, i. p. 305. § 11.

Sargus vetula, Cuv. \& V'al. vi. p. 48; Guichen. Explor. Sc. Alyér. Poiss. p. 47 ; Webb \& Berthelot, Hist. Nut. des Iles C'anar. P'oiss. p. 29 (not pl. 9. f. 2).
1). $\frac{11}{14}$.
A. $\frac{3}{13}$.
L. lat. 75-80.

Four series of molar tecth in the upper jaw and three in the lower. The space between the eyes slightly convex. A brown spot on the supraseapula, another on the angle of the opereulum; is black bloteh across the back of the tail; ventrals black.

Mediterrancan.

\section{Sargus lineatus.}

? Cuv. \&. Val. vi. p. 59.-[?? Cur. Règne Anim. Ill. Poiss. pl. 34. f. 1.]

$$
\text { D. } \frac{12}{13} \text {. A. } \frac{3}{13} \text {. }
$$

Incisors moderately broad, implanted in an oblique direction, eight in each jaw. The distance between the origin of the dorsal and the occiput is much more than that between the occiput and the end of the snout. Body with four or five very narrow black cross-streaks; tail with a broad black band; base of the pectoral and he ventral fins black.

Coast of Brazil?

a. Fine specimen. From the Collection of the Zoological Socicty.

\section{Sargus noct.}

Sargus noct, (Ehrenberg) Cuv. \& Val. vi. p. 51; Rüpp. N. W Fische, p. 110 ; Guichen. Explor. Sc. Alyér. Poiss. p. 47.
D. $\frac{12}{14}$.
A. $\frac{3}{13}$.
Cæc. pylor. 5. Vert. 10/13.

Eight incisors in the upper jaw, six in the lower; four series of molars in the upper, three in the lower. Dorsal spines rather strong, the rays of the dorsal and anal fin short. On each side of the tail, on the lateral line, a round black spot.

Red Sea : Mediterranean.

Valeneiennes describes the air-bladder as simple; but Rïppell informs us that it is bifureate anteriorly and posteriorly.

a. Adult: stuffed: not good state. Red Sca. Iresented by J. Burton, Esq.

\section{Sargus argenteus.}

Cur. \& Val. vi. p. 60.

$$
\text { D. } \frac{12}{14} \text {. A. } \frac{3}{1 .} \text {. L. lat. } 65 \text {. I. transv. 9/16. }
$$

Incisors moderately broad, implanted in a rather oblique direction ; three series of molars in the ruper jaw, two in the lower. The 
diameter of the eye is $3 \frac{1}{2}$ in the length of the head, $1 \frac{1}{3}$ in that or the snout, and equal to the distanee between the eyes. The crown of the head is slightly convex; a very slight protuberance above the upper anterior angle of the orbit. The pectoral fins extend scarcely to the origin of the anal, the rentrals to the vent; the second anal spine is longer and stronger than the third, and 2 2 in the length of the head. Silvery, with a black band across the back of the tail; ventrals blackish.

Coast of Brazil.

a. Rio Janeiro. Presented by A. Fry, Esq.

\section{Sargus auriventris.}

Peters, Wiegm. Archiv, 1855, p. 243.

$$
\text { D. } \frac{11}{14} \text {. A. } \frac{3}{11} \text {. }
$$

Bluish, shining; a narrow golden longitudinal streak above the ventrals. (Pet.)

This species does not appear to have a black eaudal spot.

Mozambique.

\section{Sargus annularis.}

Sparulus, Orid. v. $106 \& 107$.

Sparus, Rondel. v. c. 3 ; Salvian. f. 177 ; Gesner. pp. 180, 1056, 1058 ; Willughby, p. 308. pl. 5. f. 2.

Sparus, no. 12, Artedi, Genera, p. 37.

Sparus annularis, L. Gm. p. 1270;Bl. Schn.p. 272; De la Roche, Am. Mus. xiii. p. 342 . pl. 24. f. 13.

- smaris, Brïn. Pisc. Mass. p. 40.

- haffara, Risso, Ichth. Nice, p. 244.

Sciæna melanura, Pall. Zoogr. iii. p. 254.

Sargus annularis, Geoffr. Deser. Eg. Poiss. pl. 18. f. 3 ; Cuv. \& Val. vi. p. 35 . pl. 142 ; Nordm. in Demid. Voy. Russ. Mérid. iii. p. 386, Poiss. pl. 4. f. 1; Guichen. Explor. Sc. Algér. Poiss. p. 47.
D. $\frac{11}{12-13}$.
A. $\frac{3}{11}$.
L. lat. 55.
L. transv. $6 / 13$.
Cæe. pylor. 4. Vert. 9/14.

Incisors, broad, implanted vertically. The diameter of the eje is four times in the length of the head, and $1 \frac{1}{2}$ in that of the snout; the distance between the eyes is more than their diameter, and slightly convex. The pectoral fins extend slightly beyond the origin of the anal; the ventrals are much shorter and remote from the rent. The second and third anal spines are nearly equal, and rather longer than the diameter of the eye. Silvery: back with several more or less distinet cross-bars; axil not black; a broad black band across the back of the tail behind the dorsal fin; lateral line very conspicuous, greyish.

Mediterranean; Canary Islands.

a. Adult: bad state; has been in ehloride of zinc. Mediterranean. Purehased of Mr. Frank. 
b. Half-grown: bad state; has been in chloride of zinc. Mediterranean. Purchased of Mr. Frank.

c. Adult: bad state; has been in chloride of zinc. Malta. From the Haslar Collection.

(l. Many young specimens. Malta. From the Haslar Collection.

$e, f$. Adult: bad state. From the Old Colleetion.

\%, h. Adult. Lisbon.

i. Adult. Lanzarote. From the Rer. R. T. Lowe's Collection.

li. Adult.

l. Adult.

im. Half-grown.

n. Young. From the Haslar Collection.

\section{Sargus flavolineatus.}

C'uv. S. I'al. vi. p. 60.

$$
\text { D. } \frac{13}{11} \cdot \text { A. } \frac{3}{10} \text {. }
$$

Ineisors broad, implanted in a rertieal direction. No transvirse hands or caudal spot. Bluish, with 13-14 golden longitudinal bands (in life); vertical fins greyish. ( $\Gamma^{\top} a l$.)

Shores of Cuba.

\section{Sargus unimaculatus.}

Maryr. p. 153.

Perea unimaculata, Bloch, taf. 308. f. 1 (bad).

Grammistes unimaculatus, Hl. Schr. p. 184.

Sparus salin, Lacép. iv. pp. 1:36, 138.

Sargus humeri-naculatus, Quoy \&. Guim. Voy. Freye. Zool. p. 297.

__ unimaculatus, Cur. \& Val. vi. p. (j2.

Cynadus brama, Gironox. Syst. ed. Gray, p. 56.

I. $\frac{13}{11}$ A. $\frac{3}{10}$. L. lat. 49. 'L. transv. 9/17. Cxe. pylor. 5 ( $7, I^{*} a$ l.). Tert. 10/14*.

Incisors broad, each with a noteh. The diameter of the eye is four times in the length of the head, and $1 \frac{1}{2}$ in that of the snont; the distanee between the eyes equals their diameter: there is a protuberance above the anterior angle of the orbit. 'The pectoral fins extend nearly to the origin of the soft portion of the anal fin; the ventrals do not reach to the vent. The sceond anal spine is curred, and much longer and stronger than the thind, nourly onehalf the length of the head. Reddish-silvory : a large hlack. bloteh hehind the shoulder, below the lateral. line.

Atlantie shores of 'l'ropical Ameriea.

a. Adult. Brazil. Presented by Lord Stuart.

b. Adult: skeleton. Brazil. P'resenter by Loud Stuart.

c. Adult. Bahia. Purehased of M. Parzurlaki.

c. Adult: skin : bad state. Rio Janciro. J'resented by Th. Thompson, Esr.

* Valenciennes sars fiftem, which certainly is incorrect 
e. Adult: not good state. Guatemala. Purchased of Mr. Frank. $f$. Adult: bad state. Puerto Cabello. Purchased of Mr. Brandt. g-i. Adult: skins. Jamaiea. From Dr. Parncll's Collection.

k. Adult. From the Haslar Collection.

l. Half-grown: bad state. From the Haslar Collection. m. Adult : stuffed.

Skeleton.-The skeleton differs very little from that of S. vulgaris. The occipital erest and the neural spines are not quite so clevated as in that species, and the upper maxillary bone is not pierced by a foramen. The length of the abdominal portion of the vertebral column is to that of the caudal as $1: 1 \cdot 3$. The length of the first interhæmal equals that of the first vertebra to the seventh.

\section{Sargus ovis.}

Sparus, Schœpff, Schriften der Gesellsch. Nat. Freunde, viii. p. 152.

Sparus ovis, Mitch. Trans. Lit. \& Phil. Soc. Nev York, i. p. 392. pl. 2. f. 5 .

Sargus ovis, Cur. \& Val. vi. p. 53 ; Storer, Report, p. 36 ; Dekay, Nero York Fauna, Fishes, p. 89. pl. 8. f. 23; Holbr. Ichth. S. Carol. p. 51. pl. 8. f. 2.
D. $\frac{12}{11(\text { Val. 13) }}$.
A. $\frac{3}{10}$.
L. lat. 46 .
L. transv. 8/18.

Ineisors broad, quadrilateral. A reeumbent spine in front of the dorsal. The diameter of the eye is six times in the length of the head, and $2 \frac{1}{2}$ in that of the snout. The distance between the eyes is more than twice their diameter*. The pectoral fins extend nearly to the origin of the anal fir. The second anal spinc is longer and stronger than the third, about one-third the length of the head. Body with five blackish cross-bars.

a. Twenty-two inches long: stuffeci. N. Amcrica. Presented by Edward Doubleday, Esq.

b. Adult: skin. From Gronov's Collection.

\section{Sargus rhomboides.}

Sparus rhomboides, Linn. Syst. Nat. i. p. 427 ; Shav, Zool. iv. p. 447 : Schopff, Schrift. der Naturf. Freunde Berlin, viii. p. 153.

Sargus rhomboides, Cuv. \& Val. vi. p. 68. pl. 143, cop. by Dekay, Nerv York Fauna, Fishes, p. 93. pl. 71. f. 228.

Lagodon rhomboides, Holbr. Ichth. S. Carol. p. 56. pl. 8. f. 1.

$$
\text { D. } \frac{12}{11} \text {. A. } \frac{3}{10} \text {. Cæe. pylor. } 4 \text {. }
$$

A recumbent spine before the dorsal fin. Incisors moderately broad, each with a notch; two series of molars in each jaw. Body with longitudinal stripes, and sometimes with several dusky erossbars. A black blotch at the origin of the lateral line.

Southern shores of the United States.

* These measurements are taken from the rery large specimen in the British Museum, and may be found different in younger indiriduals. 


\section{Sargus fasciatus.}

Sargus fasciatus, Cur. \&. Vul. vi. p. 59; Cinichen. Explor. Sc. Algér. Poiss. p. 48; ? Valene. in Webb of Berthelot, IIist. Nat. Iles Canor. Porss. p. 29 (not fig.).
D. $\frac{11}{12}$.
A. $\frac{3}{10}$.
L. lat. 60 .
L. transv. 9/16.

The height of the body is $3 \frac{1}{3}$ in the total length, the length of the head four times. Molars small, in two series. Incisors $\frac{10}{8}$, narrow, elongate, implanted in an oblique direction; lips rery thick and fleshy; snout rather elongate, twice the diameter of the eye. 'The pectorol fin scarcely reaches to the origin of the anal. Whitish (in spirits), with seven broad brown cross-bands, each three times as broad as the interspaces between.

? Brazil, Cuv. \& Val.; Mediterranean, Guich.; Canary Islands, Vul.

a. Fine specimen. From the Haslar Collection.

\section{Sargus cervinus.}

Charax cervinus, Lowe, Trans. Zool. Soc. ii. p. 177.

? Sargus cervinus, Valenc. in Webb \&-Berthelot, Hist. Nat. Mes Cunar. Poiss. p. 29.

Sargus fasciatus, Valenc. l. c. pl. 9. f. 2 (not descript.).

- hottentottus, Smith, Ill. Zool. S. Afi: Fishes, pl. 23. f. 1.
D. $\frac{11}{12-13}$.
A. $\frac{3}{11}$.
L. lat. 58-60*.
L. transv. 9/16.

The height of the body is $2 \frac{1}{2}$ in the total length, the length of the head four times. Molars small, in two series; ineisors $\frac{12}{8}$, narrow, elongate, implanted in an oblique direction; lips very thick and fleshy; snout rather produced, twice the diameter of the eyo. The pectoral reaches beyond the origin of the anal. Shining golden. with seven brown cross-bands, broader than the interspaces between them.

Madeira; Canary Islands; Cape Scas.

a. Very fine specimen Lanzarote. From the Rev. R. T. Lorre's Collection.

b. Stuffed. Cape Seds. Purchased of Sir A. Smith.-Type of S. hottentottus.

c. Young. Cape Seas. Presented by Sir A. Smitll.

If we could always depend on the correctness of the descriptions given by Valenciennes, it would appear that there exist one or even two other speeies of these banded Sargi with thick lips, in the Seas of Madeira and the Canary Islands. The Rev. R. T. Lowe has kindly communicated to me his notes, taken on the spot, from seven specimens caught in Madeira; they all belong to the species with the high body, Charax cervinus, Lowe. The only discrepancy from my diagnosis, taken from a Lanzarote specimen, is, that Mr. Lowe states 65-66 seales of the lateral line; but, possibly, the small seales

* Sometimes with several supernumerary seales on the eaudal lin. 
eovering the caudal fin have been reckoned. Very different is the description of Valenciennes, which, if correct, clearly shows that he had a fish scarcely identical specifically with Charax cervinus, Lowe. On the other hand, the figure of Sargus fasciatus, given by him, agrees well with Mr. Lowe's fish, but not with that described in the 'Hist. Nat. des Poiss.' under that name, and said to have a body much more elongate than in Sargus lineatus. There is, apparently, confusion in the descriptions of M. Valenciennes, who, moreover, in the text refers the figure with the name of $S$. fasciatus to $S$. vetula. Therefore I think it of no great importance if he attribute to $S$. fasciatus $\frac{10}{10}$ incisors, whilst I find $\frac{10}{8}$. But, if the descriptions are really correct, we should have the following specific forms:-

1. Charax cervinus, Lowe. Height of the body $2 \frac{1}{2}$ in the total length. Incisors $\frac{12}{8}$. L. lat. 58-60 (66).-Madeira, Lanzarote.

2. Sargus cervinus, Val. in Webb \& Berth. Height of the body one-third of the total length. Incisors $\frac{12}{8}$. L. lat. 50.Canary Islands*.

3. Sargus fasciatus, Cuv. \& Val. Body oblong. Incisors $\frac{10}{10}$ Canary Islands, $V a l$. in Webb \& Berth.

4. Sargus fasciatus, Gthr. Height of the body one-third of the total length. Incisors $\frac{10}{8}$. L. lat. 60.-Hab. - - ? Haslar Collection.

\section{Sargus aries.}

Cuv. \& Val. vi. p. 58.

$$
\text { D. } \frac{12}{12} \text {. A. } \frac{3}{10} \text {. }
$$

Incisors very narrow and elongate. The second anal spine strong. Body with seven narrow rertical bands; rentral fins black. ( $V a l$.)

Atlantic coasts of South America.

\section{Sargus ambassis. (Plate XXVIII. fig. A.)}
D. $\frac{12}{12}$. A. $\frac{3}{11}$.
L. lat. 50.
L. transv. $\frac{7-8}{16}$.

A recumbent spine before the dorsal fin. Incisors narrow, im planted in a rather oblique direction; two series of molars in both the jaws. Nape of the neck very convex; the upper profile of the head descending in a straight line. The diameter of the eye is $4 \frac{2}{3}$ in the length of the head, half the length of the snout, and less than the distance between the eyes. The pectoral fins extend to the vertical from the second soft ray of the anal fin; the second anal spine is rather shorter and not stronger than the third, and $3 \frac{2}{3}$

* Mr. Lowe observes: "Sargus cervinus, Val., is, I think, merely a larger example of my Charax cervinus, the less depth being due to the irregular contraction in a dried speeimen, such as almost, if not quite, all the fishes sent by Webb to Valeneiennes were." 
in the length of tho head. Body uniform greenısh, with golden longitudinal streaks; dorsal, anal, and ventral fins blackish; axil blackish. Atlantic coasts of the United States.

a. Adult. New York. Purehased of Mr. Brandt as S. ovis.

b. Adult: skin. New York. From Dr. Pamell's Collection.

c. Thirteen inches long: not good state. N. America. Purchased of Mr. Warwick.

d. Adult: skin. From Gronov's Collection.

e. Adult: skeleton. Old Collection.

Description.-This species appears to have been confounded with the following North American fishes, which also exhibit a procumbent dorsal spine :-

1. With Sargus ovis, which has broad quadrilateral incisors.

2. With Sargus rhomboides, which has moderately broad incisors, each with a noteh.

3. Perhaps with Sargus aries (a more southern species), which has the body marked with seven cross-bars.

4. With Chrysophrys aculeatus, which, according to Valenciennes' description, has three series of molars. In our species the anterior incisors, although sufficiently flattened, are so narrow, that a superficial observer might take them for conical eanine-like teeth, as in Chrysophrys.

Our speeies, which I call $S$. ambassis, from the recumbent spine by which the genus Ambassis is distinguished, has the body elevated; its greatest depth is below tho sixth dorsal spine, where it is contained $2 \frac{1}{2}$ in the total length. The nape of the neck deseends abruptly in a somewhat irregular curve, whilst the upper profile of the head is straight. The distance between the origin of the dorsal fin and the occiput is shorter than the length from the oceiput to the snout. The longth of the head is nearly one-fourth of the total; the head is rather eompressed, the distance between the eyes being one-fourth of the length of the head. The snout is elevated, rather pointed, and slightly produeed; the præorbital is rhombic, as wide as high; the upper maxillary reaches to the rertical from the posterior nostril. The eye is of moderate size, situated in the rertical from the oceiput. There are six series of seales between the preorbital and the limb of the præoperculum, which is covered at the angle with a few irregular scales besides; th opereulum has a narrow space along its base sealeless, the remainaer is eovered with scales like the suband interoperculum. The suprascapula is seale-like, striated, and there is a eurved series of similar seales ascending from the suprascapula to the nape.

The dorsal fin begins above the opereular margin and extends to the rertical from the 37th scale of the lateral line, its distance from the eaudal fin being equal to one-half the length of the head. The spines are of moderate sizo and taper very much at their extremity: the first is short; the fourth is the longest, one-half the length of the head; the following gradually decrease in length to the last, which is fire-eighths of the longest. The upper margin of the dorsal 
is very slightly convex, but the posterior angle is rounded; the rays differ little in length, the posterior ones excepted, and are about three-fourths of the longest spine. The caudal fin is forked, one of the middle rays being not quite one-half of the rays of the upper lobe, which is longer than the lower. The distance of the caudal fin from the anal is much less than that from the dorsal. The origin of the anal falls vertically below the end of the spinous dorsal or the $22 \mathrm{nd}$ scale of the lateral line, its end below the 39 th scale; it is much lower than the soft dorsal and has a slightly eurved margin, nearly parallel to its base. The spines are moderately strong: the first nearly one-half the length of the second; the second not stronger and rather shorter than the third, and contained $3 \frac{2}{3}$ in the length of the head; the first ray is rather longer than the last spine. The pectoral fin has a few vely small scales at the base; the fifth ray exceeds the others in length, reaching to the second ray of the anal fin. The base of the ventrals falls entirely behind that of the pectorals; they are elongate, the first ray extending to the origin of the anal; the spire is about one-half of the length of that ray. There is a long scaly flap inserted at the base of the ventral.

The scales are minutely eiliated at the outer margin, higher than wide; one of the largest covers one-half of the eye.

"The incisors have a conical root and the erown slightly compressed and flattened; there are six in the upper jaw and eight in the lower. The molars are arranged in two series, the inner of which contains the larger ones; all are of moderate size, but they gradually become larger posteriorly.

The scales are grecnish, with an olive margin and golden centre; the dorsal, anal, and ventral fins and the axil are blackish.

\begin{tabular}{|c|c|c|}
\hline \multicolumn{3}{|c|}{ inches. lines. } \\
\hline Total length...... & 10 & 8 \\
\hline Height of the body & 4 & 3 \\
\hline 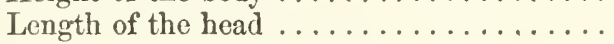 & 2 & 9 \\
\hline Distance between the eyes ............. & 0 & $8 \frac{1}{3}$ \\
\hline Length of the snout $\ldots \ldots \ldots \ldots \ldots \ldots$ & 1 & $2^{3}$ \\
\hline 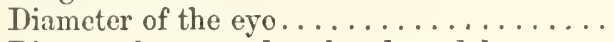 & 0 & 7 \\
\hline Distance between dorsal and cuudal ..... & 1 & 4 \\
\hline between anal and eaudal ....... & 1 & 1 \\
\hline Length of the fourth dorsal spine $\ldots . . .$. & $\mathrm{i}$ & 4 \\
\hline — of the twelfth dorsal spine........ & 0 & 10 \\
\hline - of the second dorsal ray $\ldots . . . \ldots$ & 1 & 0 \\
\hline - of the second anal spine........ & 0 & 9 \\
\hline - of the first anal ray............ & 0 & $10 \frac{1}{2}$ \\
\hline - of the pectoral............... & 3 & 0 \\
\hline 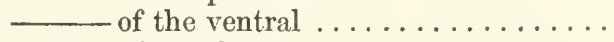 & 2 & 1 \\
\hline 一 一 of a scale $\ldots \ldots \ldots \ldots \ldots \ldots \ldots$ & 0 & 4 \\
\hline Height of a scale $\ldots \ldots \ldots \ldots \ldots \ldots \ldots \ldots$ & 0 & $5 \frac{1}{3}$ \\
\hline
\end{tabular}

Slieleton.-The jaw-bones, being armed with teeth much smaller than those of Sargus vulgaris, are therefore not so strongly developed 
as in that species. The intermaxillaries have their posterior processes elonyate, with their base widened; the groore in. which they move does not extend to the rertical from the anterior margin of the orbit. There are also no protuberances on the descending branches of the bone, which are uniformly wide to their extremity. The maxillary has the lower extremity very slightly bent forwards, and is without a foramen. The mandibulary is rather short and clevated, without a free space between the articular and dentary bones; there are fire distinct pores from its muciferous channel. The head of the romer is broad, flat, triangular. The lower limb of the properculum is one-third shorter than the posterior; both meet at a nearly right angle, which, however, is ronnded. The interior ridge descends obliquely forwards, is flat, not prominent, with a rudimentary muciferous channel behind. The operculum is irregularly quadrangular, half as wide as high, with the upper side shortest and deeply notehed; the ridge on its inner surface is very feeble. The sub- and interopereulum are of nearly equal length and width. The turbinal bone is tubiform anteriorly, widened and fiat posteriorly. The praorbital is large, rhombic, the remainder of the infraorbital ring narrow; there is a bony plate at its inner side to support the eyeball from beneath. The frontal bones, between the orbits, are rather flat, with three low ridges and several pores and grooves. The occipital crest is high, strong, triangular, with the upper margin very slightly convex, and extends to above the centre of the orbit, terminating posteriorly with the occipital. The inner of the lateral ridges is rery fecble, the outer one moderately developed. The basal portion of the brain-capsule is slightly compressed. The pubic bones are of moderate length; each of them is formed by three lamellæ of nearly equal development.

There are ten abdominal and fourteen caudal vertebra, the length of the former portion of the rertebral column being to that of tho caudal as $1: 1 \cdot 44$. There are three spurious interneurals, each with a small process above, directed forwards; the first two dorsal spines have one common interneural, with the horizontal spinous process, which is visible externally. The first interhamal exhibits a peculiar transformation into a conical cavity, but in a slighter degree than in Gerres gula.

The incisors are very narrow, slightly curred, and six or eight in number; there is a band of small setiform and minute granular teeth behind them. The molars are small and arranged in two series in both the jaws.

\section{CHARAX.}

Charax, Risso, Eur. MEérid. iii. p. 353; Cur. \& Val. ri. pp. 9, 71.

Narrow incisors and a single series of small molar teeth in both the jaws. Cheeks sealy. The spines of the dorsal (eleren) folding into a groore; three anal spines. Opereles not ármed. Seales of moderate size. Five branchiostegals. Pyloric appendages in small number. air-bladder simple.

Mediterramean; Canary Islands. 


\section{Charax puntazzo.}

Aldrov. Do Pisc. p. 182 ; Ray, Synops. p. 130.

Sparus puntazzo, L. Gm. p. 1272.

- annularis, Brïnn. Pisc. Mass. p. 37.

- acutirostris, De la Roche, Ann. Mus. xiii. p. 348. pl. 24. f. 12. Charax acutirostris, Risso, l.c. p. 354.

_ puntazzo, Cuv. \& Val. vi. p. 72. pl. 144; Nordm. in Demid. Voy. Russ. Mérid. iii. p. 387. pl. 4. f. 2; Guichen. Explor. Sc. Alyêr. Poiss. p. 48.
D. $\frac{11}{13-14}$.
A. $\frac{3}{12}$.
L. lat. 55-60.
Cæe. pylor. 7.

Silvery, with blackish vertical bands; a black blotch on each side of the tail. Snout produced.

Mediterranean; Canary Islands.

a. Adult. Dalmatia.

b. Very fino specimen, $19^{\prime \prime}$ long. Lanzarote. Presented by the Rev. R. T. Lowe.

\section{Fourth Group. PAGRINA.}

Sparida with conieal teeth in front and molars on the sides.

Synopsis of the Genera.

* Cheelss naked.

D. $\frac{10}{9}$ A. A. $\frac{3}{8}$

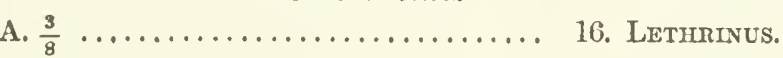

** Cheeks sealy.

Canine teeth; molars in a single series .........

17. Spheronon.

Canine teeth; the upper molar teeth in two series.

18. Pagrus.

Canine teeth none

19. Pagellus.

Canine teeth; the upper molar teoth in three and more series

20. Chrysophrys.

\section{LETHRINUS*}

Lethrinus, Cuv. Règne Anim.; Cuv. \& Val. vi. p. 272.

Cheeks naked. Cardiform teeth in front of the jaws, with the

* 1. Lethrinus gothofredi, Cuv. \& Val.vi. p. 286; Rïpp. N. W. Fische, p. 120.

-Red Sea.

2. - fasciatus, Cuv.\& Val. vi. p. 290.-Trincomalee.

3. - frenatus, Cuv. \& Val. vi. p. 291.-Ceylon.

4. - korely, Cuv. \& Val. vi. p. 292.-Pondicherry.

5. — maculatus, Cuv. \& Val. vi. p. 292.-Pondicherry.

6. - cmereus, Cuv. \& Val. ri. p. 293.-Ceylon.

7. — microdon, Cuv. \& Vil. vi. p. 295.-Buru.

8. - olivaceus, Cuv. \& Val. vi. p. 295.-Sunda Sea.

9. - waigiensis, Cuv. \& Val. vi. p. 297. -Waigiou; New Guinea. 
addition of canines; lateral teeth in a single series-eonical, or conical and molar-like, or obtuse molars. Formula of the fins: D. $\frac{10}{9}$. A. $\frac{3}{8}$. Seales of moderate size. L. lat. 45-50. Six branchiostegals. Two or three short pyloric appendages; air-bladder generally notched posteriorly, and with short laterai appendages.

From the Eastern shores of Africa through all the East Indian and Australian Seas to Polynesia; and one species on the Western coast of Africa.

I. Species with all the lateral teein more or less conical, without true molars.

A. With a blackish blotch above the pectoral fin.

\section{Lethrinus rostratus.}

Lethrinus rostratus, (Kuhl \& van IIass.) Cur. \& Val. vi. p. 296 ; Bleck. Verh. Batav. Genoolsch. xxiii. Spar. p. 13.
D. $\frac{10}{9}$.
A. $\frac{3}{8}$.
I. lat. 50 .
L. transv, 6/16.

The height of the body is four times in the total length; the length of the head $3 \frac{1}{5}$. The snout very elongate and pointed. The length of the diameter of the eyes is more than the width of the distance between them, and $2 \frac{1}{2}$ in the length of the snout; the upper maxillary does not reach to the vertical from the anterior nostril. Canine teeth moderate; the teeth of the lateral scries slightly compressed, pointed; the hindmost only of the upper jaw blunt and molar-hke. Dorsal spines moderate; the third rather shorter than the longest ray, and $3 \frac{1}{2}$ in the length of the head; the third anal spine intermediate between the seeond spine and the first ray. Caudalis emarginate. Olive (in

10. Lethrinus sordidus, Cuv. \& $V^{\gamma}$ al. vi. p. 298.-New Guinea.

11. - flaveseens, Cuv. \& Val, vi. p. 299.-Tongatabu.

12. - azureus, Cuv. \& V Val. vi. p. 300.-New Ireland.

13. - exruleus, Cuv. \& V Tal. vi. p. 301.-Seychelles.

14. - croeeopterus, Cur. \& Val. vi. p. 302.-Seychelles.

15. — argenteus, Cuv. \& Val. vi. p. 303.-Seyehelles.

16. - borbonieus, Cuv. \& Val. vi. p. 303.-Isle de France.

17. — geniguttatus, Cuv. \& $\mathrm{Val}$. vi. p. 304.-East Indies.

18. — genivittatus, Cuv. \& Val. vi. p. 306. pl. 159. - Habitat — ?

19. Sparus chærorhynehus, Bl. Schn. p. 278.-Lethrinus ehærorhynehus, Cuv. \& Val. vi. p. 308.-Japan?

20. Lethrinus vireseens, Cuv. \& Val. vi. p. 308 - Habitat - ?

21. Russell, pl. 89. - Lethrinus karwa, Cuv. \& Val. vi. p. 311.-East Indies.

22. Lethrinus abbreviatus, (Ehrenb.) Cuv. \& Val. vi. p. 312.-Red Sea.

23. — crythropterus, Cuv. \& Val. vi. p. 313.-Ulea.

24. - - erythraeanthus, Cuv.\& Val. vi. p. 314.-Luganor.

25. - alboguttatus, Cuv. \& Val. vi. p. 314.-Bonin.

26. - xanthopterus, Cuv. \& V $\mathrm{ral}$. vi. p. 315.-Ulea.

27. Sparus miniatus, (Forst.) Bl. Schn. p. 281.-Lethrinus miniatus, Cuv. \& Val. vi. p. 315.-Paeifie.

28. Lethrinus anatarius, Richardson. Ichthyol. Voy. Sulph. p. 145.-Chineso Sea.

29. - eyanoxanthus, Riehards. Ic. pl. 4. f. 1.-Australia.

30. - -... cinnabarinue, Richards. Ic. pl. 4. f. 2.-A Astrnlia. 
spirits); head, body, dorsal and anal fins clouded with brownish; a quadrangular blackish blotch between the pectoral and the lateral line; the rays of the ventrals white, the membrane between blackish. Each joint of the rays of the vertical fins with a brownish streak.

Sunda and Molucea Seas.

a. Adult. Moluccas.

b. Half-grown. Amboyna. Purchased of Mr. Frank.

c. Half-grown. Ceram. From Madame Ida Pfeiffer's Collection.

d. Twenty-three inches long: skin: not good state. Ceylon. Collected by E. F. Kelaart, M.D.

\section{Lethrinus amboinensis.}

Bleeker, Amboina, v. p. 490.
D. $\frac{10}{9}$.
A. $\frac{9}{8}$.
L. lat. 48.

The height of the body is rather less than one-fourth of the total length; the length of the head is $3 \frac{3}{5} \mathrm{in}$ it. The snout is rather pointed, but not much longer than the diameter of the eye; the upper maxillary does not reach to the vertical from the orbit. Canine teeth of moderate size; the lateral teeth conical, and not obtusely rounded. The third and fourth dorsal spines longest, rather more than one-half of the height of the body. Caudalis emarginate, with pointed lobes. Head uniform olive; a large blackish blotch between the pectoral and the lateral line; back and sides largely marbled with blackish; baso and spines of tho dorsal fin and the pectoral rays variegated with violet.

Sea of Amboyna.

a. Half-grown. Amboyna. Purchased of Mr. Frank.

\section{Lethrinus moensii.}

Bleeker, Natuurk. Tydschr. Nederl. Ind. 1855, ix. p. 435.
D. $\frac{10}{9}$.
A. $\frac{3}{8}$.
L. lat. 48 .

The height of the body is about four times in the total length, the length of the head $3 \frac{2}{5}$ to 4 . The snout is pointed, and mueh longer than the diameter of the eye, which is $3-3 \frac{1}{2}$ in the length of the head. Space between the eyes flat. The upper maxillary bone does not reach to the vertical from the anterior margin of the eye. Canine teeth large, curved; lateral teeth conical. The third dorsal spine longest, lower than one-half of the height of the body. Caudalis forked, with pointed lobes, the upper of which is longer. Greenish; snout and eheeke deep violet; body with seven indistinet erossbands. In young and half-grown individuals a blackish blotch below the anterior half of the soft dorsal, and partly below the lateral line; opercular membrane red; each spine and ray of the dorsal fin with a brown spot at the base.

Seas of Groot-Oby, Batjan, and Timor; Louisiade Arehipelago. 
a. Adult: skin. Copang.

b, c. Adult: stuffed. Louisiade Archipelago. Presented by the Lords of the Admiralty.

d. Adult: stuffed. Louisiade Archipclago. Voyage of the Rattlesnake.

\section{Lethrinus nematacanthus.}

Blecker, Japan, p. 403, and Verhand. Batav. Genootsch. xxvi. Japan, p. 91 . tab. 6 .
D. $\frac{10}{9}$.
A. $\frac{9}{8}$.
L. lat. 48 .

The height of the body is nearly four times in the total length, the length of the head 4 to $3 \frac{3}{4}$; the snout is slightly elongate and pointed; the diameter of the eye is $1 \frac{1}{2}$ in the length of the snout. The upper maxillary bone reaches to or nearly to the vertical from the anterior margin of the eye. Canine tecth moderate; the lateral teeth conieal, the posterior ones more obtuse and rather rounded*. Dorsal spines slender; the second is the Iongest, flexible, longer than the longest ray, and than one-half of the length of the hearl. Caudalis slightly emarginate. Olive, slining golden, with four or five orungecoloured Iongitudinal bands; head and body with indistinet and irregrular brownish spots; a blackish blotch between the pectoral and the lateral line; spines and rays of all the fins (cxcept of the pectorals) with brownish spots.

Sea of Japan; Louisiade Archipelago.

a. 8"long; filament 1 "long: stuffed. Louisiade Archipclago. Presented by the Lords of the Admiralty.

b. $6^{\prime \prime}$ long; filament indistinet: stuffed. Louisiade Arehipelago (30 fathoms). Voyage of the Rattlesnake.

\section{Lethrinus richardsonii.}

Lethrinus hæmatopterus, Richardson, Zool. Sulph. Fishes, p. 1.H. pl.64. f. 1-3; Bleck. Verhand. Batur. Genootsch. xxvi. Japun, p. 91 (not Schleg.).
D. $\frac{10}{9}$.
A. $\frac{3}{8}$.
L. lat. 48 .
L. transv. 5/17.

The height of the body is $3-3 \frac{1}{4}$ in the total length, the length of the head $3 \frac{1}{2}$. The snout is slightly elongate and pointed; the diameter of the eye is rather moro than the width between the orbits, and $1 \frac{1}{2}-1 \frac{2}{3}$ in the length of the snout. The upper maxillary reaches to the vertical from the anterior nostril. Canine teeth rather small; all the teeth of the lateral series conieal, none molar-like. Dorsal and anal spines rather stoutt; the fourth and fifth longest, but distinctly shorter than the rays, and about $2 \frac{1}{2}$ in the length of the head. Caudalis emarginate. Brownish olive (in spirits), indistinctly

* This docs not agree with the figure, which exhibits all the luteral recth conical, pointed, and small.

+ 'The figure quoted represents them too slender. 
marbled with darker; a black roundish blotch between the lateral line and the pectoral fin.

China Sea.

a. Adult: stuffed. China. Presented by J. R. Reeres, Esq. Original specimen of the figure quoted.

b, c. Adult : skins. China. Purchased of Mr. Warwick.

d. Half-grown. China.

e. Half-grown. China.

$f$. Half-grown: bad state. Hong Kong. From the Haslar Collection.

g. Half-grown. Hong Kong. Presented by Sir J. Richardson.

h. Half-grown. Hong Kong. Presented by Sir J. Richardson.

i. Half-grown.

$k$. ? Young. From the Collection of the Zoological Socioty.

B. Without blackish lateral bloteh.

\section{Lethrinus reticulatus.}

Cuv.\& Val. vi. p. 298; Bleeker, Banda, iii. p. 96.
D. $\frac{10}{9}$.
A. $\frac{3}{8}$.
L. lat. 43 (48?).

The height of the body is $3 \frac{1}{2}-4$ in the total length, the length of the head $3 \frac{3}{4}$; the snout is pointed, scarcely longer than the diameter of the eye, which is one-third of the length of the head; tho upper maxillary bone reaches nearly to the vertical from the anterior margin of the eye. Canine teeth distinct and curred; lateral teeth conical, the posterior ones obtuse. Caudalis emarginate, with pointed lobes. Olive or rose-coloured: head and body with violet specks, arranged in irregular transverse bands; generally two violet streaks from tho eye to the snout; the spinous dorsal marbled with violet; ventral fins riolet; the rays of the vertical fins with fine crossstreaks. $(B l$.

Seas of Now Guinea and Banda.

\section{Lethrinus chrysostomus.}

Richards. Voy. Ereb.\& Terr. Ichthyol. p. 118. pl. 60. f. 6, 7.
D. $\frac{10}{9}$.
A. $\frac{3}{8}$.
L. lat. 48.
L. transv. 5/16.

The height of the body is three simes in the total length, the length of the head $3 \frac{1}{4}$. The snout is elongate and pointed, and the cye, in adult specimens, of rather small size, its diameter being less than the distance between the eyes, or nearly one-third of the length of the snout*. The upper maxillary reaches to the vertical from the posterior nostril. Canine teeth rather strong; the teeth in the

* In immature specimens of 6 " length, the eye appears larger and the snout less elongate, the diameter of the former being $1 \frac{1}{2}$ in the length of the latter. The lateral teeth have more the appearance of molars, and become more pointed with age only. 
lateral series are of moderate size, conical and pointed, the hindmost rather shorter and blunt. Dorsal spines moderate; the third is rather shorter than the longest ray, and $3 \frac{4}{5}$ in the length of the head. Olive, each scale of the back and of the sides with a black rertical streak at its base ; head, dorsal, caudal, anal, and ventral fins blackish brown; the caudal variegated with lighter.

Norfolk Islands ; Australian Seas.

a. Adult. Norfolk Islands. Presented by Sir J. Richardson.-Type of the species.

b. $18^{\prime \prime}$ long: stuffed. Voyage of H.M.S. Herald.

c. Adult : stuffed. Cape York. Voyage of the Rattlesnake.

d. Young: stuffed. Cape York. Voyage of the Rattlesnake.

$e$. Half-grown : stuffed. Victoria. Voyage of H.II.S. Herald.

\section{Lethrinus latifrons.}

Lethrinus variegatus, Cur. \&. Val. vi. p. 287. elongatus, Cuv. \& Val. vi. p. 289.

? Lethrinus semicinetus, C'uv. \& Val. vi. p. 294.

Lethrinus latifrons, Rï̈p. N. W. Fische, p. 118. taf. 28. f. 4 ; Bleek. Celeb. i. p. 220.

D. $\frac{10}{9}$. A. $\frac{3}{8}$. I. lat. 50 . Cæc. pylor. 2.

The height of the body is five times in the total length, the length of the head $3 \frac{2}{5}$; the diameter of the eye is $3 \frac{1}{2}$ in the length of the head, and $1 \frac{1}{2}$ in that of the snout; the snout is pointed, and the upper maxillary bone does not reach to the vertical from the anterior margin of the orbit. The interspace between the eyes equals onethird of the greatest depth of the body. Canine tecth large; all the lateral teeth conical. The fourth dorsal spine is the longest, higher than the soft dorsal, and $2 \frac{1}{2}$ in the length of the head. Greenish, with five or six darker eross-bands; the rays of the dorsal and candal fins variegated with darker, the other fins immaculate.

Red Sea; East Indian Scas.

II. Species with distinct molar teeth.

A. With a blackish lateral blotch.

\section{Lethrinus harak.}

Sciæna harak, Forsk. p. 52.

Lethrinus harak, Rïpp. N. W. Fische, p. 116. taf. 29. f. 3 ; ? Bleek. Verhand. Batav. Genootsch. xxiii. Spar. p. 15.

? Lethrinus erythrurus, Cur. \& Val. vi. p. 293.

P Lethrinus rhodopterus, Bleek. Singapore, i. p. 65.
D. $\frac{10}{9}$.
A. $\frac{3}{8}$.
I. lat. 47 .
L. transv. 6/14.

The height of the body is $3 \frac{1}{2}$ in the total length, the length of the head four times; the snout moderately elongate and pointed. The diameter of the oye is longer than the distance betwoen the eyes, and 
$1 \frac{3}{4}$ in the length of the snout. There is a slight protuberance before the upper anterior angle of the eye ; the upper maxillary reaehes to the vertical from the anterior nostril. Canine and molar teeth moderate. Dorsal spines rather fecble; the fourth is the longest, rather shorter than the highest ray, and 23 in the length of the head. Caudalis slightly emarginate. Greenish olive, with an oblong lateral bloteh of blackish colour below the lateral line and below the middle of the dorsal fin.

Red Sea ; East Indian Seas.

a. Adult: stuffed. Red Sea. From Dr. Rüppell's Collection.

\section{B. Without blackish lateral bloteh.}

\section{Lethrinus ramak.}

Sciæna ramak, Forsk. p. 52.

Lethrinus ehrenbergii, Cuv.\& Val. vi. p. 312.

— ramak, Riipp. N. W. Fische, p. 117. taf. 28. fig. 3.
D. $\frac{10}{9}$.
A. $\frac{8}{8}$.
L. lat. 48.
L. transv. 6/15.

The height of the body equals the length of the head, and is $3 \frac{3}{4}$ in the total. The snout is rather elongate and pointed; the length of the diameter of the eyes is rather more than the width of the distance between them, and one-half the length of the snout; the upper maxillary bone does not reach to the vertical from the anterior nostril. Canine and molar teeth rather smail. Dorsal spines moderate, the fourth nearly equal to the longest ray, and one-third of the length of the head. Caudalis emarginate. Uniform olive; in life with an indistinet shining yellowish longitudinal streak.

Red Sea. [? Sea of Ceylon.]

a. Adult: stuffed. Red Sea.

b. ? Adult: skin. Ceylon. Presented by E. F. Kelaart, M.D.

\section{Lethrinus cocosensis.}

Bleeker, Kokos, p. 40.

$$
\text { D. } \frac{10}{9} \text { A. A. } \frac{3}{8} \text {. L. lat. } 50 \text {. }
$$

The height of the body is four times in the total length, the length of the head $3 \frac{5}{6}$. The diameter of the eyes is $3 \frac{1}{2}$ in the latter, and more than the distance between them. The snout is longer than the eye, and the upper maxillary bone does not reach to the vertical from the anterior margin of the orbit. The posterior teeth are molars; eanunes moderate. The fifth dorsal spine longest, one-third shorter than the height of the body, and shorter than the rays. Caudalis forked, with pointed lobes. Olive, with four or five orange-coloured or red longitudinal bands; fins immaculate, reddish yellow, the spinous dorsal brown-edged. ( $B l$.)

Sea of Nova Selma (Kokos Islands) 


\section{Lethrinus atlanticus.}

P Lethrinus atlanticus, Cuv. \& $\mathrm{Val}$. vi. p. 275.
D. $\frac{10}{9}$.
A. $\frac{3}{8}$.
L. lat. 45 .
L. $\operatorname{trans} \mathrm{s} .5 / 13$.

The height of the body equals the length of the head, and is $3 \frac{2}{3}$ in the total; the longitudinal diameter of the eyes is much more than the width between them, and $1 \frac{1}{3}$ in the length of the snout; the upper maxillary bone reaches to the vertical from the posterior nostril. Canino teeth moderate, the molars rather small. Dorsal spines moderate; the fourth is the longest, rather longer than the longest ray, and $2 \frac{1}{2}$ in the length of the head. Uniform greenish olive, the spinous dorsal blackish.

West coast of Africa.

a. 6" long. River Niger. From Mr. Fraser's Collection.

Although my description differs from that of Valenciennes in several points, I have littlo doubt that the fishes themselves are identical, whilst the descriptions are taken from specimens of different age.

\section{Lethrinus kallopterus.}

Bleeker, Act. Soc. Nederl. i, Manado en Makassar, p. 47.

$$
\text { D. } \frac{10}{9} \text {. A. } \frac{3}{8} \text {. L. lat. } 50 \text {. }
$$

Tho height of the body equals the length of the head, and is $3 \frac{1}{2}$ in the total. The snout is pointed and much longer than the diameter of the eye, which is $3 \frac{4}{5}$ in the length of the head; the upper maxillary reaches to the vertical from the anterior margin of the cye. Canine teeth large; molar tecth. The third and fourth dorsal spines longest, one-third only of the height of the body, whilst the soft dorsal is one-half of it; caudalis slightly emarginate. Above olive, snout and cheeks red-spotted; the rays of the fins beautifully red; the spinous dorsal and the anterior portion of the soft spotted with violet and yellow; the anal fin and tho base of the caudal spotted with yellow. (Bl.)

Sea of Manado.

\section{Lethrinus nebulosus.}

Seiæna nebulosa, Forsk. p. 52.

Lethrinus nebulosus, Cav. S. Ial. vi. p. 284; Rüpp. N. W. Fische, p. 118. - centurio, Cuv. S. Val. vi. p. 301 ; Peters, Wiegm. Arch. 1855, p. 243.

esculentus, Cuv. \&.Val.pl. 158.

$$
\text { D. } \frac{10}{9} \text {. A. } \frac{3}{8} \text {. I. lat. } 48 \text {. L. transv. 6/15. }
$$

The height of the body is $3 \frac{1}{2}$ in the total length, the length of the head four times. The snout is rather clongate and pointed. The length of the diameter of the eyes is rather more than the width of the distance between them, and $1 \frac{3}{4}$ in the length of the snout; the 
upper maxillary reaches to the vertieal from the anterior nostril. There is a slight protuberanee before the upper anterior angle of the orbit. Canne and molar teeth moderate. Dorsal spines moderate ; the fourth rather shorter than the longest ray, and one-third of the length of the head; candalis forked, with pointed lohes. Olive; bluish spots on the sides of the head.

Red Sea ; Seyehelles; Coast of Mozambique.

a. Adult: stuffed. Red Sea. From Dr. Rüppell's Colleetion.

\section{Lethrinus opercularis.}

Cuv. \& Val. vi. p. 289 ; Bleeker, Verhand. Batav. Genootsch. xxiii. Spar. p. 14.
D. $\frac{10}{9}$.
A. $\frac{3}{8}$.
L. lat. 44 .

The height of the body is $3 \frac{1}{3}$ in the total length, the length of the head $3 \frac{1}{2}-3 \frac{2}{3}$; the diameter of the eye is $1 \frac{1}{2}$ in the length of the snout; the præorbital higher than the orbit. The molars of moderato size. The fourth, fifth and sixth dorsal spines are the longest. Greenish olive, the scales on the back with a pearl-coloured spot; the opereular margin red; dorsal and anal fins rose-coloured, transparent, with violet margin. $(B l$.)

Seas of Bataria, Bantam, and Samarang.

\section{Lethrinus xanthotænia.}

? Lethrinus ornatus, Cur. \& Val. vi. p. 310.

Lethrinus xanthotænia, Blecker, Natuurk. Tydschr. Nederl. Lnd. 1851, ii. p. 176.

$$
\text { D. } \frac{10}{9} \text {. A. } \frac{3}{8} \text {. L. lat. } 50 \text {. }
$$

The height of the body is $3 \frac{1}{4}$ in the total length, the length of the head $3 \frac{1}{2}-3 \frac{3}{4}$; the diameter of the eye is $2 \frac{1}{3}-3$ times in the latter, and equal to the length of the snout. Canine teeth small, the posterior teeth short, tubereular. The fourth, fifth ard sixth dorsal spines iongest; eaudalis slightly cmarginate. Greenish olive, with five or six yellow longitudinal bands; the opercular membrane, the dorsal and caudal fins red, the other fins yellow. $(B l$.

Seas of Jara and Sumatra.

\section{Lethrinus leutjanus.}

? Bodianus leutjanus, Lacép. iv. p. 281.

? Lethrinus leutjanus, Cuv. \&. Val. vi. p. 309.

Lethrinus leutjanus, Bleek. Verhand. Bat. Genootsch. xxiii. Spar. p. 14.

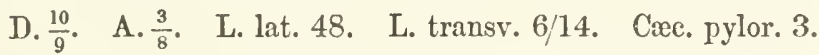

The height of the body is $3 \frac{1}{4}$ in the total length, the length of the head $3 \frac{1}{2}$. The snout is rather elongate and pointed. The diameter of the eye equals the width between the orbits, and is one-half the length of the snout. The upper maxillary reaches to the rertical 
from the anterior nostril. Canine teeth moderate; the posterior teeth of the upper jaw are rather obtuse and molar-like. Dorsal spines moderate; the fourth is the longest, and $2 \frac{1}{2}$ in the length of the head; caudalis emarginate. Reddish olive (in spirits); the seales on the back with a very distinct pearl-coloured spot in the centre.

West coast of Sumatra.

a. Fine specimen. From the Haslar Collection.

b. Half-grown. From the Haslar Collection.

\section{Lethrinus glyphodon. (Plate XXV.) \\ D. $\frac{10}{9}$. A. $\frac{3}{8}$. L. lat. 48 . L. transr. $6 / 15$.}

The height of the body is $2 \frac{4}{5}$ or 3 times in the total length, the length of the head $3 \frac{1}{3}$. The snout is elongate and pointed. The diameter of the eyc equals the willth between the orbits, and is onehalf the length of the snout. The upper maxillary reaches to the vertical from the posterior nostril. Canine teeth moderate, the molars large, and with a longitudinal groore on the crown. Jorsal spines rather slender; the third, fourth and fifth are the longest, and about one-third of the length of the head. Caudalis emarginate. Uniforn olive (in a dried state).

Louisiade Archipelago.

a. Adult. Louisiade Archipclago. From Mr. Macgillivray's Collection.

b. Adult. Louisiado Archipelago (fifteen fathoms). Voyage of tho Rattlesnake.

Deseription. - The general form of this species is rather stout and elevated, the greatest lieight of the body, above the base of the rentrals, being one-third of the total length, or eren more. The upper profile of the neck is convex, and is continued into that of the head, which is straight. The length of the head is $3 \frac{1}{3}$ in the total; the snout elongate and pointed, twice the diameter of the eyc. The upper maxillary reaches to the vertical from the posterior nostril when the mouth is elosed, and is entirely hidden beneath tho largo præorbitil, which is rather higher than long. The diameter of the eye is one-fifth of the length of the head, and equals the space between the orbits, which is flat or very slightly convex. Tho opereulum and suboperculum are corered with seales, and the former terminates in a very obtuse point with a slight notch above it.

The spines of the dor'sal fin are rather slender, shightly compressed on one side. The third, or the third, fourth and fifth spines are the longest, about one-third the length of the head, but rather shorter than the fifth and sixth rays, which form the highest part of the soft dorsal. The ceudal is slightly emarginate, with the lobes somewhat pointed. The ancl spines are rather stronger, but shorter, than those of the dorsal fin: the first is three-fifths of the second, the sceond intermediate in length between the first and third; the third is $3 \frac{1}{3}$ in 
the length of the head, and rather shorter than the first ray, whieh equals the longest dorsal spine. Of the pectoral rays the third is the longest, reaching to the vertical from the origin of the anal fin; it is one-third of the total length. The ventral fins are inserted behind the peetorals, and reach nearly to the origin of the anal; their length is $4 \frac{4}{5}$ in the total ; the spine is rounded, and about twothirds of the adjacent ray. There are four canine teeth in the upper jaw, and two in the lower. The molars are broad, and the largest ones have a longitudinal groove, the crown exhibiting two tubercles; the groove and the tubercles are less distinct in the larger of the speeimens; the three anterior lateral teeth are more conical; there are six or eight teeth in the upper jaw, and eight in the lower. A villiform band behind the canines.

The ground-colour is now yellowish olive (rose-coloured in life?), with a golden longitudinal streak along each series of scales. The fins are colourless.

\begin{tabular}{|c|c|c|}
\hline & inches & \\
\hline Total length ....... & 13 & \\
\hline Height of the body & 4 & 11 \\
\hline Length of the head $\ldots \ldots \ldots$. & 4 & \\
\hline Diameter of the eyo............. & 0 & 10 \\
\hline Length of the third (or fourth) dorsal spine. & 1 & \\
\hline - of the sixth dorsal ray $\ldots \ldots \ldots$ & 1 & \\
\hline $\begin{array}{l}\text { - of the third anal spine } \\
\text { - of the first anal ray }\end{array}$ & 1 & \\
\hline - of the peetoral fin. & $\begin{array}{l}1 \\
3\end{array}$ & \\
\hline of the ventral fin... & 2 & \\
\hline
\end{tabular}

\section{Lethrinus mahsena.}

Sciæna mahsena, Forsk. p. 52.

Lethrinus bungus, (Ehrenbg.) Cur. \& Val. vi. p. 279.

— mahsena, Cuv. \& Val. vi. p. 313 ; Riipp. N. W. Fische, p. 119. taf. 29. f. 4 (dorsal spines rather too slender).

D. $\frac{10}{9}$ A. $\frac{3}{8}$. L. lat. 47. L. transv. 5/15. Cæe. pylor. 3 .

The height of the body is three times in the total length, the length of the head $3 \frac{1}{3}$. The upper profile of the head somewhat gibbous above the eyes (at least, in adult specimnns). The eye is not very large, its diameter being $2 \frac{1}{2}$ in the length of the snout, which is very moderately produced. The upper maxillary reaches to the vertical from the anterior margin of the eye. Lips fleshy. Canines very large ; the posterior molar teeth with a distinet longitudinal impression. Dorsal spines rather compressed and broad on one side ; the third is nearly equal to the longest ray, and $3 \frac{1}{2}$ in the length of the head; the pectoral fins reach beyond the origin of the anal ; caudal forked, with rounded lobes. Greenish; in adult preserved spceimens several indistinet lighter eross-bands.

Red Sea.

a. Sixteen inches long: stuffed. Red Sea. Presented by J. Burton, jun., Esq. 


\section{Lethrinus mahsenoides.}

? Lethrinus mahsenoides, Cuv.\& Val. vi. p. 286.

Lethrinus mahsenoides, Bleek. Ver. Bat. Genootsch. xxiii. Spar.p. 15.

$$
\text { D. } \frac{10}{9} \text {. A. } \frac{3}{8} \text {. L. lat. } 48 \text {. L. transt. 6/15. }
$$

The height of the body is three times in the total length, the length of the head. $3 \frac{3}{4}$; the diameter of the eye is $3 \frac{1}{2}$ in the latter, and $1 \frac{1}{2}$ in the length of the snout and in the height of the præorbital. Canine tceth strong, molars moderate. The fourth. fifth and sixth dorsal spines longest. Uniform grecnish olive, tho opercular membrane red.

Seas of Batavia (and Amboyna); Philippine Islands.

a. Fine specimen. Philippines.

?b. Half-grown. Amboyna. Purchased of Mr. Frank. .

\section{Lethrinus hæmatopterus.}

Lethrinus hæmatopterus, Temm. \&: Schleg. Faun. Japon. Poiss. p. 74. pl. 38 (not Richards, or Bleek.).
D. $\frac{10}{9}$.
A. $\frac{3}{8}$.
L. lat. 48.
L. $\operatorname{trans} \nabla \cdot \frac{6}{15-16^{\circ}}$.

The height of the body is three times in the total length, the length of the head $3 \frac{1}{2}$. The snout is rather elongate and pointed. The diameter of the eye is rather less than the distance between the eyes, and $2 \frac{1}{3}$ in the length of the snont. The upper maxillary reaches scarcely to the vertieal from the anterior nostril. Canine teeth moderate; the teeth of the lateral serics blunt, rounded molars, with a very indistinct impression on the crown. Dorsal spines inoderate, very much tapering; the third shorter than tho longest ray, and nearly one-third the length of the head; caudalis emarginate. Greenish olive, each scale of the back and of the sides with a blackish spot at the base. The soft portions of the dorsal and anal fins red.

Sea of Japan.

a. Twenty inches Iong: stuffed. Japan. Purchased of Mr. Frank.

\section{Lethrinus latidens.}

Cuv. \& Val. vi. p. 316.

$$
\text { D. } \frac{10}{10} \text {. A. } \frac{3}{9} \text {. }
$$

Snout short. A series of molar teeth in the upper jaw, the second of which is twice as broad as long; the three posterior ones are still larger. Six molar teeth in the lower jaw, two of which are large. A blackish appendage behind each dorsal spine. Coloration uniform ; axil of the pectorals and three spots on the anal fin black. ( $\mathrm{Val}$.)

New Guinea. 


\section{SPHERODON.}

Chrysophrys, sp., Cuv. \& I al. vi. p. 134.

Sphærodon, Rüpp. N.W. Fische, p. 112.

Pagrus, sp., Bleek. Gilolo, p. 54.

Jaws with several eonical canine-like teeth in front, and with a single series of molars on the sides. Cheeks scaly. Dorsal fin with ten spines, which can be received in a groove; three anal spines. Scales of moderate size. Six branchiostegals. Pyloric appendages in small number.

Red Sea; East Indian Arehipelago.

\section{Sphærodon grandoculis.}

Scirena grandoculis, Forsk. p. 53; L. Gm. p. 1305.

Sparus grandoculis, Bl. Schn. p. 276; Lacép. iv. p. 111.

Chrysophrys grandoculis, Cuv. \& Val. vi. p. 134.

Sphærodon grandoculis, Rüpp. $\boldsymbol{N}$. W. Fische, p. 113. taf. 28. f. 2.
D. $\frac{10}{10}$.
A. $\frac{3}{9}$.
L. lat. 46.
L. transs. 5/16. Cæc. pylor. 3.

Vert. 10/14.

Eyes large. The dorsal spines equal on both sides; the third anal spine longest; the spinous dorsal with two series of bluish spots, some of the rays of the dorsal and anal fins with a black spot behind their base.

Red Sea.

$a, b$. Adult: stuffed. Red Sea. Presented by Dr. Rüppell.

\section{Sphærodon heterodon.}

Pagrus heterodon, Bleeker, Gilolo, p. 54.
D. $\frac{10}{10}$.
A. $\frac{3}{9}$.
L. lat. 48 .
L. transv. 5/14.

The height of the body is $3 \frac{3}{4}$ in the total length, the length of the head $3 \frac{2}{5}$; the diameter of the eye is $2 \frac{2}{5}$ in the latter; the pricorbital is half the width of the orbit. Dorsal spines not elongate. Rosecoloured; the scales with violet margins; base of the pectorals violet.

Seas of Halmaheira and Amboyna.

a. Young. Amboyna. Purchased of Mr. Frank.

?b. Adult : skin : bad state. Ceylon. Collected by F. Kelaart, M.D.

$$
\text { A. } \frac{3}{10} \text {. }
$$

\section{PAGRUS*}

Pagrus, Cuv. Règne Anim.; Cuv. \& Val. vi. p. 141.

Several pairs of strong, eonical, canine-like teeth in the outer

* 1. Sparus hurta, L. Mus. Ad. Fried. ii. p. 73 ; Syst. Nat. i. p. $469^{\circ}$; L. Gm. p. $1272 ;$ Bl. Schn. p. 273 ; Risso, Ichth. Nice, p. 255.-Aurata hurta, Risso, Eur. Mérid. p. 358.- Pagrus hurta, Cuv. \& Val. vi. p. 152.? Cynædus torvus, Gronov. Syst. cd. Gray, p. 54.-Mediterranean.

2. Sciæna lata, Solander.-Pagrus latus, Richardson, Ann. \& Mag. Nat. Hist. 1842, ix. p. 392.-New Zealand (identical with P. guttulatus or unicolor?).

3. Dentex macrocephalus, Cuv. Règne Anim. Ill. Poiss. pl. 35. f. 2 (seo p. 366) 
series of both the jaws; the molars are arranged in two series. Cheeks scaly. The spines of the dorsal (twelve, rarely eleven) are sometimes elongate, and can be received in a groove; three anal spines. Scales of moderate size. Six branchiostegals. Pyloric appendages in small number (in one species none); air-bladder simple.

Mediterranean; Coasts of Africa; Atlantie shores of the United States; Edst Indian and Australian Seas.

A. Species with the dorsal spines not elongated.

\section{Pagrus vulgaris.}

Пáypos, Aristot. viil. cap. 13 \& 17.

Pagrus, Rondel. v. e. 15. p. 142.

Sparus, no. 4, Artedi, Genera, p. 36.

Thuamel, iv. cap. 2. p. 29.

Sparus pagrus, Limn. Syst. Nat. i. p. 469 ; Brïnieh, Pise. Mass. p. 94 ; Risso, Kehth. Nice, p. 241; De la Roche, Amm. Mus. xiii. p. 317; Martens, Reise nach Vencdig, ii. p. 425.

- argenteus, $73 l$. Schn. p. 271.

Pagrus vulgaris, Cuv. \& Val. vi. p. 142. pl. 148; Farrell, Brit. Fishes, i. p. 116, figure eopied from Cuv. \& Val. l.c. (not description or vignette); Webb \& Berthel. Hist. Nat. Iles Canar. Poiss. p. 32; Guichen. Explor. Scient. Algér. Poiss. p. 49.
D. $\frac{12}{10}$.
A. $\frac{3}{8}$.
L. lat. 56 .
L. transv. 6/13. Vert. 9/15.

The height of the body is $3 \frac{1}{3}$ in the total length, the length of the head $3 \frac{2}{3}$; the diameter of the eye is $1 \frac{1}{3}$ in the distance between tho: eyes, and $1 \frac{2}{3}$ in the length of the snotit. The upper profile of the neek and head is parabolic; an obtuse protuberance before the upper anterior angle of the eye; the preorbital is $1 \frac{1}{3}-1 \frac{1}{4}$ as long as high. and has an incision in front. Dorsal spines not elongate; the second anal spine stronger, but not longer, than the third, one-fourth of the length of the head; pectoral elongate, reaching to the fourth soft ray of the anal fin. Silvery; back rose-eolomed.

Mediterranean; Sea of Madeira and of the Canary Islands.

a. Adult.

b. Very fine specimen. Lanzarote. From the Rev. R. T. Lowe's Colleetion.

c. Half-grown. Orotava. Presented by the Rer. R. T. Lowe.

d. Adult: skin. From the Colleetion of the Zoological Society.

Yarrell has entirely mistaken this fish, and, as we shall sec hereafter, some other species of the Sparidx. The specimen from which he made the deseription and a drawing of the dentition (pp. 117-119) is in the Collection of the British Muscum, and belongs to Pagellus erytnmmus. The figure of the fish and the notes on the synonymy (pp.116-117) are taken from the 'Histoire Naturelle des Poissons, par Cuv. \& Val.' It appears to mo highly probable that Pagrus vulgavis does not reach so far northwards as the coast of Great Britain, as I have neither met with this species on the coast or in fish-markets, nor found a British specimen among th." numerous skins of British 
Sparidx in the Collection of the British Museum. The speeimens mentioned in Mr. White's Catalogue of British Fishes as belonging to Pagrus vulgaris are likewise Pagellus erythrinus.

\section{Pagrus orphus.}

Aurata orphus, Risso, Eur. Mérid. iii. p. 356.

Pagrus orphus, Cur. \& Val. vi. p. 150. pl. 149; White, Catal. Brit. Fishes, p. 17; Webb \&. Berthel. Irist. Nat. Iles Canar. Poiss. p. 32.

D. $\frac{12}{10}$. A. $\frac{3}{8}$. Cæe. pylor. 5 .

The height of the body is one-third of the total length, the length of the head one-fourth; the diameter of the eye is one-third of the length of the head, and less than the distance between the eyes. The upper profile of the head is parabolic between the origin of the dorsal fin and the eye; thence it descends abruptly to the snout, and is rather concave. The lower jaw projects slightly beyond the upper. Præorbital elevated. Dorsal spines not elongate; the second anal spine stronger, but not longer, than the third; pectoral elongate, reaching to the fourth soft ray of the anal fin. Rose-coloured, with a blue cross-band between the eyes.

Coast of Nizza (and of Cornwall?); Canary Islands.

ı. 21" long: stuffed. Polperro, Cornwall. Presented by J. Couch, Esq.

It is not without doubt that I follow the opinion of $\mathrm{Mr}$. White and refer this specimen to the above species. It is evidently somewhat deformed by stuffing, and does not appear to have the dentition of a true Pagrus.

\section{Pagrus laniarius.}

Cuv. \& Val. vi. p. 163 .
D. $\frac{12}{10}$.
A. $\frac{3}{8}$.
L. lat. 54-58.
L. transv. 8/16.

The height of the body is $3 \frac{2}{5}$ in the total length, the length of the head $3 \frac{4}{5}$. The distance between the eyes is rather flat, and nearly equals the diameter of the eye, which is $1 \frac{2}{3}$ in the length of the snout. The upper profile from the nape to the snout is nearly straight, obliquely descending. The maxillary bone with a prominence situated near its base, and received in a noteh of the procorbital. The præorbital is nearly as high as long; there are ten series of seales between the preorbital and the interior ridge of the præopereulum, the limb of which is covered with seales. The outer pair of canines in the upper jaw bent ontwards. Dorsal spines rather strong, compressed on one side; the second and third anal spines strong, and nearly equal to one-third of the length of the head; peetoral not reaching to the anal fin. Uniform reddish.

Cape Seas.

a, b. Adult: stuffed. Cape Seas. From Sir A. Smith's Collection c. Adult: skin. False Bay. 


\section{Pagrus unicolor.}

Chrysophrys uncolor, Quoy \& Gaim. Voy. Uran. p. 299.

Pagrus mirolor, C'uv. 5. I'tl. vi. p. 162; Richardson, Ichth. China, p. 242.

D. $\frac{12}{10}$. A. $\frac{3}{8}$. L. lat. 52. L. transs. S/17. Cace. pylor. 5.

The height of the body is $2 \frac{2}{3}$ in the total length, the length of the hear $3 \frac{1}{2}$; the diameter of the eye equals the distance between the eyes, and is $1 \frac{1}{3}$ in the length of the snout*; a very slight protuberance above the upper anterior angle of the eye; the prieorbital is $1 \frac{2}{3}$ as long as high; there are six or seven series of scalles on the preoperculum. Dorsal spines not elongate; the second anal spine rather longer, but not stronger, than the thind, one-third of the length of the head; the pectoral reaches to the third anal spine, and is $4 \frac{1}{2}$ in the total length. Silvery; back darker, with silvery specks, sometimes disappearing in preserved specimens.

New Zealand ; Anstralian Seas. (Chinese Seas?)

a. Young. New Zealand. Presented by Sir J. Richardson. b, c. Young. New Zealand. Presented by Sir J. Richardson. d, e. Yomng. New Zealand. From the Haslat Collection. $f-h$. Young. New Zealand. From the Haslar Collection.

$i$. Adult: bad state; has been in chloride of zine. Sydney. Presented by Sir J. Richardson.

k. Fine specimen. Port Jackson. Colleeted by Mr. Mategillivray.

1. Skeleton. Port Jackson. Collected by Mr. Macgillivray.

m. Half-grown. Norfolk Island. Presented by Sir J. Richardson.

n. Half-grown. Norfolk Island. Presented by Sir J. Riehardson.

$\checkmark$ Adult: stuffed. Moreton Island (12 fathoms). Toyage of the liattlesnake.

p. Adult: skin. Australia. Purchased of M[r. Warwick.

q, r. Adult: skins. Australia. Purchased of Mr. Gould.

s. Arlult: bad state. Hong Kong? Presenterl by Sir J. Richardson.

$t$, $u$. Adult: skins. Cape of Good Hope? From Mr. Macgillivray's ('ollection.

1. Halt'-grown : skin.

$w, x$. Young. From the Haslar Collection.

$y, z$. Young. From the Haslar Collection.

a. Many young specimens. From the Haslar Collcetion.

Pagrus miropterus, established by Valeneiennes from an apparently faulty drawing (Cuv. \& Val. vi. p. 163), may prove to be identieal with this species.

The following specimens probably belong to a ditferent and unknown species; but being half-skins only, and deformed by stufting, they do not admit of any satisfactory deseription. If we put aside their general form and their great size, they agxe best with $Y^{\prime}$. unicolor.

"In y. anir indiriduals equal to the length of the snout. 
$a, b .29^{\prime \prime}$ long: stuffed. Houtman's Abrolhos.

c, d. 24" long: stuffed. Houtman's Abrolhos.

$e, f$. Half-grown: skins. Houtman's Abrolhos.

Skeleton. - The maxillary bone is of neurly equal width in the middle and at the extremities, and has the anterior edge slightly emarginate; the intermaxillary is joined to the posterior extremity of the former, and has the posterior processes of moderate length, rather shorter than the descending branch. The mandibulary is somewhat elevated, with a narrow free interspace between the articular and dentary pieces; there are four or five distinct openings of the muciferous channel, which runs along its lower surface. The head of the vomer is triangular, and has the anterior margins slightly swollen. The turbinal bones are very long, tubiform, brcadest posteriorly, where they together form a suture, and divergent anteriorly, to receive the processes of the intermaxillaries. The proorbital is quadrangular, not much narrower posteriorly than anteriorly, and one-third longer than wide; the remainder of the infraorbital ring is narrow; there is a concave plate at its inside to support the eyeball from beneath, and joined to the entopterygoid by a hammerlike process. The axes of the limbs of the præoperculum form an obtuse angle; the angle of the margin is rounded. There runs a rather strong ridge parallel to the margins of the præopcreulum, with a rudimentary muciferous channel and several distinet foramina. The operculum is irregularly quadrangular, with an interior ridge descending obliquely in a backward direction. The subopereulum is nearly vertically situated and pointed above; the interoperculum with the lower margin rounded. The frontal bones are rather flat, obliquely situated, their highest point being at their meeting with the occipital crest. The supraoccipital is horizontally situated, and has a high triangular erest, the upper maryin of which is swollen. Of the lateral crests the outer one only is developed, and transformed into a very distinct channel with about five openings. The base of the skull is slightly compressed, and there is a wide eavity in tho basisphenoid before the occipital joint. The pubic bones are of moderate length; each is formed by three lamellæ, the inner of which is broadest.

There are ten abdominal and fourteen caudal vertebrce, the length of the former portion of the vertebral column being to that of the latter as $1: 1 \cdot 4$. There are three spurious interneural spines in front, styliform ; nearly all the others are di]ated: the second is the longest, the following gradually decreasing in length. The first interhæmal is strong, and equal in length to the first seven vertebræ. Some of the ribs have epipleural spines.

There are four canine teeth in both jaws. 'The molars are of nearly equal size, and small; two scries in the upper jaw. In the lower jaw they are arranged in two series on the middle part only standing in a single series anteriorly and posteriorly. 


\section{Pagrus major.}

Chrysophrys major, Temm. \& Schleg. Fuun. Jupom. Poiss. p. 71 . pl. 35.
1). $\frac{12}{10}$.
A. $\frac{3}{8}$.
I. lat. 55.
L. transv. $7 / 15$.

The distance between the eyes equals their diameter, which is $1 \frac{1}{2}$ in the length of the snout. The preorbital is $1 \frac{1}{3}$ as long as high; a slight protuberance before the upper anterior angle of the eye. Limb of the preoperculum naked. Dorsal spines moderate, slightly compressed on one side: the fourth is the longest; the seeond anal spine rather stronger, but not longer than the third, which is one-third of the length of the head. Molars small, in two series, sometimes with a third of rudimentary teeth. Uniform reddish.

Japanese and Chinese Seas. (West coast of Australia?)

a. Adult: stuffed. China. Presented by J. R. Reeves, Esq.

b. Half-grown. China.

c. Adult: stuffed. Japan.

\section{Pagrus tumifrons.}

Chrysophrys tumifrons, Temm. \& Schleg. Fann. Jupon. Poiss. p. 70. pl. 34 .

$$
\text { D. } \frac{12}{11} \text {. A. } \frac{3}{10} \text {. }
$$

Nape rery gibbous, the profile of the head deseending abruptly ; the height of the body is $2 \frac{1}{2}$ in the total length. Eye large; the eleft of the month wide, extending to below the eye. Dorsal spines equal in strength, moderate; the second and third anal spines nearly equal. Uniform reddish. (Schleg.)

Japanese Sea.

13. Species with some of the dorsal spines tlexible and elongate.

\section{Pagrus cardinalis.}

Sparus cardinalis, Lacêp. iv. p. 141.

Chrysophrys cardinalis, Cur. \& V Val. vi. p. 130; Fam. Japon. Poiss. p. 69. pl. 33: Richurdson, Ichth. China, p. 241.

$$
\text { D. } \frac{12}{10} \text {. A. } \frac{3}{9} \text {. }
$$

The helght of the body is $\frac{2}{5}$ ths of the total length; a slight protuberance above the eyes. Molur teeth small, in two series, sometimes with a third series of rudimentary teeth. The first two dorsal spines very prominent, but much shorter than the third and fourth, which are elongate, filiform; the second and third anal spines cqual. Reddish; back covered with small greyish specks.

Chinese and Japanese Seus.

a. Half-grown: stufled: bad state. China. Presented by J. R. linver, Ese. 


\section{Pagrus auriga.}

Pagrus bertheloti, Vulene. in Webb \&. Berthel. Hist. Nut. Iles Canar. I'viss. p. 33. auriga, Valenc. in Webl \& Berthel. Hist. Nut. Iles Canar. Poiss.

p. 34; Guichen. Explor. Scient. Alyćr. Poiss. p. 49. pl.4. f. 1.
D. $\frac{11}{11}$.
A. $\frac{3}{8}$.
I. lat. 50 .
L. transv. 6/15.

The greatest depth of the body is beneath the sixth dorsal spine, where it is $2 \frac{2}{3}$ in tho total length ; the diameter of the eye is onefourth the length of the head. There are eight series of seales between the præorbital and the angle of the præoperculum. The length of the pectoral is $3 \frac{1}{4}$ in the total ; the third and fourth dorsal spines filiform, the former $\frac{3-4}{5}$ of the depth of the body. Red : back sometimes sparingly spotted with blue.

Canary Islands; Madeira; Mediterrancan.

a. Skeleton. Madeira. Presented by the Rev. R. T. Lowe.

6. Half-grown. Orotava (Teueriffe). Presented by the Rev. R. T. Lowe.

c. Very fine specimen. Orotava. Presented by the Rev. R. T. Lowe. -These specimens do not show the cross-bands mentioned by Valcneicnues.

ঐ. Young: bad state; has been in chloride of zinc. From the Haslar

Collection.--With brown cross-bands.

Pugrus berticloti and auriya are the same fish according to the observations of the Rev. R.T. Lowe, the former representing old specimens of the latter. In specimen $c$, which is twelve inches long, the third dorsal spine also is more than one-half the height of the body, whilst in the fishes on which Pagrus bertheloti was founded, the length of the same spine is $2 \frac{1}{2}$ in the height of the body.

\section{Pagrus ehrenbergii.}

Cur. \&. Vul. vi. p. 155.

$$
\text { D. } \frac{12}{10} \text {. } 1 . \frac{3}{9(C . \& V .8)} \text {. L. lat. } 54 \text {. }
$$

The height of the body is $3 \frac{1}{3}$ in the total length. The first two dorsal spines short, but very enspienously prominent between the seales; the third, fourth, and fifth spines elongate and filiform, the former of which is the longest, and sometimes reaches backwards to the soft portion of the fin. Red; back covered with blue spots.

Mediterranean.

a. Young. Coast of Africa. From the Haslar Collection.

b. Adult: stuffed: not good state.

\section{Pagrus filamentosus.}

C'ue. \& Vrel. vi. p. 158.

$$
\text { D. } \frac{12}{10} \text {. } 1 . \frac{3}{8} \text {. 1. lat. } 54 \text {. L. transv. (i/15). }
$$

'The height of the borly is $2 \frac{1}{2}$ in the total bength, the length of the 
head $3 \frac{3}{4}$; the diameter of the eye is less than the distance between the eyes, one-third the length of the head, and $1 \frac{1}{5}$ in that of the snont. There are five series of scales between the præorbital and the angle of the prooperculum. The first two dorsal spines very short, but projecting between the scalcs; the third very elongate, the fourth less; the fifth not flexible; the second anal spine stronger and longer than the third, $2 \frac{1}{3}$ in the length of the head. Uniform red, shining golden ; the spinous dorsal violet.

Sea of Mamritius.

a. Adult. Mauritius. From the Collection of the Zoological Society.

\section{Pagrus spinifer.}

Sparus spinifer, Forsk. p. 32; L. Gm. i. p. 1273; Bl. Schn. p. 281. Russell, ii. p. 1. pl. 101.

Pagrus spinifer, Cur. 5 V I al. vi. p. 156; Rüpp. N. W. Fische, p. 114. Iongifilis, Cuv. \&. Val. vi. p. 159 ; Bleek. Celeb. iii. p. 756.
D. $\frac{12}{10}$.
A. $\frac{3}{9}$.
L. lat. 50 .
L. transv. 22.

The height of the body is $2 \frac{1}{2}$ in the total length, the length of the head $4 \frac{1}{2}$; the diameter of the eye is one-third of the latter. The first two dorsal spines very short [and the first not projecting from the scaly sheath of the fin?]; the third very elongate and filiform; some of the following spines flexible, and in some of the specimens also filiform, but shorter than the third; the second and third anal spines nearly equal. Uniform rose-coloured; the spinous dorsal black-edged.

Red Sea; East Indian Seas.

Rïppell has not found any pyloric appendages in this species.

a. Young. China. $-\Lambda \cdot \frac{4}{8}$.

\section{Pagrus argyrops.}

Sparus argyrops, Linn. Syst. Nat. p. 471 ; Shaw, Zool. iv. p. 426; 137. Schn. p. 277.

Schoepf, Schrift. Naturf. Freunde Berlin, viii. p. 153.

Sparus xanthurus, Lacep. iv. p. 120.

Labrus versicolor, Mitch. Thans. Lit. \&. 1'hil. Soc. New York, i. p. 404. pl. 3. f. 7.

Pagrus argrrops, Cur. \& Iral. vi. p. 164 ; Agassiz in Spix, Pisc. Brasil. p. 117. tab. 64; 1) ckay, New York Fu Bairel, Ninth Smithson. Report, p. 333; Holbr. Ichth. S. Curol. p. 175. pl. 25 . f. 1.

$$
\text { D. } \frac{12}{12} \text {. A. } \frac{3}{11} \text {. L. lat. 50. L. transv, 20-23. }
$$

'The height of the body is $2 \frac{2}{3}$ in the total length. Canine tceth feeble; molars rery small, in two series. 'The second and third dorsal spines elongatc, filiform, the third shorter than the sccond. Brownish, golden shining; a narrow, vertieal, blackisl spot in the middle of each side.

Atlantic coasts of the United States. 


\section{PAGELLUS*.}

Pagellus, Cuv. \& Val. vi. p. 169.

The anterior teeth card-like, without canines, the outer series generally containing larger ones than those behind. Several series of rounded molar teeth in both the jaws. Cheeks scaly. The spines of the dorsal (eleven to thirteen) can be received in a groove; three anal spines. Opercles not armed. Scales of moderate size. Six branchiostegals. Pyloric appendages in small number; air-bladder simple.

Mediterrancan; Atlantic (except the shores of North America).

\section{Pagellus erythrinus.}

? 'Es $\rho \theta$ pivos, Aristot. 10. cap. 11.

Erythrinus, Bellon.p. 185; Rondel. v. cap. 16. p. 144; Sulcian. f. 239 ; Aldror. ii. cap. 9. p. 154; Gesner, p. 365 ; Willughby, c. 10. p. 311. tab. 5. f. 6 ; Ray, p. 134 .

Sparus, no. 3, Artedi, Genera, p. 36.

Sparus erythrinus, Lim. Syst. i. p. $469 ;$ L. Gm. p. 1272; $\mathrm{Bl}$. Schn. p. 275; Shane, Nut. Mise. xx. pl. 8:34; Risso, Ichth. Nice, p. 240; Martens, Reise nach Vinedig, ii. p. 425; Duhamet, Pèches, iv. c. 2. p. 29.

Sparus pagellus, Lacép. iii. p. 86.

Pagrus erythrinus, Risso, Eur. Méril. iii. p. 361.

Pagellus erythrinus, Cuv. \& Val. vi. p. 170. pl. 150; Yarrell, Brit. Fishes, i. p. 120, fig. cop. from Cur. \&. I ul. (not descript. and vignette; not Whité); Norelm. in Demid. Voy. Russ. Méril. p. 388; Guichen. Explor. Scient. Algér. Poiss. p. 50 ; Couch in Loudon's Mag. Nut. Hist. v. p. 17. f. 3 ; Parn. Fishes, Finth of Forth, p. 43. pl. 27.

Pagellus rostratus, Love, Trans. Zool. Soc, ii. p. 177.

Pagrus vulgaris, Yurell, Brit. Fishes, i. p. 117-119 (descript. and vignette, but not figure and synonymy, which belong to the trie Puyrus valgaris); White, Catal. Brit. Fishes, p. 17 (not synon.).

Pagellus canariensis, Valenc. in Webb and Berthelot, Hist. Nat. Iles Canar. Priss. p. 35. pl. 10. f. 2.

D. $\frac{12}{10}$. A. $\frac{3}{9}$. L. lat. 60 . L. transv. $\frac{6-7}{16}$. Caec. pylor. 4 . Tert. 10/14.

The height of the body is $3 \frac{1}{4}$ in the total length, the length of the head $3 \frac{1}{2}$; the diameter of the eye equals the distance between the eyes, and is $3 \frac{2}{3}$ in the length of the head and $1 \frac{1}{2}$ (twice in large specimens) in that of the snout. The pracorbital is $1 \frac{1}{2}$ or $1 \frac{1}{3}$ as long as high, with the maxillary edge slightly notched (in adult specimens). There are six series of scales between the præorbital and the angle of the prooperculum. In both jaws two series of molars only. The posterior nostril ovate. Uniform red.

Mediterranean; Black Sea; coasts of the Peninsula, of France and Great Britain; Canary Islands. [Cape Scas?]

a. 19" long: stuffed. Firth of Forth. From Dr. Parnell's Collection.

* 1. Pagellus breviceps, $(n)$ \& $I^{\prime} \prime l$. ri. p. 19\%.--Mediterranean 
し. 21" long: skin : not good state. Brixham. From Mr. Yarrell's Colleetion (cfr. Yarrell, Brit. Fish. pp. 117, 118).

c. $20^{\prime \prime}$ long: stuffed. Plymouth. Presented by Lieut. H. F. Spence, R.N.

cl-f. 20" long: skins. Plymouth. From Mr. Yarrell's Collection. 9. 20" long: skin. Devonshire, From Mr. Yarrell's Collection.

h. Half-grown. Lisbon.

i. Half-grown: stuffed. Lisbon. Presented by G. Hough, Esq.

k. Fine specimen. Orotava. Presented by the Rev. R. T. Lowe.

7. Adult: stuffed. Santa Cruz (Teneriffe).

m. Half-grown. Adriatic. Purchased of Mr. Frank.

n. Half-grown. Mouth of the Danube.

$o, p$. Adult: skins. From Mr. Yarrell's Collection.

\%. Adult: skins. From the Collection of the Zoologieal Soeicty.

$r$. Half-grown: bad state. From the Haslar Collection.

s. Half-grown: stuffed.

1, $u$. Young: skins: not good state. From Mr. Yarrell's Collection. v. Young: not good state. Purchased of Mr. Warwick.

w. Adult: skeleton.

'There is an important error in Valenciennes' deseription of this fish, by whieh some of the eonfusion among the Sparoid fishes in Yarrell's work may have originated. Valenciennes attributes eight anal rays to this fish (p. 176), whilst the figure (pl. 150) correctly represents nine. All the European specimens that I have exammed invariably exhibited the same number, viz. nine, and by this eharacter alone Pugellus erythrinus may be readily distinguished from Peugrus vulgaris, which has constantly cight only. I have seen a single specimen of $P . t y y t h$ rinus, which formed an exeeption in having ten anal rays; but this came from the Cape, and may prove to be a separate species.

'Thus, even without having the original specimens from Yarrell's Collection, one could easily see that the description and the rignette representing the dentition, which Yarrell has given in the article on I'ugrus vulyaris, were taken from specimens of Pagellus erythrinus.

'The article on the fish which he has described under the name of Pagellus erythrinus is eomposed of several elements. The figure, alhove all, is a copy, taken from the Hist. Nat. Poiss., Cuv. \& Val., 1). 150 , and, so far, there is no mistake about the fish; but with regard to the rest, cfr. Payellus owerii, p. 478 of this Catalogue.

Finally, there are two other speeimens in the British Museum Collection, which, perhaps, are types of separate species; but in a group where it is necessary to prove the eonstaney of the distinctive charaeters, and where the species are so difficult of recognition, I think it better to refrain from establishing species upon doubtful charaeters.

Var.? Spec. nov.?

$\therefore$ ' 'Wwenty-three inches lonir: skin. South Devon. From Mr. Yarrell's Collection.-DMolats in hoth jaws irregularly arranged, 
and giving the appearance of three series. I observe that this specimen is not the type, either of the description given by Yarrell of Pagellus erythrinus, or of the vignette.

\section{VAR.? Spec. nov.?}

y. Adult: stuffed. Cape Seas. From Sir A. Smith's Collection.Anal with ten soft rays.

Skeleton.-The maxillary bone is compressed, oblong, with a groove near its posterior extremity for the articulation with the extremity of the intermaxillary; there is another longitudinal groove at its upper extremity for the articulation with the palatine bone. The intermaxillary is stout, joined to the maxillary, and has the posterior process rather longer than the deseending branch, but not reaching to the vertical from the orbit. The mandibula is stout, and there is no free space between the dentary and artieular bones; five pores lead into the rudimentary muciferous ehannel running at its lower surface. The anterior part of the vomer is broad, flat, subtriangular; the posterior is continued into the sharp erest of the basisphenoid. The palatine bones are ereseent-shaped, and situated nearly vertically ; their upper portion is bent forwards, reaching as far as the turbinal bone, and is joined to the maxillary. 'The turbinal bones are long, tubiform. The proorbital is longer than high, slightly coneave at the maxillary margin; from its inner side arises a plate to support the eyeball from beneath. The remainder of the infraorbital areh is narrow, muciferous. There are three singular conical cavities at the upper surface of the skull: a single one between the posterior extremities of the turbinal bones, and another on each side, above the anterior angle of the orbit. The frontal bones are truneated anteriorly, with the upper surfaee slightly convex, roughened by pores and grooves. The oecipital erest is rather stout, and, with two others on each side, well developed; the external is mueiferous. The brain-eapsule is very slightly swollen on each side ; the basisphenoid has a large opening before the oeeipital joint, and is compressed to a sharp ridge, obliquely aseending to the vomer. The praoperculum has an obtuse and strong ridge, with the muciferous channel very rudimentary ; the horizontal limb is shorter than the vertical ; the angle and the lower margin are striated, the strix not terminating in points. The opereulum is nearly twice as high as wide, irregularly quadrangular, with the posterior side slightly emarginate and the lower angle much produeed downwards; its inner surface is furnished with an oblique bony rilge. The subopereulum is obliquely situated, the interoperenlum nearly horizontally. 'The pubic bones are of moderate length; each is formed by three lamella, the interior of which are joined together, without free space between; the outer one is much less developed, and situated nearly in the same plane with the interior; the anterior extremities of the bones diverge.

There are ten abdominal and fourteen eaudal vertebret, the length of the former portion of the vertcbral colum being to that of the 
latter as $1: 1 \cdot 47$. The first spurious interneural spine has a strong spine, pointing forwards; the other interneurals are much dilated, and in immediate contact with one another. The first interhomal is of moderate length and strength. Some of the ribs have long epipleural spines.

The teeth of the anterior portion of the jaws form a villiform band, with an outer series of rather stronger ones; posteriorly they assume a more granular character, and pass finally into two series of moderate molars, the larger of which are placed in the inner series. 'The new teeth, replacing the old ones, are developed below, and protected by, the latter.

\section{Pagellus centrodontus.}

Orphus, Rondel. v. cap. 25. p. 157 ; Aldrov. ii. cap. ii. p. 158.

Pagrus, Aldrov. p. 151.

Sparus orphus, Lacép. iv. p. 146.

- pagrus, Penn. Brit. Zool. iii. p. 212. pl. 42 ; Bl. taf. $267 ; B l$. Schn. p. 271; Turton, Brit. Faun. p. 98.

- aurata, Don. Brit. Fishes, iv. pl. 89; Turton, Brit. Fuun. p. 97. Duhamel, ii. sect. 4. cap. 2. p. 30.

Sparus centrodontus, De la Roche, Ann. Mus. xiii. p. 345. pl. 23 . f. 2. - massiliensis, Risso, Ichth. Nice, p. 247, and Lur. Mérid. p. 357. Pagrus vulgaris, Flem. Brit. An. p. 211.

Pagellus centrodontus, Cuv. \& Val. vi. p. 180; Parn. Fishes Firth of Forth, p. 46. pl. 27 ; Yarrell, Brit. Fishes, i. p. 123; Webb \& Berthel. Hist. Nat. Mles Canar. Poiss. p. 34. pl. 7. fig. 3; Guichen. Explor: Sc. Alger. Poiss. p. 50.

D. $\frac{12}{12}$. A. $\frac{3}{12}$. L. lat. 75. L. transv. 7/16. Cæe. pylor. 4. Vert. 10/14.

The height of the borly is $2 \frac{3}{4}$ to $3 \frac{1}{4}$ in the total length, the length of the head $3 \frac{1}{2}$; the diameter of the eye is rather more than the distance between the eyes, equal to the length of the snout and $3 \frac{1}{2}$ in that of the head. The pracorbital is much narrower posteriorly than in front, and not notehed. There are seven series of seales between the preorbital and the angle of the propoperculum. Teeth very fine, intermixed posteriorly with minute molars, more or less irregularly arranged. 'The pectoral reaches to the origin of the anal. Silvery, back rose-coloured; a large black bloteh on the shoulder.

Mediterranean; Canary Islands ; coasts of the Peninsula, France, and Great Britain; North Sea.

«. Adult: stuffed. Firth of Forth.

b. Adult: stuffed. Firth of Forth. From Dr. Parnell's Collection.

c. Adult: slin. South Devonshire. From Mr. Yarrell's Collection.

d. Adult: bad state; has been in chlorirle of zine. English coast.

Presented by Mr. E. Gerrard.

e. Adult: stuffed. English coast.

f. Adult: skin. English coast. From Mr. Yarrell's Collection.

y. Half-grown: skin. English coast. From Mr. Yarrell's Collection.

$h$. Very large and fine specimen. Lanzarote. l'resented by the Rer. R. 'T. Lowe. 
i. Adult: not good state.

$k$. Adult: stuffed. From Mr. Yarrell's Collection.

l. Half-grown: skin. From Mr. Yarrell's Collection.

$m, n$. Half-grown: stuffed.

o. Half-grown: bad state: stuffed.

p. Adult: skeleton: not good state.

Monstrosity? 13 inches long and $5 \frac{1}{2}$ inehes high; the pectoral reaches far beyond the origin of the anal. (See figure given by Yarrell.) q. Polperro. Presented by J. Couch, Esq.

Skeleton.-The maxillary bone is oblong, with the anterior margin nearly straight, and with the posterior convex and provided with a noteh; the articular groove in which the palatine bone moves is very shallow; the articulation with the intermaxillary is near its lower extremity. The intermaxillary is moderately strong, with the posterior process shorter than the descending branch. The mandibula somewhat elevated; there is a free space between the dentary and articular bones; five or six small openings lead into the rudimentary mueiferous channel. The head of the vomer is very broad, flat, triangular, whilst the posterior part tapers and passes into the sharp ridge of the basisphenoid. The palatine bones are narrow, situated in a nearly vertical direction ; they terminate superiorly in a process, rectangularly bent forwards for the junction with the maxillary bone, and reaching as far as the turbinal bone. The nasal (ethmoid) is rather elongate, with two longitudinal impressions, in which are received the processes of the intermaxillary bones. The turbinal bones are provided with irregular grooves and eavities, and widened at both extremities. The præorbital is twice as long as wide, whilst the remainder of the infraorbital ring is very narrow; from the inside of the preorbital arises a comparatively small plate to support the eyeball from beneath. The frontal bones are truncated anteriorly; their upper surface is slightly convex, and roughened by pores and grooves. The occipital crest is moderate, and does not extend on the frontal bones; the two lateral crests, and especially the outer one, are comparatively much more developed. The brain-capsule is slightly compressed; the basisphenoid has the usual large opening before the occipital joint, and is compressed anteriorly into a sharp ridge. The prooperculum has a very low ridge, and the muciferous channel is eolsequently mdinientary : the horizontal limb is shorter than the vertical; both meet at a rounded angle, which, like the whole margin, is entirely smooth. The opereulum is twice as high as wide, irregularly quadrangular, with the upper side oblique, the posterior curved, and with an acute lower angle; there is an oblique bony ridge at its inner surfuce. The suboperculum is nearly vertically situated; the interopereulum broad, with the lower margin rounded. The pubie bones are of moderate length; cach is formed by three lamella, the outer of which is the most fecble, and situated nearly in the same plane with the interior; both the bones diverge anteriorly. 
There are ten abdominal and fourteen caudal vertebre, the length of the former portion of the rertebral colnmn being to that of the latter as $1: 1 \cdot 24$. The three spurious interneurals are not spiniferous: the first interhæmal is of moderate length and strength.

\section{Pagellus owenii.}

I'agellus acarne, (not Cur.) Parn. Fishes Firth of Forth, p. 24. pl. 27; I arrell, Brit. Fishes, i. p. 122* (fig. not accurate); White, Cat. Brit. Fishes, p. 19.

Pagellus erythrimus, Farell, l.e. p. 120, descr. and vignette [not fig. or synun.].

$$
\text { D. } \frac{12}{11} \text {. A. } \frac{3}{10} \text {. L. lat. } 68 \text {. L. transv. 6/13. }
$$

The height of the body equals the length of the head and is $3 \frac{2}{3}$ in the total; the drameter of the eye is nearly equal to the distance between the eyes, $1 \frac{1}{3}$ in the length of the snont, and $4 \frac{1}{2}$ in the length of the head. The proorbital is narrower posteriorly, its greatest depth being about $1 \frac{1}{2}$ in its greatest length. There are three series. of molars in the upjer jaw and two or three in the lower. Silvery red, with a dark violet spot in the axil.

Only known at present from the coasts of the British Isles.

$a, b$. Fourteen inches long . slins. Plymouth. From Mr. Tarrell's Collection.

c. Fourteen inches long: stuffed. Firth of Forth. From Dr. Parnell's Collection.

d. Fourteen inches long: stuffed.

$e, f$. Fonrteen inches long: skins. From Mr. Yarrell's Collection.

Description.-This fish, known to British ichthyologists under the name of the "Axillary Bream," has been confounded by then with the Aecrne of the Mediterranean, which appears to spread to the southern coasts of England in a few instances only. Both fishes are very similar to each other; but the British species has eonstantly three series of molars in the upper jaw, whilst the southern specimens exhibit two only, as is stated by Curier and confirmed by the specimens in the British Musenm. If there is any irregularity in the arrangement of the series of the upper molar teeth, and therefore a doubt about their number, they appear to form four series rather than three, and never two.

I have mentioned above that the article on Pagellus erythrinus in 'Yarrell's Fishes' treats of a different species, except the figure, which is a copy, as acknowlerged by himself. That part of the description which is composed by himself, contains very few specific characters which might not be attributed to other Sparida as well as to the species in question. But there is one sentence which clearly shows that Yarrell could not have had a specimen of $P^{\prime}(t-$ gellus erythrimus for this description, as he professes; he says, p. 122. "The last two or three soft rays of both dorsal and anal fins are invested together in one sealy covering." 'This is the case in 1 '. owenii and in P. acarne from the Mediterranean. but not in Pargellus ery- 
thrinus. And if we consider, together with this character, the vignette of the same page, representing the molar teeth of the upper jaw in three regular series, as in $P$. owenii, and never in $P$. erythrinus or $P$. acarne, we cannot have any doubt that this description and this vignette were taken from specimens of $P$. owenii.

One point only appears to contradict this view, namely the formula of the fins, in which Yarrell attributes eight soft rays to the anal. But I have stated above that there is a misprint in this very number in the Hist. Nat. Poiss., and Yarrell in reproducing it clearly shows that he copied the formula from that work, in order to bring his description more into aceordance with that of a work which he appears to have considered as infallible. Thus, Yarrell not only confounds four speeies of fish, but increases this confusion by publishing figures and deseriptions of them, part of which are taken from the work of a better informed author, and part from specimens totally distinct from the one intended to be described.

The fish from which Yarrell has taken his artiele on P. erythrmus is again described under the name of "Axillary Bream," p. 122*. The article on that fish is merely a reproduction of Dr. Parnell's observations; it is, as stated above, different from the Acarne of the Mediterranean, and I have named it in honour of Prof. $R$. Owen.

The general form is very much like that of $P$. acarne. The head is one-third of the total length, without caudal; the snout appears to be rather more elongate, the distance between the extremity of the snout and the lower posterior angle of the præorbital being $2 \frac{2}{5}$ in the length of the head. There are five series of seales on the cheek. A large ereseent-shaped space on the angle of the prooperculum is naked.

The anterior teeth in both jaws are villiform, the outer series being formed by somewhat larger but equal teeth. Further posteriorly the teeth become granular, and, gradually assuming the character of molars, they form three regular series in the upper jaw ; each series contains six or seren molars, and they are all of nearly equal size, exeept the last two of the inner series, which are onethird larger than those around them. The lower jaw is generally armed with two series only, but occasionally the inner series is broken up in the middle, forming a third series, which, however, does not extend so far as the others; each series eontains six or seven molars, and the posterior ones of the inner series are nearly twice as large as the others.

The body is rather thick, and its greatest depth is $3 \frac{2}{3}$ in the total length.

The spines of the fins are rather slender ; the fourth of the dorsal fin is the longest and $2 \frac{2}{3}$ in the length of the head; the soft dorsal is much lower. Caudalis forked.

The scales are somewhat irregularly arranged, especially on the anterior portion of the trunk nearest to the head; the posterior margin of most of them has a more or less distinet noteh in its upper half. The lateral line is slightly curved, and runs parallel to the back. 
inches. lines.

Total length................ $14 \quad 6$

Length of the head ............ 4 . 3

Height of the body . . . . . . . . . . 4 4

Diameter of the eye ............ 10

Length of the fourth dorsal spine ..... $1 \quad 6$

\section{Pagellus acarne.}

?"Акарva, Athen. viii. cap. 13.

? Acarne, Plin. xxxii. cap. 11.

Acarne, Rondel. xv. cap. 20. p. 151; Dhthancl, Pc̈ches, ii. sect. iv. c. 2 . p. 32 .

Sparıs berda, Risso, Iclith. Nice, p. 252.

Pagrus acarne, C'ur'. Règme Anim.; Risso, Eur. Iféril. iii. p. 361.

Pagellus acarne, Cuv. \& I Tul. vi. p. 191 ; Cuv. Rigne Anim. Ill. Poiss. pl. 35. f. 1; Givichen. Explor. Scient. Alyér. Poiss. p. 51.
D. $\frac{12}{11}$.
A. $\frac{3}{10}$.
L. lat. 72 .
L. transv. 5/13. Vert. 22.

The height of the body equals the length of the head, and is $3 \frac{2}{3}$ in the total; the diameter of the eye is nearly equal to the distance between the eyes, rather less than the length of the snout, and $3 \frac{1}{2}$ in tho length of the head. The proorbital is narrower posteriorly, its greatest depth being $1 \frac{1}{2}$ in its greatest length. There are five series of scales between the preorbital and the angle of the præoperculum. In both jaws two series of molars only. Reddish, shining golden; a deep brownish-red spot in the axil.

Mediterranean; from the Canary Islands to the coasts of Great Britain.

a. Fine specimen. Lanzarote. Presented / the Rer. R. T. Lowe.

b. Half-grown. Lisbon.

c. Half-grown. Cornwall. Museum Leach.

\section{Pagellus bogaraveo.}

Sparus bogaraveo, Brïnn. P'isc. MLuss. p. 49; Lacḱp. iv. pp. 111, 112 ; Risso, Ichth. Nire, p. 249.

Pagrus bugravella, Kisso, Eur. Mŕritl. p. 359.

Duhamel, P'êches, sect. 4. pl. 1. f. 1.

Pagellus bogaraveo, Cur. of F"al. vi. p. 196.

D. $\frac{12-13}{12-11} \cdot \quad$ A. $\frac{3}{11-12} \cdot \quad$ L. lat. 70 . L. transv. $7 / 14$. Vert. 22.

The height of the body equals the length of the head, and is $3 \frac{2}{3}$ in the tutal; the diameter of the eye is a little more than the distance between the eyes or than the length of the snout, and is one-third of the length of the head. The preorbital is rather narrow and elongate, its greatest depth being $2 \frac{1}{3}$ in its length There are six series of seales between the præorbital and the angle of the proopereulum. In both jaws two series of small molars. Silvery, back rose-coloured.

From the Mediterranean to the British Channel.

a. Adult. Cadiz. From the Haslar Collection.

$b$. Adult: skin. Mediterranean. From the Collection of the Zoological Society. 


\section{Pagellus mormyrus.}

Móppupos, Aristot. vi. cap. 17 ; Athen. vii. p. 313.

Móp $\mu \nu \lambda$ os, Oppian, i. v. 100.

Mormyus, Plin. xxxii. cap. 11 ; Bellon. p. 183 ; Rondel. v. c. 22. p. 153 ; Sale. f. 184; Gesner, p. 547 ; Aldrov. ii. c. 19. p. 184; Wi. lughby, p. 329 ; Ray, p. 134.

Sparus, no, 9, Aitedi, Genera, p. 37.

Sparus mormyrus, L. Syst. Nat. p. 472; Briinn. Pisc. Mass. p. 14 L. Gm. p. $1279 ; \mathrm{Bl}$. Schn. p. 277; Martens, Reise nach Venediy ii. p. 425.

Pagrus mormyrus, Geoffi. Descr. Eg. Poiss. pl. 18. f. 3.

Pagellus mormyrus, Cuv. \& IFal. vi. p. 200; Webb \& Berthelot, Hist Nat. Iles Canar. Poiss. p. 35; Guichen. Explor. Srient. Alger. Puise p. 51.

Pagellus goreensis, Cuv. \&. Val. vi. p. 203.

pernambucensis, Cux. \&. Val. vi. p. 210.

D. $\frac{11}{12}$. A. $\frac{3}{10}$. L. lat. 63-65. L. transv. 6/12-14. Vert. 10/14.

The height of the body is $3 \frac{1}{2}$ in the total length, the length of the head $3 \frac{3}{4}$; the diameter of the eye is one-fifth of the length of the head, $2 \frac{1}{3}$ in that of the snout, and $1 \frac{1}{3}$ in the distance between the eyes. The mouth is very protractile, and the upper maxillary beut, with the concavity downwards and forwards. The molar teeth in fou series in the upper jaw, and in two or three in the lower. Silvery, shining golden, with seven narrow blackish cross-bars, and some times with seren other more indistinct ones between.

Mediterrancan; Canary Islands; North-west coast of Africa; Atlantic coasts of Tropical America.

a. Fine specimen. Lanzarote. From the Collection of the Rev. R.

'T. Lowe.

6. Adult: not good state. Sicily. Presented by W. Swainson, Rsq $c$, d. Young. Malta. From the Haslar Collection.

e. Half-grown. Dalmatia.

f. Half-grown : skin. Mediterranean. From the Collection of the Zoological Socicty.

g. Half-grown: skin: bad state. From Mr. Yarrell's Collection.

h. Young: skin. From Mr. Yarrell's Collection.

i. Adult : bad state. (Cape of Good Hope?) From the Haslar Collection.

$k$. Adult: skelcton. From the Haslar Collection.

In all the specimens I found the number of the dorsal spines and the dentition as stated by Valeneiennes for $P$. goreensis, which, l have no doubt, is identical with $P$. mormyrus.

The following Soutl Anerican specimens, probably identical with Pugellus pernambucensis, do not differ from those of the other side of the Atlantie Ocean.

l, m. Half-grown. Nt. Vincent. From Mr. Margillivray's Collection. n. Half-grown: skeleton. St. Vincent. From Mr. Diacgillirray's Collection.

Shelfton.-I cannot agree with Valenciennes riow, that the sko- 
leton of this fish does not offer any remarkable peculiarity. The maxillary bone is crescent-shaped, with the anterior side emarginate and both extremities narrowest. The intermaxillary is broad, shorter than the maxillary, and its extremity forms an articulation with the anterior side of the latter; the posterior processes are broad, very elongated, much longer than the descending branch of the bone; they do not reach to the vertical from the orbit. The mandibula is very stout, and there is no free space between the dentary and articular bones. The anterior portion of the vomer forms a very broad and concave plate. The palatine bones are crescent-shaped, and situated in a nearly vertical direction; their upper portion is much developed, bent forwards, reaching as far as the turbinal bone, and joined to the maxillary. The nasal (ethmoid) is very elongate, with two longitudinal impressions, in which are receired the processes of the intermaxillary bones. The turbinal bones, are exceedingly long and tubiform. The præorbital is much longer than high, whilst the remainder of the infraorbital ring is very narrow : from the inside of the præorbital arises a broad plate, supported by a strong process, which is attached to the entopterygoid. The frontal bones slightly diverge anteriorly to receive the extremity of the nasal; their upper surface is roughened by pores and grooves. The occipital crest, with two others on cach side, is moderately elevated. The brain-capsule is slightly compressed; the basisphenoid has a large opening before the occipital joint, and its anterior portion is compressed into a ridge. The praoperculum has an obtuse and strong ridge, with the muciferous channel very rudimentary ; the horizontal limb is much shorter than the vertical; the angle is rounded and striated, the striæ not terminating in points. The operculum is twice as high as wide, quadrangular, with the upper side oblique; its inner surface is furnished with an oblique bony ridge terminating in an obtuse point. The suboperculum is nearly vertically situated, the interoperculum obliquely. The glossohyal is styliform, the urohyal triangular, with the posterior side notched. The lower pharyngeal bones are very elongate, with both the extremities pointed. The pubic bones are of moderate length ; each is formed by three lamellæ, the interior of which is broadest.

There are ten abdominal and fourteen caudal vertebrce, the length of the former portion of the vertebral column being to that of the latter as $1: 1 \cdot 33$. The first interhæmal is of moderate strength and length. Some of the ribs have long epipleural spines.

The teeth of the anterior portion of the upper jaw form a villiform band, with an outer series of rather stronger ones. The two outer bands of the molars contain small teeth, which are somewhat irregularly arranged. The molars of the third series, nine in number, gradually become larger posteriorly; the fourth series extends to one-half only of the length of the third, and has small molars; there are, finally, granular teeth, forming two oblique and short series. The anterior teeth of the lower jaw are equal, short, and cardiform ; there are two series of molars in the posterior portion of the jaw, those of the inner one heing large and broad ; this series is anteriorly 
double, contrining teeth equal to those of the outor onc. The pharyngeal teeth aro cardiform.

The comparison of tho skeletons of Juropean and West Indian specimens proves the identity of I'aydlus pernambucensis with I'. mormyrus.

\section{Pagellus lithognathus.}

Cuv. \&. Val. vi. p. 204. pl. 151.
D. $\frac{11}{10}$.
A. $\frac{3}{8}$.
I. lat. $43-50$.
I. transv. 5/13. Vert. 22.

Aclult.-The height of the body is $4 \frac{1}{2}$ in the total length; the diameter of the eye is seven times in the length of the head, and $3 \frac{1}{2}$ in that of the snout. 'The upper maxillary bone (of adult specimens) is very thick, swollen, and hard like stome. The molar teeth in the upper jaw form a band, and are irregularly arlanged; throo sories in the lower. Uniformly coloured.

Cape of Good Hope.

a. 'Thirty-six inches long: stuffed.

Young.- The height of the body is nearly equal to the length of the head, and about 33 in the total; the diameter of the oye is onefifth of the length of the head, about one-half of that of the snont, and $1 \frac{1}{3}$ in the distance hetween tho eyes. 'The mouth is very protractile and the upper maxillary bent, with the concavity downwards and forwards, but not swollen. The molar teeth are rather small, arranged in three regular series in the upper jaw, and in one complete or in two incomplete series in the lower. 'The dorsul spines are moderute, slightly compressed on one side; the fourth, fifth and sixth are longest, their length being equal to tho distance between the third and seventh spines. Coloration uniform (in a driod stato); in life with five brownish cross-bands.

b. $9 \frac{1}{2}$ "long: stuffed. Cape Seas. Prespnted by Sir $\Lambda$. Smith.

c. 10" long: akin. From Gronov's Collection.

\section{CHRYSOPHRYS*}

Chrysophrys, Cuv. Règne Anim.; Cuv. \& Val. vi. p. 81.

Four or six conical canine teeth and three or more series of rounded molar teeth in both jaws. Cheeks scaly. The spines of the dorsal (eleven or twelve) can be received in a groove; threo anal spinos. Seales of moderato size. Six branchiostegals. Pyloric ap-

* 1. Sparus bilobatus, Lacép. iv. p. 141.-Chrysophrys bilobata, Cuv. \& Vul. vi. p. 125. - From a drawing.

2. Renard, fol. 21. no. 214.-Chrysophrys coracinus, Cuv. \& Val. vi. p. 133. - Ile de France.

3. Sparus fuscesccns, var., Lacép. iii. pl. 17. f. 3.-Chrysophrys madagascariensis, Cuv. \& Val. vi: p. 135. - From a drawing.

4. Sparus annularis, $\mathrm{Bl}$. Laf. 271.-Chryвophrys annularis, C'uv. \& Val. vi. p. 139.-P'rhaps an imainary species.

5. Sparus forsteri, B3. Shlin. 1. 282.-Chrysophrys forsteri, C'un, \& V'ul. vi. p. 140. - Pacilie. 
pendages in small number; air-bladder sometimes notehed, or with rery short appendages.

Round the coasts of Africa; Indian Ocean; East Indian Scas . Pacific ; Atlantic coasts of the United States.

\section{Chrysophrys aurata.}

X $\rho \dot{v} \sigma o \phi \rho v s$, Aristot. i. c. 5 , ii. c. 17 , iv. c. 10 , v. c. 10 , vi. c. 17 , viii. c. $2,13,15,19$; Athen. vii. p. 328 ; Alian, xiii. c. 28 , xvi. c. 12 ; Oppian, i. p. 7.

Aurata, Columell. viii. c. 16 ; Plin. ix. c. 16 ; Bellon. pp. 192, 193; Rondel. v. c. 2. p. 115 ; Salvian, fol. 174. b. 175 ; Giesner, pp. 110 , 128; Willughby, p. 307. tab. 5. fig. 5; Ray, p. 131.

Aurata vulgaris, Aldrov. ii. c. 15. p. 171.

Sparus, no. 1, Artedi, Genera, p. 35; Gronov. Mus. 1ehthyol. p. 38. no. 90.

Sparus aurata, L. Syst. Nat. i. p. 467 ; Hassclq. Iter Palest. p. 337 : L. Gm. p. 1270 ; Bl. taf. 266 ?; Bl. Schn. p. 270 ; Risso, Ichthyol. Nice, p. 234 ; Brïnnich, Pisc. Mass. p. 36 ; Lacép. iv. p. 57 ; Martens, Reise nach Venedig, ii. p. 424.

Duhamel, Pêches, ii. sect. 4. pl. 11. f. 1.

Mochar, Osbeck, Nov. Act. Nat. Cur. iv. p. 100.

Sparus scriptus, Bl. Schn. p. 279.

Chrysophrys aurata, Cuv. \& Val. vi. p. 85. pl. 145; Guichen. Explor Scient. Alger. Poiss. p. 48; Yarrell, Brit. Fishes, i. p. 111 ; White. Catal. Brit. Fishes, p. 17 *.

D. $\frac{11}{13}$. A. $\frac{3}{11}$. L. lat. 76 . L. transv. 8/17. Cre. pylor. 4.

Vert. 10/14.

The height of the body is $3 \frac{1}{3}$ in the total length, the length of the head four times; the distance between the eycs is rather more than their diameter, which is $1 \frac{2}{3}$ in the length of the snout. Tho præorbital is $1 \frac{1}{2}$ as long as high; a slight protuberance abore the upper anterior angle of the eye. Dorsal spines moderate, of equal strength ; the second and third anal spines nearly equal in size, one-tourth of the length of the head. The spinous portion of the dorsal conspicuously higher than the soft. Back bluish, belly silvery; a dark violet blotch above the angle of the opereulum; a bright yollow band between the eyes.

Mediterranean; western shores of the Peninsula and of France. Occasionally southern shores of England.

a. Adult. Dalmatia.

b. Half-grown. South Deronshire. Muscum Leach.

c. Adult: stuffed. English coast.

\section{Chrysophrys crassirostris.}

Cuv. \& Ial. vi. p. 98. pl. 146.

$$
\text { D. } \frac{11}{13} \text { A. } \frac{3}{11} \text {. L. lat. } 85 \text {. }
$$

The height of the body is $3 \frac{1}{2}$ in the total length, the length of the

* The skin, mentioned by Mr. White as in the Collection of the Britiah Museum, was afterwards referred by him to Pagrus orphus. 
head four times; the distance between the eyes is more than their dianeter. Dorsal spines rather feeble, of equal strength; the spinous portion of the fin not, or searcely higher than the soft; the second anal spine rather stronger than the third, $4 \frac{1}{2}$ in the length of the hear. Back bluish, belly silvery; body striped; a largo black bloteh above the angle of the opereulum; a bright yellow band between the oyes. ( $V a l$.)

Mediterranean.

\section{Chrysophrys globiceps.}

Cuv. Fal. vi. p. 100.

D. $\frac{12}{11} \cdot \quad$ A. $\frac{3}{11}$.

Closely allied to Chrysophrys aurata.

The prxorbital is not so high. Dorsal spines rather feeble, of equal strength. Batk bluish, belly silvery; a blackish blotch above the angle of the opereulum; a bright yellow band between the eyes. Young individuals with three or four eross-bands, each formed by a double series of black points. ( $\mathrm{Val}$.)

Cape of Good Hope.

\section{Chrysophrys cæruleosticta.}

Cur. \& Val. vi. p. 110; Webb \&. Berthelot, Hist. Nat. Iles C'anctr. p. 31. pl. 6. f. 2.
D. $\frac{12}{11}$.
A. $\frac{3}{9}$.
L. lat. 50 .
Caec. pylur. 4.

The height of the body is one-third of the total length; the diameter of the eye is one-fourth of the length of the head, and $1 \frac{1}{2}$ in the distance between the eyes. The upper profile, between the dorsal fin and the snout, forms a quarter of a circle; the crown is slightly convex. Praopereulum with three series of seales. Incisors conical, strong; four series of molars in the upper jaw, three in the lower; no single large molur. 'The third dorsal spine longest, three-sevenths of the height of the body; pectorals very long, extending to the fourth soft ray of the anal. Red, shiuing golden; back with small blue spots arranged in four or five series; a yellow band between the tyes; dorsal fin minutely dotted with blackish.

North-west coast of $\Lambda$ frica.

Acoording to the statement of Valenciennes, the air-bludder is furnished with a great number of short and obtuse appendages on each side.

\section{Chrysophrys laticeps.}

Cynædus, sp., Gronov. Zoophyl. no. 213.

Chrysophrys latiecps, Cuv. \&. Val. vi. 1. 122; Cuv. Règne Anim. Ill. Poiss. pl. 34. f. 2.

lerea leonina, Gronos. Syst. ed. Gray, p. 113.
1). $\frac{11-12}{11-10}$.
A. $\frac{3}{8}$.
I. lat. 65 .
L. transv. 8/17. Vert. $10 / 14$.

The lieight of the body is 23 in the total length, the length of the 
head $3 \frac{2}{3}$. 'The upper profile of the neck is slightly parabolic, and that of the head straight, obliquely desecnding. The spuee between the eyes is very slightly convex, and equal to $1 \frac{1}{3}$ diameter of the eye; the length of the snout is twice this diameter. 'The præorbital is $1 \frac{1}{3}$ as long as high, and covers the maxillary bone nearly entirely. There are twelve series of scales between the proorbital and the interior ridge of the procopereulum, the limb of which is entirely covered with scales. In both jaws one series of larger molars only ; interiorly with a band of granular molar teeth irregularly arranged. Dorsal spines moderate, compressed on one side; the second and third anal spines nearly equal, and $3 \frac{1}{2}$ in the length of the head. Reddish.

Cape Seas.

a. Adult: stuffed.

b. Half-grown: stuffed.

c. Half-grown : stuffed: not good state. Cape Seas. Presented by Sir A. Smith.

d. Half-grown : skin. False Bay.

e. Adult: skin. From Gronov's Collection.

\section{Chrysophrys cristiceps.}

? Chrysophrys cristiceps, Cuv. \&. Vul. vi. p. 132.
D. $\frac{12}{10}$.
A. $\frac{3}{8}$.
L. lat. 60.
L. transv. 9/22.

The space between the head and the origin of the dorsal fin is elevated, and the height of the body beneath this space is $2 \frac{3}{4}$ in the total length, the length of the head $3 \frac{2}{3}$. The space between the eyes is very convex, and equal to $1 \frac{1}{3}$ diameter of the eye; the length of the snont is twice this diameter. The proorbital is rather longer than high, and covers the maxillary bone nearly entirely. There are ten series of scales between the preorbital and the interior ridge of the præopereulum, the limb of which is entirely eovered with scales. In both jaws one series of larger molars only; interiorly with a band of granular molar teeth irregularly arranged. Dorsal spines modorate, compressed on one side; the second and third anal spines nearly equal, and $3 \frac{1}{2}$ in the length of the head. Reddish, irregularly marbled with greyish.

Cape Seas.

a. Adult: stuffed.

\section{Chrysophrys gibbiceps.}

Chrysophrys gibbiceps, Cuv. \& Val. vi. p. 127. pl. 147.
D. $\frac{11-12}{11-10}$.
A. $\frac{3}{8}$.
I. lat. 53.
I. transv. 9/18.

Napo very gibbous; profile of the head abruptly descending. 'The greatest depth of the body is beneath the nape, whore it is three times in the total length; the length of the heal is $3 \frac{2}{3}$ in the same. The proorbital is as long as high ; its maxillary edgo is emarginate, 
and the greater part of the maxillary bone cannot be hidden below the præorbital; limb of præoperculum scaly; a protuberance above the upper anterior angle of the eyc. Molars small anteriorly, numerous, and irregularly arranged; two large ones on eaeh side, bchind the middle of each jaw. Dorsal spines moderate, of nearly equal strength; the third and fourth nearly equal in length; the second and third anal spines are $3 \frac{1}{2}$ in the length of the head. Red; the soft portions of the dorsal and anal fins black.

Cape of Good Hopc.

a. 23" long: stuffed. Cape Seas. Purchased of Mr. Argent.

b. 21" long: stuffed. Cape Seas. Purchased of Sir A. Smith.

๑. 21" long: not good state: stuffed. Cape Seas. Purchased of Sir A. Smith.

d. $17^{\prime \prime}$ long: skin. False Bay

\section{Chrysophrys calamus.}

Pagellus calamus, Cuv. \& Val. vi. p. 206. pl. 152.

? Pagellus penna, Cuv. \& Val. vi. p. 209; Guichen. in Ramon de la Sagra, Hist. Cub. Poiss. p. 82.

D. $\frac{12}{12}$. A. $\frac{3}{10-11}$. L. lat. 50-56. L. transv. $7 / 19$ Vert. 22.

The height of the body is $2 \frac{3}{4}$ in the total length, the length of the head $3 \frac{3}{4}$. Forehead broad, with a protuberance before the upper angle of the orbit; the upper profile of the snout abruptly descending; the præorbital very large, higher than long; the upper maxillary with a prominent knob at its upper extremity (sometimes absent); the posterior opening of the nostrils a very long slit. Molars above in three series, beneath in two. Canines very distinct with age, and sometimes bent outward. Greenish, with golden longitudinal streaks; dorsal and anal spotted with blackish; ventral blackish.

Atlantic shores of Tropical America.

a. Adult. Bahia. Purchased of M. Parzudaki.

b. Half-grown. Trinidad. Presented by J. B. Richardson, Esq.

c. Fine specimen. Cuba. From the Collection of the Zoological Society.

$d-h$. Adult: skins. Jamaica. From Dr. Parnell's Collection.

$i-m$. Half-grown: skins. Jamaica. From Dr. Parnell's Colleetion.

n. Fifteen inches long: stuffed.

o. Adult: stuffed.

p. Half-grown : stuffed.

This species has very distinct canines when in mature age, and therefore it cannot remain in the genus Pagellus, to which it was reforred by Valeneiennes.

Payellus microps, Guichen. l. c. p. 83. pl. 3. f. 1, appears to be differcnt from the above species, although closcly allied. It is said to have two series of molars in the upper jaw. 


\section{Chrysophrys sarba.}

Russell, pl. 91.

Sparus sarha, Forsk. p. 31 ; L. G'm. p. 1275; 13l. Schn. p. 280 ; Lecrp. iv. pp. 97, 103. bufonites, Lacep. iv. pp. 141, 143. pl. 20. f. 3.

- psittacus, Lacép. iv. pp. 141, 143.

('hrysophrys sarba, Cuv. \& Vul. vi. p. 102; liïm. N. W: Fische. p. 110 pl. 28. f. ].

_ chrysargyra, C'uc. ৫. Tul. vi. p. 107.
D. $\frac{11}{12-13}$.
A. $\frac{3}{11}$.
L. lat. 55 .
I. transv, $7 / 14$.

The height of the body is $2 \frac{2}{3}$ in the total lengtli, the length of the hearl four times; the distance between the eyes is rather more than their diameter, which is $1 \frac{2}{3}$ in the length of the snout. The plieorbital is $1 \frac{1}{3}$ as loug as high; a slight protuberance above the uplere anterior angle of the eye. The incisors are broad, obtuse; the molars in great number, forming four series, aborc and heneath: a large ovate molar at the posterior end of each juw. Dorsal spines moderate, rather compressed, broader on one sicle; the fourth is the longest; the second and third anal spines nearly erpual, 2.3 in the length of the head. Silvery, witl about fouteen indistinct longitudinal streaks in preserved sjecimens.

From the Red sea to the Ile de France and to the Molneca Sea.

11. Adult: stuffed, lied Sea. From the Frankfort Museum.

b. 21 "long: stuffed. From the Collection of the Zoological Socicty.

\section{Chrysophrys haffara.}

Sparus haffira, Forsk. p. 33; L. Gm. p. 1276; Bl. Schn. p. 279.

C'hrysophryz haffara, C'ue. \& Vul. vi. p. 108; Rüpp. N. W. Fische, p. 111. taf. 29. f. 1.

$$
\text { D. } \frac{11}{13} \text {. A. } \frac{3}{10-11} \text {. Ciece. pylor. } 3 \text {. }
$$

The height of the body is one-third of the total length, the length of the head one-fourth. The upper profile of the head is parabolic, prominent above the nostrils, and truneated in front. Dorsal spines moderate, of equal strength; the second anal spine rather stronger; but seareely longer than the thircl, $3 \frac{1}{2}$ in the length of the head; the spinous portion of the dorsal fin higher than the soft. Uniform silvery.

Red Sea.

\section{Chrysophrys bifasciata.}

Valent. Amb. iii. p. 147 ; Renard, ii. 19, 91 (very bad).

Chiotoron bifasciatus, Forsk. p. 64.

Holocentrus rabaji, Lacép. iv. p. 725.

Sparus mylio, Lacip. iv. p. 131, iii. pl. 26. f. 2.

I sabrus catenula, Lacép. iii. p. 467. pl. 26. f. 3.

('hrysophrys bifasciata, C'ue.s.Val.vi. p. 118; Rüpp. N. W' Fische, p. 112.
D. $\frac{11}{13}$.
A. $\frac{3}{10-11}$.
I. lat. 50 .
L. transr. 1 ; 12.

The leeight of the borly is nearly three tumes in the lotal length. 
the length of the head $3 \frac{2}{3}$; the diameter of the eye is $1 \frac{1}{2}$ in the distance between the eyes, and $2 \frac{1}{4}$ in the length of the snout. The proorbital is $1 \frac{1}{2}$ as long as high ; a slight protuberanec ubove the upper anterior angle of the eye. The incisors are broad, obtuse ; the molars in great number anteriorly, posteriorly larger, and forming three series. Dorsal spines rather strong and compressed, broader on one side; the fourth is slightly longer than the third and fifth; the second anal spine longer and stronger than the third, and $2 \frac{3}{4}$ in the length of the head. Silvery, with two black cross-bands from the nape, one through the eye, the other along the posterior margin of the operculum.

Red Sea; East Indian Seas.

a. Adult: stuffod. Red Sea. From the Frankfort Museum.

\section{Chrysophrys aries.}

Temm. \&. Schleg. Faun. Japon. Poiss. p. 68. pl. 31 ; Bleek. Terhand. Batav. Genootsch. xxvi. p. 87.
D. $\frac{11}{13-14}$.
A. $\frac{3}{11-12}$.
L. lat. 58.
L. transv. 8/14.

The height of the body is $2 \frac{1}{2}$ in the total length, the length of the head $4 \frac{1}{6}$; the drameter of the eye is equal to the distance between the eyes, and $1 \frac{1}{2}$ in the length of the snout; forehead somewhat swollen and prominent. The proorbital is $1 \frac{1}{4}$ as long as ligh. The incisors aro rather broad, triangular, pointed; the molars form three serics in the upper jaw and three in the lower, the middle containing several larger teeth. Dorsal spines moderate and somewhat compressed, a little broader on one side; the third, fourth, and fifth are longest; the second anal spine rather stronger, but not longer than the third, and $2 \frac{1}{2}$ in the length of the head. Coloration uniform, with indistinet longitudinal streaks.

Chinese and Javanese Seas.

a. Adult. China.

$b, c$ Half-grown. China.

\section{Chrysophrys taurina.}

Chrysophrys taurina, Jenyns, Zool. Beagle, Fishes, p. 56. pl. 12 ; Valenr. Voy. Vémus, v. p. 330.

_ cyanoptera, Valenc. l. c. Poiss. pl. 4. f. 2.
D. $\frac{12}{12}$.
A. $\frac{3}{10}$.
L. lat. 50 .

The height of the body is $3 \frac{1}{2}$ in the total length, the length of the head four times; the diameter of the eye is twice in the length of the snout. Præorbital elevated. There are four series of scales on the præoperculum and operculum. Above, three series of molar tecth, without a large oval one at the back; two scries in the lower jaw. Dorsal spines moderate; anal spines ratlıce stout, the sceond being a little stronger and longer than the third. White, with four darkbrown much-interrupted hands, giving a mottled appearance.

Chatham Island (Galapagos Archipelago) 


\section{Chrysophrys hasta.}

Sparus hasta, Bl. Schn. p. 275.

Coius datnia, Buch. Ham. Fish. Gang. p. 88. pl. 9. f. 29.

Chrysophrys longispinis, Cux. \&.Vul. vi. p. 116 ; Bleeker, Verhand. Batat. Genootsch. xxv. Nalez. Ichth. Faun. Beng. \& IHind. p. 93.

— berda, Cur. \& Val. vi. p. 113 ; Richardson, Ichth. China, p. 240. - longispinis, Faun. Japon. Poiss. p. 68. p). 32 ; Richardson, Ichth. China, p. 240.

- - schlegelii, Bleeker, Japan, p. 400, and Verhand. Batar. Genootsch. xxvi. p. 86 .

- calanara, Cant. Cutal. p. 48 (not C. $\& \cdot V$.).

- xanthopoda, Richardson, Ichth. China, p. 211.

- auripes, Richardson, l. $c$.
D. $\frac{11-12(13)}{11-10(9)}$.
A. $\frac{3}{8-9}$.
L. lat. 42-45.
L. transv. $\frac{4-5}{11}$.

The height of the body is $2 \frac{2}{3}$ in the total length, the length of the head $3 \frac{2}{3}$; the eye is relatively mueh larger in immature specimens, in which it equals the distance between the eyes, and is $1 \frac{1}{4}$ in the length of the snout. In adult specimens the diameter of the eje is $1 \frac{3}{4}$ in the width of the forehead and twiee in the length of the snout. The præorbital is twice as long as high, and, especially in very large speeimens, considerably notehed, to reecive the posterior extremity of the maxillary bone. There is a rery slight protuberance abore the upper anterior angle of the eye. The incisors are comeal. pointed, of moderate strength; the molars in great number, above in four or even five series, beneath in three, sometimes in four. Dorsal spines strong, compressed, broader on onc side; the fourth is the longest; the seeond anal spine very strong, $1 \frac{1}{2}$ in the length of the head. Opereulum with a rather prominent spine. Silvery; anal blackish, dorsal adged with blackish.

Bay of Bengal, entering the rivers; Chinese and Japanese Seas.

A. Western speeimens with 11 dorsal spines: Sparus hasta, Bl. Schn., Chrysophrys berda, Valenc., but not Sparus berda, Forsk.

a. 15" long: skin. Ceylon. Colleeted by E. F. Kelaart, M.D.

b. $17^{\prime \prime}$ long: stuffed. From the Colleetion of the Zoologieal Society.

c. Adult: stuffed. Bay of Bengal. From Dr. Cantor's Collection as Pagrus flavipinnis.

d. Half-grown. Madras. Presented by J. C. Jordon, Esq.

e. Adult: stuffed.

f. Half-grown. From the Collection of the Zoologieal Society.The second ray of the anal fin is transformed into a spine.

B. Western specimens with 12 dorsal spines: Coius datnia, Buch. Ham., Chr. longispinis, Valene., Bleek.

g. Fine specimen. Caleutta. Presented by G. R. Waterhouse, Esq.

h. Aduit: stuffed. Ganges at Caleutta. Purehased of Mr. Warwiek.

i. Adult: stuffed. Bay of Bengal. From Dr. Cantor's Colleetion as Pagrus flavopinnis. 
C. Western specimen with 13 dorsal spines.

k. Adult: stuffed.

D. E'asteru specimens with 11 dorsal spines: Chr. longispinis, Schleg., Richards., Chr. aunthopoda, Richards., Chr. schlegelii, Bleek.

l. Half-grown. China.

m. Half-grown. Clina. Presented by J. R. Reeves, Esq.

n, o. Adult: stuffed. China. Presented by J. R. Reeves, Esq.-

Types of Chr. vanthopoda and Chr. auripes, Richardson.

$p, q$. Adult and half-grown: skins. China. Purchased of Mr. Warwick.

$r$. Adult: stuffed. Japan.

s. Adult. From the Haslar Collection?

t. Adult: stuffed. (Named Chr. maryinata?)

u. ? Adult: bad state. N.W. Australia. Presented by Sir J. Richardson.

The fine series of specimens in the Collection of the British Museum has enabled me not only to rectify the synonymy, but to form also a judgment on the differences observed in fishes from different localities. Above all, there are three fishes described by older authors: Sparus berla by Forskål, from the Red Sea, Sp. hasta by Schneider, from the coast of Coromandel, and Coius datnia by Buchanan Hamilton, from the Bay of Bengal. The description of the first would appear too insufficient to admit of a decision but for the figure given by Rüppell, which undoubtedly represents the same fish. We shall afterwards see that it is highly probable that the Red Sea fish must be separated from those of the East Indies, and that Valenciennes is wrong in applying the name of Sp.berda to the latter. Not having had specimens from the Red Sea, or the figure published by Rüppell, Valenciennes was unable to compare both species. Thus the second name, Sp. hasta, given by Schneider, has the right of priority. Schneider had a specimen with eleven dorsal spines, and he gives a good diagnosis, by which the fish may be easily recognized; and his specimen coming from the coast of Coromandel, cannot be identified with Forskål's fish. With regard to Coius datnia, Buch. Ham., I have shown above (p. 283) that Cuvier was entirely wrong when he confounded it with Datnia argentea (Therapon argenteus, m.); the description given by Buchanan Hamilton is quite correct, and there cannot be the least doubt, from the dentition stated, that this ichthyologist described a Sparoid fish. The figure is excellent, and agrees with the specimen $(g \cdot)$ of the British Museum Collection as if it were drawn from it.

In the sixth volume of the 'Histoire Naturelle des Poissons,' Valeneiennes confounds, under the name of $C h r$. berda, Bengal specimens of Sparus hasta with eleven dorsal spines, and Sp. berda, Forsk. Under the name of $\mathrm{Chr}$. longispinis, he unites specimens from Japan and those from Bengal with twelve dorsal spines.

Schlegel and Riippell have not compared their specimens with examples from other localities: the former applies Valenciennes's name 
of Chr. longispinis to those from Japan - the latter correctly restores Forskil's namo to the Red Sea fish (the following species), and gives an excellent figuro.

Sir J. Riehardson, in his Report on the Ichthyology of the Seas of China and Japan, has, in my opinion, entirely mistaken these fishes in the British Museum Collection, the Chinese and Japanese specimens of which only he has examined. Ho refer's those preserved in spirits (sp. l, m.) to Chr. berda; another (sp. r.), deformod by stuffing, and probably purchased in Holland, to Chr. longispinis; finally, two other stuffed specimens $(n, o)$, presented by Mr. Reeves, and differing little from each other, which better retained their natural form, were consider d by him as types of two new speciesChr. auripes and xanthopoda (? xanthopus).

Bleeker made no reference to $C h r$. berda, Valenc., probably because he though it identical with the fish described by Forskâl and Rüppell, and endeavoured to show a specific differenee betweon the Bengal specimens and those from the Japanese Seas,-taking for tho former the name of Chr. Tongispinis, and for the latter anew denomination, Chr. schlegelii. All the Bengal specimens of his Collection exhibited twelve dorsal spines, and examples with eleven wero unknown to him.

After having thus illustrated the symonymy of this and the following species, I shall make some remarks on the differences found in tho specimens from different localities, and first compare the Red Sea fish with those from the East Indies. Although not having a specimen from the Red Sea, the figure given by Riippell appears to be quite correet, like all contained in his admirable works on the fishes of tho Red Sea, and fully sufficient for the purpose. From that figure it may be seen that the Red Sea fish has a mueh higher body even than those from Bengal, which are said to be higher than those from Japan; secondly, it has the second anal spine much shorter than any of the East Indian or Japaneso specimens ; thirdly, there is a very conspicnous opercular spine in all the specimens from the East Indies, Japan, and China, but nothing of it is mentioned in the Red Sea fish or marked in the figure, - a character which certainly would not have been overlooked by so accurate an observer as Dr. Rüppell. From these differences I am induced to believe that Sparus berda, Forskil, forms a really separate species.

In the East Indian specimens the following differeneos were observed:-

1. Bleeker states the Bengal fish to be higher than that from Japan; I found, in specimens of the samo size, the height of the body, absolutely, and compared with tho total length, exactly the same. There are, moreover, Bengal specimens in the British Musom Collection with a body not so decp as may be observod in exanples from China. There is some rariation in this respect in all the species of fishes, according to their sex, or to the season in which they are eaught. At all events, the difference appears to be less than between the lied Sea fish and the species firm the Fast Indies.

2. Blecker states cleven rlorsal spines for the Japanese fish, and 
twelve for the Bengalese. It is evident from my examination that the number varies in the latter. It must be eonsidered a rule in those fishes with a truly single dorsal fin, composed of a spinous and soft portion, that often one or two soft rays, nearest to the spines, are transformed into true spines, the number of the latter thus appearing to be increased. That is the ease in this species, where we find specimens with eleren spines and eleven rays, or others with twelve spines and then with ten rays only. This view is very nicely illustrated by a speeimen of this (and of other) species in the British Museum Collection, where the sceond ray of the anal fin is transformed into a true spine. A variation of the spines, corresponding to that of the rays, is much less observed in those Acanthopterygii which have the dorsal divided by a more or less deep noteh.

3. Valenciennes says that his Chr. longispinis from Japan and Bengal has a somewhat longer second anal spine than the other (Chr. berda, Val., from Pondicherry), and Bleeker states nearly the contrary, viz. that the Bengal fish has that spine longer than the Japanese one. There is variation also in this respect: immature and half-grown specimens have that spine generally relarively longer ; but wo find specimens of the same size, from Japan and Bengal, where this spine is equal.

4. I could not observe a conspicuous difference in the height of the dorsal fin, as stated by Bleeker.

5. The examination of any of the Sparoids in different ages shows that the molar teeth are subjected not only to a regular reproduction, like the front teeth, but also to a different arrangement. Therefore the number of the series of molars and their shape ean be used as a specific character only when founded on the examination of several speeimens. If there aro several series of molars, the inner series generally contains the smallest ones and extends more or less backwards, so that sometimes a specimen appears to have one series more than another. This is the ease in the two fishes on which Sir J. Richardson has founded Chr. auripes and canthopoda, the latter of which had lost moreover one of the eanines. Both the specimens are stuffed skins, one-half of which only is preserved.

\section{Chrysophrys calamara.}

Calamara, Russell, i. pl. 92.

Chrysophrys calamna, Cuv. \& Val. vi. p. 117 ; Bleeker, Verhand. Batar. Genootsch. xxiii. Spar. p. 10.

- berda, Bleek. Topogr. Batav, and Ichth. Madura.

$$
\text { D. } \frac{11}{11} \text {. A. } \frac{3}{9} \text {. L. lat. } 35 \text {. }
$$

The height of the body is $2 \frac{2}{3}-2 \frac{3}{4}$ in the total length, the length of the head about four times; the diameter of the eye is one-fourth of the latter and equal to the length of the snout. The molars in four or five series, tho largest ones in the outer series. The praorbital is much lower than the orbit. There are five series of seales between the præorbital and the angle of the proopereulum. Dorsal 
spines strong; the fourth is the longest, one-third of the length of the head; pectoral fins longer than the head, and reaching to the origin of the anal; rentral fins shorter than the head, with the spine as long as one-third the height of the body ; the second anal spine very strong, $2 \frac{1}{5}-2 \frac{1}{2}$ in the length of the head; caudal emarginate, with the lobes obtuse. Silvery-greyish, with twelve darker longitudinal streaks; the vertical fins black-edged. (Bl.)

Indian Archipelago.

\section{Chrysophrys berda.}

Sparus berda, Forsk. p. 32 ; Lacep. iv. pp. 31, 105.

Chrysophrys berda, Rïpp. N. W. Fische, p. 120. taf. 27. f. 4 (ngt Cuv. \& $V a l$.).

$$
\text { D. } \frac{11}{11-12} \text {. A. } \frac{3}{10} \text {. }
$$

The height of the body is $2 \frac{1}{4}$ in the total length, the length of the head $3 \frac{2}{3}$. The proorbital is twice as long as high, and notched to receive the posterior extremity of the maxillary bone. Dorsal spines strong, compressed, broader on one side; the fourth is the longest, one-half the length of the head, and equal in length to the second anal spine. (Operculum without spine?) Coloration uniforrm. (Riipp.)

Red Sea.

\section{Chrysophrys australis. (Plate XXVIII. fig. B.)}

\section{D. $\frac{11}{10-11}$. A. $\frac{3}{8}$. I. lat. $44-45$. I. transv. 5/13.}

The height of the body is rearly one-third of the total length, the length of the head one-fourth. The diameter of the eye is $4 \frac{2}{3}$ in the latter, and $1 \frac{1}{2}$ in the length of the snout. The molars in four series in the upper jaw and in three in the lower; the posterior ones are the largest. The procorbital is rather lower than the orbit. There are five series of scales between the præorbital and the angle of the præoperculum. Dorsal spines strong; the fourth is the lungest, and nearly one-half of the length of the head. The second anal spine very strong, equal in length to the fourth of the dorsal. Silvery, with shining golden longitudinal streaks; edge of the spinous dorsal and axil black.

Australian Seas, entering rivers.

a. Sixteen inches long: stuffed.

b. Adult. From the Haslar Collection.

c. Adult: skin. Port Essington. Voyage of H.M.S. Fly.

d. Adult: skin. Port Jackson. Purchased of J. Gould, Esq.

$e, f$. Adult and half-grown: skins. Australia. Purchased of Mr. Warwick.

y, h. Adult: skins. Harvey River. (Fresh water, West Australia.)

Description.-This species belongs to tho group with the body elevated and the anal spines strong, which is formed by Chr. berdin. kasta, and calamara, all being Last Indian speeies. 'The horly is rery' 
compressed, and its greatest height is nearly one-third of the total. The head is relatively rather small, its length being one-fourth of the total; its width between the eyes is $3 \frac{1}{2}$ in its length. The profile of the nape is strongly curved, and descends abruptly like that of the head, which has a slight protuberance between the eyes. The distance from the occiput to the dorsal fin is much longer than to the snout. The snout is moderately elevated, equal to $1 \frac{1}{2}$ diameter of the eye; the upper maxillary, which is nearly entirely hidden by the procorbital, reaches to the vertical from the anterior margin of the orbit. The præorbital has the maxillary edge slightly emarginate, and is $1 \frac{1}{2}$ as long as high. The nostrils are placed before the upper angle of the orbit and remote from each other; the posterior is an elongate slit, the anterior a very small ovate opening. There are five series of scales between the præorbital and the angle of the præoperculum; the inferior limb and the angle are naked. Operculum, sub- and interoperculum covered with scales; the former has the posterior point not prominent. The suprascapula is striated, like the series of scales ascending to the nape of the neck.

The origin of the dorsal fin falls vertically above the root of the pectorals, and its end above the 34 th scale of the lateral line. The spines are strong, compressed, and much broader on one side: the first is two-fifths of the second; the fourth is the longest, nearly one-half of the length of the head; the following gradually dccrease, the last being about two-thirds of the fourth. The soft portion of the fin is rather lower than the spinous, and has the posterior extremity rounded; the fifth and sixth rays are longest, and about threequarters of the longest spine. The distance between the dorsal and caudal fins is rather less than the depth of the tail beneath the extremity of the dorsal fin. The caudal fin is emarginate, with pointed lobes; one of the middle rays is one-half of one of the outer ones. The origin of the anal fin falls vertically below the fifth dorsal ray, and its end a little behind that of the dorsal fin. The first spine is very short; the second is equal to the fourth dorsal spine, though stronger; the third is more feeble and shorter. The anterior rays equal the third spine, and the posterior ones gradually become shorter. The pectoral fin is elongate, and reaches to the origin of the soft anal, the fourth ray exceeding the others in length. The ventrals are much shorter; they are inserted behind the pectorals, and do not extend to the vent; the spine is compressed and rather strong, about three-quarters of the adjacent ray.

The scales are minutely ciliated, higher than long, nearly elliptical but for the posterior margin, which is straight; one of the largest covers four-fifths of the eye.

There are six canine-like teeth in each of the jaws, with a'villiform band behind them. The outer series of the lateral ones is formed by rather conical teeth. There are four series in the upper jaw, the posterior teeth gradually becoming larger; the posterior tooth of the third series is the largest of all. There are three series only in the lower jaw, which have the largest teeth also posteriorly; but there are several other small ones at the hindmost extremity of the jaw. 
The teeth of the upper ${ }_{1}$ haryngeal bones are exeecdingly fine, villiform; those of the lower ones setifurm, with an outer series of larger ones, hook-like.

The eoloration is now uniform silvery, with golden longitudinal streaks; the dorsal fin is blaekish, with a black edge on the spinous portion. The eaudal fin has a broad blackish margin; anal and ventrals blackish; axil black.

\begin{tabular}{|c|c|c|}
\hline & inch & line \\
\hline Total length...... & 9 & 3 \\
\hline Length of the head & 2 & 4 \\
\hline Height of tho body $\ldots \ldots \ldots \ldots \ldots \ldots$ & 3 & 3 \\
\hline Diameter of the yye .............. & 0 & 6 \\
\hline Distanee between the eyes . . . . . . . . . & 0 & 8 \\
\hline Length of the fourth dorsal spine ..... & 1 & \\
\hline — of the eleventh dorsal spine $\ldots$. & 0 & 9 \\
\hline of the fifth dorsal ray . . . . . . . . & 0 & 10 \\
\hline - of the second anal spinte . . . . . . & 1 & 1 \\
\hline - of the third anal spine $\ldots . .$. & 0 & 10 \\
\hline - of the pectoral............ & 2 & 7 \\
\hline - of the ventral ............ & 1 & \\
\hline - of the ventral spine. . . . . . . . . & 1 & \\
\hline _ of a scale . . . . . . . . . . . & 0 & \\
\hline eight of a seale. & 0 & \\
\hline
\end{tabular}

\section{Chrysophrys aculeata.}

? Aurata bahamensis, Catesby, IIist. Carol. p. \& pl. 16.

? Sparus chrysops, L. Gm. p. $1277 ;$ Bl. Schn. p. 277.

Chrysophrys aculeata, Cuv. \& Val. vi. p. 137.

$$
\text { D. } \frac{12}{12} \text {. A. } \frac{3}{12} \text {. Vert. } 10 / 14 \text {. }
$$

Body rather elongate. A reenmbent spine before the dorsil. Molar teeth small, in three series in the upper jaw. Limb of the præopereulum scaly. Pectoral elongate. Silvery, reddish on the sides, with golden longitudinal streaks; dorsal and anal fins redilish brown; ventrals red. ( $V a l$.

Atlantic Coasts of the United States.

This fish may prove to be a speeies of Sargus, having a recumbent dorsal spine, like the other North American Sargi. It appears to be very near to Sargus ambassis, from which, however, it must be different (if the description of Valeneiennes is correct), having the body mueh more elongate, and tho upper molars arranged in three series. 


\section{Fifth Group. PIMELEPTERINA,}

Sparide with cutting teeth in front, and with teeth on the palate. One genus only.

\section{PIMELEPTERUS*.}

Pimelepterus, (Lacép.) Cur. Règne Anim.; Cuv. \& Val. vii. p. 254. Kyphosus, (Lacép.) Cuv. Règne Anim.

In both jaws a single antcrior scries of cutting teeth, implanted by a horizontal posterior process, behind which is a band of villiform teeth; fine teeth on the vomer, the palatine bones, and on the tongue. The soft portions of the rertical fins thickly enveloped by minute scales; cleven dorsal and three anal spines. Præoperculum generally denticulated. Scalcs of moderate size, bony. Seven branchiostegals. Pyloric appendages sometimes in small number, sometimes exceedingly numerous. Air-bladder notched posteriorly and sometimes antcriorly.

Apparently in all the tropical scas.

\section{Pimelepterus boscii.}

Pimelepterus boscii, Lacép. iv. pp. 429, 430; Cuv. \& Val. vii. p. 258. pl. 187, eop. by Dekay, New York Fauna, Fishes, p. 100. pl. 20. f. 56; Valenc. in Webb \& Berth. Hist. Nat. Iles Canar. Poiss. pl. 19.

Pimelepterus incisor, Valenc. l. e. p. 47 (not Curier).

? Pimelepterus oblongior, Cuv. \& Val. vii. p. 264.
D. $\frac{11}{12}$.
A. $\frac{3}{31}$.
L. lat. 66.
L. transv. 10/20.
Vert. 9/16.

The height of the body is three times in the total length, the length of the head $4 \frac{1}{4}$; the distance between the eyes is $2 \frac{1}{2}$ in the length of the head. The longest dorsal spine is about one-fifth of the height of the body, rather longer than the soft portion of the dorsal, and nearly equal to the longest anal ray. The horizontal process of the teeth not much longer than the vertical. Uniform brownish (in a preserved state); a silvery streak along the præorbital.

Tropical parts of the Atlantic; Sea of Madeira.

a. Adult : skin. Jamaica. From Dr. Parnell's Collection.

b. Adult: stuffed. Cuba. From Dr. Poey's Collection.

c. Half-grown: stuffed. Madeira. From the Rev. R. T. Lowe's Collection.

* 1. Pimelepterus dussumieri, Cuv. \& Val. vii. p. 273; Cuv. Règұ̨e Anim. Ill. Poiss. pl. 43. f. 1.-Bay of Bengal.

2. Pimelepterus raynaldi, Cuv. \& Val. vii. p. 274.-Sunda Sea.

3. Pimelepterus oblongior, Cant. Catal. p, 174.-Pinang.

4. Pimelepterus incisor, Cuv. \& Val. vii. p. 266 (not Valenc. in Webb \& Berth.).-Brazil.

5. Pimelepterus indicus, Cuv. \& I Fl. vii. p. 270; Faun.Japon. Poiss. p. 86.Japanese Sea.

6. Pimelepterus lrevifrons, Tschudi, Fuun. Peruan. Ichthyol. p. 18.-Linua. 


\section{Pimelepterus fuscus.}

Xyster fuscus, (Commers.) Lacép. v. pp. 484, 485.

Pimelepterus fuscus, Cuv. \& Val. vii. p. 264; Rïpp. N. W. Fische, p. 34. taf. 10. f. 3 .

I) $\frac{11}{12}$ A. $\frac{3}{11}$. L. lat. 68 . L. transv. $12 / 22$. Cæc. pylor. ea. 1000.
Vert. $9 / 16$.

The height of the body is one-third of the total length; the distance between the eyes is $2 \frac{1}{3}$ in the length of the head. The soft portions of the dorsal and anal fins lower than tho longest dorsal spine. The horizontal portion of the incisors three timos as long as the vertical. Uniform greyish.

Cape of Good Hope; Red Sea.

a. 21 inches long: stuffer. Red Sea. From Dr. Rüppell's Collertion.

b. 25 inches long: stuffed.

c, 21 inches long: stuffed.

d. Young. Old Collection, as Chcetodon cyprinoides.

\section{Pimelepterus waigiensis.}

Pimelepterus waigiensis, Quoy \& Gaim. Voy. Freyc. Zool. p. 386. pl. 62. f. 4 .

Pimelepterus marciac, Cuv. \& Val. vii. p. 267; Rüpp. N.W.Fisehe, p. 35. D. $\frac{10-11}{15-14}$. A. $\frac{3}{13}$. L. lat. 75 . L. transv. 12/20. Cæe. pylor. 5-6.

The hoight of the body is $2 \frac{2}{3}$ to $2 \frac{3}{4}$ in tho total length. The breadth between the eyes is $2 \frac{2}{5}$ in the length of the head. The spinous dorsal fin is rather higher than the soft portion and the anal. The horizontal part of the incisors is distinctly longer than the vertical. Greyish; a silvery streak along the præorbital.

Coasts of New Guinca, Java, and Amboyna.

a. Adult. Old Collection, as Chatodon cyprinoides.

b. Half-grown. Purchased of Mr. Frank.

c. Half-grown. Amboyna. Purchased of Mr. Frank.

d. Half-grown: stuffed. From the Collection of the Zoological Society.

e. Young. India.

\section{Pimelepterus lembus.}

Cuv. \& Val. vii. p. 269; Bleck. Batav. p. 469.
D. $\frac{11}{14}$.
A. $\frac{3}{13}$.
L. lat. 60 .
L. transv. 10/18.

The height of the body is $3 \frac{1}{3}$ in the total length; the space between the eyes is $2 \frac{2}{3}$ in the length of the head; the horizontal portion of the incisors is twice tho length of the vertical. The spinous portion of the dorsal fin higher than the soft. Bluish, with brown longitudinal streaks; a golden band from the muzzle through the eye to the opereulum; another from the maxillary to the pricopereulum.

Seas of Batavia and Vanicolo.

a. Adult: not good state. Moluceas. Purehased of Mr. Frank. 


\section{Pimelepterus ternatensis.}

Bkeker, Ternate, ii. p. 604.
D. $\frac{11}{14}$.
A. $\frac{3}{13}$.
L. lat. 60 .

The height of the body is one-third of the total length. The spinous portion of the dorsal rather lower than the soft. Greenish, with brownish longitudinal streaks.

Sea of Ternate.

\section{Pimelepterus tahmel.}

Sciæna tahmel, Forsk. p. 53.

Pimelepterus altipinnis, Cuv. \& Val. vii. p. 270; Bleek. Banka, ii. p. 727.

Pimelepterus tahmel, Rüpp. N.W. Fische, p. 35. taf. 10. f. 4.
D. $\frac{11}{12}$. A. $\frac{3}{11}$.
L. lat. 60 .
L. transv. 9/21.

The height of the body is $2 \frac{3}{4}$ in the total length; the distance between the eyes is $2 \frac{2}{3}$ in the length of the head; the soft portions of the dorsal and anal fins elevated, mueh higher than the spinous. Greyish, with numerous reddish-brown longitudinal stripes. [Pyloric appendages in very great number.]

From the Red Sea through the Indian Ocean and Archipelago to New Guinea.

a. Adult: stuffed. Red Sea. From Dr. Rüppell's Colleetion.

b. Fine specimen. Philippine Islands.

c. Young. Amboyna. Purchased of Mr. Frank.

d. Young.

I here subjoin, as an appendix to this family, the description of a fish which I had no opportunity of examining, and which appears to be nearer the family Pristipomatide, from which, however, it differs by its peculiar dentition.

\section{BORIDIA.}

Boridia, Cuv. \& Val. v. p. 154.

Two dorsal fins, the first with eleven spines. In each jaw three or four series of molar-like teeth; the anterior teeth also molar-like; no teeth on the palate. Cheeks scaly, fins scaleless. Scales of moderate size, not ciliated. Præoperculum denticulated.

Brazil.

\section{Boridia grossidens.}

Cuv. \& Val. v. p. 154. pl. 114.

$$
\text { D. } 11 \mid \frac{1}{13} \text {. A. } \frac{3}{11} \text {. }
$$

Body rather elongate. Caudal forked; spines of the fins of moderate strength and length.

Brazil. 


\section{A D DENDA}

\section{Page 3. Gasterosteus aculeatus}

appears to be found in Iceland.-('fr. Feluer, Fisthe Islouts, p. I:-9.9

\section{Page 4. Gasterosteus argyropomus.}

The amended diagnosis is-

$$
\text { D. } 1 / 1 \mid \frac{1}{12} \text {, A. } \frac{1}{10} \text {. P. 9. Vert. } 1 / 1 \text {. }
$$

Body without any plates. Dorsal spines short, serrated. Insertion of the rentrals rather nearer the first dorsal spine than the seremil: their extremities reach to the tip of the ventral plate. 'L'ho pusterion margin of the candal fin truncated.

Page 4, 2a. Gasterosteus williamsoni.

Giourd, U. S. Parif. R. R. Ztrmed. Fishes, p. 93, and Proc. Ar. Nut. Sc. Priluel. 185i, p. 13:3.

$$
\text { D. } 1|1| \frac{1}{11} \cdot \text { A. } 1 / 7 .
$$

Body without any plates. Dorsal spines exignous and slender, not serrated. Insertion of the rentrals sliglitly in adranee of the secom dorsal spine, their extremitics mot reaching the tip of the ventral plate. The posterior marewin of the eandal fin subcrescentic. (Gii.)

Williamson's Pass (Califurnia).

Page 8. Add to the Symopsis of the Genera:-

Two dorals. Neither preopereular nor ven-

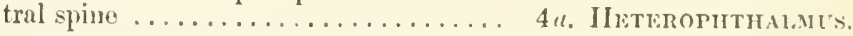

Two dorsals. Proopercular spine none; one ventral spine..................... 7 . Mrripristis.

Page 12. $\Lambda$ dd another genus of BERYCIDE:-

\section{$4 a$. HETEROPHTHALMUS.}

Heterophthalmus, Blecter, Act. Ser. Sc. Indo-Nederl, i. Menmento on Makicass. p. 42.

Muzzle very short, truneated, with the jaws nearly equal. Eye very large. Villiform tecth in the jaws and on the palatine bones. 
none on the vomer. Wight branchiostegals. Opereular bones serrated; præoperculum without spine. Sicales small, ctenoid. Two separate dorsals; ventrals six-rayed, without spine; eaudal forked; anal with two spines. Abdomen serrated.

Sea of Manado.

\section{Heterophthalmus katoptron.}

Bleek. l. c. p. 43.

$$
\text { D. } 5 \mid \frac{1}{14} \text {. A. } \frac{2}{12} . \quad \text { V. } 6 . \text { L. lat. } 60 \text {. }
$$

Eye with a double lobe beneath the pupil. (Bl.) Sea of Manado.

Page 51. Add 1 the Synopsis of the Genera:-

* Lateral line none. Pseudobranchia none; two dorsals. 54a. Lense's.

Page 62. Paralabrax nebulifer.

Figured by Girard in U. S. Pacif. R. R. Exp. Fishes, p. 33. pl. 12. f. 1-4.

Page 63. Paralabrax clathratus.

Figured by Girard in U. S. Pacif. R. R. Exp. Fishes, p. 34. pl. 12. f. 5-8.

\section{Page 67. Labrax multilineatus.}

Syn.: Labrax chrysops, Givard in U. S. Pacif. R. R. Exp. Fishes, p. 29. pl. 11. f. 1-4.

Page 74. Add as a doubtful species to LUCIOPERCA :-

1. Stizostedion boreus, Girard in U. S. Pacif. R. R. Fishes, p. 31. pl. 11. f. 5-8.-Northern rivers of North Amcrica.

\section{Page 77. BOLEOSOMA.}

Fishes closely allied to this and the preceding genus are described by Girard under the name of Arlince effulgens, Proc. Acad. Nat. Sc. Philad. 1859, p. 64, - of Estrella atromaculata, 1. c. p. 65, - of Oligocephalus* lepidus, humeralis, and linsleyi, l. e. p. 67,-of Alvordius maculatus and of Catonotus fasciatus, p. 68.

\section{Page 88. ANTHIAS.}

Add as uncertain species:-

1. Anthias lepidolepis, Bleck. Act. Soc. Sc. Indo-Nederl.ii. p. 37.-Amboyna.

2. - hechtii, Bleek. l.c. p. 38.-Amboyna.

3. Centropristis macrophthalmus, Miill. \& Trosch. in Schomb. Hist. Barbad. p. 666.-Caribbean Sea.

* The praiseworthy attempt to form a generic name according to the rules of scientific naturalists has not bcen attended with success, the name Oligocephalus denoting a fish with a few heads, - and not with a small head, which Mr. Girard intended to signify. 


\section{Page 89. Anthias borbonius.}

Syu. : Serranus delissii, Benn. Proc. Comm. Zool. Soc. i. p. 126.

\section{Page 89. 2a. Anthias manadensis.}

Bleeker, Act. Soc. Sc. Indo-Nederl. i. Manado en Makass. p. 39.

$$
\text { D. } \frac{10}{17} \text { A. A. } \frac{3}{7} \text { L. lat. } 45 \text {. }
$$

The third dorsal spine a little longer than those which follow; ventrals not elongate; the caudal lobes very pointed and produced. Red : each dorsal seale shining golden, with an olive basal spot; body with two, head with three rose-coloured bands; the soft dorsal dotted with yellow. $(B l$.)

Sea of Manado.

\section{Page 89. 2b. Anthias pleurotænia.}

Bleeker, Act. Soc. Sc. Indo-Nederl. ii. Amboina, p. 34.

$$
\text { D. } \frac{10}{17} \text {. A. } \frac{9}{7} \text {. L. lat. } 52 \text {. }
$$

The third dorsal spine, the second ray of the rentral, and the caudal fin elongate. The denticulations at the angle of the prxoperculum stronger. Rose-coloured, with two pearl-coloured bands along the lower half of tho sides of the body. $(B l$.)

Sea of Amboyna.

\section{Page 89. 2c. Anthias cheirospilos.}

Blecker, l. .. p. 36.

$$
\text { D. } \frac{10}{7} \text {. A. } \frac{3}{7} \text {. L. lat. } 40 .
$$

The third dorsal spine very long, filiform, the rentral and caudal fins elongate. The denticulations at the angle of the præopereulum stronger. Rose-eoloured : tho soft dorsal black at the top; anal and caudal fins violet posteriorly; peetorals with a riolet blotch; ventrals violet, with rose-coloured longitudinal bands. (Bl.)

Sea of Amboyna.

\section{Page 91. Anthias macrophthalmus.}

I have lately aseertained that both the specimens from which the diagnosis was taken are from the Mauritins, and should be referred to Serranus filamentosus, Val., from which I do not know how to distinguish the Centropristis macrophthalmus of Miuller and Trosehel. The latter therefore forms, for the present, an unecrtain species of Anthias, whilst it is replaced by

\section{Anthias filamentosus.}

Serranus filamentosus, C'uv. \& Val. vi. p. 500.

Centropristis filamentosus, Miill. \&'Trosch. in Schomb. Irist. Barb. p. 806.

Serranus mitis, Benn. Proc. Comm. Zool. Soc. i. p. 127.

Diagnosis as given of Contropristis macrophthalmus (p. 91). 
a. Large.specimen: stuffed. Ile de France. From Dr. Jauvicr's Collection.

b. Finc specimen. Mauritius. From the Collection of the Zoologieal Society.-Typo of Serranus mitis.

\section{8 a. Anthias zonatus.}

Serranus zonatus, Cuv. \& I Tal. vi. p. 509.

? Serranus argyrogrammicus, Cuv. \& Val. viii. p. 472.

Serranus telfairii, Berm. 7'oc. Comm. Zool. Soc. i. p. 127.

This species is described as Scrranus zonatus, p. 103, but it evidently bclongs to Anthias.

\section{Page 95. Anthias cichlops.}

In a separate copy of Blceker's paper "Diagnostisehe Beschryvingen van nieuwe Vischsoorten van Sumatra," published in Natuurk. Tydschr. Nederl. Indie, iv. 1853, the number of the dorsal spines is wrongly stated to be five, which is evidently a misprint. The proper referenee to this species is-Natuurk. Tydschr. Nederl. Ind. iv. 1853, p. 245 ; and the number of the dorsal fin $\frac{10}{16}$.

Page 99. Add to the uncertain species in Note $\S:-$.

5. Serranus diktiophorus, Bleek. Aot. Soc. Sc. Indo-Nederl. i. Manado en Makass. p. 38.

\section{Page 103. Serranus flamentosus and zonatus} are to be referred to Anthias.

\section{Page 107. 15 a. Berranus amblycephalus.}

Blesker, Act. Soc. Sc. Indo-Nederl. ii. Amboina, p. 32.
D $\frac{11}{16}$.
A. $\frac{3}{8}$.
L. lat. 120.

The height of the body is $3 \frac{1}{2}$ in the total length, the length of the head $3 \frac{1}{6}$; the diameter of the eye is $4 \frac{1}{2}$ in the latter. Snout entirely acaly. Spiniform denticulations at the angle of the preopereulum; sub-and interoperculum entirc. The third, fourth and fifth dorsal spines longest, and as high as the soft portion. Yellowish-brown, with seven brownish-violet cross-bands : the first between the cyes, and trifid below the eye; the second across the neck; the fifth above the anal spines; all the bands with black spots along the margins. (Bl.)

Sea of Amboyna.

\section{Page 141. Serranus hexagonatus.}

Syn.: Serranus stellans, Bleeker, Act. Soc. Sc. Indo-Nederl. i. Ambonna, p. 29. 


\section{Page 154. $127 a$. Serranus melanotænia.}

Bleeker, Act. Soc. Sc. Irido-Nederl. ii. p. 33.
D. $\frac{9}{14}$.
A. $\frac{3}{8}$.
L. lat. 110.

The height of the body is one-fourth of the total length. Roseeoloured, with a broad black band from the eye to the end of the dorsal; body and vertieal fins dotted with white, the dots on the snout, baek, and dorsal fin edged with violet; a large round black spot above, on the base of the eaudal. (Bl.)

Sea of Amboyna.

\section{Pàge 161.}

The name of Plectropoma cyanostigma is to be altered into that of Plectropoma ocellatum, the former having been given by Bleeker to a fish whieh is identieal with Plectropoma leopardinum (p. 157).

\section{Page 169. Pogonoperca ocellata.}

Aceess to the Acta Soc. Scicnt. Indo-Nederl. was only to be obtained after the printing of the family of Percida was nearly finished. It is now erident, from the excellent deseription by Dr. Bleeker eontained in the 2nd volume, p. 31, that the abore fish is identical with Grammistes punctatus, Cuv. \& Val., mentioned in this Catalogue, p. 171. A generie separation from Grammistes, however, appears to be fully justified, and the proper denomination therefore will be Poyonoperea punctata. The speeies not being new, 1 have not considered it necessary to give the figure.

From Amboyna.

\section{Page 178. Genyoroge bengalensis.}

The formula of tho fins has been onitted:-

$$
\text { D. } \frac{11}{14} \text {. A. } \frac{3}{8} \text {. L. lat. } 65 \text {. }
$$

\section{Page 179. Genyoroge cæruleovittata.}

Syu. : Diacope angulus, Benn. Proc. Comm. Zool. Soc. i. p. 127.

Page 179. $5 a$. Genyoroge spilura.

Diacope spilura, Bemr. Proc. Comm. Zool. Soc. 1832, p. 182.

$$
\text { 1). } \frac{11}{12} \text {. A. } \frac{3}{8} \text {. }
$$

On each side five broad, parallel, red longitudinal bands; a large black blotch before the base of the caudal fin; the spinous part of the dorsal with a narrow blackish margin superiorly and inferiorly. (Benn.)

Sea of Ceylon. 


\section{Page 222. AMBASSIS.}

Aad to the diagnosis: Scales deciduous, generally large ; in some species very small.

\section{Page 255. Add a new genus of PERCID正:-}

\section{4a. LEMBUS*.}

Lateral line none. Branchiostegals six; pseudobranchix absunt. Body subfusiform; eleft of the mouth rather wide, with the lower jaw longest. A band of villiform teeth in tho jaws and on the vomer; 110 eanines or palatino teeth. Opereles neitler scrrated nor armed. Two dorsals, the first with seven slender spines; anal spines indistinct. Seales rather small, ctenoid. Air-bladder present.

Fresh waters of Ecuador.

\section{Lembus maculatus.}
B. 6. D. $7 \mid \frac{1}{9}$.
A. $\frac{2}{9}$.
L. lat. 57.
L. transv. 22.

Yellowish, irregularly spotted with blackish: back with fivo dark cross-bars; a black bloteh behind tho extremity of the opereulum; three blackish streaks radiating from the eye; the vertical fins dotted with blackish.

\section{a. Andes of Eeuador. From Mr. Fraser's Collection.}

Description.-This fish is one of the most interesting additions in the eollections sent home by $\mathrm{Mr}_{\mathrm{r}}$. Fraser. It is a true representative, in South America, of the Perches of the $\Lambda$ retic regions. It offers, however, several modifieations of the typical eharacters, the most important of which appears to be tho absence of the lateral line. In gencral appearance it resembles Lucioperea, or some of the other elongate Porches, its greatest height below the spinous dorsal being one-fifth of the total length (without caudal $\dagger$ ). The body is rather thick, its greatest thickness between the opereles being fivesixths of the height. The tail is compressed. The length of the head is one-third of the total; it is rather depressed, broad and flat superiorly, the width between the orbits being $4 \frac{1}{2}$ in the length of the head, or $1 \frac{2}{3}$ the diameter of the eye. The snont is produced, depressed, with the lower jaw longest, and with the eleft of the mouth wide, the upper maxillary reaching nearly to below the middle of the eye. There are two nostrils on each side, far apart from each other: the posterior is near the upper angle of the orbit; the anterior is minute, and close to the upper extremity of the maxillary bone. The eye is of moderate size, one-seventh the length of the head, situated high up the sides, so that its margin interferes

* From $\lambda \epsilon \mu \beta$ os, a small, long, swift boat.

$r$ The candal fin is lost in the single specimen, which is otherwise rery well plescl'ved. 
with the upper profile of the head. The præopereulum has the posterior margin subvertical, the angle and the lower margin rounded; it is longer than high, and has no serrature whatever. The operculum and suboperculum are slightly produced posteriorly into a flexible point. The branchiostegous membrane is fixed to the isthmus, without touching that of the other side. The head is entirely corered with small scales, except the snout.

The spinous dorsal commences at some distance from the vertical from the base of the pectorals, and is composed of seren slender flexible spines, entirely separated from the soft dorsal ; the first spine is rather shorter than the second, the length of which is one-half that of the head; the following become gradually shorter. Tho second dorsal commences nearer to the root of the caudal than to the occiput; it is subquadrangular and rather elerated; the first ray is the shortest, undivided, and may be considered as a spine; the following rays gradually become longer to the last two, which are considerably higher than the spinous dorsal. The commencement and the end of the anal fin fall vertically behind those of the soft dorsal, which it resembles in form; the first two rays are undivided; the sixth branched ray is the longest, higher than the spinous, and lower than the soft dorsal. The pectoral is rounded, and composed of slender branched rays; it does not extend on to the vent. The ventral is inserted exactly below the pectoral, and composed of one feeble spine and fire rays, the fourth of which is the longest, nearly reaching to the rent.

The scales are rather small, etenoid, pentangular, with tho basal margin vertical: there is no trace of a lateral lino.

Each of the jaws is armed with a band of villiform teeth, the posterior of which are more cardiform: no canines. The romerine band is narrow, angularly bent; palatine bones smooth. The pharyngeal bones are separated from each other and toothed, as in the typical Percidce.

The intestines are badly preserved; picees of an air-bladder, however, could be easily detected.

\begin{tabular}{|c|c|}
\hline & \\
\hline Total length (without caudal) .......... & 5 \\
\hline Height of the body $\ldots \ldots \ldots \ldots \ldots$ & 1 \\
\hline Thiekness of the body ............. & 0 \\
\hline Length of the head $\ldots \ldots \ldots \ldots \ldots$ & 1 \\
\hline een the orbits $\ldots \ldots \ldots \ldots$ & 0 \\
\hline e.............. & 0 \\
\hline nd dorsal spine $\ldots \ldots$ & 0 \\
\hline e last dorsal ray $\ldots . . . \ldots$ & 1 \\
\hline - of the sixth anal ray $\ldots \ldots \ldots$ & 1 \\
\hline of the pectoral $\ldots \ldots \ldots \ldots \ldots$ & \\
\hline 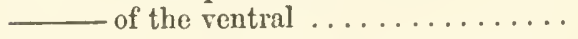 & 1 \\
\hline
\end{tabular}

Page 286. Add to the doubtful species of PRISTIPOMA :-

8. Pristipoma scapularc, Tschudi, Faun. Peruan. Ichthyol. p. 12.-Const of Peru.-It does not appcal to he a species of this genus. 
ADDRNDA.

507

Page 305. Add to the doubtful species of HAMULON:-

3. Hæmulon modestum, Tschudi, Faun. Peruan. Ichthyol. p. 11.-Coast of Peru.-It does not appear to be a species of this genus.

Page 339.

7. Gerres waigiensis, Quoy \& Gaim., is identical with Gerres argyreus, p. 353.

Page 355. Scolopsis margaritifer.

Syn.: Scolopsis margaritifer, Less. Voy. Duperr. Zool. Poiss. p. 198.

Page 360. Scolopsis temporalis.

Syn. : Scolopsis temporalis, Less. Voy. Duperr. Zool. Puiss. p. 197. pl. 26.

Page 381. Pentapus aurolineatus.

Syn.: Dentex lycogenis, Benn. Proc. Comm. Zool. Soc. i. p. 127.

Page 437. Add to the doubtful speeies of SARGUS :-

2. Sargus arenosus, Dekay, Nëw York Fauna, Fishes, p. 91. pl. 22. f. 67.Coast of New York. 



\section{ALPHABETICAL INDEX.}

abbreviatus (Gerres), 345. abbreviatus (Lethrinms), 454 .

abdominalis (Serranus), 97

abu mgaterin, 3:3).

Acanthopterygii, 1.

Acaraya, 198.

Acarne, 480.

acarne(Pagellus), 478,480 .

acarne (Pagrus), 181 ).

aсcепsแm, $16 \%$.

Acerina, 72.

accinil, 73 .

acimac's (Gerves), 351.

Acropoma, $2: 0$.

aculeata (Clirysophrys),

$4 !)(j$.

aeuleatum (Plectropoma), 16 i3.

aculcatus (Gasterostcus), $2,5(x)$.

aculeatus (Obolarius), 2 . acuta (Perea), 60.

acutirostris (Charax), 453.

acutirostris(Serranus), 135

acutirostris (Sparus), 4 ini,

adriaticus, 8 t.

adustus, 22, 37,45 .

senea (Cichla), 2:6.

ancus (Centrarchus), 256. xneus (Serranus), 134.

affine (Diagramma), 319. affinis (Beryx), 11, 13.

akuara, $1+1$ ).

albidus (Labrax), (33.

albo-amreus (Lutjanus), 185.

albo-anreus (Mesoprion), 185.

albofuscus (11olocentrus), 108.

albofuseus (Serranns), 108. alboguttata (Diacope), 182. alboguttatus (Lethrinus), 454.

alboguttatus (Scrianus), 129.

albomaculatus (Scrranus), 105 . alborubrum (IIoloeentrum), $: 36$.

albovittalum (Diagrammia), 330 .

albulus (Bryttus), 259.

album (II:emulon), 311. alcedo (Smaris), 388. alcedo (Sparus), 388. alexandrinus (Scrranus), $9 !$.

alta (Ambassis), 227.

alfipimis, 499.

altivelioides (Serranus), $12 \%$

altivelis (Scrianus), 152.

Alrordins, 5 (1)1.

Ambassis, 2020, 50,5.

ambassis (Centropomus), 22:3.

ambassis (Sargus), 419. ambigua (1)atnia), 270 .

ambiguus (1)ules), 270 .

amblycephahus (Sorranus), $5(13$.

amblyuropterus(Apogon), $2+6$.

amblyuropterus (Apogonichthys), 246.

amblyuropterus (Chilo(lip)rerus), 24?.

amboinensis $(\Lambda$ pogon $), 234$

amboinensis (Genyoroge), 183.

amboinensis (Lethrinus), 455.

amboinensis (Mosoprion), 183.

amboinensis (Serranus), 156.

americana(Lucioperca), 74 americana (Perca), 65.

americamum ( $\Lambda$ pogon), 247.

amcricanus(Amphibrion), 169.

americanus (Apogonichthys), $2 \frac{1}{2} 7$.

americanus (Labrax), Gi.

Amia, 2:30).
Amphacanthus, 28.

Amphiprion, 10, 29 .

analis (1)iacope), 175 .

analis(Hapalogenys), 318

analis (Mesoprion), 194

analis (Serranus), las:;.

anatarius (Lethrinus), 454 . angularis (Serranus), 126.

angulosus (Labrus), 46.

angulus (Diacope), 505.

angustatus (Smaris), 390.

annularis (A pogon), 239.

annularis (Chrysophrys), 483.

annularis (Diacope), 204.

annularis(Mesoprion),204

annularis (Sargus), 445.

ammularis (Sparns), 445, $453,483$.

amulatum (Plectropoma), 1 .

Anoplogaster, 8, 12.

Anoplus, 26.4 .

Anthias, 88.

anthias (Lutjanus), 88.

antillaums(Conodon),30:

Anyperodon, 95.

apeltes, 7:

aper (Coracinus), 426

Apharens, $273,385$.

Aphredoderidx, 271 .

Aphredoderus, 271 .

Aplodactylus, 434 .

Apogon, 229.

Apogonichthys, 245.

Apogonina, 222 .

apogonoides (Ambassis), 224.

apogonoides (Chilodis pterus), 249 .

appendix (Labrus), 261.

appendix (Pomotis), 261, $2 f^{\circ}$.

Aprion, 81 .

aprion (Apogon), 247.

aprion (Apogonichthys),

247 .

aprion (Gerres), 35'.

Apsilus, 8:2. 
apua, 140.

aquila (Seirena), 169.

aquilensis (Pomotis), 261.

ara, 147.

arabica (Perea), 248.

arabicus (Centropomus),

248.

arabicus (Chilodiptorus), 248.

arara, 97.

arctidens(Haplodactylus), 435 .

arcuatum (Hæmulon), $305 \bar{~}$ arenatus (Priacanthus), 215.

arenatus (Rhypticus),173. arenosus (Sargus), 507. areolata (Perca), 149.

areolatum (Plectropoma), 156.

areolatus (Serranus), 149. argentata (Perca), 192. argentatus (Labrus), 192. argentea (Datnia), 283. argentea (Perca), 270. argentea (Sciæna), 291. argenteum (Holocentrum), 28.

argenteum (Pristipoma), 291.

argenteus (Apogon), 245. argenteus (Bodianus), 393. argenteus (Casio), 393. argenteus (Eucinostomus), 339.

argenteus (Lethrinus), 454.

argenteus (Mesoprion). 185.

argenteus (Pomadasis), 291.

argenteus (Priacanthus), 215

argenteus (Sargus), $\mathbf{4 4 .}$

argenteus (Sparus), 388, 466.

argenteus (Therapon). 283.

argentimaculata (Discope), $19^{\circ} 2$.

argentimaculata (Scixna), 192.

argentimaculatus (Mesoprion), 192.

argentinus (Holocentrus), 97.

argentinus (Serranus), 97. aryus (Cephalopholis), 115 argus (Holocentrus), 104. argus (Serranus), 115. argyrea (Cichla), 353. argyrea (Scixna), 353 argyreuru ('Pristipoma), ig:?.

argyreus(Gerres), 353,507. argyrogrammieus (Serranns), 1(13, 503.

argyropomus, 4, 500.

argyrops (Pagrus), 472.

argyrops (Sparus), 472.

argyrosoma (Ijcogenis), 355.

argyrozona (Dentex), 368. argyrozona (Priopis), 22\%. aries (Chrs sophrys), 489. aries (Sargus), 419.

Arlina, 501 .

armatus (Chrotodon), 81. armatus (Enoplosus), 81. aroubiensis (Apogon), 241 Arripis, 252.

ascensionis (Amphacanthus), 28.

asconsionis (Holocentrum), 28.

ascensionis (Lutjanus), 28 . ascensionis (Perca), 28.

areensionis (Sargus), 437. Asper, 78.

asper (Perca), 74.

asperilinguis (Anthias), 89 aspersus (Serranus), 99.

Aspro, 78.

atlierinoides, 404.

atlanticum (Oreosoma), 214.

atlanticus (Lethrinus), 459 atlanticus (Sparus), 130. atrarius, 86 .

atrobranchus, 86.

atromaculata, 501.

auctorum (Lobotes), 338 .

Aulacoeephalus, 173.

aurantiaca (Diacope), 175.

aurantius (Lutjanrss), 326.

aurantius (Serranus), 118.

Aurata, 484.

aurata (Chrysophrys), $\mathbf{4 8 4 .}$ auruta (Perca), 356.

aurata (Scolopsis), 356.

surata (Sparus), 476, 484. auratum (Pristipoma), 287

auratus (Centropomus), 230.

auratus (Holocentrus), 97 . auratus (Scolopsis), 356.

auratus (Serranus), 97.

aureoviridis (Sphyrana),

79.

auriflammn, 404, 405.

anriga (Dules), 266.

auriga (Pagris), 471.

auripes(Chrysophrys), 490

auritum (Pristipoma), 29.3 auritus (Apogon), 24li.

auritus (Apogonichtliys), 246 .

auritus (Tabrus), 261. auritus (Pomotis); 261 .

auriventris (Sargus), $\mathbf{1 4 5}$.

aurolineatum(I Iamulon), 316 .

aurolineatus (Mesoprion), 184.

aurolineatus (Pentapus), $351,57 \%$

aurolineatus(Sparus),381. aurolubens (Centropristes), 207.

aurorubens (Mesoprion), 207.

aurovittatus (Lutjanus), 356.

aurovittatus (Mesoprion), 186.

aurorittatus(Mrullus), 403. australasioa (Macquaria), 286.

australis (Chrysophrys), 494.

aust ralis(Trachichthys), 10 awoara (Serranks), 150. axillario (A pogon), 232. axillaris (Diacope), 175 . axillaris (Myripristis), 19. ayu (Bodianus), 198.

aya (Mesoprion), 198.

azuraureus (Caesio), 392.

azureus (Iothrinus), 451.

baculis, 222.

bahamensis ( 1 urata), 496. balinensis (A pogon), 241.

balteaturu (Diagramma), 328.

balteatus (Plectorhynchus), 327.

balteatus (Sinaris), 389.

balteatus (Upeneus), 402. bandanensis ( $\Lambda$ pogon), 238.

bandi (Mullus), 397.

Banjos, 264.

banjos (Anoplus), 264.

barbatus (Minllus), 401.

barberinoides, 406 .

burberinus, 405 .

barlovi, 222 .

bataviensis(Serranus), 129

batjanensis (Ambassis), 225.

Bellonü (Synagris), 370.

bengalensis (Cienyoroge), 178,504 .

bengalensis (Iolocen(rus), 178 
benmebari (Priacanthus), 218.

bennetti (Dules), 270.

bennettii (Pristipoma), 298.

bensasi (Mullus), 399.

bensasi (Upeneoides), 399

berda (Chrysophrys), 490, 493,494 .

berda (Sparus), 408, 494.

bertheloti (Pagrus), 471.

Berycidæ, 8.

Beryx, 8, 12.

biaculeatus(Gasterostous), 5.

biaculeatus (Upeneus), 410

bicolor (Pristipoma), 288.

bicolor (Rlypticus), 173.

bicolor (Snecticus), 173.

bifasciata (Chrysophrys), 488.

bifasciatum (Diploprion), 174.

bifasciatus (Apogon), 238.

bifasciatus (Chrtodon), 488.

bifasciatus (Heterognathodon), 364

bifasciatus (Mullus), 407.

bifasciatus (Upeneus), 407.

biguttatus (Serranus), 155.

bilineata (Perca), 171.

bilineatum (Pristipoma), 287.

bilineatus (Anthias), 357.

bilineatus (Scolopsides), 357.

bilineatus (Upeneus), 411. bilobata (Chrysophrys) 483.

bilobatus (Sparus), 483.

bilobus (Gerres), 339.

bimaculatus (Scolopsis), 357.

binotatum, 28,40 .

binotatus (Coius), 339 .

bipunctatus(Dentex), 378 . bitaniata (Diacope), 191.

biteniatus (Mesoprion), 191.

bitreniatus (Upeneus), 398 . bivittatus (Centropristis), 82.

bivittatus (Serranus), 82. bivittatus (Upeneoides), 398.

bivittatus (Upenens), 398. bleekeri (Apogon), 245.

bleekeri (Mesoprion), 208. bleekeri (Myripristis), 20. bleekeri (Scolopsis), 361. blochii (Cantharus), 416. blochii (Dentex), 378.

blochii (Diagramma), 329.

blochii (Plectorhynchus), 329.

blochii(Priacanthus), 218. boelang (Serranus), 112.

boenack (Bodianus), 112.

boenack (Serranus), 112.

bogaraveo (Pagellus), 480.

bogaraveo (Sparus), 480 .

Bogoda, 222.

bogoda (Ambassis), 228.

bogoda (Chanda), 228.

bolıar (Diacope), 190.

bohar (Lutjanus), 190.

boliar (Mesoprion), 190.

bohar (Sciæna), 190.

Boleosoma, 77.

bonariense (Hæmulon), 312.

bollariensis (Priacanthus), 216.

bontoides (Serrauus), 149.

bontoo, 138 .

Boops, 418.

boops (Anthias), 216.

boops (Perca), 216.

boops (Priacanthus), 216.

boops (Sparus), 418.

borbonicus (Lethrinus), 454.

borbonicus (Myripristis), 19.

borbonicus (Serranus), 89 145 .

borbonius (Anthias), 89, 502.

borensis (Diacope), 199.

borensis (Mesoprion), 199 .

borens, 501 .

Boridia, 499 .

boscii, 497 .

botche, 19.

bottonensi (Dincope), 181

bottonensis (Genyoroge), 181.

bottonensis (Mesoprion), 181 .

boutton(Holocentrus), 181

bouzetianus (Therapon), 274.

bovinum (Plectropoma), 166.

Box, 418 .

Boxaodon, 395.

brachycentrus, 5 .

brachyrhynchus (Rhynchichthys), 50 .

brama (Cantharus), 416.

brama (Cynædus), 446.

brama (Sparns), 410 .

brandesii, 407. brasilianum (Plectropo-

ma), 164 .

brasikianus (Gerres), 341.

brasiliensis (Centropristis), 85.

breviceps (Pagellus), 473.

breviccps (Pomotis), 261.

brisbanii (Grystes), 251.

britannus (Sparus), 352.

brunneus (Epinephclus), 107.

brunneus (Serranus), 107.

Bryttus, 258.

buccanella (Meso prion), 198.

bufonites (Sparus), 488.

bugaravella (Pagrus), 480 . bungus (Lethrinus), 463.

buphthalmos (Anthias), 87

bürgeri (Glancosoma), 211

buruensis (Ambassis), 226

buruensis (Apogon), 245.

Caballerote, 194.

cabrilla (Perca), 106.

cabrilla (Serranus), 106.

cærulaureus (Cæesio), 392.

cæruleolineata (Diacopo), 209.

cæruleopunctata (Genjoroge), 182.

cxeruleo-punctatus (Holocentrus), 97.

cæruleopunctatus (Mesoprion), 182.

cæruleopunctatus (Serranus), 97.

cœruleosticta (Chrysophrys), 485.

croruleovittata (Diacope), 179.

cerulcovittata (Genyoroge), 179,504 .

cærmlescens (Aphareus), 386.

cxruleus (Cantharus), 417 creruleus (Lethrinus), 454 .

Cresio, 265, 273, 390 .

calamara (Chrysophrys), $490,493$.

calamus (Chrysophrys), 487.

calamus (Pagellus), 487.

calcarifer, 68 .

Callanthias, 87.

calvetii (Diacope), 205.

Camuri, 79.

canadensis (Lucioperca), 75.

canariensis (Boops), 418.

('anariensis(Pagellus), 47:3 eancellata (Datnia). 276. 
cancellatoides, 283.

cancellatus(Scolopsis),361 cancellatus (Therapon),

276.

caninus (Scolopeis), 364. caninus (Serranus), 133.

canna, 310, 311.

Cantharina, 41.2 .

cantharinum (Pristipoma), 303.

Cantharus, 413.

centharus, 414.

cantoris (Apogon), 243.

capensis (Dipterodon), 426

capensis (Pertaceros), 212

capensis (Sargus), 442.

Capcuna, 316.

capeuna (Serranus), 316.

Caprodon, 88, 93.

carauna, 120.

carbonarium, 76 .

carbunculus, 79 .

cardinalis (Chrysophrys), 470 .

cardinalis (Pagrus), 470.

cardinalis (Serranus) 97.

cardinalis (Sparus), 470.

carinata (Monocentris), 9.

carinatus (Ainphiprion),

10.

carinatus (Apogonich-

thys), 247.

caripa, 293 .

Carjpe, 293.

carolinus (l'riacantlus), 219.

carponotatus(Mesoprion), 190.

carui, 185.

eatapluracta (Scixna), 9.

cataphractus (Gisteracan-

thus), 2.

cataphractus (Gasteros. teus), 2.

catenula (Labrus), 488.

catesbyi (l'omotis), 261.

cathurine, 298.

Catochenum, 339.

Catonotus, 501.

catus (Coius), 200.

catus (Scrranus), 130.

caudalis (Mesoprion), 191

caudanotatus(Mesoprion),

185.

canclavituta(Datnia), 284

caudarittatus (Dules), 267

caldiaviltatus (Iolocen-

trus), 2107.

caudimacula (I Irmulon) :31:3.

cauclominculatum (IIolo-

centivum), 41. caudovittatus ('Therapon),

20 's.

cavifrons, $2 \mathrm{ZS}$.

coldifus (1)entex), 377.

celebicus (Scrramus), 139.

celebions (Synagris), 377.

Centrarchus, 200 .

Centriscus, 2,7 .

centrodontus (Pagcllus), $47 i$.

controdontus(Sparus), $\mathbf{4 7 6}$

Centropomus, 74,79 .

Centropristis, $82,174,252$.

centurio(Diagramma),322 centurio (Icthrinus), 460.

ceramensis (Apogon), 235.

cernium (Polyprion), 169.

Cernua, 72.

cernua, 72.

cervinus (Charax), 418.

cervinus (Sargus), $4 \%$.

cetti (Dentex), $34 ; 7$.

cetti (Sparns), $36 \%$.

ceylonicus (Apogon), 229,

$2+4$.

ceylonicus (Mulloides),

404.

ceylonicus (Upencus), +0.t.

Chxrorlynchus, 454.

Chertorlon, 81.

cliatodon (Pomotis), 268.

chetodonoides (Diagrammis ), 326

chictodonoirles(Lutjanus), 320 (i)

chretodomoirles (Plectorhynchus), 3206.

(hirtopterus, 273, 385.

Chanda, 2:2.2.

clammus (Perca), 106.

('hiarax, 45:2.

Clscilodipterus, $2+8$.

cheirospilos, $5(t)$.

chemserydros, tot.

chema (Anthias), 111.

chilensis (Pereichthys), (il.

ehilodipteroides (Scombrops), 249.

Cliiloripterus, 218.

chinensis (Cnidon), 68.

cliirtals, 185.

chlorocephalus(Serranus), l(k).

chloronotum, 286.

chloropterum (I'lectropoma), 164 .

ehiorostigma (Serranus), 1 !).

dilorurum(I'lectropoma), 107.

diristianum, 46 ; chromis (Ifæmulon). 310. chiomis (Pereit), 3|(1).

clirysargyna (Clirysophrys), iss.

dirysargyretur (I lon), 314 .

cliryselis (Smaris), 338.

chry sobation (I'ristipoma), $2 \$ 9$.

chrysomelanurus (Sparus), 111

Chrysophrys, 4ti., 483.

chrysopleturon, Ho.

chrysopomus (Apogon), ¿2t).

chrysops (sparus), titg.

chrysuptera ( $P\left(\mathrm{re}^{2}\right)$ ) 1:39.

chrysopterum (1I:mu-

lon), 313.

chrysopterus (Chilodipter(us), 30.5.

chry *opterus (Iutjantss), :ilis.

clirysosoma ( $\Lambda$ pogon ), 237 clirysostomus (Lethrinus), 457 .

chrysotmua (Apogon), 242

clirysoticuia (Diagramma), 333 .

elurysotemia (Mesoprion), 192.

chrysozona (Crsio), 3i!n. chry surus (Grammistes), isci.

clirysurus (Mesoprion), 186.

clirysurus (Sparus), 196. cichlops (Anthius).!5, it 13. cichlops (Serranus), !5.

ciliata (Perca), li:.

ciliata (Percichthrs), 6:2.

ciliata (Scirna), H4.

ciliatus (Holocentrus).,95.5

cjliatus (Scolopsis), 3isi.

cinctum(Diagramma), 325

cinctum (Plectropona), 102.

cineraseens (Diagramma) 3:3:3.

cinereus (Tethrmus), 453. cincreus ('Therapon), 276 . cinmabarinus (Lethrinus), 4.4.

(innabarinus (Upeneus), 401.

citrinus (Lobotes), 337.

civis (Diacope), 184 .

civis (Genyoruge), 181.

clathratus, (i:3, ixil.

C'niclon, (is.

ron'inea (1)iaropx), 180.

roccinets (A pogon), 2:29. 
coccoi (Microichthrs), 2.29 cocosensis(Lethrinus), 459 coioides (Bola), 127. coioides (Serranus), 127. Colas, $186^{\circ}$.

collaris (Scolopsides), 356 . colonus (Serranus), 101. commersonii (Ambassis), $22: 3$.

commersonii (Labrus), 289.

commersonii (Pristipoma), 289.

conceptionis (Ccntropristis), 84 .

conceptionis(Pristipoma). 300 .

conceptionis (Serranus) 84.

concinnus, 6 .

Conodon, 273, 304.

convexifrons (Pomotis), 262.

Coracinus, 426 .

coracinus (Chrysophrys), 483.

Corniger, 28.

cornigerum

trum), 49.

(Holocen-

cormutum (Holocentrum), 45.

cormutus (Anoplogaster), 12.

coro, 297.

coronatus (Serranus), 124.

corrina (Perca), 291.

Corvulus, 230.

crapao, 137.

crassilabris(Upeneus), 41$]$

crassirostris (Clirysophrys), 484.

crassispinum (Diagramma), 319

Crenidens, 424, 427, 431 . crenidens (Sparus), 424. creolus (Serranus), 100. cristiceps (Chrysophrys), 486.

eroceopterus (Lethrinus), 454.

Crochilus, 114.

crocro, 296.

cruentatus (Labrus), 215

cruentatus (Priacanthus),

$$
215 .
$$

rruentatus (Sparus), 124.

cuniug (Sparus), 390.

cupreis (Apogon), 237.

curridens (Gymnocrotaphus), 432 .

curieri (Gasterosteus), 5. cuvieri (Therapon). 282. (vanescens (boxnodou).

395.

cyanescens (Erythrichthys), 395.

cyasosoma (Ajogon), $2+2$.

cyanopodus, 98.

cyanoptera(Chrysophrys), 189.

cyanopterus (Mesoprion), 184.

cyanostigma (Plectropoina), 157.

cyanostigma (Serrants), 117.

cyanostigmatoides (Serrants), 117.

cyanotxnia(Apogon), 242.

cyanoxanthus(Lethrinus). 454.

'jelostoma (Bodianus),

157.

cyclosíoma (Upeneus), ton cyclostomus, 40!).

cylindricus (Crsio), 393.

cylindricus(Serrants), 1.51

Cyncedus, 4:) 485.

cynocton (Dentex), 366 ;

cynodon(Mesoprion), 194. cynodon (Sparus), 366.

('yprinaides (C'hatodon). tis.

cyprinoides (L'peneus). 404.

damubiensis, 73

Datnia, 27t.

dlatuia (Coius), 28:3, 4\%().

Datnioides, 27.3, $3: 38$.

datnioides (Psammoperca), 69 .

decacanthus (Pentaceros), 213.

decadactylus, 14, 16 .

decemlineata (Diacope), 178.

decussatus (Mesoprion). 210.

delissii, 502.

delphini, 16.

demidoffii, 74

Dentalis, 370 .

dentatus (Apsilus), 188.

dentatus(Mesoprion), 188.

Dentex, $273,366$.

dentex (Cichla), 367 .

dentex(Plectropoma), 160 .

dentex (Spar'us), $\$ 67$.

dermochirus (Serranus), 99.

dermopterus (Serranus). 154 .

Diabasis. $: 30 \mathrm{i}$ diacantha (Perca), (i:

diacantha (Sciana), (i3.

diacanthus(Serranus), 110

Diacope, 175, 184.

diadema 42 .

Diagramma, 318, 337

diagramma (Anthias),329.

diagramma(Grammistes), 329.

diagranma (Perca), 330.

diagramnı (Sparus), 329.

diaphanus (Calliurus), 258

dichropterus, 142.

diktiophorus, 503

dimidiatus, 2 .

Diplectrum, 82.

Diploprion, 174

Dipterodon, 78, 426 .

Dipterygonotus, 395

dodecacantlioides (Mesoprion ), 206.

dodecacanthus (Mesoprion), 206 .

Doydixodon, 431.

dubius(Clisetopterus), 385.

dubius (Mullus), 411.

dubius (Priacanthus), 221.

dubius (Upeneus), 411.

Dules, 266 .

duodecim-lineata, 175.

dussumieri (Ambassis), 2.25.

dussumieri (Chanda), 225.

dussumieri (Pimelepterus), 497.

dussumieri (Pristipoma), 291.

effulgens, 501.

ehrenbergii (Lethrinis), 459.

ehrenbergii (Pagrus), 471. elegans (Hamulon), 306. elliptica (Datnia), 276.

ellipticus (Lutjanus), 357.

ellipticus(Therapon), 276 .

elongata (Perca), 64.

elongatus (Labrax), 64.

elongatus(Lethrinus), 458 .

elongatus(Mesoprion), 185 clongatus (Pomotis), 262. elongatus (Trachichthys), 10.

emarginatus (Cantharus), 416.

emarginatus(Lobotes), 337 emarginatus (Serranus), 134.

emeryii (Mesoprion), 185.

Emmelichthys, 395.

endeka-trenia (Apogon),

241 .

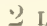


enneacanthus (Mcsoprion), 209.

enneadactylus (Pomacentrus), 356 .

enneastigma (Apogon), 236.

Enoplosus, 80.

ephippium(Plectropoma), 167.

epistictus (Serranus), 128. equula (Gerres), 3.53.

erate (Lobotes), 3.38.

erythracanthus (Lethrinus), 454 .

erythræum (Holocentrum), 32.

erythræus (Serranus), 116.

Erythrichthys, 274, 395.

erythrina (Diacope), 199

Erythrinus, 473.

erythrinus (Mesoprion), 199.

erythrinus (Pagellus), $473,478$.

erythrinus (Pagrus), 473.

erythrinus (Sparus), 473.

erythrogaster(Casio),265.

erythrogaster (Odonto-

nectes), 265.

erythrogaster (Serranus) 133.

erythrognathus (Mesoprion), 185.

erythropterus(Lethrinus), 454.

erythropterus (Lutjancis), 205.

erythropterns (Mesoprion), 20.5.

erythrostoma(Sparus),370 erythrura (Cichla), 352.

erythrurus (Lethrinus), 4.58.

erythrurus (Serranus), 99. erythrurus (Sparus), 352. esculentus (Lethrinus), 460.

Estrella, 501.

etarpe (IIesoprion), 178 .

Etelis, 79 .

Etheostoma, 77 .

Etheostomata, 77.

fallax (Pomotis), 262.

farkharii (Lobotes), 338.

fasciata (Cichla), 258.

fasciata (Perca), 109.

fasciatum (Pristipoma), 301.

fasciatus (Apogon), 241 . fasciatus (Bryttus), 260.

fasciatus (Catonotus), 501. fasciatus (Centrarclius), 258.

fasciatus (Grystes), 252.

fasciatus (Holocentrus), 104.

fasciatus (Lethrinus), 453 . fasciatus (Mullus), 241.

fasciatus (Prionodes), 96. fasciatus (Sarg12s), 418.

fascieulare, 83 .

fasciolatus (Dentex), 376 .

fax, 215,220 .

filamentosum (Catochrenum), 346 .

filamentosus (Anthias), 502.

filamentosus (Cantharus), 378.

filamentosus (Centropristis), 103,502 .

filamentosus(Dentex),371, 378,380 .

filamentosus (Gerres), 245 .

filamentosus(Pagrus),471.

filamentosus (Serranus), 103,502 .

filamentosus (Synagris), 378.

filosus (Dentex), $37 \mathbf{l}$.

fimbriatus (Scrranus), 133.

flavescens (Bodianus), 59.

flavescens (Lethrinus), $45+$

flavescens (Mesoprion), 194.

flavescens (Perca), 59.

flarescens (Serranus), 82.

flavimarginatus (Serranus), 103.

flavipes (Diacope), 175.

flaripinnis (Mesoprion), 185.

flaviventris (Dules), 267.

flavocxruleus (Holocentrus), 145.

flavo-corulcus (Serramus), 145.

flavogittatus (Scrranus), 198.

flavolineatus (II ulhus), 403

fla volineatus(Sargus), 446.

flarolineatus (Upeneus), 403.

flaro-maculatum (Diagramma), 322.

flavorittatus, 403 .

flarus (Serranus), 106.

floriclensis (Bryttus), 260.

floridensis(Calliurus), 260.

fluviatilis (Cernua), 72.

fluviatilis (Perca), 58 .

fretela, 3222 .

formosa (Perea), 305. formosa (Sciæna), 154 .

formosum (Hæmulon), 305.

formosus (Anthias), 306.

formosus (Calliurus), 259

formosus (Serramı), 154

forskalii (Crenidens), 424.

forskalii (Iolocentrus), 109.

forsteri(Chrysoplurys), 483

forsteri (Sparus), 483.

foreatus, 141.

fraterculus, 404 .

freminvillei (Doydixodon), 431 .

frenat us (A pogon), 241.

frenatus (Lethrinus), 453 .

frenatus (Scolopsis), 361.

fucatus (A pogon), 24 .

fulgens (Mesoprion), 185, 197.

fulgens(Priacanthus), 215.

fulva (Diacope), 184.

fulva (Genyoroge), 184.

fulva (Perca), 184.

fulviflamma (Diacope), 201.

fulviflamma (Mesoprion), 201.

fulviflamma (Perca), 201.

fulviflamma(Sciana),201.

fulromaculatum (Hixmulon), 301 .

fulvomaculatum (Pristipoma), 301 .

fulromaculatus (Lahrus), 301.

fulvus (Ilolocentrus), 184.

furcatum (Holocentrum), 29.

furcatus (Apharens), 385.

fureatus (Labrus), 386.

furcosus (Dentex), $3 \overline{7} 3$.

furcosus (Synagris), 373.

fuscescens (Mesoprion), 201.

fuscescens (Sparus), $4 £ 3$.

fuscoguttatus (Serranus), 127.

fuscus (A pogon), 229.

fuscus (Apsilus), 82.

fuscus (Dules), 268.

fuscus (Pimelepterus), 498.

fuscus (Serranus), 134.

fuscus (X yster), 498.

gagarella (Smaris), 388.

gaimardi (Serranus), 150

galeus (Serranus), 130.

gallinaceum, 286 .

Gasteracanthus, 2. 
rasterosteida, 1.

Fasterostcus, 2, 8.

;aterina, 32:2.

gembra (Mesoprion), 193.

reniguttatus (Letlurinus),

4.54

genivittatus (Tethrinus), 454.

Genyornge, 175.

geograplicus (Serranus), 1.0 .

georgianus ( 1 pripis), $25 \%$, georgianus (Centropris-

tis), 2.53.

gerreoides (Pentaprion). $39 k$;

Gerres, 273, :339.

glinam, 36"2.

yhcbul ('Therapon), 281.

Giaret. 38S.

gibba (Diacope), 180.

gibba (Genyoroge), Ist.

gibba (Scirena), 180.

gibbiceps (Chrysopluys), 486.

gibbosa (Perca), 201.

gibbosmu (Diagramma). $31 !$.

gibbosus (1phredoderus), 271 .

gibbosus (Holocentrus). 289.

gibbosus (Pomotis), 241 gibbus (Lutjants), IR().

gigas (Centropristis). 251 . gigas (Holocentrus), 1:2'?. gigas (Oligorus), 2.11.

gigas (Serranus), 13:.

vilberti (Ścrranus), 14\%.

gillissii (Percilia), ‥5.

Girclla, 4:7.

glaga, 247 .

Glaucosoma, 211.

globiceps (Chrysophrys), 48.5 .

gloriosus (Brytus), 260 ). glyphodon (Lethrimus) H(i:2.

gobioides (Dentex), 3i;

Gobius, 78.

godini (Apogon), 2:32.

soldmanni (Diagramma). 331.

soldmanni (Serranus), 1:); goliatl, 97.

gora (Sparus), $\mathbf{3 8 7}$.

goreensis (Box), 4:1.

goreensis(Mesoprion), I?t. goreensis (Pagellus), 4Rl. gorecnsis (Serranus). 1:3:3. gothofindi (Jallorinus), -1:3:) gracilis ( $\Lambda_{\text {rogonichtl }}$ ys), 246 .

gracilis (Perca), (i) .

gracilis (Mmaris), 329?.

grexeus (scatharus), 4.2.2.

Giammistes, 17].

grammopecilum, 2st6.

grande ('Pachymetopon), 4.2.

grandoculis (Cuntharus), 417 .

grandoeulis (Chrysophrys), f(6.).

graurtoculis (Sciena), 405.

grandoculis (Sparus), 465.

graudoculis (Spliarodon), 465.

granulata (Perca), 50)

grisea (Lucioperca), 76.

grisetum (1)iagramma),321

griseus (Cantharus), 414.

griseus (Dentex), 372.

griscus (Mesoprion), 1!4.

grossidens, 4in).

Crystes, 2 . 1.

Grystina, 2.it.

guamensis (Apogon), 20?.

guamensis (Jukes), 20 !)!.

guativere, 98.

guativere (Bodimus). 1:01.

gutaza (Labrus), Illi

grula (Gerres), 341 .

guliminda, $: 364$.

gulosus(Centrarchus).2.5.

gulosus (Pomotis), 20.

gummigutata (Pleetropoma), 166 .

guorahia, 280 ij.

guttata (Perea), 1:24.

guttatus (Bodianus), 11!).

guttatus (Inplodartylus), $4: 34$.

guttatus (Johmius), !7.

guttatus (Serranus), 117 , 119, 124.

gutta-varium (Plectropoma), libi.

guttulatus (Pagrus), 4(is.

Gymmoceplaalis, ?:2.

grimnoceplialus (Jutja11(s), "2.3.

Gymmocrotaphus, 4:32.

gymnodon (Ścicena), 388.

gymnopareius (Servanus). 10 .).

gymnopterus (Carsio), 394.

gymnosus, 145 .

gymnurus, ?".

farmatorhio(])iagramma), :3it. lisematopterus (Ietlurtnus), $4(j-4$

IIxinulon, 273, 30,5.

haffara(Chrysophrys). 4 t'

halfara (Sparus), 4t5, 4si'

hamrule (Anthias), 21!3.

hamrulu (Lutjanus), :219.

hamruhr (Priacanthus). 219.

hamruh" (Scimna), "2l!)

1Japalogenys, 273, 317

IIaplodact ylina, 4:34.

Haplodactylus, $4: 34$.

harak (Iethinus), 458.

harak (Scixna), 458 .

hartzfeldii (Apogon), 24:2.

hasta (Chrysophrys), 4(1)

liasta (Dentex), $37: ;$.

liasta (Lutjanus), 28!).

hasta (Prisi poma), :8!).

liasta (Sparus), 4:11).

liastatum (Holocentrum). 39.

hebraicum (Glaurosoma). 211.

hechtii, $50^{\circ}$

hellmuthii (Heterogniltholon), $3($ it.

Helotes, 27.2 .

helvetica (Perea), 58.

hemistictus(Serramus), 1 1!

hepatus(C'entropristis), it.

hepatus (Grammistes), 281;

hepatus (Holocentrus).St

licpatus (Labrus). $\$ 4$.

hepatus (Semanus), st

heptacanthus, fo!).

heptadiset ylus (Holocentruss), (is).

heptastigna( Ipogon).:2:3l

heptazona (Chilodipterus), 24.8.

heros (Ponnotis), 2tiis.

IIeterolon, 3(it.

heterodon (Iamulon), $31:$.

heterodon (Pagrus), fi.,

lacterodon (Sphacrodon), $4(i)$.

Icterognathodon,27:3iti-1

Heterophthahuus, 51)1 .

hexacanthus (C'entinichus), 257 .

luxacanthus (1)ipterodon), :30.

licxacanthus (Ponotis). $25 \%$

hexagonata (Perea). I 1

liexagonatus (Iloloc'mtivis), $1+1$.

lexagonatus (Simanima). 1.11) :5(1:3 
hexagonus (Lutjanus), 27. hexagonus (Myripristis), 27.

hexazona (Lobotes), 339. hexodon (Dentex), 376 . hexodon (Synagris), 376. hirundinaecus, 87 .

hispanum (Pleetropoma), 165.

hober (Centropomus),201. hoedtii, 139.

hoerenii (Apogon), 237.

hoevenii (Serranus), 138.

holbrookii (Pomotis), 261.

Holocentrum, 8, 22, 28.

holocentrum (Priacanthus), 220.

Holocentrus, 29, 36, 72, 84 .

Homodon, 252.

Hoplostethus, 8.

horridus (Serranus), 136 . hoteen (Mesoprion), 201. hottentottus (Sargus), 448. humeralis (Oligocephalus), 501 .

humeralis (Serranus), 104. humeri-maculatus, 446. humilis (Bryttus), 258. Huro, 255.

hurta (Aurata), 465.

hurta (Pagrus), 465.

hurta (Sparus), 465.

hyalosoma (Apogon), 231.

Hyperoglyphe, 337.

byp=elonotus (Apogon), 232.

hypselosoma(Dentex),37

imberbis (Apogon), 230.

imberbis (Mullus), 230.

immaculata(Diacope), 191

immaculatus(Mesoprion), 193.

immaculatus (Upeneus), 409.

impetiginosus, 142.

incisor (Pimelepterus), 497.

incisor (Pomotis), 261.

inconstans, 2.

incurvus (Lobotes), 338.

indicus (Mullus), 406 .

indicus (Pimelepterus), $4: 7$.

indicus (Upeneus), 406 . indigo (Pleetroponia), 186 inermis (Scolopsis), 357. inermis (Scrranus), 152. inopinatus, 2 .

insidiator (Smaris), 390. intermedius (Gasterosteus), 2. interrupta (Ambassis),226. intermptus (Ambloplites), 257.

interruptus(Centrarchus), 257.

iridea (Perea), 257.

irideus (Centrarchus), 257

iris (Labrus), 257.

iris (Pentapus), 380.

irradians, 83.

isodon (Mesoprion), 206.

itaiara, 99.

italica (Perca), 58.

jacobus, 19.

jacome, 85.

jaguar, 29.

jansenii (Scrranus), 99.

jansenii (Upeneus), 410.

janthinuropterus (Mesoprion), 193.

janthinurus (Mesoprion), 181.

japonicum (Acropoina), 250.

japonieum (Pristipoma), 303.

japonicus (Anthias), 354.

japonicus (Epinephclus), 109.

japonieus (Gasterosteus),9 japonieus (Gerres), 351.

japonicus (Labrax). 71 .

japonicus (Lateolabrax), 71.

japonicus (Lepisacanthus), 9.

japonicus (Lutjanus), 354. japonicus (Monocentris),9 japonicus (Mullus), 404. japonicus (Myripristis), 25 japonicus (Percalabrax), 71.

japonieus (Priacantluus), $217,218$.

japonicus (Scolopsis), 354. japonicus (Sparus), 378.

japonicus (Synagris), 378. japonicus (Upencus), 404. jarbua (Holoeentrus),278. jarbua (Scirena), 278. jocu (Anthias), 194 jocu (Mesoprion), 195. johnii (Anthias), 200.

johnii (Mesoprion). 200 jub (Sparus), 288.

juba (Grammistes), 288.

juba (T'erca), 288.

jubelini, 28fi.

jusculum (Miena), 380 ;

kakaan, 28!) kalloptcrus (Apogon),241.

ballopterus (Letlrinus), 459.

kalosoma (Apogon), 240. kapas (Gerres), 351.

karooi, 185.

karwa (Lethrinus), 454.

kasmira(Grammistes), 178

kasmira (Sciana), 178.

kate, 354.

katoptron, 501 .

kawamebari (Scrranu8), 107.

koilomatodon (Apogon), 234.

kopsii (Ambassis), 224.

korely (Lethrinus), 453.

kunhardtii, 99.

kuntee, 20 .

kurite, $3 \overline{4}$.

Kyphosus, 497.

Labrax, 63.

labrax (Perea), 63, 75

labrax (Seixna), 63.

labriformis(Serranus), 152

Labrus, 4;, 81.

lacteogittatum, 38.

lave (Holoeentrum), 47.

lavifrons, 497 .

licvis (Labrus), 158.

lxvis (Perca), 61.

lirvis (Percichthys), 61.

lala, 22:.2.

lanceolatus(Holocentrus), 107.

lanecolatus(Serranus), 107 laniarius (Pagrus), 407.

lata (Scixna), 465.

Lateolabrax, 70 .

lateralis (Apogon), 229

lateristriga, $4(5)$

Lates, 67.

laticeps (Holocent rum), 38

laticeps(Chrysophrys), $\mathbf{4 8 5}$

latidens (Lethrinus), 464.

latifasciatus (Serranus), 154.

latifrons (Lethrinus), 458.

latus (Apogon), 22?

latus (Pagrus), 46.5.

lebretoniamus, 99.

leignalhos, 21 .

Jeiopsis, 380 .

leiurus, 3 .

Jembus, 505.

lembus (Pinelepterus), 498.

lemniscatus (Serranus), $1.5 \%$

leo. 3.9.

leonina (l'erea), 4k: 
leoninus (Crenidens), 427 .

lconoicles, 28.

leopardinum (Plectropo111a), 157.

leopitrdus (IIolocentrus), 157.

leoparclus (Iabrus), 123.

leopardus (P'lectropoma), 157.

lcopirdus (Serranus), 123.

lepudolepis (Anthias), 501.

lepidopterus (Epineplielus), 97 .

lepilopterus(Serranus), 97

lepirlum (Boleosoma), 77.

lepiclus (Oligocephalus), $50^{\prime}$.

Lepisacantluus, 8 .

lepisurus (Sparus), 190.

leptacanthus (Apogon), 232.

lessonii (Diagramma),329.

lethrinoides (Dentex), 37.2.

Letluinus 453 .

leuciscus (Dules), 270.

leucogrammicus (Anyperodon), 96 .

leucogrammicus (Dipterygonotus), 396.

leucogrammicus (Emmelichthys), 396 .

leucogrammicus (Erythrichthys), 396.

leucogrammicus (Serranus), 96 .

leucostigma (Serranus), 137.

leucotænia (Scolopsis),363

leucotrnioides(Scolopsis), 363.

leucurum (Pristipoma), 286.

leutjanus (Bodianus), 461.

leutjanus(Lethrinus), 461 .

lima, 19, 28.

limbatus (Gerres), 339.

limbatus (Serranus), 125.

linea (Mesoprion), 195.

lineata (Diacope), 193.

lineata (Perea), 248, 330.

lineata (Sciæna), 64, 330.

lincatum (Diagramma), 330.

lineatum(Pristipoma),300

lineatus (A pogon), 239.

lineatus (Beryx), 13.

lineatus (Cantharus), 414.

lineatus(Centropomus), 65

lineatus (Chilodipterus), 248.

lineatus (Gerres), 339.

lincatus (Grammistes),330

lineatus (Labrax), 64 . lincatus (Mesoprion), 193.

lineatus (Pagrus), $4 \mathrm{l}$.

lincat us (Sargus), $\mathbf{H 4}$.

lineatus (ścolopsis), 361, 362.

lineatus (Scrranus), 156.

lineatus (smaris), 339 .

lincatus (Sparus), 387,414

lincolata (Diacope), 20.5.

lincolat us (Apogon), 241.

lineolatus(Contharus), 418

lincolatus (Mesoprion), $205,208$.

linsleyi, sol.

lithognathus (Pagellus), 483.

litura (Mesoprion), 194.

Lobotes, 273, 337.

longifilis (Pagrus), 472.

longimanus (Anthias), 94 .

longipinne (Holocentrum), 28.

longirostris (Labrus), 353.

longispinis(Chrysophrys), $4 ! 11$.

longulus (Bryttus), 259.

longulus (Calliurus), 259.

longulus (Pomotis), 259.

longulus (Scolopsis), 363 .

lophodon (Haplodactylus), 435.

loricatus (Gasterosteus), 2 .

loubina, 79 .

lonti, 101 .

lowei, 17.

lncidus (Gerres), 339.

Lucioperca, 74.

lucioperca, 75 .

luciopercanus, 84 .

luna (Pomotis), 261.

lunaria (Perca), 97.

lunaris (Cesio), 390.

lunulata (Perca), 185.

lunulatus (Lutjanus), 185.

lunulatus(Mesoprion), 185

lunulatus (Serranus), 97.

lupus, 33 .

lutea (Coryphina), 377.

luteus (Dentex), 377.

luteus (Lutjanus), 286.

lutcus (Synagris), 377.

luteus (Úpeneus), 404.

lutjanus, 185.

lutra (Serranus), 126.

lycogenis (Dentex), 381, 507.

lyeogenis (Scolopsides), 355.

inacolor (Diacope), 176.

macolor (Gien yoroge), 176 . macolor (Mcsoprion), 176 . Macquaria, $274,285$. macquariensis (Grystes), 2.is.

maequarieusis (Oligorus), 251 .

macracanthus (Ambassis). $2 \div-7$.

macracantbus (Gerres),

346.

macracanthus (Meso-

prion), 283.

macracanthus (Priacan-

thus), 220 .

macracantlus (Trachypoma), 167 .

macrocephalus (Bodianus), 145 .

macrocephalus (Dentex), 366,465 .

macrocephalıs (Labrus), 366.

macrochir (Pomotis), 263.

macrodon(Centropomus), $2+8$.

maerolepis(Ambassis),227

macrolepis (Bogoda), 227.

macronemus (MFtlus), 405.

macronemus (Synagris), 380 .

macronemus (Upeneus), 405.

macrophthalmus (Anthias), $91,218,502$.

macrophthalmus (Centropristis), 91, 502.

macrophthalmus (Cichla), 370.

macrophthalnus (Dentex), 370 .

macrophthalınos (Plectropoma), 165.

macrophthalmus (Priacanthus), 215.

macrophthalınus(Sparus), 370.

macroptera (Psammoperea), 69.

macropteroides (Apogon), 245.

masropterus (Apogon),

$$
241,245 \text {. }
$$

macropterus(Labrus),257.

macropterus (Briacan-

thus), 215.

macropus (Holocentrum), 31.

macropus (Priacanthus), 216.

macrosoma (Gerres), 353. macrospilos (Serranus),

149 .

macrostoma (Hremulon), 308. 


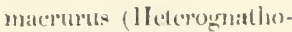
clom), 3ti,i.

matulat (Ajurus), 388.

maculatil (Perca), 130.

mactulatum (Bolcosoma), 77.

maculatum (Plectropoina), 150 .

maculatum (I'ristipoma), 29.3.

maeulatus(Alvordius), 501 maculatus (Anthias), 293. maculatus(Bodianus), 156. maculatus (Cresio), 391. maculatus (Cantharus), 417.

maculatus (Dules), 268. maculatus (IIapalogenys). 317.

maculatus (IIolocentrus), lits.

maeulatus (Jembus), 505. menlatus( Lethrinus), 458 rnacılatus (Lutjanus), 293 macolatus (Mullus), 408. mutulatus (Rhypticus),

$17: 3$

maculatus (Serranus), 108. 130 .

maculatus (I peneus), 418 mateulosus (A pogon), 2:30;. matenlosts (C'entrarchus), 257.

maculosus (Serranus), 99). madigaseariensis (Chrysoplirys), 483.

inatuas (Mesoprion), 200. malabaricus (Upeneus), 407.

Miena, 273, 386.

mixna (Śparus), 386.

mahogoni (Mesoprion),

203.

mahsena (Lcthrinus), 463. mahsena (Sciana), $40 ; 3$. malısenoides (Jethrmus)

463.

mainensis, 6 .

major (Pagrus), 470 ).

malabaricus (Mesoprion),

204.

malabaricus (Sparus), 204.

wato (1)ulcs), 270 .

manudensis(Anthias), 50 ()2. marcrae, 498.

margaritifer (Scolopsis),

$3.35,507$.

margaritifer (Serinuts), li:l.

margaritophorus (Apogion), 23.3.

maruinalis (lipinephelus). maryinalis (Sematums).

$109,1: 3,5$.

marginata (1)iacope), 181 marginata (Genyoroge)

181.

marginata (Perca), (iz).

marginata (Pereichtlys),

$6 *$.

marginatum (IIolocen-

trum), 36.

marginatus (Dentex), 373 marginatus (Dules), 265. marginatus (Mesoprion),

$[8]$.

marginatus (Pomotis). 26; Inarginatus(Serranus), 13:3 marianum, 20.

marina (Lucioperea), 7... marina (Perea), 103, 10\%; marinus (Gasterosteus), 7 . marinus (Holocentrus),

104,106 .

maroceanus (Dentex), 370

martinicus (Smaris), :37. martinicus (Upeneus), 402 massiliensis (Scorpuena).

$16 ?$.

massiliensis (Sparus), 387, 476 .

matejuels, 20.

mato (Dules), 271).

malu’i (Smaris), 389

maxuritianus (Smaris), '392.

mauritianus (Upeneus), 402.

mauritii (Grammistes) 288.

meaco, $2+t$.

mediterraneum (Diagraunma), 3:21.

mediterrancus (IIoplostethus), 9.

megachir (Serranus), 1 to.

Melanichtlıys, 427 .

melanichthys (Creniclens). 427.

melanolencum (I'lectropoma), 157.

melanoleucus (Bodianus), 157.

melanops (Bryttus), 2 (io).

melanops (Cajliurns), 2̈lol. melanops(Percichthys), (il mekinopterum (1'ristipoma ), 287.

melasorhina (I'lectropoina ), 16 iti.

melanorliynchos (.1pogon), 2+1.

molanospilos(Genyoroge). $18: 3$.

melanospilos( Mesoprion). 153.

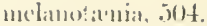

mekmotoptermin (IIolocentrums , 4;3.

melanü (Diacope), 183. melanura(Genyoroge), 183 melanura Oblata), 4\%.2. melantura (Sciana), 445 . Melanurus, 402 . melanurus(Bodianus), 147 unclanurus (stromus), 147 melanurus (Smaris), 3>9. mclanurus (sparus), 42.2. melas (A pogon), 2 t3.

melas (scrranus), 14:3.

mendola (s partis), $381 \%$. mentzelii, 140 .

nerou, 1:32.

mera, 141.

M(soprion, 17\%.

mesoprion (1)entex), 373. metallieus, 204 .

metopias (D) (2uter), 376.

metopia. (Synagris), :7т6.

microcephalus (Gasterosteus), 2 .

microchir (Meroprion), 186 .

microdon (Dentex), .752.

microdon (Ieteromatho(lon), 36 ;

mierodon (Letlurinus), 45:3

Microïchthys, 2.2?

microlepis (Ditnioides). 3:3!).

microlepis(Therapon), ; microlophus (Pomotis), 26 it.

micronotatus (Serranus), 137.

mierophthalmum (IItemulon), :306.

microphthalmus (Myripristis), 24 .

microprion (Lobotes), 372 microprion (Serranus) 116 .

mierops (Calliurus), 258. microps (Pagellus), 487.

Mieropterus, 2.5:2

inicropterus (1'ngrus), $\mathbf{4 6 8}$ microstoma (Holocentrum), 3 .

inicrostoma (Tutjanus), 289.

uniliaris (Scrrants), 99. millepunctatus, 7 . ininiuta (Diacope), 118. miniala ('Perea), $118,119$. miniatus (Letlumus), 454 miniatus (serranus), 118. miniatus (S)ames). 154 minima (Cichla), 258 . mitclibli (I're'a), (j.). 
mitis, 503.

moara (Serranus), 133.

Mochar, 484.

modestum (Hivmulon), 507.

modestus (A pogon), 237.

noensii (Lethrinus), 45.5.

moluccensis (Apogon), $2: 29$

molucensis(Upencoides),

399.

monacanthus (Plectropona), 164.

Monocentris, 8.

momochrous (Apogon), 236

nomogramma (S'colopsis), 358.

monostigma (Mesoprion), 201 .

inorio, 142.

Mormyrus, 481.

snormyrus (Pagellus), 481

mormyrus (Pagrus), 481.

mormyrus (Perea), 106.

morrhua (Serranus), $15 t$.

mucronata (Perca), 65.

mucronatum (Pristipo-

ma), 318.

mueronatus (Hapalogenys), 318.

mucronatus (Labrax), 65.

Mullida, 397.

Mulloides, 40:2.

mulloides (Dentex), 374 .

mulloides (Symagris), 374 .

Mullus, 400 ).

multidens (Dentex), 373.

multifasciatus (Mullus), 407 .

multilineatus(Labrax), $(j 7$, 501.

multitæniatus (Apogon), $209,2+2$.

murdjan, 21 .

murinus (Bryttus), 260.

murinus (Calliurus), 260.

mylio (Sparus), 488.

myriaster (Serranus), 119.

Myriodon, 174.

Myripristis, 8, 19.

mystacinus(Serranus), 109

nageb, 290.

nalua, 223,225 .

nama (Ambassis), 228.

nama (Bogoda), 228.

nama (Chanda), 2:28.

nebiulifer, 62, 501 .

nebulosa (Sciæna), $\mathbf{4 6 0}$.

nebulosus (Centropomus).

82.

nebulosus (Gasterosteus), (i.

nebulosus (letluinus), 1.59 nebulosus (Serranus), 110, 148.

nefastus (Pomotis), 261 .

nematacanthus (Lethrinus), 456.

nematopliorus (Dentex), 379.

nematophorus (Synagris), 379.

nematopterus (Apogon), 233.

nematopus (Dentex), $37 \overline{7}$. nematopus (Synagris), 377

Nemobrama, 16.

nemurus (Dentex), 378 .

nemurus (Hetcrognatho-

don), 36in.

nemurus (Synagris), 378.

niger (Lutjanus), 176.

nigra (Diacope), 176.

nigra (Grenyoroge), 176.

nigra (Scixna), 176.

nigrescens. (Corypliana), 86.

nigri (Gelres), 347.

nigri (Serranus), 112.

migricans (Centropristis), 86.

nigricans (Huro), 255.

nigricans (Labrax), 63.

nigicans (Plcctropoma), 167.

nigrieps (Serranus), 99.

nigriculus, 124 .

nigripinnis (A pogon), 235.

nigripinnis (Hapaloge-

nys), 317.

nigripinnis(Pogonias), 317

nigripinnis (Serranus), 118

uigritus (Serranus), l34.

nigro-fasciatus (Serranus),

112.

nigromaculatus (Apogon),

233.

nigrorubrum (Plectro-

poina), 158.

nigrum (Pristipoma), 289.

nilotica (Perca), 67.

niloticus (C'cutropomus),

67.

niloticus (Lates), 67 .

Niphoir, 80.

niphonius (Priacantlus), 217.

nitens (11apalogenys),317.

nitidum (Diagramma),335

nitidus (Centrarchus), 257

nitidus (Emmelichtliys),

395.

nitidus (Erythrichthys), 395 .

nitidus (Pomotis), 261.

nitidus (Pomoxis), 257. miveatus (Serranus), 130. nobilis (Iates), 68.

nobilis (Polymixia), 17.

noet (Sargus), 414.

notata (Diacope), 181.

notata (Genyoroge), 181.

notatus (Labrax), 67.

nouleny (Serranus), 1206.

nova guince (Apogon),

237.

nove hollandix (Apogon), 2.29.

noveboracensis, 4 .

novem-fasciatus (Apogon), 22?!, 24l.

novemstriatus (Apogon), $2+8$.

nubilus (Pentapodus), 35.' nubilus (Pentapus), :3:2. uuecensis (Grystes), 2j:. nufar (Dentex), 371 .

oblada (Sparus), 42.2.

Oblata. $4: 2$.

obliquatus, 305 .

oblonga (Ambassis), 2:22.

oblongior, 497

oblongus (Gerres),353,354

Obolarius, 2.

obolarius, 2.

obscurus (Centrarchus), 2.58 .

obscurus (Therapon), 275. occidentalis (Gasteros-

teus), 6 .

oceanicus (Holocentrus),

109.

oceanicus (Serranus), 10\%. ocellatum (Plectropona),

161, 504 .

octocinctus (Serranus), 109 octolineata (Diacope), 178 octolineatum (Pristipo-

ma), 303.

octolineatus (Helotes); 285 octolineatus (Mesopion), 178.

octovittata (Diacope), 180. octovittata (Genyoroge),

180.

octovittatus (Chilodiptel'us), $2+8$.

oculatus (Anthias), 92.

oculatus(Centroprist is),9*2 oculatus (Hesperanthias), 9.3.

oculatus (Serranus), 92.

Odontonectes, 265.

ohioensis (Cichla), 258 .

olfax (Serranus), 153.

oligaruthus (Plicetro-

poma). 157.

Oligocephalus, 501 
Oligorus, 251.

olivaceus (Lethrinus), 453.

olivarcus (Mesoprion), 185.

olmstcdi, 77 .

ongus, 142 .

onias (Cynxdus), 420.

opereulare (Holocen-

trum), 47 .

opercularis (Lethrinus), 461.

orbieularis (A pogon), 233 .

orbicularis (Cantharus), 416.

Oreosoma, 214.

orientale (Diagramma), $3: 6$.

orientale (Holocentrum), 36.

orientalis (Anthias), 326.

orientalis (Grammistes), 171.

orientalis (Serranus), 326.

ornatus (Lethrinus), 461.

Orphus, 476.

orphus (Aurata), 467.

orpluss (Pagrus), 467.

orplus (Sparus), 476.

osbeckii (Mæna), 387.

osbeckii (Sparus), 387.

osculatii, 65.

onatabibi (Serranus), 120.

ovatus (Gerres), 313.

orenii (Dentex), 375.

orenii (Synagris), 375.

miss (Sargus), 447.

oris (Sparus), 447.

owenii (Pagellus), 478.

oxyecphalus, 409.

oxygencios (Epinephclus), 169.

oxyrhynchus (Serranus), 114.

oxyrhynchus (Therapon), 281.

osena (Gerres), 3.2.

oyena (Labrus), 352

oyena (Smaris), 353.

pachycentrum (Serranus), 116.

Pathymetopon, 424.

Pagcllus, 473.

Pagrina, 453.

Pagrus, $465,466,476$.

parrus (Dparus), $466,476$.

paikecli, 292.

pallidus, $(i \tau$.

pantherims (Holocen-

(1019), !).

pantherinus (Sorrams), 98

pappilionarcus (Sorranus).

114. paradisæus (Callanthias), 87.

paradiseus(Pentupus),383

Paralibbrax. 62 .

pardalis(Diagramma),323

pardalis (Serranus), 148 .

pargus (Mesoprion), 185.

parkinsonii (Scrranus), 97.

parvidens, 21.

parrus, 41:2.

patachonica (Pleetropoma), 164 .

paroninus (Serranus), 120

partense (P'lectropoma), 165.

pectinatus (Scolopsis), 362

peelii (Grystes), 251.

pelamidis, 50 .

Pelates, 274.

peloritanus (Bodianus), 87

peloritanus (Callantlias), 87.

penna (Pagellus), 487.

pennanti (Perca), 88.

pentacanthus (Bodianus), 29.

pentacanthus (Centrarchus), 256.

pentacanthus (Perca), I7I.

Pentaceratina, 212.

Pentaceros, $21 \%$.

Pentaprion, 274, 396 .

Pentapus, 273, 380 .

Perca, 58.

Percalabrax, 70 .

Percearina, 73

Percichthys, 61.

Percidx, 51.

Percilia, 255.

Percina, 58.

Percoidei, 51

perdix (Apogonichthys), 247.

pernambucensis (Pagellus), 481 .

peronii (Dentex), 376 .

peronii (Pentapus), 381.

peronii (Synagris), 376 .

perotei, 302.

peroteti(Pristipoma), 302.

personatus (Seolopsis),360

pertusa (Perca), 321.

pertusum (Diagramma), $3: 1$.

pertusus (Lutjinus), 321.

peruanus (Serramus), 97.

peruvianus (Gerres), 33:9.

phreops (Scolopsis), 3is.

phact hon (Serrunus), 100.

phaiotinniatus (Mcso-

prion), 207.

philartelphicn, 82 .

phombe, 85 . pliula, 228.

Pliycis, 103.

piea (Diagramma), 326.

picta (Perca), 3:\%.

pictuın (Diagramma), 327.

pictum (Plectropoma), 1 (64

pictus (Grammistes), 327.

pictus (Lutjanus), 327.

pihloo, 292.

Pilcomi, i6

Pinclepterina, 497.

Pimelepterus, 497.

pinjalo (Cresiu), 391.

pisang (Crsio), 390.

pixanga, 98.

plebeius, 2.

Plectorhynchus, 318.

plectorhynchus (Chætodon), 326.

plectorhynchus (Diagramma), 326 .

P'lectropoma, 1:56.

plcurospilus, 407 .

pleurostigma, 407 .

pleurotania, 502 .

plumieri (Centropomus), $30 \%$.

plumieri (Conodon), 304

plumieri (Dipterodon), 2() 2

plumieri (Gerres), 340.

plumicri (Labrus), 305.

plumieri (Perca), 304.

plumieri (Sciæna), 304.

pœcilonotus (Serranus), 155 .

poecilopterum (Diagramma), $3: 29$.

parilopterum (Holocentruni), 32.

pœcilopterus (Apogon) 232.

pœcilopterus (Priacanthins), 220 .

Pocilosoma, 77.

poeti (Gerres), 341.

Pogonias, 317.

Pogonoperca, 169.

polota (Coins), 339.

polota (Datnia), 339.

polota (Datnioides), 339.

Polycentrus, 274, 396

Polymixia, 8, 16.

polyphekadion (Serranus), 123.

polypodophilus (Serranus), $12 y$.

Polypion, 168.

polystigma (Apogonichthys), 2't(i.

polysligrna (Serranus), 12!)

polstactiin (Dingrammu), :3:32, 333. 
polytrenia (Helotes), 285. polytrenioides (Diagramma), 333

pomacanthus(Mesoprion), 210.

Pomatomus, 249.

Pomotis, 261.

pomotis(Centrarchus), 256

pomotis (Scolopsides), 354

Pomoxis, 256.

popeii, 261 .

porosa (Diagramma), 337.

porosa (Hyperoglyphe), 337.

porosus (Pentapus), 382.

porosus (Upeneichthys), 400.

porosus (Upeneus), 400 .

post. 72 .

præorbitalis (Dentex), 368

præstigiator, 85.

pralinius, $20,25$.

praslin, 36.

prayensis, 409.

preciosus, 9.

Priacanthina, 215.

Priacanthus, 215.

Prionodes, 96.

Priopis, 222.

Pristipoma, 273, 286.

pristipoma (Dentex), 380 .

Pristipomatidæ, 272.

Pristipomoides, 273, 380.

Proteracanthus, 426.

Psammoperca, 69.

psittacinus, 86.

psittacus (Sparus), 488.

puella (Plectropoma), 165.

pugetti, 2.

pulchella (Perca), 42.

punctata (Girclla), 427.

punctata (Perca), 63.

punctata (Pogonoperca), 504.

punctata (Scimna), 63.

punctatissimum (Holo. centrum), 38.

punctatissimus (Serranus), 144.

punctatum (Diagramma), 323.

punctatum (Plectropoma), 156.

punctatus (Bryttus), 259.

punctatus (Crenidens), 427

punctatus (Gerres), 346.

punctatus (Grammistes), 171,504 .

punctatus (Haplodacty. lus), 434

punctatus (Holocentrus), 98.

punctatus (Lahris). 101 punctatus (Upeneus), 408 . punctulatum (Pristipoma), 290.

punctulatus(A pogon), 246

punctulatus (Serranus),

101.

pungitius, 6 .

puntazzo (Charax), 453

puntazzo (Sargus), 437.

puntazzo (Sparus), 453.

pusilla (Perca), 230.

puta (Therapon), 280.

pygmæus, 2.

quadracus, 7 .

quadrifasciatus (Apogon), 239.

quadriguttata (Diacope), 190.

quadrilineatum (Hæmulon), 316 .

quadrilineatus (Holocentrus), 282.

quadrilineatus (Pelates), 282.

quadrilineatus (Therapon), 282.

quinquelinearis (Holocentrus), 178.

quinquelineatus (Chilodipterus), $2+8$.

quinquelineatus (Mesoprion), 209.

quinquelineatus (Pelates), $28 \%$.

quoyanus (Serranus), 153.

rabaji (Holocentrus), 488.

Rabirubbia, 186.

radialis, 83 .

radians, 83 .

radiatus, 404.

radja (Diagramma), 331.

radjabou (Holocentrus), 323.

ramak (Lethrinus), 459 .

ramak (Sciæna), 459.

ranga, 228.

Rangao, 199.

rangii (Pristipoma), 286.

rangus (Mesoprion), 199.

rasor (Anthias), 93.

rasor (Serranus), 93.

ratisbonensis, 73 .

raucus (Sargus), 440.

ravenelii (Pomotis), 261.

raynaldi, 497.

reevesii (Serranus), 97.

reginæ (Aplodactylus), 434.

reticularis (Serranus), 150

reticulatum (Diagramma). 334. reticulatus (Bryttuв), 258.

reticuletus (Lethrinus),

457.

retrospinis (Holocen-

trum), 49.

retrospinis (Mesoprion), 210.

rex mullorum, 230.

rhodopterus(Apogon),233

rhodopterus (Lethrinus), 458.

rhombeus (Gerres), 341.

rhomboides (Lagodon), 447.

rhomboides (Sargus), 447.

rhomboides (Sparus), 447.

Rhynchichthys, 50.

rhyncholepis (Serranus), 105.

Rhypticus, 171.

richardi(Mesoprion), 184.

richardsonii (Lethrinus), 456.

richardsonii (Pentaceros), 212.

richardsoni (Tephræops), 432.

richii (Gerres), 339.

rivulata (Diacope), 182.

rivulata (Genyoroge), 182.

rivulatus (Denter), 366, 372.

rivulatus (Serranus), 99.

robustus (Ambassis), 22:2.

rodo, 288 .

rogaa (Bodianus), 116.

rogaa (Perca), 116.

rogaa (Serranus), 116.

rogerii (Pristipoma), 298. ronchus (Pristipoma), 298 rondeletii (Sargus), 440.

rosea (Genyoroge), 180.

roseipinnis, 239.

roseus (Serranus), $\mathbf{y} \vec{i}$.

rosmarus, 135 .

rossica, 73 .

rostratus (Holocentrus), 50

rostratus (Lethrinus), 454

rostratus (Pagellus), 473.

royeri (Smaris), 390 .

rubellus, 185.

rubens (Centropomus), 230.

ruber (Apogon), 230.

ruber (Bodianus), 198.

ruber (Dentex), 373.

ruber (Epinephelus), 98.

ruber (Gymnocephalus),

120.

ruber (Holocentrus), 41

ruber (Mullus), 401.

rubra (Perca), 36, 12:. 
rubra (Sciama), 29, 35. rubricatus (Therapon),:74 rubricauda (I'omotis), 26:" jubrum (Holocentrum).35 rubrum (P'ristipoma), 300 rutolineata (Dianope), 175. rufus ('cutroprist is), 86. rutus (Labrix), (i.). rufus (servamis), :18. rupest lis (Centroponus), (is.

ritjestris (Dentex), 370 rupestris (1)ules), $20 ;$ i rupestis (Serramus), 14.5. vipplii (scolopsirles). :-1.

ruppellii ( 1 pogon), 2:3(i. russellii (Mcsoprion), 181 ruserellii ([ puncus), 106. mutilans (.1phoureis); 396 . Rypticus, 17l.

sacer (Antlias), SR.

sal'e'estimus (( aranxamorils).

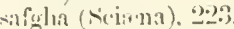

silat" (1rupis), 2.,is.

- הilar (('xutropristes), 253.

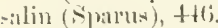

salumoides (Labrus), 2.0\%.

-ilmonoides (Grystes).25

silmumoides (Illolucentrus). 1:28

salmonoides (Nerrmuss), 1로.

Salpa. 2:3.

sulpia (30x), 420 .

salpa (spatus). t:2)

silpoides (Box), t1R.

salviani (sareus), 437.

sambra (Alpliesfes). 19!3.

sammari, 4 ;

sanclat, $\bar{T} t$.

saudlat. 7.5

sangiensis ( $A$ pogron), 235.). sanguinea (1)iacope), 175 . sullineus (Nisoplion). 204.

saponaceus (Inthius), 172 siponaceus (Rliypticus), 17.1.

sarba (C'lurysophrya). 48. salloa (Sparus), tris.

Sarrina, 430 \%.

S:uryus, 2:\%, 4:37, 414.

struns (Saryus), ffl)

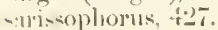

silvatilis (Pereas), 64.

сал:mus (1phimedolerus). 기.

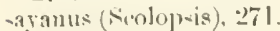
s:ipularo (Prisipoma). int
Scatharus, tou.

schlegclii (Anthias), !13.

schlegelii (Apogon), ‥29.

schlegelii (Avilacoceplatlus), 173 .

schlegelii (Chrrsoplurss), 470.

schlegelii (Erythrichtliys), $39)^{\circ}$.

selmmittii (Priacanthus), 220 .

schomburgkii (Polycentrus). :3i1(;.

scluratzer, $7: 3$.

Schraitser, 7:;

sclurankii, :310.

Sciann, $8,21,2(0,9,1,40,7 !)$

sciandlea, 414 .

Seolopsides. :35t.

Scolopsis, 273, 3.4.

Scombrols, 244 .

scorpanoides (C'entropristes). 175.

scorprenoides (Myriodon), 175.

scriba (Perea), 10.8

seriba (Serranus), 11:3.

seriptura (Lutjamus), 104. scriptus (sparus), $48 t$. sebre (Diacope), 17\%. sebxe (Diagramma), 331. seba (Genyoroge), 176 . sebac (Grammistes), 171. scbre (Mesoprion), 17ti. sebte (Ścrranus), 1:37. scmiarmatus, 3.

semicinctum (Plectrojomia) $16(0$.

scmicinctus (Letlurmus), $45 \mathrm{~s}$.

scmenctus (Yutjanus), 2019.

semicinctus (Mesoprion), "2) (19.).

semifasciatum (Pileoma), $7 \%$.

scmifasciatus (Scrranus), !R.

scmilineatus (Apogon).

")+11.

scmi!una (Sparus), 186.

semipunctatus (Serraun), 114.

senegalensis (Cantharus). $+13$.

septemfasciata (Perea), 114.

septentrionalis ( $\mathrm{P}$ (r)a a) 6 it

Serranina, 81

Sieranus, 8.?, $9.5,97$. serranus (Juijamus), 1616 ; suratogranulata (P'rra) i.). scruatum ( I'lectropoma). (1ii).

sermatus (Gasterostens),

‥

serpula (T'ristipomais), 2 servis (Giammistes). 2-5 servis (Holocentris). "-2 serrus (Therapon), 27. setigerus (Deutux), ::7! setostls ( l'ontapus). : : 20:

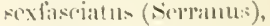
J1s'.

s'xlineatum (Pristipona), $2 x-2$.

sexlincatus (IInlotes). ons.

sexlincatus (Pelatce), 20-3 sexlineatus (Therajon). 2 2)i.

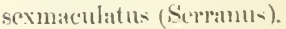
I1心.

serchellinsis (M/mpris(is), 2() .

shilpam (Seruanus), 1111

slyot:1t, :3:0.

siagonofus, -1

sillmensis (Diacoper), iTf;

sibbaldii (Diagramma), $\therefore 27$

signifer" (Bryttus), .25)(i.

sillnoo, $18, \mathrm{i}$.

simmena,

smplex (Crenidens), t2y).

simplex (Girella). 4:?!

sinensis (Sparus), :35!)

sinensis (Symagris), $: 37 !$ )

Smaris, 2073, 经,

smaris (Smaris), 38,8 .

smaris (Sparns), :325, 44.

Sinecticus, 171 .

sobra (Mesoprion), "oms.

soglio, 2 (1).

solis (l'omotis), gil.

fommolentus (Jubotes), $3:$ is.

somncerati (Serranus). 122. sordiclus (Lethrinus), 454. sparicler, 412.

sparoides (Centrarchus), 35.

sparoides (Labrus), 257.

sparulus, 44.5.

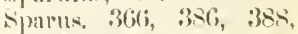
$416,+45,447,+60,47 i$, $4 \times], 4 \times 4$.

sparus (Mesoprion), lsi. speriosus (Pomotis), ¿26:3. speculum (Priacanthus). $2 \cdot 1$.

suluacrodori, $4(0.5$.

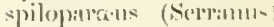
1:5.

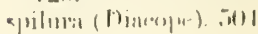


epilura (Genyoroge), 504 . spilurus (Serranus), 123. spilurus (Upeneus), 406. Spinachia, 2.

spinachia, 7 .

spinifer (Pagrus), 472

spinifer (Sparus), 472.

spinifera (Pcrea), 39.

spinifera (Sci:ena), 39.

spiniferum (Holocentrum), 39, 41 .

spiniger (Serranus), $14 f$.

spinosissimum, 36,41 .

spinosum (Holocentrum), 49.

spinosus (Corniger), 49.

spinosus (Niphon), 80.

spinulosus, 5.

splendens (Beryx), 16

Spondyliosoma, 364 .

squalidus (Tlıerapon), 275

squamipinnis (Anthias),

89.

squamipinnis (Gerres), 349

stellans, 141, 503.

stercus muscarum, 39).

stigmapomus (Serranus), 111 .

Stizostedion, 501.

Stone-Bassc, 169.

storeria (Cichla), 257 .

striata (Coryphena), 373 .

striata (Diacope), 193.

striatus (Anthias), 110.

striatus (Cosio), 392.

striatus (Dentex), 373.

striatus(Epinephelus), 10:

striatus (Holocentrus). 81

striatus (Lutjanus), 110.

striatus (Mesoprion), 193

striatus (Roceus), 65.

striatus (Serranus), 110.

stridens, 300 .

subfasciatus (Gerres), 343.

subvittatus (Mullıs), 397.

subrittatus (Upeneus), 397

suillum (Pristipoma), 302.

suillus (Serranus), 127.

Sullanaroo-kuntee, 20).

sulphureus (Upencoides), 398.

sulphureus(Upeneus),398 summana, 127, 137.

sundaicus (Upenerides), 399.

surinamense(Pristipoma), 288.

surinamensıs (Holocentrus), 338 .

sturinamensis (Lobotes), 338.

surinamensis (Lutjanus), $\because 88$. surmuletus, 401 .

susuki (Plectropoma), 160

Synagris, 273, 366, 370, 373.

synagris (Sparus), 202.

tabacariue, 85.

tæniatus (Apogon), 234.

taeniatus (Scolopsides), 357

treniocheirns, 97 .

taniops (Mesoprion), 184.

tæitiops (Serranus), 121.

tieniopterus (Apogon),235

taniopterus (Dentex), 374

treniopterns (S'colopsides), $35 \%$.

tæniopterus(Synagris),374

trmiopterus (Upeneus),

397

treniurus (Dules), 267.

tahmel, 4!).

tambuloides (Dentex), 373

tambulus (Dentex), 378 .

tanaicensis, 73 .

tasmanicus (Centropristes), 253.

taurina(Chrysophrys),489

tauvina, 141, 149.

tayenus(Priacanthus), 221

Telcostej, 1.

telescopium(Pomatomus), 250.

telfairii, 503.

temporalis (Scolopsis), 3i0, 567.

Tephræops, 431.

tephraops (Crenidens), 432.

ter-aculeatus, 3.

ternateinsis (Pimclepterus), 4!n).

teribile (Pristipoma), 294

tessellatum, $7 \pi$.

tetracantluts (Centrarchus), 258.

tetracanthus (Gasterosteus), i).

tetracantlius (Pomotis), 2 (i).

Therapon, 272,274 .

therapon(Pristipoma),293

theraps (Therapon), 274 .

thermalis (Ambassis), 225.

thermalis (Apogon), 231 , $2: 32$.

thunbergii (Dentex), 366 .

thumbergii (Diagramma), 321

tlumbergii (Labrus), 366.

tica (Diacope), 199).

tiere, $: 33,4.5$

tierroicles, 33, 41.

tigrimus(1[oln:entrus). IIt tigrinus (Serranus), 114.

tigris (Serranus), 112.

tile (Cæsio), 393.

timoriensis (Apogon), 238.

timoriensis (Diacoje), 20.5

timoriensis (Mesopurion), 205.

timoriensis (Therapon), 278.

tolu (Dentex), 373.

tonsor (Anthias), 91.

tonsor (Serranus), 91.

torquatus (Scolopsis), :3,56.

torvus (Cynadus), $4(55$.

Trachichthys, 8, 10.

trachurus, 4

Trachypoma, 167.

trachypoma, 25.

tragula (Upeneoides), 39s.

tragula (Upeneus), 398.

tranquebaricus (Sparus), 200 .

transversus (Therapon), 275 .

triacanthus (IIolocentrus), 84

triacanthus (Perca), 171.

tricolor (Cesio), 3!) .

trienspidata (Girella), 428.

trienspidatus (Box), 4:28.

trieuspidatus (Sparns). 387.

tridens(Centropristes), 91.

tridens (Lutjanus), 91.

trifasciatus, 407 .

trifurca (Perca), 91.

trifurcus (Anthias), 91.

triglyphus (Crenidens), $4 \cdot 2$.

trilobus, 86.

trimaculatus (Apogon), $233,2: 38$.

trimaculatus (Serramus), 1(1)!).

triurus (Bodianus), 338.

trivittatus (Coins), 280 ).

trivittatus (Grammistes), :3iti.

trivittatus (Pterapon), 278

irucha, 61.

truncatus (Apogon), 287.

trutta (Perea), 254

truttaceus (Arripis), 273.

truttaceus (Centropristes), 2.74.

tsirimenara(Serranus), 144

tumifrons (Pagrus), 471 .

tumifroms (Chrysophrys), 470.

tumilabloris, l:38.

typus (l'injalo), 391.

typus (Pristipomoides) 
undecimalis, 79 .

undecim-radiatus, 79 .

undulosus (Bodianus), 143

undulosus (Serranus), 143.

unicolor (Bryttus), 259.

unicolor (Chrysophrys), 468.

unicolor (Holocentrus),

167.

unicolor (Pagrus), 468.

unicolor (Pentapus), 382.

unicolor (Plectropoma), 167.

unicolor (Therapon), 277. unimaculata (Perca), 416. unimaculatus (Grammistes), 446.

unimaculatus (Mesoprion), 200.

unimaculatus (Sargus), 446.

uninotatus (Mesoprion), 202.

Upeneichthys, 400.

Upeneoides, 397.

upeneoides (Dentex), 375

upeneoides (Synagris), 375

Upeneus, 397.

ura (Serranus), 147.

urodela (Perca), 122.

urodelus (Serranus), 122. urophthalmus (Serranus),

$$
155 .
$$

urotæenia (Ambassis), 224.

vachellii (Ambassis), 2:7.

vacti, 68 .

vanicolensis (Dules), 266.

vanicolensis (Mulloides),

404.

vanicolensis (Upeneus), 404.

raria (Perca), 86.

variabilis (Cichla), 252.

variabilis (Dentex), 376 .

variabilis (Synagris), 376.

variegatus (Apogon), 246.

variegatus(Lethrinus), 458

variegatus (Serranus), 97.

variegatus (Sparus), 440.

variegatus (Upeneoides), 398.

variolosus. 139.

vermicularis(Spar11s).202. vermiculatus (Haplodactylus), 434.

versicolor (Tabrus), 472 .

vetula (Sargus), 44.

vetula (Sparus), 414. victoriæ (A pogon), 243.

vinosus (Apogon), 237.

violaceum (Holocentrum), 43.

violacelts (Myripristis), 19. virescens (Aprion), 81.

virescens (Holocentrus),

106.

virescens (Lethrinus), 454.

virgata (Datnia), 276.

virgatus (Therapon), 276.

virginicum (Pristipoma), 288.

virginicus (Lutjanus), 288. virginicus (Sparus), 288. viridense (Pristipoma), 302.

viridis (Centrarchus), 256. viridis (Genyoroge), 180.

ritianus, 175 .

vitta (Diacope), 207.

vitta (Mesoprion), 207.

vitta (Pentapns), 381 .

vitta (Serranus), 207.

vittata (Seirena), 171.

vittatus (Hypeneus), 398.

vittatus (Mullus), 397.

vittatus (Myripristis), 24.

vittatus (Pentapus), 382.

rittatus (Sparus), 288, 382.

vittatus (U peneoides), 397 , 399.

vittatus (Upeneus), 398.

vittiger (Apogon), 241.

vitulinum, 165.

rivanus (Mesoprion), 203.

vlamingii (Upeneoides), 400.

rlamingii (Upeneus), 400.

romerina (Mæna), 387.

vosmeri (Anthias), 356.

vosmeri (Lutjanus), 356.

vosmeri (Scolopsides), 356.

vulgaris (Acerina), 72.

vilgaris (Aspro), 78.

vulgaris (Box), 418.

vulgaris (Cantharus), 414.

vulgaris (Dentex), 366.

vulgaris (Mæna), 386.

vulgaris (Pagrus), $4(6,6,473$, 476 .

vulgaris (Perca), 58.

vulgaris (Pomotis), 201 .

vulgaris (Sargus), 437.

rulgaris (Smaris), 387.

vulgaris (Spmachia), 7

waigiensis (Dentex), 366 . waigiensis (Diacope), 1!1. waigiensis (Gerres), 353, 507.

waigiensis (Labrax), 69.

waigiensis (Lethrinus), 453

waigiensis (Mesoprion), 191.

waigiensis(Myriodon), 175

waigiensis (Pimelepterus), 498.

waigiensis (Y'sammoperea), 69.

waigiensis (Seorpæna), 175. waigiensis (U pencus), 406 . webbii, 17.

whitii, 81 .

williamsoni, 500 .

wolffi (Ambassis), 226.

wolgensis (Lucioperca), 74 .

xanthonotus (Cresio), 390.

xanthopleura (Heterognathodon), 365 .

xanthopoda (Chrysophrys), 490.

xanthopterum (Hæmulon), 312 .

xanthopterus (Lethrinus), 454.

santhopterygius (Mesoprion), 205.

xanthopus (Diacope), 181 . ranthotruia (Lethrinus), 461 .

xanthurus (Sparus), 472.

xanthurus (Therapon), 282

Xyster, 198.

yapilli (Mesoprion), 193.

zanana (Serranus), 123. zananella (Serranus), 116. zebra (Crenidens), 43:2. zebra (Gerres), 343. zebra (Mrena), 387.

zebra (Pileoma), 76 .

zebra (Sparus), 387.

zebra ('Teplrreops), 432. zeylonieus (Mluloides), 404.

zeylonicus (Upenens), 404. zillii, 72.

zingel, 78 .

zonuta (Girella), 429. zonatus (Anthias), 503. zonatus (Heterodon), 165. zonatus (Serranus) l (03,503 zostcrophorus (Apogon), 245.

$7 . y$ sron, 375. 


\section{CATALOGUES}

or

\section{THE ZOOLOGICAL COLLECTION}

IN

\section{TIE BRITISH MUSEUM.}

\section{VERTEBRATA.}

List of Mammalia, By Dr. J. E. Gkay, F.R.S., F.L.S. \&e. 1843. 2s. 6r.

Catalogue of the Mammalia. By Dr. J. E. Gray, F.R.S. Re.

Purt 1. Cetacen. $12 \mathrm{mo}, 1850$. 4s., with Plates.

Part 2. Seals. 12mo, 1850. 1s. 6d., with Woodents.

Part 3. Hoofed Quadrupeds. Section I. (Ungulata furci peda). $12 \mathrm{mo}$. 1852, with Plates of Genera, $12 s$.

This work contains the lescription of the genera and species, and figures of the chief character's of the genera.

List of Mammalia and Birds of Nepaul, presented by B. II. IIodgson, Esq., to the British Museum. By Dr. J. E. Gray and G. R. GraY, 12mo. 1816. $2 s$.

Catalogue of Mammalia and Birds of New Guinea. By Dr. J. E. GraY, F.R.S., and G. R. Gray, F.L.S. 8\%o. 1858. 1s. Gd. With Figures.

List of Genera and Subgenera of Birds. By G. R. Gray, F.L.S. $12 \mathrm{mo}, 1855$. $4 s$.

List of Birds. By G. R. Gray, F.L.S., F.Z.S. \&e.

Part 1. Raptorial. Edition 1, 1844; edition 2, 1948. 3s.

Part 2. Passeres. Seetion I. Fissirostres. 1848. 2s.

Part 3. Gallinx, Grallx and Anseres. 1844. 2s. (Out of print.)

Part 3. Section I. Ramphastidx. 1855. 6d.

Part 4. Columbx. 1856. 1s.9d.

List of British Birds. By G. R. Gray, F.L.S. \&e. 12mo. 1850. $4 s$.

List of the Eggs of British Birds. By G. R. GraY, F.L.S. \&c. 12mo. 1852. 2s. $6 d$.

Catalogue of Shicld Reptiles. By Dr. J. E. Gray, F.R.S. \&c.

Part 1. Testudinata. 4to. 1855. $£ 1: 10 \mathrm{~s}$. With figures of all the new species, and of the skulls of the different genera.

Catalogue of Reptiles. By Dr. J. E. Gray, F.R.S., V.P.Z.S. \&c. Part 1. Tortoises, Crocodiles and Amphisbenians. 1844. $1 \mathrm{~s}$. Part 2. Lizards. 1845. 3s. 6d.

Part 3. Snakes (Crotalidx, Viperida, Hydridx and Boidæ). 12mo. 1819. 2s. 6d. 
Catalogue of Colubrine Snakes, and $\Lambda_{\text {ppendix }}$ to Part 1. By Dr. Albert Gunther. $12 \mathrm{mo}$. 1858. $4 s$.

Catalogue of Amphibia. By Dr. J. E. Grux, F.R.S., V.P.Z.S. Part 2. Batrachia Gradientia. 12mo, 1350. 2s.6cl. With

Plates of the Skulls and 'Teeth.

Catalogue of Amphibia. By Dr. A. Gunther.

Part 2. Batrachia Gradientia. 8vo. 1858. 6s. With Plates.

Catalogue of Fish. By Dr. J. E. Gray, F.R.S., F.L.S.,V.P.Z.S,

Part 1. Cartilaginous Fish. 12mo, 1851. 3s. With two Plates.

These Catalogues of Reptiles, Amphibia, and Fish, contain the characters of all the genera and species at present known; the latter are illustrated with figures of the genera.

Catalogue of Fish, collected and described by L. T. Gronow. 12mo. 1854. 3s. $6 d$.

Catalogue of Lophobranchiate Fish. By Dr. J. J. Ka up. 12 mo. 1856. 2s. With Plates.

Catalogue of Fish. By Dr. J. J. Ka up. Bvo. With many Plates. Part 1. Apodes, \&c. 1856. $10 s$.

List of British Fish ; with Synonyma. By $\Lambda$.Wнite, F.L.S. \&c. 12mo. 1851. 3s.

List of Osteological Specimens. By Dr. J. E. GRAy, F.R.S. \&e. and G. R. GRAY, F.L.S. 12mo. 1847. $2 s$.

\section{ANNULOSA.}

Catalogue of Lepidoptera. By G. R. GRAy, F.L.S., F.Z.S.

Part 1. Papilionidx, with coloured figures of the new species. 4to. 1852. $\& 1: 5 s$.

List of Lepidopterous Insects.

Part 1. Papilionidx, \&e. 12mo. 2nd edit. 1856. By G. R. Gray, F.L.S.

Part 2. Erycinilæ, \&e. 12mo. 1847. 9d. By E. DoublfDAY, F.L.S.

Part 3. Appendix to Papilionida, Erycinidx, \&c. 1848. 9d.

List of Lepidopterous Insects, with deseriptions of new species. By Fra.icis Walkitr, F.L.S.

Part 1. Lepiloptera IIetcrocera. 12mo. 1854. 4s.

Part 2. 1854. 4s, 6d.

Part 3. 1855. 3s.

l'urt 9. 1856. $4 s$.

Part 4. $1855.3 s$.

Part 10. 1857. 3s, 6d.

Part 5. 1855. $4 s$.

Part 11. 1857. 3s, fid.

Part 6. 1855. 3s. 6d.

Part 12. 1857. 3s. 6d.

Part 7. 1856. 4s. 6d.

Part 13. 1858. 3s. 6id.

Part 8. 1856. 3s. 6d.

Part 14. 1858. 4s. 6d.

Part 15. 1858, 4s, 6d. 
List of British Lepidoptera; with Synonyma. By J. F. StepHeNs, F.L.S., and II. T. STAINTON, M.L.S.

Part 1. 12mo. Ld. 2. 1856. 23. Part 3. 1853. 9d.

Part 2. 1852. 2s. Part 4. 1854. 3s,

Iist of IIymenopterous Insects. By l. WALKER, F.L.S.

Part 1. Chalcidida. 12mo. ist6. 1s.6d.

Part 2. Additions to Chalcilidic. 1818. 2s.

Catalogue of Hymenopterous Insects. By F. SmrT, M.E.S.

Part 1. Andrenidx, \&c. 12n10. 1853. 6s., with Plates.

Part 2. Apida. 1854. 6s., with Plates.

Part 3. Mutillidæ and Pompilidæ. 1855. 6s., with Plates.

Part 4. Crabronidæ, \&e. 1856. 6s., with Plates.

Part 5. Vespidæ. 1857. 6s., with Plates.

Part 6. Formicidx. 1858. 6s., with Plates.

Catalogue of British Hymenoptera. By F. Sмiтr, M.E.S.

Part 1. Apidx. 12mo. 1855. 6s.

Catalogue of British Formicilix, Sphegida, and Vespidic. By F. SмIтH, V.P.E.S.

Catalogne of British Ichnenmonilax. By Thomas Desvignes, M.E.S. $12 \mathrm{mo}$. 1856. 1s. 9d.

List of British Aculeate Ifymenoptera ; with Synonyma, anil the description of some new species. By F. Smitr. 1851. $2 s$.

Catalogue of Dipterous Insects. By F. WA LKER, F.L.S.

Part 1. 12mo. 1848. Part 4. 1849. 6s.

3s. 6d. Part 5. Supplement I. 1854. 4s. 6d.

Part 2. 1849. 3s. 6d. Part 6. Supplement II. 1854. 3s.

Part 3. 1849. 3s. Part 7. Supplement III.1855.3s.6d.

Catalogue of Homopterous Insects. By F. WALKER, F.L.S.

With Plates.

Part 1. 12mo. 1850. 3s.6d. Part 4. 1852. $4 s$.

Part 2. 1850. 5 s.

Part 3. 185l. 3s. 6d.

Supplement. 1858. 4 s., with Plates.

Catalogue of Neuropterous Insects. By F. WALK ER, F.L.S.

Part 1. 12mo. 1852. 2s.6d. Part 3. 1853. 1s. 6d.

Part2. 1853. 3s.6d. Part 4. 1853. 1 s.

Catalcgue of Neuropterous Insects. By Dr. IIAGEN.

Part 1. Termitina. 12mo. 1858. $6 d$.

Catalogue of Hispidæ. By J. S. BALY, M.E.S. 8vo. 1858. Gs. With Plates.

Catalogne of Hemipterous Insects. By W. S. DA L I.As, F.I.S.\&e.

With Plates, Part 1. 12mo. 1851. 7s. Part 2. 1852. $4 s$.

The Catalogues of Hymenopterous, Dipterous, Homopterous and Hemipterous Insects contain the description of the species in the Museum which appenred to be undescribed.

Catalogue of British Bruclidæ, Curculionidæ, \&c. Ву Јонм

WALTON, F.L.S. $12 \mathrm{mo} .1856$ 
Catalogue of Cassidida. By Professor Bonmax. 12mo. 1856. 3s.

Catalogue of Colcopterous Insects of Madeira, By T. V. Wor,LAstox, F.L.S. 8ro. 1857. 3s.

Nomenclature of Coleopterous linsects (with characters of new species).

Part 1. Cetoniadx. 12mo. 1847. 1s. By $\Lambda$. Wиiтк, F.L.S.

Part 2. IIylrocanthari. 1317. 1s. 3l. By $\Lambda$. Whits, I. L.S.

Part 3. Buprestidac. 18.18. ls. By A. White, F.L.S.

Part 4. Cleridax. 1849. 1s.8d. liy $\Lambda$. White, F.L.S.

Part 5. Cucujiclae. 1851. 6d. By I. Sмiтh, M.E.S.

Part 6. Passalida. 1852. 8d. l3y F. Smitir, M.E.S.

Put 7. Longicornia. By 1 . Wurte, F.L.S. With l'lates. Part 1. 1853. 2s.6d. Part 2. 1855. 3s.6d.

Part 8. Cassidida. by A. Wnite. 1856. 3s.

List of Myriaporla. By G. NEwport, F.R.S. \&c. 12mo. 1814. $4 a$.

Catalogue of Myriapoda. By G. NEwPORT, F.R.S. \&c.

Part 1. Cliilopoda. $12 \mathrm{mo}$. 1856.1 s. 9 d.

List of British Anoplura, or Parasitic Insects; with Synonyma By H. Denny. 12mo. ls.

List. of Ciustacea; with Synonyma. By $\Lambda$. Wirte. 1847. $2 s$.

List of British Crustacea ; with Synonyma. By A. Write, F.L.S. $12 \mathrm{mo}$. $1850.2 s .6 \mathrm{~d}$.

Catalogne of Entozoa; with Plates. By W. Barnd, M.D., F.L.S. $12 \mathrm{mo}$. is53. $2 \mathrm{~s}$.

Catalogue of British Worms. By G. Jonnston, M.D. 8vo. With Plates.

\section{MOLLUSCA.}

Guide to the Collection of Mollusen, By Dr. J. E. Gray, F.R.S. \&.e. 8ro. Part 1. 1856. $5 s$.

Catalogue of the Mollusea. By Dr. J. E. Gray, W.M.S. \&c. Part 1. Cephalopoda Antepedia. 12mo. 1849. 4s.

Part 2. Pteropola. 1850. ls.

Catalogue of Bivalve Mollusca. By Dr. J. W. Gray, F.R.S. \&c. , Part 1. Placumiadie mil Anomblac. 12mo. $1850.4 \mathrm{~d}$.

part 2. Brachiopoda Ancylopoda. 1853.3s. Fignres of genera.

Containing the characters of the recent and fossil genera, and the descriptions of all the recent species at present kinown.

Catalogne of Plianeropmeumona or Operenlated Terrestrial Mollusca. By Dr. Louis Prerffer and 1'. J. E.Gray. 1852.5s.

Catalogue of Conchiferi. By M. Desirayes.

P'irt 1. Veneridx, \&c. 12mo. 1853. 3s.

Part 2. Petricolidic. 6d. 
List of British Mollusen and Shells; with Synonyma. By Dr. J. L. GuAY, F.R.S.

Part 1. Acephala and Brachiopoda. 12mo. 185l. 3s.6d.

Catalogne of Pulmonati. By Dr. Louis Preirfer and Dr. J. E. Gray, F.lR.S.

Part 1. 12mo. 1855. 2s. 6d.

Catalogne of Auriculida, \&c. 13y Dr.J. E. GrAY, F.R.S. 12 mo. 1857. $18,9 d$.

List of the Shells of the Canaries, described by M. D'Onnigny. 12mo. 1854. $1 s$.

List of the Shells of Cuba. described by M. D'Ornigny. $12 \mathrm{mo.}$ 1854. $1 s$.

List of the Shells of South America, leseribed by M. D'OrHIGNY. $12 \mathrm{mo}$. 1854. $2 s$.

List of the Mollusea and Shells collected and described by MM. Lydoux and Souleyet. 12mo. 1855. 8d.

Catalogue of the Collection of Mazatlan Shells. 13y P. P. CarPENTER. 12 mo. $1857.8 s$.

List of Mollusca. By Dr. J. E. Gray, F.R.S. Part 1. Volutida. 12mo. 1858. 6d.

Nomenclature of Mollusea. By Dr. W. BAird, F.L.S. \&c.

Part 1. Cyelophoridx. 12no. 1851. 1s.6d.

\section{RADIATA.}

Catalogue of Marine Polyzon. By G. Busk, P.R.S.

Part 1. Chilostoma. 12mo. 1852. 17s. With Plates.

Part 2. Chilostoma. 12mo. 1854. 15s. With Plates.

List of British Radiata; with Synonyma. By Dr. J. E. Gray, F.1R.S. $12 \mathrm{mo}$. 1848. 4s.

List of British Sponges; with Synonyma. By Dr. J. E. GraY, F.R.S. $12 \mathrm{mo}$. 1848. $10 \mathrm{~d}$.

Catalogue of the Recent Echinida. By Dr. J. E. Gray, F.R.S. Part 1. Echinida irregularin. 12mo. 3s.6d., witl Plates.

\section{BRITISH ZOOLOGY.}

List of the British Animals; with Synonyma and referenees to figures.

Part 1. Radiata. By Dr. J. E. Gray. 1818. $4 s$.

Part 2. Sponges. By Dr. J. E. Gray. 1848. 10d.

Part 3. Birds, By G. R. Gray. 1850. 4s.

Part 4. Crustacea. By A. Winte. 1850. 2s. 6d.

Part 5. Lepidopitera. By J. F. Stepiness. 1850. Ed. 2. 1856. 18. $9 d$. 
Part 6. Hymenoptern. By F. Sмiтil. 1851. $2 s$.

Part 7. Mollusea $\Lambda$ eephala and Brachiopoda. By Di. J. E. Gray, 1851. 3s, 6d.

Part 8. Fish. By $\Lambda$. Write. 1851. 3s.

Part 9. Eggs of British Birds. By G. R. Gray. 1852. $2 s .6 d$.

Part 10. Lepiloptera (continued). 13y J. F. Stepinens. 1852. $2 s$.

Part 11. Anoplura or Parasitie Inseets. By II. Densy. $1 s$.

Part 12. Lepidoptera (continued). BV J. I. STEpiress. 1852. $9 d$.

Part 13. Nomenelature of Hymenoptera. By F. Sirth. 1853. 1 s. $4 d$.

Part 14. Nomenelature of Neuroptera. By $\Lambda$. Winte. 1853. $6 d$.

Part 15. Nomenclature of Diptera. By $\Lambda$. WIIITE. 1853. Is.

Part 16. Lepidoptera (completed). By II. T. Stainton, M.E.S. 1854. $3 s$.

Catalogue of British Hymenoptera (Bees). By F. Sмдт1. 1855. 6s., with Plates.

Catalogue of British Ichneumonille. By Thomas Desvignes, M.E.S. $12 \mathrm{mo}$. 1856. is. $9 \mathrm{~d}$.

Catalogue of British Bruelida, Cureulionidæ, \&c. By JoIn WALTON, F.L.S. $12 \mathrm{mo} .1856$.

N.B.-These Catalogues ean be obtained at the Secretary's Office in the BRITISH MUSEUM; or through any Bookseller.

\section{Books illustrating on Describing parts of the Zoological Collectrons.}

The Illustrated Natural Ilistory. By the Rev. J. G. Woon, M.A., F.L.S. \&e. New edition. 12mo. 1855.

Illustrations of Indian Zoology, from the Collection of MajorGeneral Thomas IIardwicke. By Dr. J. H. Gray, F.R.S. Folio. 2 vols. 1830-1835.

7.oology of tha Voyage of H.M.S. Beagle. Edited by CiranLes DARWIN, F.R.S. 4to. 1840-1844.

Zoology of the Voyage of II.M.SS. Erebns and Terror. Edited by Sir Join Ricilardoson, M.D., F.R.S. \&e., and Dr. J. E. GraY, F.R.S. 4to, 1844-1845.

I3ritish Muscum-IIistorieal and Deserintive. 12mo. 1855.

Naturat History of the Animal Kingdom. By W. S. DAluas, F.L.S. \&c. Post 8ro. 1855.

Zoological Miscellany. By W. E. Leach, M.D., F.R.S. 8 ro. 3 vols.

Spicilegir Zoologien. 13y Dr.J. E. Gray, l'.R.S. 4to. 1829-1830. 
Zoological Miscellany. By Dr. J. E. Gray, F.R.S. 8vo. 1831. Knowsley Menagerie. Part 2. Ioofed Animals. By Dr. J. E. Gray, F.R.S. Folio. 1850.

$\Lambda$ Monograph of the Macropodidæ. By Jous Gould, F.R.S. Folio. 1841-1844.

Mammals of Australia. By Join Govld, F.R.S. Folio. 1845.

Popular History of Mammalia. By A. Wirite, F.L.S.

Popular IIistory of Birds. By A. White, F.L.S.

Genera of Birds. By G. R. Grax, F.L.S. Illustrated by plates by D. W. Mitchell, Scc. Z.S. Folio. 3 vols. 1844-1849.

The Birls of Jamaica. By P. II. Gosse, F.R.S. 8vo. 1847.

Illustrations of the Birds of Jamaica. By P. II. GossE, F.R.S. 8vo. 1849.

Monograph of Ramphastida. By JoHn Gould, F.R.S. Folio.

Birds of Australia. By JoIn Gould, F.R.S. Folio. 1848.

Report on the Iclithyology of the Seas of Clina and Japan. By Sir John Richandson, M.D., F.R.S. 8vo. 1846.

Fauna Boreali-Americana. The Fish. By Sir John Ricilard. son, M.D., F.R.S. \&e. 4to. 1836. With Plates.

Synopsis Reptilium. Part 1. Cataphracta. By Dr. J. E. GnıY, F.R.S. 8vo. 1831.

Illustrations of British Entomology. By James F. STEphens, F.L.S. 10 vols. 8 wo. $1827-1835$.

A Systematic Catalogue of British Insects. By J. F. Stepnens, F.L.S. 8vo. 1829 .

'The Nomenclature of British Insects. By J. F. Stepuens, F.L.S. 8vo. $1829 \& 1833$.

A Manual of British Coleoptera. By J. F. Stephess, F.L.S. 12 mo. 1839.

Insecta Britannica. Diptera. By F. WALKer, F.L.S. 8vo. 1851-1856.

Monographia Chalciditum. By F. WALKer, F.L.S. 8vo. 1839.

Entomology of Australia. Part l. Phasmidx. By G. R. Gra r, F.L.S. 4to.

Synopsis of species of Phasmidx. By G. R. Gray, F.L.S. 8vo. 1835.

Genera of Diurnal Lepidoptera. By Edward Dounleday, F.L.S., and J. O. WeSTwood, F.L.S. Illustrated by W. C. Hewitson. 4to. 2 vols. 1846-1850.

Monographia Anoplurorum Britannix, or British species of Parasitic Insects. By Henry Denny, F.L.S. 8vo. With Plates. 
launn Boreali-Amerienna. The Insects. By W. Kinnx, F.R.S. 4to. 1837. With Coloured Plates.

Insecta Maderensia. By T. Verson Wollaston, M.A., F.L.S. 4to. 1854. With Plates.

Malacostraca Podophthalmia Britannix. By W. E. Leacir, M.D., F.R.S. 4to. 1817-1821,

A Monograph of the Subclass Cirripedia. By Cirarles Darwin, F.1R.S. 8vo. 2 vols. 1854.

Natural History of the British Entomostrace. By W. BAIRD, M.D., F.L.S. \&c. 8vo. 1850 ,

Figures of Molluseous' Animals, for the use of Students. By Maria Emma Gray. 5 vols. 8vo. 1850-1857.

A Synopsis of the Mollusen of Great Britain. By W. E. LeAcr, M.D., F.R.S. 8vo. 1852 .

Catalogue of the Land Shells of Jamaica. By C. 1. AndMs. 8vo. 1851 .

Catalogue of Testaceous Mollusea of the North-cast Atlantic and neighbouring Sens. By R. MacANduew, l.R.S. 8vo. 1850.

Illustrations of the Gcology of Yorkshire. 13y Joirn Punurs, F.R.S. 4to. 1836.

A Monograph of the Crag Mollusca. By Searleg V. Wood, F.G.S. 4to. 1850.

A Iistory of British Starfishes. By Edwand lornes, F.R.S. 8 ro.

A IIistory of the British Zoophytes. By Georgr Johngtor, M.D. 8vo. 1838.-Ed. 2. 8vo. 1847.

A IIistory of British Sponges and Lithophytes. By Geonge Jolnnston, M.D. 8vo. 1842.

A Synopsis of the British Diatomncere. By W. Smitu, F.L.S. 8 v. 2 vols. 1854-1856. The l'lates by T. West.

Procecdings of the Zoological Socicty. Series 1 and 2.

Transactions of the Entomological Socicty. 


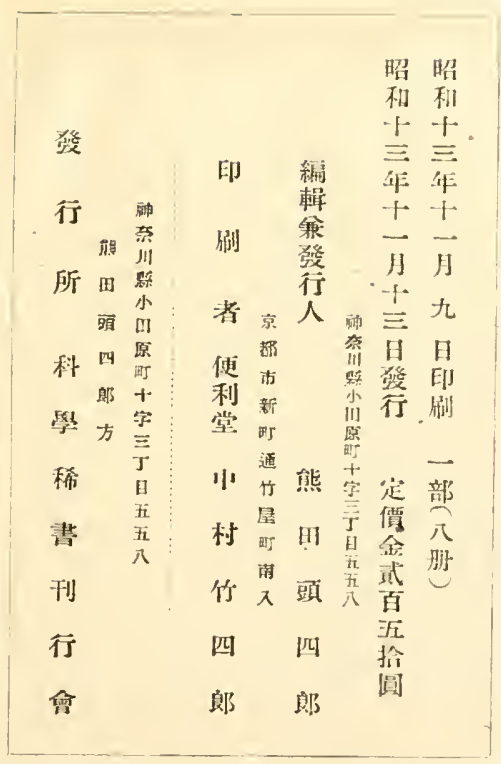







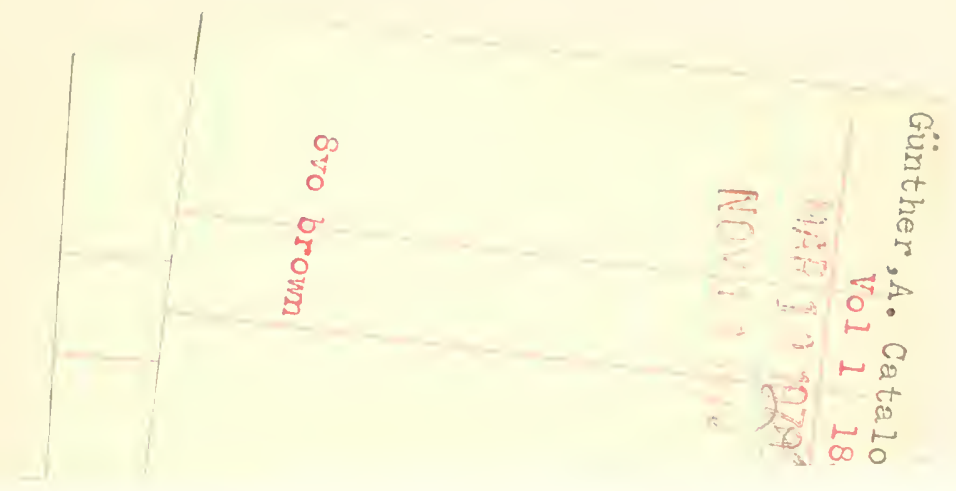


